\title{
8. SITE 652: LOWER SARDINIAN MARGIN ${ }^{1}$
}

\author{
Shipboard Scientific Party ${ }^{2}$
}

\section{HOLE 652A}

Date occupied: 18 January 1986

Date departed: 28 January 1986

Time on hole: 10 days, $13 \mathrm{hr}$

Position: $40^{\circ} 21.30^{\prime} \mathrm{N} 12^{\circ} 08.59^{\prime} \mathrm{E}$

Water depth (sea level, corrected m, echo-sounding): 3446.0

Water depth (rig floor, corrected m, echo-sounding): 3457.0

Bottom felt ( $\mathrm{m}$, drill pipe length from rig floor): 3470.5

Total depth (m): 4191.6

Penetration (m): 721.1

Number of cores: 75

Total length of cored section (m): 721.1

Total core recovered $(\mathrm{m}): \mathbf{4 4 5 . 7}$

Core recovery (\%): 61.2

Deepest sedimentary unit cored:

Depth sub-bottom (m): 683.5

Nature: calcareous sandstones and siltstones.

Age: unknown, possibly Messinian.

Measured vertical sound velocity $(\mathrm{km} / \mathrm{s}): 3.3 \mathrm{~km} / \mathrm{s}$

Igneous or metamorphic basement: None

\footnotetext{
${ }^{1}$ Kastens, K. A., Mascle, J, Auroux, C., et al., 1987. Proc., Init. Repts. (Pt. A), $O D P, 107$

2 Kim A. Kastens (Co-Chief Scientist), Lamont-Doherty Geological Observatory, Palisades, NY 10964; Jean Mascle (Co-Chief Scientist), Laboratoire de Géodynamique Sous-Marine, Université Pierre et Marie Curie, BP 48, 06230 Villefranchesur-Mer, France; Christian Auroux, Staff Scientist, Ocean Drilling Program, Texas A\&M University, College Station, TX 77843; Enrico Bonatti, Lamont-Doherty Geological Observatory, Palisades, NY 10964; Cristina Broglia, Lamont-Doherty Geological Observatory, Palisades, NY 10964; James Channell, Department of Geology, 1112 Turlington Hall, University of Florida, Gainesville, FL 32611; Pietro Curzi, Istituto di Geologia Marina, Via Zamboni, 65, 40127 Bologna, Italy; Kay-Christian Emeis, Ocean Drilling Program, Texas A\&M University, College Station, TX 77843; Georgette Glaçon, Laboratoire de Stratigraphie et de Paleoécologie, Centre Saint-Charles, Université de Provence, 3, Place Victor Hugo, 13331 Marseille Cedex, France; Shiro Hasegawa, Institute of Geology, Faculty of Science, Tohoku University, Aobayama, Sendai, 980, Japan; Werner Hieke, Lehrstuhl für Allgemeine, Angewandte und Ingenieur-Geologie, Abt. Sedimentforschung und Meeresgeologie, Technische Universität München, Lichtenbergstrasse 4, D-8046 Garching, Federal Republic of Germany; Floyd McCoy, Lamont-Doherty Geological Observatory, Palisades, NY 10964; Judith McKenzie, Department of Geology, University of Florida, 1112 Turlington Hall, Gainesville, FL 32611; Georges Mascle, Institut Dolomieu, Université Scientifique et Médicale de Grenoble, 15 Rue Maurice Gignoux, 38031 Grenoble Cedex, France; James Mendelson, Earth Resources Laboratory E34-366, Department of Earth, Atmospheric and Planetary Sciences, Massachusetts Institute of Technology, 42 Carleton Street, Cambridge, MA 02142; Carla Müller, Geol.-Paläont. Institut, Universität Frankfurt/Main, 32-34 Senckenberg-Anlage, D-6000 Frankfurt/Main 1, Federal Republic of Germany (current address: 1 Rue Martignon, 92500 Rueil-Malmaison, France); Jean-Pierre Réhault, Laboratoire de Géodynamique Sous-Marine, Université Pierre et Marie Curie, BP 48, 06230 Villefranche-sur-Mer, France; Alastair Robertson, U.S. Geological Survey, 345 Middlefield Road, Menlo Park, CA 94025 (current address: Department of Geology, Grant Institute, University of Edinburgh, Edinburgh, EH9 3JW, United Kingdom); Renzo Sartori, Istituto di Geologia Marina, Via Zamboni, 65, 40127 Bologna, Italy; Rodolfo Sprovieri, Istituto di Geologia, Corso Tukory, 131, Palermo, Italy; Masayuki Torii, Department of Geology and Mineralogy, Faculty of Science, Kyoto University, Kyoto, 606, Japan.
}

Principal Results: The sediments recovered are divided into two major divisions: Pliocene/Pleistocene hemipelagic marine sediments from 0 to 188 mbsf, underlain by barren, gypsiferous, calcareous sandy mud and mudstone interbedded with minor chemical sediments from 188 to 721 mbsf. The Pliocene/Pleistocene sediments can be further divided into two units (Units I and II) primarily based on their calcium carbonate content; the pre-Pliocene sediments can be divided in two units (Units IV and V) based on sedimentary structures and the abundance of chemical sediments. A 40-cm-thick transition zone (Unit III) divides the Pliocene/Pleistocene hemipelagic sediments from the barren pre-Pliocene sediments.

\section{Coring Results}

In more detail, the recovered lithologies were (Fig. 1):

Sedimentary Unit I: Cores 107-652A-1R to -6R; depth: 0-55.4 mbsf; age: Pleistocene. This unit consists mainly of gray calcareous muds and gray muds, with volcanic glass as a common minor constituent. Carbonate content averages $22 \%$. The succession includes four distinct sapropel layers; preliminary geochemical data suggest that these sapropels contain a mixture of marine and continental organic lipids.

Sedimentary Unit II: Cores 107-652A-7R to -20R; depth: 55.4188.2 mbsf; age: early Pleistocene-Pliocene. Sedimentary unit II consists of marly nannofossil oozes with higher carbonate content (average $48 \%$ ) than in Unit I. Four more sapropel layers were found in the upper $22 \mathrm{~m}$ of the unit. The interval between 65 and $113 \mathrm{mbsf}$ contains abundant volcanic glass. From 176 to $180 \mathrm{mbsf}$, the dominant olive gray color grades downsection into yellowish-red and brownish yellow tones, followed by intense reds and browns directly above the Miocene/Pliocene boundary. The boundary was determined by the last appearance of in-situ planktonic foraminifera at 188.2 mbsf.

Sedimentary Unit III: Interval 107-652A-20R-6, 52-92 cm depth: 188.2-188.6 mbsf; age: latest Messinian. This unit is a transitional interval between the normal marine Pliocene and the barren Messinian sediments. The unit is composed of a succession of centimeterthick layers of strongly colored (red, strong brown, reddish gray, light gray, greenish gray, and gray) clays and muds. The deepest occurrence of rare in-situ nannofossils was at $188.4 \mathrm{mbsf}$.

Sedimentary Unit IV: Interval 107-652-20R-6, $92 \mathrm{~cm}$ to -36R-CC; depth: 188.6-344.3 mbsf; age: probable late Messinian. The interva from 189 to $286 \mathrm{mbsf}$ is dominated by gray, thinly-bedded, normally-graded, gypsum- and carbonate-bearing, sandy mud, interpreted as turbidites. From 286 to 335 mbsf the lithological components are the same but the sedimentary structures differ in that there are reversely-graded sequences, frequent water escape structures, synsedimentary microfaults, and microbreccias; the shallowest occurrence of authigenic calcium sulfate and halite-dissolution molds occurs here. The unit was barren except for three specimens of $\mathrm{Am}$ monia becarii tepida and two fragments which may be from the brackish water ostracod Cyprideis, all found at 277 mbsf. The lowest core of the unit (335-345 mbsf) recovered only 14 smooth, rounded pebbles of sedimentary and low-grade metamorphic origin. The collection of varied lithologies represented by the pebbles occurs on land in the southern Apenneninic and the Sicilian Maghrebide mountain chains; this suite of rocks is unknown in Sardinia, Calabria, or on de Marchi Seamount.

Sedimentary Unit V: Core 107-652A-37R to -75R; depth: 344.8721.1 mbsf; age: undetermined (probable Messinian). The interval from 345 to 684 mbsf is characterized by a succession of dark gray, graded and cross-bedded, gypsum- and carbonate-bearing sandy muds, 


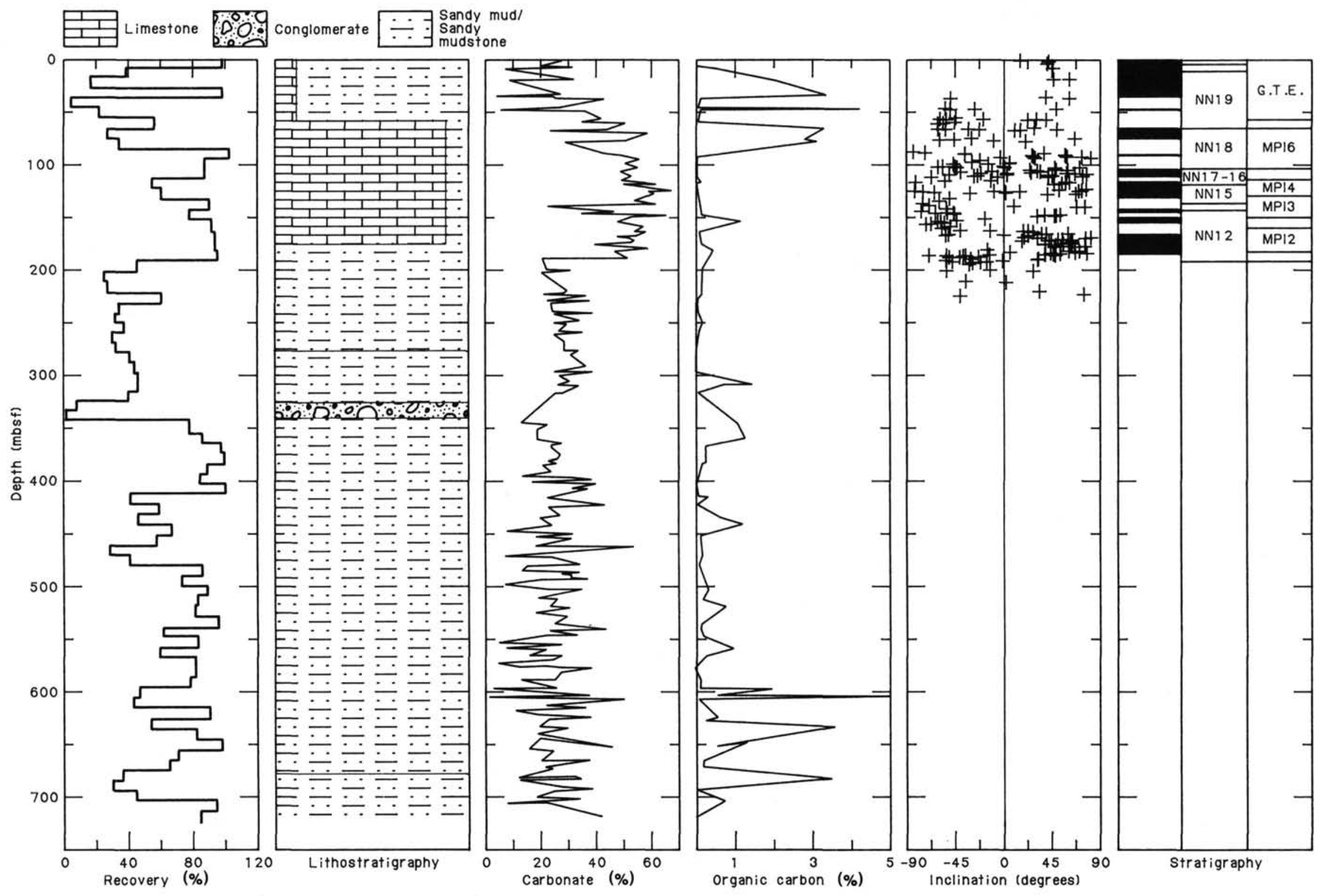




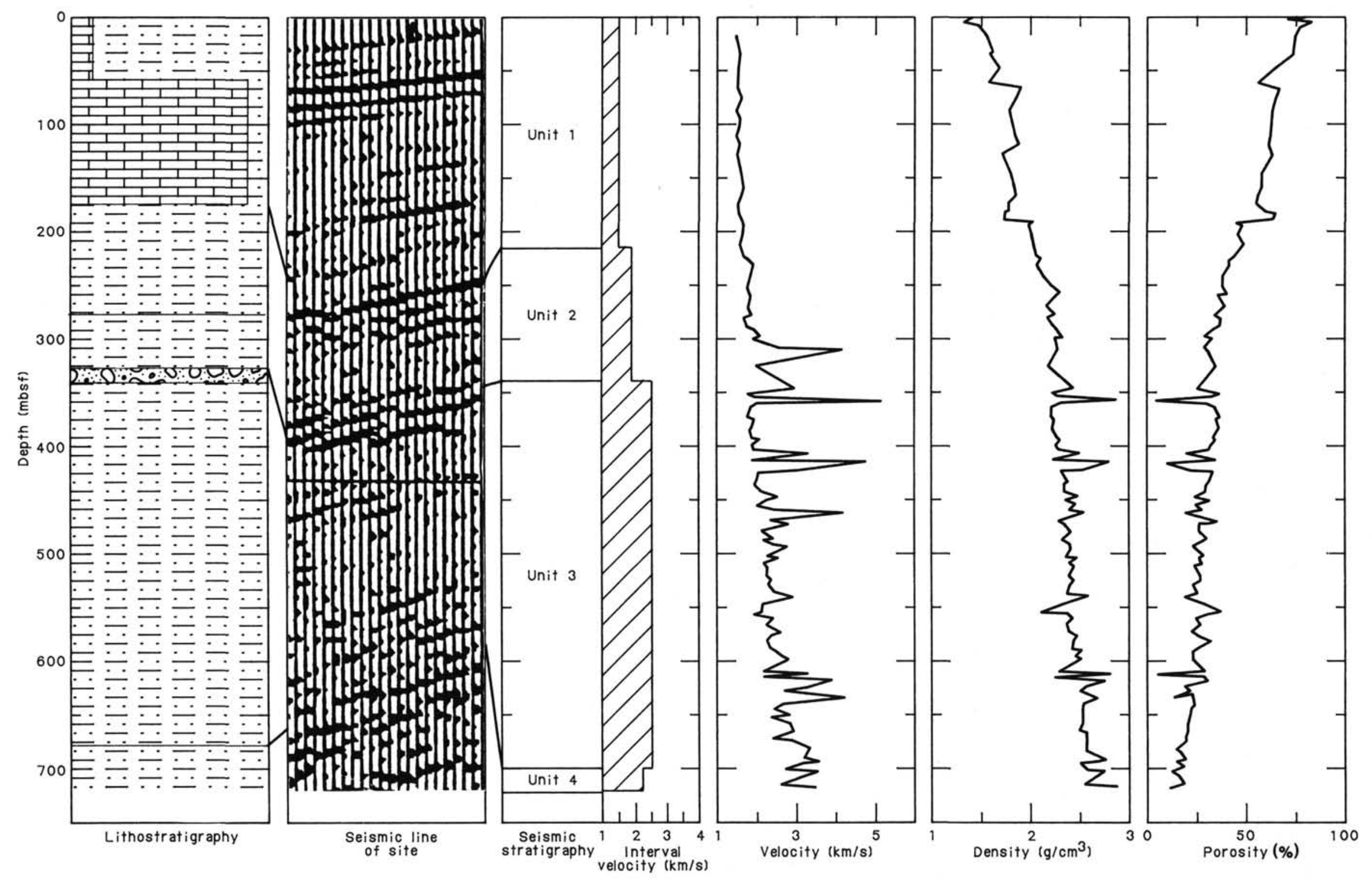

Figure 1. Summary of measurements made at Site 652. 
with several cyclic zones containing crystalline anhydrite as thick as $5 \mathrm{~cm}$ showing "chicken-wire" texture. Rare scattered plant debris, one algae-rich layer, thin finely-laminated organic carbon-rich layers, and numerous bright red (hematite?) and yellow (limonite?) millimetric horizons of inferred continental derivation are locally present. Within the interstitial waters, $\mathrm{Ca}^{2+}, \mathrm{Mg}^{2+}$, sulfate, and chlorinity reach maximum concentrations at about $500 \mathrm{mbsf}$; this suggests that the pore water chemistry of the entire sediment column is dominated by dissolution of evaporites in sedimentary Unit V. From 684 to 721 mbsf, sedimentary Unit V is well-indurated and consists mainly of dark gray calcareous siltstones, sandstones and claystones, containing highly-variable detrital elements, including pelagic micrite, platform carbonate debris, metamorphic lithic fragments, and detrital dolomite, calcite, and gypsum.

\section{Downhole Measurements}

Five successful heat flow measurements gave a thermal gradient of $14^{\circ} \mathrm{C} / 100 \mathrm{~m}$, for an average heat flow of about $4 \mathrm{HFU}$. The hole was logged between $78 \mathrm{mbsf}$ and approximately $375 \mathrm{mbsf}$ with a DIL/LSS/GR/CALI combination and a GST/NGT/CNT combination. The GST data proved valuable for identifying clay-rich/claypoor cycles in sedimentary Units IV and V (the inferred Messinian sequence).

\section{BACKGROUND AND OBJECTIVES}

\section{Regional Setting and Previous Work}

Site 652 lies on the lowermost eastern Sardinian continental margin in the central Tyrrhenian Sea (Figs. 2 and 3). The eastern Sardinian margin is an example of the class of "passive" or "Atlantic-type" margins in which continental crust has been stretched and thinned by listric normal faulting (Malinverno et al., 1981; Fabbri et al., 1981; Moussat, 1983; Rehault et al., 1986). Seismic refraction experiments reveal an eastward-thinning conti-

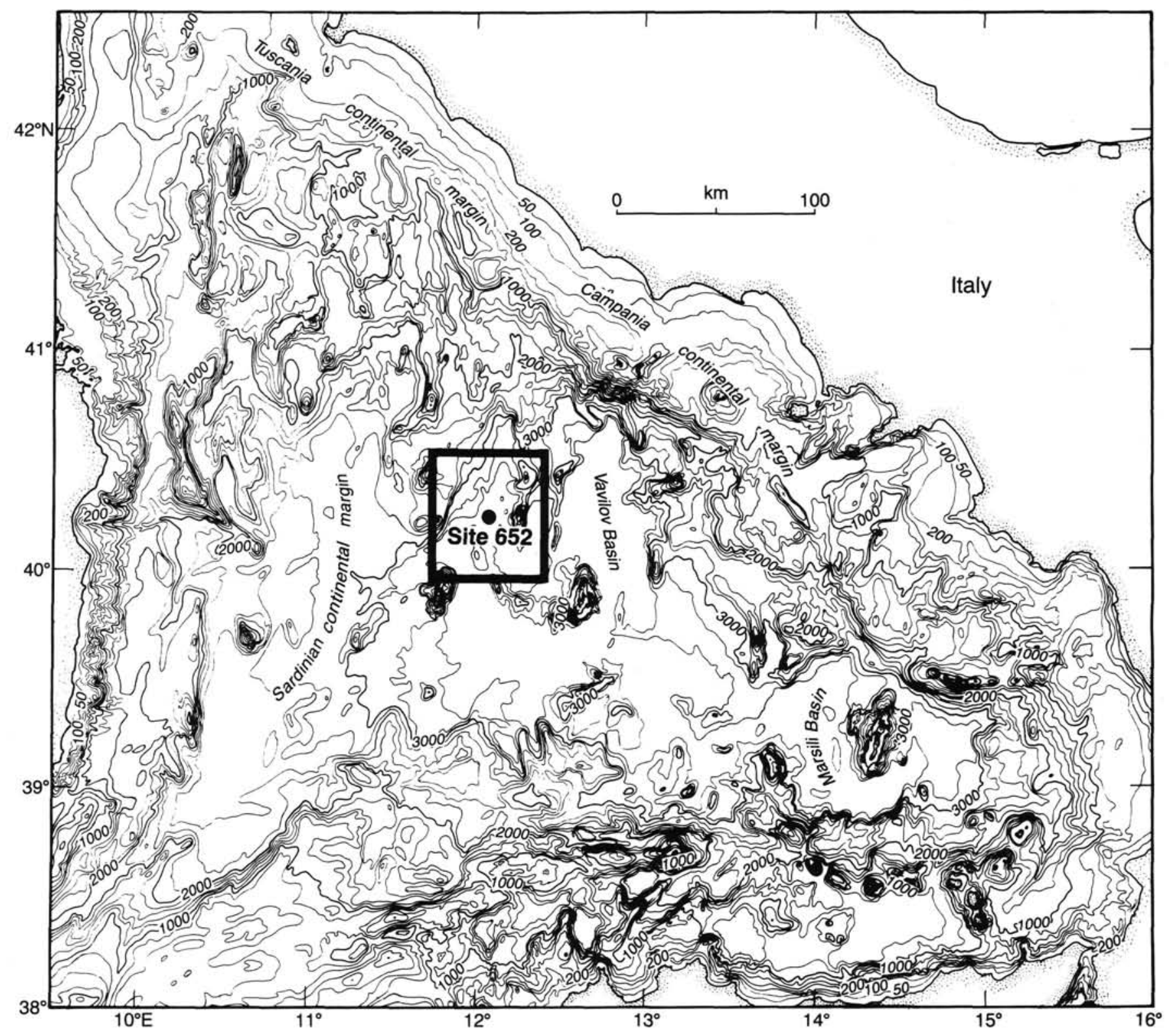

Figure 2. Site 652 is located on a small tilted block on the lowermost Sardinian continental margin, west of the Vavilov Basin. Contours in meters from International Bathymetric Chart of the Mediterranean. 


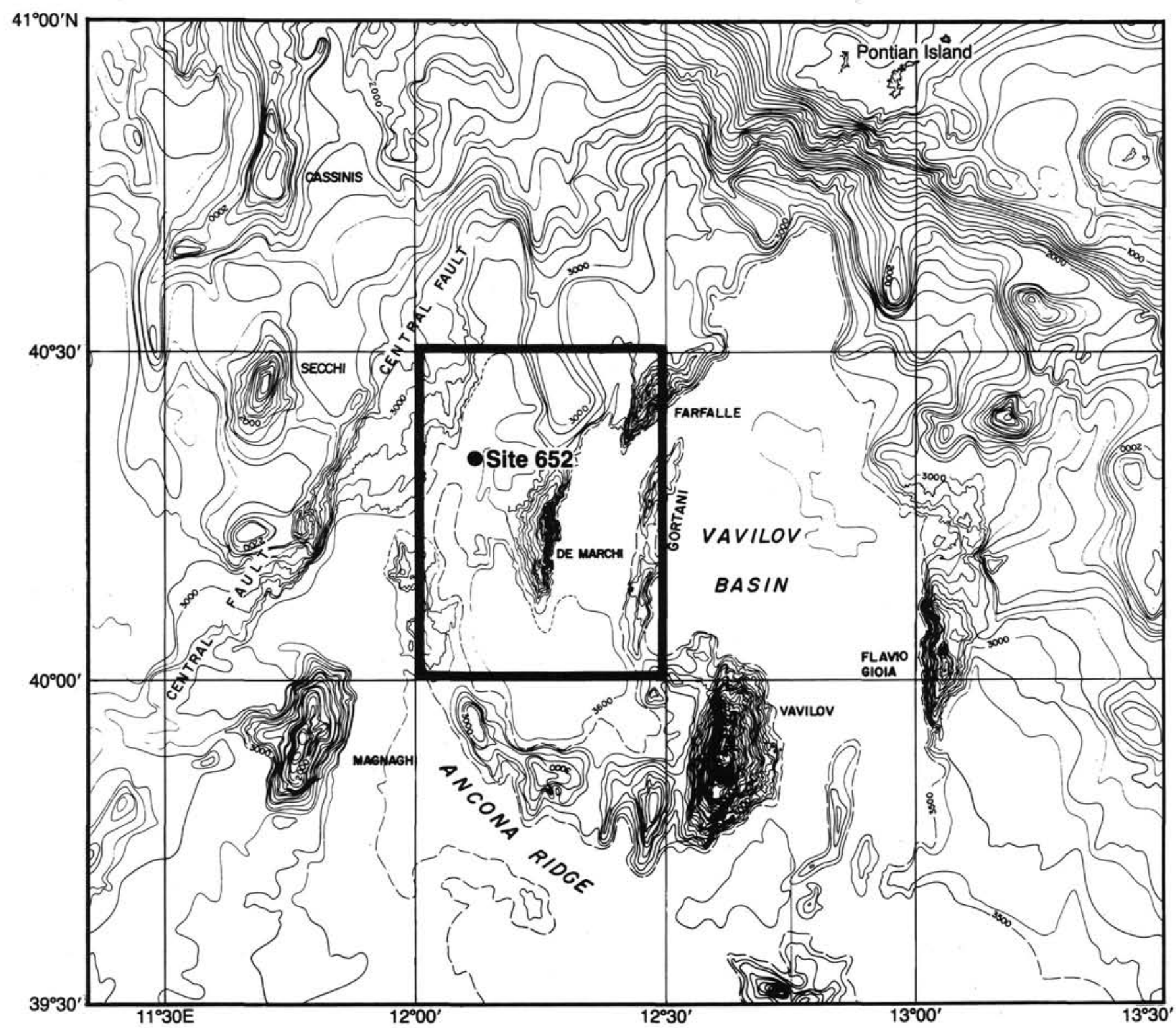

Figure 3. A northeast-trending bathymetric scarp, the so-called Central Fault, lies west of the site. Prominent asymmetric seamounts, the de Marchi and Farfalle Seamounts, lie east of the site.

nental crust (Fig. 4; Recq et al., 1984; Steinmetz et al., 1983), and seismic reflection profiles illustrate fracturing of the lower margin into a series of small, fault-bounded, tilted blocks (Figs. 4 and 5; Morelli, 1970; Finetti et al., 1970; Finetti and Morelli, 1973; Fabbri and Curzi, 1979; Moussat, 1983; Rehault et al., 1984a).

Relative to most other passive continental margins, the Sardinian margin offers to researchers the advantage of adjoining a basin which is relatively young, and a land area which sheds a relatively sparse sediment supply. Thus the early rifting history is not deeply buried and is unusually accessible to drilling. In contrast to most well-studied passive margins, this study area bounds a marginal basin or back-arc basin. Young seafloor in back-arc basins is typically deeper than seafloor of the same age in mature oceans; this implies that back-arc basin seafloor follows a different subsidence curve.

As at other passive continental margins, seismic reflection lines across the Sardinian margin reveal the existence of three distinct sedimentary sequences which are inferred to have been deposited prior to, during, and after stretching of the continental crust (Figs. 6 and 7). The lowermost unit, the pre-rift sequence, comprises subparallel seismic reflectors with a uniform dip. Typically the dip is landward (westward) although eastward dipping pre-rift sediments are seen on some fault-bounded blocks. This lowermost unit is interpreted as strata that were flat-lying when deposited, and then subsequently tilted en masse when the fault-bounded block rotated. The middle unit, the syn-rift sequence, comprises dipping reflectors with the same sense of dip as the pre-rift sequence; however the magnitude of the dip increases downsection within the syn-rift sequence, such that individual layers within the sequence, and the syn-rift sequence as a whole, thicken downdip. The middle unit is interpreted as strata that maintained a horizontal depositional surface while the faultbounded block gradually tilted under them. The uppermost unit, the post-rift sequence, comprises subparallel, subhorizontal reflectors. This uppermost unit is interpreted as strata that were deposited after motion ceased on the faults bounding the block. The cessation of tilting is inferred to coincide with the end of 
A

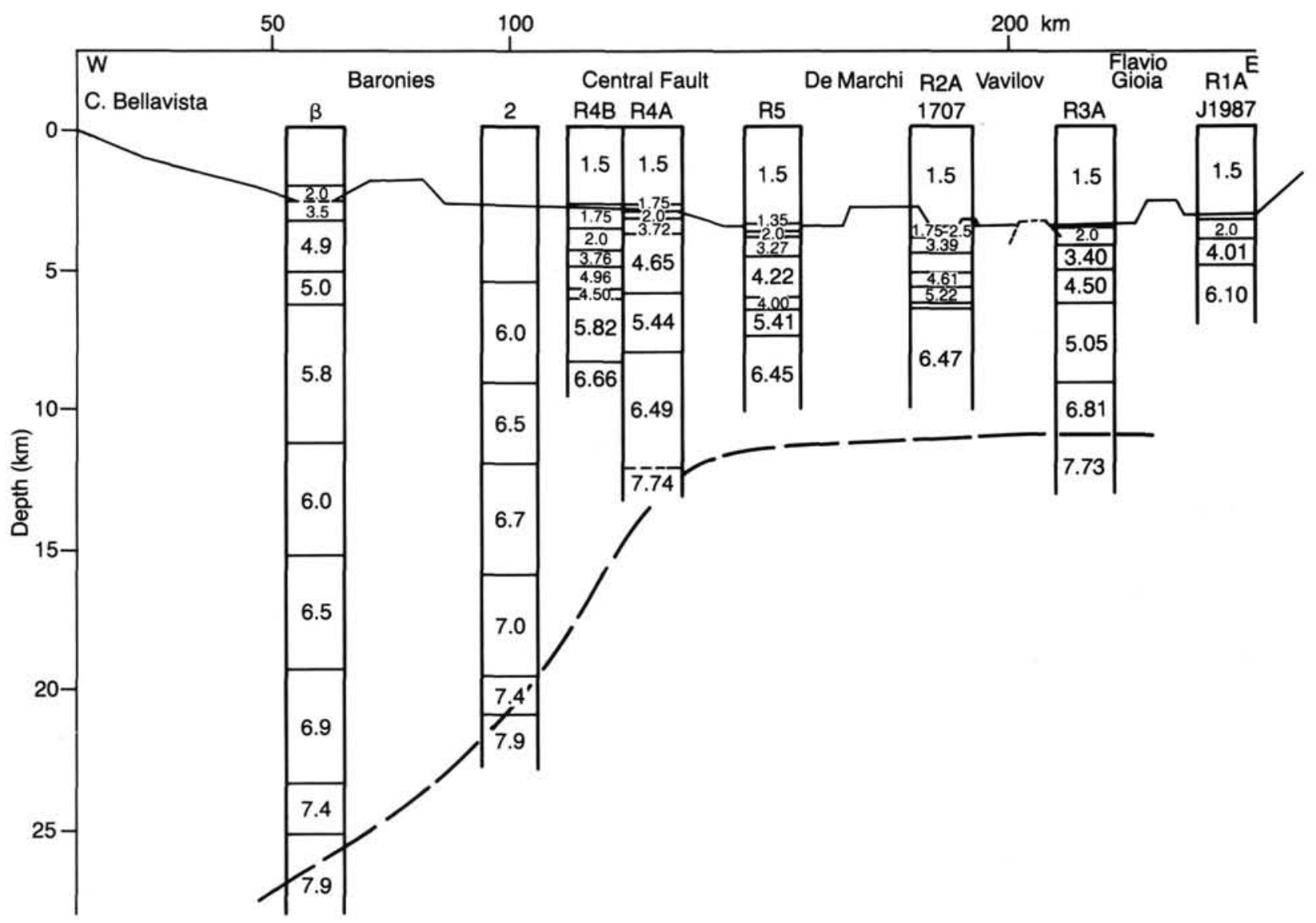

B
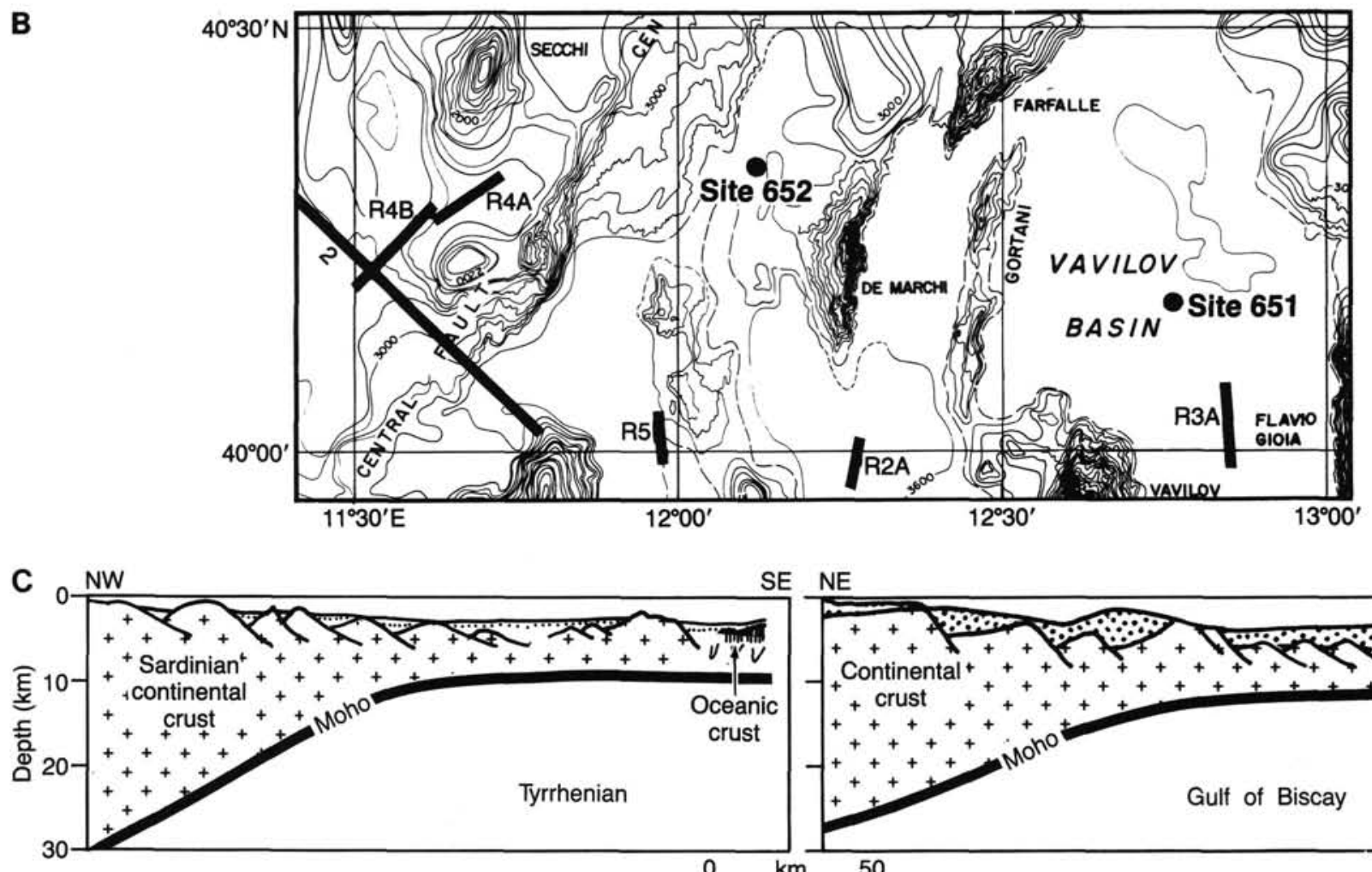

SE NE

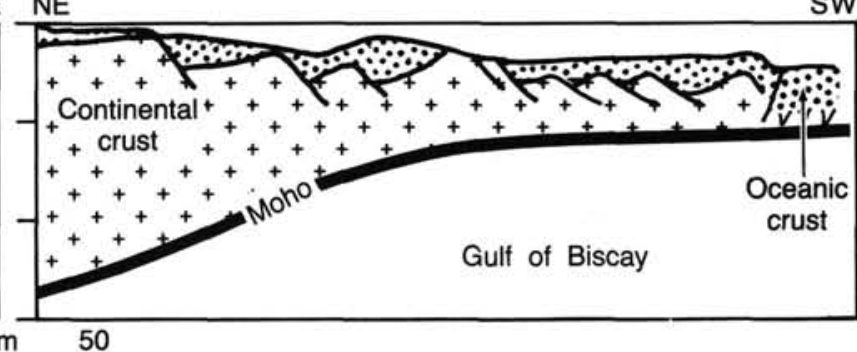

Figure 4. A. Crustal section of the Sardinian margin and Vavilov Basin deduced from refraction data (after Recq et al., 1984). B. Location of refraction experiments in the vicinity of Sites 651-652. C. Comparison between the general cross section of the Sardinian continental margin and the Gulf of Biscaye northern margin (after Malinverno et al., 1981). 


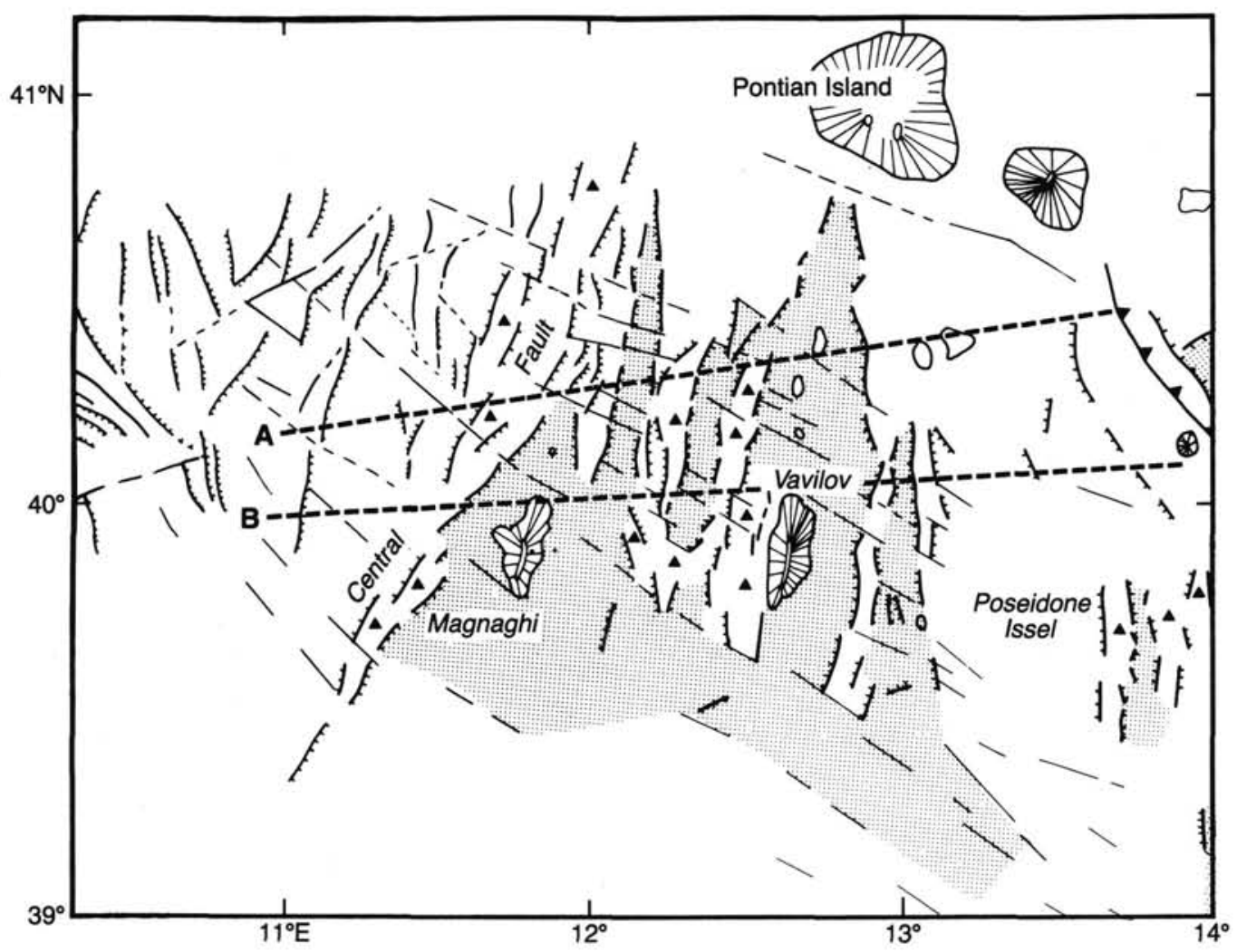

A

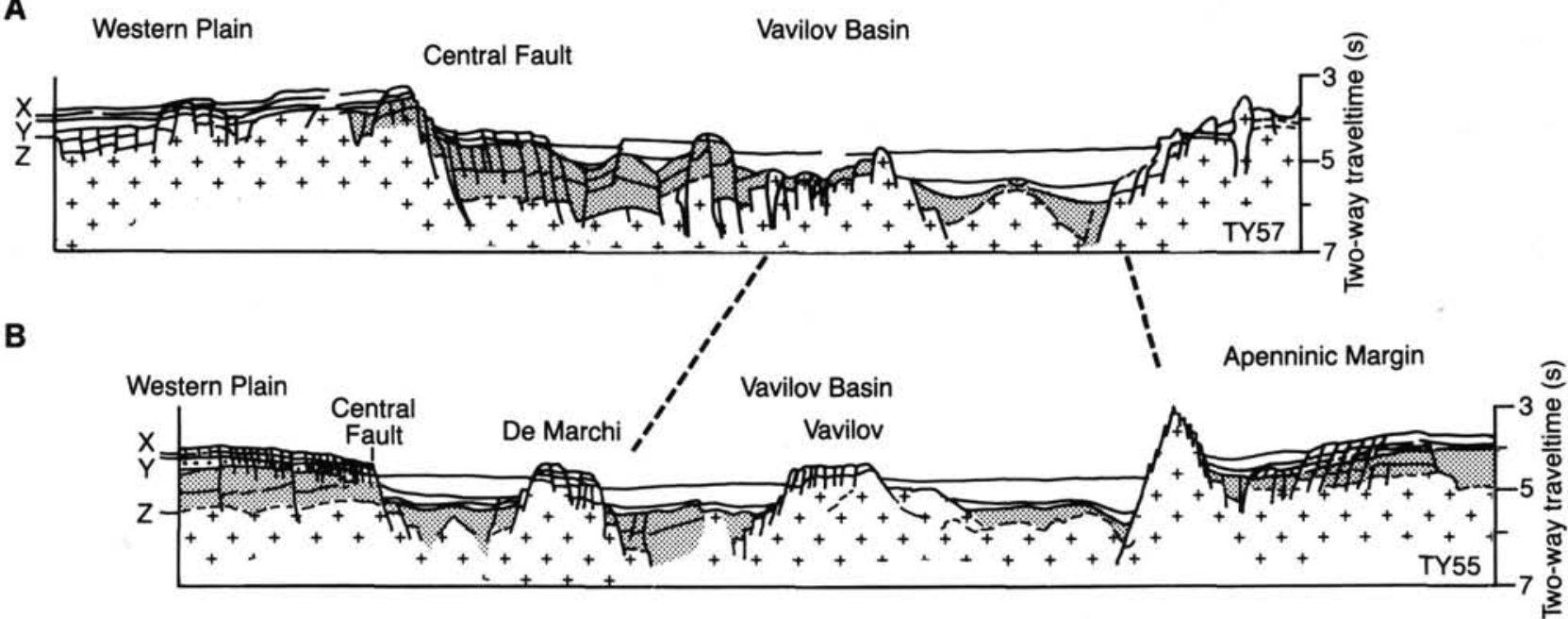

Figure 5. Upper. Schematic structural diagram of the lowermost Sardinian margin and adjacent Vavilov Basin (after Rehault et al., 1987). Shaded area: extension of the main bathymetric plain. The general structural trend of the margin is northeast (Central Fault), but subtle N $110^{\circ}-\mathrm{N} 120^{\circ}$ lineaments, possibly transfer faults, are detected in the bathymetry. Lower. Two east-west cross sections from the Sardinian margin to the Tuscanian (Apenninic) margin. ++ + : acoustic basement; shaded area: inferred pre-Pliocene sediments; dots: evaporitic facies (Messinian) (After Rehault et al., 1987).

the continental stretching stage and the beginning of formation of oceanic-type crust along the axis of the basin.

The timing of pre-, syn-, and post-rift phases in the Tyrrhenian Sea is poorly constrained; elucidating this was the major objective of Sites 652 and 654 . There was widespread agreement that the post-rift sequence is Pliocene to Pleistocene (Fabbri and Curzi, 1979; Malinverno et al., 1981; Moussat, 1983; Rehault et al., 1984b). According to the pioneering hypothesis of Selli and Fabbri (1971), who proposed a Pliocene age for the central Tyrrhenian Sea, one may expect the syn-rift sequence to be late-prePliocene.

Site 652 is located (Figs. 7 and 8) in an elongate, north-trending slope basin, on the landward (western) side of a small tilted block, near the inferred transition between thinned continental 


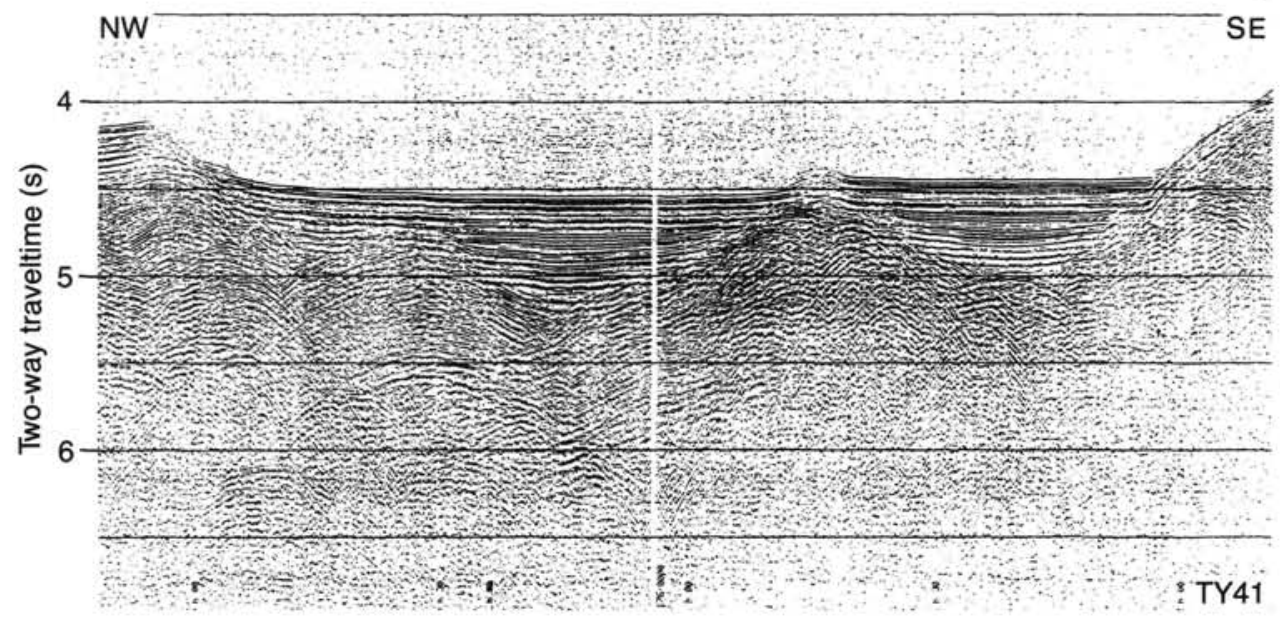

Figure 6. Single channel seismic line collected in the vicinity of Site 652 (see location on Fig. 8). Air-gun line TY41 (LGSM Villefranche), parallel to site survey line ST01, showing the tilted block on which the site was chosen.

and oceanic crust. The sediments on this particular tilted block are landward (westward) dipping, implying this block is bounded by seaward-dipping listric normal faults.

Immediately to the west of the site lies a north-northeasttrending, east-facing system of scarps known as the Faille Centrale or Central Fault (Fabbri et al., 1981; Fig. 3). The Central Fault appears to be a fundamental structural lineament of the Tyrrhenian Sea. Physiographically, the Central Fault separates the lower Sardinian slope, with water depths averaging greater than $3000 \mathrm{~m}$, from the middle slope, where water depths are generally shallower than $3000 \mathrm{~m}$.

Immediately to the east of the site lies a north-northeasttrending, asymmetric ridge known as Monte de Marchi or de Marchi Seamount (Fig. 3). de Marchi Seamount borders the Vavilov Basin and is interpreted as the easternmost tilted block of the continental margin (Figs. 3 and 5) (Moussat, 1983; Rehault et al., 1986). Dredge hauls on de Marchi Seamount have clearly demonstrated its continental nature, yielding phyllites, limestones, and granites of Carboniferous to Neogene age (Colantoni et al., 1981). Dives by submersibles made recently along the steep slopes of de Marchi Seamount have shown many outcrops of deformed phyllites and massive limestones cut by north-northeast- and northwest-trending faults (Gennesseaux et al., 1986).

\section{Objectives}

\section{Passive Continental Margin Evolution}

The primary objective at Site 652 was to document the timing of extension and subsidence of a young passive continental margin, by dating the contact between pre- and syn-rift sediments and between syn- and post-rift sediments. The timing and rate of extension and subsidence were to be compared to those at other passive margins, with the expectation that the subsidence history of this very small basin, bounded on two sides by collisional interactions, might differ significantly from passive margins fronting open oceans.

In addition to deciphering the subsidence history of the single block on which Site 652 is situated, the results from this site should permit extrapolation to adjacent blocks. Prominent reflectors present in the half-graben fill at Site 652 have been mapped throughout the Sardinian margin (Moussat, 1983); using ages for these reflectors determined at Site 652 , it should be possible to approximate the timing of tilting of other blocks on which the same reflectors are detected.

\section{Messinian Paleoenvironment}

A secondary objective at Site 652 was to recover Messinian facies in an area where the existence and/or nature of Messinian deposits appeared uncertain on seismic grounds (Fabbri and Curzi, 1979). MCS line ST01 (Fig. 7) shows a strong reflector (slightly faulted, at about $220 \mathrm{~ms}$ ), dipping toward the west, which has been tentatively interpreted as of Messinian age but of unknown nature (Rehault et al., 1986). Malinverno et al. (1981) mapped this area as a subaerial Messinian facies, possibly alluvial. Moussat (1983) stressed the apparent absence of the $B_{2}$ sequence (evaporitic sequence) in an area near Site 652.

\section{Pre-Messinian Paleoenvironment}

According to the seismic stratigraphic interpretation of Moussat (1983), the uppermost part of the inferred pre-Messinian seismic sequence is involved in the syn-rift filling of half-grabens, whereas deeper parts of the sequence are presumably pre-rift. Thus the potential recovery of Tortonian and possibly older sediments during drilling at Site 652 would increase our understanding of the evolution of the Tyrrhenian area prior to rifting. Of particular interest was the determination of whether marine conditions existed prior to the most recent phase of extension and tilting; such an observation would support the sugestion that the Tyrrhenian has experienced multiple phases of extension (Moussat, 1983; Rehault et al., 1984a).

\section{Site Selection}

Site 652 was intended to decipher the extensional and subsidence history of the lower margin, as close as possible to the ocean/continent transition. The site was therefore positioned on the easternmost tilted, fault-bounded block whose seismic reflection profiles exhibit an unambiguous geometry of apparent pre-, syn-, and post-rift sediments. The precise position of the site, at shotpoint 4250 on seismic line ST01 (Fig. 7), is constrained in the downdip direction (west) by the increasing thickness of the syn-sedimentary unit; the inferred pre-rift sediments would be too deep to reach in a single-bit hole farther west. In the updip direction (east), the location is constrained for safety considerations to avoid a recently active fault. 


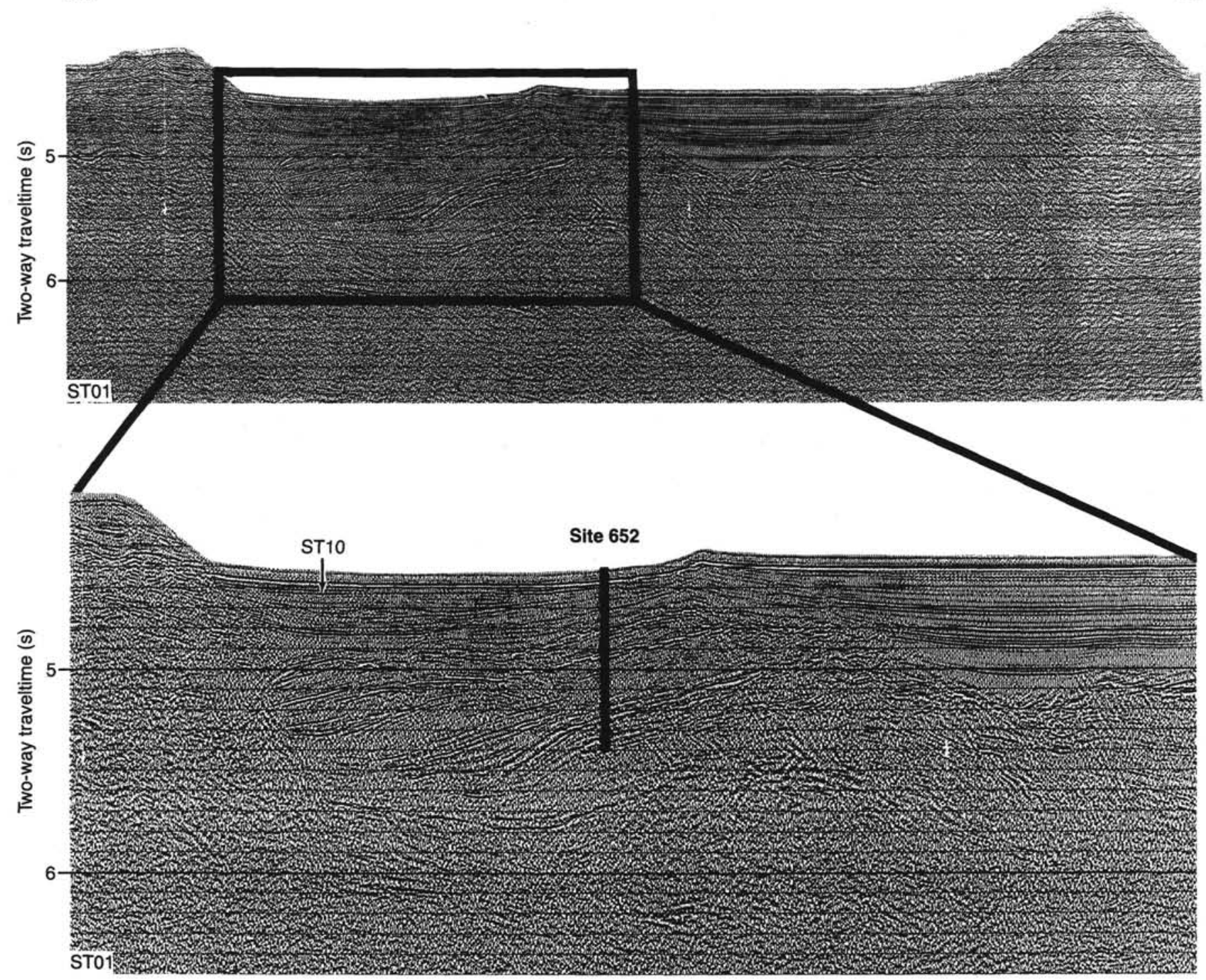

Figure 7. Section of multichannel seismic line ST01 across the lowermost Sardinian margin. Site 652 is located on a small tilted block wedged between the Central Fault and de Marchi Seamount (to the east). Note the geometric arrangement of the different reflectors, suggesting pre-rift, syn-rift, and post-rift sedimentary sequences.

\section{OPERATIONS}

\section{Strategy}

A major objective of Site 652 was to reach the contact between inferred pre-rift and syn-rift sediment on a fault-bounded tilted block. Since this contact lay at approximately $700 \mathrm{mbsf}$, rotary coring was the technique chosen. Heat flow measurements were planned at 40 -m-intervals. The proposed logging program consisted of standard Schlumberger logs plus GST and/or borehole televiewer, depending on time available and geology encountered.

There was no contingency plan for an offset second hole because the location of the site was tightly constrained by geological and safety considerations.

The approach to the site was planned to duplicate site survey line ST01 from east-southeast to west-northwest. The tilted block trends slightly east of north; thus an approach along course $300^{\circ}$ ensured that small across-track deviations from plan would be relatively harmless, although along-track positioning would be critical. Because the acceptable drilling location was so tightly constrained, a first pass was planned to calibrate the site survey multichannel profile with the Resolution's single channel seismic profile, to be followed by the beacon drop on a second eastsoutheast pass. The time of the beacon drop was to be determined from the single channel seismic profile. Since the site lay on a westward-sloping seafloor, final position of the ship relative to the beacon could be adjusted with respect to water depth, with the constraint that the proposed site had a water depth $72 \mathrm{~m}$ deeper than the crest of a small knoll $1.1 \mathrm{~km}$ east-southeast of the site.

\section{Approach to Site}

On the transit from Site 651 to the turning point for the Site 652 approach, the ship was navigated using the global positioning system (GPS). As the turning point was approached, Loran $C$ was giving positions approximately $11 / 2 \mathrm{mi}$ southwest of the GPS positions (as had been the case for the approach to Site 651). However the transit satellite fix at 2347 on 17 January 


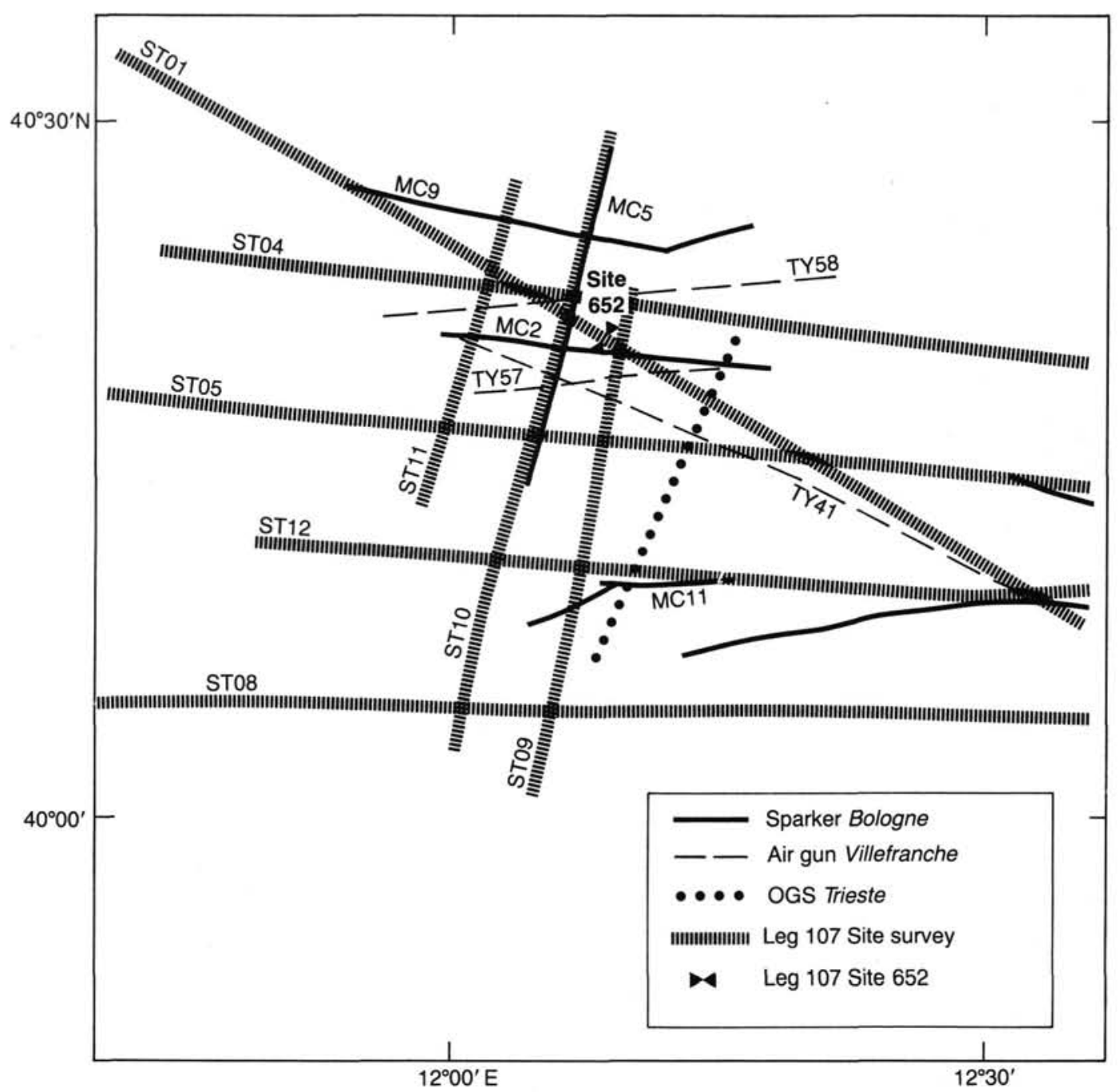

Figure 8. Site 652 location and seismic lines in the vicinity of the site. Most of the seismic data are single channel lines, with the exception of the Leg 107 site survey data collected in 1985.

agreed with the GPS rather than the Loran positions, so the turn to begin the survey was made on the GPS position.

At 0021 on 18 January the ship slowed to $6 \mathrm{kt}$ and changed course to $303^{\circ}$. Two Bolt 80 in. ${ }^{3}$ water guns and a $500-\mathrm{m}$ Teledyne streamer were deployed beginning at 0028 . Processing, filtering, and recording techniques for seismic data are described in the "Underway Geophysics" section, this chapter. Bathymetric data were also collected at 12 and $3.5 \mathrm{kHz}$ during the approach.

Soon after the turn the discrepancy between the Loran and GPS fixes increased to up to $5 \mathrm{nmi}$ and it was noted that the Loran $\mathrm{C}$ warning lights for cycle skip were lit for both master/slave pairs. There were no more usable Loran data from that time until approximately an hour after the beacon drop. Until the end of the night GPS window (at 0140), the ship was navigated using GPS; transit satellites at 0122 and 0132 plus the crossing of de Marchi Seamount at the appropriate time confirmed the GPS position. The ship then continued on the same heading at the same speed, navigating by dead reckoning. At 0240 the ship crossed the target site. Agreement between the site survey and Resolution data was excellent on both seismic and $3.5 \mathrm{kHz}$ profiles. The dead-reckoned Resolution position agreed well with the site survey position.
The ship continued west-northwest for 4 more miles to verify the agreement between site survey and Resolution data. At 0317 a Williamson turn to heading $116^{\circ}$ was initiated. As the turn was completed an unpredicted transit satellite fix arrived (time 0318 , elevation $66^{\circ}$ ) which showed the ship to be north of the desired track. As the ship ran east-southeast, it quickly became obvious that both the bathymetry and the sub-bottom geology differed drastically from those on either the site survey profile or the Resolution west-northwest-bound track. The beacon drop was therefore deferred to a third pass over the site. This decision was confirmed by transit satellite fixes at 0420 and 0506 which both showed the ship even farther north than the dead-reckoned position. Motivated by the 0507 satellite fix, the ship changed course to $130^{\circ}$ at 0439 to steer back down to the desired track. The east-southeast pass was prolonged until $12^{\circ} 20^{\prime} \mathrm{E}$ because the satellite alerts predicted that this strategy would give us two satellites with good elevations on the west-northwest beacondropping pass.

A Williamson turn back to course $300^{\circ}$ was initiated at 0621 . A transit satellite fix at 0657 confirmed our position on the desired line. However, when we crossed the northern edge of de Marchi seamount at 0707 , the water depth was $50 \mathrm{~m}$ deeper than on our first pass, suggesting we were $0.5 \mathrm{mi}$ north of our 
first track. Consequently, the ship altered course to $298^{\circ}$ at 0710 . As the target site was approached, both the bathymetry and the seismic data agreed with the site survey data, and the decision to drop on this pass was reconfirmed. The beacon was dropped at 0820 on 18 January at a dead-reckoned position of $40^{\circ} 21.01^{\prime} \mathrm{N}$, $12^{\circ} 08.86^{\prime} \mathrm{E}$

The ship continued with the same heading and speed while waiting for a satellite fix scheduled for 0837 to tie the end of the dead reckoned track. This fix did not come in, so the seismic gear was pulled and the ship reversed course to return to the beacon. With the ship in dynamic positioning mode over the beacon, the water depth was found to be $70 \mathrm{~m}$ deeper than at the crest of the small knoll east of the site (as opposed to $72 \mathrm{~m}$ on the site survey profile). This difference was judged to be less than the measurement error, and the decision was made to drill at the beacon.

The average position of GPS and transit satellite fixes received while on station gave a final position of $40^{\circ} 21.30^{\prime} \mathrm{N}$, $12^{\circ} 08.59^{\prime} \mathrm{E}$. The Loran position determined from the $\mathrm{X}$ and $\mathrm{Z}$ slaves was $40^{\circ} 21.19^{\prime} \mathrm{N}, 12^{\circ} 08.40^{\prime} \mathrm{E}$. Loran time delays were as follows: X, 13127; Z, 13127. The Loran signal from the Y slave was unusable.

\section{Coring}

A conventional rotary (RCB) coring system bottom hole assembly was run with a long tooth core bit. The precision depth recorder (PDR) depth at the site was $3457 \mathrm{~m}$ (corrected) but side echoes suggested that spud depth might be deeper. This proved to be the case when a water core was taken at a depth close to $3457 \mathrm{~m}$. Actual bottom was located at $3470.5 \mathrm{~m}$ with a mud-line punch core.

Routine RCB cores in muds and oozes continued from the mud line down to core $24 \mathrm{R}$ at 228 mbsf (Table 1). At the Miocene/Pliocene boundary, recovery dropped markedly, from $64 \%$ in the calcareous muds and marly nannofossil oozes of lithostratigraphic Units I and II, to $38 \%$ in the gypsiferous sandy silts and calcareous clays and muds of lithostratigraphic Unit IV. The change in recovery corresponds to an abrupt downsection decrease in carbonate content from greater than $50 \%$ to less than $30 \%$; perhaps the higher carbonate content makes the core sticky enough to avoid falling out of the liner.

Successful heat flow runs were made at $36,75,113,151$, and 190 mbsf. While recovering the heat flow probe following Core 107-652A-24R, the sand line parted at the crown sheave. Fortunately, the lower portion of the line tangled itself into a knot faster than the weight could pull it downhole and the heat flow tool was left suspended about $1000 \mathrm{~m}$ off bottom. The line and heat flow tool were painstakingly recovered. Approximately $7 \mathrm{hr}$ were lost in this maneuver, but the potentially much more devastating loss of the hole was avoided. The batteries in the heat flow probe were dead on arrival; since the Uyeda probe holds data in volatile memory, thermistor data from this lowering were lost.

Routine RCB coring continued in stiff mud and mudstone. While drilling Core 107-652A-35R, four distinct changes of formation were noted: the first $3 \mathrm{~m}$ drilled similarly to the previous several cores; the next $3 \mathrm{~m}$ dropped down almost instantly; the next meter was hard and slow to drill and caused considerable torquing of the drill string; and the final $2 \mathrm{~m}$ were hard but did not cause torquing. Recovery in this core was only $0.8 \mathrm{~m}$; the material resembled the overlying cores and probably came from the upper $3 \mathrm{~m}$ of the cored interval. Core 107-652A-36R was hard and slow to drill ( $64 \mathrm{~min}$ ) but did not cause torquing. Recovery in Core 107-652A-36R consisted of 14 rounded pebbles in the core catcher. Considerable geological significance has been read into these 14 pebbles (see "Lithostratigraphy" and "Discussion and Conclusions" sections, this chapter), so it is inter-
Table 1. Coring summary for Site 652.

\begin{tabular}{|c|c|c|c|c|c|c|}
\hline $\begin{array}{l}\text { Core } \\
\text { no. }\end{array}$ & $\begin{array}{c}\text { Date } \\
(\operatorname{Jan} .1986)\end{array}$ & Time & $\begin{array}{l}\text { Sub-bottom } \\
\text { depths } \\
\text { (m) }\end{array}$ & $\begin{array}{l}\text { Length } \\
\text { cored } \\
\text { (m) }\end{array}$ & $\begin{array}{l}\text { Length } \\
\text { recovered } \\
\text { (m) }\end{array}$ & $\begin{array}{c}\text { Recovery } \\
(\%)\end{array}$ \\
\hline $1 \mathrm{R}$ & 18 & 1930 & $0.0-3.6$ & 3.6 & 3.6 & 99.4 \\
\hline $2 \mathrm{R}$ & 18 & 2100 & $3.6-17.0$ & 13.4 & 5.2 & 38.6 \\
\hline $3 R$ & 18 & 2230 & $17.0-26.7$ & 9.7 & 1.8 & 18.5 \\
\hline $4 \mathrm{R}$ & 19 & 0015 & $26.7-36.4$ & 9.7 & 9.6 & 98.9 \\
\hline $5 R$ & 19 & 0345 & $36.4-45.8$ & 9.4 & 0.4 & 4.6 \\
\hline $6 \mathrm{R}$ & 19 & 0515 & $45.8-55.4$ & 9.6 & 2.0 & 20.9 \\
\hline $7 \mathrm{R}$ & 19 & 0700 & $55.4-64.9$ & 9.5 & 5.3 & 55.4 \\
\hline $8 \mathrm{R}$ & 19 & 0830 & $64.9-74.5$ & 9.6 & 2.6 & 27.1 \\
\hline $9 \mathrm{R}$ & 19 & 1130 & $74.5-84.2$ & 9.7 & 3.3 & 34.2 \\
\hline $10 \mathrm{R}$ & 19 & 1315 & $84.2-93.8$ & 9.6 & 9.7 & 101.5 \\
\hline $11 \mathrm{R}$ & 19 & 1500 & $93.8-103.0$ & 9.2 & 8.1 & 88.0 \\
\hline $12 \mathrm{R}$ & 19 & 1630 & $103.0-112.7$ & 9.7 & 8.4 & 86.8 \\
\hline $13 R$ & 19 & 2015 & $112.7-122.3$ & 9.6 & 5.3 & 54.7 \\
\hline $14 R$ & 19 & 2200 & $122.3-131.9$ & 9.6 & 5.8 & 60.6 \\
\hline $15 \mathrm{R}$ & 19 & 2315 & $131.9-141.5$ & 9.6 & 8.7 & 90.3 \\
\hline $16 R$ & 20 & 0130 & $141.5-151.2$ & 9.7 & 7.6 & 78.4 \\
\hline $17 \mathrm{R}$ & 20 & 0500 & $151.2-160.8$ & 9.6 & 8.9 & 92.3 \\
\hline $18 \mathrm{R}$ & 20 & 0630 & $160.8-170.5$ & 9.7 & 9.1 & 93.5 \\
\hline $19 \mathrm{R}$ & 20 & 0815 & $170.5-180.2$ & 9.7 & 9.0 & 92.6 \\
\hline $20 \mathrm{R}$ & 20 & 0945 & $180.2-189.8$ & 9.6 & 9.1 & 94.7 \\
\hline $21 R$ & 20 & 1315 & $189.8-199.7$ & 9.9 & 4.5 & 45.1 \\
\hline $22 \mathrm{R}$ & 20 & 1445 & $199.7-209.1$ & 9.4 & 2.4 & 25.4 \\
\hline $23 R$ & 20 & 1630 & $209.1-218.7$ & 9.6 & 2.6 & 26.6 \\
\hline $24 R$ & 20 & 1815 & $218.7-228.4$ & 9.7 & 6.0 & 62.0 \\
\hline $25 R$ & 21 & 0515 & $228.4-238.1$ & 9.7 & 3.4 & 34.5 \\
\hline 26R & 21 & 0715 & $238.1-247.7$ & 9.6 & 3.1 & 32.3 \\
\hline $27 R$ & 21 & 0900 & $247.7-257.4$ & 9.7 & 3.6 & 37.4 \\
\hline $28 \mathrm{R}$ & 21 & 1045 & $257.4-267.1$ & 9.7 & 3.0 & 30.4 \\
\hline $29 \mathrm{R}$ & 21 & 1245 & $267.1-276.7$ & 9.6 & 3.0 & 31.4 \\
\hline $30 \mathrm{R}$ & 21 & 1500 & $276.7-286.3$ & 9.6 & 4.0 & 41.3 \\
\hline $31 R$ & 21 & 1715 & $286.3-295.9$ & 9.6 & 4.3 & 44.6 \\
\hline $32 \mathrm{R}$ & 21 & 1930 & $295.9-305.6$ & 9.7 & 4.6 & 47.0 \\
\hline $33 R$ & 21 & 2130 & $305.6-315.3$ & 9.7 & 4.6 & 47.4 \\
\hline $34 \mathrm{R}$ & 21 & 2330 & $315.3-325.0$ & 9.7 & 4.0 & 40.9 \\
\hline $35 \mathrm{R}$ & 22 & 0130 & $325.0-334.7$ & 9.7 & 0.8 & 8.3 \\
\hline 36R & 22 & 0400 & $334.7-344.3$ & 9.6 & 0.1 & 1.0 \\
\hline $37 R$ & 22 & 0600 & $344.3-354.0$ & 9.7 & 7.7 & 79.3 \\
\hline $38 \mathrm{R}$ & 22 & 0815 & $354.0-363.7$ & 9.7 & 8.3 & 85.6 \\
\hline $39 R$ & 22 & 1030 & $363.7-373.4$ & 9.7 & 9.4 & 96.9 \\
\hline $40 \mathrm{R}$ & 22 & 1245 & $373.4-383.0$ & 9.6 & 9.5 & 99.1 \\
\hline $41 R$ & 22 & 1515 & $383.0-392.7$ & 9.7 & 8.7 & 89.8 \\
\hline $42 R$ & 22 & 1730 & $392.7-402.4$ & 9.7 & 8.3 & 85.4 \\
\hline $43 R$ & 22 & 2000 & $402.4-412.1$ & 9.7 & 9.7 & 100.4 \\
\hline $44 R$ & 22 & 2200 & $412.1-421.8$ & 9.7 & 4.0 & 41.4 \\
\hline $45 R$ & 23 & 0000 & $421.8-431.5$ & 9.7 & 5.7 & 59.0 \\
\hline $46 R$ & 23 & 0230 & $431.5-441.1$ & 9.6 & 4.4 & 45.8 \\
\hline $47 R$ & 23 & 0430 & $441.1-450.7$ & 9.6 & 6.5 & 67.7 \\
\hline $48 \mathrm{R}$ & 23 & 0630 & $450.7-460.3$ & 9.6 & 5.6 & 58.3 \\
\hline $49 R$ & 23 & 0830 & $460.3-470.0$ & 9.7 & 2.7 & 27.6 \\
\hline $50 \mathrm{R}$ & 23 & 1045 & $470.0-479.6$ & 9.6 & 3.9 & 41.0 \\
\hline SIR & 23 & 1330 & $479.6-489.2$ & 9.6 & 8.3 & 86.0 \\
\hline $52 \mathrm{R}$ & 23 & 1600 & $489.2-498.8$ & 9.6 & 7.1 & 73.8 \\
\hline $53 \mathrm{R}$ & 23 & 1915 & $498.8-508.5$ & 9.7 & 8.6 & 89.1 \\
\hline $54 \mathrm{R}$ & 23 & 2300 & $508.5-518.1$ & 9.6 & 7.9 & 82.5 \\
\hline $55 \mathrm{R}$ & 24 & 0300 & $518.1-527.8$ & 9.7 & 8.0 & 82.1 \\
\hline $56 \mathrm{R}$ & 24 & 0700 & $527.8-537.4$ & 9.6 & 9.2 & 95.8 \\
\hline $57 R$ & 24 & 1030 & $537.4-546.6$ & 9.2 & 5.7 & 61.7 \\
\hline $58 \mathrm{R}$ & 24 & 1330 & $546.6-556.3$ & 9.7 & 8.1 & 83.9 \\
\hline $59 \mathrm{R}$ & 24 & 1715 & $556.3-566.0$ & 9.7 & 5.7 & 58.8 \\
\hline $60 \mathrm{R}$ & 24 & 2115 & $566.0-575.6$ & 9.6 & 7.9 & 81.9 \\
\hline $61 R$ & 25 & 0000 & $575.6-585.2$ & 9.6 & 7.9 & 82.6 \\
\hline $62 \mathrm{R}$ & 25 & 0315 & $585.2-594.9$ & 9.7 & 7.7 & 79.0 \\
\hline $63 R$ & 25 & 0645 & $594.9-604.5$ & 9.6 & 4.5 & 46.6 \\
\hline $64 R$ & 25 & 1000 & $604.5-614.2$ & 9.7 & 4.2 & 43.6 \\
\hline $65 R$ & 25 & 1245 & $614.2-624.5$ & 10.3 & 9.3 & 89.8 \\
\hline $66 \mathrm{R}$ & 25 & 1530 & $624.5-634.2$ & 9.7 & 5.2 & 54.0 \\
\hline $67 R$ & 25 & 1900 & $634.2-643.8$ & 9.6 & 8.0 & 83.1 \\
\hline $68 \mathrm{R}$ & 25 & 2245 & $643.8-653.4$ & 9.6 & 9.4 & 97.7 \\
\hline $69 \mathrm{R}$ & 26 & 0200 & $653.4-663.1$ & 9.7 & 6.9 & 71.0 \\
\hline $70 \mathrm{R}$ & 26 & 0500 & $663.1-672.8$ & 9.7 & 6.4 & 66.2 \\
\hline $71 \mathrm{R}$ & 26 & 0830 & $672.8-682.5$ & 9.7 & 3.5 & 35.7 \\
\hline $72 R$ & 26 & 1115 & $682.5-692.2$ & 9.7 & 2.9 & 30.3 \\
\hline $73 R$ & 26 & 1430 & $692.2-701.9$ & 9.7 & 4.3 & 44.5 \\
\hline $74 R$ & 26 & 2000 & $701.9-710.5$ & 8.6 & 8.1 & 94.5 \\
\hline $75 \mathrm{R}$ & 27 & 0130 & $710.5-721.1$ & 10.6 & 9.0 & 84.9 \\
\hline
\end{tabular}


esting to note that drilling characteristics of Cores 107-652A$35 R$ and $-36 R$ suggest that the pebble horizon and associated unusual lithologies may be as thick as $15 \mathrm{~m}$.

Below the pebble horizon, in the gypsum-bearing clay and silt sequence of lithostratigraphic Unit Va, recovery improved to $71 \%$. Core disturbance was minimal, especially for rotary coring, with fine laminae, microfaults, and slump structures beautifully preserved. As Core 107-652A-37R came on deck, the seagoing tug Jumbo Primo arrived from Naples with mail and a variety of other supplies and materials which had not reached the vessel in Malaga. Later that same day, a film crew from Dutch National Television arrived by helicopter; they stayed aboard the vessel for 3 days filming routine shipboard activities.

Starting with Core $107-652 \mathrm{~A}-52 \mathrm{R}$ at $500 \mathrm{mbsf}$, the rate of penetration dropped from $16 \mathrm{~m} / \mathrm{hr}$ to $9 \mathrm{~m} / \mathrm{hr}$ to less than $5 \mathrm{~m} /$ $\mathrm{hr}$ in the space of four cores. The cores themselves did not give evidence of a change in lithology to account for this apparent resistance to penetration; bit problems were suspected although no abnormal signs of torque, cone wobble, or other normal signs of bit wear were detected. The rate of penetration slowed still further at the contact between the siltstones and mudstones of lithostratigraphic Unit Va and the indurated siltstones and sandstones of Unit Vb (683 mbsf). Cores 107-652A-74R and $-75 \mathrm{R}$ required more than $3 \mathrm{hr}$ apiece to cut. The core diameter during the previous $24 \mathrm{hr}$ of coring had decreased from $2-3 / 8^{\prime \prime}$ ' to $2-1 / 8^{\prime \prime}$ suggesting that the bit cones were beginning their terminal wobble. According to any reasonable interpretation of the seismic stratigraphy, the pre-rift/syn-rift contact at $730 \mathrm{~ms}$ subbottom had been penetrated by this time. Although deeper penetration would have been laboriously achievable, the next anticipated lithologic change (an internal reflector within the pre-rift sequence) would have been days away at the rate of penetration experienced on the previous two cores. This goal was not considered worth the time, and the hole was terminated at $721 \mathrm{mbsf}$. Despite the poor rate of penetration, the overall recovery for the hole was very impressive for RCB coring.

\section{Logging}

The hole was cleaned with a $20 \mathrm{bbl}$ high viscosity mud sweep and left full of sea water. The bit was released successfully, and the pipe was pulled to the logging depth of $100 \mathrm{mbsf}$ (with pipe down). The first suite of logs comprised the dual induction log (DIL), long spacing sonic (LSS), gamma ray (GR), and caliper (CALI). This string passed easily through the Pliocene-Pleistocene section, but the pre-Pliocene section of the hole was very irregular, with diameter variations from less than 5 to greater than 13 in. over a few meters. The tools stopped completely at a bridge at $367 \mathrm{mbsf}$, and the hole was logged up from there.

A second suite of logging tools (gamma spectroscopy tool, compensated neutron tool, and natural gamma tool: GST-CNTNGT) was made up and run in the hole. This suite was all 3-5/8in. diameter tools with no caliper or centralizer springs. In spite of this, the second run was stopped at an impassable bridge at $268 \mathrm{mbsf}$ and was forced to $\log$ up from there.

The pipe was then run to bottom without rotation or circulation. A weak bridge was knocked out at $365 \mathrm{mbsf}$, and the remainder of the hole was found to be open. Seawater was circulated for $30 \mathrm{~min}$, and the pipe was pulled to $259 \mathrm{mbsf}$ for a third logging run to try to gain access to the lower portion of the hole. The third logging run again consisted of the GST-CNTNGT combination and again stopped at a bridge, this time at 369 mbsf. The interval from there to the bottom of the pipe was logged and the tool was retrieved, ending the logging exercises for the site.

Although it was frustrating not to be able to log the bottom of the hole, the logged interval did include both the Miocene/ Pliocene boundary and the intra-Messinian pebble horizon. The impenetrable bridge encountered at about 370 mbsf on logging runs 1 and 3 as well as on the wiper trip is near the top of lithostratigraphic Unit V, in which calcium sulfate in discrete layers was first encountered. This correlation suggests that the narrowing of the hole may be associated with the volume increase associated with the transformation of anhydrite to gypsum in the presence of water.

The hole was filled with weighted mud and abandoned. The pipe end arrived on deck at 2120 on January 28 as the ship got underway for Site 653 (TYR 2).

\section{LITHOSTRATIGRAPHY}

\section{Lithologic Description}

\section{Introduction}

Sediments recovered at Site 652 are divided into two major categories (Fig. 9): Pliocene/Pleistocene hemipelagic biogenic marine sediments from 0 to 188.2 mbsf (Cores 107-652A-1R to 107-652A-20R-6, $97 \mathrm{~cm}$ ) and pre-Pliocene terrigenous and chemical sediments from 188.6 to 721.1 mbsf (Cores 107-652A-20R-6, $97 \mathrm{~cm}$, to 107-652A-75R); a 40-cm transition zone lies between the two. The Pliocene/Pleistocene sediments are further divided into two units based on their calcium carbonate content, and the pre-Pliocene sediments are also divided into two units based on other lithologic and sedimentologic criteria. Together with the transitional unit, five lithostratigraphic units are described.

\section{Pliocene/Pleistocene}

Unit I: 0-55.4 mbsf (Cores 107-652A-1R through 107-652A$6 \mathrm{R})$. This unit comprises gray calcareous muds and muds. Average carbonate concentration is $22 \%$ ( 27 samples). Volcanic glass is commonly mixed within the sediment as well as pumice. Tephra layers do not occur. Thin sandy levels mainly comprised of foraminifers are frequent. This unit is entirely Pleistocene.

Four distinct sapropel layers were identified: (1) 18.41-18.54 mbsf (Core 107-652A-3R-1, 141-150 cm to 107-652A-3R-2, 0-4 $\mathrm{cm}$ ); (2) 24.14-24.30 mbsf (Core 107-652A-4R-5, 114-130 cm), (3) 24.48-24.83 mbsf (Core 107-652A-4R-5, 148-150 to 107-652A4R-6, 0-33 cm), (4) 46.17-46.32 mbsf (Core 107-652A-6R-1, 37$52 \mathrm{~cm}$ ). See discussion on sapropels below.

Unit II: 55.4-188.2 mbsf (Cores 107-652A-7R to 107-652A20R-6, $50 \mathrm{~cm}$ ). Marly nannofossil oozes, with an average carbonate content of $48 \%$ ( 54 samples), dominate in Unit II. The age is early Pleistocene-Pliocene. Between 64.9 and $112.7 \mathrm{mbsf}$ (Cores 107-652A-8R to $-12 \mathrm{R}$ ) the sediments are foraminiferal, marly nannofossil oozes; they contain abundant volcanic glass $(10 \%-35 \%)$ as minor lithologies. Between 55.4 and 176.5 mbsf (Cores 107-652A-7R to 107-652A-19R-4) the color of the sediment is more or less an olive gray to gray with frequent overprinting by yellowish brown tones. Dark gray layers throughout this interval are graded volcanic ashes, now highly altered. From 176.5 to 180.2 mbsf (Cores 107-652A-19R-5 and -6R), the marly nannofossil oozes are yellowish red and brownish yellow progressing downsection to more intense reds and strong browns directly above the Miocene/Pliocene boundary at $188.2 \mathrm{mbsf}$ (Core $107-652 \mathrm{~A}-20 \mathrm{R}-6,50-51 \mathrm{~cm})$. The boundary was determined by the last appearance of in-situ planktonic foraminifers.

Four sandy mudstone intervals, the thicknesses of which cannot be measured because of fracturing during drilling, occur between 103.0 and 112.7 mbsf (Core 107-652A-12R-1, 38-50 cm, $107-652 \mathrm{~A}-12 \mathrm{R}-3,125-128 \mathrm{~cm},-12 \mathrm{R}-4,90-102 \mathrm{~cm}$ and $-12 \mathrm{R}-4$, $111-119 \mathrm{~cm})$, which corresponds to an interval with a decreased sedimentation rate. Between 116 and $147 \mathrm{mbsf}$, the carbonate content is generally very high, sometimes reaching $60 \%$. The boundary between lower and upper Pliocene is located within this interval at $131.9 \mathrm{mbsf}$, corresponding to the maximum per- 


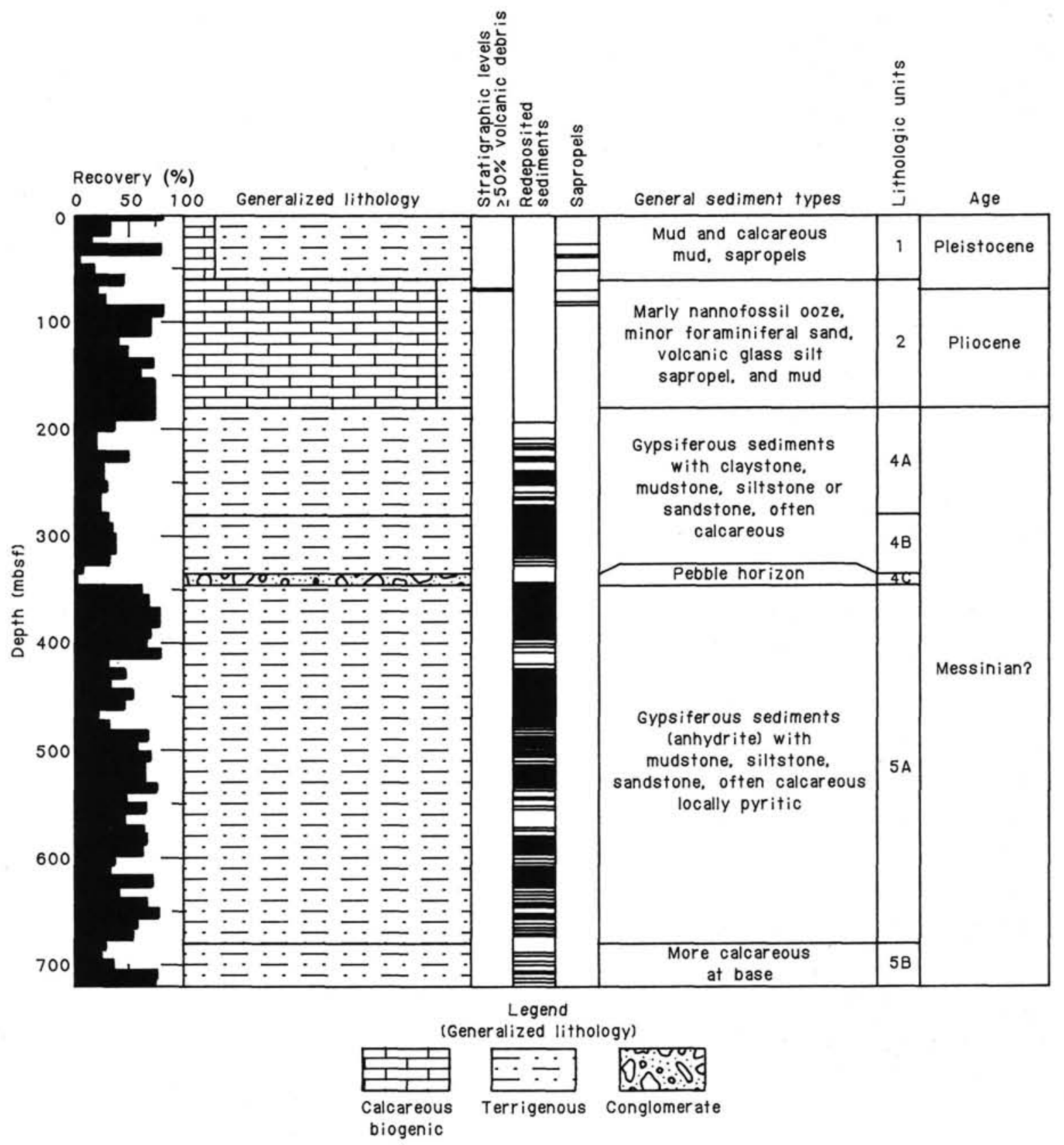

Figure 9. Synthetic lithologic column and drilling recovery at Site 652.

centage of carbonate. However, between 136.8 and $144.6 \mathrm{mbsf}$ (Core 107-652A-15R-4 to 16R-3) there is a brief significant decrease in carbonate content, which is reflected by a decrease in sedimentation rate (see "Biostratigraphy" section, this chapter) but has no visual lithologic expression. Between 141.5 and 151.2 mbsf (Core 107-652A-16R), a temporary downhole lithologic change to nannofossil ooze occurs as well documented by an increased carbonate content within this interval.

Sapropels occur at: (1) 60.10-60.25 mbsf (Core 107-652A7R-4, 20-35 cm), (2) 66.04-66.06 mbsf (Core 107-652A-8R-1, 114-116 cm), (3) 76.36-76.41 mbsf (Core 107-652A-9R-2, 36-41 $\mathrm{cm}$ ) and (4) 76.93-76.99 mbsf (Core 107-652A-9R-2, 93-99 cm). See discussion on sapropels below.

Only the uppermost part of this unit is Pleistocene, the boundary between Pleistocene and Pliocene being situated at about 85 mbsf. There is no obvious lithologic expression of this boundary.

Two occurrences of the characteristic gray clay of the underlying sediments of the uppermost part of Unit IV appear sandwiched between the distinctly colored marly nannofossil oozes of the lowermost part of Unit II at 187.8 mbsf (Core 107-652A20R-6, 0-4 cm) and 187.1 mbsf (Core 107-652A-20R-5, 83-88 cm).

\section{Transitional Zone}

Unit III: 188.2-188.6 mbsf (Core 107-652A-20R-6, 52-92 cm). This $40-\mathrm{cm}$ transitional interval ranges between the occurrence of marine planktonic foraminifers at the top and the Messinian sediments at the base. It is characterized by a succession of from 0.5 - to 4.0 -cm-thick layers of strongly colored clays and muds (Fig. 10). The basal contact is marked by a distinct color 


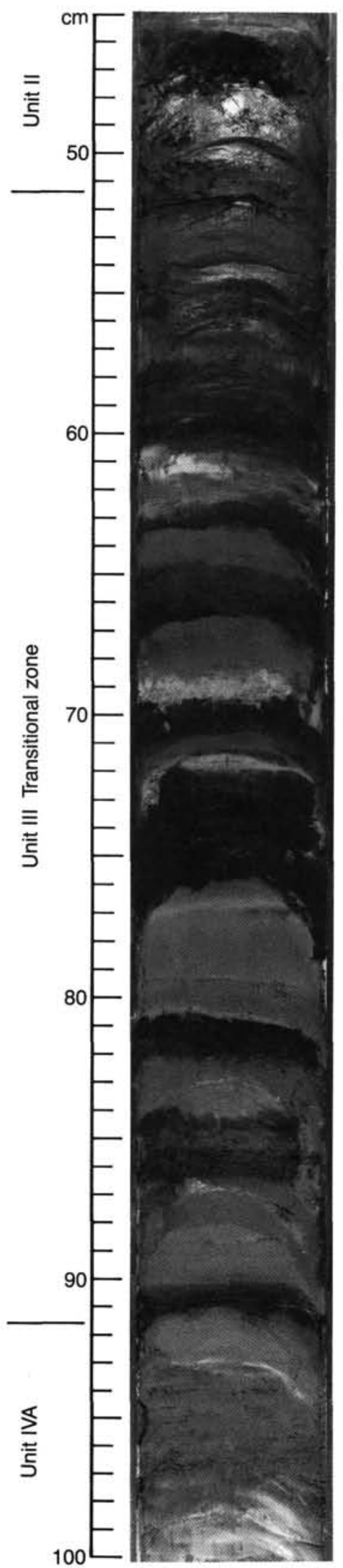

Figure 10. The alternation of distinctly colored layers within the 40-cmthick transitional zone (Unit III) and the contacts with the overlying Pliocene (Unit II) and underlying Messinian (Unit IV) sediments (Core $107-652 \mathrm{~A}-20 \mathrm{R}-6,45-100 \mathrm{~cm}$ ). change with the underlying homogeneous, gray, gypsiferous dolomitic clays, the latter with a carbonate content of $20.1 \%$. Moving down through the transitional interval the dominant colors of the alternating layers change from red and strong brown at the top of the unit to reddish gray becoming light gray and grayish green to gray at the base of the unit. This dramatic color change represents a transition from marine Pliocene to a prePliocene sedimentation environment. The deepest occurrence of rare in-situ nannofossils was observed within the transitional zone at $188.4 \mathrm{mbsf}$ (Core 107-652A-20R-6, $70 \mathrm{~cm}$ ). The calcareous component of the sediments decreases rapidly from about $50 \%$ just above the top of Unit III (e.g. $51.4 \%$ at $187.6 \mathrm{mbsf}$, Core 107-625A-20R-5, 135-138 cm), to the lower values of Unit IV. The red color of the upper part of the transitional interval and the earliest Pliocene sediments is probably produced by the presence of iron oxides. The red color becomes progressively less intense upward, disappearing at $176.5 \mathrm{mbsf}$ (Core 107-652A-19R5) near the top of the MPl1 foraminiferal zone, which was recognized at 180.2 mbsf (Core 107-652A-19R, CC).

\section{Pre-Pliocene}

The pre-Pliocene is represented by a thick nonfossiliferous series. Pre-Pliocene sediments have been subdivided into two units to take into consideration the presence of an important conglomeratic horizon recovered between 334.70 and 344.80 mbsf.

Unit IV: 188.6-344.3 mbsf (Cores 107-652A-20R-6, $92 \mathrm{~cm}$ to $107-652 \mathrm{~A}-36 \mathrm{R}, \mathrm{CC})$. Unit IV is divided into three subunits as follows:

Subunit IVa: 188.6-286.3 mbsf (Cores 107-652A-20R-6, $92 \mathrm{~cm}$ to $107-652 \mathrm{~A}-30 \mathrm{R}, \mathrm{CC})$.

This subunit is characterized by a succession of thinly bedded (often $<25 \mathrm{~cm}$ ), normally graded alternations of gypsumand carbonate-bearing sandy silts or sands and calcareous clays or muds (Fig. 11), which are interpreted as turbidites. All are gray colored. Reworked nannofossils are abundant; gypsum and carbonates are detrital. Zeolites are frequent. Micrometeorites occur in Core 107-652A-28R, CC (see "Biostratigraphy" section, this chapter, and Fig. 22).

Subunit IVb: $286.30-334.70$ mbsf (Cores 107-652A-31R to $-35 \mathrm{R})$. The lithologic components are the same as in the preceding Subunit IVa, but the sedimentary structures differ in that there are reversely graded sequences, frequent waterescape structures, synsedimentary microfaults, and microbreccias. Also, the first occurrence of crystals of authigenic calcium sulfates and the existence of cubic dissolution molds (former halite?) in the coarser intervals were noted in Cores 107-652A-33R to -35R. Examples of these chemical phenomena are illustrated in Fig. 12 (Core 107-652A-35R, 36-50 cm); mudstones with displacive lenticular gypsum crystals directly overlie a sandier interval containing tiny cubic molds. Some sandstone layers are well indurated (Core 107-652A-34R-1).

Subunit IVc: $334.70-344.80$ mbsf (Core 107-652A-36R). The recovery was very poor, consisting of only 14 pebbles in the core catcher. However, downhole logging data suggest that this conglomeratic horizon could be as thick as $14 \mathrm{~m}$ (interval 324-338 mbsf) (see "Downhole Measurements" section, this chapter), and the drilling characteristics for Cores 107$652 \mathrm{~A}-35 \mathrm{R}$ and -36 suggest a zone of unusual lithology as thick as $15 \mathrm{~m}$ (see "Operations" section, this chapter). The pebbles are rounded and smooth, and some appear flattened and elongated. Maximum dimensions are $8 \mathrm{~cm}$, minimum slightly more than $1 \mathrm{~cm}$. Thin-section examination revealed the following lithotypes.

1. Packstone (Pebble no. 5). Rudistidae, green algae, benthic foraminifers (e.g., arenaceous and Miliolidae), bioclasts and biosomata of mollusks in a minor matrix con- 
$\mathrm{cm}$

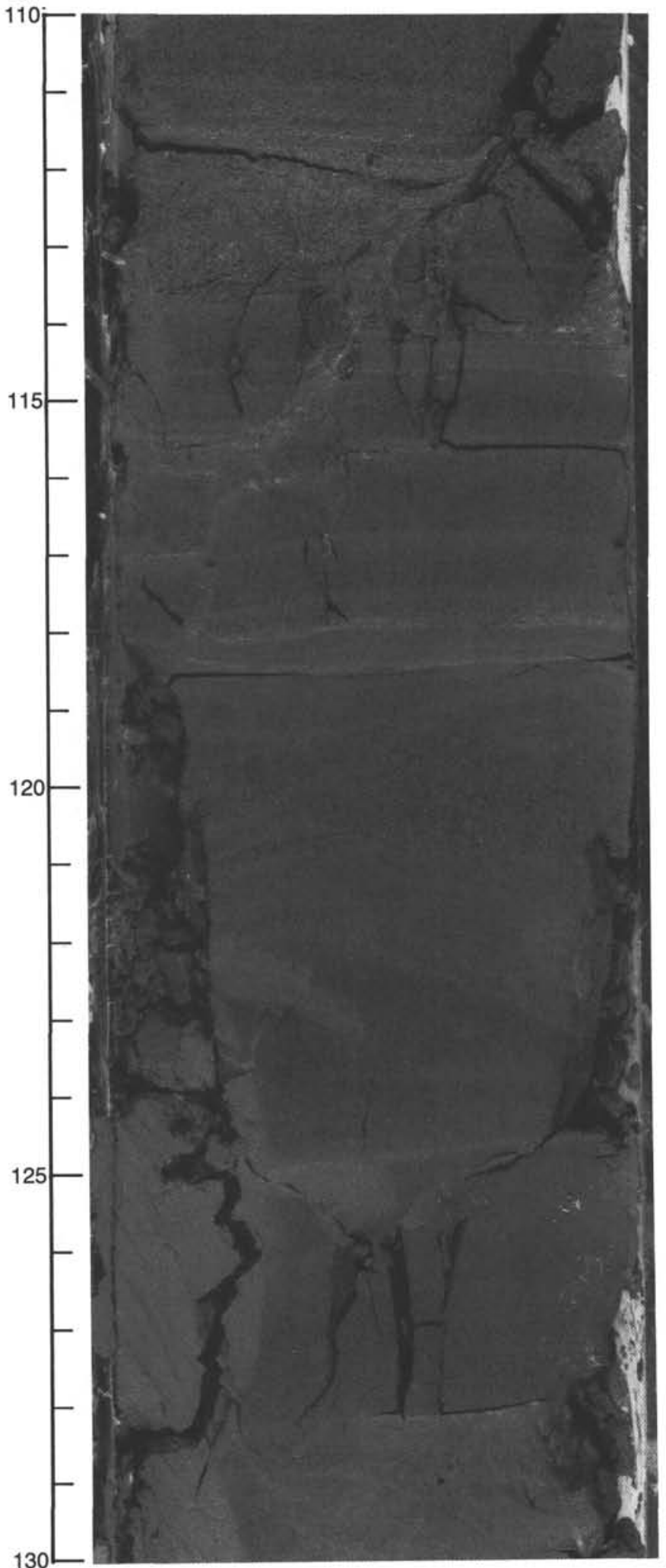

Figure 11. Several intervals of normally graded alternations of gypsumand carbonate-bearing sandy silts and muds are shown. Notable sedimentary features in the core photograph are the sharp basal contacts between the units, the fining upward of grain size within the units, parallel laminations, and a slump structure between 121 and $123 \mathrm{~cm}$. These sediments are interpreted as a turbidite sequence.

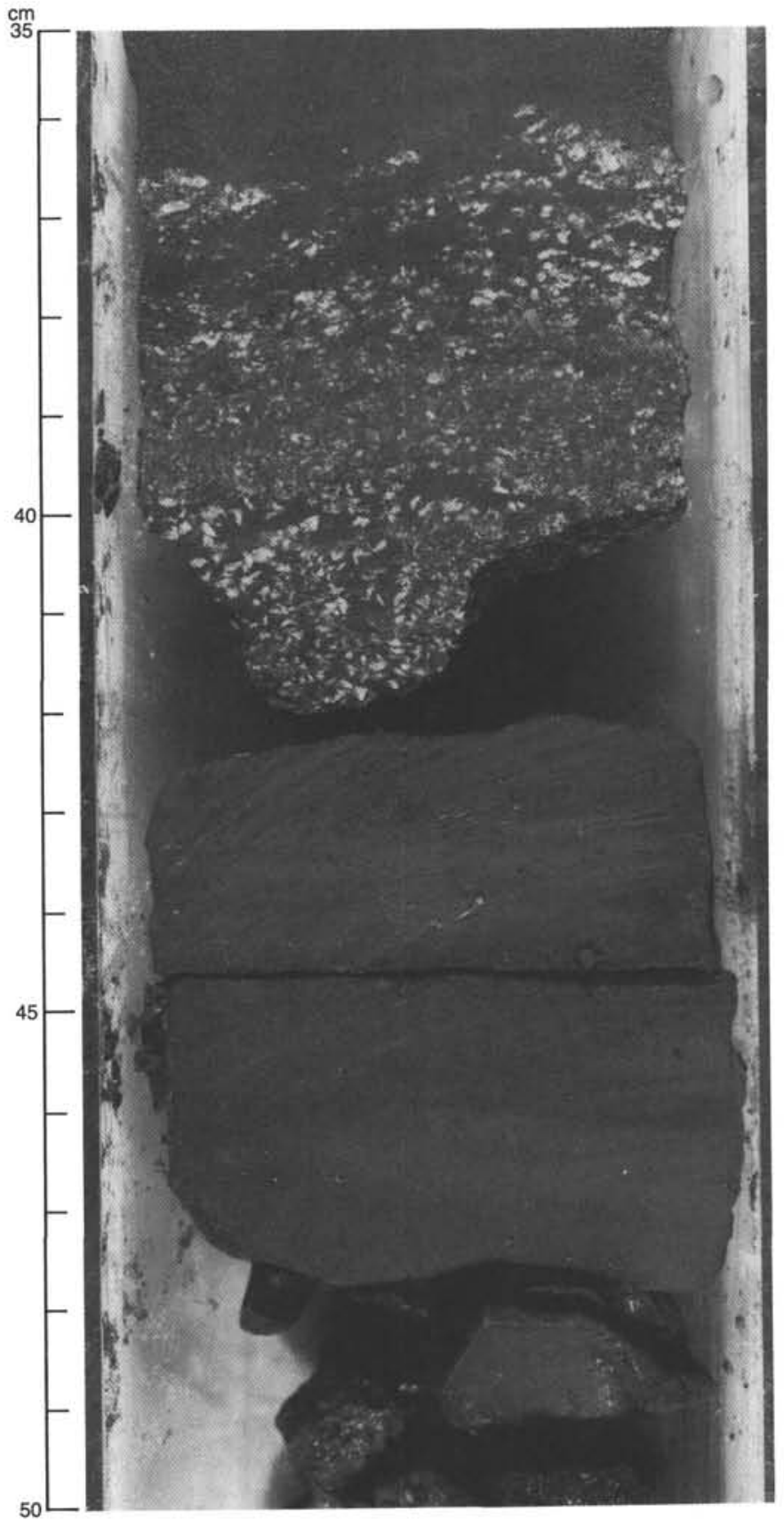

Figure 12. Displacive lenticular crystals of gypsum in a gray mudstone (Core 107-652A-35R-1, 36-42 cm) overlie a sandier mudstone containing numerous tiny cubic molds (formerly halite?) (Core 107-652A-35R$1,42-47 \mathrm{~cm})$

taining angular quartz grains, rare ostracodes, and planktonic foraminifers. Environment: penecontemporaneous debris of rudistid carbonate platform reworked into deeper water facies. Age: Late Cretaceous.

2. Mudstone (Pebble nos. 3,4,6,9,12,14). Biomicrites containing abundant calcitized radiolarians. Some pebbles also contain planktonic foraminifers, including Hedbergellae, while one contains Saccocoma-like remains. Environment: open marine, pelagic. Age: spanning possibly Late Jurassic? to middle Cretaceous.

3. Grainstone (Pebble no. 1). Large benthic foraminifers (Miogypsinids?, Amphisteginidae), bryozoa, red al- 
gae, echinid plates, mollusk fragments, micrite fragments, rare planktonic foraminifers in scarce spar cement. Environment: high-energy, shallow (less than 100-150 m) marine bank. Age: possibly Oligocene-early Miocene.

4. Quartzarenite (Pebble nos. 2, 13). Quartz, often well rounded, dominant, with very rare feldspar and opaque rhombohedral grains in a spar cement.

5. Polymictic sandstone (Pebble nos. 7, 10). The grains, mostly angular, include: metamorphic and igneous quartz, calcite, dolomite, low-grade metamorphic lithic fragments (including carbonaceous phyllites), mafic crystals, feldsparbearing lithic fragments (igneous?), glauconite, very rare bryozoa, mollusk fragments, and benthic foraminifers. Environment: post-orogenic nonmature deposits on continental slope or shelf. Age: a very tentative early-middle Miocene age may be assigned by comparison with surrounding regions (Amodio-Morelli et al., 1976; Grandjacquet and Mascle, 1978).

6. Calcareous phyllites (Pebble no. 11). Very low-grade calcareous metapelites including some ghosts and remains of biogenic origin (one benthic foraminifer and some unidentifiable grains).

Interpretation: Pebble sizes, structures, and textures suggest a nearby source which underwent subaerial erosion during the Messinian. The petrographic nature of the clasts, however, excludes the nearest structural high, de Marchi Seamount, as the only possible source, because different lithotypes crop out there (Colantoni et al., 1981; Gennesseaux et al., 1986). Other Messinian structural highs, presently covered by Pliocene-Pleistocene sediments, might represent the appropriate source area. The suite of rocks indicate a sedimentary cover related to a continental basement which is referable either to the southern Apenninic chain and/or to the Sicily Maghrebid chain. Sardinian, and possibly also Calabrian-Kabilian type basements, can be ruled out as the source area since high-grade metamorphic rocks and true geologic basement were not sampled in the conglomeratic horizon, and the lithologies of the pebbles do not match the sedimentary cover cropping out in these domains.

Unit $V: 344.8-721.1$ mbsf (Cores $37 \mathrm{R}$ to $75 \mathrm{R}$ ). Unit $\mathrm{V}$ is divided into two subunits as follows:

Subunit Va: $344.80-683.5$ mbsf (Cores $37 \mathrm{R}$ to $72 \mathrm{R}-2$ ). This unit is characterized by a monotonous succession of numerous centimeter-thick olive gray to dark gray sequences of wellgraded and cross-bedded gypsum- and carbonate-bearing sand or sandy silt and well-layered clays or muds. In some intervals crystalline anhydrite as thick as $5 \mathrm{~cm}$ has a classic "chicken wire" texture (Fig. 13) between the sequences. Although the anhydrite intervals may represent the deposition of a chemical precipitate in a subaqueous environment, later stage displacive growth of anhydrite nodules in the sediment is documented by the disrupted laminae overlying the nodules (Fig. 13). The frequent coalescing of smaller discrete nodules into continuous layers was noted. Also noted were apparent gypsum layers with a satin-spar texture which have been overgrown by secondary anhydrite nodules. The temperature estimated from the geothermal gradient for the depth $(\sim 400$ mbsf) where the anhydrite occurs is approximately $70^{\circ} \mathrm{C}$ (see "Downhole Measurements" section, this chapter) and the interstitial waters at these depths have salinities more than double that of seawater (see "Geochemistry" section, this chapter). Under these temperature and salinity conditions anhydrite, not gypsum, would be the stable phase of calcium sulfate (Hardie, 1967), which is in agreement with the above observations.

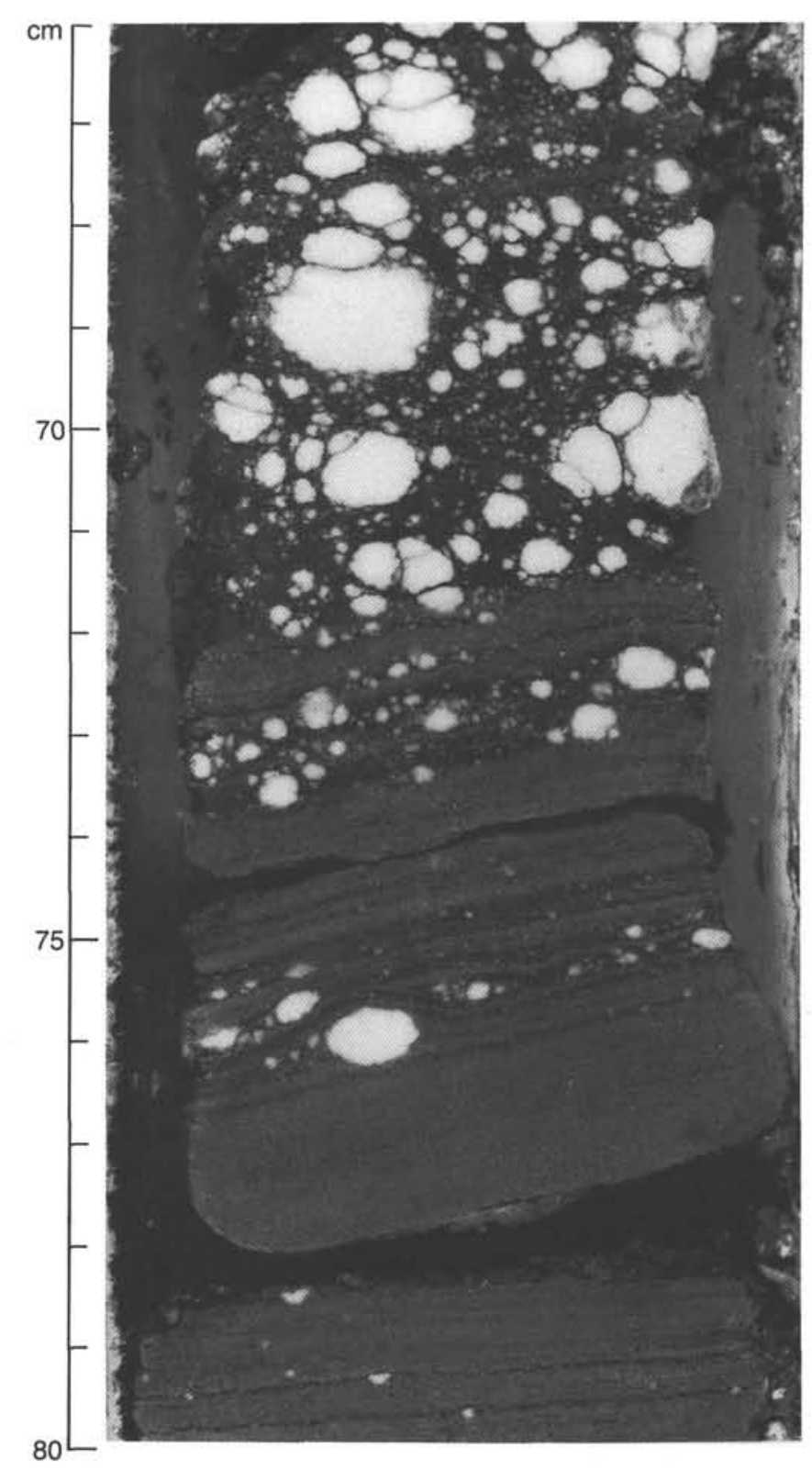

Figure 13. Discrete nodules of white anhydrite have grown displacively in a gray sandy mudstone, in places disrupting the fine laminations of the host sediment (Core 107-652A-44R-3, 66-80 cm).

From the frequency and thickness of the sulfate layers, it is possible to distinguish seven second-order cycles with increasing amount of sulfates toward the top of each cycle. These are in Core 107-652A-37R (344.30-354.0 mbsf), Cores 107-652A-38R to $-43 \mathrm{R}$ (354.0-412.10 mbsf), Core 107-652A44R (412.10-421.80 mbsf), Core 107-652A-47R (441.10-450.70 mbsf), Core 107-652A-54R (508.50-518.10 mbsf), Core 107$652 \mathrm{~A}-60 \mathrm{R}$ to $-62 \mathrm{R}(566.0-594.9 \mathrm{mbsf})$ and Core $107-652 \mathrm{~A}-$ 70R (663.10-672.80 mbsf).

Very thin, millimetric, red and yellow horizons appear in Cores 107-652A-50R to -53R (470.0-497.60 mbsf), $-56 \mathrm{R}$ (527.80-537.40 mbsf), 107-652A-58R and -59R (546.60-566.0 mbsf); they are tentatively attributed to eolian material. Scattered plant debris are present in Cores 107-652A-49R, -50R and -51R (between 460.30 and $489.20 \mathrm{mbsf}$ ). Numerous sam- 
ples from the pre-Pliocene sequence showed a significant amount of organic carbon (i.e., \% $\mathrm{C}_{\text {org }}>0.1 \%$ ) (see "Geochemistry" section, this chapter). Core 107-652A-63R (base) and -64R (between 594.90 and $614.20 \mathrm{mbsf}$ ) show finely-laminated, brownish black organic-carbon-rich clays as much as $11.4 \% \mathrm{C}_{\text {org }}$ ), which have the appearance of "black shales." Within this interval, there are two $(2.5 \mathrm{~cm}$ thick) horizons containing remnants of algae (Fig. 14). The whole formation shows frequent slumps and microfaults (see "Sedimentary Instability" section below).

The rhythmic repetition of numerous centimeter-thick sequences in Subunit Va is tentatively interpreted as reflecting tempestite deposition and bottom current reworking of sediments. The environment was apparently characterized by variable salinity and periods of high productivity, as suggested by the algal blooms.

Subunit $\mathrm{Vb}$ : 683.50-721.10 mbsf (Cores 107-652A-72R-2 to $-75 \mathrm{R})$. The main characteristic of Subunit $\mathrm{Vb}$ is the extreme induration of the sediments and the different composition of the coarse fraction. This subunit comprises alternations of dark grey calcareous siltstones, calcareous sandy siltstones, and calcareous sandstones. Convolute laminations, slumps, and reverse and normal grading are common features. The coarser fraction shows various reworked elements: pelagic micrite, platform carbonates, metamorphic rocks and minerals, quartz with undulating extinction, polycrystalline quartz, feldspar, volcanic rocks, detritic dolomite, calcite, and calcium sulfates, as well as rare planktonic foraminifers, possibly of pre-Miocene age.

\section{Sedimentation Rate}

The sediment depth versus age curve for Site 652 (Fig. 15) was constructed using paleomagnetic and biostratigraphic data. This curve cannot be considered as an accurate graph of sedimentation rate, since no correction has been applied for sediment compaction. Within the Pliocene-Pleistocene section, porosity decreases linearly downsection from about $80 \%$ to about $60 \%$, suggesting that the slope of the age vs. depth curve underestimates the sedimentation rate at the base of the Pliocene by a factor of two relative to the rate at the seafloor. In spite of this, geological significance can still be extracted from this curve; the timing and direction of breaks in slope are inferred to indicate marked changes in sedimentation rate.

Within the Pliocene-Pleistocene sequence two different general trends in the sedimentation rate can be recognized. In the lower Pliocene, about the top of the Kaena (2.92 m.y.), the sedimentation rate averages $10 \mathrm{~mm} / 1000 \mathrm{yr}$. Above the top of Kaena until the base of Olduvai a slight increase is recognized with an average sedimentation rate of $14 \mathrm{~mm} / 1000 \mathrm{yr}$. Above the base of Olduvai the average sedimentation rate is $54 \mathrm{~mm} / 1000 \mathrm{yr}$ partly explained by the amount of coarse-grained volcanic glass and pumice.

\section{Sapropels}

In total, eight sapropel intervals were recognized in Units I and II based on their distinctive very dark gray color and organic-carbon content (Table 2). Each of the recognized sapropels is designated by ST (for Sapropel Tyrrhenian) plus a chronologic number according to their appearance downcore at Site $652 \mathrm{~A}$. The age of each is also roughly estimated based on the paleomagnetic and biostratigraphic criteria; the youngest, ST-1, is late Pleistocene, while the oldest, ST-8, early Pleistocene. As core recovery was not always continuous, sapropels younger than late Pleistocene and possibly in other intervals could well have bee . missed. The preliminary organic carbon content for all of the sapropels, except ST-5, are nearly equal to or greater than $2.0 \%$. Using the definition of Kidd et al. (1978), the studied in-

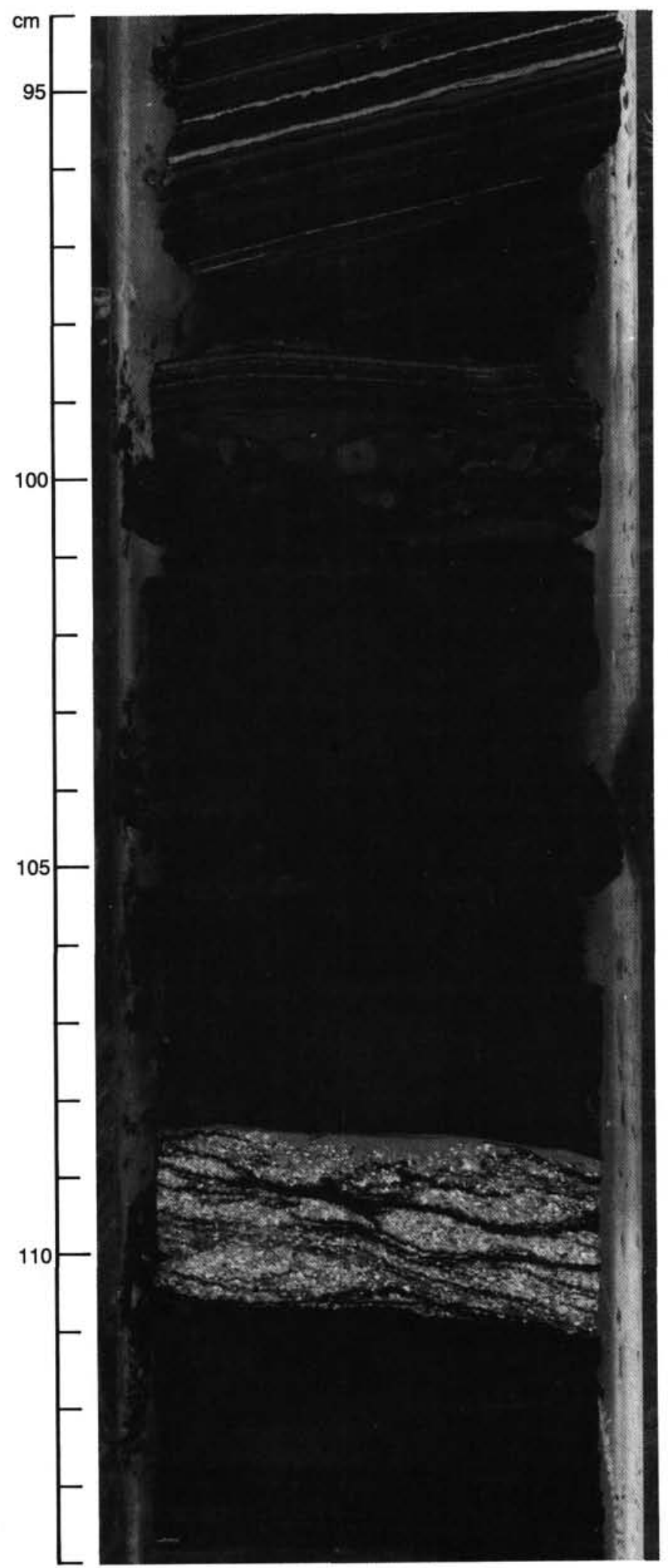

Figure 14. Very finely laminated, brownish black, organic-carbon-rich calcareous mudstones are interbedded with an iridescent, bluish gray sediment composed of algal matter $(108.5-110.5 \mathrm{~cm})$. The interval between 101 and $106 \mathrm{~cm}$ contains a paper-thin black shale with an organic carbon content of $11.4 \%$. See "Geochemistry" section, this chapter, for further discussion. Core 107-652A-64R-1, 94-114 cm. 


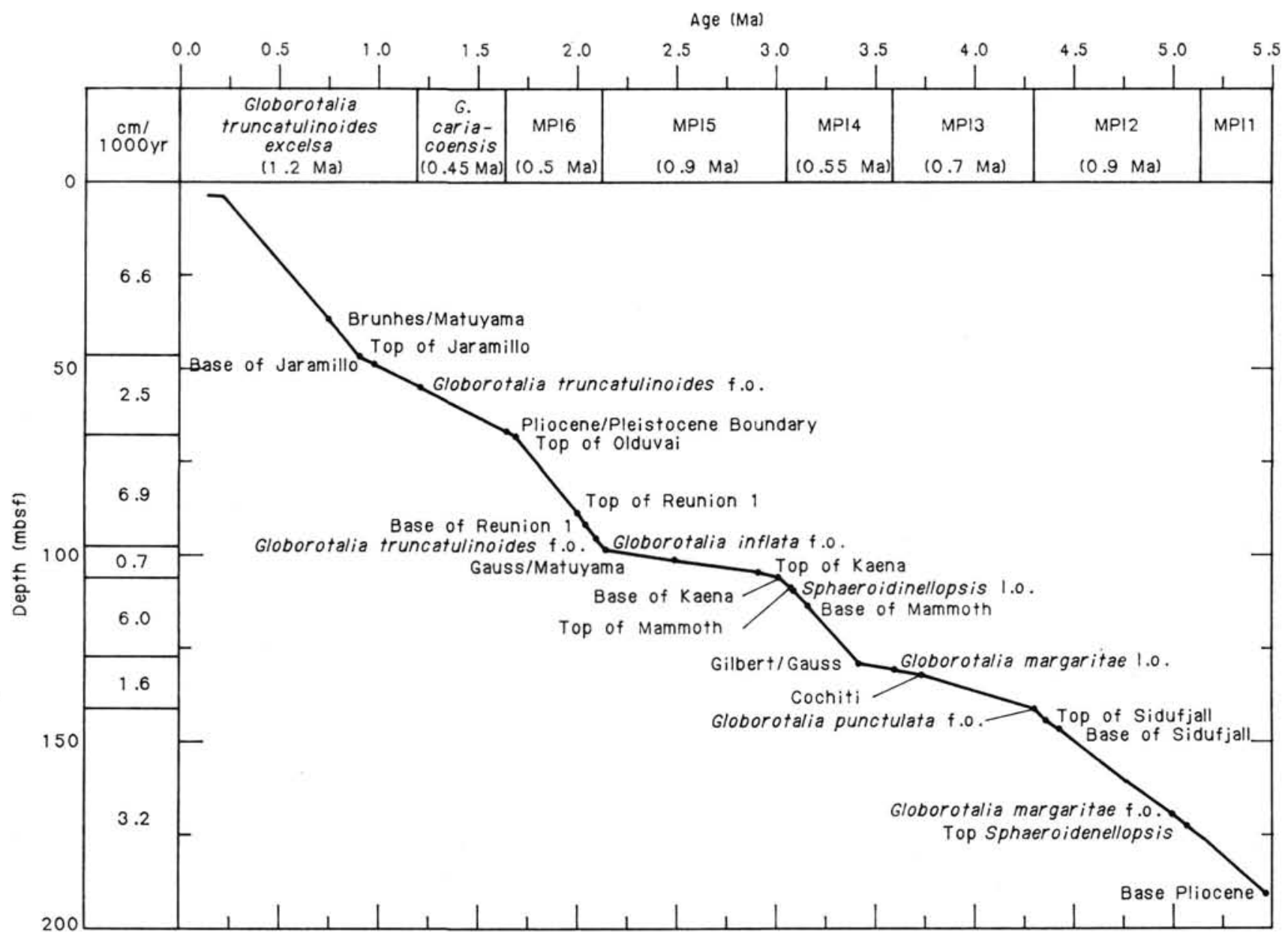

Figure 15. Sediment depth vs. age curve for Site 652 as determined from paleomagnetic and biostratigraphic studies.

Table 2. Sapropels and sapropelic layers for Hole 652A.

\begin{tabular}{|c|c|c|c|c|}
\hline Number $^{\mathrm{a}}$ & $\begin{array}{l}\text { Depth } \\
\text { (mbsf) }\end{array}$ & $\begin{array}{l}\text { Core interval } \\
(\mathrm{cm})^{\mathrm{b}}\end{array}$ & $\mathrm{C}_{\mathrm{org}}$ & $\begin{array}{c}\text { Age } \\
\text { (m.y.b.p.) }\end{array}$ \\
\hline ST-1 & $18.41-18.54$ & $\begin{array}{c}3 \mathrm{R}-1,141-150 \mathrm{~cm} \text { to } \\
3 \mathrm{R}-2,0-4 \mathrm{~cm}\end{array}$ & 1.91 & $\sim 0.3$ \\
\hline ST-2 & $24.14-24.30$ & $4 \mathrm{R}-5,114-130 \mathrm{~cm}$ & 3.36 & $\sim 0.4$ \\
\hline ST-3 & $24.48-24.83$ & $\begin{array}{c}4 \mathrm{R}-5,148-150 \mathrm{~cm} \text { to } \\
4 \mathrm{R}-6,0-33 \mathrm{~cm}\end{array}$ & 2.31 & $\sim 0.4$ \\
\hline ST-4 & $46.17-46.32$ & $6 \mathrm{R}-1,37-52 \mathrm{~cm}$ & $3.50-4.18$ & -0.8 \\
\hline ST-5 & $60.10-60.25$ & $7 \mathrm{R}-4,20-35 \mathrm{~cm}$ & 0.96 & $\sim 1.1$ \\
\hline ST-6 & $66.04-66.06$ & $8 \mathrm{R}-1,114-116 \mathrm{~cm}$ & 3.30 & $\sim 1.2$ \\
\hline ST-7 & $76.36-76.41$ & $9 \mathrm{R}-2,36-41 \mathrm{~cm}$ & 2.77 & -1.4 \\
\hline ST-8 & $76.93-76.96$ & $9 \mathrm{R}-2,93-99 \mathrm{~cm}$ & 3.11 & $\sim 1.4$ \\
\hline
\end{tabular}

a ST = Sapropel Tyrrhenian.

${ }^{b}$ Measured interval of darkest color.

tervals are, indeed, sapropels, exclusive of ST-1 and ST-5 which would be classified as sapropelic layers $(0.5 \%$ to $2.0 \%$ organic carbon).

The discovery of these sapropels is significant in that lower Pleistocene sapropels have not been previously recognized in the western Mediterranean, and no unambiguous sapropels were recovered at DSDP Sites 132 and 373 in the Tyrrhenian Sea (Cita et al., 1973; Kidd et al., 1978). Sapropel development was believed to be basically restricted to the eastern Mediterranean since the termination of the Messinian salinity crisis (Cita and Grignani, 1982; Thunell et al., 1984). Climatically controlled mechanisms were thought to have enhanced vertical stratification of the eastern Mediterranean waters, while inhibiting bottom-water formation. The resulting oxygen-deficient bottom waters would have promoted sapropel formation. In the western Mediterranean on the other hand, active bottom-water was thought to have been sufficient to keep the depths at least moderately well oxygenated. The recognition of lower Pleistocene sapropels at Hole 652A signifies periods of enhanced preservation of organic matter in the central as well as the eastern Mediterranean. This observation adds a new constraint to the hotly debated question of what climatic and oceanographic conditions are necessary for sapropel development.

The best developed of the sapropels (ST-4), which occurred in Unit I at 46.17-46.32 mbsf (Core 107-652A-6R-1, 37-52 cm), illustrates our shipboard observations. Based on our preliminary data, Figure 16 depicts changes in color, percentage carbonate, and percentage organic matter through this interval. The upper and lower boundaries between the dark gray and gray muds are gradational. The upper boundary shows a slight amount of bioturbation. Sedimentary structures in the middle of the sapropel have been disturbed during drilling, but discontinuous parallel laminations can still be distinguished between 44 and $48 \mathrm{~cm}$. Two organic-carbon-rich samples with different colors were analysed from ST-4. It is interesting to note that the gray interval beneath the darker gray has an organic carbon content of $3.50 \%$, a value greater than many eastern Mediterranean sapropels (Cita and Grignani, 1982). The preliminary shipboard organic geochemical data suggest that the organic matter in the gray interval (107-652A-6R-1, 53-55 cm) was of marine origin deposited under oxic conditions. The organic carbon con- 

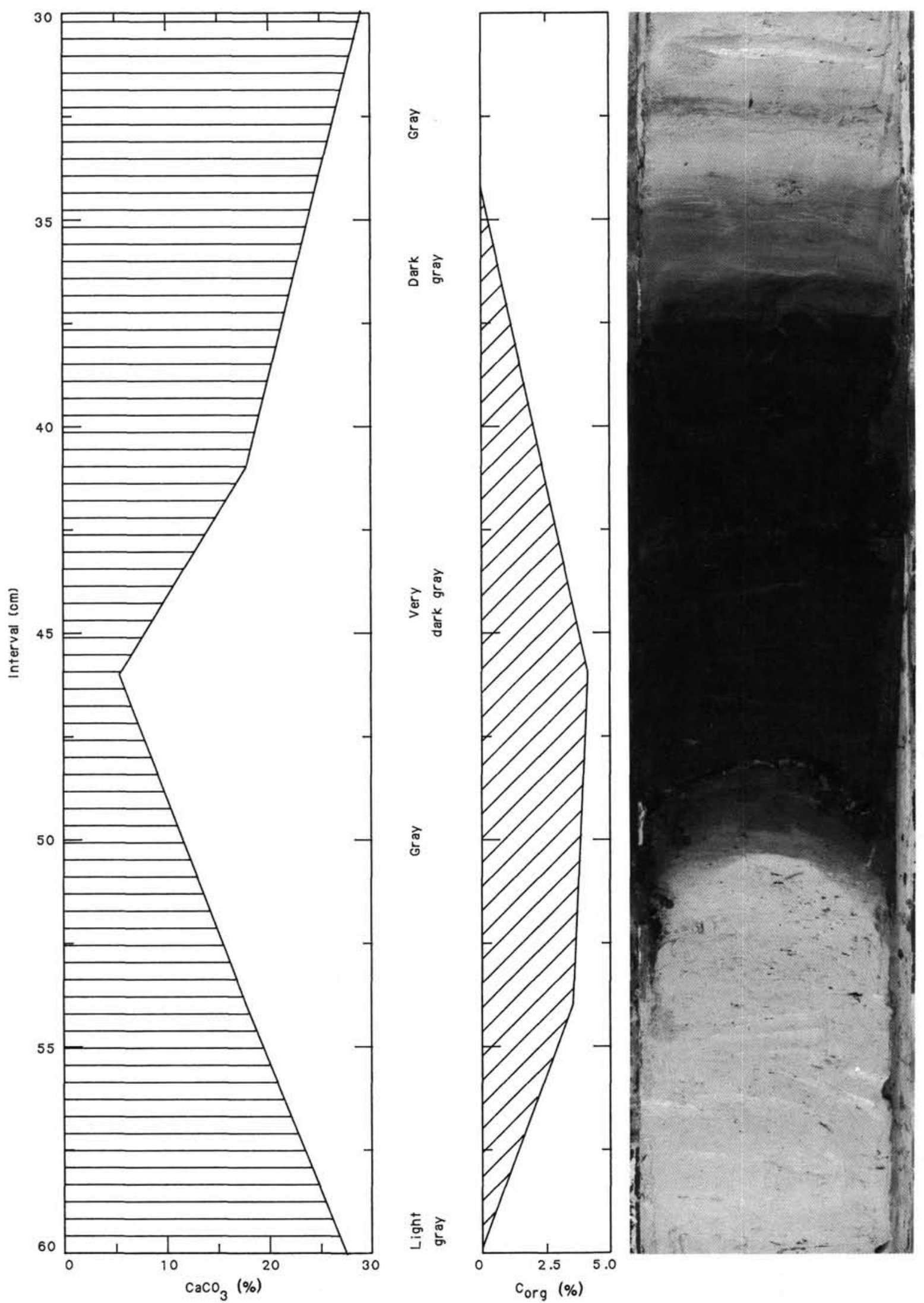

Figure 16. A core photograph of sapropel ST-4 (Core 107-652A-6R-1, 30-60 cm) showing the percentage carbonate, percentage organic carbon, and color changes with depth. Note the diffuse contacts between the lighter and darker boundaries and the apparent burrowing traces in the dark gray zone of the upper boundary. 
tent of the sample from the very dark gray interval (107-652A$6 \mathrm{R}-1,45-47 \mathrm{~cm}$ ) is $4.18 \%$. Geochemical data (see "Geochemistry" section, this chapter) suggest both a marine and continental origin for this organic matter, which was apparently deposited under anoxic conditions. The carbonate content of the darkest interval drops to a value of $5.15 \%$, suggesting either dissolution or decreased carbonate input to the sediment. Above and below this point, the carbonate content of the light gray to gray muds progressively approaches values slightly greater than the average value for Unit I calcareous muds $(22 \%)$. The geochemical and color patterns of individual sapropels in the eastern Mediterranean are generally very characteristic (Sigl and Müller, 1975); further studies will confirm or not if this is also the case for the western Mediterranean sapropels.

\section{Sedimentary Instability}

Excellent examples of all types of the structures considered to be typical of sedimentary instability are observed within the pre-Pliocene formations (Units IV and V). Only one somewhat dubious example was observed in the Pliocene-Pleistocene section, in Core 107-652A-15R-4, 80-95 cm.

Extensional microfaults are numerous and widespread in Cores 107-652A-31R to -34R (286.3-325.0 mbsf), 107-652A-37R (344.3$354.0 \mathrm{mbsf}), 107-652 \mathrm{~A}-47 \mathrm{R}$ to $-54 \mathrm{R}$ (441.1-518.1 mbsf), $107-$ 652A-56R and -57R (527.8-546.6 mbsf), 107-652A-62R to -65R (585.2-624.5 mbsf) and 107-652A-67R (634.2-643.8 mbsf) (Fig. 17). Apparent reverse faults exists in the Cores 107-652A-32R (295.9-305.6 mbsf), 107-652A-54R (508.5-518.1 mbsf), 107652A-57R (537.4-546.6 mbsf), 107-652A-63R (594.9-604.5 mbsf) and $107-652 \mathrm{~A}-65 \mathrm{R}(614.2-624.5 \mathrm{mbsf})$.

Some microtectonic measurements have been performed. In order to avoid faults produced by drilling disturbance, we have chosen only those faults overlain by unfaulted sediments, and we have separated the two fault sides and measured the pitch of slickensides on the frontal plane (Figs. 18 and 19). Measurements have been performed on Cores 107-652A-49R, -54R, -56R, -62R, and $-64 \mathrm{R}$ (Table 3 ).

The different observations indicate that the intersection line between the fault plane and the bedding plane is generally more or less horizontal, demonstrating that the strike of the fault plane is approximately parallel to the strike of the bedding planes. The dip direction of the fault plane is similar to the dip direction of the bedding planes; however, the dip of the fault plane is typically steeper than the dip of the bedding planes. Most microfaults examined show a normal sense of motion. Slickensides on some fault surfaces indicate a slight strike-slip component of motion. If we assume that the regional dip of bedding is to the west or west-northwest, as shown on seismic profiles, the direction of fault planes should be about $\mathrm{N} 0^{\circ}$ to $\mathrm{N} 30^{\circ}$. Using the "diedre droit" method (Angelier and Mechler, 1977), the construction of fault motions indicates a tensional paleostress field oriented $\mathrm{N} 100^{\circ}$ to $\mathrm{N} 130^{\circ}$, with a small strike-slip component (right lateral with respect to the north-south direction and left lateral to the east-west direction).

Slumps are frequent within the Cores 107-652A-34R (315.3$325.0 \mathrm{mbsf}), 107-652 \mathrm{~A}-45 \mathrm{R}$ and $-46 \mathrm{R}$ (421.8-441.1 mbsf), $107-$ $652 \mathrm{~A}-52 \mathrm{R}$ to $-56 \mathrm{R}(489.2-537.4 \mathrm{mbsf}), 107-652 \mathrm{~A}-61 \mathrm{R}$ to $-64 \mathrm{R}$ (575.6-614.2 mbsf) and 107-652A-67R to -68R (634.2-653.4 mbsf). In some cases (107-652A-56R and -57R, 527.8-546.6 mbsf; 107$652 \mathrm{~A}-62 \mathrm{R}, 585.2-594.9 \mathrm{mbsf}$ ) the minerals are reoriented parallel to the flanks of the minor folds; these give way to a well-expressed axial plane cleavage (Fig. 20). This implies that the deformation (i.e., the slump formation) occurred under a rather thick sedimentary load. We also observed minor structures, such as convolutions and breccias, in the same intervals and also in 107-652A-33R (305.6-315.3 mbsf), 107-652A- 51R (479.6 to 489.2 mbsf) and 107-652A-73R and -74R (692.2 to $710.5 \mathrm{mbsf})$.

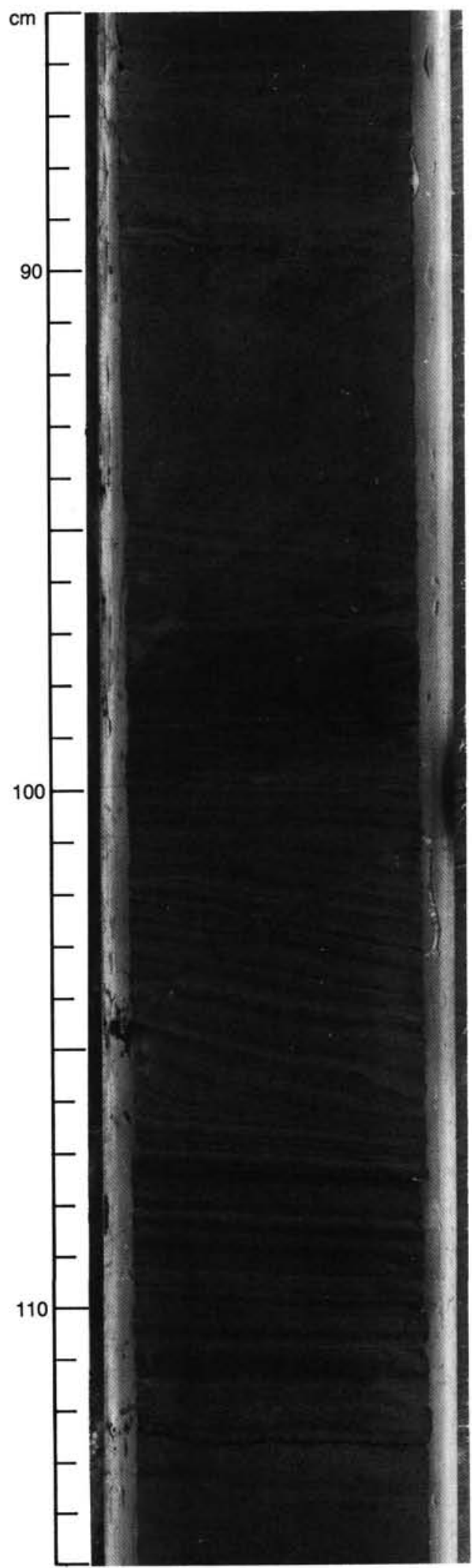

Figure 17. Example of synsedimentary microfaults (Core 107-652A$62 \mathrm{R}-1,85-115 \mathrm{~cm}, 585.2-594.9 \mathrm{mbsf}$ ). Numerous synsedimentary microfaults are present between 95 and $112 \mathrm{~cm}$; between 95 and $99 \mathrm{~cm}$ they are very flat (angle with bedding below $20^{\circ}$ ) and synthetic; below 100 $\mathrm{cm}$ they are steeper and antithetic, two well-expressed planes (at 104-105 $\mathrm{cm}$ ) show a small angle $\left(15^{\circ}\right)$; this "Riedel R" pattern confirms the normal sense of motion also shown by throw. 
A
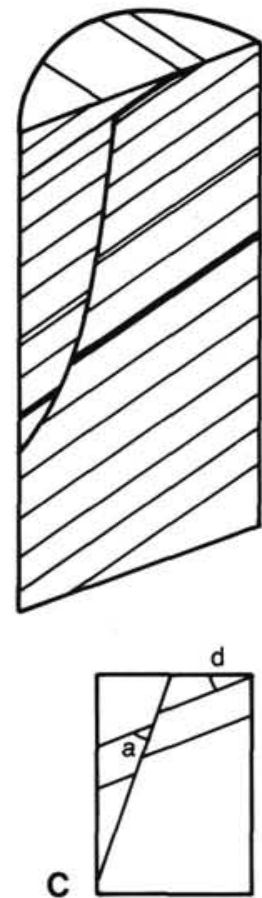
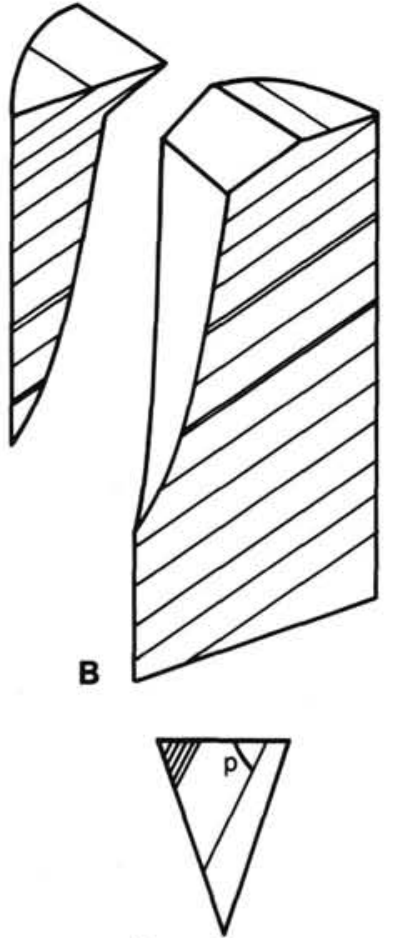

D

Figure 18. Conditions of measurement and definition of measured fault parameters. A. Piece of core before measurement. B. Piece of core after measurement. C. Lateral section: $d=$ dip of bedding, $a=$ angle between bedding and fault plane. D. Frontal view: $p=$ pitch of slickensides.

\section{Conclusions}

The Pliocene-Pleistocene formations are characterized by open marine conditions with a small influx of volcanic material. The change in calcium carbonate concentration from Units I to II is probably due to an increase in allochthonous material during Pleistocene time as there is an increase in the sedimentation rate from about $3.2 \mathrm{~cm} / 1000 \mathrm{yr}$ in Unit II to an average of 6.1 $\mathrm{cm} / 1000 \mathrm{yr}$ in Unit I. The boundary between upper Pliocene and lower Pliocene corresponds to a maximum in the carbonate content of the pelagic sequence. The repeated occurrence of sapropels possibly reflects the recurrence of anoxic conditions during the Pleistocene.

The colorful, iron-oxide-rich sediments in the 40-cm-thick transitional formation indicate a probable strong subaerial weathering of the emerged land during the Messinian drawdown with subsequent erosion into the filling basin.

The pre-Pliocene formations are characterized by periods of variable salinity culminating with the precipitation of evaporites and by possible periods of high productivity, as suggested by the algal blooms and the high organic-carbon content of the anoxic sediments. The pebble horizon may indicate a temporary fluviatile or beach environment. The most probable sedimentary environment for the pre-Pliocene units is a closed lake. The sediments are considered to have been deposited during the Messinian. The sedimentation rate would have been quite high, on the order of $50 \mathrm{~cm} / 1000 \mathrm{yr}$ based on the entire Messinian or 100 $\mathrm{cm} / 1000 \mathrm{yr}$ based only on the evaporitic part of the Messinian. The pre-Pliocene formations are clearly contemporaneous with strong extensional activity.

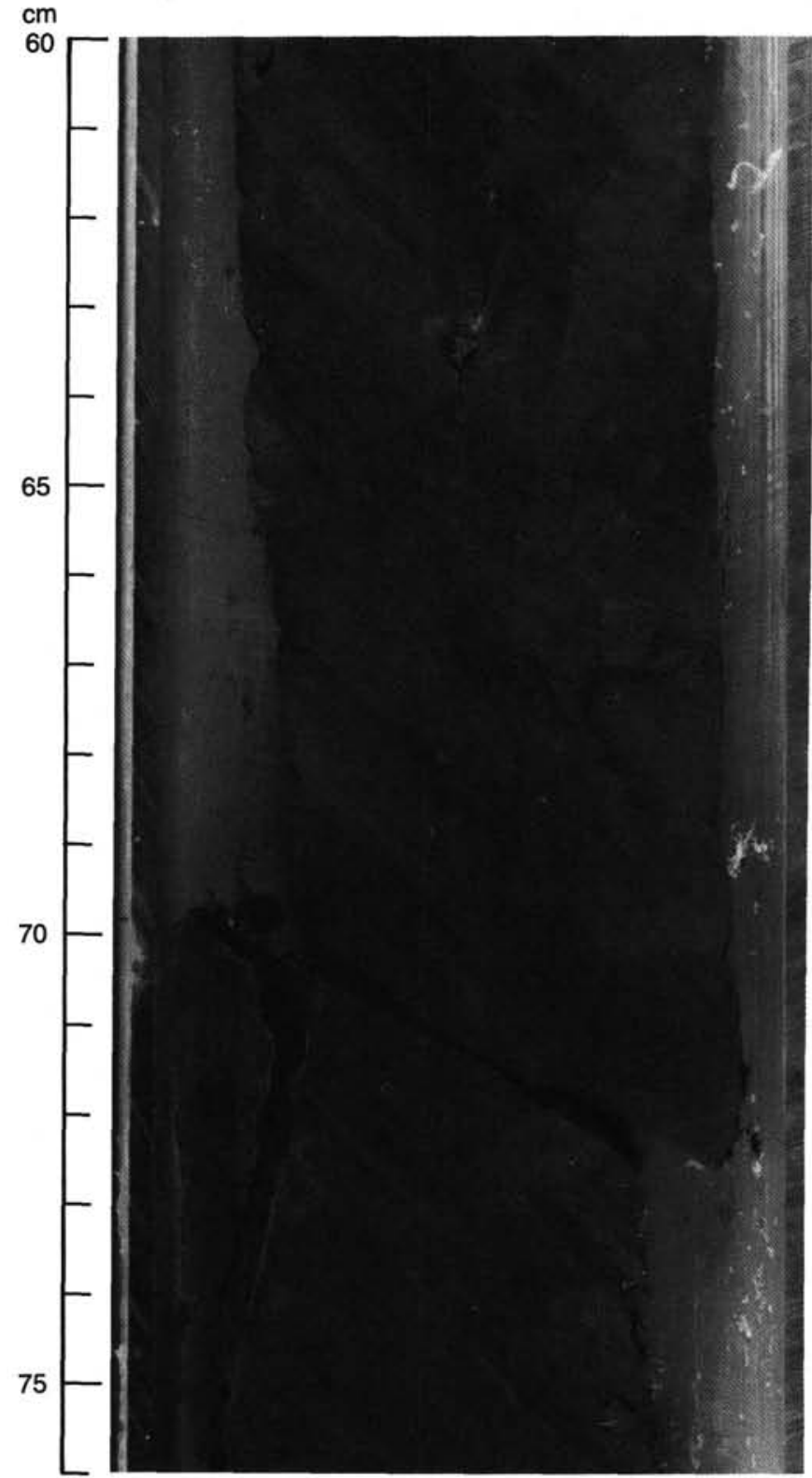

Figure 19. Example of a measured synsedimentary fault plane (107$652 \mathrm{~A}-54 \mathrm{R}-5,60-76 \mathrm{~cm}, 508.5-518.1 \mathrm{mbsf}$ ). In the lower part of the segment the two sides of the fault plane have been separated to observe and measure the slickensides (see Table 3).

Table 3. Measured fault planes for Site $\mathbf{6 5 2}$.

\begin{tabular}{ccccccr}
\hline Core, interval & $\begin{array}{c}\text { Dip } \\
\text { So }\end{array}$ & $\begin{array}{c}\text { Angle } \\
\text { So/F }\end{array}$ & $\begin{array}{c}\text { Pitch of } \\
\text { slicken- } \\
\text { sides }\end{array}$ & $\begin{array}{c}\text { Orientation } \\
\text { F/So }\end{array}$ & $\begin{array}{c}\text { Sense } \\
\text { of } \\
\text { motion }\end{array}$ & $\begin{array}{c}\text { Throw } \\
\text { (mm) }\end{array}$ \\
\hline $107-652 \mathrm{~A}-49 \mathrm{R}-1,34 \mathrm{~cm}$ & 27 & 37 & 651 & $\mathrm{~S}$ & $\mathrm{~N}$ & 9 \\
$107-652 \mathrm{~A}-54 \mathrm{R}-5,65 \mathrm{~cm}$ & 10 & 70 & $75 \mathrm{r}$ & $\mathrm{A}$ & $\mathrm{I}$ & 5 \\
$107-652 \mathrm{~A}-56 \mathrm{R}-5,95 \mathrm{~cm}$ & 5 & 40 & 751 & $\mathrm{~A}$ & $\mathrm{~N}$ & 25 \\
$107-652 \mathrm{~A}-62 \mathrm{R}-3,120 \mathrm{~cm}$ & 20 & 0 & 501 & $\mathrm{~S}$ & $\mathrm{~N}$ & $?$ \\
$107-652 \mathrm{~A}-62 \mathrm{R}-3,120 \mathrm{~cm}$ & 20 & 60 & 801 & $\mathrm{~S}$ & $\mathrm{~N}$ & 3 \\
$107-652 \mathrm{~A}-62 \mathrm{R}-3,120 \mathrm{~cm}$ & 20 & 50 & 801 & $\mathrm{~S}$ & $\mathrm{~N}$ & $\mathrm{sm}$ \\
$107-652 \mathrm{~A}-62 \mathrm{R}-3,120 \mathrm{~cm}$ & 20 & 120 & 701 & $\mathrm{~A}$ & $\mathrm{~N}$ & $\mathrm{sm}$ \\
$107-652 \mathrm{~A}-64 \mathrm{R}-1,125 \mathrm{~cm}$ & 12 & 63 & $80 \mathrm{r}$ & $\mathrm{S}$ & $\mathrm{N}$ & 3 \\
\hline
\end{tabular}

$\mathrm{I}=$ left $\mathrm{r}=$ right $\mathrm{N}=$ normal $\mathrm{I}=$ reverse; $\mathrm{A}=$ antithetic; $\mathrm{S}=$ synthetic; $\mathrm{So}=$ stratification bedding plane; $F=$ fault plane; $s \mathrm{~m}=$ small. 


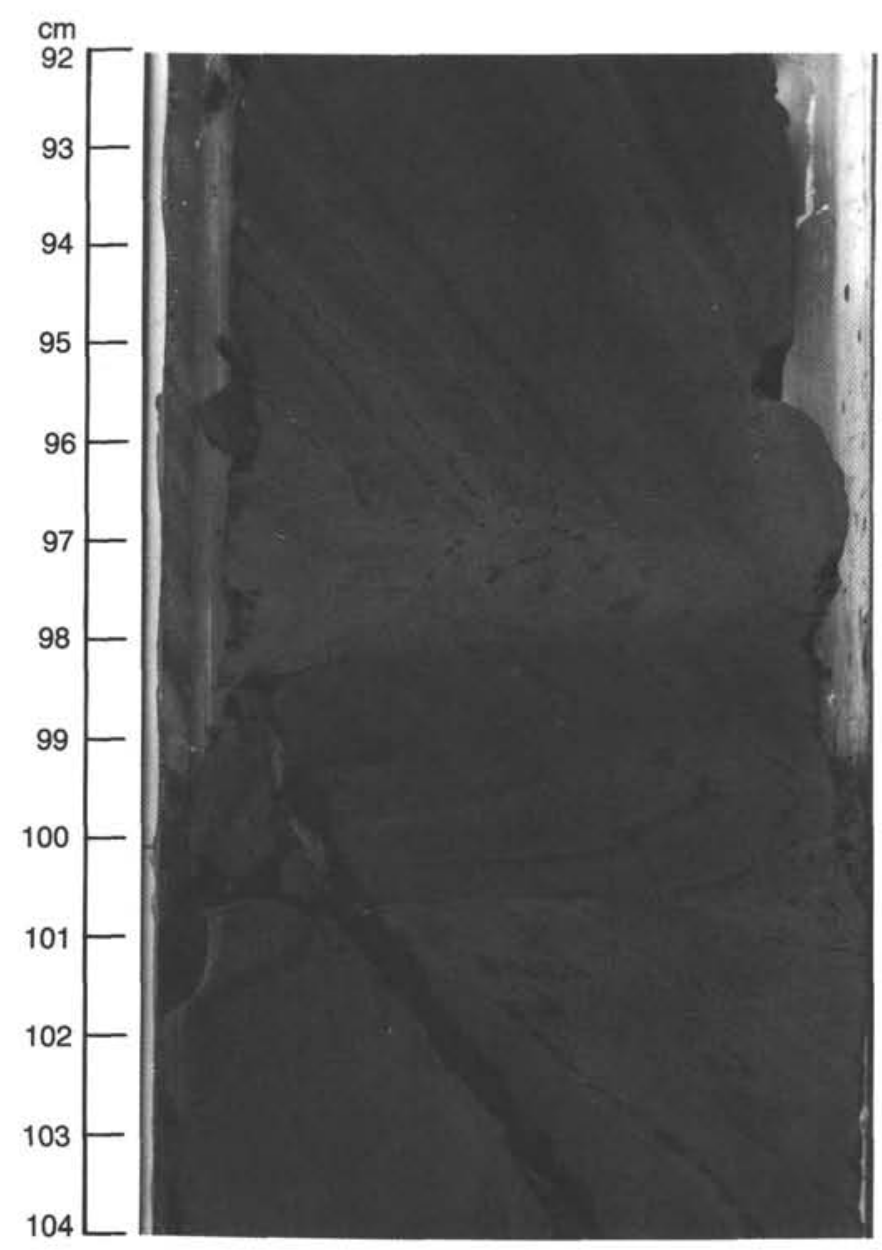

Figure 20. Example of microfolds with the development of an axial plane cleavage within a slump zone (Core 107-652A-55R-4, 92-104 cm, 518.1-527.8 mbsf).

\section{BIOSTRATIGRAPHY}

\section{Summary}

A Pliocene-Pleistocene sequence of hemipelagic sediments, $188 \mathrm{~m}$ thick, was recovered at Site 652 . It is underlain by nonmarine sediments most probably belonging to the Messinian. The age at the base of this series is unknown.

The Pleistocene is very condensed $(85 \mathrm{~m})$. Volcanic ashes occur within nannoplankton zone NN19. Several sapropel layers are present throughout the Pleistocene. Micro- and nannofossils are generally abundant and well preserved. Climatic fluctuations can be recognized throughout the Pliocene-Pleistocene by use of foraminiferal and nannoplankton assemblages.

Good agreement exists between biostratigraphic datings and the paleomagnetic results. The Pliocene-Pleistocene boundary is determined at 85 mbsf by means of planktonic foraminifers just above the top of the Olduvai event.

The Sphaeroidinellopsis MPl1 acme zone representing the base of the Pliocene is present in Core 107-652A-20R. Below this there is a marked decrease of autochthonous fossils. At the same time, the abundance of detrital material and reworked Cretaceous and Paleogene nannofossils increases downsection.

The species diversity of benthic foraminifers per sample gradually increases upsection in the lower part of the Pliocene until 112-122 mbsf. Above this level, species diversity decreases until at $84 \mathrm{mbsf}$ many species have disappeared. The base of Articu- lina tuberosa is found at 74.5 mbsf in Sample 652A-8R, CC, just above the Pliocene-Pleistocene boundary.

The sediments recovered from 190 to 720 mbsf are barren of autochthonous micro- and nannofossils, and were apparently deposited in a nonmarine environment.

The biostratigraphic results are summarized in Figure 21 .

\section{Planktonic Foraminifers}

\section{Pleistocene}

The Pleistocene interval was recovered from Core 107-652A$1 \mathrm{R}$ to about 85 mbsf (Sample 107-652A-10R-1, 75-77 cm). Two planktonic biozones (Ruggieri and Sprovieri, 1983; Ruggieri et al., 1984) are recognized. The Globorotalia truncatulinoides excelsa biozone is present from the top down to $55.40 \mathrm{mbsf}$ (Sample 107-652A-6R, CC). The Globigerina cariacoensis biozone is present from 55.40 to $85 \mathrm{mbsf}$. According to the stratotype boundary section (Vrica section, Calabria, Italy) the Pliocene/ Pleistocene boundary was recognized by the first presence of abundant specimens of left-coiling Neogloboquadrina pachyderma (Colalongo et al., 1982; Tauxe et al., 1983). Globigerinoides obliquus disappears above the boundary at about 67.15 mbsf (Sample 107-652A-8R-2, 65-67 cm). The Emilian-Sicilian boundary was recognized at the base of the Globorotalia truncatulinoides excelsa biozone (55.40 mbsf). As in the Sicilian stratotype, a level with frequent specimens of Globorotalia crassaformis, Globorotalia viola, and Globorotalia hessi is present just below the Globorotalia truncatulinoides excelsa f.o. On the basis of the studied samples, it was not possible to recognize the top of the Sicilian.

\section{Pliocene}

The Pliocene interval was completely recovered between about 85 and about 188 mbsf. The six foraminiferal biozones (Cita, 1975; Rio et al., 1984b) were recognized. MP16 biozone is present from 85 to about 100 mbsf (Sample 107-652A-11R-5, 18-20 cm). At the very base of the biozone the zonal marker (Globorotalia inflata) is rare; it is not present in the upper part of Section 4 and in the lower part of Section 3 of Core 107-652A-11R and is common to abundant from the top of Section 2 of Core 107652-11R. In the segment between about 97 and 94.5 mbsf Globorotalia truncatulinoides, Globorotalia tosaensis, Globorotalia tosaensis tenuitheca, and Sphaeroidinella dehiscens are common. MPI5 (Globigerinodes elongatus) biozone was recognized between 100 and 109.70 mbsf (Sample 107-652A-12R-5, 68-70 cm) where the Sphaeroidinellopsis spp. 1.o. was detected. Globorotalia crassaformis s.l. is more or less frequent in this interval. Globorotalia bononiensis, which appears at the top of MPl4, in Sample 107-652A-13R-2, 9-11 cm (114.30 mbsf) disappears in Sample 107-652A-11R-5, 145-147 cm, (101.2 mbsf). We note that the thickness of sediments referable to this biozone, approximately one million years long (from about 3.0 to about 2.0 m.y.b.p.), is very thin in Site 652 and a sharp reduction in the sedimentation rate is detectable. MPl4 was identified between 109.70 and $132.5 \mathrm{mbsf}$, in coincidence with the Globorotalia margaritae 1.o. (Sample 107-652A-15R, 57-59 cm). Within this biozone (Sphaeroidinellopsis subdehiscens biozone) the extinction level of Globorotalia puncticulata s.s. occurs at $122.3 \mathrm{mbsf}$ (Sample 107-652A-13R, CC). MPl3 was recognized from 132.5 to 147 mbsf (Sample 107-652A-16R-4, 80-86 cm) where the appearance of Globorotalia puncticulata was detected. Again, the thickness of this biozone is quite thin and a decrease in the sedimentation rate is detected along this interval. MPl2 was recognized between 147 and 177.1 mbsf (Sample 107-652A-19R-5, $112-116 \mathrm{~cm}$ ). Globorotalia margaritae is never abundant and is only continuously present in the samples from Sample 107-652A$18 \mathrm{R}, \mathrm{CC}$ (170.5 mbsf) upward. MPl1, characterized by abun- 


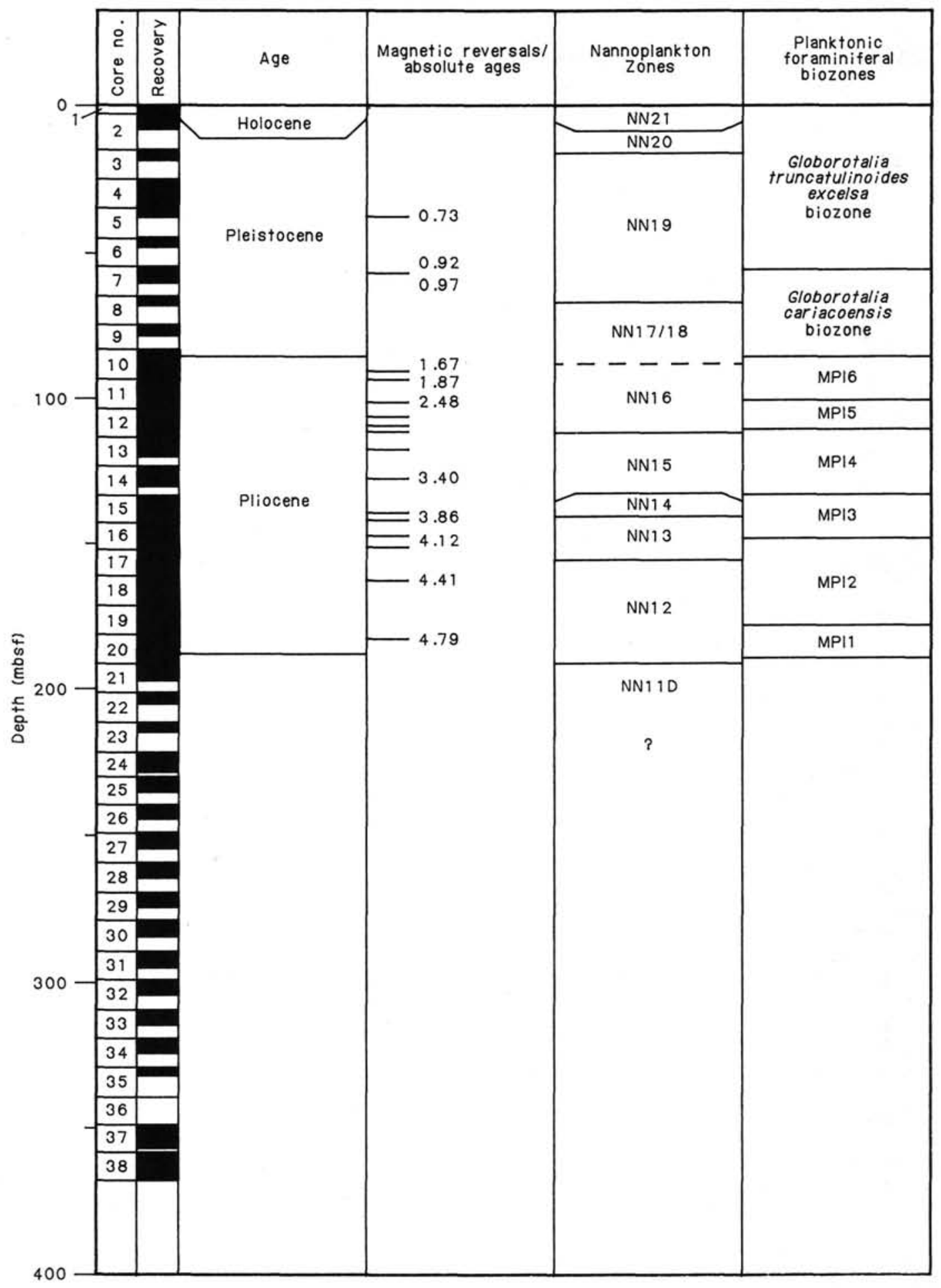

Figure 21. Summary of biostratigraphic results at Site 652 .

dant specimens of Sphaeroidinellopsis spp., has been recognized from 177.1 mbsf to the base of the Pliocene, at about 188 mbsf. At the very base and top of this biozone Sphaeroidinellopsis spp. specimens are not present. At the base the planktonic assemblage is dominated here by Globigerinoides obliquus, Globigerina spp., and Globigerinita quinqueloba.

\section{Pre-Pliocene}

From the base of the Pliocene to the base of the drilled interval of Site 652 (720 mbsf), the sequence recovered was generally barren of planktonic foraminifers. In Sample 107-652A-28R, $\mathrm{CC}$ ( $267 \mathrm{mbsf}$ ) a few black spheres, about $0.2 \mathrm{~mm}$ in diameter, tentatively referred to micrometeorites (Fig. 22) were recovered. Further studies from thin sections and SEM microscope analyses will define the nature of these findings.

\section{Benthic Foraminifers}

Benthic foraminifers occurred in almost all the samples from the top, down to $188 \mathrm{mbsf}$ of Hole $652 \mathrm{~A}$. In the top sample of Core 107-652A-1R, several specimens are present. Glomospira 


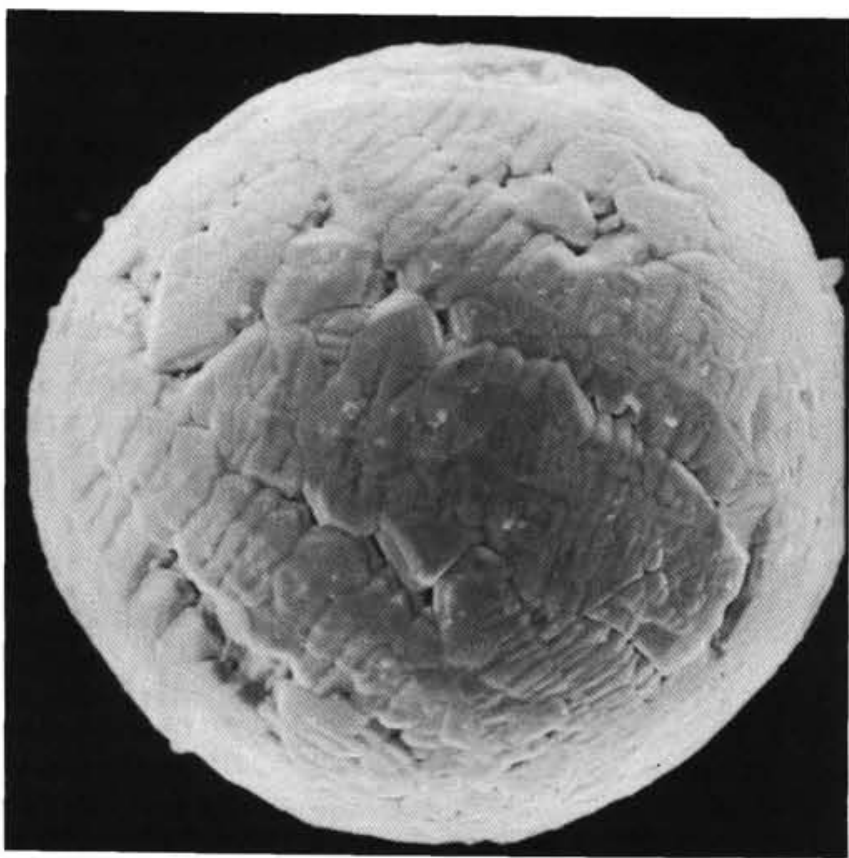

Figure 22. SEM photo of black sphere (approximately $0.2 \mathrm{~mm}$ diameter), tentatively identified as a micrometeorite. Sample is from 107 652A-28R, CC.

charoides is relatively frequent, and is associated with Rhabammina sp., Ammolagena clavata, and a few calcareous species. Such species association corresponds to the Recent Glomospira haroides assemblage which has been found below $1800 \mathrm{~m}$ in the eastern Mediterranean and below $2500 \mathrm{~m}$ in the western Mediterranean (Cita and Zocchi, 1978).

The samples of Core 107-652A-1R (3.6 mbsf) yield many species including Articulina tubulosa, Ammonia beccarii, Cibicides refulgens, Cibicides lobatulus, Elphidium crispum, Gyroidina spp., Melonis pompilioides, Neoconorbina spp., and Rosalina spp. In the sample most specimens are broken, and many shallow water species are included. They are considered as displaced. In the interval between 17 mbsf (Core 107-652A-2R, $\mathrm{CC})$ and $58 \mathrm{mbsf}(107-652 \mathrm{~A}-7 \mathrm{R}-2,116-119 \mathrm{~cm})$, only a few specimens occur. Among them, A. tubulosa, Oridorsalis stellatus, Chilostomella mediterranensis, and Gyroidina neosoldanii are regarded as autochthonous, and suggest mesobathyal or deeper environment. In some horizons, they accompany a small number of displaced specimens.

Between 59.5 mbsf (Core 107-652A-7R-3, 116-119 cm) and 188 mbsf (Core 107-652A-20R-6, 45-46 cm), many species are found, and displaced specimens are very rare. Throughout the interval, a remarkable trend in the species diversity can be recognized. The diversity value increases from 188 mbsf upsection, and attains a maximum around Core 107-652A-13R (112.7-122.3 mbsf). Between the top of this interval and about 84 mbsf (Core 107-652A-9R, CC), many species disappear.

Between 65 mbsf (Core 107-652A-7R, CC) and 77 mbsf (Core 107-652A-9R-2, 115-119 cm) A. tubulosa, O. stellatus, Quinqueloculina spp., Gyroidina spp., and Parafissurina spp. are frequent. In this interval, the first occurrence of $A$. tubulosa is found at 74.5 mbsf (Core 107-652A-8R, CC) in lower Pleistocene.

In the interval between 84 mbsf (Core 107-652A-9R, CC) and 188 mbsf, Nuttalides rugosus convexus, O. stellatus, Bolivina spp., Gyroidina spp., Silicosigmoilina tenuis, Pleurostomella spp., Stilostomella spp., Karreriella bradyi, Cibicidoides italicus, $C$. cf. robertsonianus, Pullenia spp., $Q$. venusta, and Siphonina reticulata are characteristic. The last occurrence of $C$. italicus is recognized at 107.2 mbsf (Core 107-652A-12R-3, 120$124 \mathrm{~cm}$ ) in the lower part of MPl5 zone. It is concordant with some data from the land sections (AGIP, 1982; Sprovieri and Barone, 1984).

Below 190 mbsf (Core 107-652A-20R, CC), down to $335 \mathrm{mbsf}$ (Core 107-652A-35R, CC), some specimens can be found among the well sorted very fine sand grains. They consist of only broken specimens, and seem to be reworked or displaced from the pre-Pliocene sequences. In Sample 107-652A-29R, CC (277 mbsf) three specimens of Ammonia beccarii tepida and two fragments that can possibly be referred to the brackish-water ostracod $C y$ prideis $\mathrm{sp}$. were found.

A limestone among the pebbles at 335 mbsf (Core 107-652A36R) includes several larger foraminifers with smaller benthic and planktonic forms, bryozoans, and calcareous algae. Among them, Lepidocyclina (s. 1.) sp., Pseudolepidina? sp., and Nummulites spp. can be identified.

\section{Paleoclimatic Approach}

At Site 652 , the Pleistocene is only about $85 \mathrm{~m}$ thick and therefore needs very close sampling to apply this method; this sampling has not yet been done. Furthermore, the upper part of the sediments has been strongly disturbed by drilling.

Top of Core 107-652A-1R is late Holocene in age with sinistral Globorotalia truncatulinoides excelsa and abundant well preserved Pteropods but without living benthic foraminifers. Core 107-652A-4R, CC (36 mbsf) is detrital with dominant dextral G. truncatulinoides excelsa. Occurrence of large Globigerinoides conglobatus (diameter more than $400 \mu \mathrm{m}$ ) is noted. By comparing with other Tyrrhenian and Ionian sites we propose an age of about 72,000 years (stage $4 / 5$ ). The isotopic stage 11 $(347,000-421,000 \mathrm{yr})$ was recorded in Core 107-652A-3R, CC.

\section{Nannoplankton}

At Site 652 , the sequence of hemipelagic Pliocene-Pleistocene sediments reaches a thickness of $188 \mathrm{~m}$. It is underlain by nonmarine sediments most probably belonging to the Messinian. However, the base of this sequence is of unknown age.

The Pleistocene is very condensed or reduced by erosion ( 85 $\mathrm{m})$. The Emiliania huxleyi Zone (NN21) is present from the top to Sample 107-652A-2R-1, $25 \mathrm{~cm}$, underlain by the Gephyrocapsa oceanica Zone (NN20) from Sample 107-652A-2R-1, 70 $\mathrm{cm}$, to Sample 107-652A-2R, CC. Nannoplankton are generally abundant. There are few detrital carbonate and reworked species in several layers.

Helicosphaera sp. (with two large pores) is present just above the boundary NN20/NN19 (Samples 107-652A-2R, CC, $4 \mathrm{~cm}$, and $107-652 \mathrm{~A}-2 \mathrm{R}, \mathrm{CC})$. However, at Site 652 this species is present also within Zone NN19 (Sample 107-652A-4R-1, $10 \mathrm{~cm}$ ). It seems that the lowermost part of Zone NN20 is missing.

The interval from Core 107-652A-3R to Sample 107-652A$8 \mathrm{R}-2,60 \mathrm{~cm}$ (17.0-67.0 mbsf) belongs to the Pseudoemiliania lacunosa Zone (NN19). In several levels nannoplankton are strongly diluted by the high input of volcanic ash.

The acme of the small Gephyrocapsa was recognized from Sample 107-652A-6R-1, $53 \mathrm{~cm}$, to Sample 107-652A-6R-1, 138 $\mathrm{cm}$ (about $47.0 \mathrm{mbsf}$ ). The last Helicosphaera sellii was observed in Sample 107-652A-6R, CC.

Very short intervals with abundant small Gephyrocapsa were also found within Zone NN20 (Sample 107-652A-2R-1, $125 \mathrm{~cm}$ ) and in Zone NN21 (Sample 107-652A-3R, $30 \mathrm{~cm}$ ).

Sapropel layers occur within Zone NN19 concentrated around the Jaramillo magnetic event and the Pliocene/Pleistocene boundary. They are very rich in pyrite and organic matter of marine origin; plant fragments are rare. Nannoplankton are dissolved within the sapropel of Sample 107-652A-6R-1, $45 \mathrm{~cm}$, and they are etched in the Pliocene sapropels. 
The level characterized by the abundance of large specimens of Braarudosphaera bigelowi is restricted to Sample 107-652A$8 \mathrm{R}-1,114 \mathrm{~cm}$, within the lowermost part of Zone NN19, which is in good agreement with results obtained from the other sites.

The Pliocene/Pleistocene boundary was determined by the last occurrence of Cyclococcolithus macintyrei and Discoaster brouweri between Samples 107-652A-8R-2, $60 \mathrm{~cm}$, and 107-652A$8 \mathrm{R}-2,70 \mathrm{~cm}$ ( $85.0 \mathrm{mbsf})$. The first appearance of Gephyrocapsa oceanica corresponds with this boundary.

The Pliocene sequence (85.0-189.0 mbsf) seems to be complete. All nannoplankton zones were determined with the exception of Zone NN17. This zone is always extremely short and in most cases it is impossible to recognize it. The extinction levels of Discoaster surculus and Discoaster pentaradiatus fall almost together. Furthermore the scarcity or absence of discoasters within the upper part of the Pliocene in the western Mediterranean makes it even more difficult. Fluctuations in the abundance of discoasters as well as differences in the abundance of certain species make it possible to recognize climatic changes within the Pliocene. A very distinct decrease in surface water temperature occurs within the upper part of Zone NN16 at about 2.5-2.6 Ma (Müller, 1978) which reflects the onset of the northern hemisphere glaciation. Changes of surface water temperature within the western Mediterranean are comparable with those in the northeast Atlantic (Bizon and Müller, 1977) and are related to global climatic fluctuations.

Nannoplankton Zone NN18 (Discoaster brouweri Zone) was encountered from Samples 107-652A-8R-2, $70 \mathrm{~cm}$, to 107-652A$10 \mathrm{R}-2,5 \mathrm{~cm}$. Discoasters are absent from the uppermost part; Discoaster brouweri and Discoaster triradiatus were found from Core 107-652A-9R.

There are two sapropel layers within this interval (Core 107$652 \mathrm{~A}-9 \mathrm{R}-2,36-41 \mathrm{~cm}$ and $93-99 \mathrm{~cm}$.

Nannofossils are strongly etched in the sapropel layers. Certain levels within Zone NN18 are characterized by a decrease of nannoplankton and the abundance of tiny carbonate fragments that might originate from broken small coccoliths. This phenomenon was observed in all holes drilled in the Tyrrhenian Sea and might reflect stronger climatic changes within the uppermost Pliocene. They are also expressed in the lithology by alternating marly foraminifer-nannofossil ooze and silt layers. Below this interval the lithology is more homogeneous.

Zone NN16 (Discoaster surculus) is determined from Samples 107-652A-10R-2, $107 \mathrm{~cm}$, to 107-652A-12R-4, $47 \mathrm{~cm}(86.2-$ $108.0 \mathrm{mbsf}$ ) underlain by the Reticulofenestra pseudombilica Zone (NN15) from Samples 107-652A-12R-5, $47 \mathrm{~cm}$, to $107-$ $652 \mathrm{~A}-15 \mathrm{R}-1,10 \mathrm{~cm}$ (109.0-132.0 mbsf). Discoasters are very rare within the upper part of Zone NN16 (Core 107-652A-10R); they are more common from Core 107-652A-11R. The last occurrence of Discoaster tamalis was observed in Sample 107-652A$10 \mathrm{R}-4,100 \mathrm{~cm}$.

The top of Zone NN15 is not easy to recognize. The specimens of Reticulofenestra pseudoumbilica are smaller and often they disappear. Also Sphenolithus abies which normally can be used also to determine the top of Zone NN15 is very rare or absent within the uppermost part of this zone. Very large specimens of Reticulofenestra pseudoumbilica occur from Core 107652A-15R downsection.

The Discoaster asymmetricus Zone (NN14) defined by the first occurrence of Discoaster asymmetricus at the base and the extinction of Amaurolithus tricorniculatus at its top represents a short time interval (Samples 107-652A-15R-1, $80 \mathrm{~cm}$, to $107-$ $652 \mathrm{~A}-15 \mathrm{R}-3,130 \mathrm{~cm} ; 132.8-138.3 \mathrm{mbsf})$. It is underlain by Zone NN13 (Ceratolithus rugosus Zone) recognized from Samples 107$652 \mathrm{~A}-15 \mathrm{R}-4,41 \mathrm{~cm}$, to $107-652 \mathrm{~A}-17 \mathrm{R}-1,120 \mathrm{~cm}(137.0-153.4$ mbsf), and Zone NN12 (Amaurolithus tricorniculatus Zone) from Samples 107-652A-17R-2, $120 \mathrm{~cm}$ to $107-652 \mathrm{~A}-20 \mathrm{R}-6,120$ $\mathrm{cm}$ (154.0-189.5 mbsf). The abundance of the discoasters and the distribution pattern of the different species throughout the Pliocene seems to be comparable with those from other sites drilled in the Tyrrhenian Sea. Discoasters are absent or extremely rare within the uppermost Pliocene, upper NN16 to NN18 (Core 107-652A-9R to Section 107-652A-11R-5). They are few in several levels within Zone NN18 and upper part of NN16. They are common from Section 107-652A-11R-6 (lower part of Zone NN16) represented predominantly by Discoaster brouweri and Discoaster surculus.

Discoaster tamalis (large size) and Discoaster asymmetricus are common around the boundary NN15/NN16 and within the upper part of Zone NN15. Discoaster variabilis occurs near the base of Zone NN14 and within the upper NN13 which falls together with a decrease of discoasters (Samples 107-652A-15R-3, $70 \mathrm{~cm}$, to $107-652 \mathrm{~A}-16 \mathrm{R}-2,50 \mathrm{~cm}$ ). The presence of this species is interpreted as indicator of lower surface-water temperature which has been mentioned also from Leg 42A (Müller, 1978). The lower part of Zone NN13 is characterized by the dominance of Discoaster surculus and Discoaster pentaradiatus, and Zone NN12 by Discoaster brouweri and Discoaster pentaradiatus. Discoaster surculus becomes more common again within the lower part of Zone NN12. However, throughout the whole sequence there are always some horizons poor in discoasters.

The small species of the genus Gephyrocapsa has its first occurrence within the upper part of Zone NN14. The Pliocene sediments are generally rich in well-preserved nannoplankton. In some samples a slight overgrowth of the discoasters can be observed. Reworked species are rare. Within the lowermost part of Zone NN12 detrital material increases as well as reworked Cretaceous and Eocene nannoplankton species. There is also formation of secondary dolomite.

In Sample 107-652A-20R, CC one specimen of Discoaster quinqueramus was found together with Amaurolithus tricorniculatus indicating the top of the Messinian (NN11b).

The Miocene sediments (189.0-720.0 mbsf) are barren of autochthonous nannofossils. Reworked Cretaceous and Paleogene species are common throughout the sequence indicating deposition of these sediments in a nonmarine environment.

\section{PALEOMAGNETISM}

The principal features of the Pliocene/Pleistocene magnetic polarity time scale were resolved at Site 652 . The Pliocene/Pleistocene sediments responded well to alternating field demagnetization except in the $100-120$ mbsf interval. The correlation of the magnetozone pattern to the magnetic polarity time scale was severely hindered by the poor recovery, and to some extent by core deformation, such that the correlation could not be made solely on the basis of pattern fit. We rely on the paleontological datums to tell approximately where we are in the magnetic polarity time scale; the reversal boundaries then give the precise correlation.

Five hundred twenty-three discrete 7- $\mathrm{cm}^{3}$ "cubic" samples were collected at this site. Two hundred fourteen of these were measured and demagnetized in an alternating field (AF) on board. Nearly all these on-board measurements were from the Pliocene/Pleistocene part of the section. The Messinian samples were often too weakly magnetized for Molspin fluxgate magnetometer and have been analyzed on shore using a cryogenic magnetometer and thermal demagnetization techniques.

Natural remanent magnetization (NRM) intensities in the Pliocene/Pleistocene section were generally about $10^{-6} \mathrm{G} / \mathrm{cm}^{3}$ whereas those in the Messinian deposits were often about $10^{-7}$ $\mathrm{G} / \mathrm{cm}^{3}$. Alternating fields of $100-200$ Oe were usually sufficient to eliminate a low coercivity component with steep positive inclination, probably acquired as a viscous remanence (VRM) from the drill-string. Samples with a reversed characteristic component 
often show an increase in intensity as this VRM is removed. In some intervals (namely, 100-120 mbsf), the AF cleaning does not seem to be very efficient at isolating the characteristic component. The presence of low and fluctuating inclination values indicates that mixed components are still present after AF cleaning. Thermal cleaning on shore has improved the data quality in these intervals.

The interpretation of polarity is based on the inclination of the component isolated after $\mathrm{AF}$ and thermal demagnetization (Table 4). The poor recovery in Cores 107-652A-5R to 107-652A9R and the drilling deformation of Cores 107-652A-4R, 107$652 \mathrm{~A}-10 \mathrm{R}$, and 107-652A-13R leave gaps in the data, which make it difficult to observe a polarity pattern correlative to the magnetic polarity time scale. However, we make the following tentative correlations, which are consistent with magnetobiostratigraphic correlations at Sites 650 and 651 . The base of the Thvera $\left(C_{2}\right)$ subchron is well defined at Site 652 . We observe reversed characteristic magnetizations from Core 107-652A-20R-2 downward to the base of the recovered section, and believe that the entire $500 \mathrm{~m}$ of sediments were deposited in a reversed field, part of which corresponds to the basal reversed interval in the Gilbert chron. The Miocene/Pliocene boundary occurs in Core 107-652A-20R-6, and is therefore within this reversed interval.

\section{PHYSICAL PROPERTIES}

\section{Introduction}

Site 652 on the lower Sardinian margin sampled an 721.1-mthick sedimentary sequence, ranging from Recent to probably

Table 4. Preliminary determination of magnetozone boundaries for Site 652. The samples which bracket the magnetozone boundaries are given.

\begin{tabular}{|c|c|c|c|c|c|}
\hline \multirow{2}{*}{$\begin{array}{c}\begin{array}{c}\text { Magnetozone } \\
\text { boundary }\end{array} \\
\text { Base of Brunhes }\end{array}$} & \multicolumn{2}{|c|}{ Core } & \multirow{2}{*}{$\frac{\text { Section }}{7}$} & \multirow{2}{*}{$\begin{array}{c}\begin{array}{c}\text { Interval } \\
(\mathrm{cm})\end{array} \\
34-36\end{array}$} & \multirow{2}{*}{$\begin{array}{r}\begin{array}{r}\text { Depth } \\
\text { (mbsf) }\end{array} \\
36.05\end{array}$} \\
\hline & between & $4 \mathrm{R}$ & & & \\
\hline & and & $5 \mathrm{R}$ & 1 & $30-32$ & 36.71 \\
\hline \multirow[t]{2}{*}{ Top of Jaramillo } & between & $7 \mathrm{R}$ & 1 & $92-94$ & 56.33 \\
\hline & and & $7 \mathrm{R}$ & 1 & $105-107$ & 56.46 \\
\hline \multirow[t]{2}{*}{ Base of Jaramillo } & between & $7 R$ & 1 & $142-144$ & 56.83 \\
\hline & and & $7 \mathrm{R}$ & 2 & $6-8$ & 56.97 \\
\hline \multirow[t]{2}{*}{ Top of Olduvai } & between & $10 \mathrm{R}$ & 4 & $134-136$ & 90.05 \\
\hline & and & $10 \mathrm{R}$ & 5 & $29-31$ & 90.50 \\
\hline \multirow[t]{2}{*}{ Base of Olduvai } & between & $10 \mathrm{R}$ & 7 & $10-12$ & 93.31 \\
\hline & and & $10 \mathrm{R}$ & 7 & $32-34$ & 93.53 \\
\hline \multirow[t]{2}{*}{ Top of Gauss } & between & $11 \mathrm{R}$ & 6 & $26-28$ & 101.57 \\
\hline & and & $11 \mathrm{R}$ & 6 & $48-50$ & 101.79 \\
\hline \multirow[t]{2}{*}{ Top of Kaena } & between & $12 \mathrm{R}$ & 2 & $120-122$ & 105.71 \\
\hline & and & $12 \mathrm{R}$ & 3 & $20-22$ & 106.21 \\
\hline \multirow[t]{2}{*}{ Base of Kaena } & between & $12 \mathrm{R}$ & 4 & $130-132$ & 108.81 \\
\hline & and & $12 \mathrm{R}$ & 4 & $139-141$ & 108.90 \\
\hline \multirow[t]{2}{*}{ Top of Mammoth } & between & $12 \mathrm{R}$ & 5 & $70-72$ & 109.71 \\
\hline & and & $12 \mathrm{R}$ & 5 & $98-100$ & 109.99 \\
\hline \multirow[t]{2}{*}{ Base of Mammoth } & between & $13 \mathrm{R}$ & 3 & $108-110$ & 116.79 \\
\hline & and & $13 R$ & 4 & $15-17$ & 117.36 \\
\hline \multirow[t]{2}{*}{ Top of Gilbert } & between & $14 \mathrm{R}$ & 4 & $83-85$ & 127.64 \\
\hline & and & $15 \mathrm{R}$ & 1 & $63-65$ & 132.54 \\
\hline \multirow[t]{2}{*}{ Top of Cochiti } & between & $15 \mathrm{R}$ & 5 & $145-147$ & 139.36 \\
\hline & and & $15 \mathrm{R}$ & 6 & $4-6$ & 139.45 \\
\hline \multirow[t]{2}{*}{ Base of Cochiti } & between & $15 \mathrm{R}$ & 6 & $81-83$ & 140.22 \\
\hline & and & $16 \mathrm{R}$ & 1 & $64-66$ & 142.15 \\
\hline \multirow[t]{2}{*}{ Top of Nunivak } & between & $16 \mathrm{R}$ & 4 & $75-77$ & 146.76 \\
\hline & and & $16 \mathrm{R}$ & 4 & $142-144$ & 147.43 \\
\hline \multirow[t]{2}{*}{ Base of Nunivak } & between & $16 \mathrm{R}$ & 5 & $124-126$ & 148.75 \\
\hline & and & $17 \mathrm{R}$ & 1 & $71-73$ & 151.92 \\
\hline \multirow[t]{2}{*}{ Top of Sidufjall $\left(C_{1}\right)$} & between & $18 \mathrm{R}$ & 2 & $18-20$ & 162.49 \\
\hline & and & $18 \mathrm{R}$ & 2 & $82-84$ & 163.13 \\
\hline \multirow[t]{2}{*}{ Base of Sidufjall $\left(C_{1}\right)$} & between & $18 \mathrm{R}$ & 4 & $89-91$ & 166.20 \\
\hline & and & $18 \mathrm{R}$ & 4 & $142-144$ & 166.73 \\
\hline \multirow[t]{2}{*}{ Top of Thvera $\left(C_{2}\right)$} & between & $18 \mathrm{R}$ & 5 & $33-35$ & 167.14 \\
\hline & and & $18 \mathrm{R}$ & 5 & $52-54$ & 167.33 \\
\hline \multirow[t]{2}{*}{ Base of Thvera $\left(C_{2}\right)$} & between & $20 \mathrm{R}$ & 2 & $11-13$ & 181.82 \\
\hline & and & $20 \mathrm{R}$ & 2 & $59-61$ & 182.30 \\
\hline
\end{tabular}

Messinian in age. Routine physical properties measured on the sediments included GRAPE density and thermal conductivity from full round core sections, vane shear strength, compressional-wave velocity, and index properties (porosity, bulk density, and grain density) from split sections.

Tables 5, 6, 7, and 8 list Site 652 physical-properties measurements which are also summarized in Figures 23 and 24.

Table 5. Physical properties index for Site 652.

\begin{tabular}{|c|c|c|c|c|c|}
\hline $\begin{array}{c}\text { Core } \\
\text { section }\end{array}$ & $\begin{array}{l}\text { Interval } \\
(\mathrm{cm}) \text { or } \\
\text { piece no. }\end{array}$ & $\begin{array}{c}\text { Depth } \\
\text { sub-bottom } \\
\text { (m) }\end{array}$ & $\begin{array}{c}\text { Bulk } \\
\text { density } \\
\left(\mathrm{g} / \mathrm{cm}^{3}\right)\end{array}$ & $\begin{array}{c}\text { Porosity } \\
(\%)\end{array}$ & $\begin{array}{l}\text { Grain } \\
\text { density } \\
\left(\mathrm{g} / \mathrm{cm}^{3}\right)\end{array}$ \\
\hline 1R-1 & $0-2$ & 0.00 & 1.40 & 79.9 & 2.73 \\
\hline 1R-2 & $0-2$ & 1.40 & 1.56 & 70.3 & 2.66 \\
\hline 1R-2 & $115-117$ & 2.55 & 1.32 & 82.2 & 2.65 \\
\hline 2R-1 & $100-103$ & 4.06 & 1.35 & 81.8 & 2.57 \\
\hline $2 R-4$ & $27-30$ & 8.07 & 1.47 & 76.8 & 2.51 \\
\hline $3 R-1$ & $82-85$ & 17.82 & 1.56 & 74.6 & 2.88 \\
\hline $4 R-5$ & $40-43$ & 33.13 & 1.62 & 73.5 & 2.88 \\
\hline $4 R-6$ & $17-20$ & 34.37 & 1.58 & 72.4 & 2.59 \\
\hline $6 \mathrm{R}-1$ & $111-114$ & 46.91 & 1.69 & 64.5 & 2.78 \\
\hline $7 R-3$ & $124-127$ & 59.55 & 1.59 & 56.0 & 2.87 \\
\hline $8 R-1$ & $61-65$ & 65.53 & 1.91 & 66.1 & 2.90 \\
\hline $9 \mathrm{R}-1$ & $80-83$ & 75.31 & 1.86 & 63.9 & 2.92 \\
\hline $10 \mathrm{R}-3$ & $100-103$ & 86.72 & 1.80 & 62.7 & 2.75 \\
\hline $12 \mathrm{R}-5$ & $105-108$ & 110.06 & 1.86 & 61.5 & 2.81 \\
\hline $13 R-4$ & $20-23$ & 117.41 & 1.90 & 60.7 & 2.78 \\
\hline $14 \mathrm{R}-4$ & $64-67$ & 127.45 & 1.72 & 62.6 & 2.76 \\
\hline 16R-3 & $70-73$ & 145.21 & 1.80 & 57.3 & 2.76 \\
\hline $17 R-4$ & $105-107$ & 156.76 & 1.85 & 57.6 & 2.86 \\
\hline $18 R-4$ & 93-96 & 165.85 & 1.86 & 55.1 & 2.80 \\
\hline 19R-2 & $95-98$ & 172.97 & 1.78 & 54.4 & 2.51 \\
\hline $19 \mathrm{R}-6$ & $137-140$ & 179.39 & 1.79 & 59.6 & 2.75 \\
\hline 20R-1 & $71-74$ & 180.92 & 1.75 & 63.9 & 2.73 \\
\hline 20R-5 & $135-138$ & 187.56 & 1.74 & 63.3 & 2.73 \\
\hline 21R-2 & $15-18$ & 191.46 & 2.03 & 44.2 & 2.81 \\
\hline 21R-2 & $134-137$ & 192.66 & 1.99 & 48.3 & 2.76 \\
\hline $22 R-2$ & $25-28$ & 201.46 & 2.02 & 45.3 & 2.66 \\
\hline $23 R-2$ & $27-30$ & 210.88 & 2.04 & 48.3 & 2.85 \\
\hline $24 \mathrm{R}-3$ & $63-66$ & 222.35 & 2.08 & 42.5 & 2.79 \\
\hline $24 R-4$ & $77-80$ & 223.98 & 2.12 & 40.7 & 2.79 \\
\hline 25R-2 & $14-18$ & 230.05 & 2.08 & 41.5 & 2.72 \\
\hline 26R-2 & $113-117$ & 240.75 & 2.15 & 37.5 & 2.76 \\
\hline 27R-3 & $10-13$ & 250.82 & 2.23 & 37.5 & 2.82 \\
\hline 28R-1 & $28-31$ & 257.70 & 2.31 & 40.3 & 2.80 \\
\hline 28R-2 & $8-10$ & 258.99 & 2.27 & 35.5 & 2.77 \\
\hline $29 \mathrm{R}-2$ & $8-11$ & 268.70 & 2.17 & 38.5 & 2.76 \\
\hline $30 \mathrm{R}-1$ & $14-17$ & 276.85 & 2.25 & 34.3 & 2.79 \\
\hline $30 \mathrm{R}-3$ & $55-58$ & 280.25 & 2.18 & 37.2 & 2.76 \\
\hline $31 \mathrm{R}-1$ & $143-146$ & 287.75 & 2.25 & 36.1 & 2.74 \\
\hline $31 R-3$ & $89-91$ & 290.20 & 2.28 & 32.9 & 2.76 \\
\hline $32 \mathrm{R}-2$ & $70-72$ & 298.12 & 2.33 & 28.9 & 2.80 \\
\hline $32 \mathrm{R}-2$ & $124-126$ & 298.75 & 2.26 & 32.1 & 2.79 \\
\hline $33 R-2$ & $146-148$ & 308.56 & 2.28 & 28.4 & 2.71 \\
\hline $33 R-3$ & $101-103$ & 309.64 & 2.29 & 30.1 & 2.75 \\
\hline $35 \mathrm{R}-1$ & $44-46$ & 325.44 & 2.19 & 34.8 & 2.70 \\
\hline $37 \mathrm{R}-2$ & $94-96$ & 346.76 & 2.45 & 24.6 & 2.77 \\
\hline $37 R-6$ & $6-8$ & 351.87 & 2.23 & 36.7 & 2.74 \\
\hline $38 \mathrm{R}-1$ & $21-23$ & 354.22 & 2.28 & 32.3 & 2.76 \\
\hline $38 \mathrm{R}-3$ & $111-115$ & 358.13 & 2.88 & 05.2 & 2.88 \\
\hline $38 \mathrm{R}-5$ & $9-12$ & 360.10 & 2.32 & 29.6 & 2.77 \\
\hline $39 \mathrm{R}-1$ & $26-29$ & 364.00 & 2.22 & 33.8 & 2.74 \\
\hline $39 R-7$ & $6-8$ & 372.77 & 2.22 & 36.5 & 2.69 \\
\hline $40 \mathrm{R}-1$ & $72-74$ & 374.13 & 2.24 & 34.1 & 2.74 \\
\hline $40 \mathrm{R}-7$ & $33-35$ & 382.74 & 2.23 & 36.7 & 2.71 \\
\hline 41R-2 & $50-52$ & 385.00 & 2.22 & 35.3 & 2.78 \\
\hline $41 R-6$ & $30-33$ & 392.32 & 2.27 & 32.9 & 2.73 \\
\hline $42 R-2$ & $24-27$ & 394.45 & 2.30 & 34.7 & 2.87 \\
\hline $42 R-5$ & $144-147$ & 400.15 & 2.27 & 32.0 & 2.73 \\
\hline $43 \mathrm{R}-1$ & 93-96 & 403.35 & 2.30 & 31.0 & 2.75 \\
\hline $43 R-4$ & $39-41$ & 407.30 & 2.52 & 19.4 & 2.76 \\
\hline $44 \mathrm{R}-1$ & $96-99$ & 413.08 & 2.23 & 35.0 & 2.69 \\
\hline $44 R-3$ & $75-77$ & 415.86 & 2.81 & 08.9 & 2.85 \\
\hline $45 \mathrm{R}-1$ & $137-139$ & 423.18 & 2.54 & 22.2 & 2.86 \\
\hline $45 \mathrm{R}-2$ & $62-64$ & 423.93 & 2.32 & 32.8 & 2.88 \\
\hline $46 \mathrm{R}-1$ & $60-62$ & 433.13 & 2.39 & 30.7 & 2.73 \\
\hline 46R-3 & $100-102$ & 435.51 & 2.35 & 29.3 & 2.68 \\
\hline 47R-1 & $64-66$ & 441.75 & 2.36 & 29.0 & 2.68 \\
\hline
\end{tabular}


Table 5 (Continued).

\begin{tabular}{|c|c|c|c|c|c|}
\hline $\begin{array}{l}\text { Core } \\
\text { section }\end{array}$ & $\begin{array}{l}\text { Interval } \\
(\mathrm{cm}) \text { or } \\
\text { piece no. }\end{array}$ & $\begin{array}{c}\text { Depth } \\
\text { sub-bottom } \\
\text { (m) }\end{array}$ & $\begin{array}{c}\text { Bulk } \\
\text { density } \\
\left(\mathrm{g} / \mathrm{cm}^{3}\right)\end{array}$ & $\begin{array}{c}\text { Porosity } \\
(\%)\end{array}$ & $\begin{array}{c}\text { Grain } \\
\text { density } \\
\left(\mathrm{g} / \mathrm{cm}^{3}\right)\end{array}$ \\
\hline $47 R-5$ & $32-34$ & 447.43 & 2.48 & 23.7 & 2.74 \\
\hline $48 \mathrm{R}-1$ & $8-10$ & 450.79 & 2.36 & 31.7 & 2.72 \\
\hline $48 \mathrm{R}-3$ & $130-133$ & 455.02 & 2.46 & 24.6 & 2.79 \\
\hline $49 \mathrm{R}-1$ & $23-25$ & 460.54 & 2.40 & 27.4 & 2.84 \\
\hline $49 \mathrm{R}-2$ & $95-97$ & 462.72 & 2.56 & 18.9 & 2.88 \\
\hline $50 \mathrm{R}-1$ & $59-62$ & 470.62 & 2.29 & 35.9 & 2.92 \\
\hline $50 \mathrm{R}-2$ & $90-113$ & 472.63 & 2.36 & 30.4 & 2.86 \\
\hline 50R-3 & $9-11$ & 472.81 & 2.34 & 25.8 & 2.76 \\
\hline 51R-1 & $13-15$ & 479.75 & 2.41 & 25.6 & 2.73 \\
\hline 51R-5 & $126-128$ & 486.78 & 2.34 & 30.0 & 2.77 \\
\hline $51 R-6$ & $44-46$ & 487.46 & 2.36 & 28.2 & 2.79 \\
\hline $52 \mathrm{R}-1$ & $78-80$ & 490.00 & 2.42 & 28.2 & 2.87 \\
\hline $52 R-3$ & $138-140$ & 493.60 & 2.42 & 23.1 & 2.45 \\
\hline 53R-3 & $146-148$ & 503.28 & 2.38 & 29.1 & 2.74 \\
\hline $53 R-4$ & $14-16$ & 503.46 & 2.49 & 26.3 & 2.89 \\
\hline $54 \mathrm{R}-1$ & $96-98$ & 509.48 & 2.41 & 27.7 & 2.78 \\
\hline $54 \mathrm{R}-3$ & $132-135$ & 512.85 & 2.46 & 23.6 & 2.80 \\
\hline $55 \mathrm{R}-3$ & $30-32$ & 521.42 & 2.40 & 27.0 & 2.80 \\
\hline 55R-5 & $106-117$ & 525.27 & 2.41 & 25.4 & 2.75 \\
\hline 55R-5 & $145-148$ & 525.58 & 2.47 & 27.4 & 2.93 \\
\hline 56R-2 & $32-34$ & 529.64 & 2.42 & 23.7 & 2.73 \\
\hline 57R-1 & $26-28$ & 537.68 & 2.39 & 25.7 & 2.78 \\
\hline $57 \mathrm{R}-3$ & $62-64$ & 541.04 & 2.60 & 18.7 & 2.79 \\
\hline $58 \mathrm{R}-1$ & $48-50$ & 547.10 & 2.35 & 28.5 & 2.72 \\
\hline $58 \mathrm{R}-6$ & $30-32$ & 554.42 & 2.12 & 37.4 & 2.59 \\
\hline 59R-1 & $7-9$ & 556.39 & 2.40 & 30.1 & 2.91 \\
\hline $59 \mathrm{R}-4$ & $18-20$ & 560.90 & 2.43 & 24.1 & 2.83 \\
\hline $60 \mathrm{R}-1$ & $16-18$ & 566.18 & 2.38 & 26.5 & 2.79 \\
\hline $60 R-5$ & $106-108$ & 573.08 & 2.42 & 22.2 & 2.83 \\
\hline $61 R-2$ & $2-4$ & 577.14 & 2.49 & 26.2 & 2.78 \\
\hline $61 R-4$ & $146-148$ & 581.58 & 2.45 & 31.7 & 2.76 \\
\hline $62 \mathrm{R}-3$ & $91-93$ & 589.13 & 2.44 & 25.9 & 2.79 \\
\hline $62 R-4$ & $112-114$ & 590.84 & 2.52 & 23.2 & 2.77 \\
\hline $63 R-1$ & $114-116$ & 596.06 & 2.48 & 26.5 & 2.70 \\
\hline $63 R-3$ & $75-77$ & 598.67 & 2.51 & 22.9 & 2.85 \\
\hline $64 \mathrm{R}-1$ & $105-107$ & 610.57 & 2.30 & 29.7 & 2.53 \\
\hline $64 R-3$ & $59-61$ & 613.01 & 2.82 & 05.7 & 3.03 \\
\hline $65 \mathrm{R}-1$ & $70-72$ & 614.92 & 2.25 & 29.6 & 2.53 \\
\hline $65 R-4$ & $2-4$ & 618.73 & 2.77 & 30.6 & 2.90 \\
\hline $66 \mathrm{R}-1$ & $90-92$ & 625.41 & 2.59 & 19.2 & 2.80 \\
\hline $66 \mathrm{R}-3$ & $74-76$ & 628.25 & 2.52 & 21.8 & 2.77 \\
\hline $67 R-1$ & $107-109$ & 635.28 & 2.69 & 13.7 & 2.85 \\
\hline $67 R-3$ & $144-146$ & 628.49 & 2.56 & 22.6 & 2.76 \\
\hline $67 R-5$ & $144-146$ & 641.65 & 2.57 & 24.0 & 2.69 \\
\hline $68 \mathrm{R}-1$ & $146-148$ & 645.26 & 2.55 & 22.1 & 2.83 \\
\hline $68 \mathrm{R}-6$ & $51-53$ & 651.82 & 2.57 & 21.7 & 2.71 \\
\hline $69 \mathrm{R}-1$ & $2-4$ & 653.43 & 2.56 & 21.8 & 2.74 \\
\hline $69 R-4$ & $70-72$ & 658.61 & 2.54 & 21.0 & 2.70 \\
\hline $70 \mathrm{R}-2$ & $64-66$ & 665.26 & 2.51 & 20.9 & 2.71 \\
\hline $70 R-4$ & $24-26$ & 667.86 & 2.58 & 21.3 & 2.73 \\
\hline $71 R-1$ & $78-80$ & 673.59 & 2.58 & 20.1 & 2.71 \\
\hline $71 R-2$ & $45-47$ & 674.76 & 2.58 & 20.9 & 2.78 \\
\hline $72 \mathrm{R}-1$ & $54-56$ & 683.05 & 2.59 & 15.3 & 2.78 \\
\hline $72 \mathrm{R}-2$ & $80-82$ & 684.81 & 2.58 & 16.9 & 2.76 \\
\hline $73 R-1$ & $4-6$ & 692.23 & 2.77 & 19.7 & 2.92 \\
\hline $73 R-3$ & $8-10$ & 695.29 & 2.69 & 15.6 & 2.76 \\
\hline $73 R-3$ & $99-101$ & 696.20 & 2.51 & 18.4 & 2.70 \\
\hline $74 \mathrm{R}-1$ & $4-6$ & 701.95 & 2.59 & 19.1 & 2.68 \\
\hline $74 \mathrm{R}-2$ & $54-56$ & 703.95 & 2.75 & 12.6 & 2.82 \\
\hline $74 R-5$ & $52-54$ & 708.43 & 2.69 & 16.4 & 2.68 \\
\hline $75 R-4$ & $23-25$ & 715.24 & 2.57 & 19.3 & 2.72 \\
\hline $75 \mathrm{R}-6$ & $111-113$ & 719.14 & 2.89 & 13.1 & 2.75 \\
\hline
\end{tabular}

\section{Results}

\section{GRAPE Density}

Bulk density was determined by gamma ray attenuation porosity evaluation (GRAPE) for the entire length of every core. The GRAPE density appears constant in the upper part of the hole $(0-60 \mathrm{mbsf})$ at about $1.5 \mathrm{~g} / \mathrm{cm}^{3}$. It increases progressively to $2.0 \mathrm{~g} / \mathrm{cm}^{3}$ between 60 and $190 \mathrm{mbsf}$ and seems to be fixed at
Table 6. Compressional velocity for Site 652 .

\begin{tabular}{|c|c|c|c|}
\hline $\begin{array}{l}\text { Core } \\
\text { section }\end{array}$ & $\begin{array}{l}\text { Interval } \\
(\mathrm{cm})\end{array}$ & $\begin{array}{l}\text { Depth } \\
\text { sub-bottom } \\
\text { (m) }\end{array}$ & $\begin{array}{l}\text { Compressional } \\
\text { velocity } \\
(\mathrm{km} / \mathrm{s})\end{array}$ \\
\hline $3 \mathrm{R}-1$ & $82-85$ & 17.82 & 1.522 \\
\hline $4 R-6$ & $17-20$ & 34.37 & 1.627 \\
\hline $6 \mathrm{R}-1$ & $111-114$ & 46.91 & 1.570 \\
\hline $8 R-1$ & $61-65$ & 65.53 & 1.560 \\
\hline $9 R-1$ & $80-83$ & 75.31 & 1.673 \\
\hline $10 \mathrm{R}-3$ & $100-103$ & 86.72 & 1.545 \\
\hline $10 \mathrm{R}-6$ & $140-143$ & 93.12 & 1.626 \\
\hline $11 \mathrm{R}-5$ & $105-108$ & 100.86 & 1.615 \\
\hline $12 \mathrm{R}-5$ & $105-108$ & 110.06 & 1.560 \\
\hline $13 R-4$ & $20-23$ & 117.41 & 1.624 \\
\hline $14 \mathrm{R}-4$ & 64-67 & 127.45 & 1.559 \\
\hline $15 \mathrm{R}-1$ & $134-137$ & 133.25 & 1.607 \\
\hline 16R-3 & $70-73$ & 145.21 & 1.652 \\
\hline $17 R-4$ & $105-107$ & 156.76 & 1.736 \\
\hline $18 \mathrm{R}-4$ & $93-96$ & 165.85 & 1.675 \\
\hline 19R-2 & $95-98$ & 172.97 & 1.602 \\
\hline 20R-1 & $71-74$ & 180.92 & 1.612 \\
\hline 21R-2 & $15-18$ & 191.46 & 1.754 \\
\hline 21R-2 & $134-137$ & 192.66 & 1.734 \\
\hline $22 \mathrm{R}-2$ & $25-28$ & 201.46 & 1.712 \\
\hline $23 R-2$ & $27-30$ & 210.88 & 1.657 \\
\hline 24R-3 & $63-66$ & 222.35 & 1.776 \\
\hline $24 R-4$ & $77-80$ & 223.98 & 1.819 \\
\hline $25 \mathrm{R}-2$ & $14-18$ & 230.05 & 1.981 \\
\hline $26 \mathrm{R}-2$ & $113-117$ & 240.75 & 1.900 \\
\hline $27 R-3$ & $10-13$ & 250.82 & 1.864 \\
\hline $28 \mathrm{R}-1$ & $28-31$ & 257.65 & 1.933 \\
\hline $28 \mathrm{R}-2$ & $8-10$ & 258.99 & 1.903 \\
\hline $29 \mathrm{R}-2$ & $8-11$ & 269.90 & 1.852 \\
\hline $30 \mathrm{R}-1$ & $14-17$ & 276.85 & 1.935 \\
\hline 30R-3 & $55-58$ & 280.26 & 1.784 \\
\hline $31 \mathrm{R}-1$ & $143-146$ & 287.75 & 1.819 \\
\hline $31 \mathrm{R}-3$ & $89-91$ & 290.20 & 1.991 \\
\hline $32 \mathrm{R}-2$ & $70-72$ & 298.12 & 2.130 \\
\hline $32 \mathrm{R}-2$ & $124-126$ & 298.75 & 1.986 \\
\hline $33 \mathrm{R}-2$ & $146-148$ & 308.56 & 2.606 \\
\hline $33 R-3$ & $101-103$ & 309.64 & 4.220 \\
\hline $35 \mathrm{R}-1$ & $44-46$ & 325.44 & 2.022 \\
\hline $37 \mathrm{R}-2$ & $94-96$ & 346.76 & 3.009 \\
\hline $37 \mathrm{R}-6$ & $6-8$ & 351.87 & 1.856 \\
\hline $38 \mathrm{R}-1$ & $21-23$ & 354.22 & 1.984 \\
\hline $38 \mathrm{R}-3$ & $111-115$ & 358.13 & 5.212 \\
\hline $38 \mathrm{R}-5$ & $9-12$ & 360.10 & 2.040 \\
\hline $39 \mathrm{R}-1$ & $26-29$ & 364.00 & 1.905 \\
\hline $39 \mathrm{R}-7$ & $6-8$ & 372.77 & 1.823 \\
\hline $40 \mathrm{R}-1$ & $72-74$ & 374.13 & 1.974 \\
\hline $40 \mathrm{R}-7$ & $33-35$ & 382.74 & 1.933 \\
\hline $41 \mathrm{R}-2$ & $50-52$ & 385.00 & 1.903 \\
\hline 41R-6 & $30-33$ & 392.32 & 1.963 \\
\hline $42 \mathrm{R}-2$ & $24-27$ & 394.45 & 2.095 \\
\hline $42 R-5$ & $144-147$ & 400.15 & 1.961 \\
\hline $43 \mathrm{R}-1$ & $93-96$ & 403.35 & 1.970 \\
\hline $43 R-4$ & $39-41$ & 407.30 & 3.376 \\
\hline $44 \mathrm{R}-1$ & 96-99 & 413.08 & 1.948 \\
\hline $44 R-3$ & $75-77$ & 415.86 & 4.820 \\
\hline $45 \mathrm{R}-1$ & $137-139$ & 423.18 & 3.080 \\
\hline $45 R-2$ & $62-64$ & 423.93 & 2.100 \\
\hline $46 \mathrm{R}-1$ & $60-62$ & 432.11 & 2.067 \\
\hline $46 R-3$ & $100-102$ & 435.51 & 2.025 \\
\hline $47 \mathrm{R}-1$ & $64-66$ & 441.75 & 2.197 \\
\hline
\end{tabular}

about $2.0 \mathrm{~g} / \mathrm{cm}^{3}$, below $190 \mathrm{mbsf}$ to the bottom of the hole at 721.1 mbsf.

\section{Index Properties and Compressional Velocity}

Porosity, bulk density, compressional velocity, and grain density are plotted relative to sub-bottom depth in Figures 23 and 24 and are listed in Tables 5 and 6.

The bulk density values are in good agreement with the porosity values and reflect the same trend changes along the cores. To a first approach, two main physical property units can be 
Table 6 (Continued).

\begin{tabular}{|c|c|c|c|}
\hline $\begin{array}{c}\text { Core } \\
\text { section }\end{array}$ & $\begin{array}{c}\text { Interval } \\
(\mathrm{cm})\end{array}$ & $\begin{array}{c}\text { Depth } \\
\text { sub-bottom } \\
\text { (m) }\end{array}$ & $\begin{array}{c}\text { Compressional } \\
\text { velocity } \\
(\mathrm{km} / \mathrm{s})\end{array}$ \\
\hline $47 R-5$ & $32-34$ & 447.43 & 2.578 \\
\hline $48 \mathrm{R}-1$ & $8-10$ & 450.79 & 2.301 \\
\hline $48 R-3$ & $130-133$ & 455.02 & 2.078 \\
\hline 49R-1 & $23-25$ & 460.54 & 2.503 \\
\hline $49 \mathrm{R}-2$ & $95-98$ & 462.76 & 4.275 \\
\hline 50R-1 & $60-63$ & 470.62 & 2.400 \\
\hline 50R-3 & 9-11 & 473.10 & 2.871 \\
\hline 51R-1 & $13-15$ & 479.74 & 2.165 \\
\hline 51R-5 & $126-128$ & 486.87 & 2.473 \\
\hline 51R-6 & $44-46$ & 487.55 & 2.246 \\
\hline $52 \mathrm{R}-2$ & $78-80$ & 491.49 & 2.476 \\
\hline $52 \mathrm{R}-3$ & $138-140$ & 493.59 & 2.846 \\
\hline $53 \mathrm{R}-3$ & $146-148$ & 503.19 & 2.323 \\
\hline $53 R-4$ & $14-16$ & 503.45 & 2.622 \\
\hline $54 \mathrm{R}-1$ & $96-98$ & 509.47 & 2.228 \\
\hline $54 \mathrm{R}-3$ & $132-135$ & 512.92 & 2.320 \\
\hline $55 \mathrm{R}-3$ & $30-32$ & 521.41 & 2.316 \\
\hline 55R-5 & $145-148$ & 525.56 & 2.401 \\
\hline $56 \mathrm{R}-2$ & $32-34$ & 529.23 & 2.368 \\
\hline 56R-6 & $11-13$ & 535.42 & 2.485 \\
\hline $57 R-1$ & $26-28$ & 537.67 & 2.508 \\
\hline 57R-3 & $62-64$ & 541.03 & 2.972 \\
\hline 58R-1 & $48-50$ & 547.09 & 2.191 \\
\hline $58 \mathrm{R}-6$ & $30-32$ & 554.41 & 2.175 \\
\hline $59 \mathrm{R}-1$ & $7-9$ & 556.38 & 2.025 \\
\hline $59 R-4$ & $18-20$ & 560.99 & 2.467 \\
\hline $60 \mathrm{R}-1$ & $16-18$ & 566.77 & 2.303 \\
\hline $60 \mathrm{R}-5$ & $106-108$ & 573.67 & 2.666 \\
\hline $61 R-2$ & $2-4$ & 577.13 & 2.433 \\
\hline $61 R-4$ & $146-148$ & 581.57 & 2.309 \\
\hline $62 \mathrm{R}-3$ & $91-93$ & 589.12 & 2.411 \\
\hline $62 R-4$ & $112-114$ & 590.83 & 2.543 \\
\hline 63R-1 & $114-116$ & 596.05 & 2.695 \\
\hline $63 R-3$ & $75-77$ & 598.66 & 2.875 \\
\hline $64 \mathrm{R}-1$ & $105-107$ & 610.56 & 2.246 \\
\hline $64 \mathrm{R}-3$ & $59-61$ & 613.10 & 3.330 \\
\hline $65 R-1$ & $70-72$ & 614.91 & 2.230 \\
\hline $65 R-4$ & $2-4$ & 618.73 & 3.960 \\
\hline $66 \mathrm{R}-1$ & $90-92$ & 625.41 & 3.322 \\
\hline $66 \mathrm{R}-3$ & $74-76$ & 628.25 & 2.764 \\
\hline 67R-1 & $107-109$ & 635.28 & 4.284 \\
\hline $67 R-5$ & $114-146$ & 641.65 & 2.745 \\
\hline $68 \mathrm{R}-1$ & $146-148$ & 645.25 & 2.508 \\
\hline $68 \mathrm{R}-6$ & $51-53$ & 651.82 & 2.910 \\
\hline $69 \mathrm{R}-1$ & $2-4$ & 653.43 & 2.414 \\
\hline $69 \mathrm{R}-4$ & $70-72$ & 658.61 & 2.898 \\
\hline $70 \mathrm{R}-2$ & $64-66$ & 665.25 & 2.970 \\
\hline $70 R-4$ & $24-26$ & 667.85 & 2.963 \\
\hline $71 \mathrm{R}-1$ & $78-80$ & 673.59 & 2.491 \\
\hline $71 \mathrm{R}-2$ & $45-47$ & 674.76 & 2.933 \\
\hline $72 \mathrm{R}-1$ & $54-56$ & 683.05 & 3.338 \\
\hline $72 \mathrm{R}-2$ & $80-82$ & 684.81 & 3.325 \\
\hline $73 R-1$ & $4-6$ & 692.23 & 3.263 \\
\hline $73 R-3$ & $8-10$ & 695.29 & 3.596 \\
\hline $73 R-3$ & $99-101$ & 696.20 & 3.208 \\
\hline 74R-1 & 4-6 & 701.95 & 2.772 \\
\hline $74 \mathrm{R}-2$ & $54-56$ & 703.95 & 3.608 \\
\hline $74 \mathrm{R}-5$ & $52-54$ & 708.43 & 3.202 \\
\hline $75 R-4$ & $23-25$ & 715.24 & 2.680 \\
\hline $75 R-6$ & $111-113$ & 719.14 & 3.506 \\
\hline
\end{tabular}

distinguished in Hole 652A: Unit 1 from the seafloor to about $330 \mathrm{mbsf}$ and Unit 2 below this depth to the bottom of the hole.

A more detailed study allows the definition of several subunits which are as follows:

1. Physical Properties Unit 1-A: From the seafloor to about 60 mbsf showing a downsection decreasing porosity $(80 \%-56 \%)$ and density values increasing from $1.40 \mathrm{~g} / \mathrm{cm}^{3}$ at the mud line to $1.70 \mathrm{~g} / \mathrm{cm}^{3}$.

2. Physical Properties Unit 1-B: From 66 to about $187 \mathrm{mbsf}$ with a downsection decreasing porosity $(66 \%-54 \%)$ and density values decreasing from 1.91 to $1.74 \mathrm{~g} / \mathrm{cm}^{3}$. This decrease of density is interesting and atypical.
Table 7. Thermal conductivity for Site $\mathbf{6 5 2}$.

\begin{tabular}{|c|c|c|c|}
\hline $\begin{array}{l}\text { Core } \\
\text { section }\end{array}$ & $\begin{array}{l}\text { Interval } \\
(\mathrm{cm})\end{array}$ & $\begin{array}{l}\text { Depth } \\
\text { sub-bottom } \\
\text { (m) }\end{array}$ & $\begin{array}{c}\text { Thermal } \\
\text { conductivity } \\
\left(10^{-3} / \mathrm{cal} \cdot \mathrm{cm}^{2} \cdot \mathrm{s} \cdot \mathrm{deg}\right)\end{array}$ \\
\hline 1R-1 & 100 & 1.00 & 2.1931 \\
\hline IR-2 & 75 & 2.15 & 2.5235 \\
\hline 1R-3 & 32 & 3.22 & 2.2874 \\
\hline 2R-2 & 75 & 5.85 & 2.2851 \\
\hline $2 \mathrm{R}-3$ & 60 & 7.20 & 2.6187 \\
\hline 3R-1 & 85 & 17.85 & 2.3354 \\
\hline $4 \mathrm{R}-3$ & 80 & 30.50 & 1.8760 \\
\hline $4 R-4$ & 80 & 32.00 & 2.6028 \\
\hline $4 R-5$ & 80 & 33.50 & 2.6626 \\
\hline 5R-1 & 23 & 36.63 & 2.9070 \\
\hline $6 \mathrm{R}-1$ & 111 & 46.91 & 2.9073 \\
\hline 7R-1 & 63 & 56.03 & 2.8040 \\
\hline 7R-2 & 26 & 57.16 & 2.7608 \\
\hline $7 R-3$ & 76 & 58.86 & 2.8360 \\
\hline $7 R-4$ & 29 & 59.89 & 2.4904 \\
\hline $8 R-1$ & 75 & 65.65 & 2.7799 \\
\hline $8 \mathrm{R}-2$ & 75 & 68.15 & 2.8873 \\
\hline $10 \mathrm{R}-1$ & 75 & 84.95 & 2.5366 \\
\hline 11R-1 & 75 & 94.55 & 3.1060 \\
\hline $12 \mathrm{R}-2$ & 75 & 105.25 & 2.9908 \\
\hline $13 \mathrm{R}-1$ & 70 & 113.40 & 3.3415 \\
\hline $13 R-2$ & 70 & 114.90 & 3.1699 \\
\hline $14 R-2$ & 77 & 124.97 & 3.0303 \\
\hline $14 \mathrm{R}-4$ & 75 & 127.15 & 3.0532 \\
\hline $15 \mathrm{R}-2$ & 77 & 134.17 & 3.0474 \\
\hline $15 R-4$ & 77 & 137.17 & 3.2152 \\
\hline 17R-2 & 77 & 153.47 & 3.2830 \\
\hline $19 \mathrm{R}-2$ & 73 & 172.73 & 3.1178 \\
\hline 19R-3 & 72 & 174.23 & 3.1061 \\
\hline 21R-1 & 79 & 190.59 & 3.2355 \\
\hline $24 R-4$ & 94 & 224.14 & 4.2228 \\
\hline 25R-2 & 75 & 230.65 & 4.2418 \\
\hline 27R-2 & 80 & 250.00 & 3.8879 \\
\hline 28R-2 & 75 & 259.65 & 3.6629 \\
\hline
\end{tabular}

Table 8. Shear strength measurements for Site 652 .

\begin{tabular}{lrrr}
\hline $\begin{array}{c}\text { Core } \\
\text { section }\end{array}$ & $\begin{array}{c}\text { Interval } \\
(\mathrm{cm})\end{array}$ & $\begin{array}{c}\text { Depth } \\
\text { sub-bottom } \\
(\mathrm{m})\end{array}$ & $\begin{array}{c}\text { Shear } \\
\text { strength } \\
(\mathrm{kPa})\end{array}$ \\
\hline 8R-1 & 69 & 65.59 & 24.7608 \\
$8 \mathrm{R}-2$ & 58 & 66.98 & 25.6612 \\
9R-1 & 77 & 75.27 & 26.5616 \\
10R-4 & 81 & 89.51 & 45.9200 \\
11R-4 & 94 & 99.24 & 48.8204 \\
12R-4 & 66 & 108.16 & 33.3145 \\
12R-4 & 100 & 108.60 & 152.4820 \\
13R-4 & 76 & 117.95 & 58.0342 \\
14R-4 & 54 & 127.34 & 58.0342 \\
15R-1 & 104 & 132.94 & 26.1723 \\
16R-3 & 79 & 145.29 & 85.3445 \\
17R-4 & 120 & 156.90 & 83.0686 \\
18R-4 & 102 & 166.32 & 89.8962 \\
19R-3 & 120 & 174.70 & 69.4135 \\
19R-6 & 130 & 179.30 & 61.4480 \\
20R-1 & 67 & 180.87 & 72.8273 \\
20R-5 & 112 & 187.32 & 79.6548 \\
20R-CC & 7 & 189.60 & 72.8273 \\
$21 \mathrm{R}-1$ & 100 & 190.80 & 87.6203 \\
21R-3 & 113 & 193.93 & 52.3446 \\
$22 \mathrm{R}-2$ & 36 & 201.56 & 73.9652 \\
$23 \mathrm{R}-2$ & 29 & 210.89 & 47.7929 \\
$24 \mathrm{R}-3$ & 66 & 222.36 & 136.5510 \\
$25 \mathrm{R}-3$ & 10 & 231.50 & 73.9652 \\
& & & \\
\hline & & & \\
\hline
\end{tabular}

3. Physical Properties Unit 1-C: From 187 to $330 \mathrm{mbsf}$, the porosity decreases from $44 \%$ to $28.5 \%$ and the density increases from 1.99 to $2.29 \mathrm{~g} / \mathrm{cm}^{3}$.

4. Physical Properties Unit 2 ranges from about $330 \mathrm{~m}$ to the bottom of the hole. It was not possible to distinguish clear subunits. This unit is characterized by well-marked and constant 

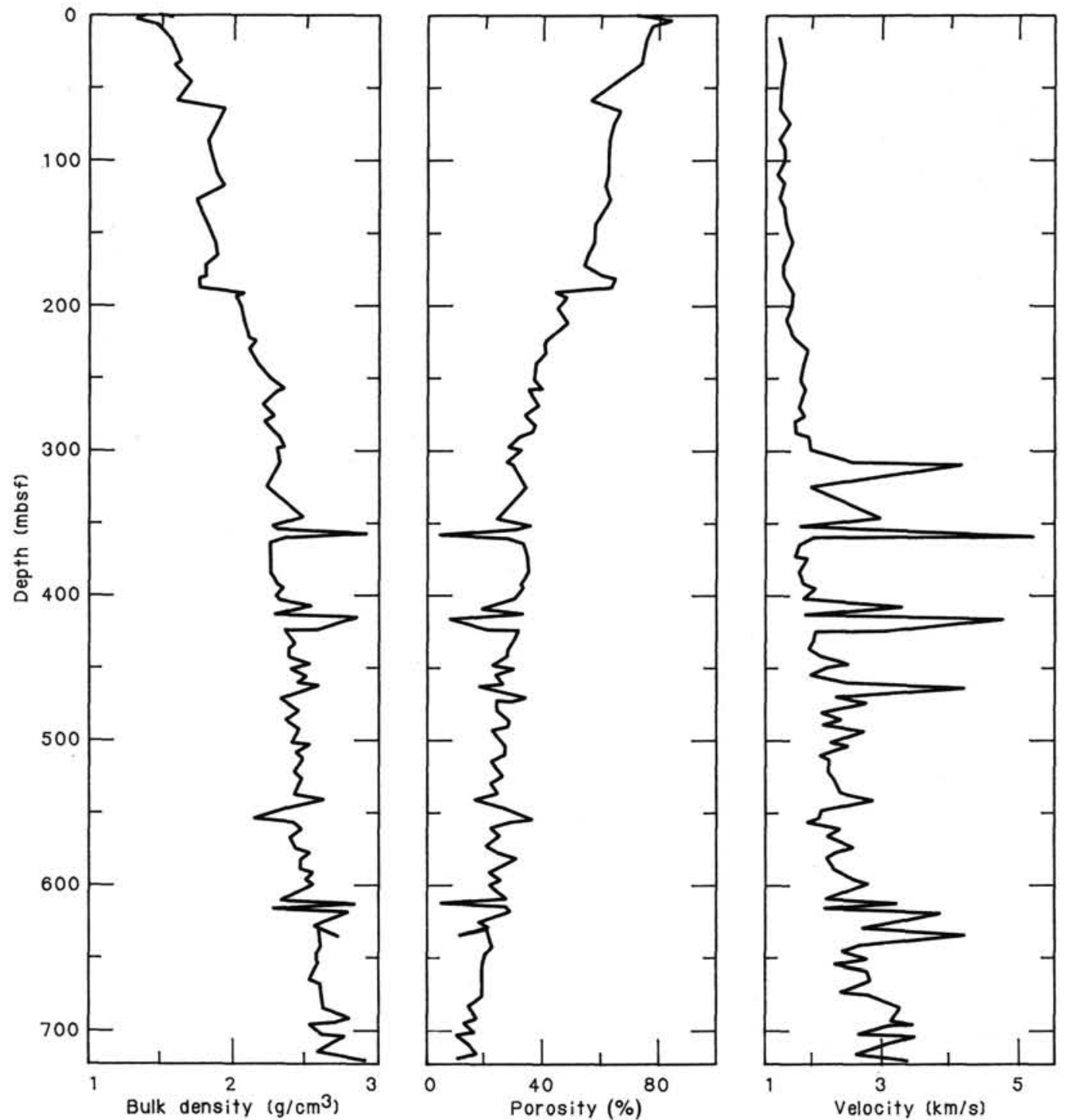

Figure 23. Bulk density, porosity, and velocity vs. depth at Site 652 .

porosity and density trends, interrupted by isolated high and low data points. The porosity values range from about $36 \%$ at $330 \mathrm{mbsf}$ to $13 \%$ at the bottom of the hole. The mean values are associated with clays. The low values $(5 \%-15 \%)$ are associated with well-cemented sandstone, gypsum samples, and to one sample (at $610 \mathrm{mbsf}$ ) containing a high percentage $(11 \%)$ of organic matter. The bulk density curve is symmetrical to the porosity curve; the mean values range from 2.19 to $2.60 \mathrm{~g} / \mathrm{cm}^{3}$ and represent the clays. Here again, five to eight peaks correspond to measurements done on sandstone and gypsum samples. It has to be noted that the deepest measurements (between 680 and $721.1 \mathrm{mbsf}$ ) could define a third unit characterized by a variability of density and porosity.

The compressional-wave velocity plot shows also two main trends:

1. From the seafloor to about $300 \mathrm{mbsf}$ the velocities measured on samples show a constant increase from $1.52 \mathrm{~km} / \mathrm{s}$ at the mud line to $2.00 \mathrm{~km} / \mathrm{s}$ at $298 \mathrm{mbsf}$.

2. Between $300 \mathrm{mbsf}$ and the bottom of the hole: this trend is characterized by a steeper gradient. The measured velocities range from 2.0 to $3.3 \mathrm{~km} / \mathrm{s}$ vs. depth. This interval is complex. We can observe a majority of low values which were measured on clayrich samples; these data constitute the body of the trend. A set of high values is superimposed to the trend and includes about 10 data points. These measurements correspond to cemented sandstones (as high as $4.2 \mathrm{~km} / \mathrm{s}$ ) and/or gypsum samples (as high as $5.2 \mathrm{~km} / \mathrm{s}$ ). Here again the deepest values, between 660 and $721.1 \mathrm{mbsf}$, suggest a possible third unit.

\section{Shear Strength Measurements}

Measurements were done between 65.6 and 231.5 mbsf (Fig. 24). The sediments were too disturbed and soft above $65.6 \mathrm{mbsf}$, and too indurated below $231.5 \mathrm{mbsf}$. The few data we have show an increase of shear strength vs. depth from 24.76 to $73.96 \mathrm{kPa}$. The two anomalously high values $(152.48 \mathrm{kPa}$ at $108.6 \mathrm{mbsf}$ and $136.55 \mathrm{kPa}$ at $222.4 \mathrm{mbsf}$ ) correspond to measurements on ash layers.

\section{Thermal Conductivity}

Thermal conductivity curve is plotted on Figure 24. Extensive discussion of these data will be found in the "Downhole Measurements" section, this chapter. 


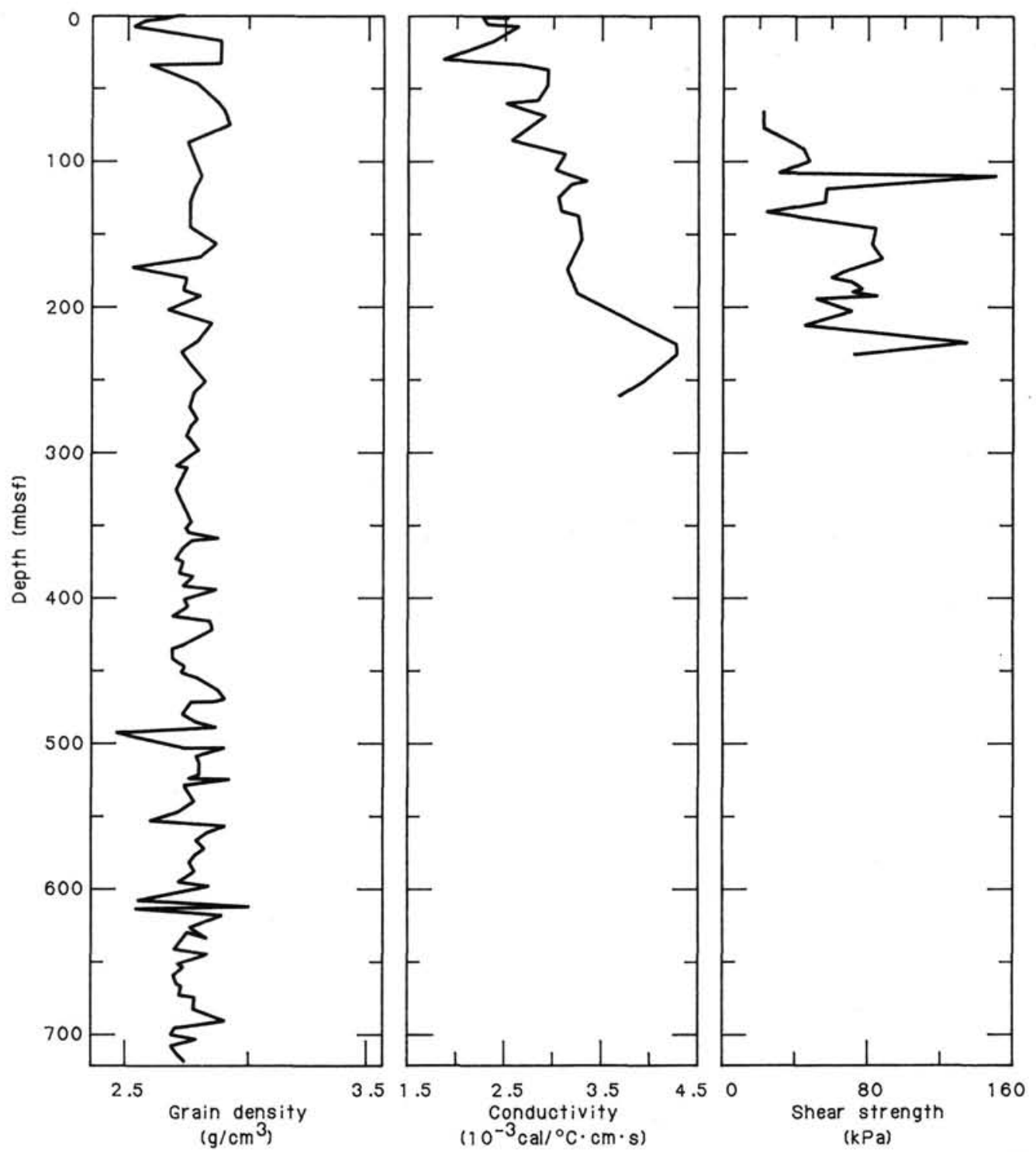

Figure 24. Grain density, thermal conductivity, and shear strength vs. depth at Site 652 .

\section{Discussion - Conclusion}

The physical property measurements at Site 652 show a set of trends, units, and subunits which are in good agreement with both the lithology and acoustic stratigraphy.

\section{Correlation with Lithostratigraphy}

The physical properties analysis at Site 652 underlines the main lithologic units and their boundaries as follows:

1. Lithostratigraphic Unit I, from 0 to 55.4 mbsf (see "Lithostratigraphy" section, this chapter), correlates with a clear gradient of downhole decreasing porosity and increasing density.

2. Lithostratigraphic Unit II (55.4-188.2 mbsf) can be approximately correlated with our physical properties Unit 1-B. This unit is characterized by a decrease of density and of porosity. The base of this unit is underlined by a high porosity $(64 \%)$.

3. The transition between lithostratigraphic Units II and IV is marked by an important change of density and porosity at about 190 mbsf which correlates well with the appearance of barren pre-Pliocene sediments ("Lithostratigraphy" section).
4. Lithostratigraphic Unit IV (188.6-344.8 mbsf) shows well defined porosity and density trends. The first important change of velocity also occurs near the base of this unit.

5. Lithostratigraphic Unit Va (344.8-721.1 mbsf) appears complex on the density, porosity, and velocity curves. Tentatively, seven or eight cycles could be identified. Each of them starts with a high velocity peak at $309.6,358.1,407.3,415.8$, $462.7,541,625.4$, and $635.3 \mathrm{mbsf}$. The porosity and density also identify some of these levels. In a first interpretation, the physical properties seem to correlate with the second-order cycles observed in the lithology. The rich organic matter level (610 mbsf) is characterized by a low velocity, a low density, and a low porosity.

6. Lithostratigraphic Unit $\mathrm{Vb}(683.5-721.1 \mathrm{mbsf})$ is clearly observed in the physical properties and shows alternation of high and low values of porosity, density, and velocity. This can be explained by the diversified lithology observed in this unit.

\section{Correlation with the Seismic Data}

It is interesting to compare the velocity of each main interval defined in the site survey seismic lines with the average velocity measured on the cores: 
1. The average laboratory-measured compressional velocity between the mud line and $215 \mathrm{mbsf}$ is $1.636 \mathrm{~km} / \mathrm{s}$. This is 0.122 $\mathrm{km} / \mathrm{s}$ higher than the $1.514 \mathrm{~km} / \mathrm{s}$ velocity computed from the seismic data for Seismic Unit 1 .

2. The velocities measured between 215 and 340 mbsf have an average of $2.089 \mathrm{~km} / \mathrm{s}$, which is comparable to the seismic velocity of Seismic Unit $2(1.914 \mathrm{~km} / \mathrm{s})$

3. The measured average velocity between 340 and $700 \mathrm{mbsf}$ is $2.654 \mathrm{~km} / \mathrm{s}$, nearly the same as the computed velocities from the site survey seismic line $(2.61 \mathrm{~km} / \mathrm{s})$ for Seismic Unit 3 .

4. The deepest measurements (between 660 and $719 \mathrm{mbsf}$ ) have an average velocity of $3.315 \mathrm{~km} / \mathrm{s}$. This interval was not identified by the velocity analysis: Seismic Unit 4 is characterized, on the site survey line, by a low interval velocity $(2.3 \mathrm{~km} /$ s). According to the correlations between the sedimentary units and the seismic line, this deepest unit was sampled at the site. The discrepancy, between computed velocities on the site survey line and measured velocities on discrete samples, has important consequences: either the computed velocity is right and the prerift unit was not sampled by Hole $652 \mathrm{~A}$, or, more likely, the prerift unit was sampled and the computed velocity will have to be re-evaluated.

\section{GEOCHEMISTRY}

\section{Introduction}

Using methods outlined in the explanatory notes, numerous carbonate and interstitial water analyses were performed on sediments of Site 652. These investigations cover all sedimentary units and nicely corroborate results obtained by other lines of investigation.

\section{Carbonate Analyses}

Data on carbonate content of sample splits are listed in Table 9 and displayed as depth curves in Figure 25.

In this plot two major units correspond to the Pliocene/Pleistocene succession (Cores 1R through 20R-6, $50 \mathrm{~cm}, 188.2 \mathrm{mbsf}$ ) and the Messinian(?) series in the underlying sediments down to a total depth of 720 mbsf: whereas the older, nonmarine facies of the Messinian average $20-30$ weight $\%$ of $\mathrm{CaCO}_{3}$, the onset of fully marine conditions in the lower Pliocene led to the deposition of hemipelagic biogenic oozes averaging 50 weight $\%$ $\mathrm{CaCO}_{3}$. The contact between these units is fairly abrupt.

In the Pleistocene/Pliocene succession (Fig. 26) several second-order phases of carbonate sedimentation can be discerned. Most of these are of relatively short (less than 1 m.y.) duration, and in some instances correspond to coeval sediments exposed in classical land section in Sicily. Duration and interval have been specified by paleontological methods.

In land section in Sicily, sediments overlying the Messinian/ Pliocene boundary are nannofossil chalks of the Trubi Formation (Decima and Wezel, 1973). In Hole 652, the equivalent time is represented by calcareous sediments in the depth interval of 110-188 mbsf. Sandwiched between two homogeneous layers of about $56 \% \mathrm{CaCO}_{3}$, we found a thin layer between 136 and 144 mbsf, averaging only $35 \% \mathrm{CaCO}_{3}$. This layer corresponds to a period of reduced sedimentation rate inferred from paleontological investigation (Fig. 26; see also "Biostratigraphy" section, this chapter). This observation implies that carbonate sedimentation is the determining factor in sedimentation rate for the Pliocene. In contrast, fluctuations in Pleistocene sedimentation rates appear to be unaffected by variability in carbonate sedimentation. Carbonate concentrations gradually decline from values around $50 \%$ to well below $30 \%$ in younger sediments with no apparent correlation with changes in sedimentation rate. Throughout the Pleistocene, the input of siliciclastic and volcanogenic components is the determining factor for sedimentation rates, as was the case for Sites 650 and 651 .
Table 9. Carbonate and organic carbon at Site 652.

\begin{tabular}{|c|c|c|c|c|c|}
\hline Sample & $\begin{array}{c}\text { Depth } \\
\text { (m) }\end{array}$ & $\underset{(\%)}{\mathrm{CaCO}_{3}}$ & $\begin{array}{l}C_{o r g} \\
(\%)\end{array}$ & $\begin{array}{c}\text { Total } \\
\underset{(\%)}{N}\end{array}$ & $\mathrm{C} / \mathrm{N}$ \\
\hline $1-1,0-2$ & 0.0 & 25.30 & & & \\
\hline $1-2,0-2$ & 1.5 & 26.64 & & & \\
\hline $1-2,51-52$ & 2.0 & 25.42 & & & \\
\hline $1-2,115-117$ & 2.6 & 23.89 & & & \\
\hline $2-2,41-47$ & 5.5 & 19.55 & 0.01 & 0.00 & - \\
\hline $2-2,98-100$ & 6.1 & 31.06 & 0.00 & 0.01 & - \\
\hline $2-3,30-31$ & 6.9 & 30.51 & & & \\
\hline $2-3,119-120$ & 7.8 & 6.65 & 0.43 & 0.08 & 5.4 \\
\hline $2-4,27-30$ & 8.4 & 9.52 & & & \\
\hline $3-1,83-84$ & 17.8 & 31.67 & & & \\
\hline $3-1,118-119$ & 18.2 & 21.68 & & & \\
\hline $3-2,0-1$ & 18.5 & 21.69 & & & \\
\hline $3-2,1-2$ & 18.51 & 18.38 & 1.91 & 0.13 & 14.7 \\
\hline $3-2,18-19$ & 18.7 & 8.29 & & & \\
\hline $4-4,80-81$ & 32.0 & 26.98 & & & \\
\hline $4-5,40-43$ & 33.1 & 32.28 & 0.03 & 0.07 & - \\
\hline $4-6,17-20$ & 34.4 & 24.24 & 2.31 & 0.27 & 8.6 \\
\hline $4-6,22-24$ & 34.45 & 24.62 & 1.72 & 0.13 & 13.2 \\
\hline $5-1,6-7$ & 36.5 & 25.11 & 0.09 & 0.00 & - \\
\hline $5-1,27-28$ & 36.7 & 42.77 & & & \\
\hline $6-1,33-35$ & 46.1 & 24.80 & 0.02 & 0.09 & - \\
\hline $6-1,40-42$ & 46.2 & 17.81 & & & \\
\hline $6-1,45-47$ & 46.25 & 5.15 & 4.18 & 0.28 & 14.9 \\
\hline $6-1,53-55$ & 46.3 & 17.81 & 3.50 & 0.36 & 9.7 \\
\hline $6-1,99-100$ & 46.8 & 27.77 & 0.10 & 0.03 & 3.3 \\
\hline $6-1,111-114$ & 46.85 & 25.65 & & & \\
\hline $6-1,133-134$ & 47.0 & 36.11 & & & \\
\hline $7-1,21-22$ & 55.6 & 41.99 & & & \\
\hline $7-3,1-2$ & 58.4 & 33.99 & 0.05 & 0.03 & - \\
\hline $7-3,69-70$ & 59.1 & 49.20 & & & \\
\hline $7-3,126-127$ & 59.6 & 50.86 & & & \\
\hline $7-4,30-32$ & 60.2 & 50.05 & 0.96 & 0.01 & - \\
\hline $8-1,56-57$ & 65.45 & 43.89 & & & \\
\hline $8-1,61-65$ & 65.5 & 37.60 & & & \\
\hline $8-1,113-115$ & 66.0 & 23.23 & 3.30 & 0.03 & - \\
\hline $8-3,81-82$ & 68.7 & 59.33 & & & \\
\hline $9-1,80-83$ & 75.3 & 50.39 & & & \\
\hline $9-2,37-39$ & 76.4 & 29.66 & 2.77 & 0.14 & 19.8 \\
\hline $9-2,96-99$ & 77.0 & 28.11 & 3.11 & & \\
\hline $10-3,100-103$ & 88.2 & 43.28 & & & \\
\hline $10-4,81-82$ & 89.5 & 49.31 & & & \\
\hline $10-6,140-143$ & 93.1 & 55.78 & 0.01 & 0.10 & - \\
\hline $11-3,98-99$ & 97.8 & 50.18 & & & \\
\hline $11-5,130-133$ & 101.1 & 55.35 & 0.01 & 0.00 & - \\
\hline $12-2,78-79$ & 105.3 & 47.80 & & & \\
\hline $12-5,105-108$ & 110.1 & 53.03 & 0.01 & 0.00 & - \\
\hline $13-1,61-62$ & 113.3 & 48.75 & & & \\
\hline $13-3,80-81$ & 116.5 & 62.08 & & & \\
\hline $13-3,119-120$ & 116.9 & 49.38 & 0.16 & 0.07 & 2.7 \\
\hline $13-4,20-23$ & 117.4 & 55.53 & 0.00 & 0.00 & - \\
\hline $13-4,52-53$ & 117.7 & 51.13 & & & \\
\hline $14-1,62-63$ & 122.9 & 67.87 & & & \\
\hline $14-2,71-72$ & 124.5 & 58.77 & & & \\
\hline $14-3,94-95$ & 126.2 & 61.35 & 0.04 & 0.02 & - \\
\hline $15-1,136-137$ & 133.3 & 53.98 & & & \\
\hline $15-2,19-20$ & 133.6 & 54.40 & & & \\
\hline $15-4,18-19$ & 136.6 & 62.08 & 0.09 & 0.02 & 4.5 \\
\hline $15-4,39-40$ & 136.8 & 37.54 & & & \\
\hline $15-5,99-100$ & 138.9 & 21.72 & & & \\
\hline $16-2,82-83$ & 143.8 & 46.93 & & & \\
\hline $16-3,10-13$ & 144.6 & 33.82 & & & \\
\hline $16-4,1-2$ & 146.0 & 52.68 & 0.15 & 0.05 & 3.0 \\
\hline $16-4,66-67$ & 146.7 & 65.86 & & & \\
\hline $16-4,73-74$ & 146.8 & 65.78 & 0.00 & 0.08 & - \\
\hline $16-5,44-45$ & 147.9 & 52.71 & & & \\
\hline $17-2,68-69$ & 153.4 & 47.10 & 1.20 & 0.30 & 4.0 \\
\hline $17-5,113-114$ & 158.3 & 57.46 & & & \\
\hline $18-2,46-47$ & 162.8 & 53.77 & & & \\
\hline $18-2,80-81$ & 163.2 & 58.27 & 0.06 & 0.06 & - \\
\hline $18-3,81-82$ & 164.6 & 57.18 & & & \\
\hline $18-4,93-96$ & 166.2 & 54.59 & & & \\
\hline $18-5,85-86$ & 167.7 & 47.02 & & & \\
\hline $18-6,93-96$ & 169.2 & 52.82 & & & \\
\hline $19-1,47-48$ & 171.0 & 54.09 & & & \\
\hline $19-2,55-58$ & 172.6 & 52.64 & & & \\
\hline $19-4,8-9$ & 175.1 & 39.25 & 0.17 & 0.00 & - \\
\hline $19-5,61-62$ & 177.1 & 44.54 & & & \\
\hline $19-6,137-140$ & 179.4 & 59.31 & & & \\
\hline
\end{tabular}


Table 9 (Continued).

\begin{tabular}{|c|c|c|c|c|c|}
\hline Sample & $\begin{array}{l}\text { Depth } \\
\text { (m) }\end{array}$ & $\begin{array}{c}\mathrm{CaCO}_{3} \\
(\%)\end{array}$ & $\begin{array}{l}\mathrm{C}_{\text {org }} \\
(\%)\end{array}$ & $\begin{array}{c}\text { Total } \\
\mathrm{N} \\
(\%)\end{array}$ & $\mathrm{C} / \mathrm{N}$ \\
\hline $20-1,71-74$ & 180.9 & 45.79 & & & \\
\hline $20-1,100-101$ & 181.2 & 46.33 & 0.45 & 0.05 & 9.0 \\
\hline $20-5,135-138$ & 187.5 & 51.36 & & & \\
\hline $20-6,129-130$ & 189.0 & 20.10 & & & \\
\hline $21-1,100-101$ & 199.8 & 22.36 & & & \\
\hline $21-2,15-18$ & 200.4 & 30.39 & 0.14 & 0.04 & 3.5 \\
\hline $22-2,25-28$ & 201.5 & 19.82 & & & \\
\hline $23-1,100-101$ & 219.1 & 29.18 & & & \\
\hline $24-2,83-84$ & 221.0 & 27.65 & & & \\
\hline $24-2,93-94$ & 221.1 & 20.91 & & & \\
\hline $24-3,63-66$ & 222.3 & 21.69 & & & \\
\hline $24-4,9-10$ & 223.3 & 24.17 & 0.15 & 0.21 & - \\
\hline $24-4,77-80$ & 224.0 & 21.90 & & & \\
\hline $24-4,112-113$ & 224.3 & 36.03 & & & \\
\hline $25-1,40-41$ & 228.8 & 21.24 & & & \\
\hline $25-1,61-62$ & 229.0 & 34.57 & & & \\
\hline $25-1,72-73$ & 229.1 & 37.40 & 0.02 & 0.05 & - \\
\hline $25-2,14-18$ & 230.0 & 23.13 & & & \\
\hline $26-2,40-41$ & 240.0 & 24.14 & 0.08 & 0.08 & - \\
\hline $26-2,89-90$ & 240.5 & 38.53 & & & \\
\hline $26-2,113-117$ & 240.7 & 23.46 & & & \\
\hline $26-c, 5-6$ & 247.5 & 34.07 & & & \\
\hline $27-1,111-112$ & 248.8 & 27.32 & 0.21 & 0.03 & 9.1 \\
\hline $27-3,1-2$ & 250.7 & 23.67 & 0.19 & 0.03 & 6.3 \\
\hline $27-3,10-13$ & 250.8 & 29.38 & & & \\
\hline $28-1,28-31$ & 257.7 & 25.75 & 0.10 & 0.00 & - \\
\hline $28-2,7-10$ & 259.0 & 34.93 & & & \\
\hline $28-2,99-100$ & 259.9 & 24.19 & & & \\
\hline $29-1,121-122$ & 268.3 & 28.45 & & & \\
\hline $29-c, 8-11$ & 276.4 & 27.85 & 0.01 & 0.00 & - \\
\hline $30-1,8-10$ & 276.8 & 33.29 & & & \\
\hline $30-3,55-58$ & 280.3 & 29.51 & 0.00 & 0.12 & - \\
\hline $31-1,143-146$ & 287.7 & 34.89 & & & \\
\hline $31-3,89-91$ & 290.2 & 36.01 & & & \\
\hline $32-1,66-67$ & 296.6 & 24.37 & & & \\
\hline $32-1,97-98$ & 296.9 & 23.82 & & & \\
\hline $32-1,98-99$ & 296.95 & 25.14 & & & \\
\hline $32-1,112-113$ & 297.0 & 38.42 & 0.00 & 0.00 & - \\
\hline $32-2,40-41$ & 297.4 & 24.80 & & & \\
\hline $32-2,70-72$ & 297.7 & 36.28 & & & \\
\hline $32-2,125-127$ & 298.3 & 25.58 & & & \\
\hline $33-1,33-34$ & 305.9 & 30.23 & & & \\
\hline $33-3,49-50$ & 309.1 & 25.49 & 1.45 & 0.09 & 16.1 \\
\hline $34-2,50-51$ & 309.9 & 33.31 & 0.69 & 0.02 & 34.5 \\
\hline $34-2,60-61$ & 317.3 & 27.56 & & & \\
\hline $35-1,44-46$ & 317.4 & 24.73 & 0.08 & 0.00 & - \\
\hline $37-1,49-50$ & 344.8 & 12.80 & & & \\
\hline $37-2,94-96$ & 346.7 & 22.33 & 1.10 & 0.00 & - \\
\hline $37-6,6-8$ & 351.9 & 18.27 & & & \\
\hline $38-1,21-23$ & 354.2 & 18.77 & & & \\
\hline $38-4,99-100$ & 359.5 & 18.84 & & & \\
\hline $38-5,9-12$ & 360.1 & 16.73 & 1.30 & 0.01 & 13.0 \\
\hline $39-1,28-29$ & 364.0 & 27.32 & & & \\
\hline $39-2,6-8$ & 365.3 & 23.42 & & & \\
\hline $39-3,81-82$ & 367.7 & 23.31 & 0.25 & 0.05 & 5.0 \\
\hline $40-1,72-74$ & 374.1 & 26.82 & & & \\
\hline $40-4,100-101$ & 378.9 & 25.47 & & & \\
\hline $40-5,118-120$ & 380.6 & 23.11 & 0.27 & 0.09 & 3.0 \\
\hline $40-7,33-35$ & 382.7 & 22.37 & 0.26 & 0.00 & - \\
\hline $41-1,100-101$ & 384.0 & 24.87 & 0.16 & 0.12 & - \\
\hline $41-2,50-52$ & 385.0 & 20.25 & & & \\
\hline $41-6,30-33$ & 390.8 & 23.43 & & & \\
\hline $42-2,27-29$ & 394.5 & 12.53 & & & \\
\hline $42-3,61-62$ & 396.3 & 29.77 & & & \\
\hline $42-4,144-146$ & 398.6 & 37.93 & & & \\
\hline $42-6,49-50$ & 400.7 & 16.20 & & & \\
\hline $43-1,48-52$ & 402.9 & 39.12 & 0.00 & 0.00 & - \\
\hline $43-1,76-77$ & 403.2 & 40.04 & & & \\
\hline $43-4,38-40$ & 407.25 & 30.64 & & & \\
\hline $43-4,40-41$ & 407.3 & 36.78 & & & \\
\hline $44-2,119-120$ & 414.8 & 26.84 & 0.11 & 0.02 & 5.5 \\
\hline $44-3,93-96$ & 416.0 & 21.61 & 0.36 & 0.02 & 18.0 \\
\hline $45-1,137-139$ & 423.2 & 43.10 & 0.03 & 0.01 & - \\
\hline $45-2,62-64$ & 423.9 & 22.08 & & & \\
\hline $46-1,60-62$ & 432.1 & 26.72 & & & \\
\hline $46-3,55-56$ & 435.1 & 18.87 & & & \\
\hline $46-3,100-102$ & 435.5 & 19.29 & 0.69 & 0.01 & - \\
\hline $47-1,64-66$ & 441.7 & 23.62 & 1.22 & 0.00 & - \\
\hline
\end{tabular}

Table 9 (Continued).

\begin{tabular}{|c|c|c|c|c|c|}
\hline Sample & $\begin{array}{l}\text { Depth } \\
\text { (m) }\end{array}$ & $\begin{array}{c}\mathrm{CaCO}_{3} \\
(\%)\end{array}$ & $\begin{array}{l}C_{\text {org }} \\
(\%)\end{array}$ & $\begin{array}{c}\text { Total } \\
\underset{(\%)}{N}\end{array}$ & $\mathrm{C} / \mathrm{N}$ \\
\hline $47-3,97-98$ & 445.1 & 15.24 & & & \\
\hline $47-5,32-34$ & 447.4 & 37.50 & & & \\
\hline $48-1,8-10$ & 450.8 & 31.63 & & & \\
\hline $48-2,37-38$ & 452.6 & 17.53 & 0.15 & 0.00 & - \\
\hline $48-3,130-133$ & 455.0 & 31.10 & & & \\
\hline $49-1,109-110$ & 461.4 & 17.68 & & & \\
\hline $49-2,23-25$ & 462.0 & 20.99 & & & \\
\hline $49-2,95-97$ & 462.8 & 53.50 & & & \\
\hline $50-1,59-62$ & 470.6 & 7.79 & 0.20 & 0.03 & 6.7 \\
\hline $50-2,47-48$ & 472.0 & 24.58 & & & \\
\hline $50-2,85-86$ & 472.4 & 5.90 & & & \\
\hline $50-3,9-11$ & 473.1 & 24.2 & & & \\
\hline $51-1,13-15$ & 479.7 & 34.20 & 0.09 & 0.00 & - \\
\hline $51-1,79-80$ & 480.4 & 14.55 & & & \\
\hline $51-4,46-47$ & 484.6 & 12.78 & & & \\
\hline $51-5,126-128$ & 486.9 & 33.67 & & & \\
\hline $51-6,44-46$ & 487.5 & 26.41 & & & \\
\hline $52-1,41-42$ & 489.6 & 30.82 & & & \\
\hline $52-2,78-80$ & 491.5 & 30.50 & & & \\
\hline $52-3,138-140$ & 493.6 & 37.26 & & & \\
\hline $52-4,83-84$ & 494.5 & $19: 43$ & & & \\
\hline $53-1,70-71$ & 499.5 & 6.33 & & & \\
\hline $53-3,146-148$ & 503.3 & 22.61 & 0.36 & 0.04 & 9.0 \\
\hline $53-4,14-16$ & 503.4 & 34.61 & & & \\
\hline $54-1,39-40$ & 508.9 & 25.12 & & & \\
\hline $54-1,96-98$ & 509.5 & 25.73 & & & \\
\hline $54-3,119-120$ & 512.7 & 17.98 & 0.18 & 0.08 & - \\
\hline $54-3,132-135$ & 512.8 & 26.01 & 0.16 & 0.03 & 5.3 \\
\hline $55-1,60-61$ & 518.7 & 22.65 & & & \\
\hline $55-2,60-61$ & 520.2 & 23.98 & 0.80 & 0.10 & 8.0 \\
\hline $55-3,30-32$ & 521.4 & 30.23 & & & \\
\hline $55-5,145-148$ & 525.6 & 17.53 & & & \\
\hline $56-2,32-34$ & 529.6 & 29.25 & & & \\
\hline $56-6,11-13$ & 535.4 & 23.89 & 0.16 & 0.05 & 3.2 \\
\hline $57-1,26-28$ & 537.7 & 29.25 & & & \\
\hline $57-3,62-64$ & 541.0 & 43.93 & 0.15 & 0.03 & 5.0 \\
\hline $57-3,89-90$ & 541.3 & 23.30 & & & \\
\hline $57-3,119-120$ & 541.6 & 22.37 & & & \\
\hline $58-1,21-22$ & 546.8 & 32.80 & & & \\
\hline $58-1,48-50$ & 547.1 & 21.71 & 0.23 & 0.05 & 4.6 \\
\hline $58-6,30-32$ & 554.4 & 3.96 & & & \\
\hline $59-1,7-9$ & 556.4 & 27.03 & & & \\
\hline $59-2,140-150$ & 559.2 & 7.19 & 1.00 & n.d. & \\
\hline $59-4,18-20$ & 561.0 & 21.57 & & & \\
\hline $60-1,16-18$ & 566.2 & 15.60 & & & \\
\hline $60-1,87-88$ & 566.9 & 27.1 & 0.26 & 0.08 & 3.2 \\
\hline $60-3,100-101$ & 570.0 & 23.70 & & & \\
\hline $60-5,106-108$ & 573.1 & 3.18 & & & \\
\hline $61-1,146-148$ & 577.1 & 12.11 & & & \\
\hline $61-2,2-4$ & 577.15 & 21.33 & & & \\
\hline $61-2,100-101$ & 578.1 & 26.82 & & & \\
\hline $61-2,106-107$ & 578.15 & 37.94 & 0.00 & 0.04 & - \\
\hline $61-5,90-91$ & 582.5 & 26.94 & & & \\
\hline $62-3,91-92$ & 589.1 & 24.43 & 0.14 & 0.16 & - \\
\hline $62-4,112-114$ & 590.8 & 12.21 & & & \\
\hline $63-2,139-140$ & 597.8 & 25.54 & 0.13 & n.d. & - \\
\hline $63-3,40-42$ & 598.3 & 2.07 & 1.98 & 0.40 & 5.0 \\
\hline $64-1,23-24$ & 604.7 & 37.51 & 0.55 & 0.00 & - \\
\hline $64-1,92-94$ & 605.4 & 17.58 & 10.22 & 0.67 & 15.3 \\
\hline $64-1,103-104$ & 605.5 & 16.25 & 11.41 & 0.39 & 29.3 \\
\hline $64-1,104-111$ & 605.55 & 1.21 & 8.45 & 0.38 & 22.2 \\
\hline $64-1,104-107$ & 605.57 & 18.28 & 9.57 & 0.24 & 39.8 \\
\hline $64-3,0-1$ & 607.5 & 6.23 & 0.40 & n.d. & - \\
\hline $64-3,22-23$ & 607.7 & 30.46 & 0.00 & 0.07 & - \\
\hline $64-3,59-61$ & 608.1 & 44.75 & 0.14 & 0.00 & - \\
\hline $64-4,2-4$ & 609.0 & 50.53 & & & \\
\hline $65-2,9-11$ & 615.8 & 19.15 & & & \\
\hline $65-2,55-57$ & 616.3 & 16.81 & & & \\
\hline $65-2,77-79$ & 616.5 & 35.83 & & & \\
\hline $65-2,91-94$ & 616.6 & 10.78 & & & \\
\hline $65-2,109-111$ & 616.8 & 16.43 & & & \\
\hline $65-4,2-4$ & 618.7 & 9.61 & & & \\
\hline $65-6,105-108$ & 622.8 & 17.30 & & & \\
\hline $66-1,90-92$ & 625.4 & 37.88 & 0.60 & 0.18 & 3.4 \\
\hline $66-3,24-25$ & 627.7 & 22.62 & & & \\
\hline $66-3,119-120$ & 628.7 & 21.93 & 0.25 & n.d. & - \\
\hline $67-1,107-109$ & 635.3 & 18.65 & 3.58 & 0.19 & 18.9 \\
\hline $67-2,77-78$ & 636.5 & 29.43 & & & \\
\hline
\end{tabular}


Table 9 (Continued).

\begin{tabular}{|c|c|c|c|c|c|}
\hline Sample & $\begin{array}{c}\text { Depth } \\
\text { (m) }\end{array}$ & $\begin{array}{c}\mathrm{CaCO}_{3} \\
(\%)\end{array}$ & $\begin{array}{l}C_{\text {org }} \\
(\%)\end{array}$ & $\begin{array}{c}\text { Total } \\
\mathrm{N} \\
(\%)\end{array}$ & $\mathrm{C} / \mathrm{N}$ \\
\hline $67-5,144-146$ & 641.6 & 17.34 & & & \\
\hline $68-1,2-4$ & 653.4 & 45.55 & 0.53 & 0.11 & 4.8 \\
\hline $68-1,24-25$ & 644.0 & 15.18 & & & \\
\hline $68-1,146-148$ & 645.3 & 19.69 & 1.57 & 0.12 & 13.0 \\
\hline $69-3,47-48$ & 656.9 & 14.70 & & & \\
\hline $69-4,70-72$ & 658.6 & 24.54 & & & \\
\hline $70-2,64-66$ & 665.2 & 20.96 & 0.39 & 0.13 & 3.0 \\
\hline $70-3,119-120$ & 667.3 & 19.43 & 0.22 & n.d. & - \\
\hline $70-4,24-26$ & 667.8 & 37.3 & & & \\
\hline $71-1,78-80$ & 673.6 & 21.47 & 0.19 & 0.14 & - \\
\hline $71-2,45-47$ & 674.8 & 23.70 & & & \\
\hline $72-1,24-25$ & 682.7 & 12.05 & & & \\
\hline $72-1,54-56$ & 683.0 & 31.77 & & & \\
\hline $72-2,55-57$ & 684.6 & 34.62 & & & \\
\hline $72-2,80-82$ & 684.9 & 9.83 & 3.51 & 0.14 & 25.0 \\
\hline $73-1,70-71$ & 692.9 & 28.47 & 0.64 & 0.22 & 3.0 \\
\hline $73-2,119-120$ & 694.9 & 38.01 & 0.02 & & \\
\hline $73-3,99-100$ & 696.2 & 24.15 & 0.11 & n.d. & - \\
\hline $74-1,4-6$ & 701.9 & 17.92 & & & \\
\hline $74-2,54-56$ & 703.9 & 33.99 & & & \\
\hline $74-4,0-1$ & 706.4 & 16.73 & 0.78 & n.d. & - \\
\hline $74-4,97-98$ & 707.4 & 7.87 & & & \\
\hline $74-5,52-54$ & 708.4 & 21.95 & & & \\
\hline $75-c, 1-2$ & 720.0 & 41.28 & 0.06 & n.d. & - \\
\hline
\end{tabular}

In sediments of inferred Messinian age carbonate concentrations cluster around $20 \% \mathrm{CaCO}_{3}$ with major fluctuations resulting from grain size effects: Coarse grained siltstones and sandstones apparently are more calcareous due perhaps to a higher contribution of allochthonous carbonate (as much as 50\%), while mudstones and claystones range from $10 \%$ to $20 \%$ $\mathrm{CaCO}_{3}$. The carbonate content of Messinian(?) sediments is further discussed in "Downhole Measurements" section, this chapter.

\section{Interstitial waters}

The presence of nonmarine facies underlying the marine series of Pliocene/Pleistocene age leaves a distinct imprint on the chemistry of interstitial waters obtained from sediments of all ages (Table 10, Fig. 27). Whereas in preceeding holes of this cruise diagenesis of authigenic and allochthonous minerals determined the composition of the pore fluid, concentration gradients in Hole $652 \mathrm{~A}$ are best explained by assuming dissolution of evaporitic minerals at depth, and subsequent migration along concentration gradients toward the seawater/sediment interface. In comparison, effects of dolomitization on $\mathrm{Mg}^{2+}$ and $\mathrm{Ca}^{2+}$ content, of sulfate reduction, and of neoformation of silicates are not readily discernible, and the shapes of the respective curves suggest an almost conservative behavior. In depth plots of major ions, concentrations of salinity-related components (calcium, magnesium, chlorinity, and sulfate) reach a maximum at about 495 mbsf. This interval corresponds to a maximum depth of occurrence of abundant evaporitic sulfate minerals in the recovered sediments. From the shape of the individual curves with depth, we can formulate some preliminary hypotheses about: (1) flux of components from the underlying salts to the deep water body overlying this site, (2) suggest mineral species present in the evaporite-bearing zone, and (3) get some ideas about changes in physical properties at the Messinian/Pliocene boundary. These hypotheses have to be verified by more detailed studies in subsequent investigations.

The most prominent ions are $\mathrm{Cl}^{-}$and $\mathrm{Ca}^{2+}$ with concentrations of $1430 \mathrm{mmol} / \mathrm{L}$ and $238 \mathrm{mmol} / \mathrm{L}$, respectively, at a depth of approximately 560 mbsf. $\mathrm{SO}_{4}{ }^{2-}$ concentrations deviate little from a mean value of about $26 \mathrm{mmol} / \mathrm{L}$. The most abundant mineral of evaporite facies is anhydrite at this depth. According to Manheim and Sayles (1974), a reasonably straight gradient of any one ion in concentration/depth curves suggests that time since emplacement of salt was long enough and subsequent sedimentation was slow enough to permit equilibration between diffusion/compaction and dissolution at depth. A simple formula permits calculating the flux of a component along this gradient:

$$
F=-K \frac{d c}{d x}
$$

where $\mathrm{K}$ is the diffusion coefficient of a given component (in the case of $\mathrm{Cl}^{-}, \mathrm{K}=3 \times 10^{-6} \mathrm{~cm}^{2} / \mathrm{s}$ ), dc is the difference in concentration between seawater and pore water at $560 \mathrm{mbsf}$ (i.e., $230 \mathrm{mmol} / \mathrm{L}$ ), and $\mathrm{dx}$ is the path length, that is the thickness of overlying sediments $(56,000 \mathrm{~cm})$. The resulting flux of $\mathrm{Cl}^{-}$to the lower water column overlying the sediments thus amounts to about $1.6 \times 10^{-8} \mathrm{mmol} / \mathrm{L} \mathrm{Cl}^{-} / \mathrm{s} / \mathrm{cm}^{2}$.

From the shape of the magnesium depth plot, we may infer that magnesium concentrations also are controlled by dissolution of evaporite minerals and are little affected by diagenetic uptake by carbonates and silicates along the path. Considering the ample supply of magnesium from below, we can expect that dolomitization and smectite formation in the overlying sediments has reached an equilibrium. X-ray diffraction studies may be a suitable means for verifying this. Possible magnesium-bearing candidates for dissolution are the minerals kieserite $\left(\mathrm{MgSO}_{4} \cdot \mathrm{H}_{2} \mathrm{O}\right)$ and certain magnesium halides, but their presence in the Messinian sediments of this depth ( $560 \mathrm{mbsf}$ ) has yet to be confirmed. The steady concentration curve for samples underlying sample $652-51 \mathrm{R}-4,140-150 \mathrm{~cm}$ suggests that this interval indeed corresponds to the peak of evaporite facies evolution in the sequence studied here.

In the case of chlorinity and magnesium, we observe no gradient in samples overlying the Messinian/Pliocene boundary at approximately 180 mbsf. In samples overlying this boundary, straight lines connect the concentrations with that of the seawater/sediment interface.

\section{Organic Geochemistry}

Hole 652A provided samples of elevated organic carbon content in the Pleistocene as well as in the Messinian(?) succession. In the first case, sapropels of a few centimeters thickness (see "Lithostratigraphy" section, this chapter) with organic carbon concentrations greater than $2 \%$ were encountered in Samples 4R-6, 17-20 cm (34.4 mbsf); 6R-1, 45-55 cm (46.3 mbsf); 8R-1, $113-115 \mathrm{~cm}$ (66.9 mbsf); 9R-2, 37-39 cm (76.5 mbsf); and 9R-2, 96-99 cm (77.0 mbsf) (see Table 9). If we assume a linear sedimentation rate on the order of that computed for over- and underlying sediments (about $5 \mathrm{~mm} / 1000 \mathrm{yr}$ ), most of these layers must have been deposited over several hundreds of years in an environment of reduced benthic activity.

Invariably, these organic-matter-rich strata are sandwiched between organic-matter-lean sediments. Average values of $\mathrm{C}_{\text {org }}$ content for hemipelagic background sediment are only $0.1 \%$ $\mathrm{C}_{\text {org }}$ by unit weight, whereas an average of nine sapropelic samples yielded $2.8 \% \mathrm{C}_{\text {org }}$ (see Fig. 28).

The lower contact appears to be gradational in some cases, with reciprocal concentration of mineral carbon and organic carbon accompanying the lithological changes. In other instances, graded bedding and sharp basal contacts are found. Thus, these sapropels are very similar to the ones described from previous DSDP sites throughout the eastern Mediterranean (Kidd et al., 1978).

Using an empirical relationship between organic matter content, benthic consumption, and sedimentation rate (Mueller and 


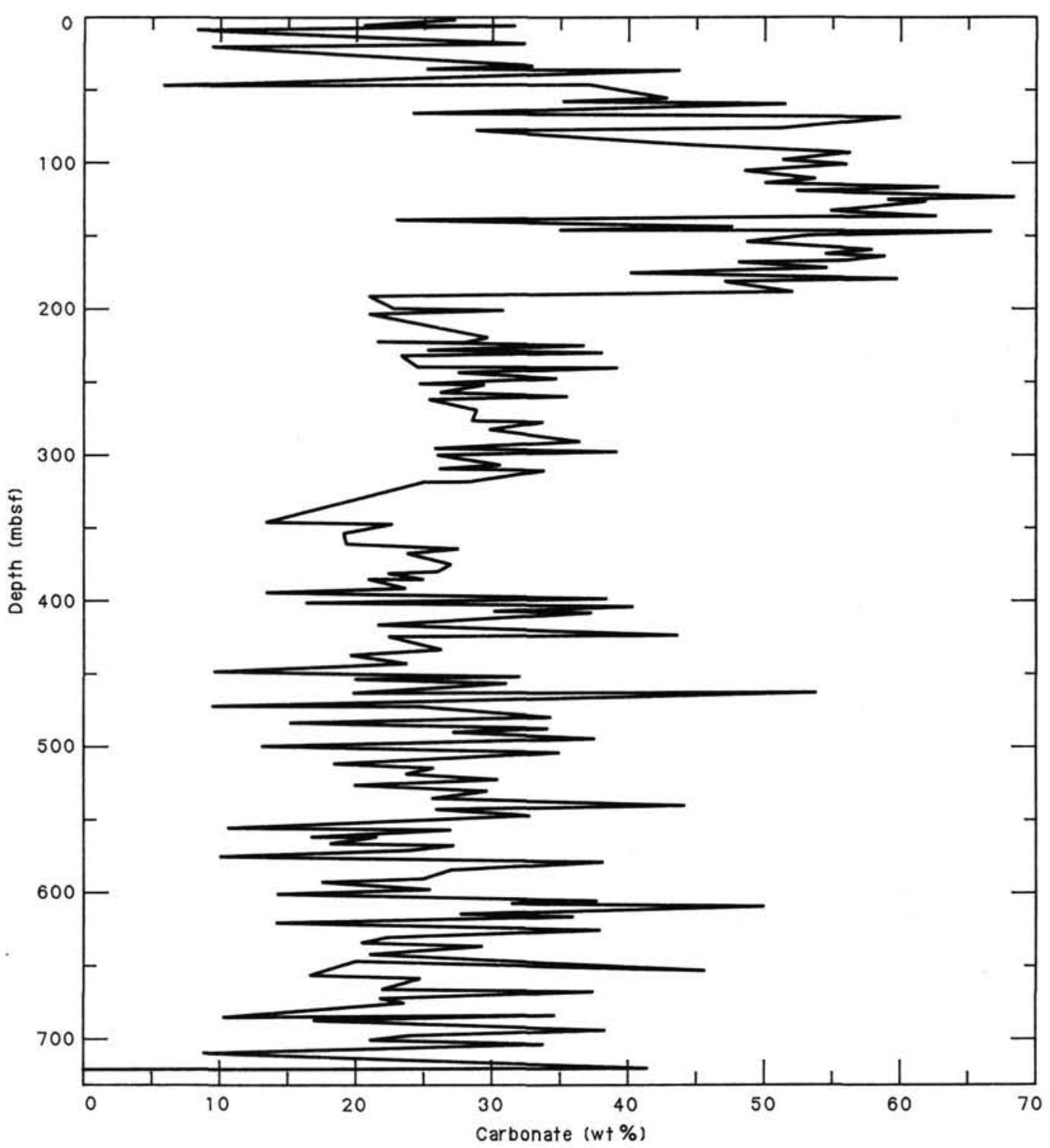

Figure 25. Plot of weight $\% \mathrm{CaCO}_{3}$ vs. depth for Hole $652 \mathrm{~A}$.

Suess, 1979), we can roughly estimate the amount of primary production in the euphotic zone of the overlying water column for various times within the Pleistocene and Pliocene: $\mathrm{PP}=\mathrm{C}$ $\times\left(\mathrm{D}(1-\mathrm{P}) / 0.003 \mathrm{~S}^{0.3}\right)$; where $\mathrm{PP}=$ primary productivity $(\mathrm{gCl}$ $\left.\mathrm{m}^{2} / \mathrm{yr}\right), \mathrm{C}=$ weight $\% \mathrm{C}_{\text {org }}, \mathrm{D}=$ grain density, $\mathrm{P}=$ porosity, and $\mathrm{s}=$ linear sedimentation rate in $\mathrm{cm} / 1000 \mathrm{yr}$. This relationship is valid only for hemipelagic sediments.

Values thus computed for the background values of the Pleistocene and Pliocene succession indicate relatively low productivity, ranging from a minimum of $2 \mathrm{gC} / \mathrm{m}^{2} / \mathrm{yr}$ at the top of the Pliocene to $86 \mathrm{gC} / \mathrm{m}^{2} / \mathrm{yr}$ in the lowermost Pliocene. Recent primary production over the continental margins of the Mediterranean Sea is in the range of $100 \mathrm{gC} / \mathrm{m}^{2} / \mathrm{yr}$ (Romankevich, 1984).

Organic carbon concentrations in the pre-Pliocene nonmarine sediments drilled from about $188 \mathrm{mbsf}$ to the total depth of 721 mbsf were found to contain elevated values when compared to the marine succession. An average of $0.34 \% \mathrm{C}_{\text {org }}$ was computed for the background lithology, with a relatively high standard deviation of 0.39 . With respect to background lithology, we assume that, in analogy to modern lacustrine or marginal marine sediments, organic carbon concentrations may be as high as $1 \%$ without requiring anaerobic conditions in the lower water column (Demaison and Moore, 1980).

On the other hand, anaerobic conditions were most likely established during the deposition of sediments in Core 64R (604.5$614.2 \mathrm{mbsf}$ ). Section 1 of this core contains an approximately 50 -cm-thick interval of laminated, petroliferous oil shales with a maximum $\% \mathrm{C}_{\text {org }}$ of $11.4 \%$. These "paper shale"-like sediments are laminated on a millimetric scale and consist of alternations of organic and inorganic layers resembling varves or certain boghead deposits. In these sediments, aquatic euryhaline algaemost notably of colony-forming chlorophyceae related to the genus Botryococcus braunii - were deposited as distinct layers and could be indicative of massive blooms in highly productive surface waters. Intercalations of clastic sediments represent times of lower surface productivity or increased input of clastics. The excellent preservation of these fine laminations (Fig. 29), the extremely high organic carbon content, and the nature of the organic matter (see below) suggest a restricted and possibly brackish, highly productive, anoxic basin equivalent to the famous Green River Formation of the Western Interior of the United States and the Messel oil shale in Germany. This kind of envi- 


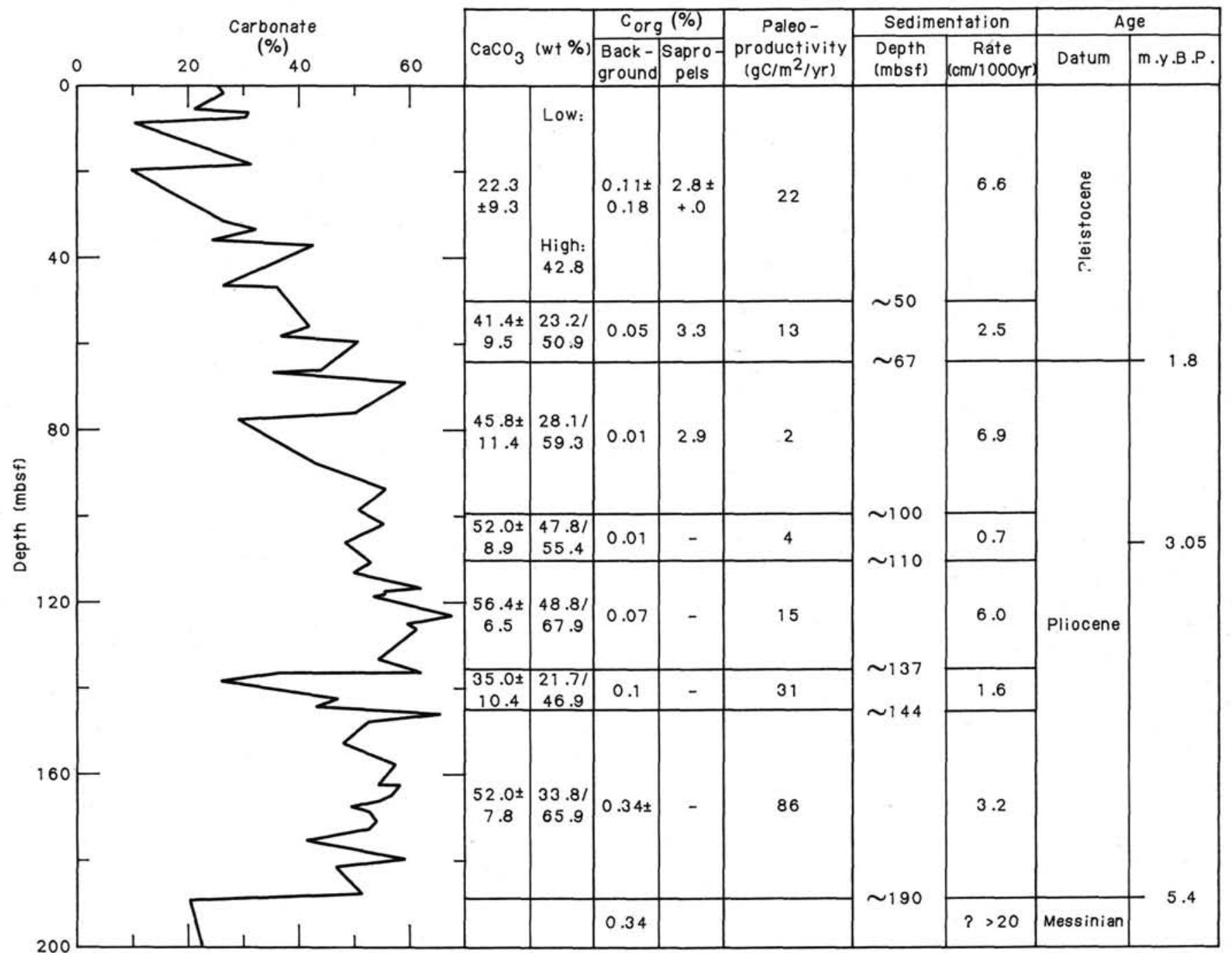

Figure 26. Plot of weight $\% \mathrm{CaCO}_{3}$ vs. depth for the Pliocene/Pleistocene interval of Hole $652 \mathrm{~A}$. Average values for individual components were computed for sedimentary units or paleontological units (see Fig. 15). Average $\mathrm{C}_{\text {org }} \%$ were computed without sapropel values to give values of background lithologies. Also given is a computed value for paleoproductivity based on sedimentation rate and organic carbon content (see text for explanation).

Table 10. Summary of interstitial water analyses from Site 652 .

\begin{tabular}{lrllllllll}
\hline \multicolumn{1}{c}{ Sample no. } & Depth & Sal. & Alk. & $\mathrm{pH}$ & $\mathrm{Cl}^{-}$ & $\mathrm{SO}_{4}{ }^{2-}$ & $\mathrm{Ca}^{2+}$ & $\mathrm{Mg}^{2+}$ & $\mathrm{Ca} / \mathrm{Mg}$ \\
\hline Surface & 0.0 & 39.0 & 2.39 & 8.19 & 608 & 29.7 & 6.8 & 64.8 & 0.11 \\
1R-1, 140-150 & 1.4 & 37.9 & 3.17 & 7.72 & 614 & 30.1 & 15.4 & 62.5 & 0.25 \\
9R-1, 140-150 & 75.9 & 38.5 & 2.89 & 7.43 & 645 & 24.5 & 17.9 & 59.0 & 0.30 \\
14R-3, 140-150 & 126.7 & n.d. & 2.33 & 7.33 & 625 & 23.6 & 26.9 & 57.8 & 0.47 \\
20R-5, 140-150 & 187.6 & 45.0 & 1.98 & 7.35 & 673 & 22.6 & 44.9 & 56.7 & 0.79 \\
25R-1, 140-150 & 229.8 & 47.0 & 2.38 & 7.12 & 770 & 25.9 & 63.1 & 56.2 & 1.12 \\
30R-2, 140-150 & 279.6 & n.d. & 2.68 & 7.22 & 842 & 28.2 & 70.7 & 67.2 & 1.05 \\
38R-4, 140-150 & 359.9 & 65.0 & n.d. & 7.26 & 998 & 27.9 & 104.9 & 67.9 & 1.54 \\
43R-5, 140-150 & 409.8 & 70.5 & 1.72 & 6.90 & 1080 & 26.9 & 131.4 & 82.7 & 1.59 \\
51R-4, 140-150 & 485.5 & 95.0 & n.d. & n.d. & 1428 & 25.4 & 237.7 & 95.2 & 2.50 \\
59R-2, 140-150 & 559.2 & 82.5 & 2.02 & 6.87 & 1368 & 25.1 & 176.0 & 75.9 & 2.32 \\
64R-2, 140-150 & 607.4 & 82.0 & 2.40 & 7.21 & 1323 & 21.8 & 171.9 & 74.0 & 2.32 \\
\hline
\end{tabular}

Chemical analyses of interstitial water samples, Leg 107/Hole 652A. Sample no.: Hole 652A, Core-Section, Interval. Depth is given in meters below seafloor. Sal.: Salinity in parts per thousand; Alk.: Alkalinity in $\mathrm{mmol} / \mathrm{L} ; \mathrm{Cl}^{-}, \mathrm{SO}_{4}{ }^{2-}, \mathrm{Ca}^{2+}, \mathrm{Mg}^{2+}$ are given in $\mathrm{mmol} / \mathrm{L}$. n.d. $=$ not measured. 


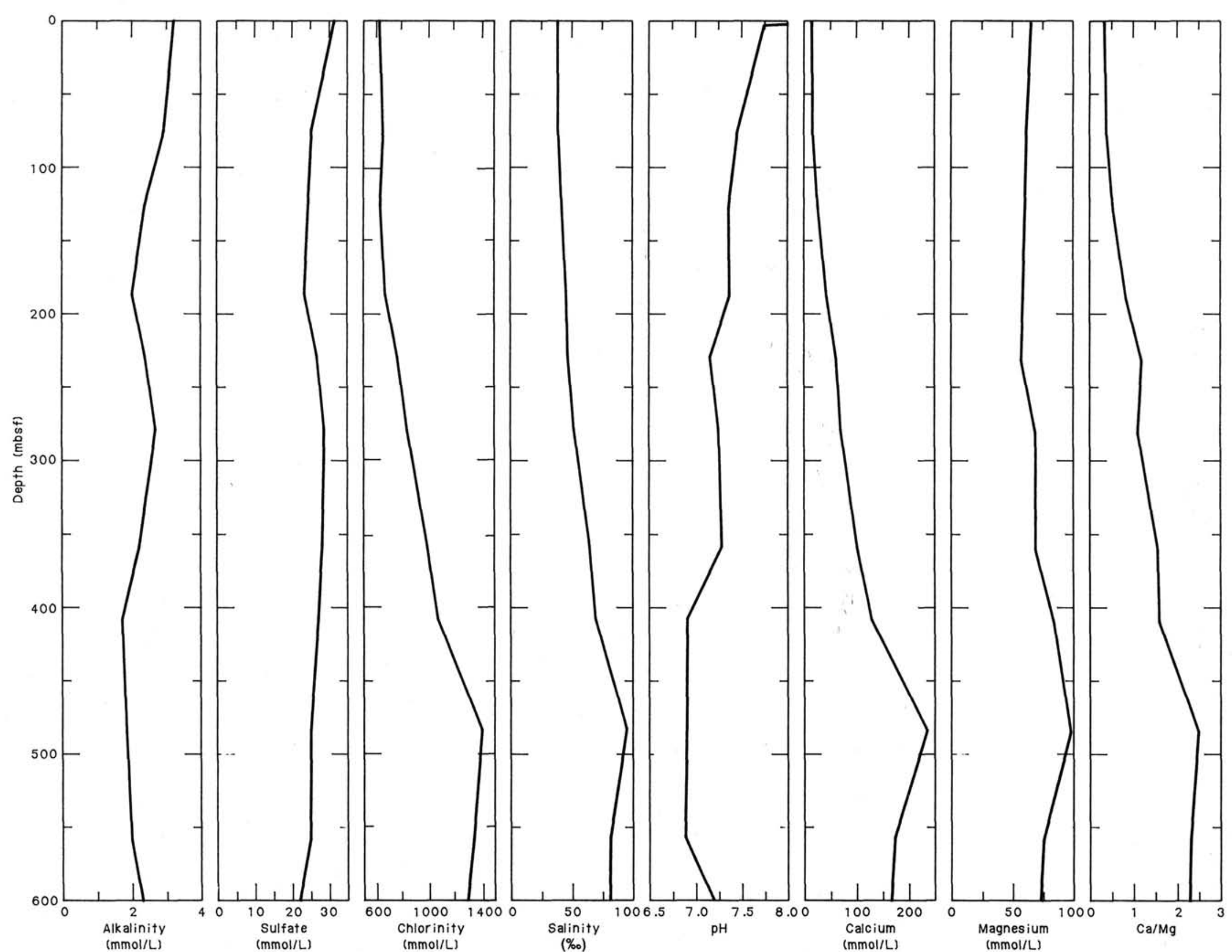

Figure 27. Plot of major ions, $\mathrm{pH}$, salinity, and $\mathrm{Ca} / \mathrm{Mg}$ ratios vs. depth in interstitial waters of Hole $652 \mathrm{~A}$ 


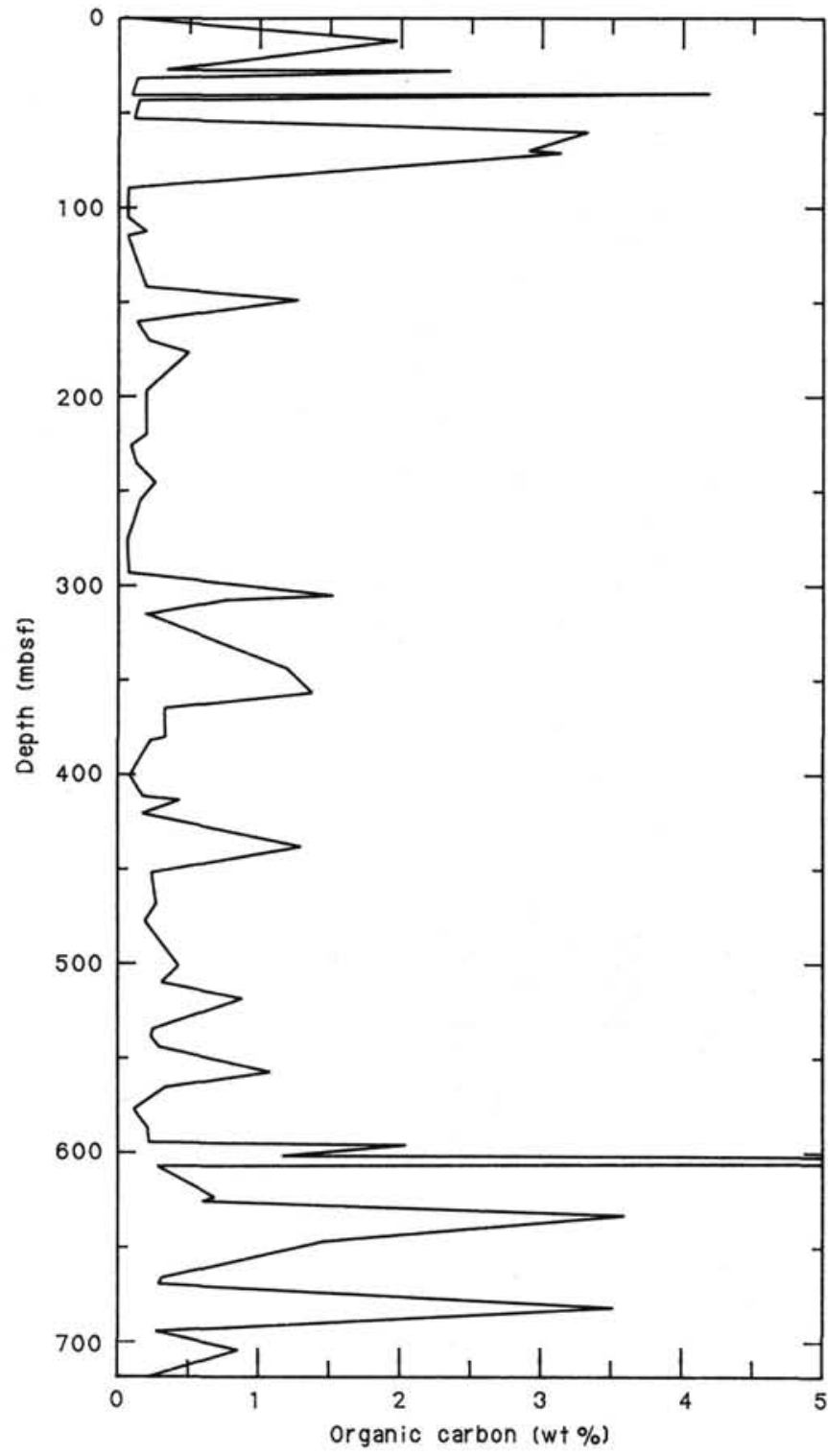

Figure 28. Weight $\%$ organic carbon vs. depth, Hole $652 \mathrm{~A}$.

ronment, found today in saline lakes like the Great Salt Lake of Utah, is commonly associated with evaporitic facies.

Sediments containing enough kerogen type I, lipid-rich with abundant aliphatic chains, are regarded as excellent oil source rocks. The sediments drilled in this interval may indeed be an ideal oil source rock as verified by the results of downhole gas monitoring and gas chromatography performed on the saturated fraction of a methanol/toluene total extract of this rock. These results are presented and briefly discussed in the following section.

\section{Hydrocarbon Extracts}

We extracted the soluble organic matter of seven samples of Pleistocene and Messinian age in order to (1) get an idea of the provenance and the thermal maturity of organic matter in organic-carbon-rich sediments, (2) contrast these organic-carbonrich sediments with adjacent lean sediments, and (3) reconstruct environments of deposition with the emerging geochemical fingerprints. (Methods used are described in the "Explanatory
Notes" section, this volume.) Results are given in Figure 30 and Table 11.

Preliminary evaluation of geochemical fingerprints suggest that Pleistocene sapropels of Hole 652 are immature and contain a mixture of marine and continental lipids. In the case of Sample 4R-6, $17 \mathrm{~cm}$ and $6 \mathrm{R}-1,40 \mathrm{~cm}$, anoxic conditions in the environment of deposition are indicated by low pristane/phytane ratios. In contrast, the organic-matter-rich Sample $6 \mathrm{R}-1$, $53 \mathrm{~cm}$, separated by a few centimeters from the latter, suggests dominant preservation of marine derived organic matter under oxic conditions.

Two samples of Messinian age were particularly interesting because a thermal gradient flow of $14^{\circ} \mathrm{C} / 100 \mathrm{~m}$ (see "Downhole Measurements" section, this chapter) led to thermal cracking of oil precursors and resulted in the formation of considerable amounts of $n$-alkanes in these sediments. Sample 59R-2, 140 $\mathrm{cm}$ at 560 mbsf represents Messinian background lithology in spite of its relatively high $\mathrm{C}_{\mathrm{org}}$ content of $1 \%$. The saturated hydrocarbons are dominated by medium length $n$-alkanes with a maximum at $n-C_{22}$. Thermal evolution removed all traces of odd-even predominance inherited from organic source material. Judging from the pristane/phytane ratio of 1.4, the environment of deposition was oxic. In contrast to this finding for the background lithology, extracts of Sample $64 \mathrm{R}-1,103 \mathrm{~cm}$, are characterized by short chain $n$-alkanes with a maximum at $n-C_{15}$ and a low pristane/phytane ratio of 0.3 . This suggests an aquatic source of kerogen and pronounced anoxia in the sediment. Safety of the JOIDES Resolution was never at stake during drilling as this oil-shale-bearing interval was only about $50 \mathrm{~cm}$ thick.

\section{$C_{I}-C_{5}$ Hydrocarbons Measured at Site 652}

Site 652 was never considered a safety hazard, because of the minor overall quantities of gas recovered. The gas did, however, show a distinct trend which can be related to thermal maturation of the sedimentary organic matter. No gas was found in sediments shallower than 115 mbsf. Analysis of vacutainers yielded extremely minor quantities of gas throughout the entire hole. No gas pockets were observed through the core liner, so the lack of free gas was not suprising. Of more inierest were the results of the headspace analysis. At approximately $115 \mathrm{mbsf}$ small amounts of methane (approximately $2-3 \mathrm{ppm} / 10 \mathrm{~cm}^{3}$ of sample) were measured. Low amounts of $C_{1}$ were present in all samples taken below this depth, while hydrocarbon gas of higher molecular weight was not detected until approximately 380 mbsf. At this depth, the amount of $C_{1}$ in the sediment began to increase and small amounts of $C_{2}$ through $C_{4}$ were measured (see Table 12 and Fig. 31). Quantities of $C_{1}$ through $C_{4}$

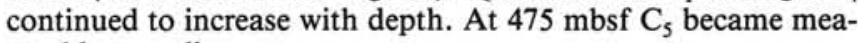
surable as well.

With regard to safety, a decrease in the ratio of $C_{1}$ to the combined quantities of $\mathrm{C}_{2+}$ is of more consequence than an increase in overall values with depth. In the safety monitoring procedures of ODP, potential hazards from accumulations of hydrocarbon gases are evaluated by the ratio $\mathrm{C}_{1} / \mathrm{C}_{2-5}$ (Emeis and Kvenvolden, 1986). Vacutainer studies have characterized gases with ratios greater than 1000 to be of biogenic origin, and those less than 50 to be of thermogenic origin (Simoneit, 1982). Although the actual delimiting values from vacutainer studies cannot be directly related to the values of the ratios attained from headspace analysis, preliminary investigation of the two methods suggests a higher resolution of the headspace technique in sediments of low overall gas concentration (compare Figs. 31 and 32). While vacutainers contain a comparably higher proportion of volatile methane, thermal heating during the headspace technique desorbs gas of higher molecular weight adsorbed to sediment particles. Further studies are necessary to confirm this finding. 


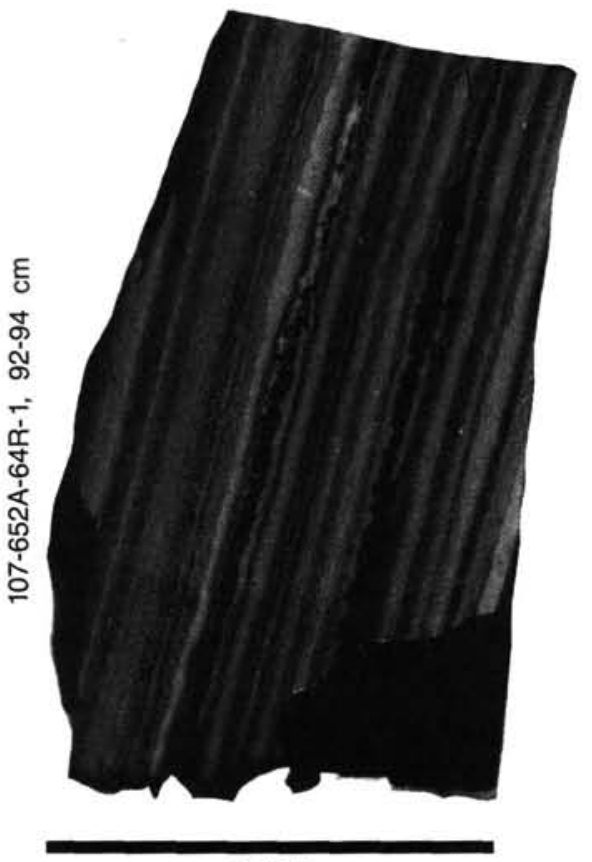

$1.7 \mathrm{~cm}$

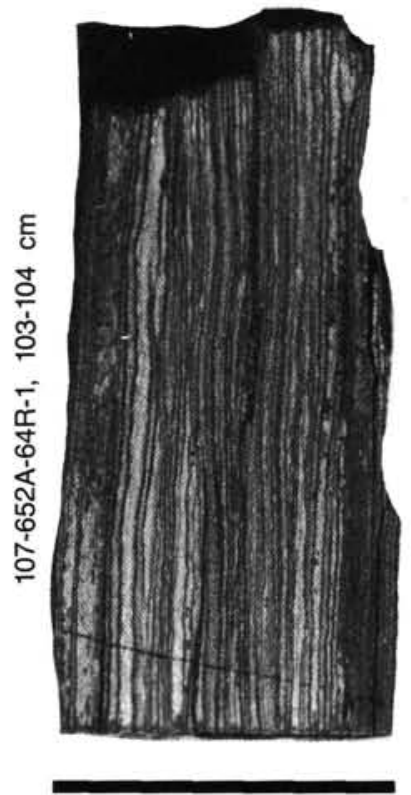

$0.9 \mathrm{~cm}$

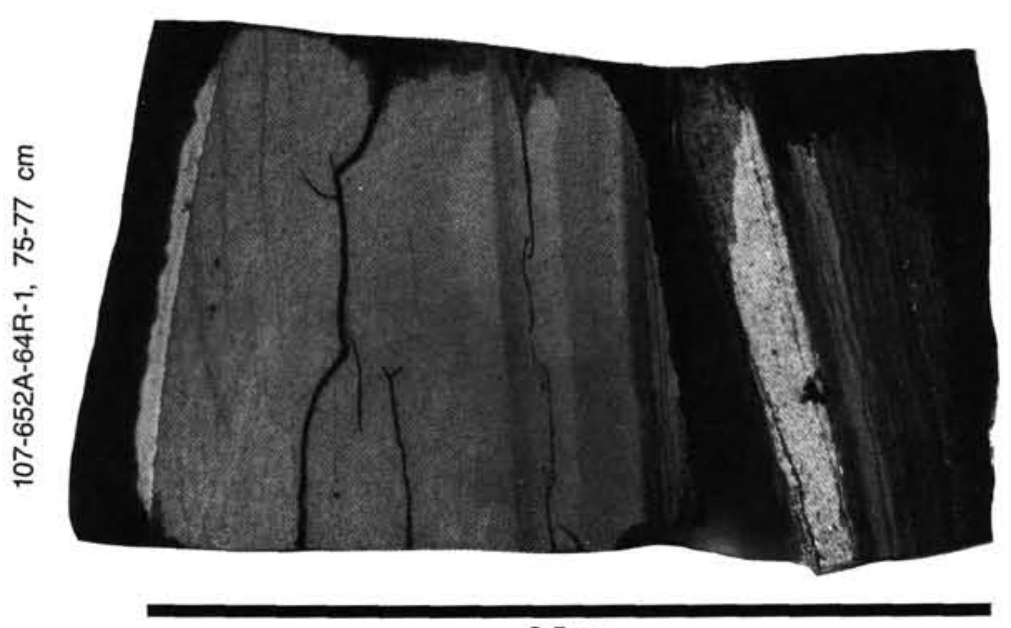

$3.5 \mathrm{~cm}$

Figure 29. Close-up photographs of Messinian oil shales. Note fine-scale lamination of organic and lithic components.

Once $\mathrm{C}_{2+}$ was present, the ratios determined from headspace analysis were always very low and continued to decrease as the highly organic-carbon-rich sequence, beginning at approximately 600 mbsf, was approached (Fig. 29). Quantities of the individual gases also increased.

The low quantities of $\mathrm{C}_{1}$ in the upper sediments, the low, decreasing $\mathrm{C}_{1} / \mathrm{C}_{2-5}$ ratio, and the increasing quantities of $\mathrm{C}_{2}$ through $\mathrm{C}_{5}$ indicate that these gases were formed thermogenically and migrated away from the source. The largest quantities of $\mathrm{C}_{2}$ through $\mathrm{C}_{5}$ and the lowest ratio $\mathrm{C}_{1} / \mathrm{C}_{2-5}$ are associated with the high concentration of organic matter at approximately $600 \mathrm{mbsf}$, suggesting that this material might be the source of the hydrocarbons. Thermal genesis of organic matter begins between $60^{\circ} \mathrm{C}$ and $100^{\circ} \mathrm{C}$ and will yield significant amounts of $\mathrm{C}_{2}$ through $\mathrm{C}_{6}$ (Hunt, 1979). Furthermore, the rate of generation approximately doubles when the temperature increases by $10^{\circ} \mathrm{C}$ (Waples, 1982). At Site 652, the in-situ temperature at the depth of the organic-rich sediments is close to $100^{\circ} \mathrm{C}$ and the thermal gradient was measured at $14^{\circ} \mathrm{C} / 100 \mathrm{~m}$. The thermal conditions at Site 652 are well within the requirements for a thermogenic origin of the sampled hydrocarbon gases. Further confirmation for thermal maturation are the increasing $i-\mathrm{C}_{5} / n-\mathrm{C}_{5}$ values. High values of $i-\mathrm{C}_{5} / n-\mathrm{C}_{5}$ have been shown to correlate well with increasing thermal conditions (Whelan and Hunt, 1982).

\section{SEISMIC STRATIGRAPHY}

Site 652 is located on the easternmost tilted block of the lower Sardinian continental margin at shotpoint 4250 on MCS line ST01 (Fig. 7, "Background and Objectives" section, this chapter). Line ST01 and previous single-channel seismic lines show a good penetration of about $1.2 \mathrm{~s}$ below seafloor. The section comprises a series of acoustic units well differentiated by high-amplitude reflectors (Fig. 7). At Site 652 five seismic units separated by strong reflectors can be distinguished before a basementlike reflector at about $1.2 \mathrm{~s}$ bsf (Fig. 33). 
Table 11. Characteristics of saturated hydrocarbon extracts, Site 652.

\begin{tabular}{|c|c|c|c|c|c|c|c|c|}
\hline Sample & $\begin{array}{l}\text { Depth } \\
\text { (m) }\end{array}$ & $\mathrm{T}\left({ }^{\circ} \mathrm{C}\right)$ & $\mathrm{C}_{\mathrm{org}} \%$ & $\mathrm{Pr} / \mathrm{Ph}$ & $\mathrm{Pr} / \mathrm{C} 17$ & $\mathrm{C} 29 / \mathrm{C} 17$ & CPI & Remarks \\
\hline $2-2,40$ & 5.5 & 13 & 0.01 & 11.1 & 1.0 & 0.1 & 1.1 & $\begin{array}{l}\text { Immature marine } \mathrm{OM} \text {, } \\
\text { oxic }\end{array}$ \\
\hline $4-6,17$ & 34.4 & 16 & 2.31 & 0.7 & 1.1 & 0.9 & 2.0 & $\begin{array}{l}\text { Immature mixed } \mathrm{OM}, \\
\text { anoxic (?) }\end{array}$ \\
\hline $6-1,33$ & 46.1 & 18 & 0.02 & 0.8 & 0.9 & 0.3 & 1.3 & $\begin{array}{l}\text { Immature marine } \mathrm{OM} \text {, } \\
\text { anoxic (?) }\end{array}$ \\
\hline $6-1,40$ & 46.2 & 18 & 4.18 & 0.5 & 1.2 & 1.9 & 0.9 & $\begin{array}{l}\text { Immature terrigenous/ } \\
\text { marine, anoxic }\end{array}$ \\
\hline $6-1,53$ & 46.3 & 18 & 3.50 & 7.2 & 0.9 & 0.2 & 1.3 & $\begin{array}{l}\text { Mixed, maturing OM, } \\
\text { oxic }\end{array}$ \\
\hline $59-2,140$ & 559.2 & 90 & 1.00 & 1.4 & 0.5 & 1.2 & 1.1 & $\begin{array}{l}\text { Mature, mixed OM, } \\
\text { oxic }\end{array}$ \\
\hline $64-1,103$ & 605.5 & 96 & 11.41 & 0.3 & 0.1 & 0.2 & 1.3 & $\begin{array}{l}\text { Mature, aquatic } \mathrm{OM} \text {, } \\
\text { anoxic }\end{array}$ \\
\hline
\end{tabular}

$\mathrm{T}\left({ }^{\circ} \mathrm{C}\right)=$ In-situ temperature, extrapolated from thermal gradient of $14^{\circ} \mathrm{C} / 100 \mathrm{~m} ; \mathrm{CPI}=$ Carbon Preference Index $=2\left(n-C_{29}\right) /\left(n-C_{28}+n-C_{30}\right)$; ratios of individual compounds computed by peak integration after manual background correction.

Table 12. Quantities of measured hydrocarbon gases, Site 652 .

\begin{tabular}{|c|c|c|c|c|c|c|c|}
\hline Depth & $C_{1}$ & $C_{2}$ & $\mathrm{C}_{3}$ & $n-\mathrm{C}_{4}$ & $i-\mathrm{C}_{4}$ & $n-\mathrm{C}_{5}$ & $i-\mathrm{C}_{5}$ \\
\hline \multicolumn{8}{|c|}{ Headspace analysis (ppm/10 $\mathrm{cm}^{3}$ of sample) } \\
\hline 117.2 & 3.0 & 0.0 & 0.0 & 0.0 & 0.0 & 0.0 & 0.0 \\
\hline 147.5 & 3.6 & 0.0 & 0.0 & 0.0 & 0.0 & 0.0 & 0.0 \\
\hline 178.0 & 1.8 & 0.0 & 0.0 & 0.0 & 0.0 & 0.0 & 0.0 \\
\hline 250.7 & 3.0 & 0 & 0 & & & 0 & 0.0 \\
\hline 380 & 62.7 & & & & & & 0.0 \\
\hline 47 & 131.5 & 12.5 & & 2.9 & & & 1.0 \\
\hline 513.0 & 159.0 & 25.0 & 24.0 & 5.0 & 9.4 & 4.0 & 4.0 \\
\hline 541.9 & 175.8 & 33.2 & 44.4 & 12.9 & 12.4 & 5.1 & 2.7 \\
\hline 559.3 & 386.0 & 47.0 & 87.0 & 66.0 & 105.0 & 28.0 & 82.7 \\
\hline 607.0 & 513.5 & 76.6 & 142.6 & 95.4 & 167.5 & 30.2 & 107.8 \\
\hline 629.0 & 224.0 & 54.5 & 145.6 & 215.0 & 129.1 & $\begin{array}{l}30.2 \\
49.7\end{array}$ & 250.0 \\
\hline 667.0 & 894.0 & 137.0 & 209.0 & 72.0 & 19.0 & 2.0 & 1.0 \\
\hline 695.2 & 297.7 & 40.3 & 42.2 & 12.7 & 23.1 & 4.1 & 6.5 \\
\hline 705.0 & 977.7 & 105.1 & 77.3 & 17.9 & 32.3 & 5.3 & 7.6 \\
\hline
\end{tabular}

Vacutainer analysis (ppm per volume)

\begin{tabular}{rrrrrrrr}
378.0 & 5.0 & 0.0 & 0.0 & 0.0 & 0.0 & 0.0 & 0.0 \\
385.0 & 0.8 & 0.0 & 0.0 & 0.0 & 0.0 & 0.0 & 0.0 \\
405.0 & 5.0 & 0.0 & 0.0 & 0.0 & 0.0 & 0.0 & 0.0 \\
415.0 & 3.0 & 0.0 & 0.0 & 0.0 & 0.0 & 0.0 & 0.0 \\
483.0 & 16.8 & 1.1 & 0.0 & 0.0 & 0.0 & 0.0 & 0.0 \\
493.0 & 2.5 & 0.0 & 0.0 & 0.0 & 0.0 & 0.0 & 0.0 \\
511.0 & 6.5 & 0.0 & 0.0 & 0.0 & 0.0 & 0.0 & 0.0 \\
549.0 & 27.7 & 6.0 & 5.9 & 1.3 & 0.8 & 0.9 & 0.3 \\
618.0 & 205.6 & 10.5 & 9.1 & 7.1 & 3.9 & 0.0 & 5.9 \\
627.0 & 208.5 & 12.9 & 13.4 & 0.0 & 9.5 & 3.8 & 4.0 \\
637.0 & 171.6 & 5.2 & 3.7 & 1.4 & 2.1 & 0.0 & 0.0 \\
647.0 & 184.0 & 5.8 & 4.4 & 1.8 & 2.3 & 0.0 & 0.0 \\
696.0 & 160.0 & 7.2 & 5.5 & 0.0 & 1.8 & 0.0 & 0.0 \\
705.0 & 198.5 & 5.6 & 3.9 & 0.0 & 1.6 & 2.4 & 0.0 \\
\hline
\end{tabular}

\section{Seismic Unit One}

Seismic Unit One extends from the seafloor to the top of a series of high-amplitude reflectors. Numerous small vertical displacements are seen at the bottom of the unit. Unit One is about $0.29 \mathrm{~s}$ thick at Site 652 . Interval velocity is $1.514 \mathrm{~km} / \mathrm{s}$. This indicates that the base of Unit One should be at about $215 \mathrm{mbsf}$. Toward the west Unit One thickens slightly. Maximum thickness is $325 \mathrm{~m}$. Unit One contains a few discontinuous high-amplitude reflectors indicating probable coarser layers. Several small unconformities can also be detected within Unit One. The most obvious lies at about $115 \mathrm{mbsf}$.

\section{Seismic Unit Two}

This unit is bounded by two high-amplitude reflectors. The thickness maintains an average value of $0.13 \mathrm{~s}$. The interval velocity is $1.914 \mathrm{~km} / \mathrm{s}$; thickness should therefore be about $125 \mathrm{~m}$. This indicates that the base of Unit Two lies at $340 \mathrm{mbsf}$. The basal reflectors of Unit Two, like those of Unit One, show numerous small vertical displacements (with an average offset of $15-20 \mathrm{~m}$ ). This indicates probable tectonic activity or a slightly flowing underlying layer. Laterally toward the west, Unit Two changes its acoustic character and thickens.

\section{Seismic Unit Three}

At Site 652 this unit shows a thickness of $0.28 \mathrm{~s}$. Assuming an interval velocity of $2.61 \mathrm{k} \mathrm{m} / \mathrm{s}$, the total thickness of the unit should be about $360 \mathrm{mbsf}$. Its base lies at about $700 \mathrm{mbsf}$. The basal reflectors of Unit Two as well as the uppermost reflectors of Unit Three have very high amplitudes and show an irregular surface, posibly indicating erosion. Toward the west, Unit Three thickens and changes in seismic characteristics (Figs. 7 and 33). In the axis of the half-graben, seismic Unit Three contains a feature which can be considered typical of flowing material. The interval velocity gives a value of $3.4 \mathrm{~km} / \mathrm{s}$ in this sedimentary body which could reflect the presence of evaporites.

\section{Seismic Unit Four}

Seismic Unit Four consists of mainly discontinuous and highamplitude reflectors. The seismic characteristics indicate either dislocated material or erosional events. At the site this unit has a thickness of about $0.2 \mathrm{~s}$. The computed interval velocity for this unit is $2.3 \mathrm{~km} / \mathrm{s}$, giving a thickness on the order of $230 \mathrm{~m}$ and a depth for its base at about $900-930$ mbsf.

\section{Seismic Unit Five and Pseudobasement}

An acoustic sequence almost free of internal reflectors is detected beneath Unit Four. This last unit is bounded at its base by an irregular basement surface. The thickness of Unit Five is $0.24 \mathrm{~s}$. Its thickness is $400 \mathrm{~m}$ assuming an interval velocity of $3.2 \mathrm{~km} / \mathrm{s}$. The top of the basementlike reflector lies at about 1300-1350 mbsf.

\section{Previous Lithologic and Stratigraphic Interpretations}

The prominent reflectors bounding the different seismic units have been identified and tentatively dated by Fabbri and Curzi (1979) and by Moussat (1983). The proposed dating indi- 

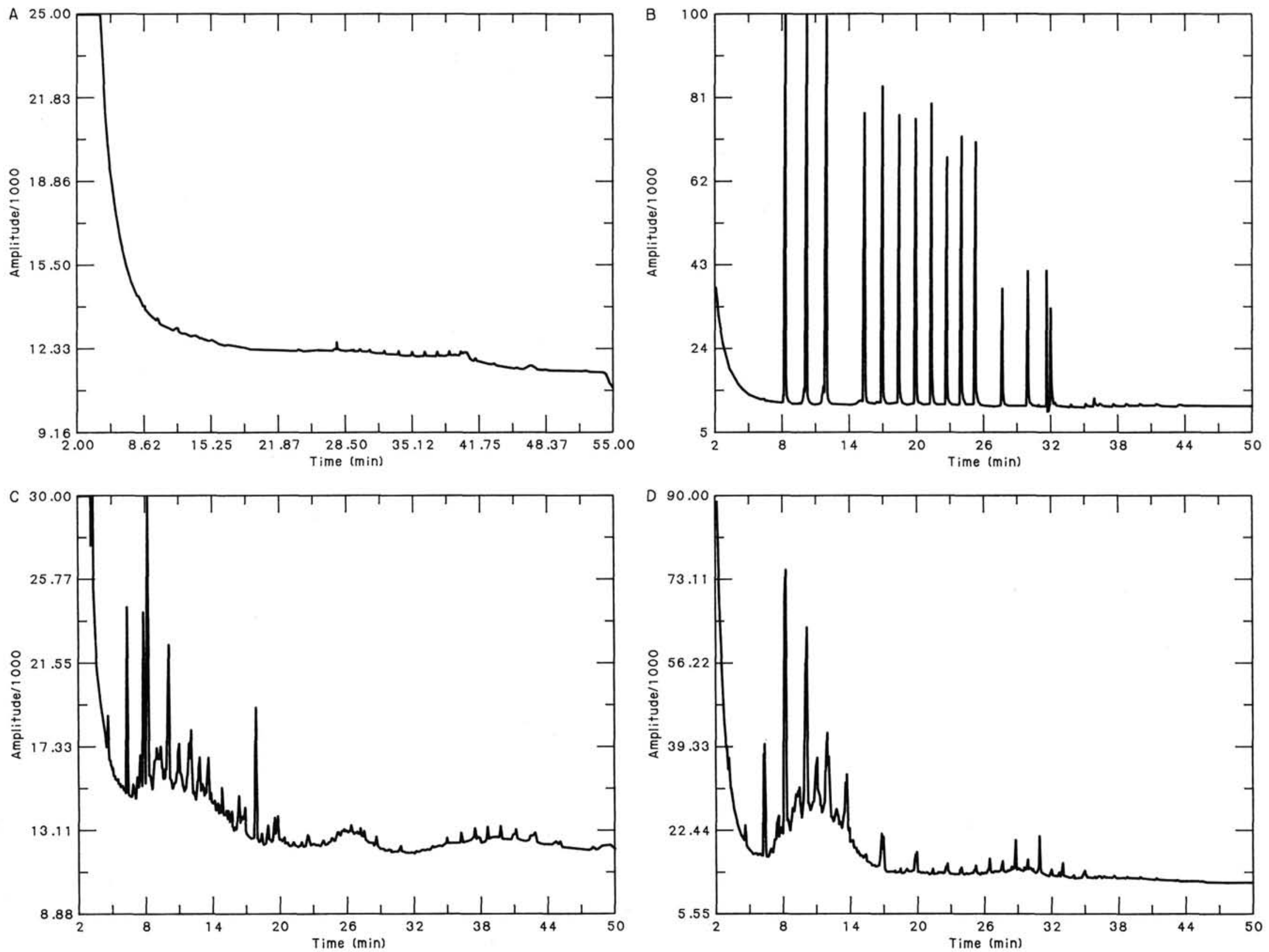

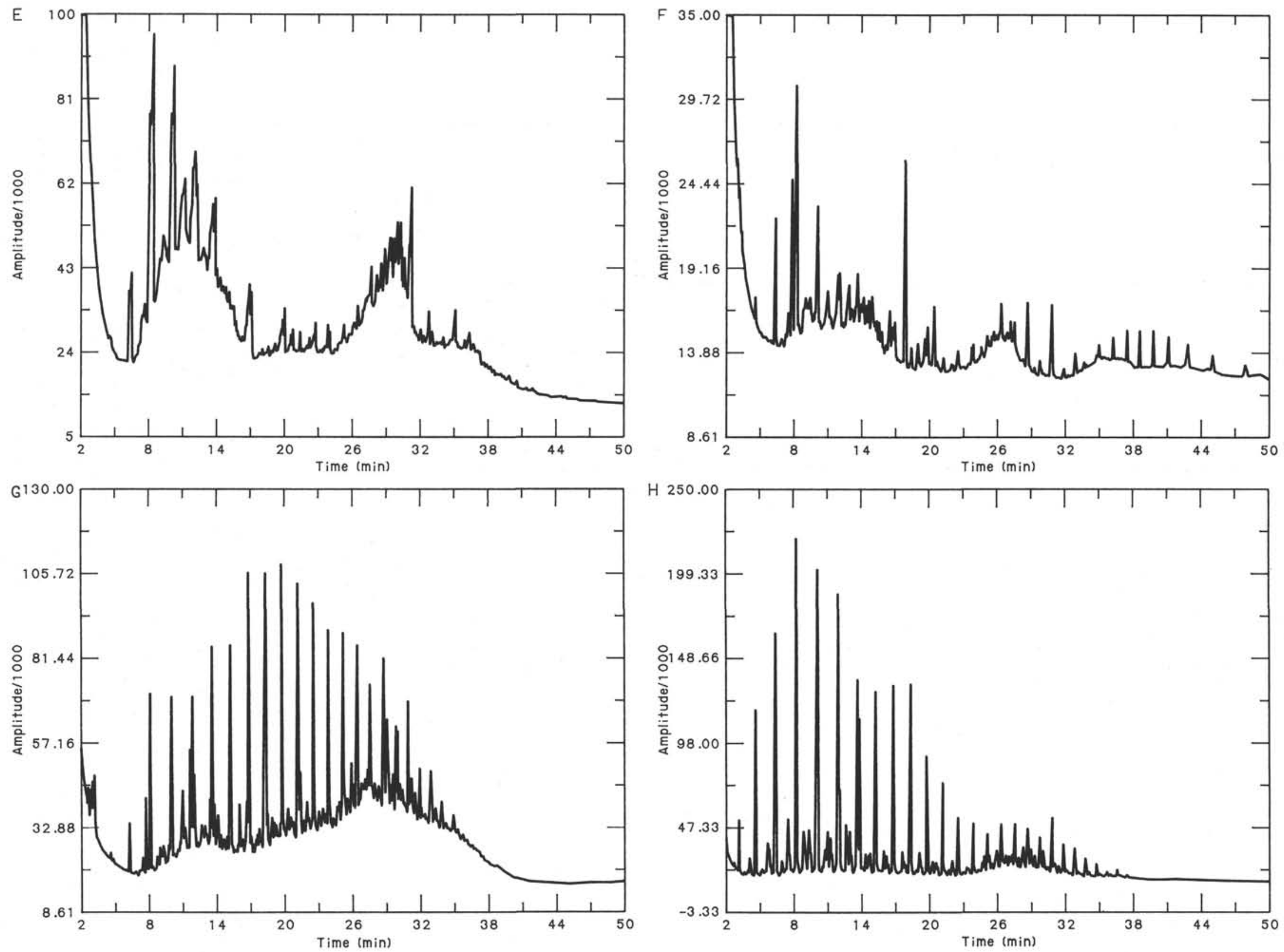

Figure 30. Gas chromatography traces of saturated hydrocarbons extracted from sediments of various lithologies encountered in Hole $652 \mathrm{~A}$. A. Flame ionization detector hexane blank. B. Standard high molecular weight $n$-alkane test. C. Sample 2R-2, 40-45 cm. D. Sample 4R-6, 17-20 cm. E. Sample 6R-1, 40 cm. F. Sample 6R-1, 53-55 cm. G. Sample 59R-2, 140 cm. H. Sample $64 \mathrm{R}-1,103 \mathrm{~cm}$. See text for explanation. 


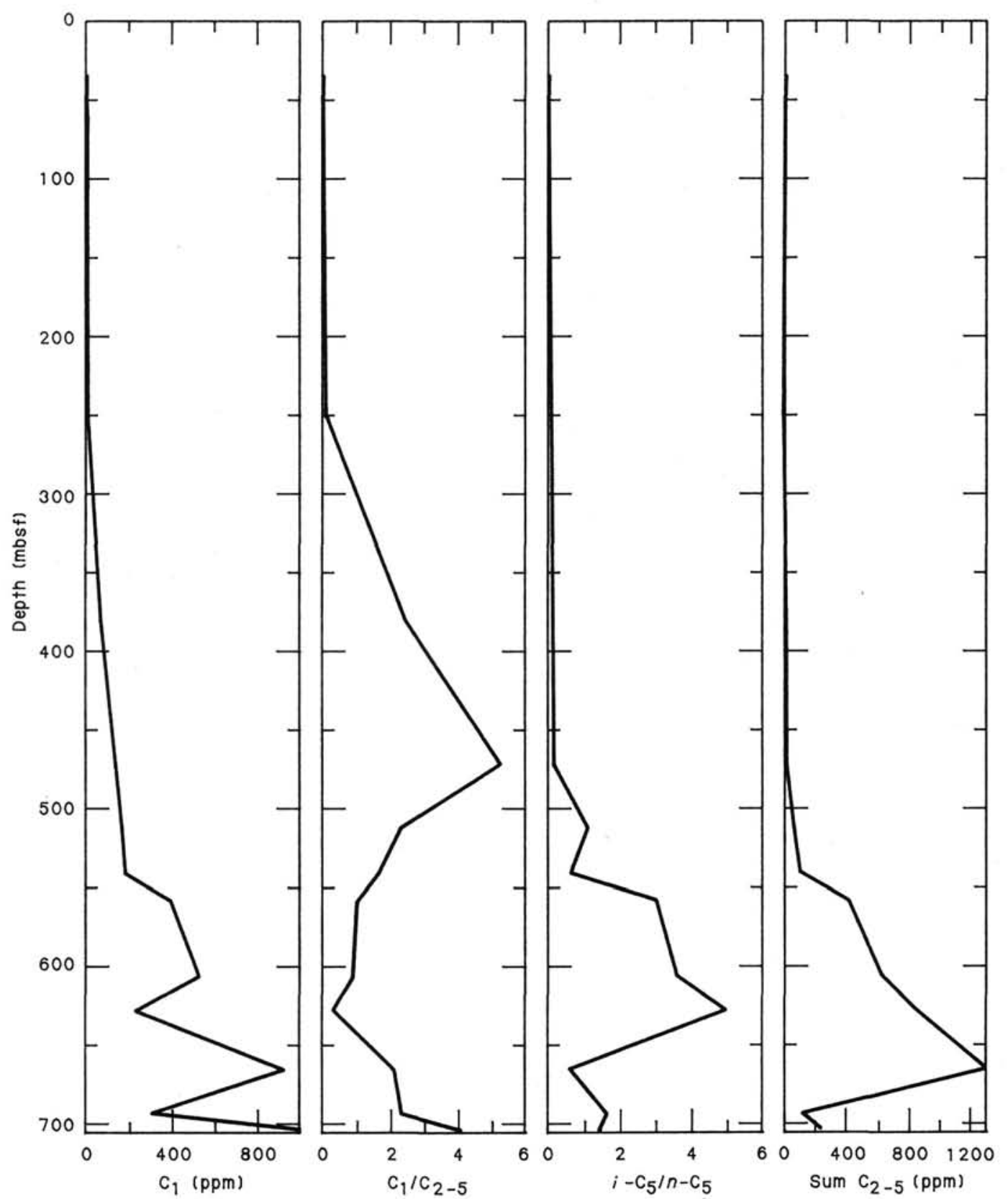

Figure 31. Headspace analysis of hydrocarbons, Site 652.

cates a Pliocene to Quaternary age for Seismic Unit One; the top of our Seismic Unit Two is referred as the "Y" unconformity, interpreted as the top of the Messinian. Neither Fabbri and Curzi (1979) nor Moussat (1983) indicate the presence of the $B_{2}$ sequence, representing the Messiniam evaporites, below the "Y" unconformity. Moussat (1983) indicates however the presence of the $B_{3}$ sequence and of a " $Z$ " sequence, interpreted respectively as pre-evaporitic Miocene sequence and the top of the acoustic basement (Fabbri and Curzi, 1979). The " $Z$ " reflector correlates well with the pseudobasement of MCS line ST01. The $B_{3}$ sequence would then represent Seismic Units Three to Five. Rehault et al. (1986) more recently proposed a tentative stratigraphic interpretation of line ST01. Below thin upper Messinian (Seismic Unit Two), these authors note the presence of a sequence inferred to be Messinian (unknown facies) or possibly Tortonian.

\section{Synthetic $\boldsymbol{P}$-wave Seismogram}

The synthetic $P$-wave seismogram (Fig. 34) was generated using laboratory measurements of compressional wave velocity and bulk density (see "Physical Properties" section, this chapter). The data were linearly interpolated into an evenly-spaced 1-m grid and input to a single one-dimensional conventional synthetic seismogram as in previous Leg 107 holes. The synthetic seismogram is briefly compared with both a section of Site survey MCS line ST01, near Site 652 (Fig. 32) and the lithology.

The following points should be noted:

1. The base of Seismic Unit One corresponds to a prominent reflector on the seismogram at about $220 \mathrm{mbsf}$. There is a $32-\mathrm{m}$ discrepancy between the predicted base of Pliocene-Pleistocene 


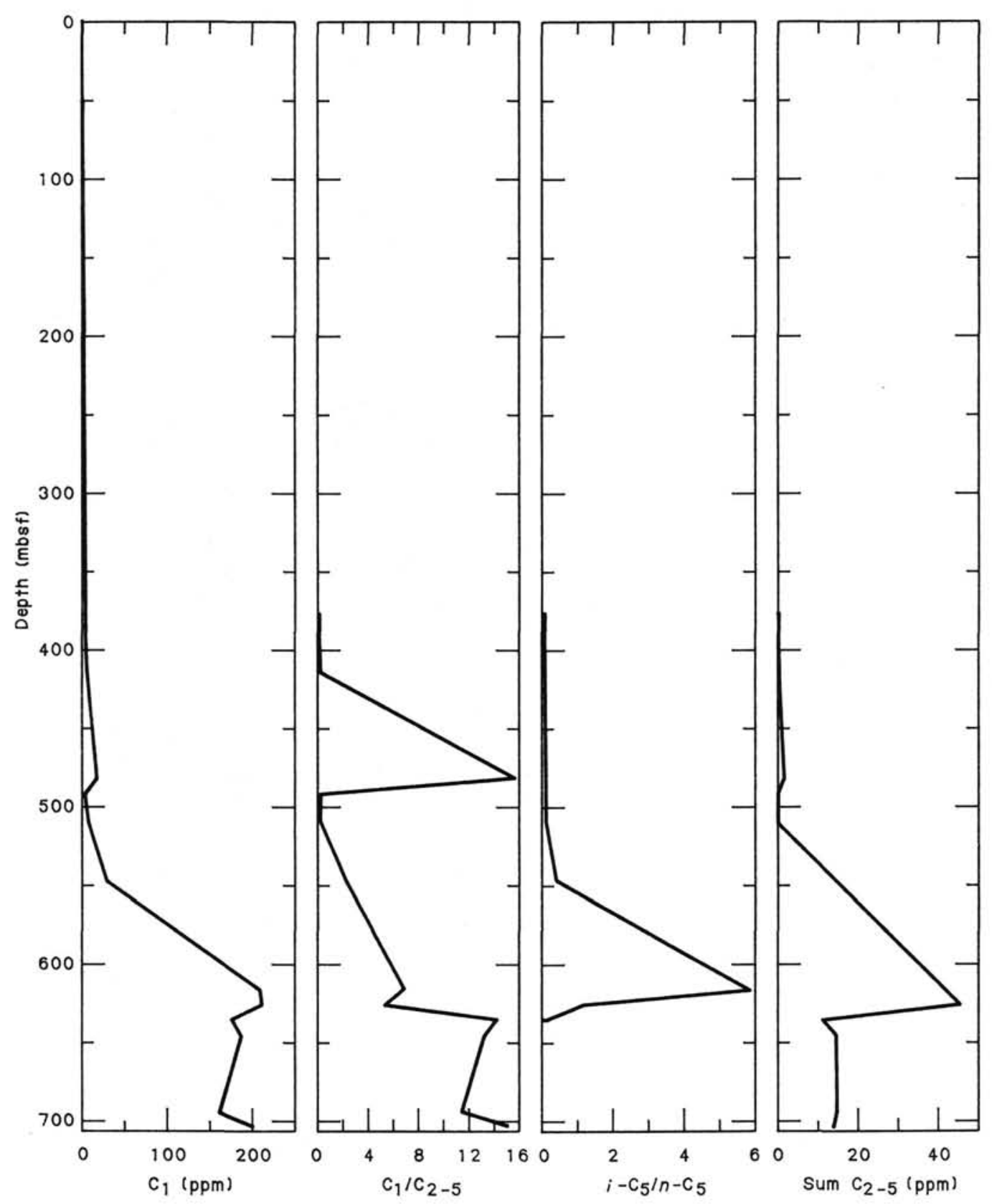

Figure 32. Vacutainer analysis of hydrocarbons, Site 652 .

sediments as deduced from the MCS line and the drilling results. However lithologic descriptions indicate that the uppermost Messinian, between 189 and 220 mbsf, is made of rather homogeneous calcareous clay. The high amplitude-reflector that lies at about 220 mbsf corresponds to the first occurrence of gypsiferous layers in the upper Messinian while the boundary between lower Pliocene and latest Messinian is well expressed on the seismogram by a high-amplitude reflector at $190 \mathrm{mbsf}$.

2. The base of Seismic Unit Two corresponds to a conglomeratic layer recovered between 334.70 and 344.80 mbsf.

3. Seismic Unit Three contains a series of high-amplitude reflectors. These correlate with gypsiferous layers and/or with sandstones interbedded within siltstones and shales.

4. The boundary between Units Three and Four is not very well expressed on the seismogram. Actually the lithology shows a progressive increase of sandstone layers, still interbedded within siltstones, shales, and thin anhydrites.

Drilling at Site 652 established the following points:

1. Seismic Unit One clearly correlates with Pliocene and Pleistocene hemipelagic sediments but also includes the uppermost Messinian sediments made mostly of calcareous clay.

2. Seismic Unit Two corresponds to alternations of gypsum, carbonate-bearing sandy silts, and calcareous clays and muds (most of lithostratigraphic Unit IV). The bottom of the unit correlates strictly with the base of lithostratigraphic Unit IV (pebble layer).

3. Seismic Units Three and Four correlate with a monotonous succession (gypsiferous thin layers, carbonate-bearing sand, 


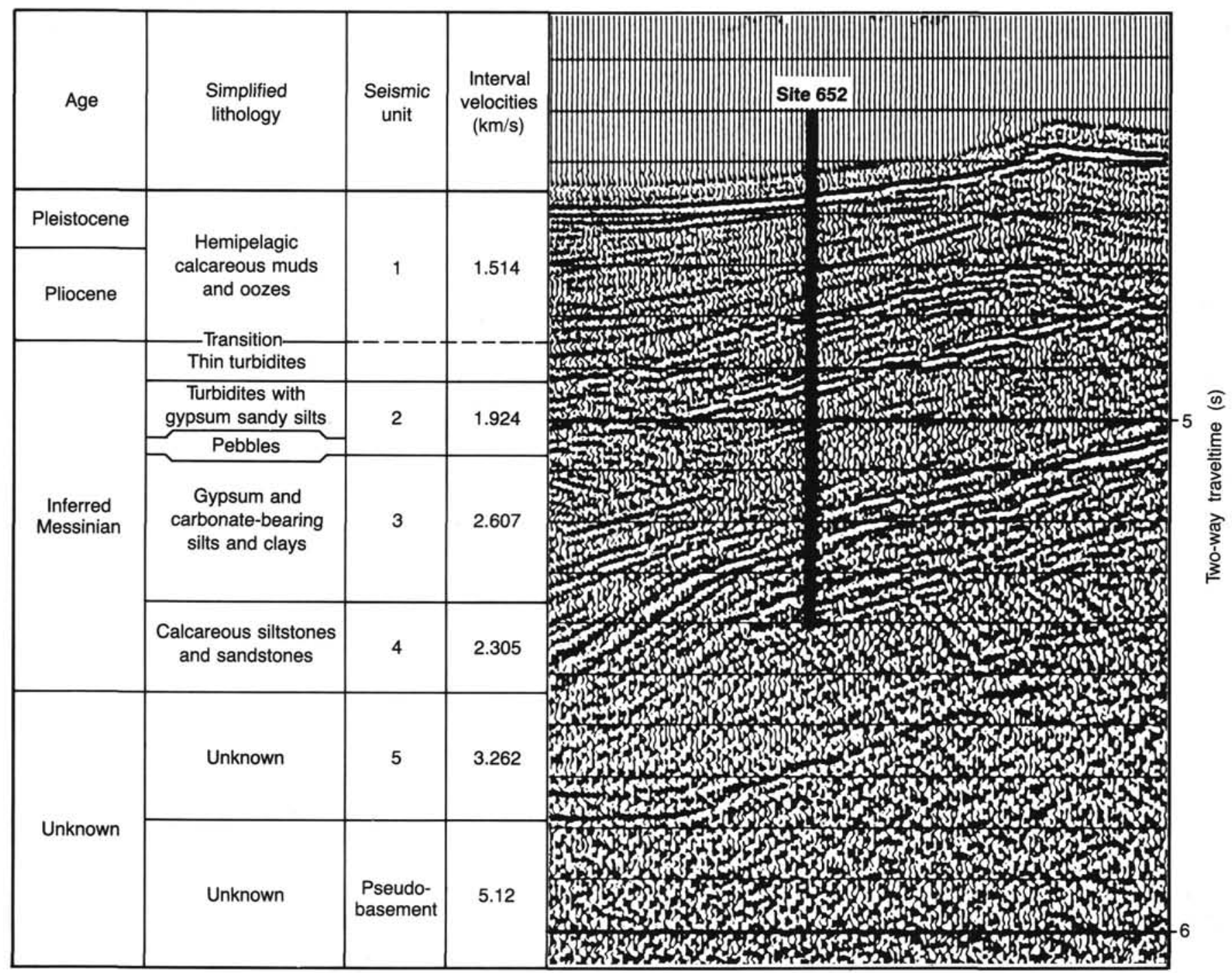

Figure 33. Seismic units at Site 652 (From MCS Site survey line ST01), including correlations with interval velocities, main lithologic units, and time scale.

sandy silt, clays, and thin anhydrites) which corresponds to lithostratigraphic Unit V. The transition from Seismic Unit Three to Four is characterized by a progressive increase and thickening of indurated calcareous siltstones and sandstones.

4. Site 652 bottomed at 721 mbsf in indurated dark gray shale and siltstone, considered to be part of the upper levels of Seismic Unit Four.

5. Seismic Unit One (Pliocene and Pleistocene) can be interpreted as a post-rift sequence, even if minor faulting and unconformities are detected at this level. Seismic Units Two and Three show a marked thickening toward the west (Fig. 7). They are considered as sedimentary sequences deposited during the progressive block rotation (syn-rift sequences). Seismic Unit Three also shows a lateral change in acoustic facies. In the thickest section (toward the west) the unit contains a lens of acoustically transparent material, characterized by an interval velocity of 3.4 $\mathrm{km} / \mathrm{s}$. This layer may indicate the presence of an evaporitic body, which could represent the lateral equivalent of lithostratigraphic Units IV and V (essentially made of alternations of gypsum, carbonate-bearing sandy silts, and calcareous clays and muds). The upper levels of Seismic Unit Four correlate with indurated continental sediments which can pertain to the tip of the pre-rift sequence, according to the geometry seen on the seismic line.

\section{DOWNHOLE MEASUREMENTS}

\section{Summary of Logging Operations}

Logging operations at Site 652 began at 0330 on 27 January 1986. No difficulties were experienced during drilling, and everyone anticipated an excellent hole for logging; such optimism, however, proved to be unfounded. After standing up at 259.5, 269.5 , and 349.5 mbsf, the velocity-resistivity-gamma ray-caliper (LSS-DIL-GR-CALI) tool string would not pass below 371.5 mbsf, and logs were recorded up from that depth. On the second run in the hole the induced gamma ray spectrometry tool (GST) was run in place of the lithodensity tool (LDT) in the nuclear combination, because of its additional weight and lack of centralizer springs. The tool string would not pass below 269.5 mbsf and logs were recorded up from that depth.

At 2300 on 27 January, pipe was run down to $429.5 \mathrm{mbsf}$ in an attempt to reopen the hole. Although $8000 \mathrm{lb}$ weight on bit was needed to clear a bridge at $271.5 \mathrm{mbsf}$, the top drive was never picked up and only minimal circulation of sea water was used. The NGT-CNT-GST combination was again run into the hole and stood up at $371.5 \mathrm{mbsf}$. Logs were recorded up to 269.5 mbsf, to overlap with the previous run. No log could be recorded below 371.5 mbsf. 


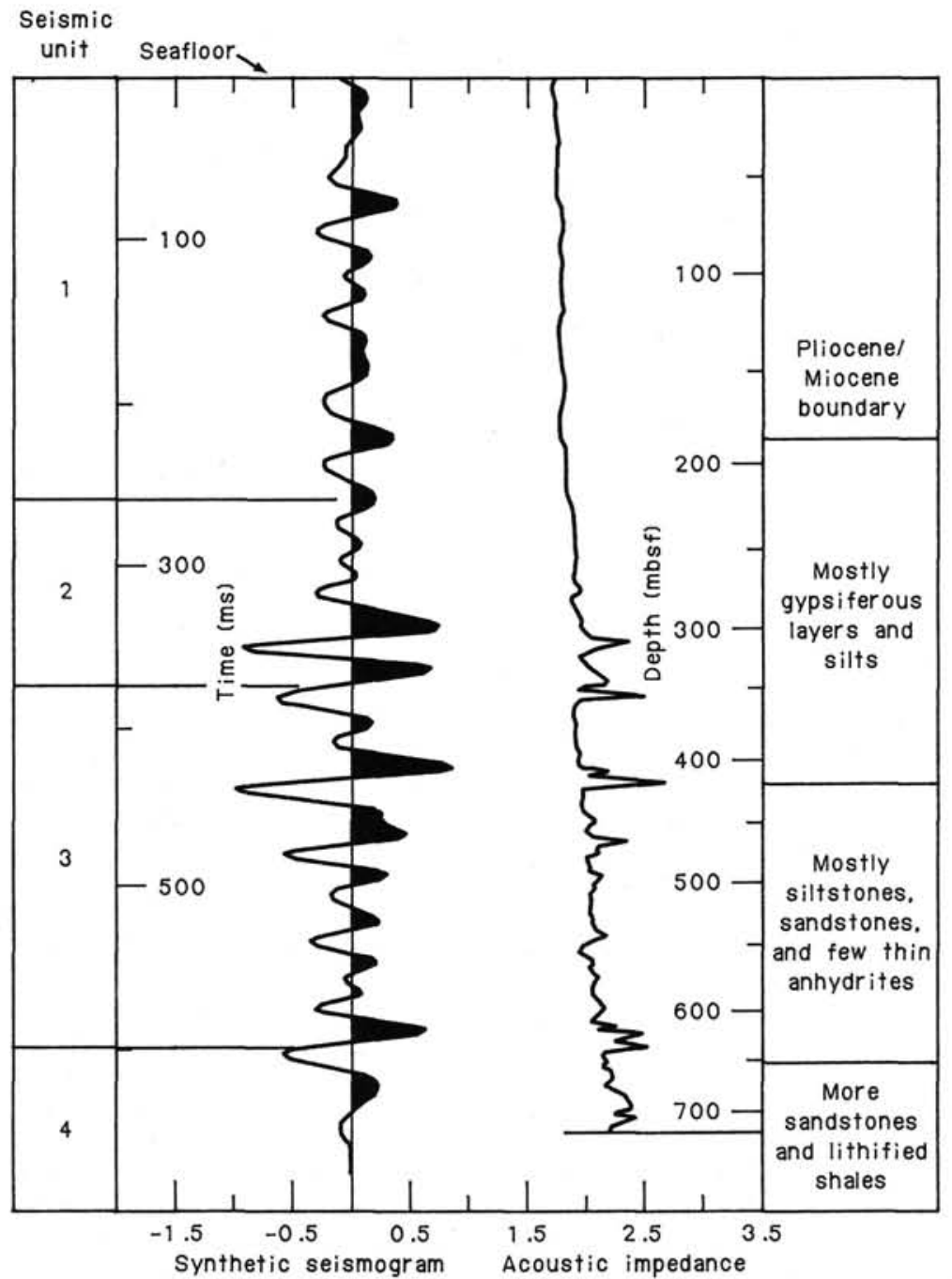

Figure 34. Synthetic seismogram, calculated from shipboard physical properties measurements, allows correlations of core features with seismic reflectors. Correlations with seismic units are shown.

A description of the logging tools used at Site 652 is given in the "Explanatory Notes" section, this volume. Table 13 summarizes the recorded logs.

\section{Discussion of Results}

\section{Log Data Quality}

Log data quality may be seriously degraded in excessively large sections of the borehole or by rapid changes in the hole diameter. These effects are seen clearly at Hole 652A and limit the accuracy of the log data. Resistivity and velocity measurements are the least sensitive to borehole conditions, while nuclear measurements (neutron porosity and natural and induced spectral gamma ray) are most seriously impaired. A brief description of the applied corrections is presented below.

The velocity log, which was initially affected by noise in the 260-275 mbsf and 320-340 mbsf intervals, has been recomputed from the four original traveltime curves to produce a more reliable result (Fig. 35). The algorithm makes use of the redundancy of traveltime measurements to calculate a log uncompensated for hole enlargement or sonde tilt (even for hole enlargements greater than 24 in., velocity errors are quite small, because of the large source-receiver separations used). The resulting log shows a general increase of velocity with depth up to $3.5 \mathrm{~km} / \mathrm{s}$ at 331.5 mbsf, and good correlation with electrical and nuclear logs.

The response of resistivity logs is less influenced by hole enlargements. According to the tool manufacturer, corrections of the spherically focused resistivity are required when the hole size exceeds 12 in. (30.48 cm; Schlumberger, 1972); at Hole 652A the caliper $\log$ is saturated at its maximum reading (13.5 in.) down to 169 mbsf, and shows variable values (6 in.-13.4 in.; $15.2-34.0 \mathrm{~cm}$ ) throughout the rest of the hole. The average computed correction, however, is less than $13 \%$, the average resistivity being $0.72 \Omega \cdot \mathrm{m}$. As far as the induction log is concerned, correction is necessary only when there are large contributions to the signal by the borehole fluid, i.e., when the salinity of the drilling fluid exceeds $70,000 \mathrm{ppm}$. Since seawater was used as the drilling fluid, the correction was less than $3 \%$, the average resistivity being $0.7 \Omega \cdot \mathrm{m}$.

In general the induction deep resistivity is less than the medium or shallow resistivities, suggesting invasion of seawater into the sediments during the time between drilling and logging. This is supported by chemical analyses made aboard ship shortly after drilling which also indicate saline (low resistivity) pore waters (see "Geochemistry" section, this chapter). Resistivity data are not completely reliable in the $259.5-286.5$ mbsf interval, due to frequent sticking of the tool during the recording. 
Table 13. Summary of log measurements at Hole 652A.

\begin{tabular}{|c|c|c|c|c|}
\hline Mnemonic & Tool & Measurement & Unit & $\begin{array}{l}\text { Depth } \\
\text { (mbsf) }\end{array}$ \\
\hline CALI & Caliper & Hole size & inches & $73.0-354.5$ \\
\hline GR & Natural Gamma Ray & Natural radioactivity & GAPI & $73.0-356.5$ \\
\hline DIL & Dual Induction & $\begin{array}{l}\text { Deep, medium, and focused } \\
\text { resistivity }\end{array}$ & $\Omega$-m & $73.0-364.5$ \\
\hline LSS & Long Spacing Sonic & $\begin{array}{l}\text { Sonic transit time (short and } \\
\text { long spacing) }\end{array}$ & $\mu \mathrm{s} / \mathrm{ft}$ & $73.0-352.0$ \\
\hline $\mathrm{CNT}$ & Compensated Neutron & Porosity & $\%$ & $73.0-353.0$ \\
\hline NGT & $\begin{array}{l}\text { Natural Gamma } \\
\text { Spectrometry }\end{array}$ & $\begin{array}{l}\text { Total }(\mathrm{Th}+\mathrm{U}+\mathrm{K}) \text { and computed } \\
(\mathrm{Th}+\mathrm{K}) \text { natural radioactiv- } \\
\text { ity uranium, thorium, } \\
\text { potassium }\end{array}$ & $\begin{array}{l}\text { GAPI } \\
\text { ppm } \\
\text { weight } \%\end{array}$ & $73.0-345.5$ \\
\hline GST & $\begin{array}{r}\text { Induced Gamma } \\
\text { Spectrometry }\end{array}$ & $\begin{array}{l}\text { Elemental yields }(\mathrm{Ca}, \mathrm{Cl}, \mathrm{H}, \mathrm{Fe} \text {, } \\
\quad \mathrm{S}, \mathrm{Si})\end{array}$ & & $73.0-363.5$ \\
\hline
\end{tabular}

The influence of hole enlargements on the nuclear logs is very clear opposite the large washout between 73 and 145 mbsf (see log section following the barrel sheets); the lower gamma ray and higher neutron porosity values indicate attenuation by the borehole fluid, particularly from 107 to $144 \mathrm{mbsf}$. The same effect is also observed on the curves of the elemental yields. Therefore, natural gamma ray has been corrected for hole size and neutron porosity for hole size, standoff, and pressure according to Schlumberger's (1985) correction charts. No correction algorithm is available to correct natural and induced spectral gamma ray. Due to the saturation of the caliper log these corrections partially remove the hole size effect, thus they can be considered reliable only from a qualitative point of view.

\section{Log Interpretation}

Due to the extremely poor conditions of the hole in the upper part of the logged interval (73-169.5 mbsf) the interpretation of the logging data was limited to the lower part of the Pliocene and to the Messinian sediments: an improvement of the log quality was observed in this section, related to a change in physical properties (see below). Indication of the better quality of log readings was provided by cross-correlations of the different curves shown in Figure 35.

In addition to the traditional natural radioactivity, velocity, and resistivity curves, the data from the induced gamma ray spectrometry tool (GST) proved to be very useful in developing a more accurate lithostratigraphy (core recovery in the Miocene section was only $29 \%$ ). This tool indicates the proportions of the total spectrum attributed to the following elements: $\mathrm{Ca}, \mathrm{Si}$, $\mathrm{H}, \mathrm{S}, \mathrm{Cl}$, and $\mathrm{Fe}$. As their sum is always one the yields do not reflect the actual elemental composition. Therefore, the following yield ratios may be computed to detect changes in the macroscopic properties of the formation:

$$
\begin{array}{ll}
\mathrm{LIR}=\text { lithology-indicator ratio } & \mathrm{Si} /(\mathrm{Ca}+\mathrm{Si}) \\
\mathrm{IIR}=\text { iron-indicator ratio } & \mathrm{Fe} /(\mathrm{Ca}+\mathrm{Si}) \\
\mathrm{PIR}=\text { porosity-indicator ratio } & \mathrm{H} /(\mathrm{Ca}+\mathrm{Si}) \\
\mathrm{GIR}=\text { gypsum/anhydrite indicator ratio } & \mathrm{S} /(\mathrm{Ca}+\mathrm{Si})
\end{array}
$$

LIR reads close to 1 in siliceous silts and sands, 0.2 in dolomites, and 0 in limestone. IIR can be used to detect clays, since clay minerals tend to contain iron and pyrite-rich layers. PIR indicates porosity changes: Figure 35 shows the good correlation between the neutron porosity (quantitative) and the PIR (qualitative) curve. Finally, GIR is related to the presence of gypsum or anhydrite.

Logs indicate that the bottom of lithostratigraphic Unit II (169.5-188.2 mbsf) and Unit III (188.2-188.6 mbsf) are marked by a steady increase of iron content; the top of the Messinian corresponds to a 2-m-thick low-carbonate iron-rich clay. The
Messinian sediments from 191 mbsf to the top of the pebble interval (lithostratigraphic Unit IVc; 324 mbsf) are characterized by the presence of layers of gypsiferous claystone-mudstone, 1$2 \mathrm{~m}$ thick, cyclically interbedded with gypsiferous sands and silts. The former are distinguished by higher porosity, lower velocity-resistivity, and high iron-silicon content (black bars in Fig. 35). The low carbonate content is also confirmed by the results of shipboard measurements indicating the $\mathrm{CaCO}_{3}$ ranges from $10 \%$ to $20 \%$ in claystones and mudstones (see "Geochemistry" section, this chapter).

A plot of thorium vs. potassium concentration (Fig. 36) has been used to identify the major clay minerals in the logged interval. Because the composition of clay minerals is quite variable, each of them is represented by a general area rather than by a single point. The figure shows that most of the values fall in the field of montmorillonite, and subordinately of chlorite and kaolinite. The presence of such minerals and in particular the predominance of montmorillonite is quite common in Messinian sediments of the Tyrrhenian area; the clay fraction of Messinian sediments recovered at DSDP Sites 132 and 373 contains great amounts of well-crystallized smectites (Ryan et al, 1973; Chamley et al., 1978), which represent as much as $100 \%$ of the clay mineralogy. In the absence of shipboard XRD/XRF analyses the iron indicator ratio curve indicates a marked enrichment in iron opposite the clay layers, suggesting that these clays may be similar to the nontronites-iron beidellites described by Chamley et al. (1978). These clays may have formed in the soils of higher standing areas exposed as the water level dropped during the Messinian. Their deposition interbedded with carbonaticgypsiferous sands and silts would be the result of the enhanced continental erosion in combination with tectonic activity.

Gypsiferous carbonatic sands and silts are characterized on logs by higher velocity-resistivity, lower porosity, high carbonate content $\left(\mathrm{CaCO}_{3}\right.$ shipboard measurements range from $20 \%$ to $38.5 \%$ ). A good qualitative calibration of the logging data against cores was performed in the interval 307-325 mbsf, corresponding to Cores 107-652A-33R to 107-652A-34R. The core recovery was only $44 \%$, but the uniformity of log readings allows a tie of logs to cores. According to the LIR-IIR curves this section consists of prevalent gypsiferous carbonatic sands and silts, delimited at the top and bottom by claystone/mudstone. This interpretation is confirmed by the smear slides and $\mathrm{CaCO}_{3}$ analysis results, which range from $25.5 \%$ to $33 \%$. A close examination of cores also reveals that silts and sands are cemented with carbonate, thus explaining the increase of velocity with respect to the clays.

The gypsum-indicator ratio (GIR) does not indicate a preferential distribution of gypsum opposite clay intervals; in the logged section of Unit V, however, it is more abundant than anywhere else in the cores, along with a dramatic increase in the 


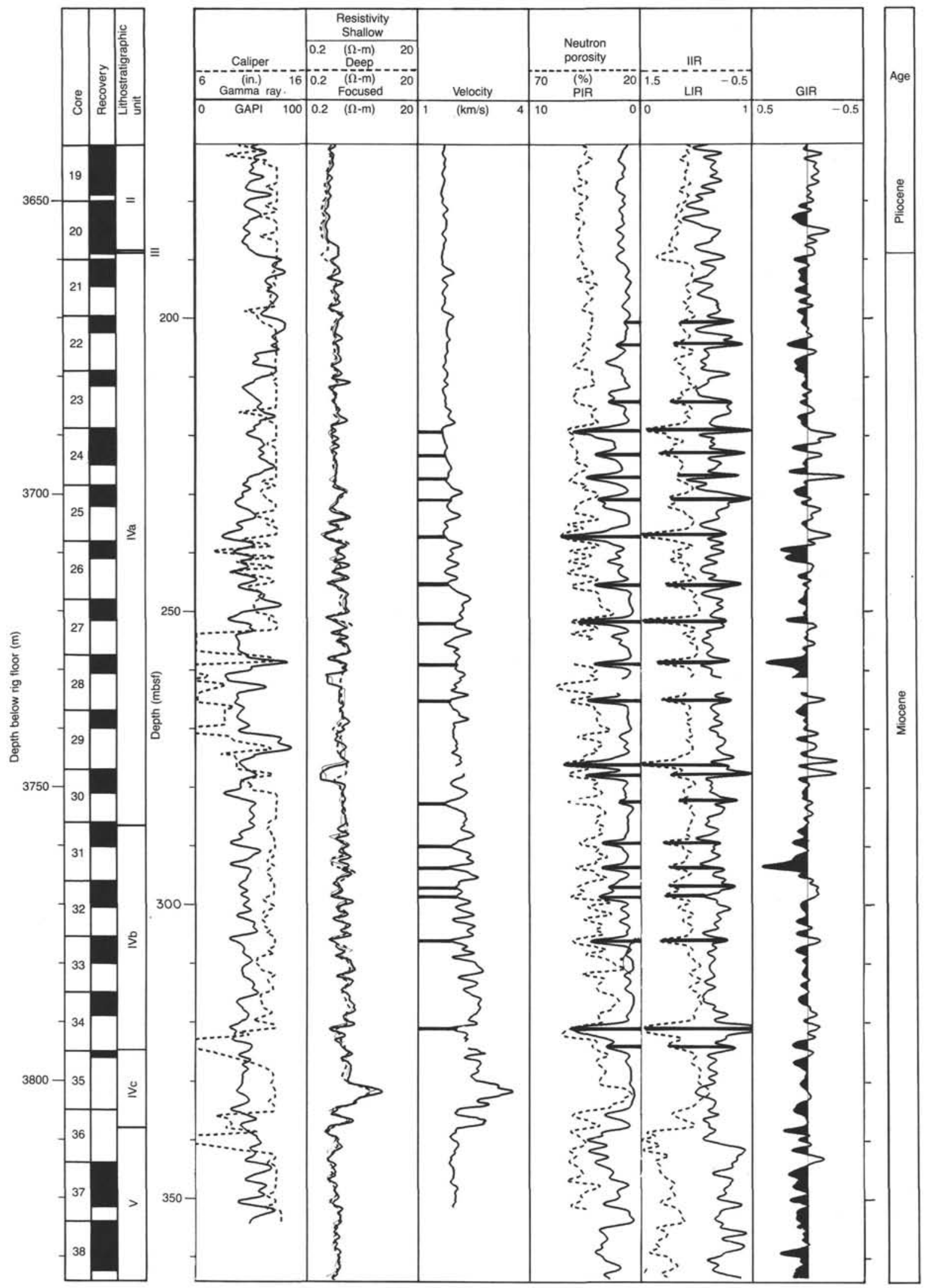

Figure 35. Logging data at Hole 652A. Gamma ray and neutron porosity are corrected for borehole effects; velocity has been recomputed from the original traveltimes. LIR (lithology indicator ratio), IIR (iron indicator ratio), PIR (porosity indicator ratio), GIR (gypsum/anhydrite indicator ratio). Clay-rich levels are indicated by black bars: they correspond to low velocity-resistivity and high porosity values, and to an increase in the silica and iron content. 


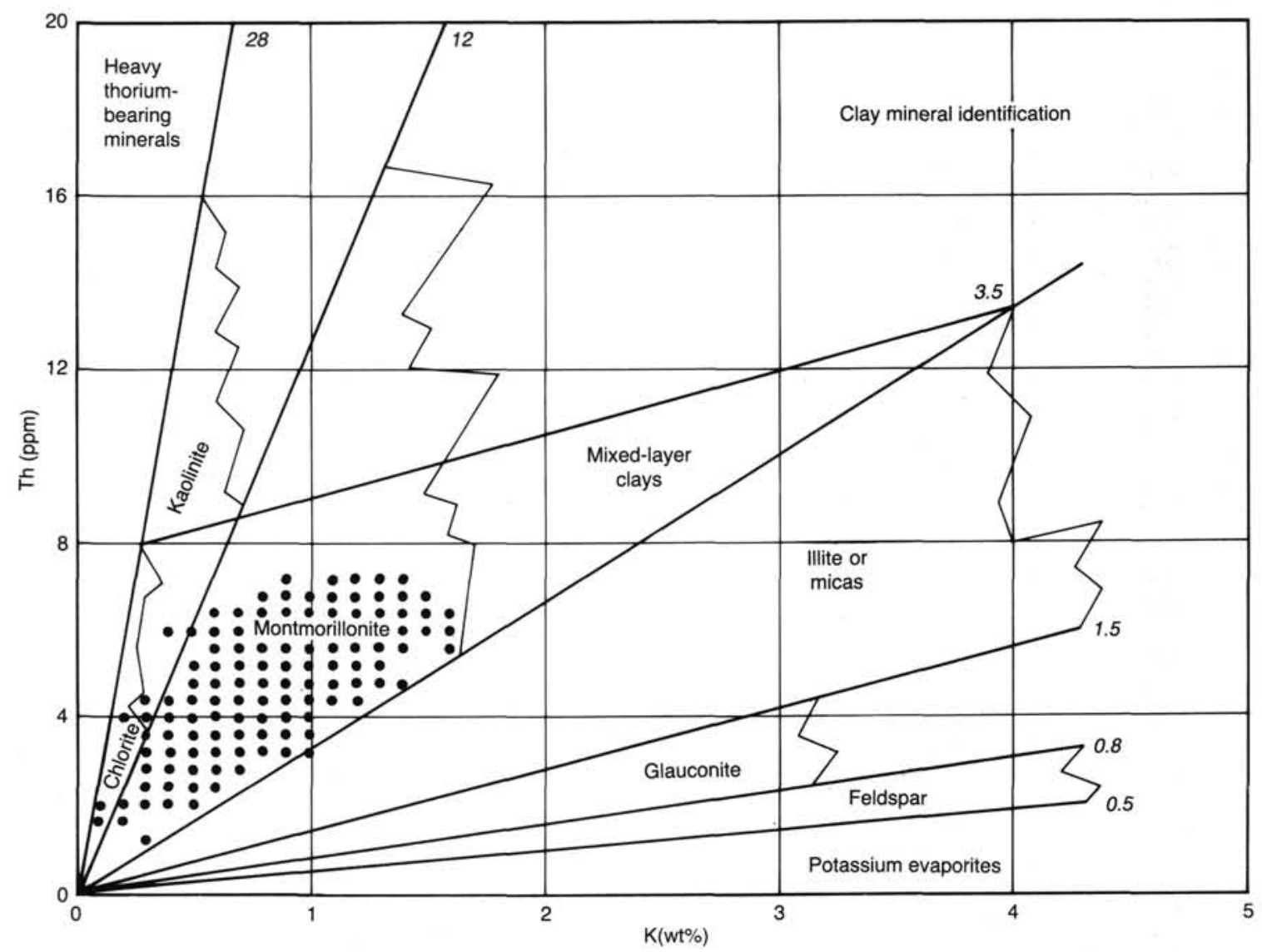

Figure 36. Plot of thorium vs. potassium concentrations for clay-mineral identification in the Miocene sediments of Hole $652 \mathrm{~A}$. Because the composition of clay minerals is quite variable, each mineral is represented by a general area rather than by a single point. Lines represent points of constant $\mathrm{Th} / \mathrm{K}$ ratio. Most of the logged values fall in the field of montmorillonite, but chlorite and kaolinite are also present.

iron content. Both these features are confirmed by Cores 107$652 \mathrm{~A}-37 \mathrm{R}$ to $107-652 \mathrm{~A}-38 \mathrm{R}$, which consist primarily of gypsumbearing clay and mud rich in iron oxides. No sediment was recovered in Core 107-652A-36R, but logs clearly indicate that the top of Unit V occurs at 338 mbsf.

The overlying lithostratigraphic Unit IVc consists of 14 loose pebbles recovered in the core catcher of Core 107-652A-36R. Logs in this interval show a different signature from adjacent sediments that allows the identification of the top of the unit at 324 mbsf. The discrepancy between the depth of this boundary on cores ( $334.7 \mathrm{mbsf}$ ) and logs is explained by the extremely low recovery in Cores 107-652A-35R to $107-652 \mathrm{~A}-36 \mathrm{R}$.

\section{Comparison of Logging and Physical-Property Measurements}

Figure 37 shows the physical-properties data from logs and cores. High velocity $(3-5 \mathrm{~km} / \mathrm{s})$ and low porosity $(<5 \%)$ samples corresponding to streaks of gypsum or anhydrite have been omitted from the physical-properties data because their thickness $(<5 \mathrm{~cm})$ is less than the tool resolution.

Agreement between log and sample velocities is quite good throughout the section. Pliocene sediments to 189 mbsf show a uniform low velocity of $1.6-1.7 \mathrm{~km} / \mathrm{s}$. The Pliocene-Miocene boundary at $189 \mathrm{mbsf}$ is not marked by a sharp change in velocity (i.e., by a seismic reflector), but by a gradual and steady increase becoming more evident in the log data below 230 mbsf. This depth marks the onset of gypsum- and carbonate-bearing sands and silts of lithostratigraphic Units IVa and IVb.
The pebble interval, at 324-337.5 mbsf, exhibits the highest velocity values, $2.7-3.5 \mathrm{~km} / \mathrm{s}$; the bottom of this unit is indicated by the sudden drop of velocity to $2.0 \mathrm{~km} / \mathrm{s}$.

Raw neutron porosity and neutron porosity corrected for hole size, pressure, and standoff are shown plotted against the laboratory porosities in Figure 37. The corrected neutron porosities are considerably lower than the raw porosities. In the Pliocene section (down to $189 \mathrm{mbsf}$ ), the corrected neutron porosities are smaller than the sample measurements, probably a reflection of the amount of elastic rebound undergone by these high porosity samples as they are brought to the surface. In the Miocene sediments, the corrected neutron porosities are larger than the corresponding sample values. This is due to (1) less elastic rebound effect in a stiffer (e.g., higher velocity) sediment, (2) bound water in clays "seen" by the neutron tool, and (3) insufficient correction of the neutron response for the borehole effects.

Alternatively, a synthetic porosity curve calculated from the deep induction log is shown plotted along with the core data in Figure 36. This calculation assumes that Archie's (1942) relationship

$$
\mathrm{R}(\text { formation })=\mathrm{R}(\text { water }) \times \text { porosity }^{-2}
$$

is here applicable. $\mathrm{R}$ (formation) was taken to be the measured deep induction resistivity, and $\mathrm{R}$ (water) values were calculated from the measured pore-water salinities and temperature data. In high porosity sediments this assumption is often untenable, 


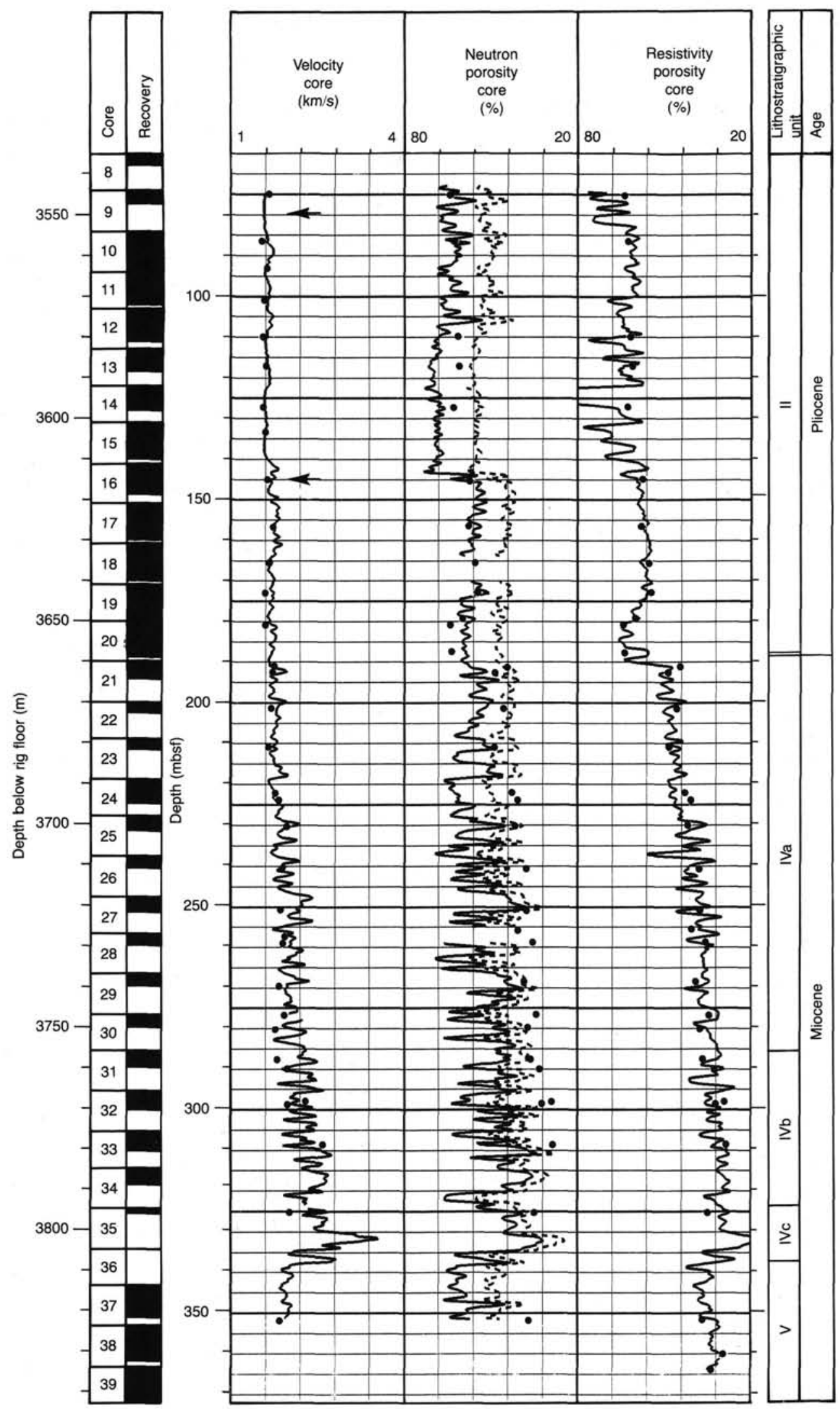

Figure 37. Physical properties from logs (lines) and cores (points) at Hole 652A. The arrows delimit the large washout as detected from caliper and nuclear logs; in this section the original neutron log readings (solid line) are significantly affected by neutron absorption by the borehole fluid (log porosities higher than core porosities). The dashed curve represents porosity values corrected for borehole size. Logs are smoothed using a 5-point running average filter. Data acquired every $0.15 \mathrm{~m}$. 
but the agreement between the calculated and measured porosities throughout the interval is striking, even in the washed-out section at the top of the hole. Computed porosities average $63 \%$ in the logged Pliocene sediments. In the pre-Pliocene sediments, a rapid decrease in porosity is observed; over a distance of less than $200 \mathrm{~m}$, porosity decreases to an average value of $37 \%$. Further examination of the samples will help to reveal the cause of the rapid reduction of pore space.

\section{HEAT FLOW}

\section{Introduction}

Site 652 was drilled on one of the easternmost tilted blocks of the Vavilov rift-basin western margin, between the Central Fault zone and de Marchi Seamount (Fig. 38). At this site, reflection seismic data permit recognition of a Pliocene-Pleistocene post-rift sequence and thick syn-rift and pre-rift series below the Upper Messinian unconformity.

\section{Data}

Five excellent temperature measurements were obtained at Site 652 with the same Uyeda-T-Probe downhole recorder and sensor (thermistor 14 combination), thus minimizing calibration errors that may arise from the use of different measuring systems. Figure 39 displays the temperature vs. time records of the measurements. An average bottom water temperature of $13.30^{\circ} \mathrm{C}$ was measured.

The downhole measured temperatures of Hole $652 \mathrm{~A}$ plotted vs. sub-bottom depth fit a nearly straight line (Fig. 40); a mean gradient of $140^{\circ} \pm 20^{\circ} \mathrm{C} / \mathrm{km}$ can be calculated, taking into account the sea-bottom water temperature. Nevertheless the gradient gradually decreases with depth from $165^{\circ} \mathrm{C} / \mathrm{km}$ in the upper interval $(0-36.4 \mathrm{mbsf})$ to $105^{\circ} \mathrm{C} / \mathrm{km}$ in the lowermost interval (151.2-189.8 mbsf, Table 14).

Thermal conductivities were measured at several depths along recovered cores using the needle-probe method. Unfortunately only a few measurements are available because of technical fail- ures in the equipment and calibration program. Figure 24 shows the thermal conductivities plotted vs. sub-bottom depth. Table 14 gives the harmonic mean conductivities for several depth intervals. Note the high thermal conductivity over the interval $189.8-267$ mbsf giving a harmonic mean of $1.61 \mathrm{Wm}^{-1{ }^{\circ}} \mathrm{C}^{-1}$ $\left(3.8510^{-3} \mathrm{cal} \mathrm{cm}^{-2} \mathrm{~s}^{-1}\right)$ for $\mathrm{n}=5$ measurements. Calculated heat flow determinations for the same intervals are also given in Table 14. The mean heat flow value is $160 \mathrm{~mW} / \mathrm{m}^{2} \pm 17 \mathrm{~mW} /$ $\mathrm{m}^{2}=3.82 \pm 0.4$ HFU.

\section{Comments}

Assuming a normal constant heat flow with depth, as a first approximation, the decrease in the temperature gradient downhole is compensated by the increase in the thermal conductivity over the depth interval of measurements of the temperature gradient.

\section{Conclusions}

We determined a heat flow value of $160 \pm 17 \mathrm{~mW} / \mathrm{m}^{2}$ at Site 652 based on five temperature and conductivity measurements made on the recovered sediments.

This heat flow value is in the range of those obtained at Site 651 in the Vavilov Basin and at Site 650 in the Marsili Basin (144 and $162 \mathrm{~mW} / \mathrm{m}^{2}$, respectively). The high heat flow at these three sites is consistent with the inferred presence of hot mantle material at shallow depth beneath or intruding the stretched continental lithosphere. Nevertheless, along surficial profiles, variability and anomalies in the heat flow distribution are recognized in the central Tyrrhenian in conjunction with the regional structural pattern and localized volcanic activity.

A linear extrapolation of the temperature profile obtained at Site 652 in the uppermost 189.8 mbsf to total depth gives a temperature of about $130^{\circ} \mathrm{C}$ at the bottom of the hole compared with the $60^{\circ} \mathrm{C}$ critical temperature. This is a high temperature considering the diagenetic evolution of the sediments, in particular clay minerals, and the dolomitic and sulfate crystallization. It is also probable that the high heat flow regime has enhanced

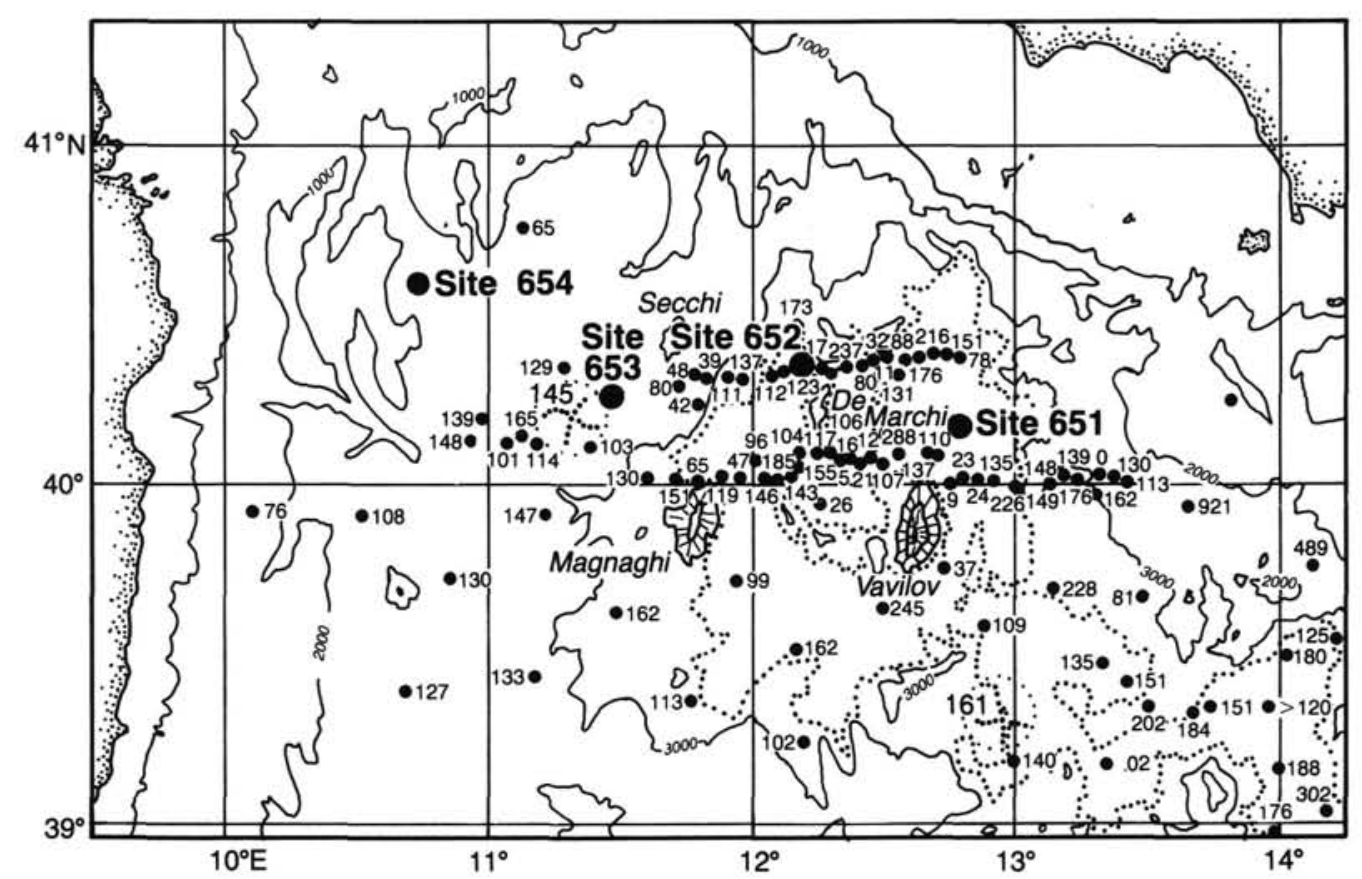

Figure 38. Heat flow distribution across central and western Tyrrhenian Basins (after Della Vedova et al., 1984). Heat units are shown in $\mathrm{mW} / \mathrm{m}^{2}$. 

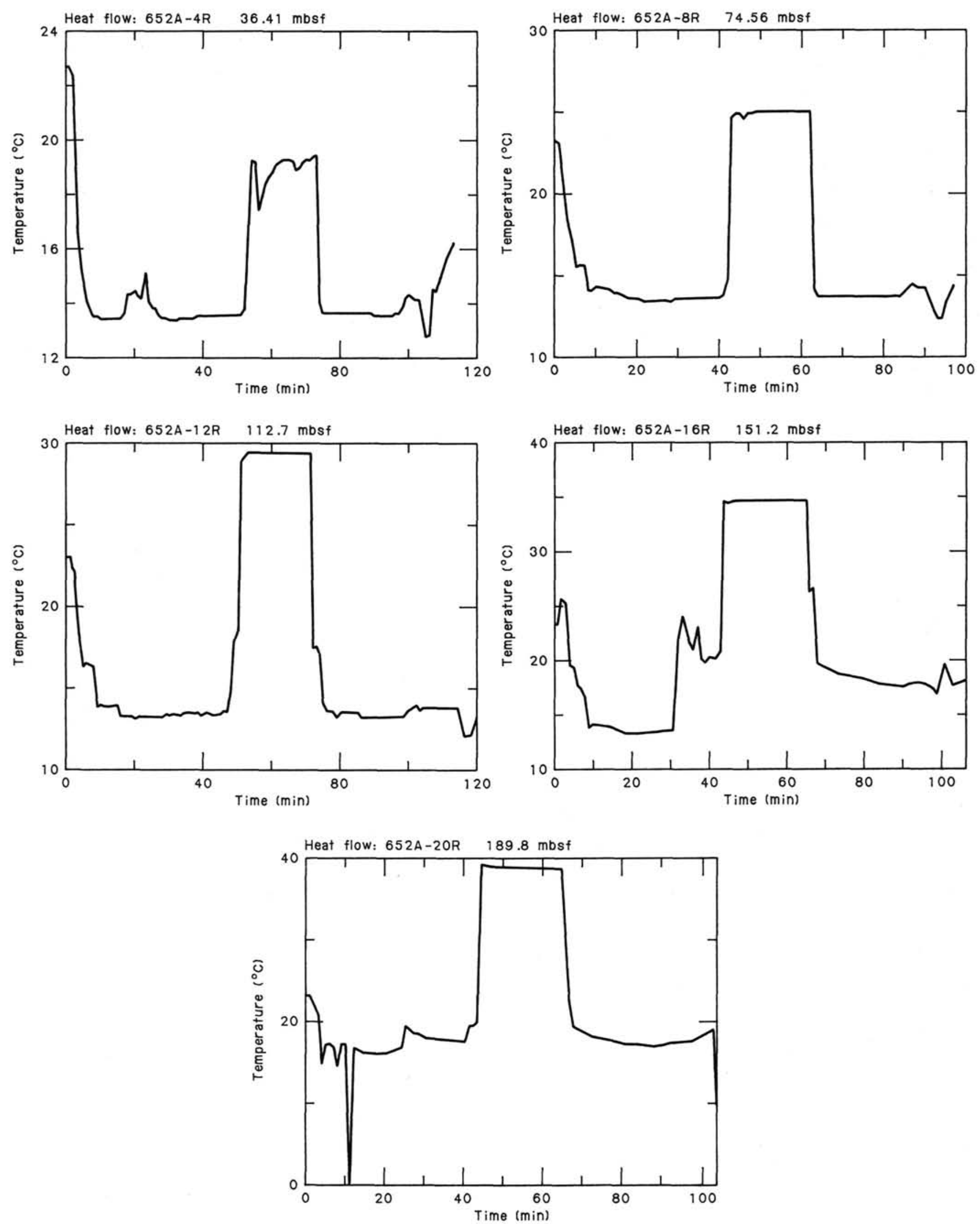

Figure 39. Downhole temperature measurements in Hole 652A at sub-bottom depths of $36.41,74.56,112.7,151.2$, and $189.8 \mathrm{~m}$. 


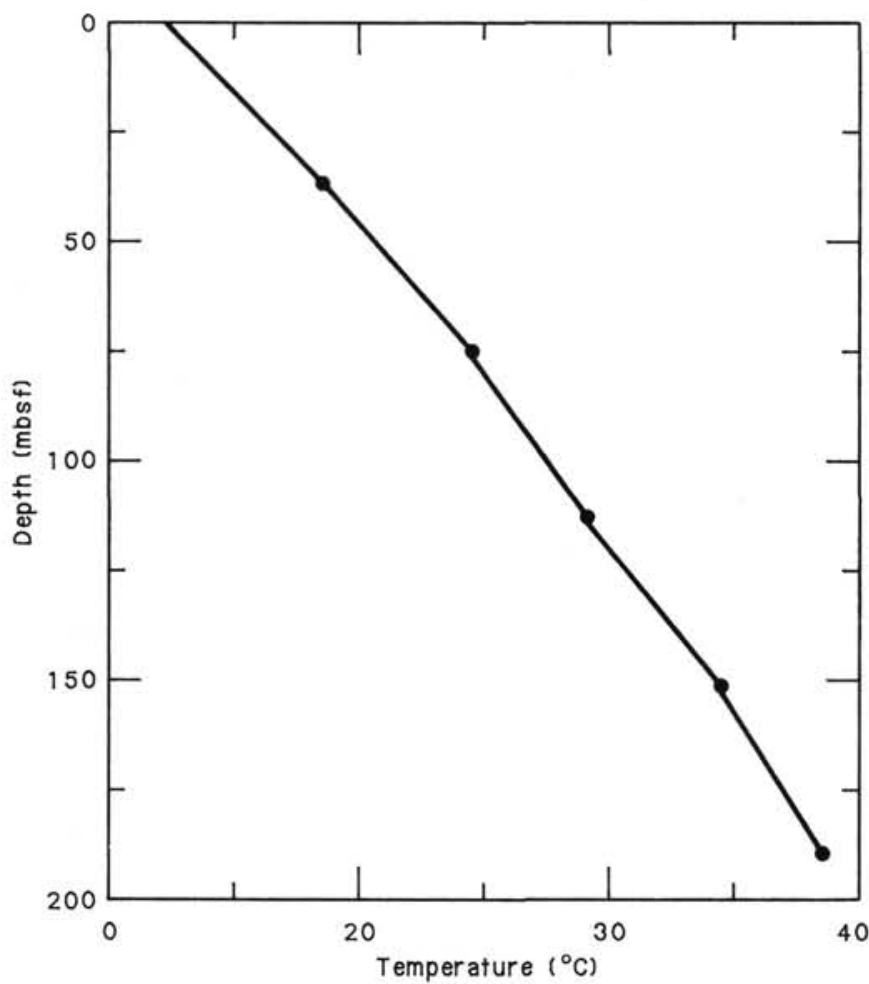

Figure 40. Plot of sediment temperature vs. bottom depth in Hole 652A.

thermal maturation of organic-carbon-rich sediments of the western deep margin of the Vavilov Basin (see "Geochemistry" section, this chapter).

\section{DISCUSSION AND CONCLUSIONS}

\section{Overview}

Site 652 achieved its primary objective of documenting the sedimentary sequences deposited prior to, during, and after the main episode of stretching of a passive continental margin. Unfortunately, the sediments at the pre-rift/syn-rift contact and within the lower syn-rift sequence were not datable with shipboard techniques. A complete Pliocene/Pleistocene section was obtained, which appears to be suitable for detailed comparisons of biostratigraphy, magnetostratigraphy, and stable isotope stra- tigraphy. Finally, the lower $540 \mathrm{~m}$ of Hole $652 \mathrm{~A}$ recovered an unusual pre-Pliocene (presumed Messinian) clastic and evaporitic facies which is tentatively interpreted as lacustrine.

\section{Pliocene-Pleistocene Sediments}

The Pliocene-Pleistocene sediments are characterized by open marine conditions, with a significant influx of volcanic material, notably in the Pleistocene and upper Pliocene. The Pliocene/ Pleistocene boundary has no obvious lithological expression.

Repeated sapropelic intervals incorporate both marine and continental organic carbon. Organic matter has apparently been preferentially preserved under conditions of anoxic bottom water during these brief intervals of the Pleistocene. Prior to the drilling of this site, late Pliocene and early Pleistocene sapropels were mostly viewed as an eastern Mediterranean phenomenon, and explanations for their origin were sought in local processes such as vertical stratification of the water column following increased fresh water input from the Nile and/or Black Sea. The geochemical and color patterns of individual sapropels in the eastern Mediterranean have proved to be quite distinctive, so it should be possible to determine whether individual Tyrrhenian sapropels correlate with Ionian and Levantine Sea sapropels. If so, an explanation must be found for the Pleistocene sapropels which is equally applicable both east and west of the Sicily Channel.

The lowermost Pliocene and the Miocene/Pliocene transition zone are characterized by a strong red-brown coloration which is attributed to iron oxides. The iron oxide component suggests that these sediments had been subaerially weathered during the Messinian drawdown and were reworked during and immediately after the terminal Messinian transgression.

\section{Pre-Pliocene Sediments}

The pre-Pliocene sequence at Site 652 is characterized by a thick sequence of subaqueously-deposited, clastic sediments. The entire sequence, from 189 mbsf to the base of the hole at 721 mbsf, is barren of autochthonous fauna.

\section{Environment of Deposition}

The environment in which the pre-Pliocene sequence was deposited seems to have been highly variable through time. Frequent, thin evaporitic interbeds indicate periods of higher bottom-water salinity. Algae- and organic-carbon-rich beds suggest periods of higher productivity. The pebble horizon at $335 \mathrm{mbsf}$ may indicate a temporary fluviatile or beach environment. The presence of millimetric red and yellow laminae rich in iron oxide

Table 14. Heat flow at Site 652.

\begin{tabular}{lcccrcr}
\hline & $\begin{array}{c}\text { Interval } \\
\text { temperature } \\
\text { increase } \\
\begin{array}{l}\text { Depth } \\
\text { (mbsf) }\end{array}\end{array}$ & $\begin{array}{c}\text { Thermal } \\
\text { gradient }\end{array}$ & $\begin{array}{c}\text { Thermal } \\
{ }^{\circ} \mathrm{C} / \mathrm{km}\end{array}$ & $\begin{array}{l}\text { Conductivity } \\
\mathrm{Wm}^{-1} \mathrm{C}^{-1}\end{array}$ & $\mathrm{n}$ & \multicolumn{2}{c}{ Heat flow } \\
\hline 36.4 & $6.0 \pm 0.1$ & $165 \pm 3$ & $0.98 \pm 0.06$ & 10 & $162 \pm 10$ & $3.87 \pm 0.24$ \\
38.16 & $5.65 \pm 0.05$ & $148 \pm 1.5$ & $1.17 \pm 0.05$ & 8 & $173 \pm 9$ & $4.13 \pm 0.21$ \\
38.14 & $4.6 \pm 0.05$ & $121 \pm 1.5$ & $1.20 \pm 0.08$ & 3 & $145 \pm 10$ & $3.46 \pm 0.24$ \\
38.5 & $5.2 \pm 0.05$ & $135 \pm 1.5$ & $1.32 \pm 0.1$ & 6 & $178 \pm 10$ & $4.25 \pm 0.24$ \\
38.6 & $4.05 \pm 0.05$ & $105 \pm 1.5$ & $1.33 \pm 0.1$ & 4 & $140 \pm 10$ & $3.34 \pm 0.24$ \\
74.56 & $11.65 \pm 0.08$ & $156 \pm 1.5$ & $1.075 \pm 0.06$ & 18 & $167 \pm 10$ & $3.99 \pm 0.21$ \\
112.7 & $16.25 \pm 0.08$ & $144.2 \pm 1.5$ & $1.12 \pm 0.08$ & 21 & $161.5 \pm 13$ & $3.86 \pm 0.31$ \\
151.2 & $21.45 \pm 0.08$ & $142 \pm 1.5$ & $1.17 \pm 0.1$ & 27 & $166 \pm 17$ & $3.96 \pm 0.4$ \\
189.8 & $25.5 \pm 0.08$ & $134.4 \pm 1.5$ & $1.20 \pm 0.1$ & 31 & $161 \pm 15$ & $3.84 \pm 0.36$ \\
76.64 & $9.8 \pm 0.05$ & $128 \pm 1.5$ & $1.26 \pm 0.1$ & 9 & $161 \pm 13$ & $3.84 \pm 0.31$ \\
115.24 & $13.85 \pm 0.08$ & $120 \pm 1.5$ & $1.283 \pm 0.1$ & 13 & $154 \pm 12$ & $3.68 \pm 0.28$ \\
77.2 & & & $1.61 \pm 0.08$ & 5 & & \\
\hline
\end{tabular}

Note: $\mathrm{n}=$ number of conductivity measurements/interval.

To be mentioned: Temperature from logging at $350 \mathrm{mbsf} \rightarrow \mathrm{T}=56.7 \pm 2^{\circ} \mathrm{C}$; expected temperature according average $14^{\circ} \mathrm{C} / 100 \mathrm{~m}$ gradient $=62.3^{\circ} \mathrm{C}$,

Water temperature was near equilibrium in the hole at time of measurement. 
may indicate that there was land exposed nearby, if the laminae are indeed derived from subaerial weathering and brought to the site by eolian transport. However we found no mudcracks or other direct evidence of subaerial exposure in the cores. We consider that the most probable sedimentary environment for the pre-Pliocene units (other than the pebble horizon) is lacustrine. Evidence for a euryhaline or lacustrine environment includes the total absence of normal marine organisms, the very rare occurence of Ammonia becarii and Cypridies, the presence of Botryococcus-type algae, the extreme fluctuations of salinity and productivity inferred from lithologic variability, and the inferred proximity of subaerial source areas for significant input of eolian sediment.

\section{Age of the Pre-Pliocene Sequence}

The pre-Pliocene sequence hampered shipboard attempts at stratigraphic control. The only in-situ flora or fauna recovered from the pre-Pliocene sequence were three specimens of Ammonia becarii tepida, fragments of ostracodes, and possible algae. The upper $40 \mathrm{~m}$ of the pre-Pliocene are reversely magnetized, which taken in context of the magnetostratigraphy of the overlying sediments implies that this interval lies within the lowermost reversed interval in the Gilbert geomagnetic epoch (i.e., between 4.79 and 5.41 m.y.b.p. according to Harland et al., 1982). Below this depth, the natural remnant magnetization was too weak for shipboard measurement. Preliminary shore-based work suggests that this reversed magnetic polarity continues to the base of the drilled section. Additional shore-based paleomagnetic and pollen-stratigraphic studies may further constrain the age of the barren units.

Because of the presence of evaporites, the reversed magnetic polarity, and the position of these barren sediments beneath the Pliocene, a Messinian age has been tentatively assigned to the interval from 189 to 721 mbsf. We speculate that the pebble horizon at approximately 335 mbsf may correlate with the intraMessinian erosional event which is expressed elsewhere in the Mediterranean as an unconformable contact between the upper and lower evaporites. If so, lithostratigraphic Unit IV between 189 and 330 mbsf would be the lateral equivalent of the upper evaporite, while lithostratigraphic Unit Va (and possibly Vb) would be the lateral equivalent of the lower evaporites. In this context, it is interesting to note that within lithostratigraphic Unit Va, it is possible to distinguish several second-order sedimentary cycles within the sequence of alternating clastic and chemical sediments. Each of these cycles is about $10 \mathrm{~m}$ thick, and is characterized by an increase in the abundance of sulfate toward the top of the cycle (see "Lithostratigraphy" section, this chapter). Cyclic sedimentation is also known in the lower evaporites of Sicily (Heimann and Mascle, 1974; Decima and Wezel, 1973; Garrison et al., 1978).

Although we are reasonably confident that most of the barren, evaporite-bearing interval was deposited during the Messinian, we cannot totally exclude the possibility that the base of this sequence was deposited in a pre-Messinian, early-rift continental environment analogous to the modern east African rift valley lakes.

\section{Tectonic Significance}

Numerous microstructures indicative of sedimentary instability are found in the pre-Pliocene sequence. These features include numerous synsedimentary normal faults, less common reverse faults, slumps, convoluted bedding, and breccias. In contrast, only one, poorly-developed, possible slump was observed in the Pliocene-Pleistocene section.

Preliminary measurements on microfaults suggest a direction of extension between $100^{\circ}$ and $130^{\circ}$. (Note that since the cores were not oriented, this line of reasoning incorporates an as- sumption that the dip of bedding in the cores is parallel to the regional dip of reflectors in seismic reflection profiles). This inferred east-southeast direction of extension is consistent with seismic reflection data which show north-northeast-striking normal faults (Moussat, 1983), and with an inferred north-northwest/south-southeast direction of opening of the Vavilov Basin (e.g., Moussat, 1983; Moussat et al., 1985; Rehault et al., 1987; Malinverno and Ryan, 1986).

A preliminary comparison between the lithostratigraphy and the seismic reflection data indicates that:

1. The uppermost pre-rift sequence appears to coincide with the highly-indurated lowest 30 or $40 \mathrm{~m}$ of sedimentary Unit V. We cannot rule out the possibility that these indurated, barren sediments were deposited in a pre-Messinian continental environment which was situated above modern sea level before the onset of rifting. However, we consider it more likely that the pre-rift to syn-rift transition occurred during the Messinian.

2. Most of the pre-Pliocene section, presumably of Messinian age, can be interpreted as syn-rift deposits. Ages within this interval have not been determined, other than to speculate that the pebble horizon between 335 and 345 mbsf may coincide with the intra-Messinian erosional event.

3. The transition from syn-rift to post-rift sedimentation occurred during Pliocene time.

4. Minor tectonic activity may have continued or resumed in the Pleistocene. The seaward-dipping fault which bounds the eastern edge of the tilted block at Site 652 has displaced Pleistocene sediments as well as the seafloor; however, the sense of motion in the Quaternary has been reverse rather than normal, suggesting reactivation of the fault in a new stress regime rather than continued motion.

\section{REFERENCES}

AGIP, 1982. Foraminiferi Padani-Atlante iconografico e distribuzione, (2nd ed.): Milano (AGIP).

Amodio-Morelli, L., et al., 1976. L'arco calabro-peloritano nell'orogene appenninico-maghrebide. Mem. Soc. Geol. Ital. 17:1-60.

Angelier, J., and Mechler, P., 1977. Sur une méthode graphique de recherche des contraintes principales, également utilisables en téctonique et en seismologie: la méthode des dièdres droits. Bull. Soc. Geol. France, 29:6,1309-1318.

Archie, G. E., 1942. The electrical resistivity log as an aid in determining some reservoir characteristics. Pet. Technol., 5(1).

Berggren, W. A., Kent, D. V., and van Couvering, J. A., 1984. Neogene chronology and chronostratigraphy. In Snelling (Ed.), Geochronology and geological record, Geol. Soc. London, Spec. Paper.

Bizon, G., and Müller, C., 1977. Remarks on some biostratigraphic problems in the Mediterranean Neogene. In Biju-Duval,B., and Montadert, L. (Eds.), Structural History of the Mediterranean Basins. Paris (Technip), 381-390.

Broecker, W. S., and Van Donk, J., 1970. Insolation changes, ice volume, and the ${ }^{18} \mathrm{O}$ record in deep-sea cores. Rev. Geophys. Space Phys., 8:169-198.

Chamley, H., Dunoyer de Segonzac, G., and Melieres, F., 1978. Clay minerals in Messinian sediments of the Mediterranean area. In Hsü, K. J., Montadert, L., et al., Init. Repts. DSDP, 42, Pt. 2: Washington (U.S. Govt. Printing Office), 389-397.

Cifelli, R., 1974. Planktonic foraminifera from the Mediterranean and adjacent Atlantic waters (cruise of the Atlantic II, 1969). J. Foraminiferal Res., 4:171-183.

Cita, M. B., 1975. Studi sul Pliocene e le strati di passaggio del Miocene el Pliocene, VIII. Planktonic foraminiferal biozonation of the Mediterranean deep sea record: a revision. Rev. Ital. Paleontol. Stratigr., $81: 527-544$.

Cita, M. B., and Zocchi, M., 1978. Distribution patterns of benthic foraminifera on the floor of the Mediterranean sea. Oceanol. Acta, 1(4):445-462.

Cita, M. B., Chierichi, M. A., Cliampo, G., Moncharmont, Z. M., D'Onofrio, S., Ryan, W.B.F., and Scorziello, R., 1973. The Quater- 
nary record of the Tyrrhenian and Ionian Basins of the Mediterranean Sea. In Ryan, W.B.F., Hsü, K. J., et al., Init. Repts. DSDP, 13: Washington (U.S. Govt. Printing Office), 1405-1415.

Cita, M. B., and Grignani, D., 1982. Nature and origin of late Neogene Mediterranean Sapropels. In Schlanger, S. O., and Cita, M. B. (Eds.), Nature and Origin of Cretaceous Carbon-rich Facies: London (Academic Press), 165-196.

Colalongo, M. L., Pasini, G., Pelosio, G., Raffi, S., Rio, D., Ruggieri, G., Sartoni, S., Selli, R., and Sprovieri, R., 1982. The Neogene/ Quaternary boundary definition: a review and a proposal. Geogr. Fis. Din. Quat., 5:59-68.

Colantoni, P., Fabbri, A., Gallignani, P., Sartori, R., and Rehault, J. P., 1981. Carta Litologica e Stratigraphica dei Mari Italiani. Litografia artistica cartografica, Firenze.

Decima, A., and Wezel, F. C., 1973. Late Miocene evaporites of the central Sicilian Basin, In Ryan, W.B.F., and Hsü, K., et al., Init. Repts. DSDP, 13: Washington (U.S. Govt. Printing Office), 12341240.

Demaison, G. J., and Moore, G. T., 1980. Anoxic environments and oil source bed genesis. AAPG Bull. 64:1179-1209.

Emeis, K. C., and Kvenvolden, K. A., 1986. Shipboard organic geochemistry on JOIDES Resolution. ODP Tech. Note 7.

Emiliani, C., 1978. The cause of the ice ages. Earth Planet. Sci. Lett., $37: 349-352$.

Fabbri, A., and Curzi, P., 1979. The Messinian of the Tyrrhenian Sea: seismic evidences and dynamic implications. G. Geol., 43,2:215-248.

Fabbri, A., Gallignani, P., and Zitellini, N., 1981. Geologic evolution of the Peri-Tyrrhenian sedimentary basins. In Wezel, F.C. (Ed.), Sedimentary basins of Mediterranean margins. Bologna (Technoprint), 101-126.

Finetti, I., and Morelli, C., 1973, Geophysical exploration of the Mediterranean Sea. Boll. Geofis. Teor. Appl, 15:263-340.

Finetti, I., Morelli, C., and Zarudzki, E., 1970. Reflection seismic study of the Tyrrhenian Sea. Boll. Geofis. Teor. Appl., 12,48:311-346.

Garrison, R. E., Schreiber, B. C., Bernoulli, D., Fabricius, F., Kidd, R. B., and Melieres, F., 1978. Sedimentary petrology and structures of Messinian evaporitic sediments in the Mediterranean Sea, Leg 42A, Deep Sea Drilling Project, In Hsü, K., and Montadert, L., et al., Init. Repts. DSDP 42, Pt. 1: Washington (U.S. Govt. Printing Office), 571-612.

Gennesseaux, M., Rehault, J.-P., Thomas, B., Colantoni, P., Fabbri, A., Lepvrier, C., Mascle, G., Mauffret, A., Polino, R., Robin, C., and Vanney, J., 1986. Resultats de plongées en submersible Cyana sur les blocs basculés de la mer Tyrrhénienne centrale et le volcan sous-marin Vavilov. C.R. Acad. Sci. Paris Ser. A, T302,12:785-792.

Grandjacquet, C., and Mascle, G., 1978. The structure of the Ionian Sea, Sicily and Calabria-Lucania. In Nairn, A.E.M., et al. (Eds.), The Ocean Basins and Margins: New York (Plenum Press), 4B,257329.

Hardie, L. A., 1967. The gypsum-anhydrite equilibrium at one atmosphere pressure. Am. Mineralogist, 52:171-200.

Harland, W. B., Cox, A., Lewellyn, P. G., Pickton, C.A.G., Smith, A. G., and Walters, R., 1982. A Geologic Time Scale: Cambridge (Cambridge Univ. Press)

Hassan, M., and Hossin, A., 1975. Contributions à l'étude des comportements du Thorium et du Potassium dans les roches sédimentaires. C.R. Acad. Sci., Paris Ser. A, T280,533-535.

Heimann, K. O., and Mascle, G., 1974. Les séquences de la série évaporitique méssinienne, C.R. Acad. Sci. Paris Ser. A, 279,1967-1970.

Hunt, J. M., 1979. Petroleum Geochemistry and Geology: San Francisco (Freeman and Co.).

Hutchison, I., Von Herzen, R., Louden, K., Sclater, J., and Jemsek, J., 1985. Heat flow in the Balearic and Tyrrhenian basins, Western Mediterranean. J. Geophys. Res., 90(B1):685-701.

Kidd, R. B., Cita, M. B., and Ryan, W.B.F., 1978. Stratigraphy of eastern Mediterranean sapropel sequences recovered during Leg $42 \mathrm{~A}$ and their paleoenvironmental significance. In Hsü, K. J., Montadert, L., et al., Init. Repts. DSDP, 42A: Washington (U.S. Govt. Printing Office), 421-443.

Malinverno, A., 1981. Quantitative estimates of age and Messinian paleobathymetry of the Tyrrhenian Sea after seismic reflection, heat flow and geophysical models. Boll. Geofis. Teor. Appl., 23,90-91: 159-171.
Malinverno, A., and Ryan, W.B.F., 1986. Extension in the Tyrrhenian Sea and shortening in the Apenninic as a result of arc migration driven by a sinking of the lithosphere. Tectonics, 5,2:227-245.

Malinverno, A., Cafiero, M., Ryan, W.B.F., and Cita, M. B., 1981, Distribution of Messinian sediments and erosional surfaces beneath the Tyrrhenian Sea: geodynamic implications. Oceanol. Acta, 4: 489-496.

Manheim, F. T., and Sayles, F. L., 1974. Composition and origin of interstitial waters of marine sediments based on deep sea drill cores. In Goldberg, E. D. (Ed.) The Sea 5:527-568.

Mankinen, E. A., and Dalrymple, G. B., 1979. Revised geomagnetic polarity time scale for the interval 1-5 m.y.B.P., J. Geophys. Res., $84: 615-626$.

Moussat, E., 1983. Evolution de la Mer Tyrrhenienne centrale et orientale et de ses marges septentrionales en relation avec la neotectonique dans l'Arc Calabrais [Thesis]. Univ. P. et M. Curie, Paris.

Moussat, E., Rehault, J. P., Fabbri, A., and Mascle, G., 1985. Evolution geologique de la mer Tyrrhenienne, C.R. Acad. Sci. Paris Ser. A., 301:491-496.

Morelli, C., 1970. Physiography and magnetism of Tyrrhenian Sea. Boll. Geofis. Teor. Appl., 12,(48):275-309.

Mueller, P. J., and Suess, E., 1979. Productivity, sedimentation rate, and sedimentary organic matter in the oceans - I. Organic carbon preservation. Deep Sea Res., 26A:1347-1362.

Muerdter. D. R., and Kennett, J. P., 1983. Late Quaternary planktonic foraminiferal Biostratigraphy, Strait of Sicily, Mediterranean Sea. Mar. Micropaleontol., 8:339-359.

Müller, C., 1978. Neogene calcareous nannofossils from the Mediterranean - Leg 42 of the Deep Sea Drilling Project. In Hsü, K. J., Montadert, L., et al., Init. Repts. DSDP, 42, Pt.1: Washington (U.S. Govt. Printing Office), 727-752.

Muller, D. C., 1985. Computer method to detect and correct cycle skipping on sonic logs, In Trans. SPWLA, paper R.

Murat, A., and Glaçon, G., 1985. In Rapport des campagnes à la mer du Marion Dufresne. T.A.A.F. Campagne Strabon.

Parker, F. L., 1955. Distribution of planktonic foraminifera in some Mediterranean sediments. Papers in Marine Biology and Oceanography, London (Pergamon) 204-241.

Recq, M., Rehault, J.-P., Steinmetz, L., and Fabbri, A., 1984. Amincicement de la croute et accretion au centre du bassin Tyrrhenien d'apres la sismique refraction. Mar. Geol., 55:411-428.

Rehault, J.-P., Moussat, E., and Fabbri, A., 1987. Structural evolution of the Tyrrhenian back-arc basin. Mar. Geol., 74:123-150.

Rehault, J.-P., Tisseau, C., and Foucher, J. P., 1984a. Structure, subsidence et flux thermique de la Mer Tyrrhénienne Centrale: essais de modélisation. CIESM, (29th meeting) 11-19 October 1984, Lucerne.

Rehault, J.-P., Mascle, J., and Boillot, G., 1984b. Evolution géodynamique de la Mediterranee depuis l'Oligocéne. Mem. Soc. Geol. Ital., 27:85-96.

Rio, D., Sprovieri, R., Di Stefano, I., and Raffi, I., 1984a. Globorotalia truncatulinoides (d'Orbigny) in the Mediterranean upper Pliocene geologic record. Micropaleontology, 30:12-1-137.

Rio, D., Sprovieri, R., and Raffi, I., 1984b. Calcareous plankton biostratigraphy and biochronology of the Pliocene-lower Pleistocene succession of the Capo Rosello area, Sicily. Mar. Micropaleotol. 9:135180.

Romankevich, E. A., 1984. Geochemistry of Organic Matter in the Ocean. Berlin (Springer).

Ruggieri, G., Rio, D., and Sprovieri, R., 1984. Remarks on the chronostratigraphic classification of Lower Pleistocene. Boll. Soc. Geol. Ital., 103:252-259.

Ruggieri, G., and Sprovieri, R., 1983. Recenti progressi nella stratigraffia del Pleistocene inferiore. Boll. Soc. Paleontol. Ital., 22(3):315321.

Ryan, W.B.F., Hsü, K. D., et al., 1973. Site 132. In Ryan, W.B.F., Hsü, K. D., et al., Init. Repts. DSDP, 13: Washington (U.S. Govt. Printing Office), 402-464.

Schlumberger, 1972. The Essentials of Log Interpretation Practice. Paris (Services Techniques Schlumberger).

1985. Log Interpretation Charts. New York (Schlumberger Well Services).

Selli, R., and Fabbri, A., 1971, Tyrrhenian: a Pliocene deep sea. Rend. Cl. Sci. Fis. Mat. Acc. Naz. Lincei, 50:104-116. 
Sigl, W., and Muller, J., 1975. Identification and correlation of stagnation layers in cores from the eastern Mediterranean Sea. Rapports Proces Verbaux CIESM: 23:277-279.

Simoneit, B.R.T., 1982. Shipboard organic geochemistry and safety monitoring Leg 64, Gulf of California. In Curry, J. R., Moore, D. G., et. al., Init. Repts. DSDP, 64 (Pt. 2): Washington (U.S. Govt. Printing Office), 723-727.

Sprovieri, R., and Barone, G., 1984. I Foraminiferi benthonici della sezione pliocenica di Punta Piccola (Agrigento, Sicilia). Geol. Rom.

Steinmetz, L., Ferricci, F., Hirn, A., Morelli, C., and Nicolich, R., 1983. A $550 \mathrm{~km}$ long Moho traverse in the Tyrrhenian Sea from O.B.S record $\mathrm{P}_{\mathrm{n}}$ waves. Geophys. Res. Lett., 10:428-431.

Tauxe, L., Opdyke, N., Pasini, G., and Elmi, C., 1983. Age of the PlioPleistocene boundary in the Vrica section, southern Italy. Nature, 304:125-129.
Todd R., 1958. Foraminifera from Western Mediterranean Deep-Sea cores. Rep. Swed. Deep-Sea Exped., 3:169-215.

Thunnell, R., Williams, D., and Belyea, P., 1984. Anoxic events in the Mediterranean Sea in relation to the evolution of late Neogene climates. Mar. Geol., 59:105-134.

Van Donk, J., 1976. ${ }^{18} \mathrm{O}$ record of the Atlantic Ocean for the entire Pleistocene Epoch. In Cline, R. M., and Hays, J. D. (Eds.), Investigation of Late Quaternary paleoceanography and paleoclimatology. Mem. Geol. Soc. Am. 145:147-163.

Waples, D., 1982. Organic Geochemistry for Exploration Geologists. Boston (Int. Human Res. Develop. Corp.).

Whelan, J. K., and Hunt, J. M., 1982. $\mathrm{C}_{1}-\mathrm{C}_{8}$ Hydrocarbons in Leg 64 Sediments, Gulf of California. In Curray, J. R., Moore, D. G., et al., Init. Repts. DSDP, 64 (Pt.2): Washington (U.S. Govt. Printing Office), 763-779. 
Summary Log for Hole 652A

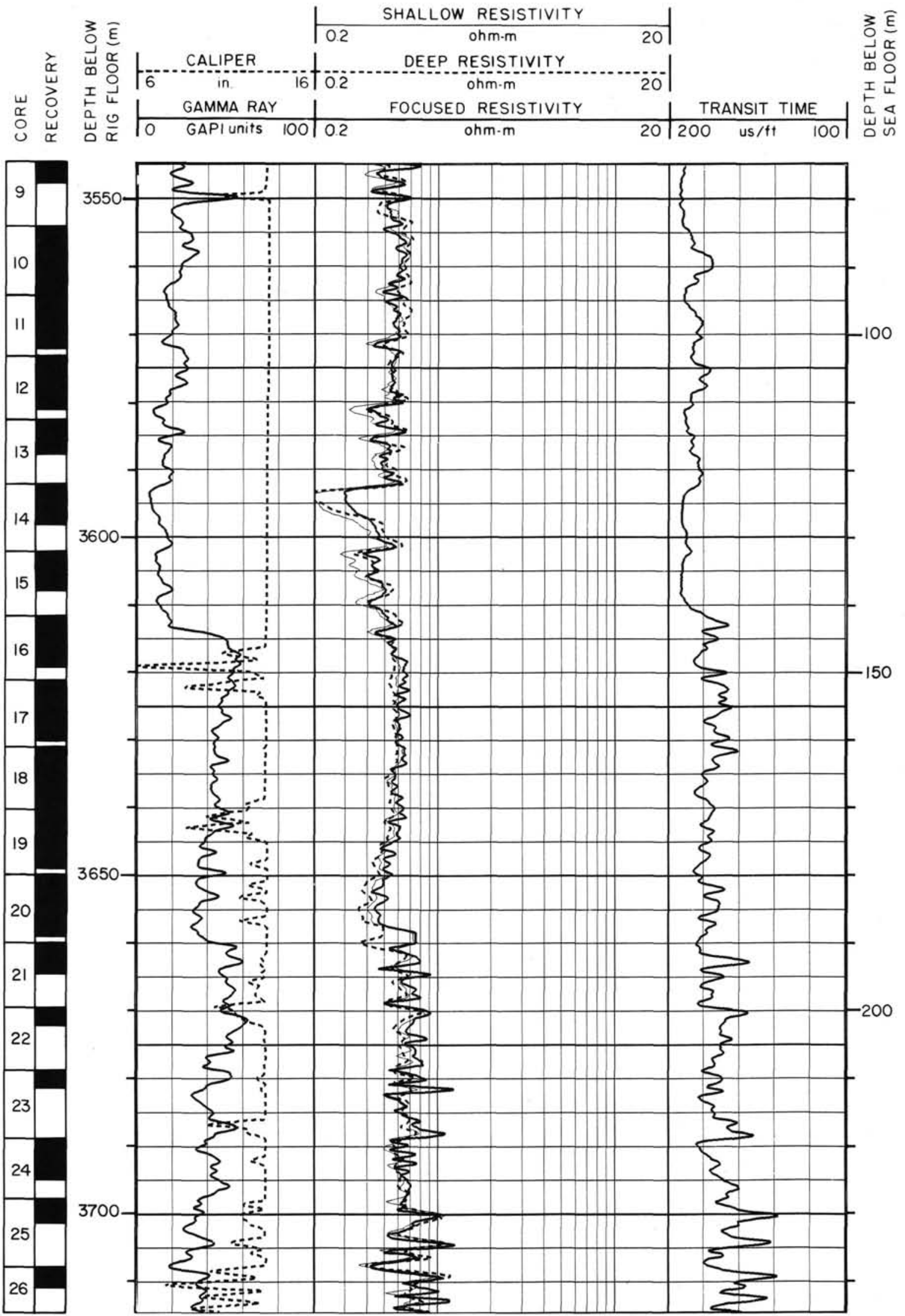




\section{Summary Log for Hole 652A (continued)}
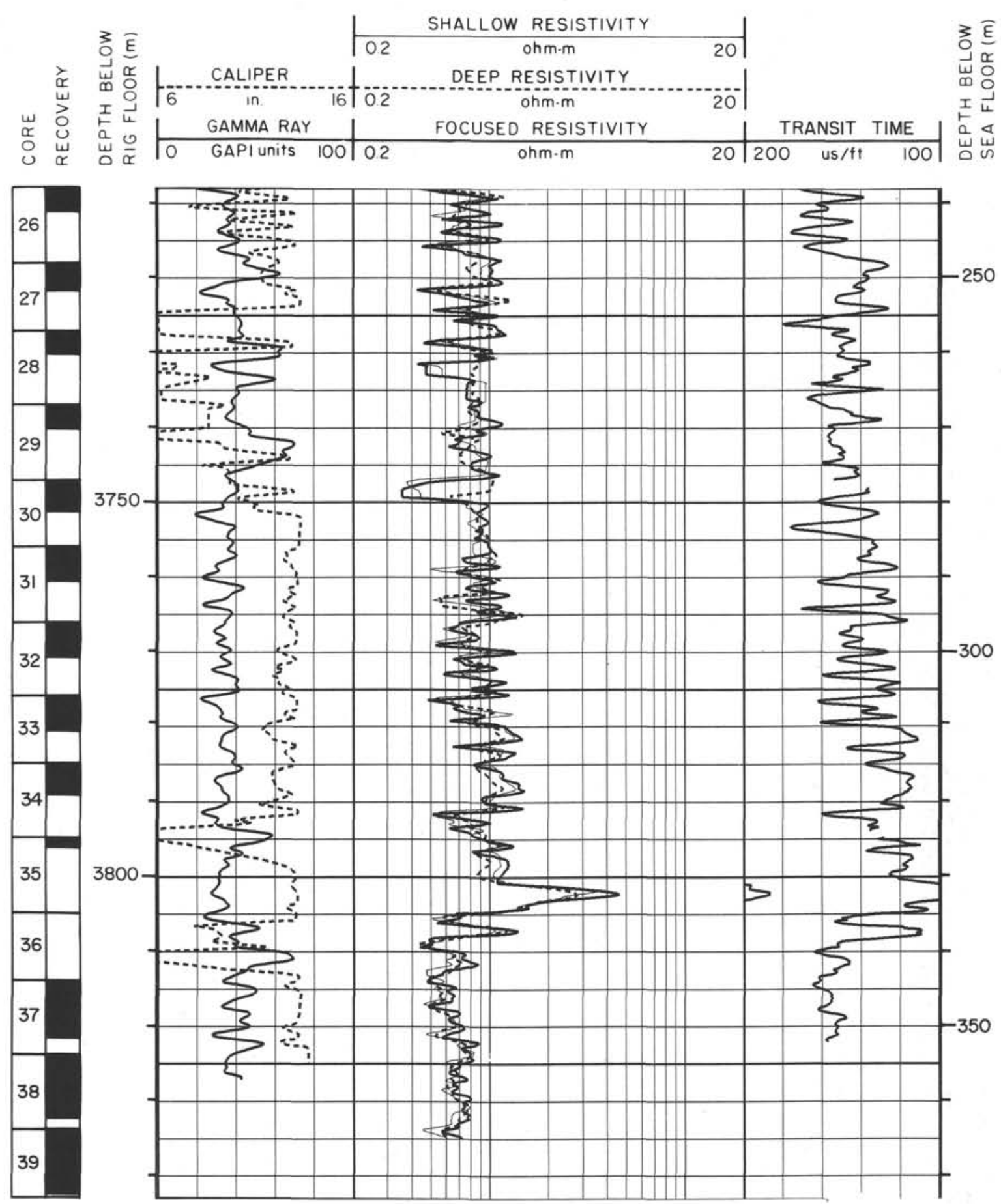
Summary Log for Hole 652A (continued)
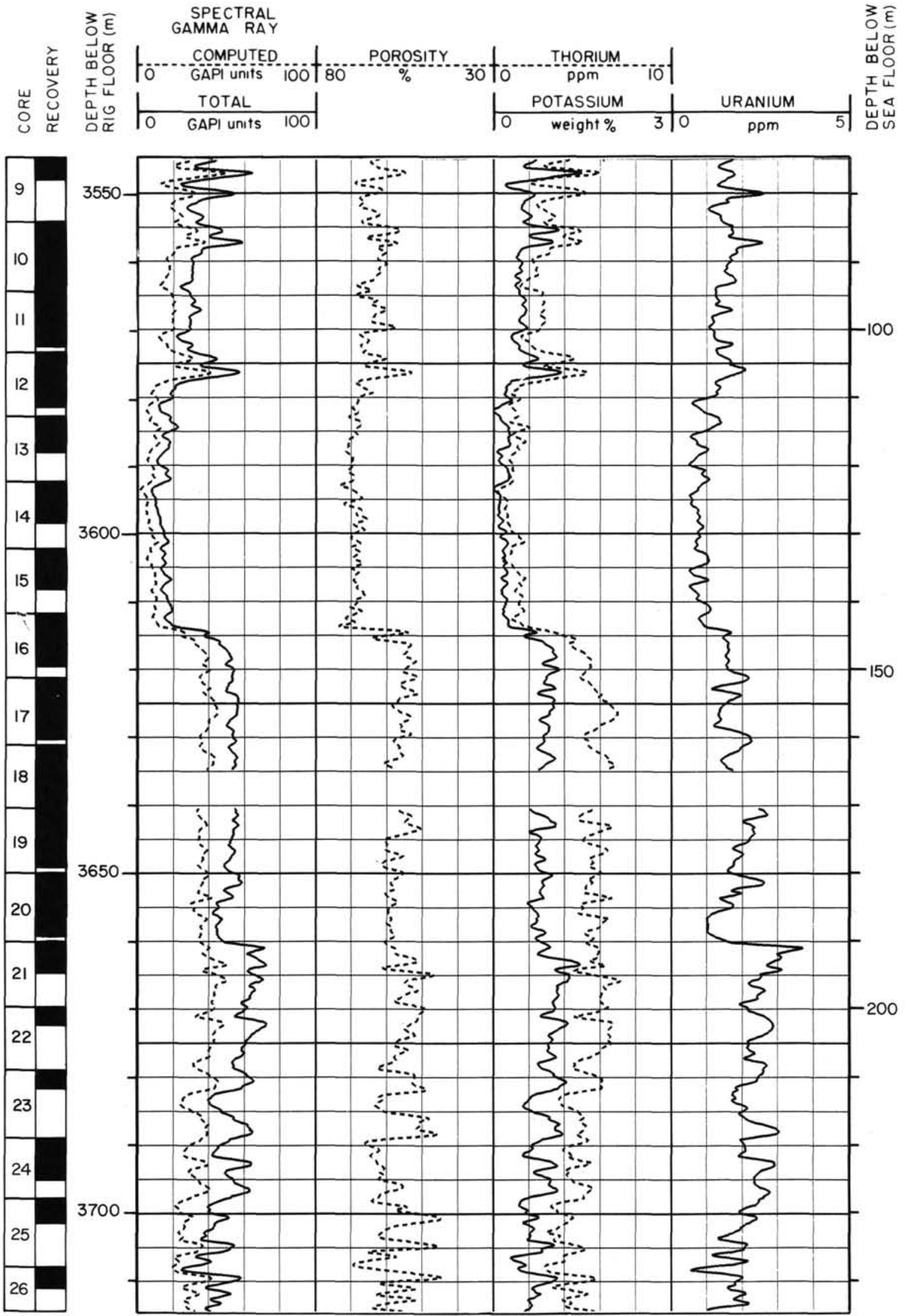
Summary Log for Hole 652A (continued)
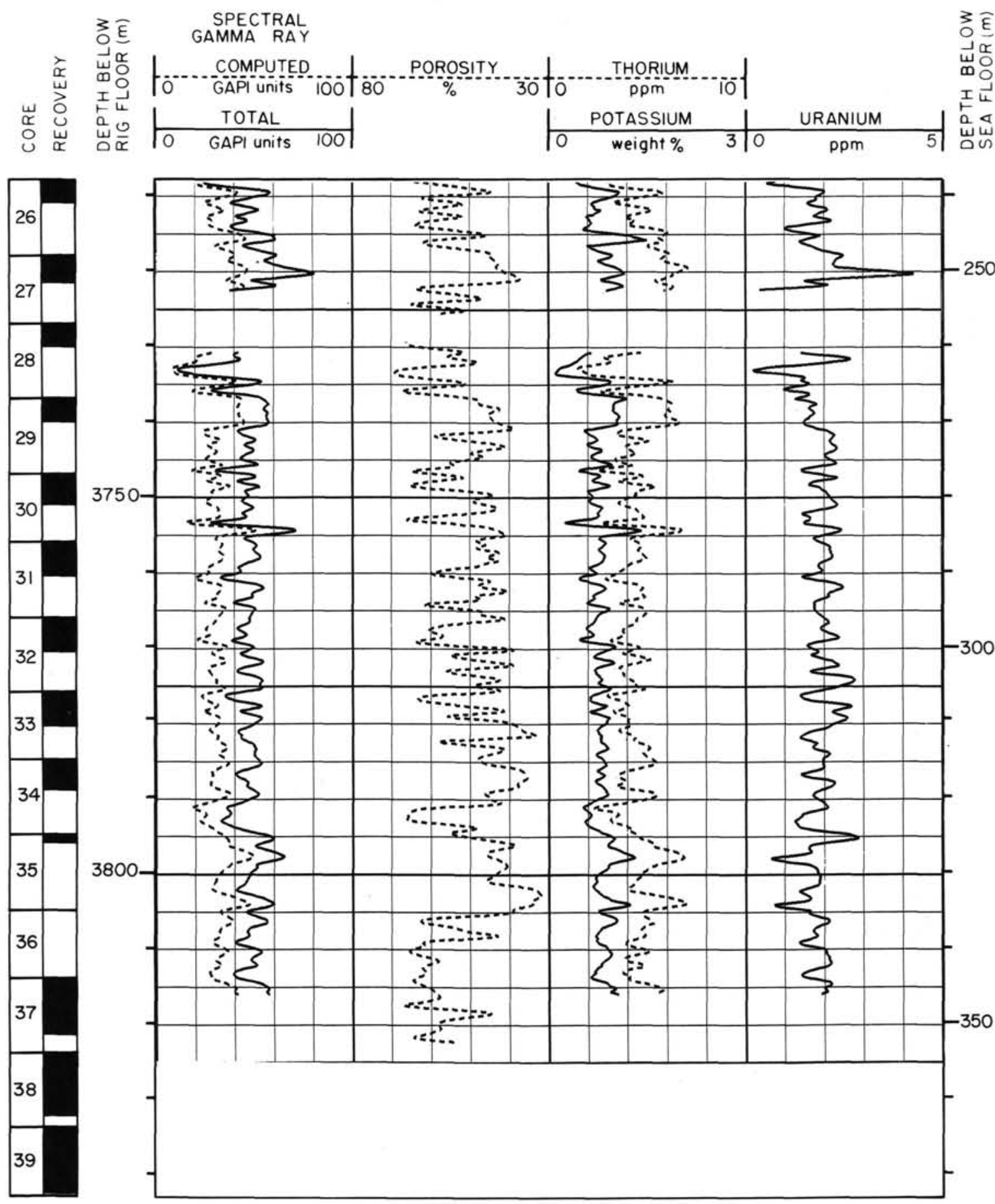
Summary Log for Hole 652A (continued)
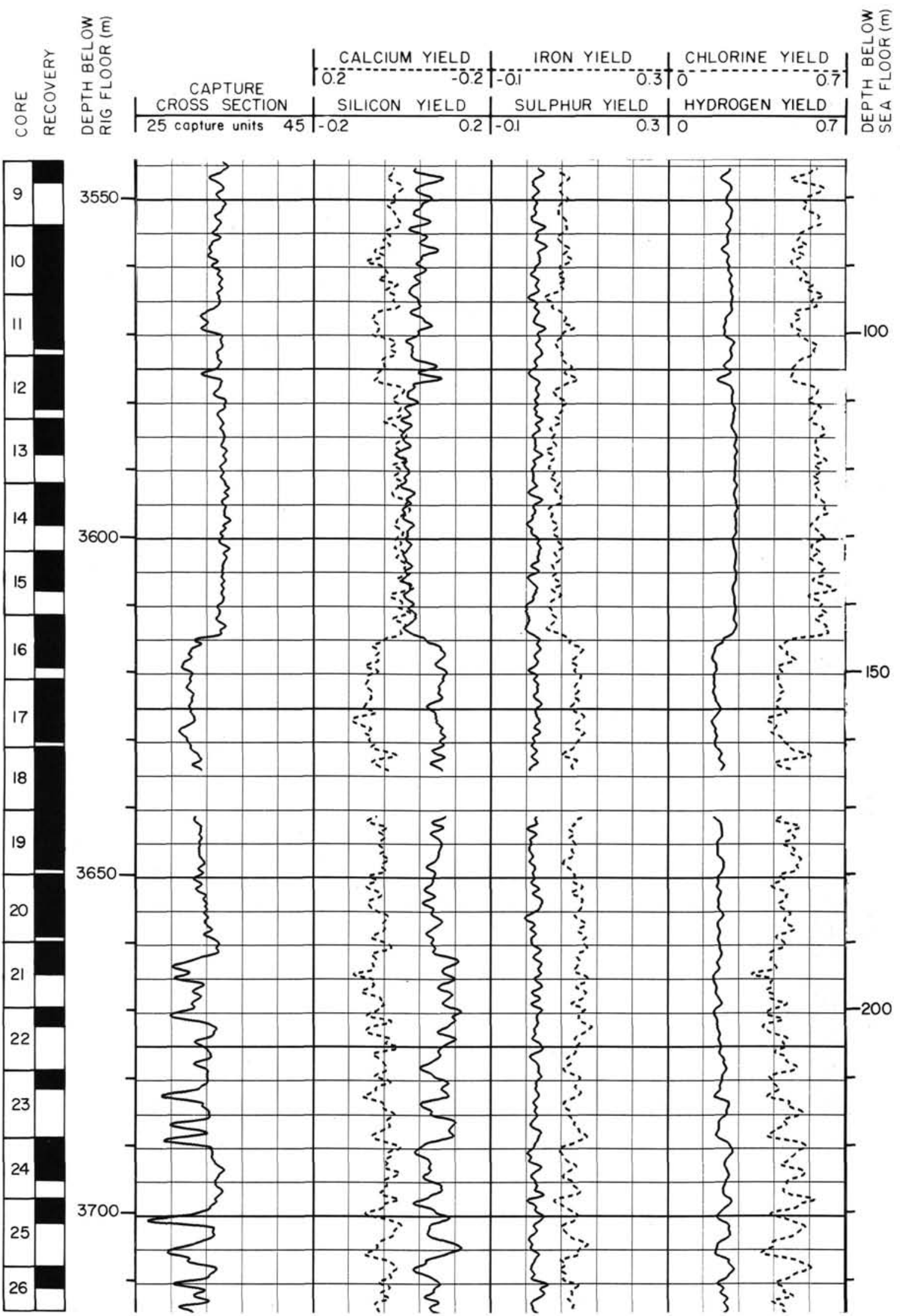
Summary Log for Hole 652A (continued)

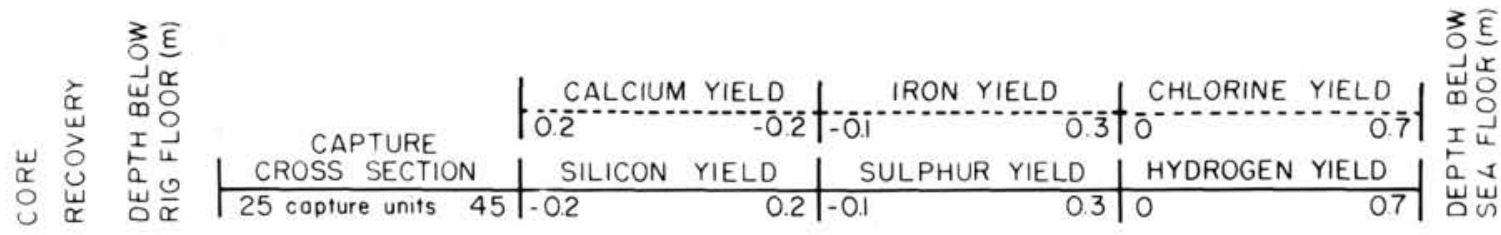

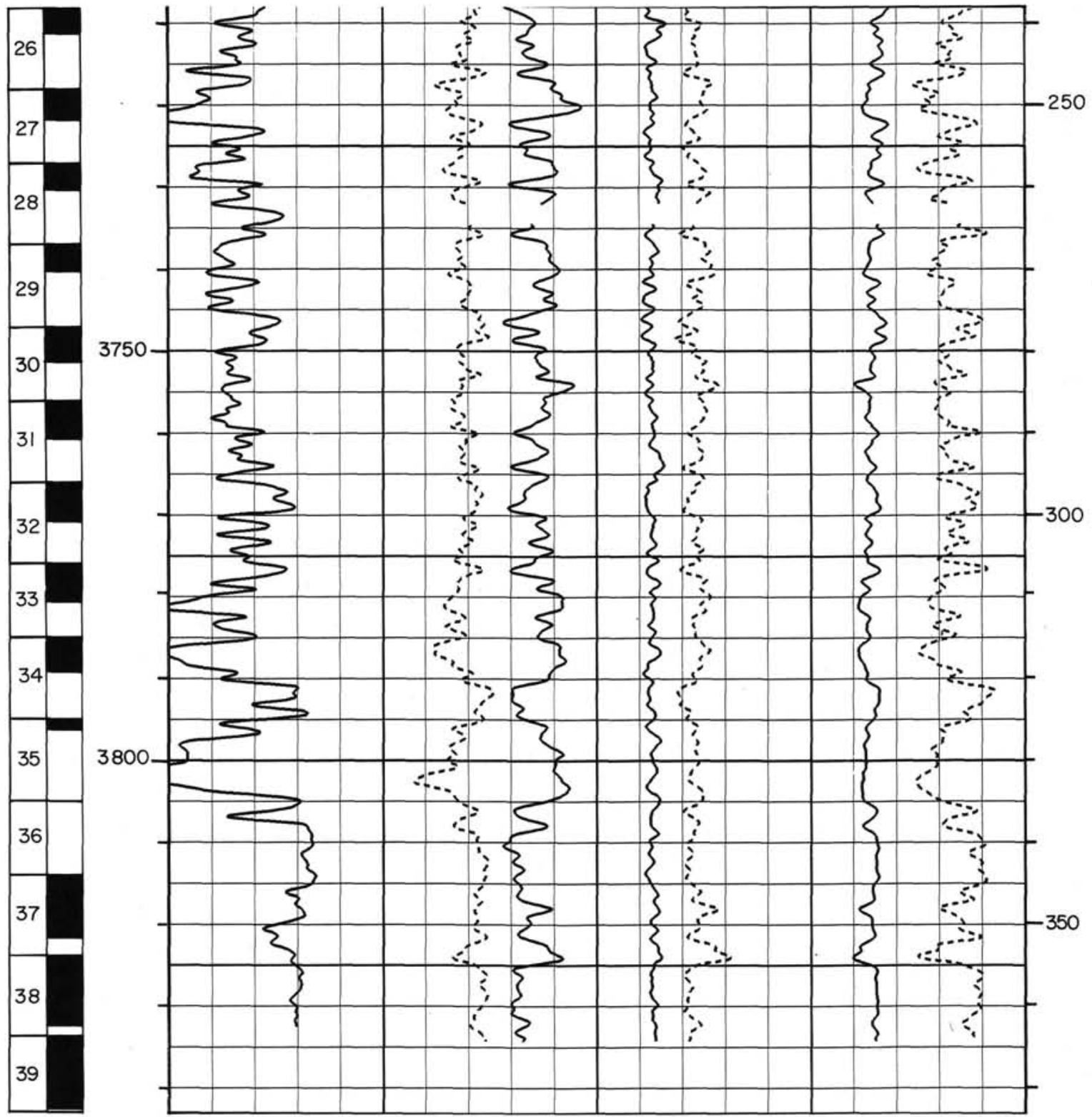




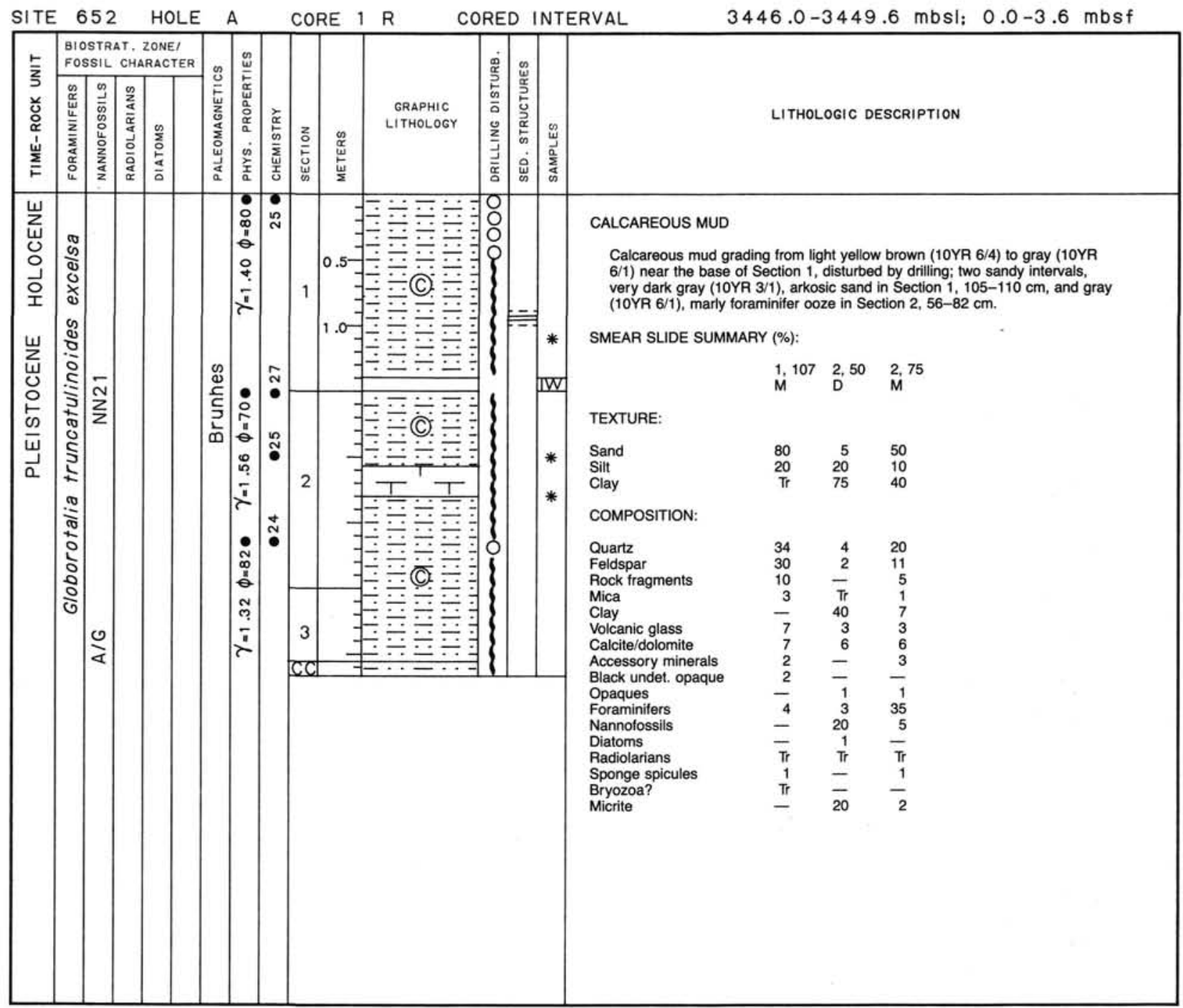




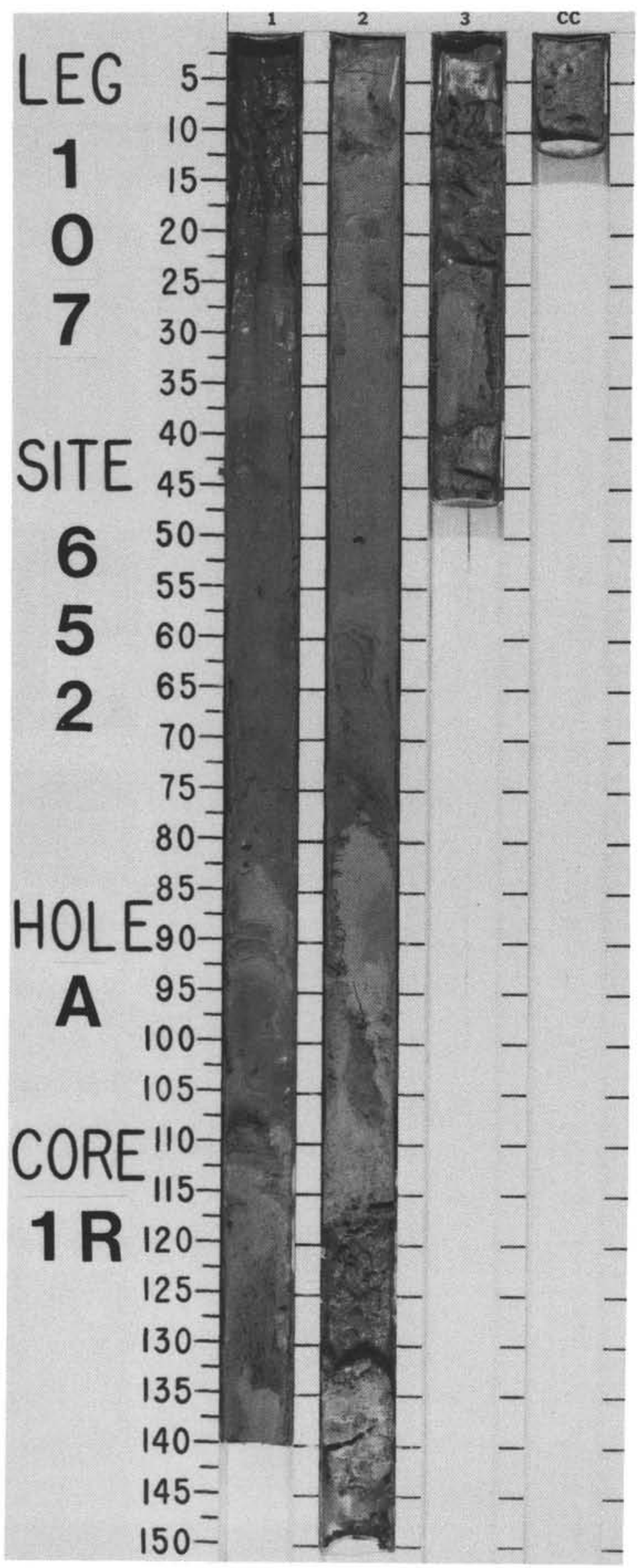




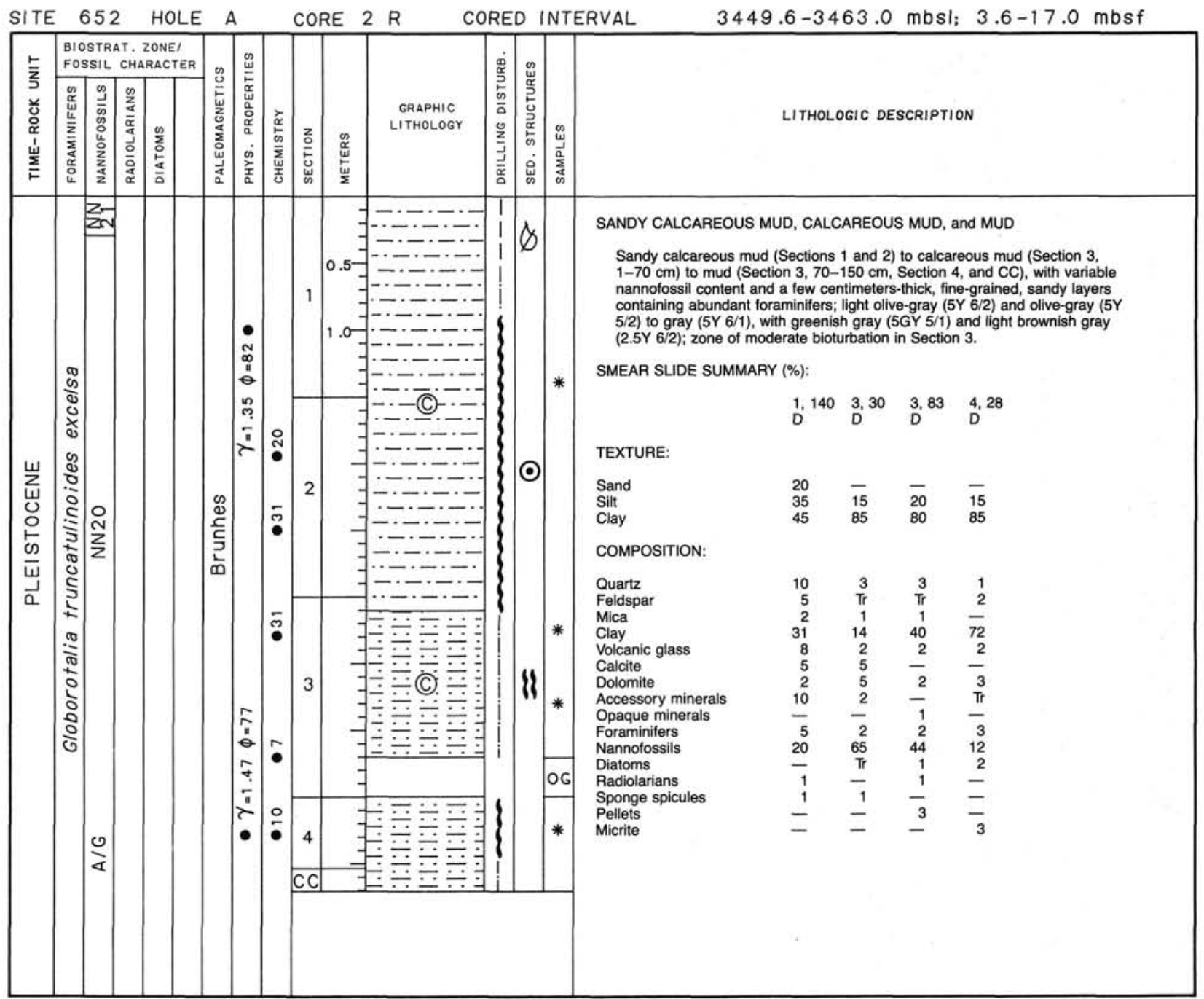




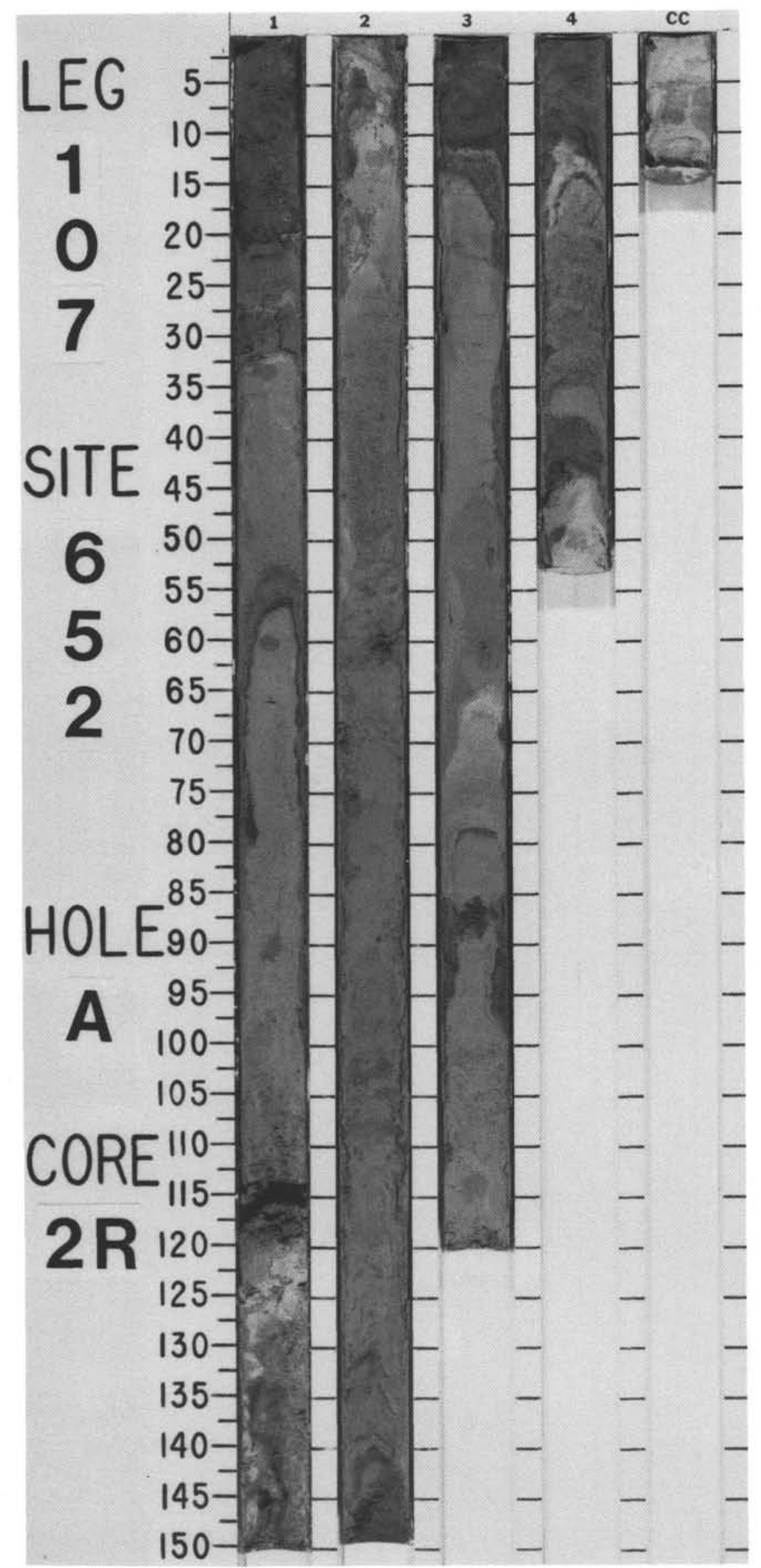




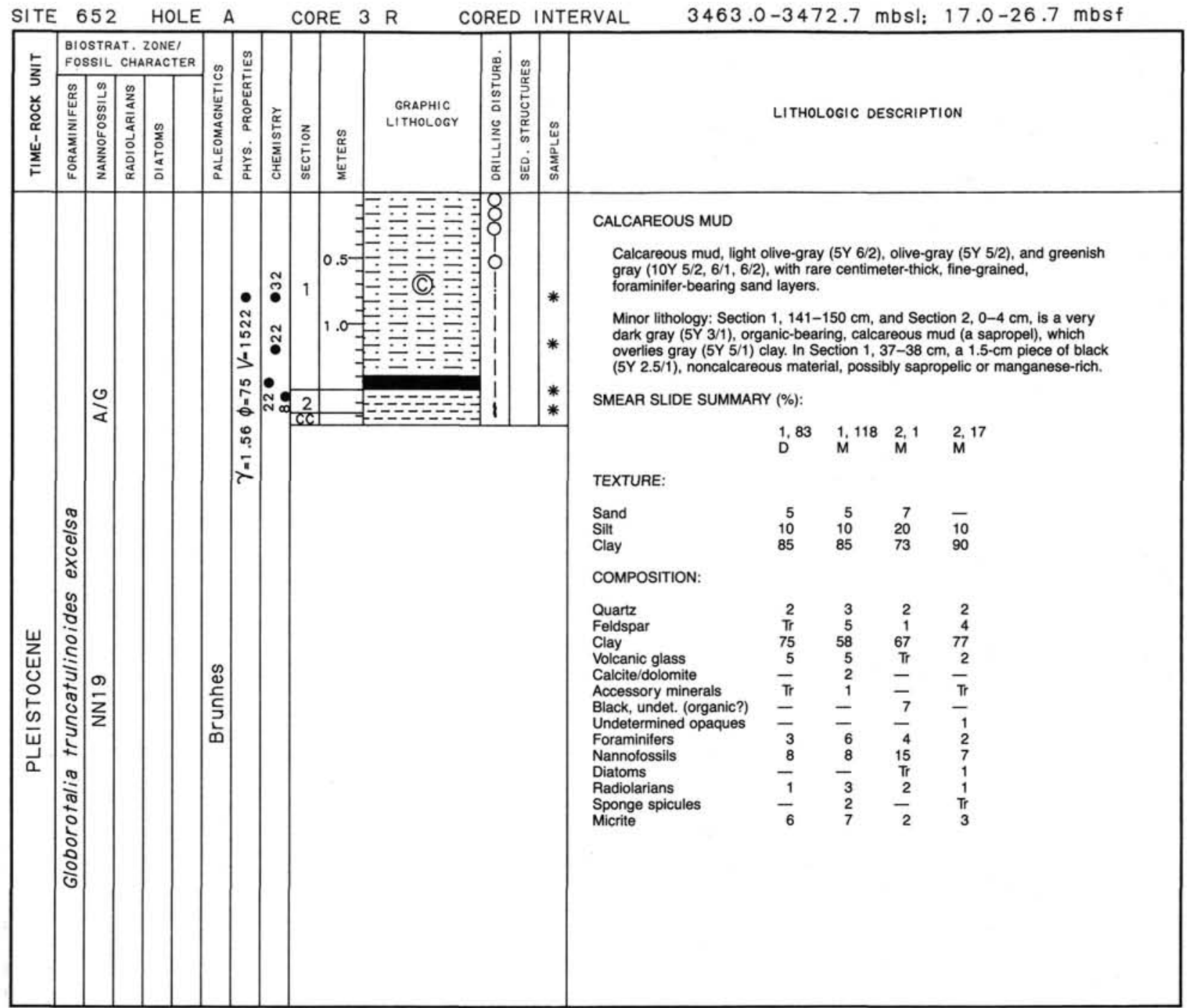




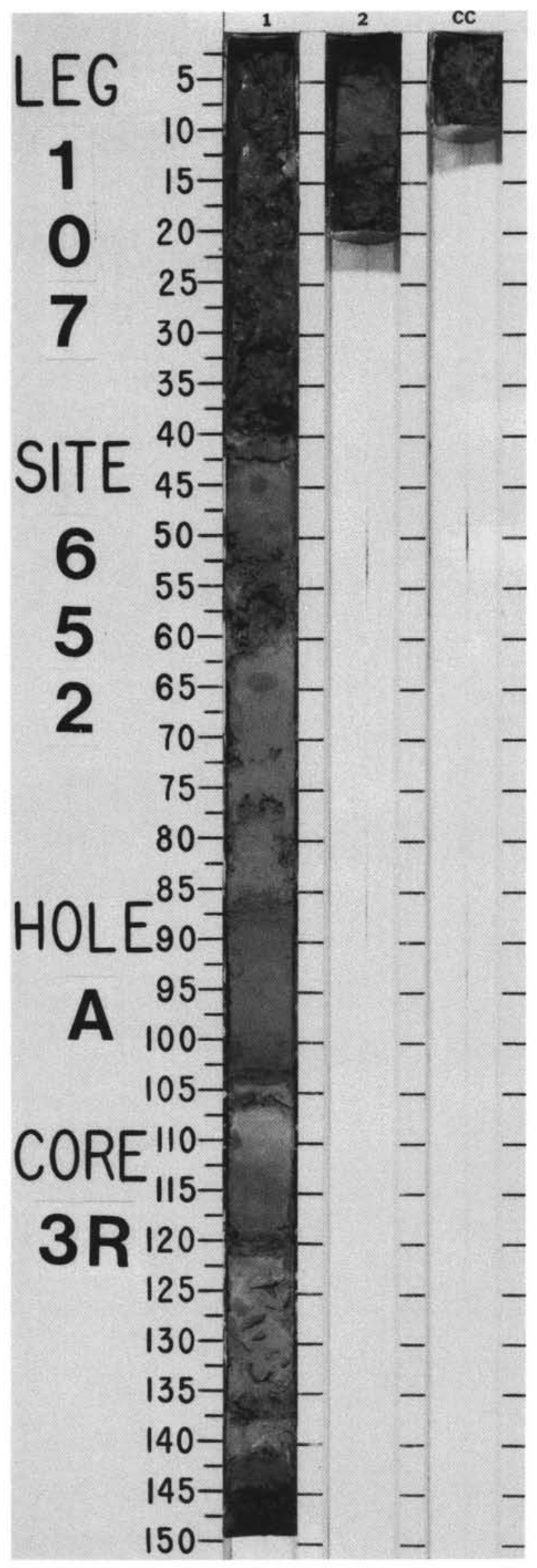




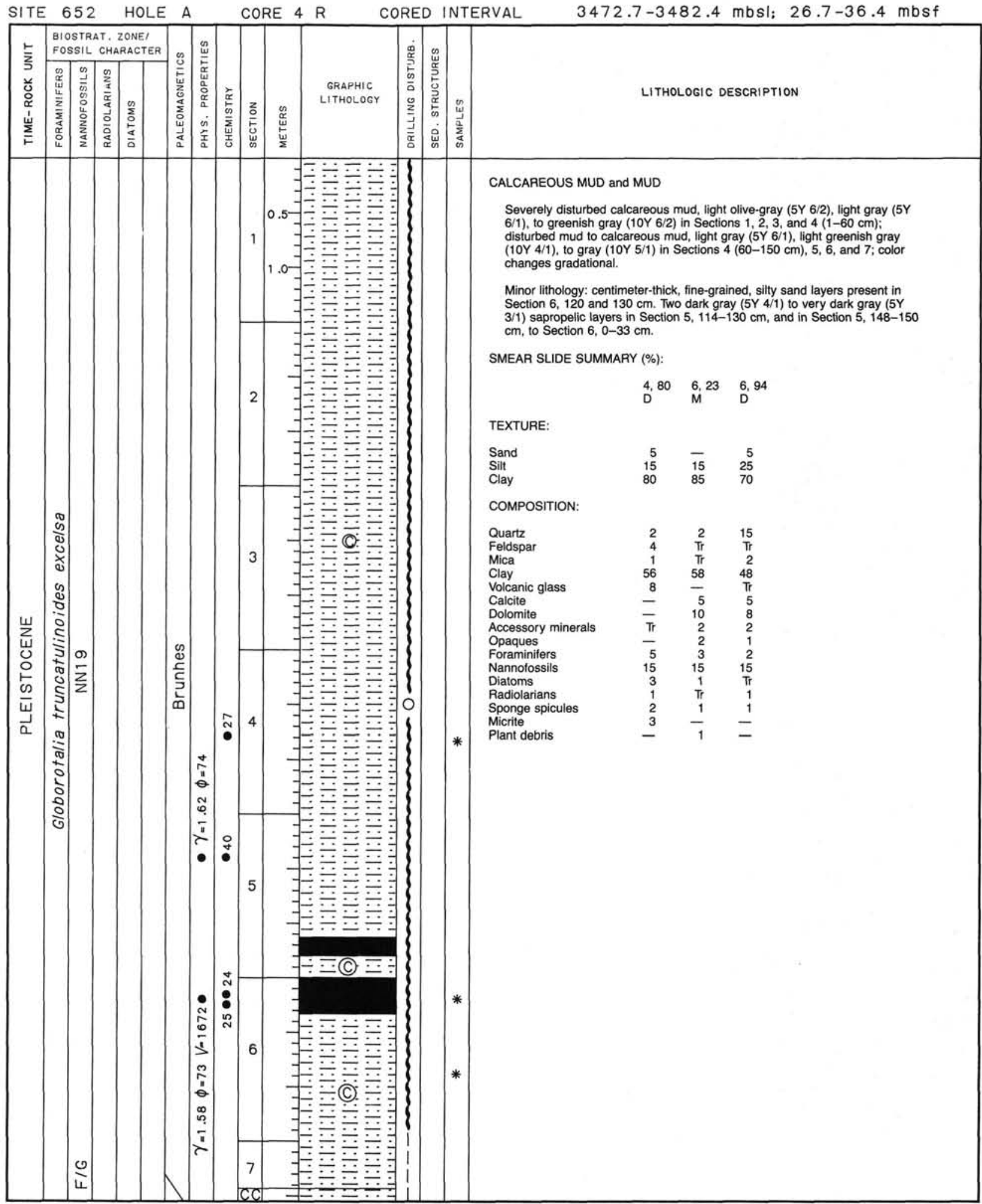




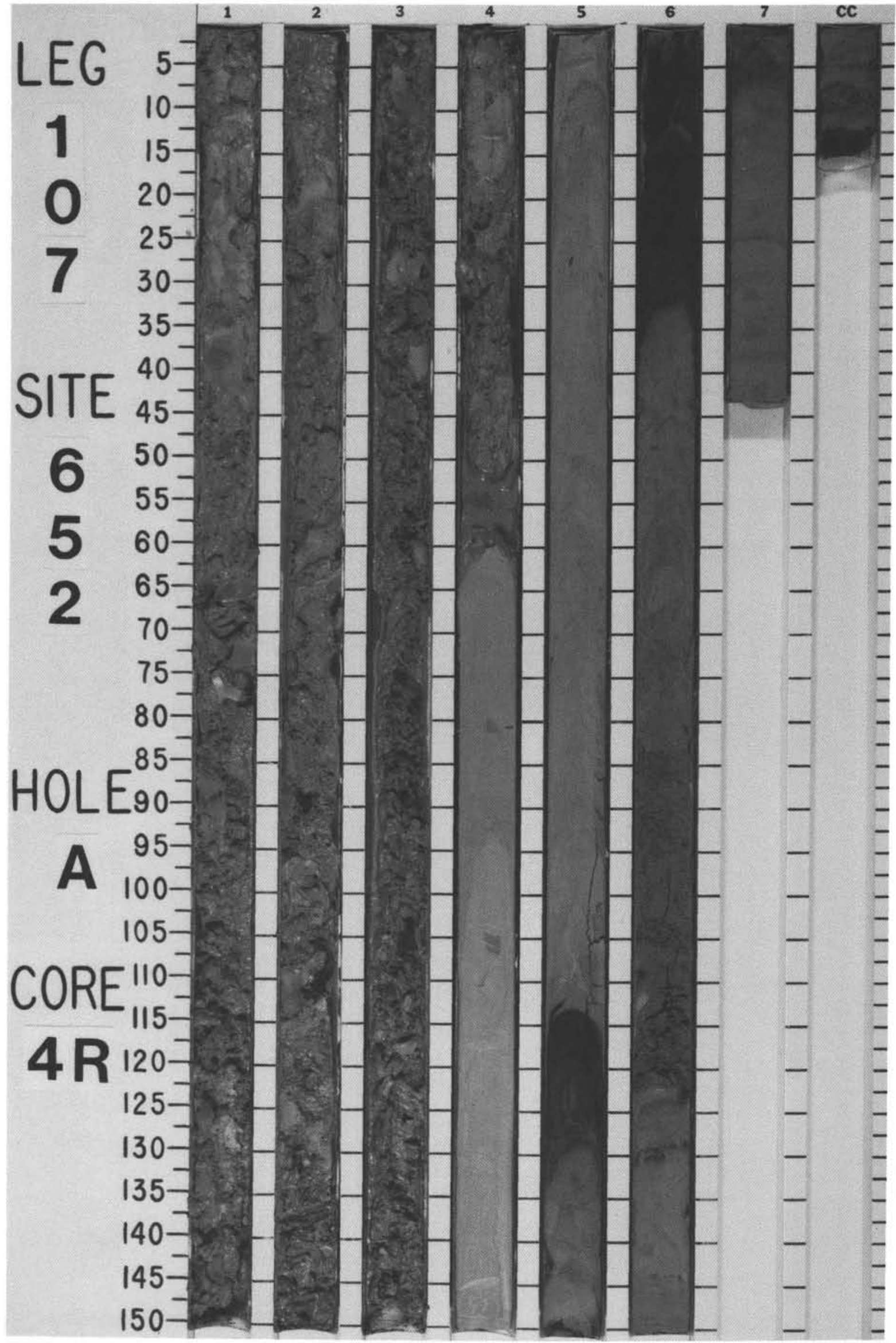




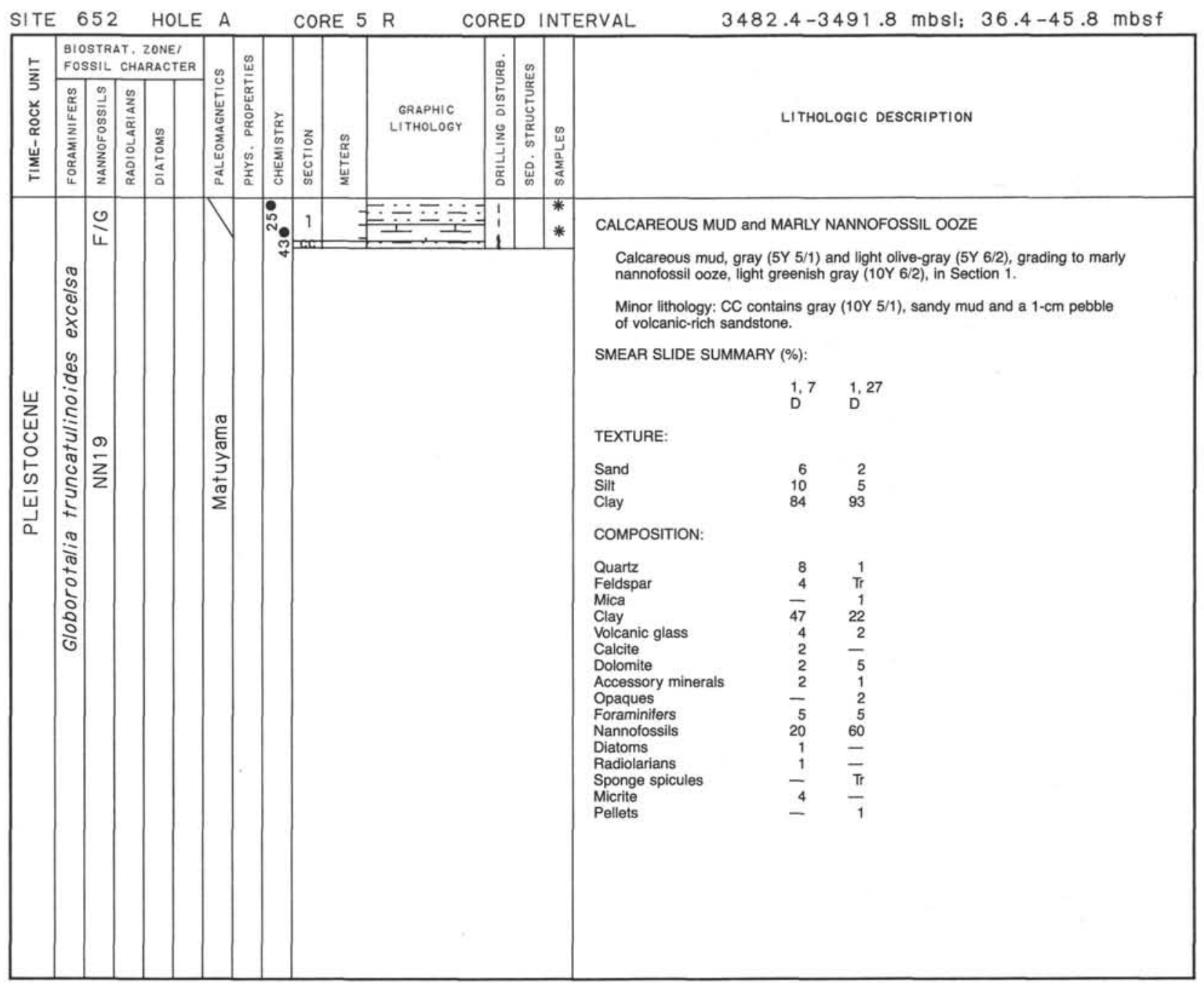




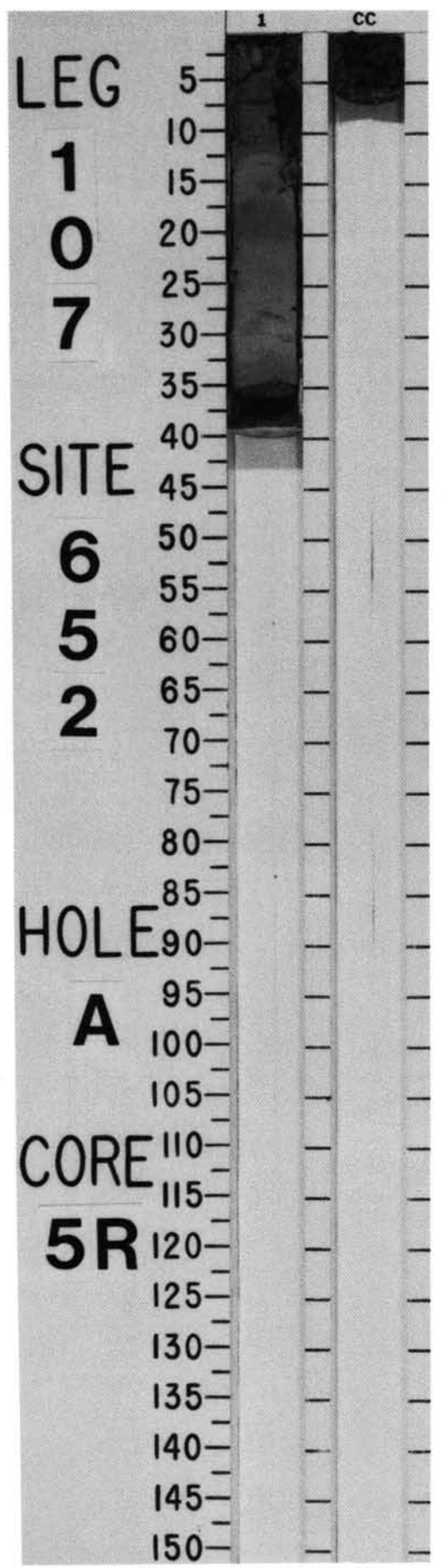




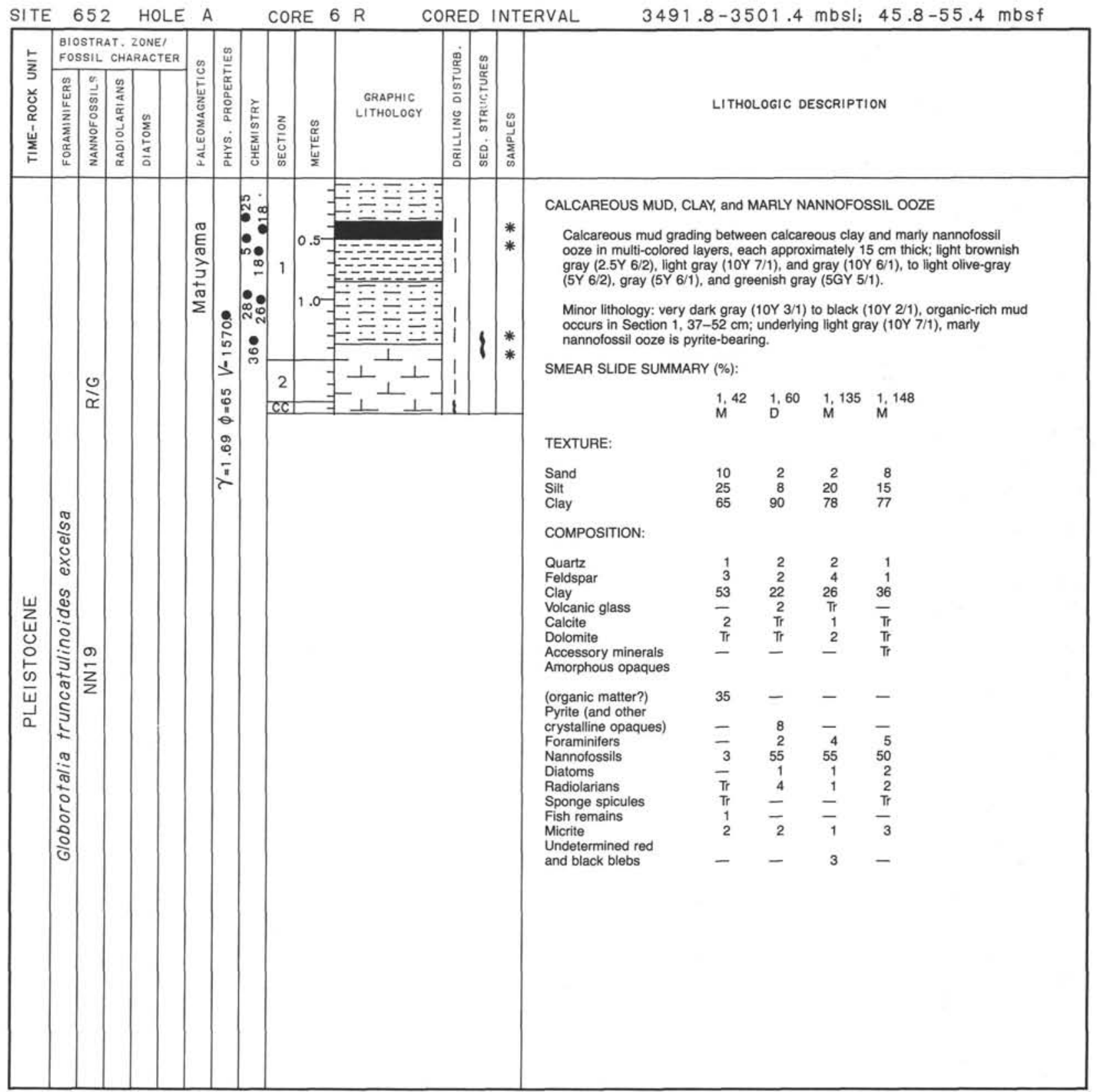




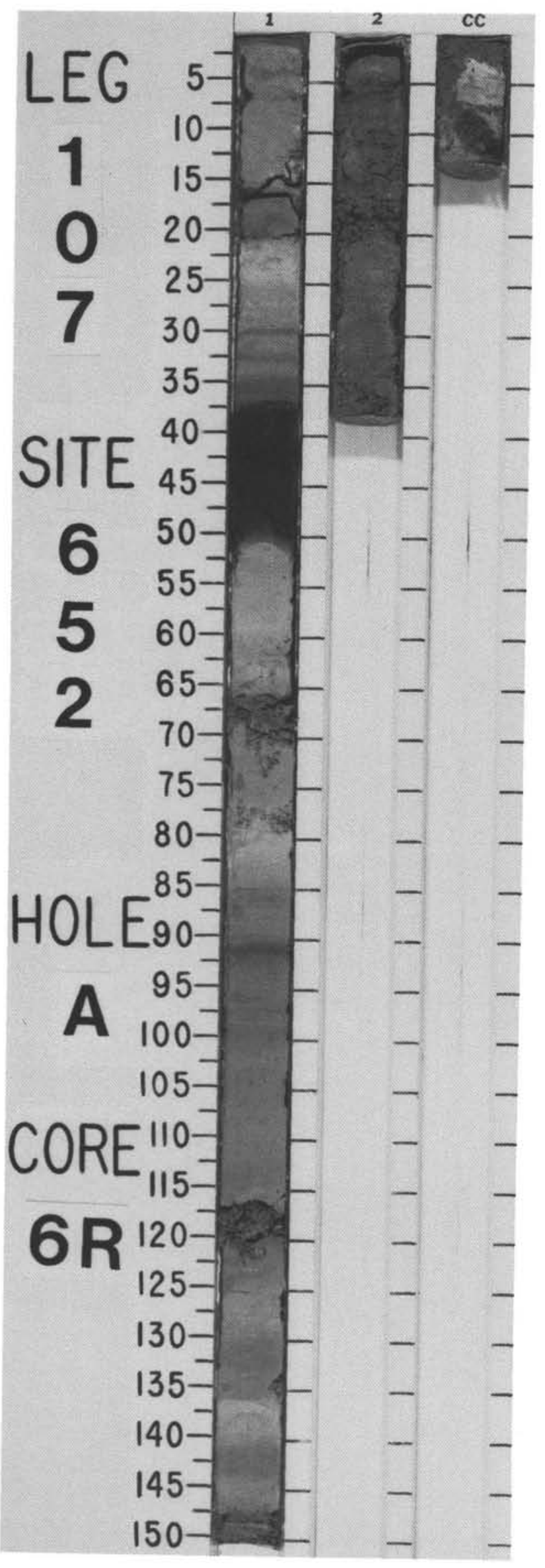




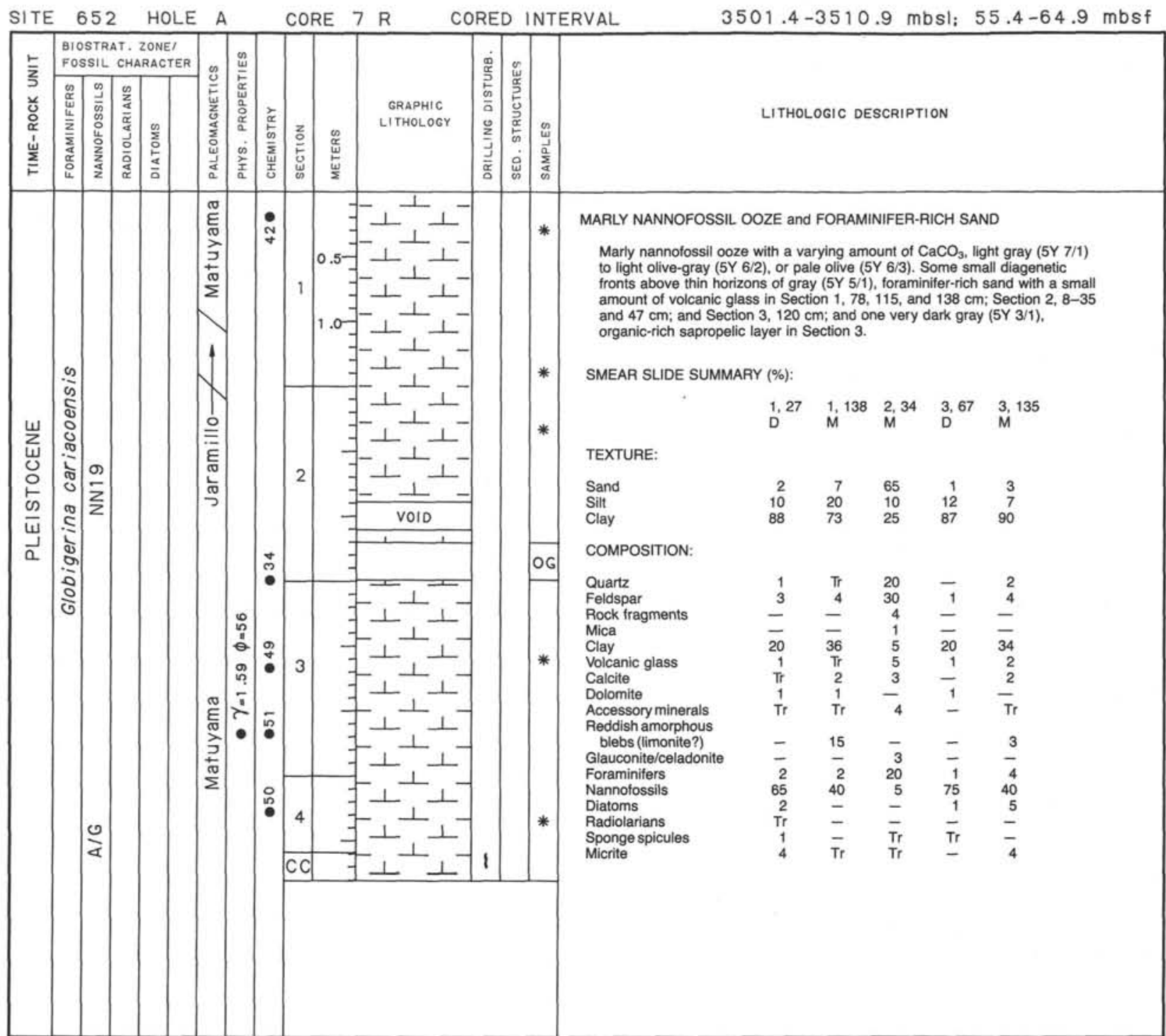




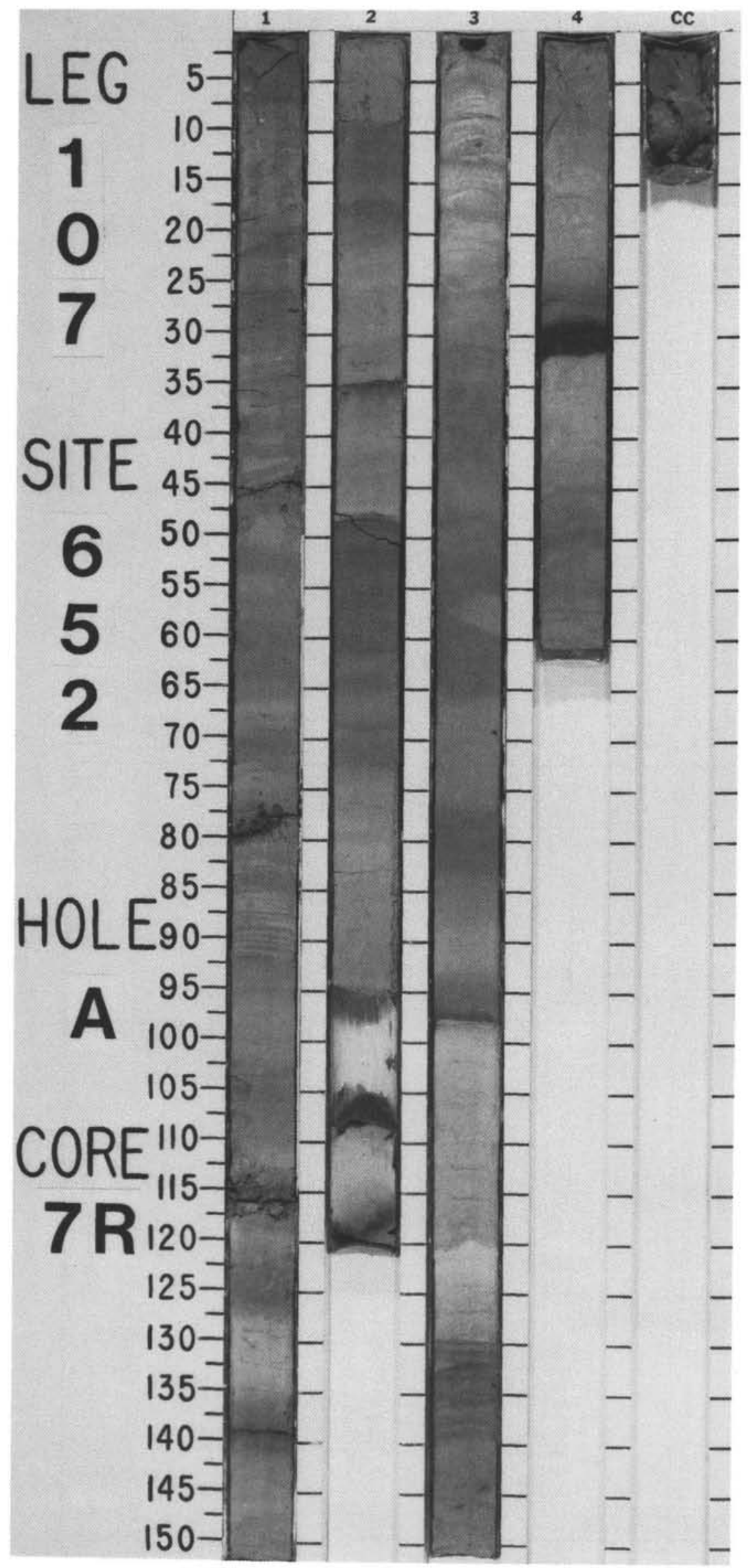




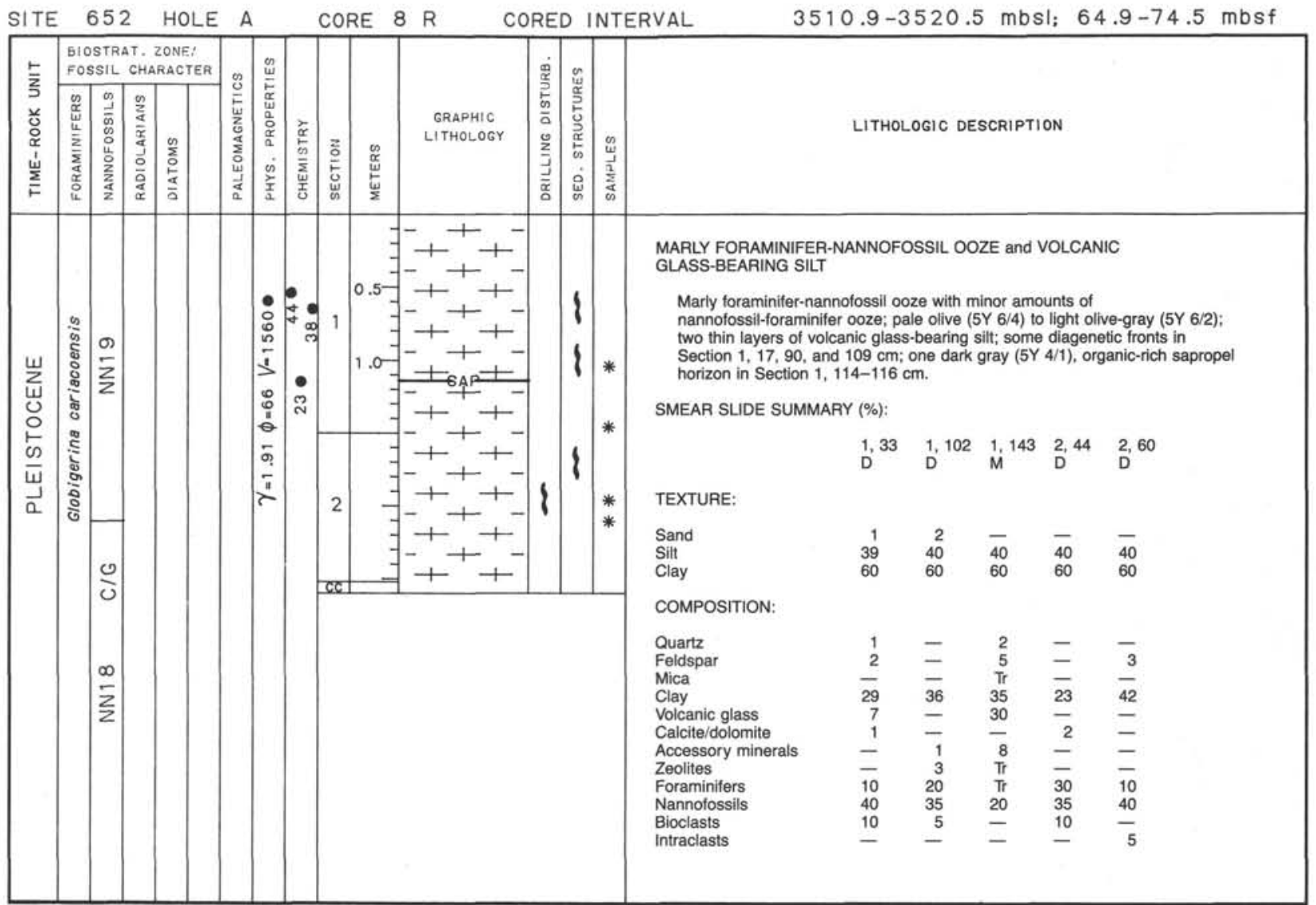

SITE 652 HOLE A CORE 9 R CORED INTERVAL 3520.5-3530.2 mbsl; $74.5-84.2 \mathrm{mbsf}$

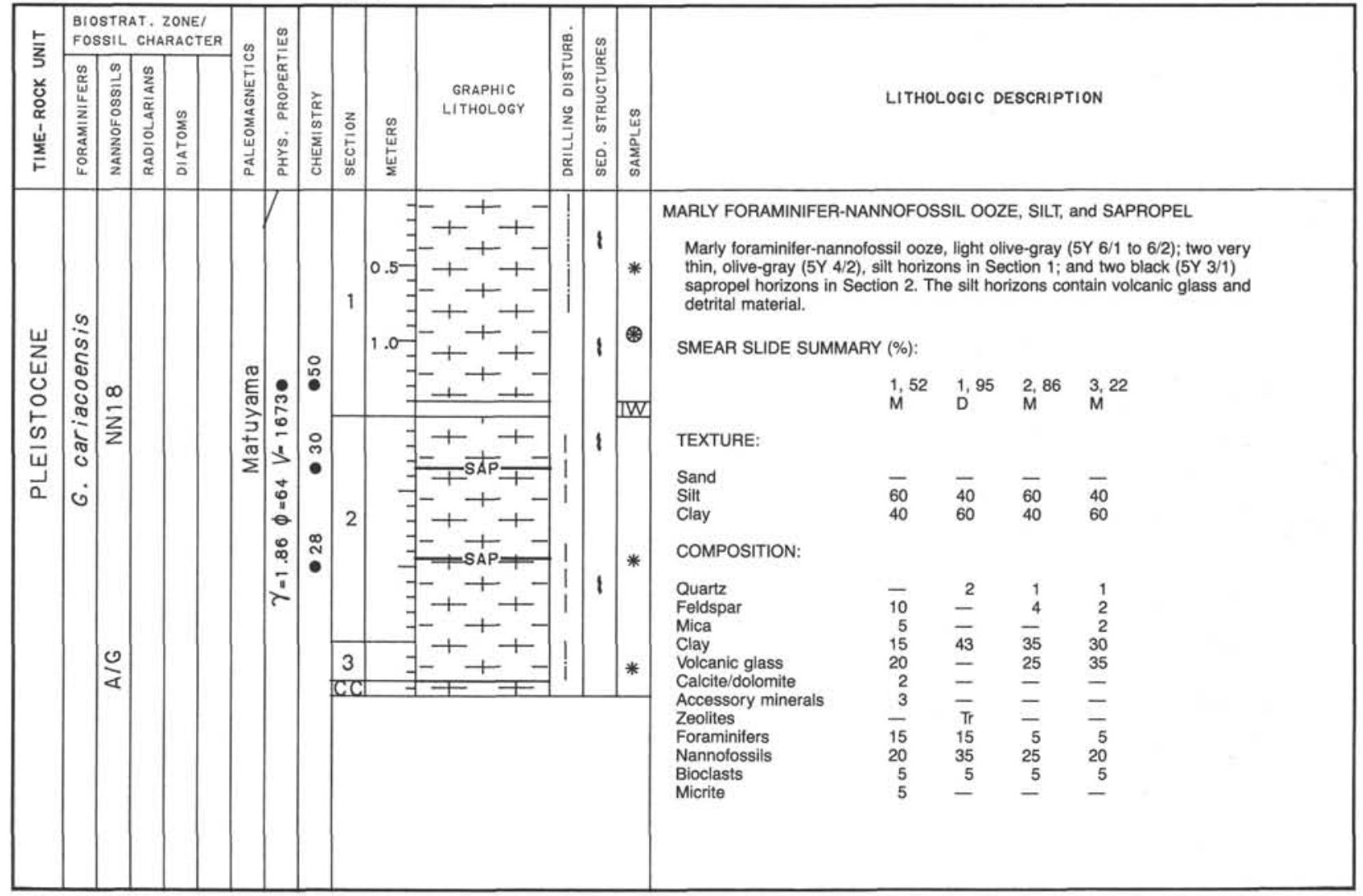




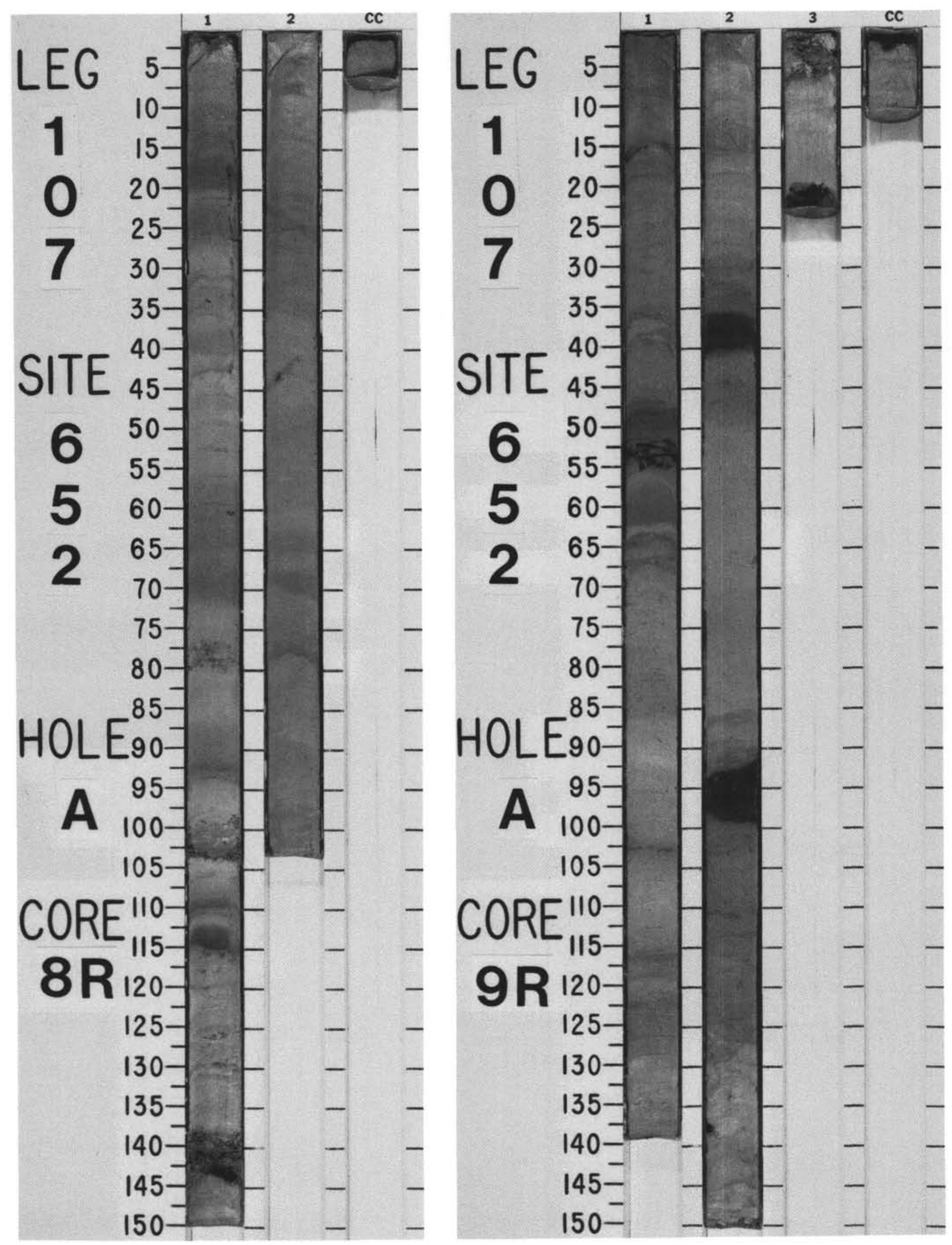


SITE 652 HOLE A CORE $10 \mathrm{R}$ CORED INTERVAL $3530.2-3539.8 \mathrm{mbsl} ; 84.2-93.8 \mathrm{mbSf}$

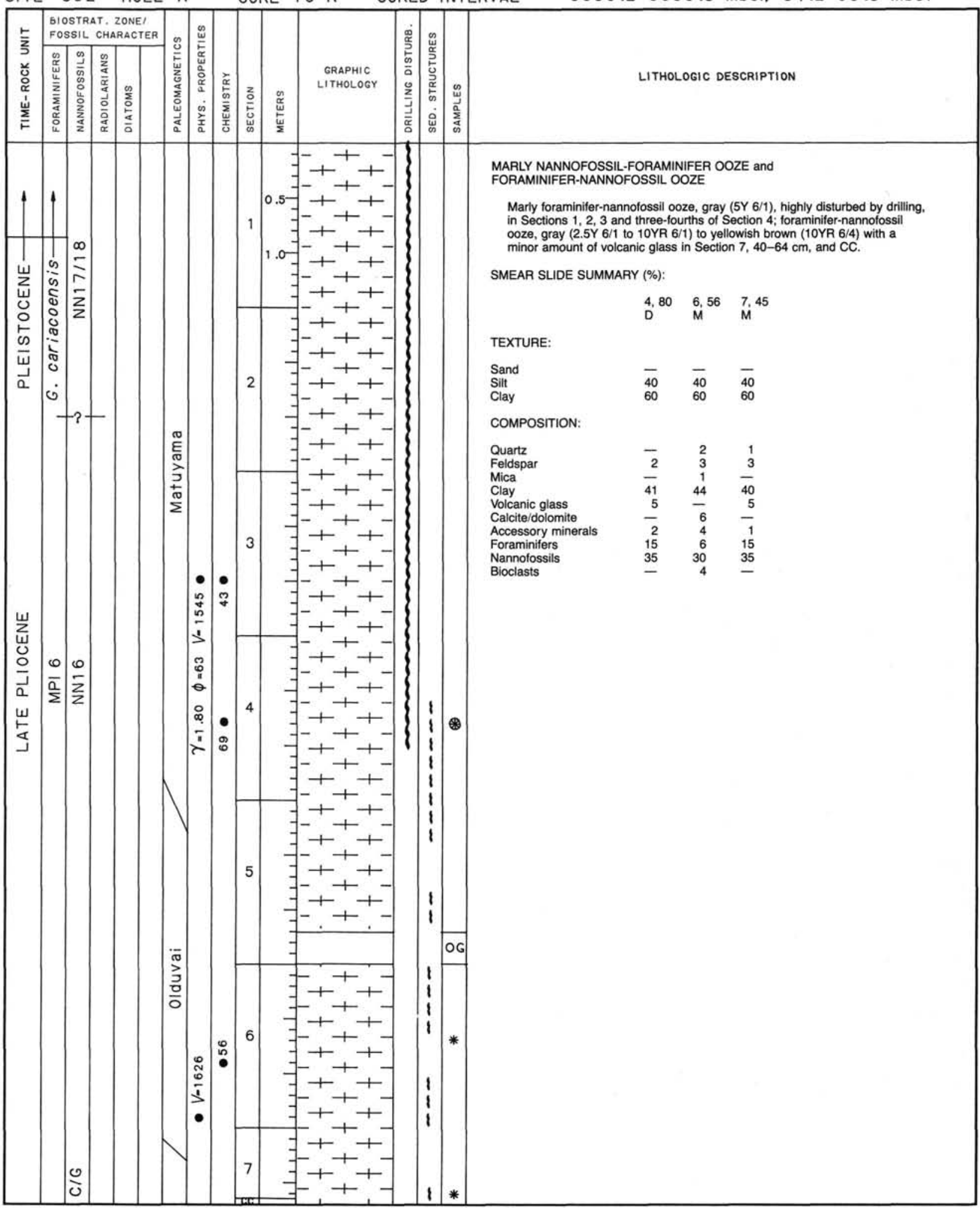




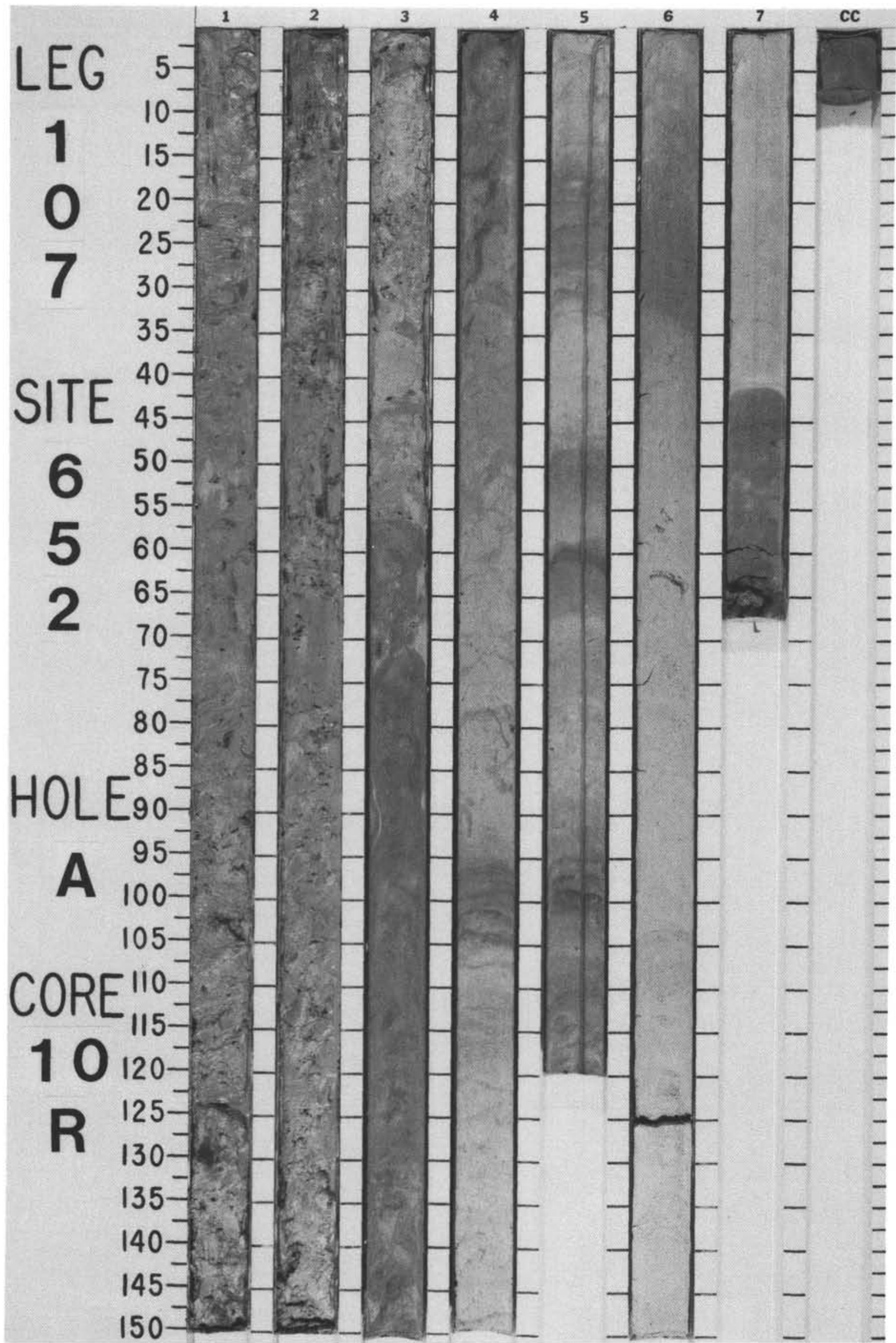




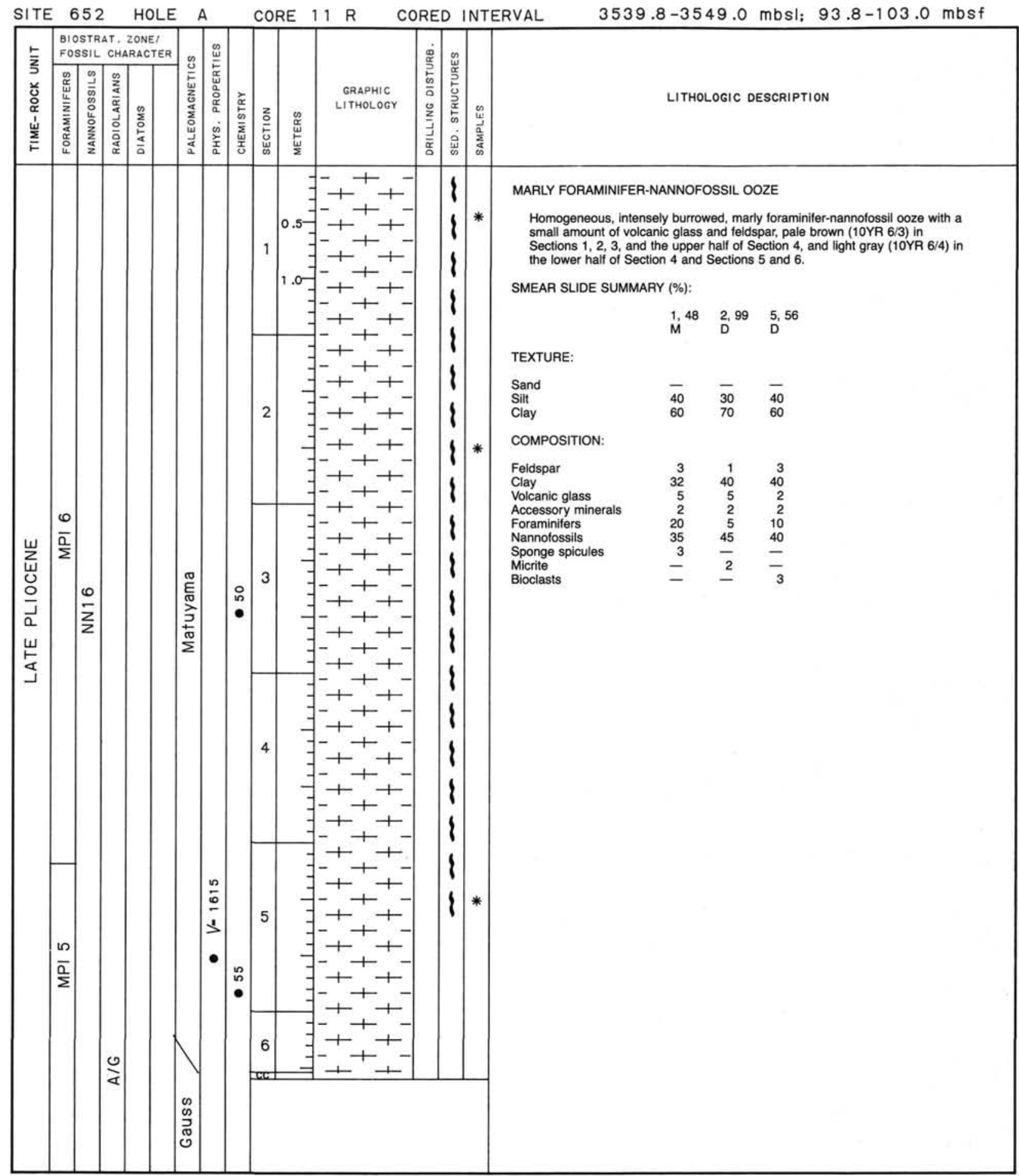




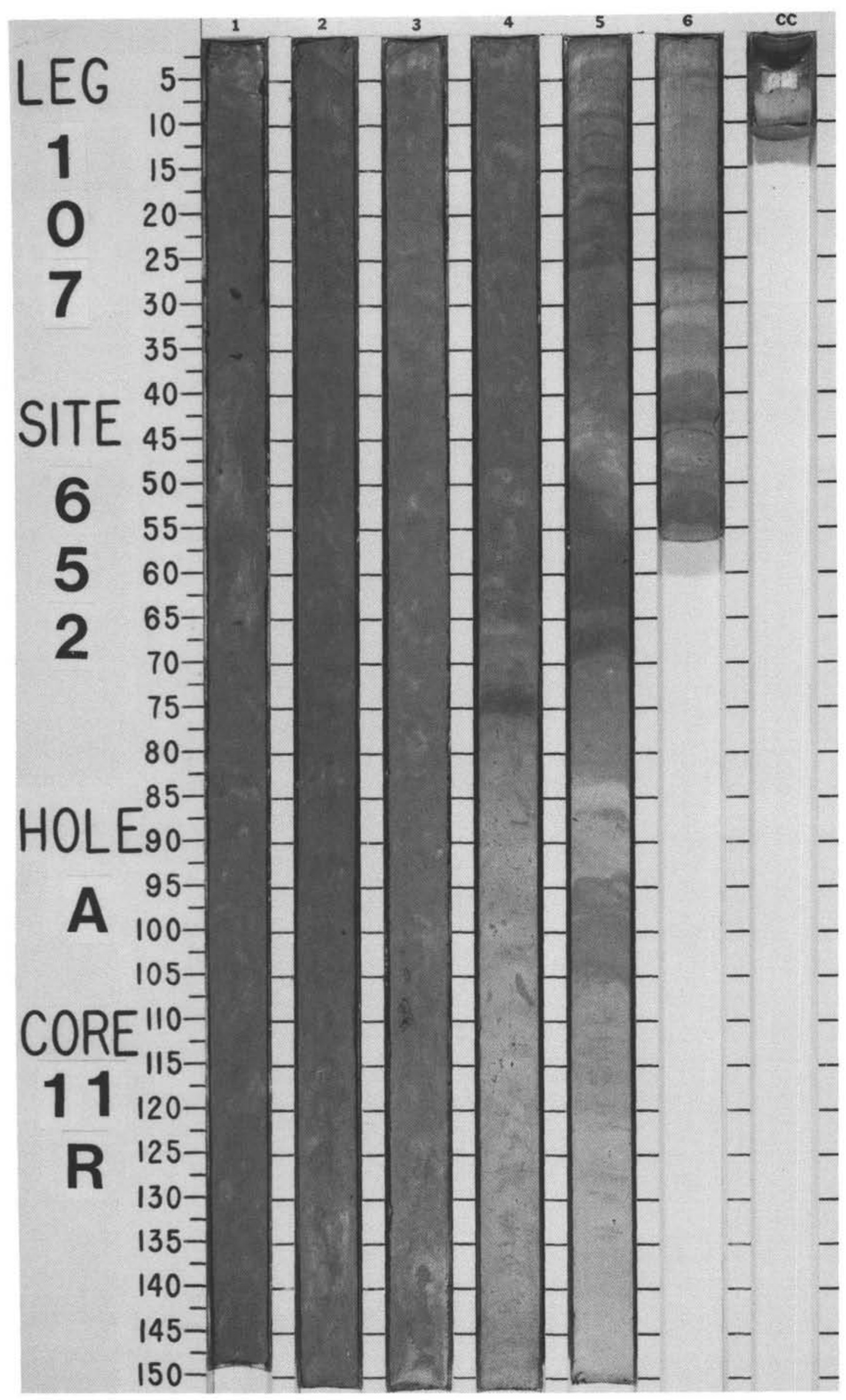




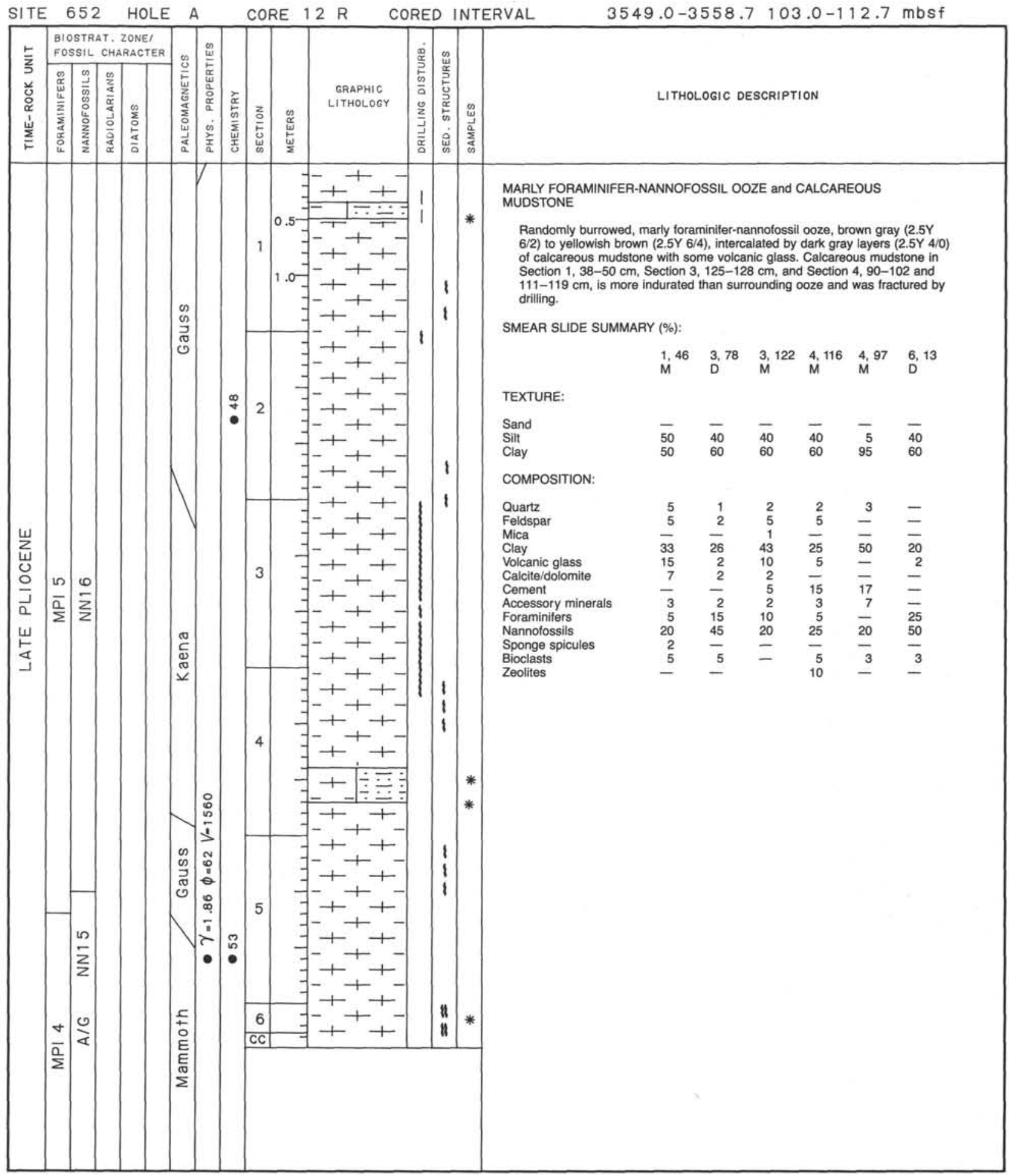




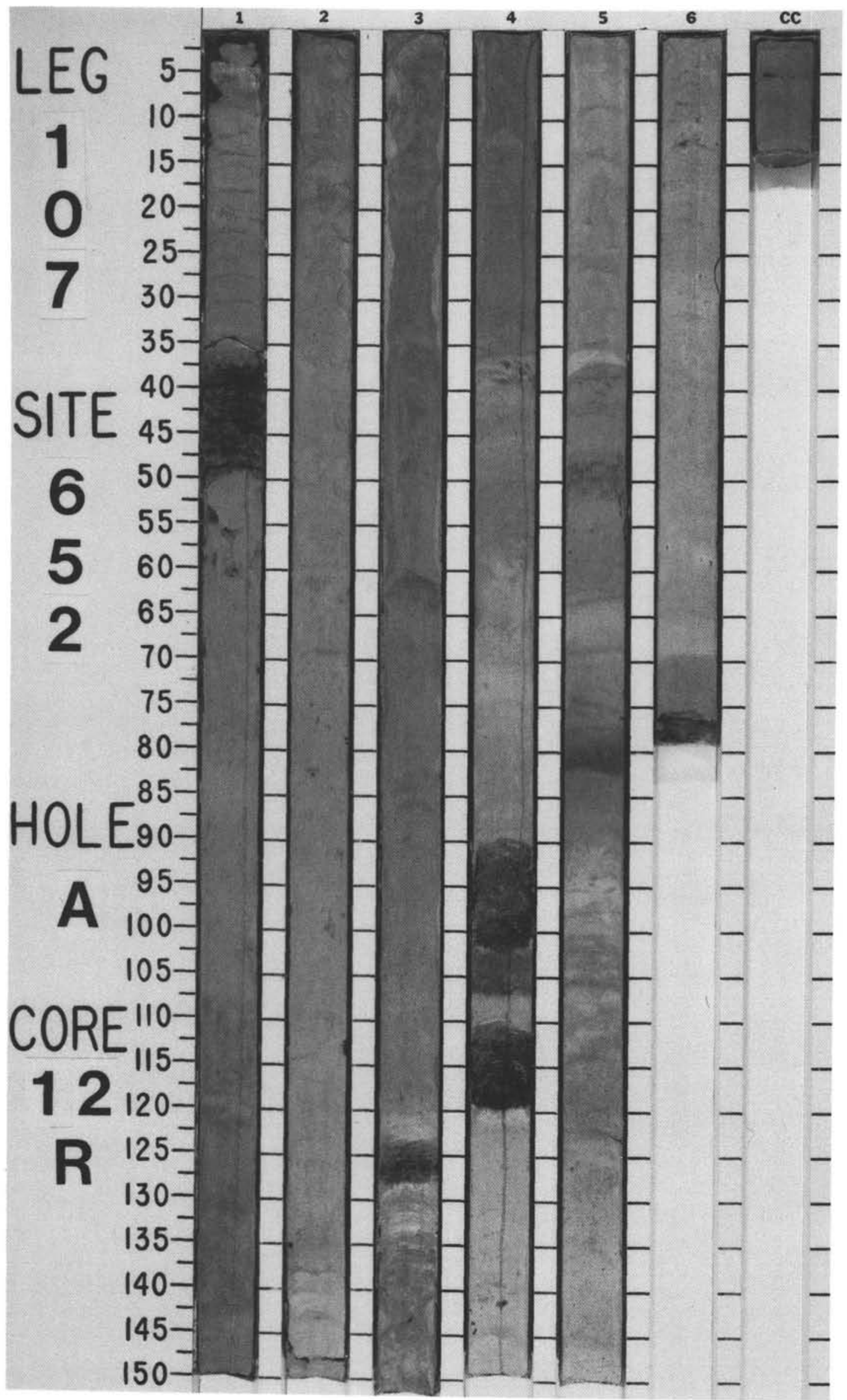




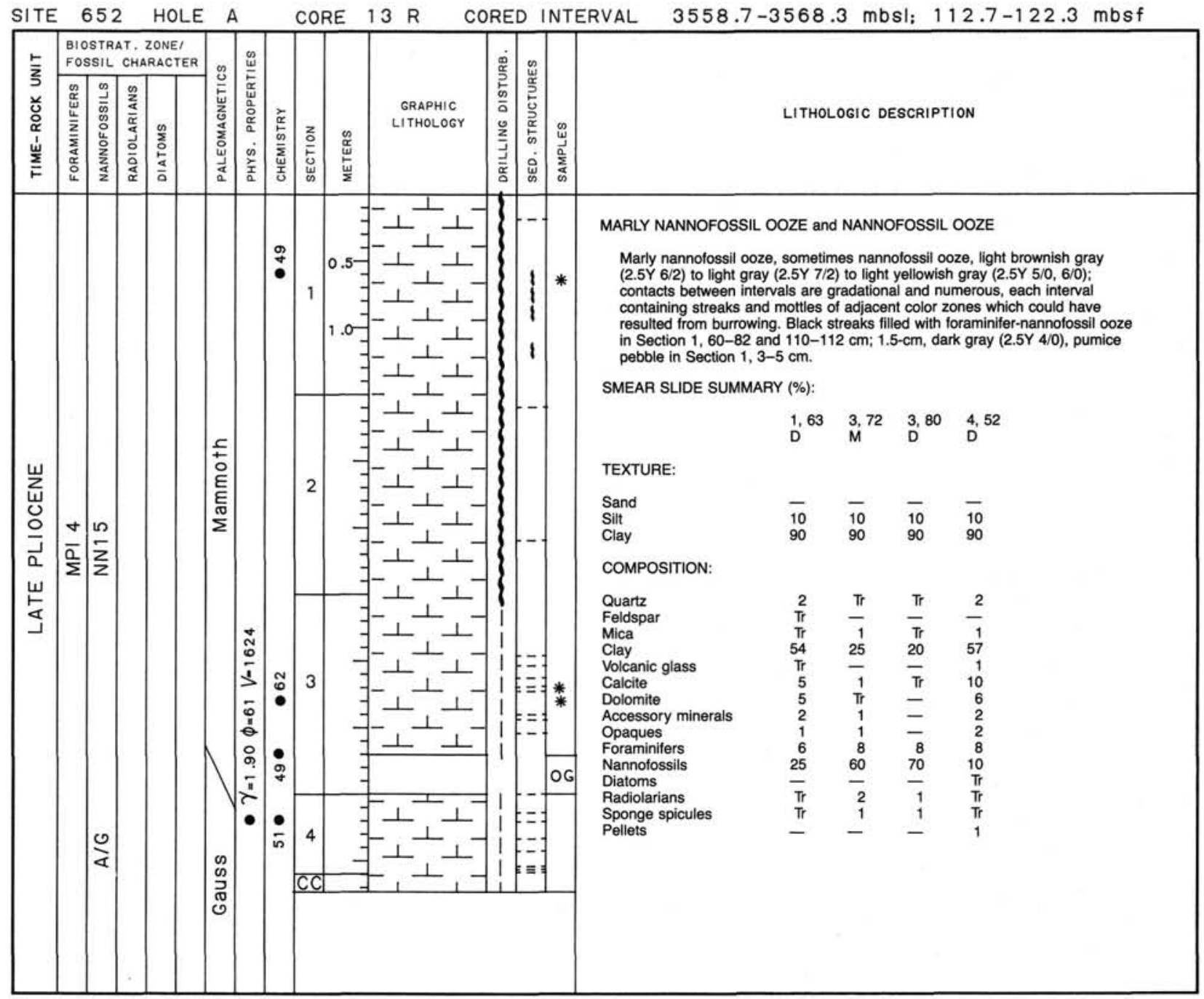




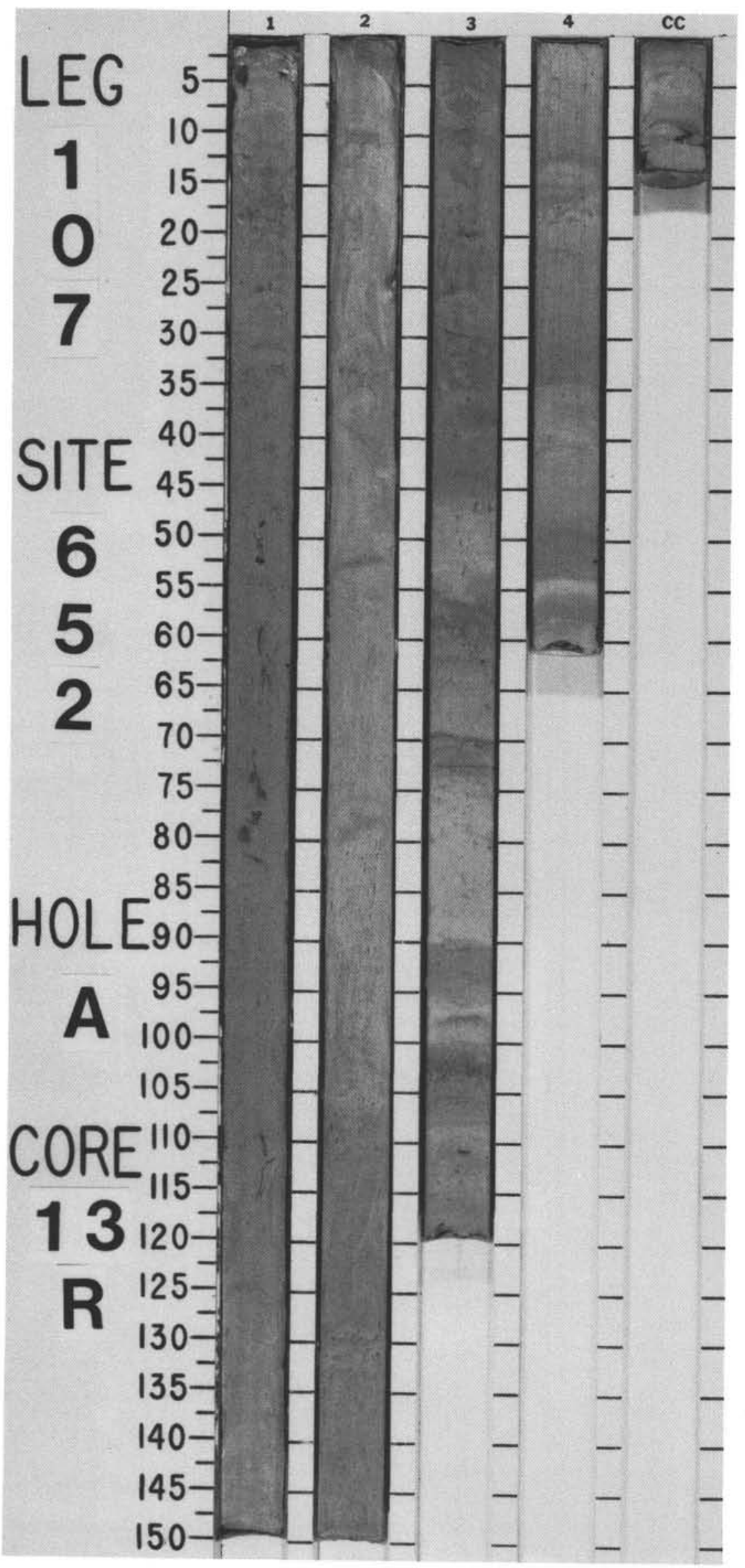




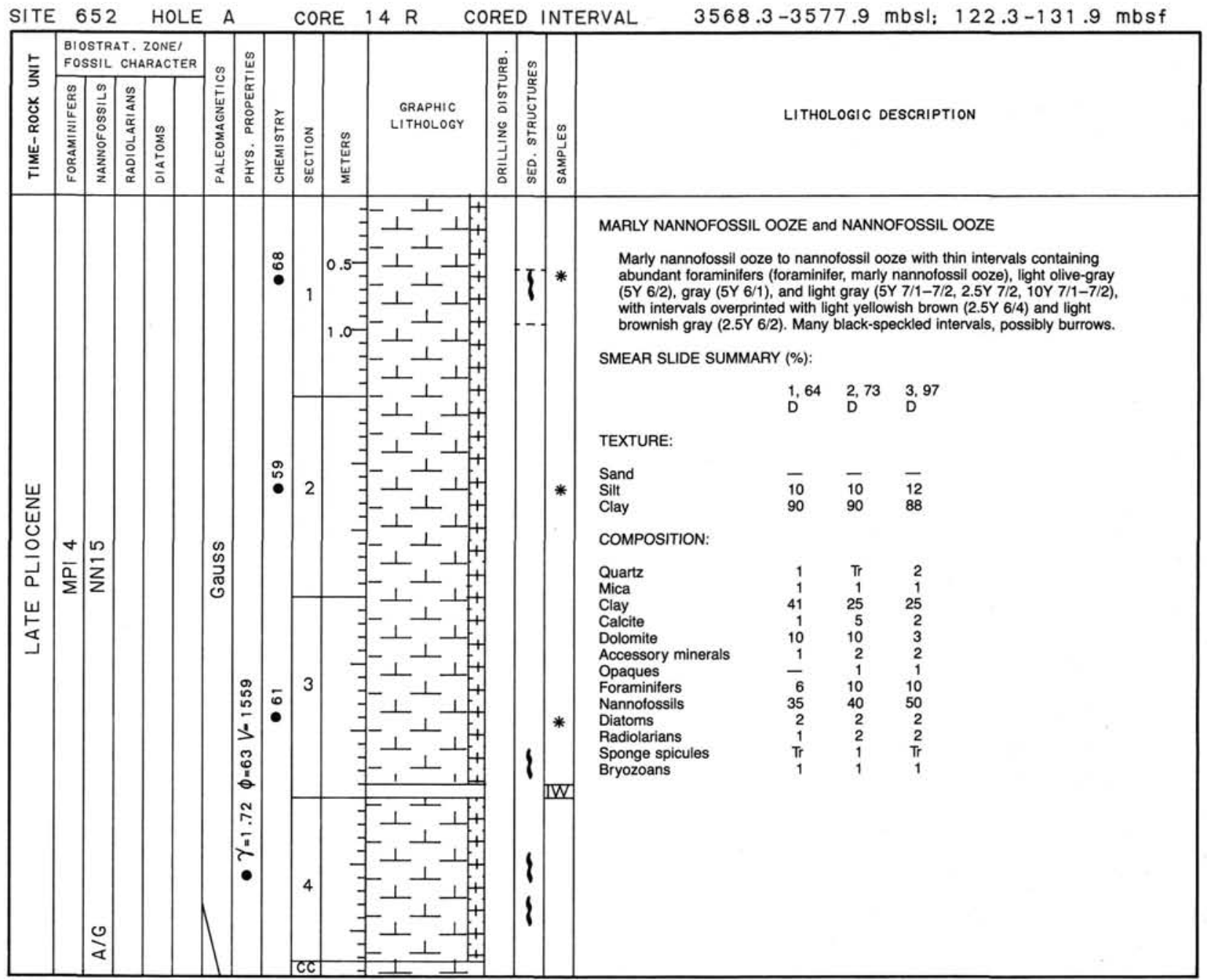




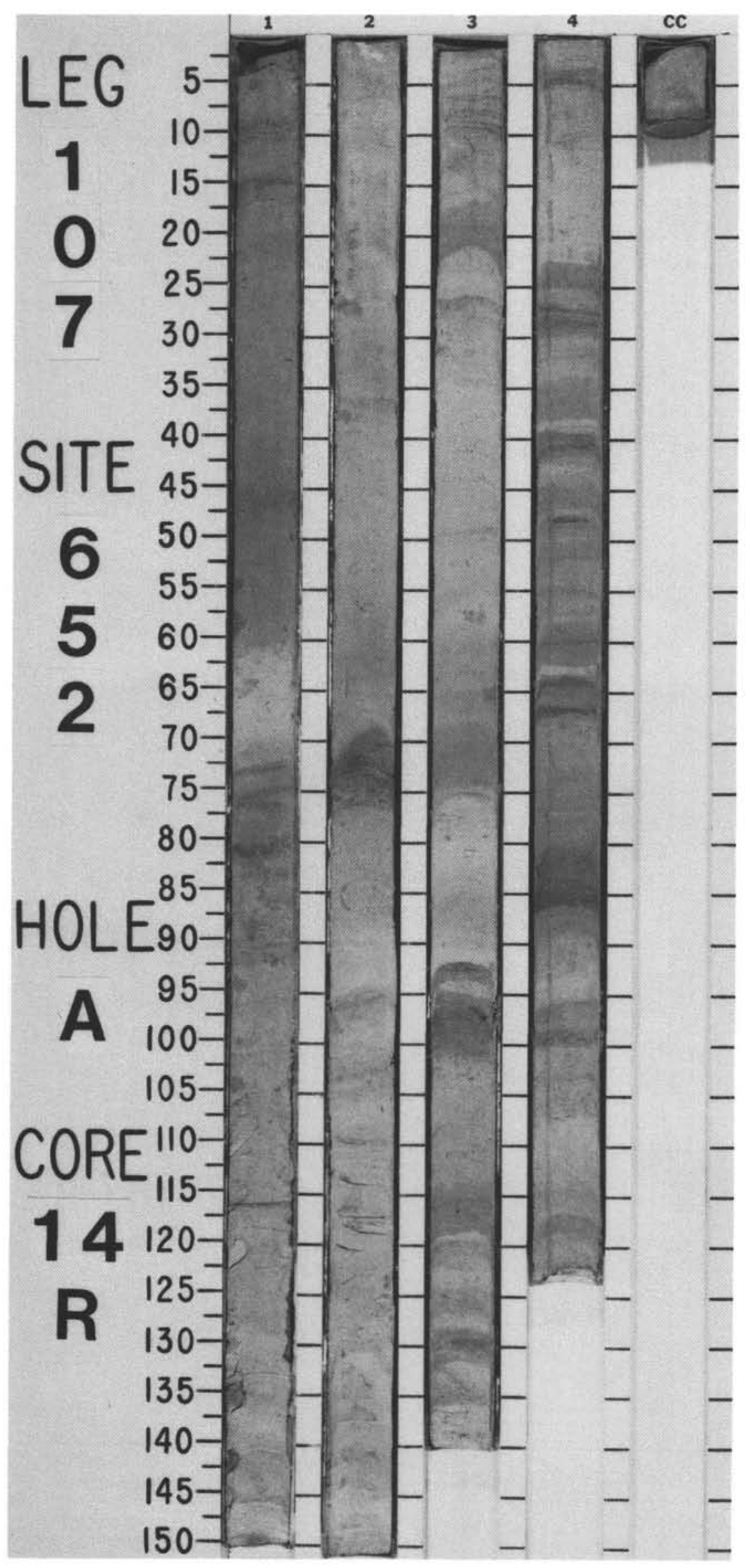




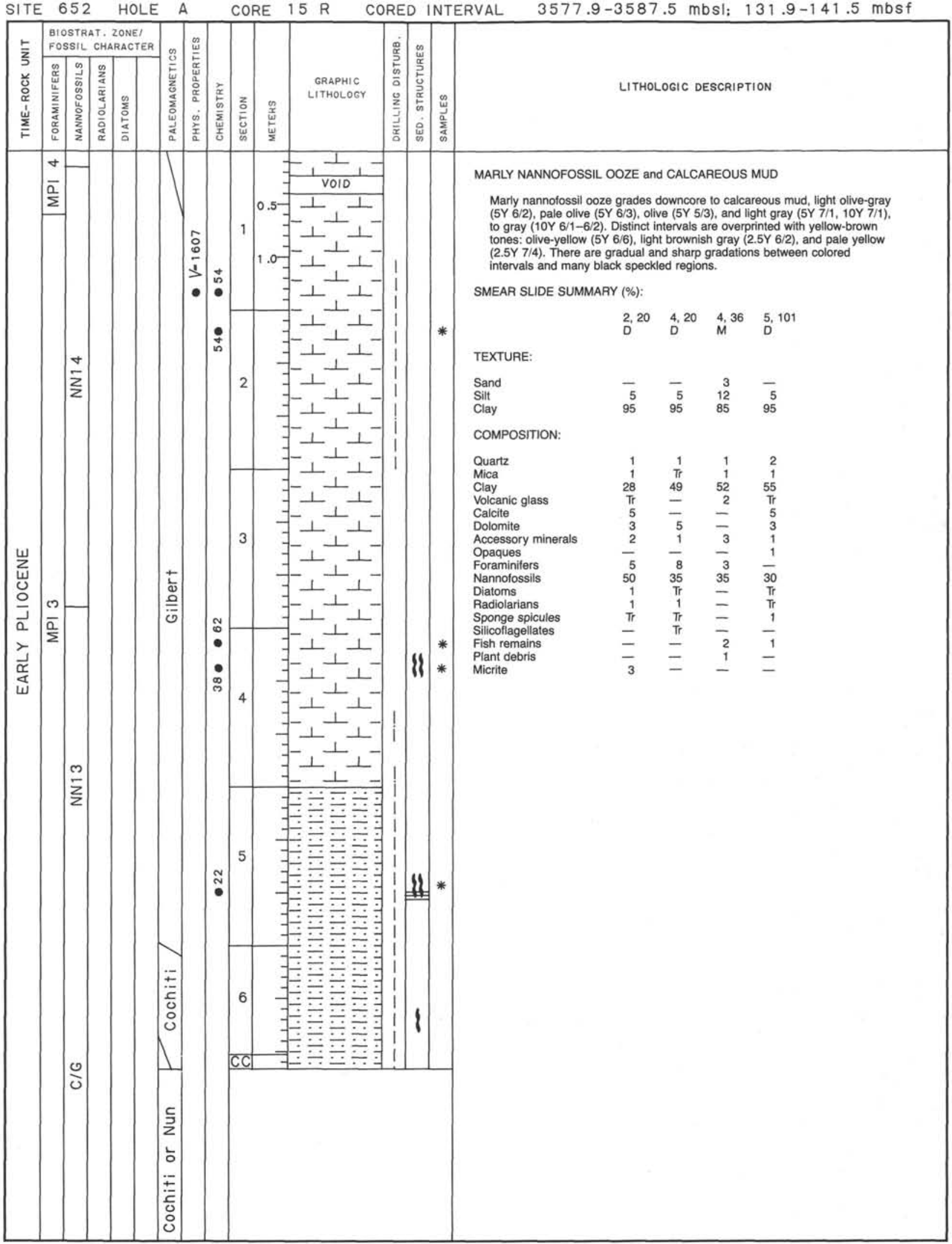




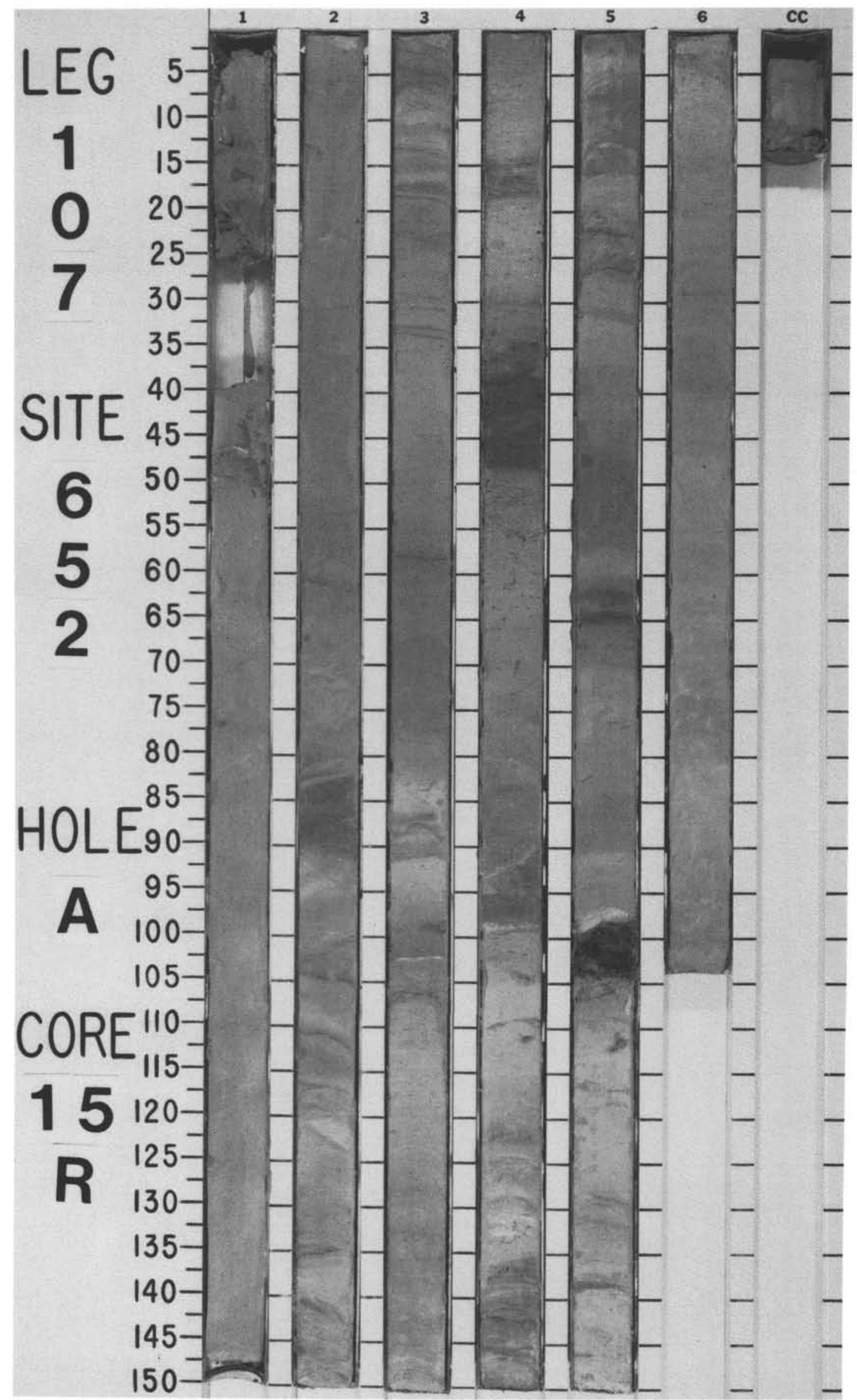




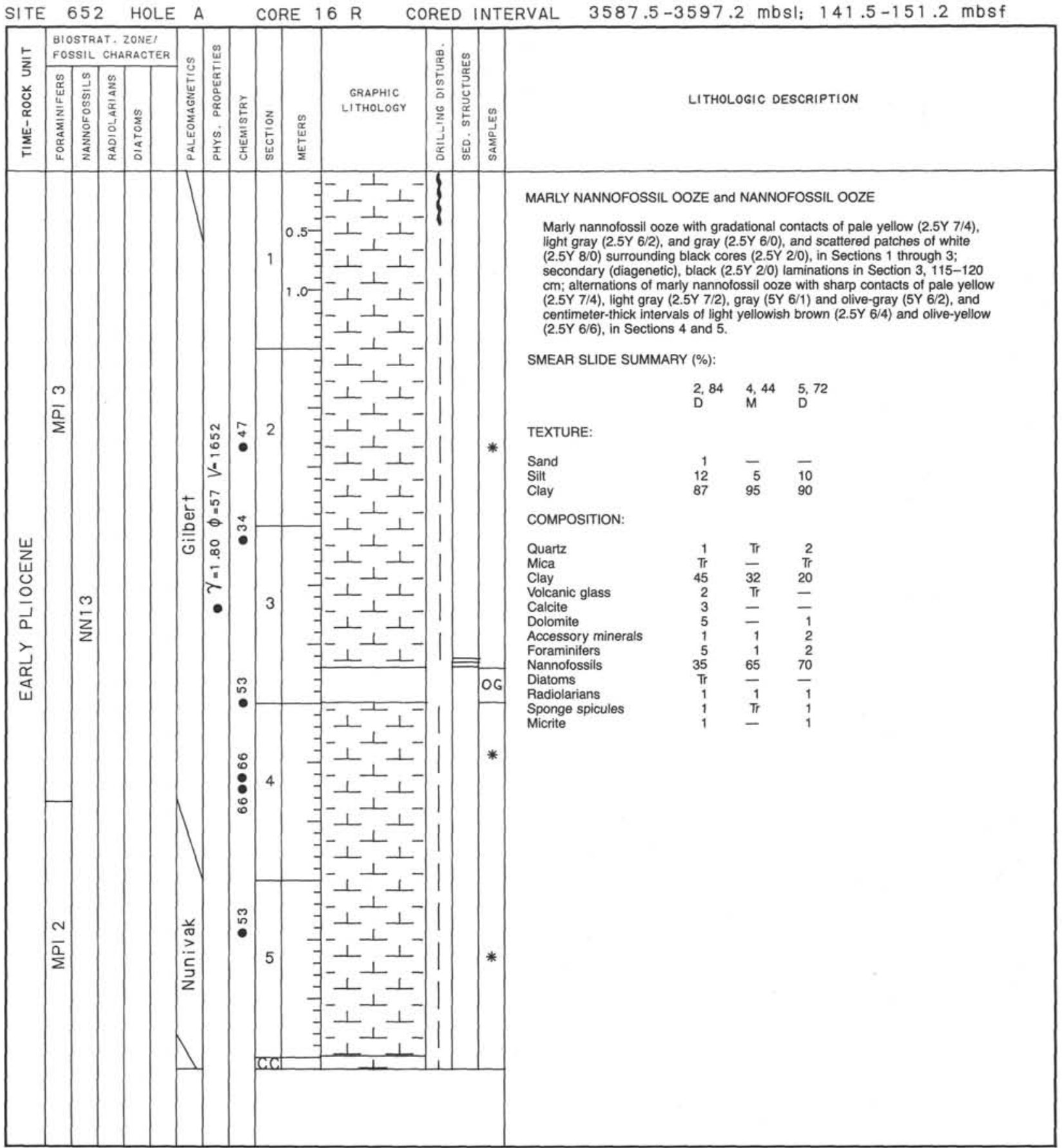




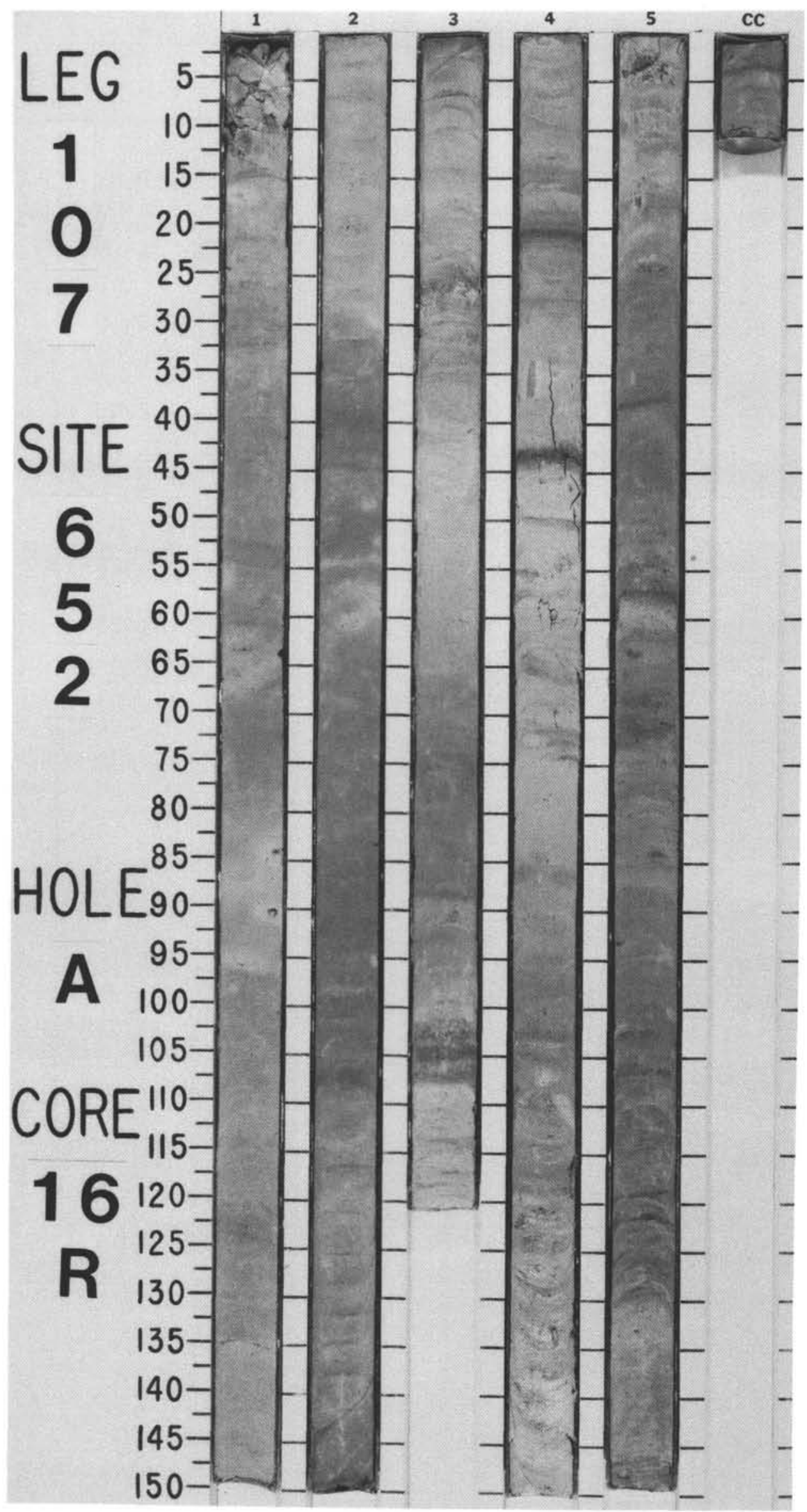




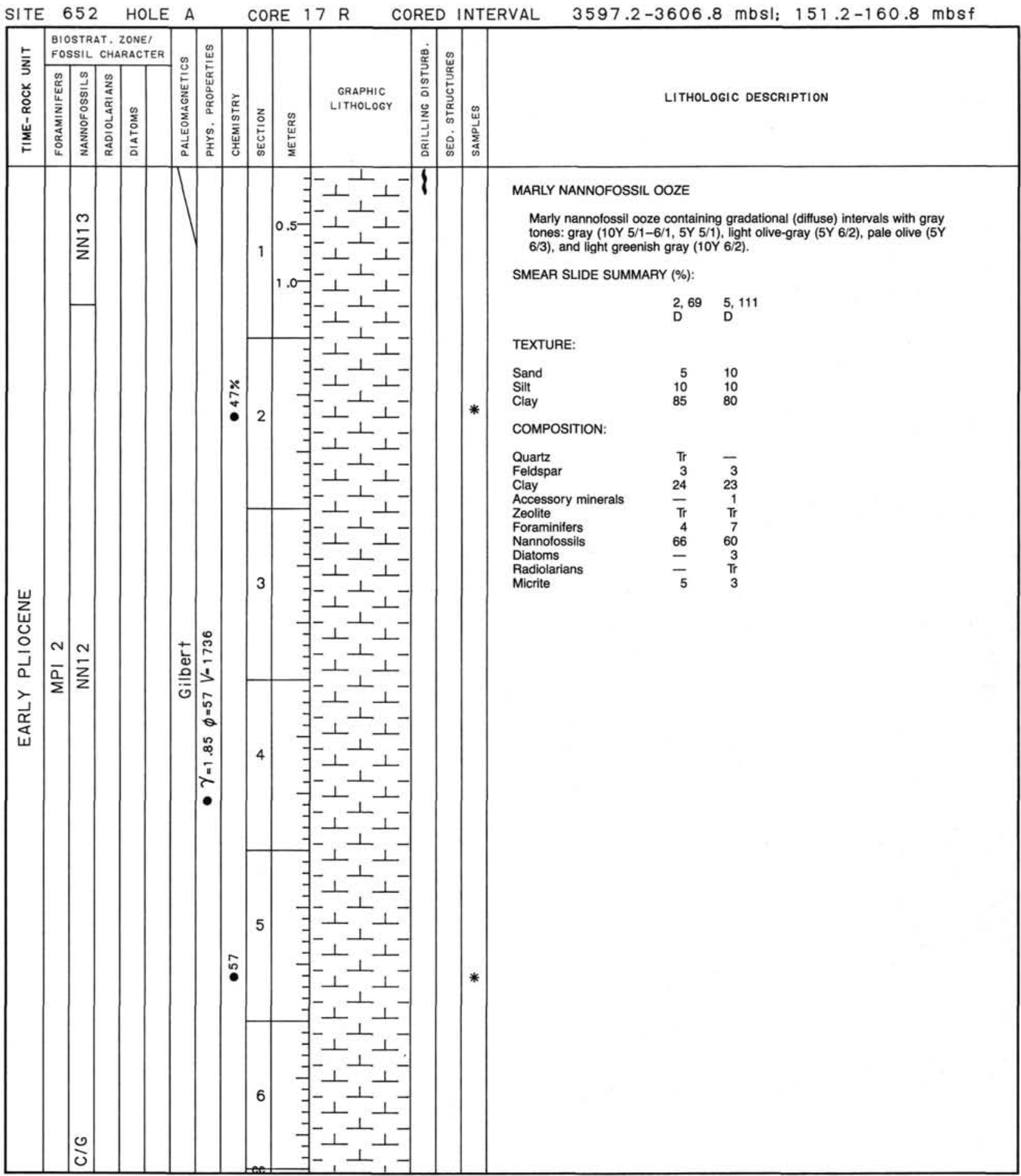




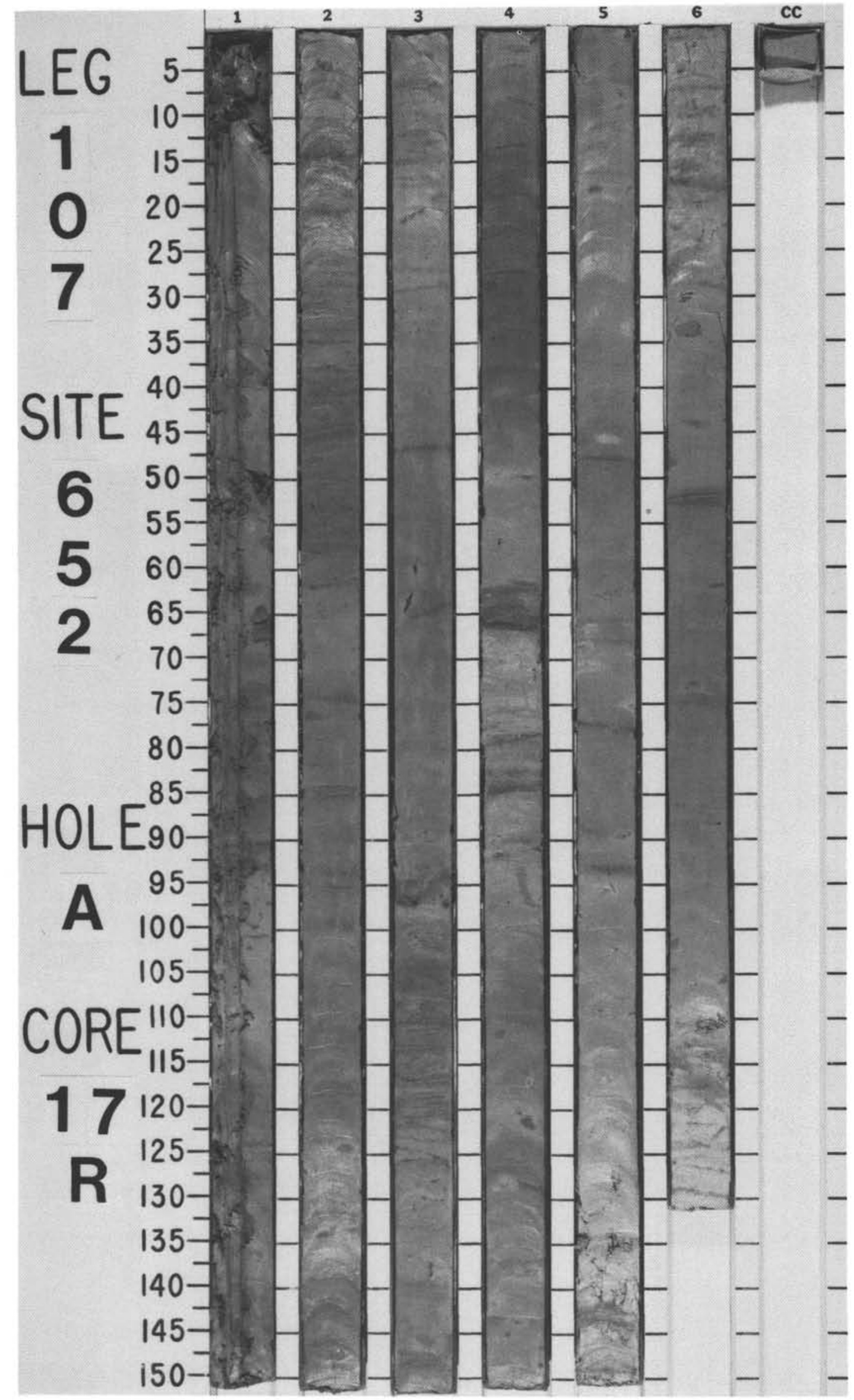




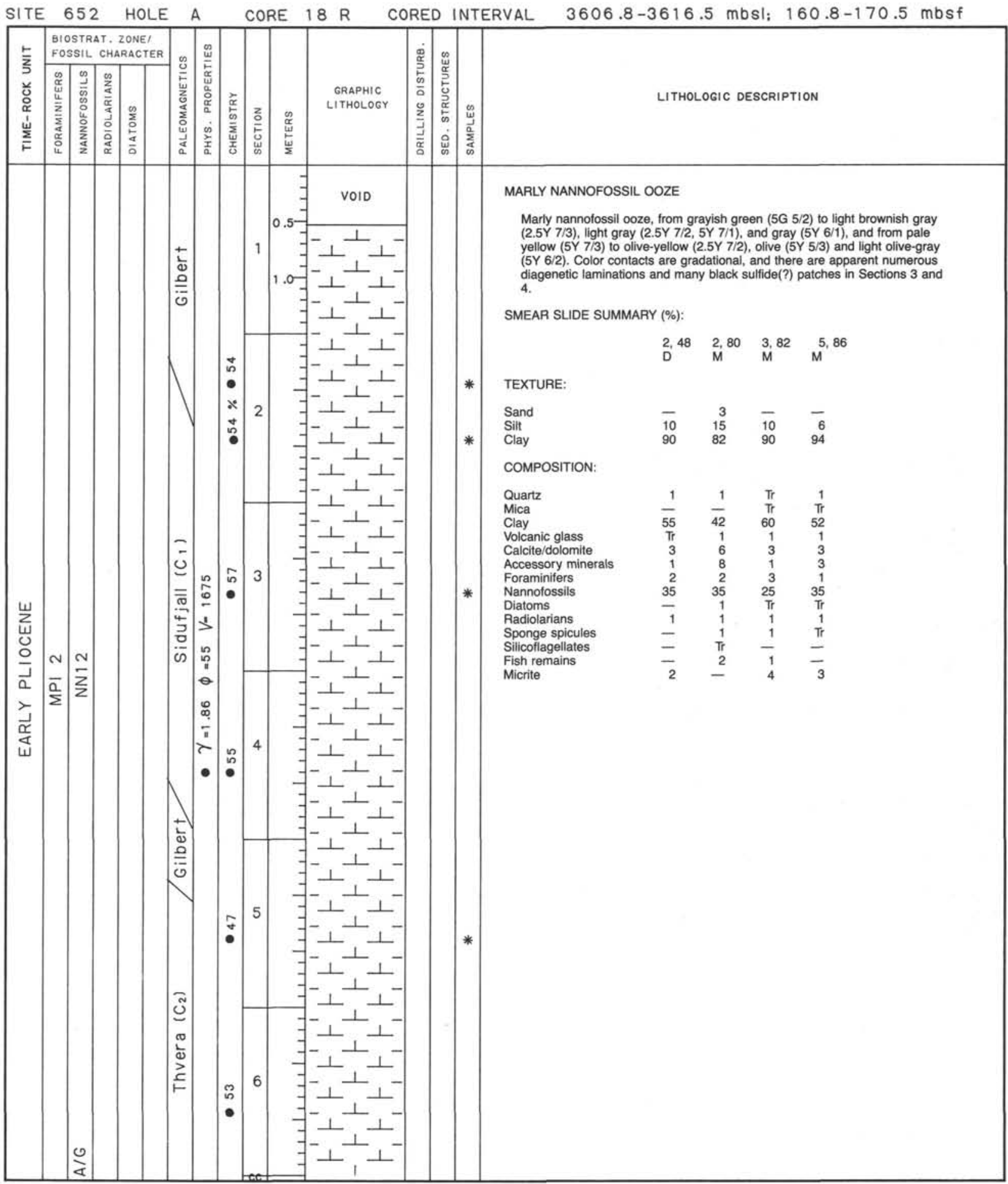




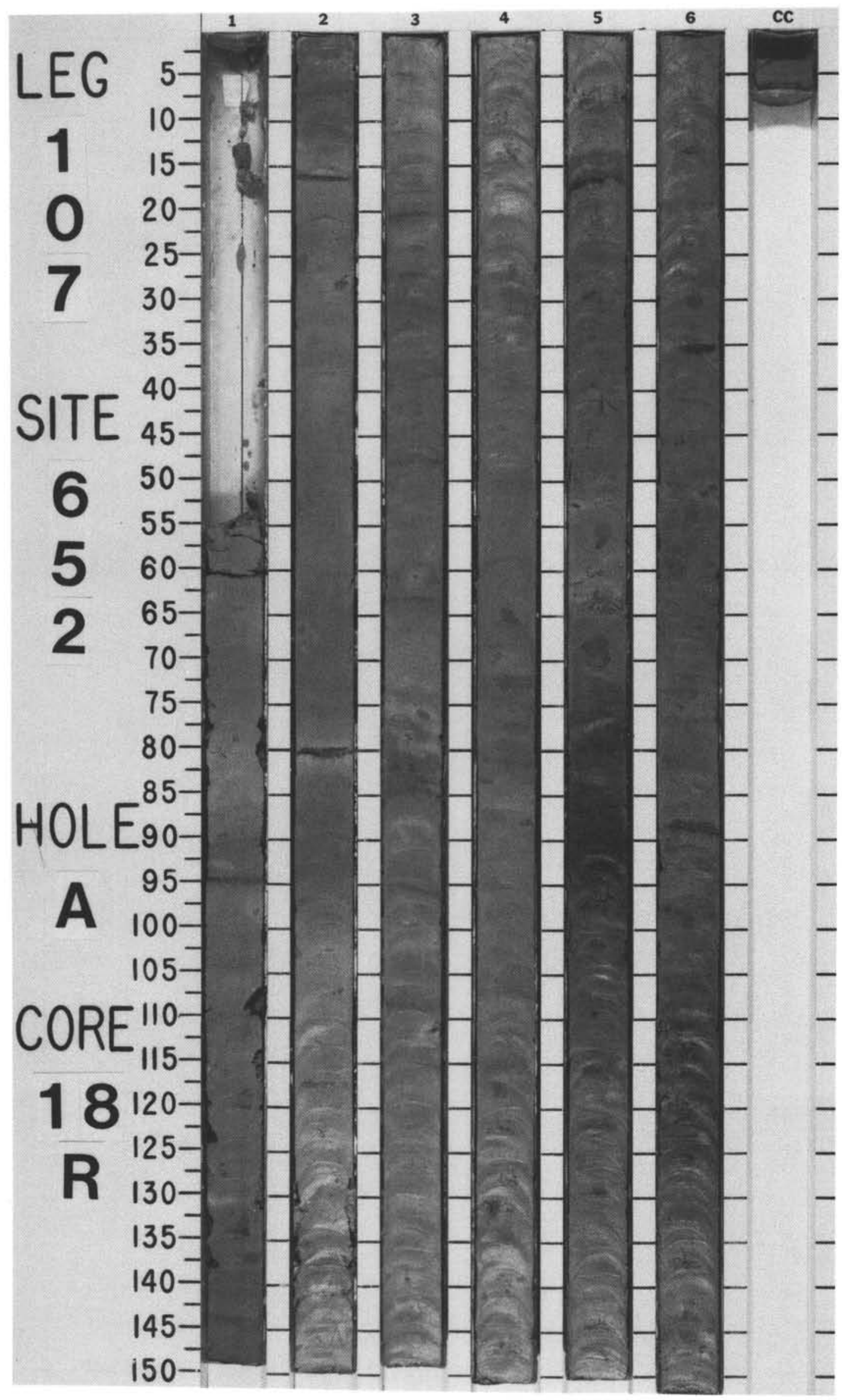




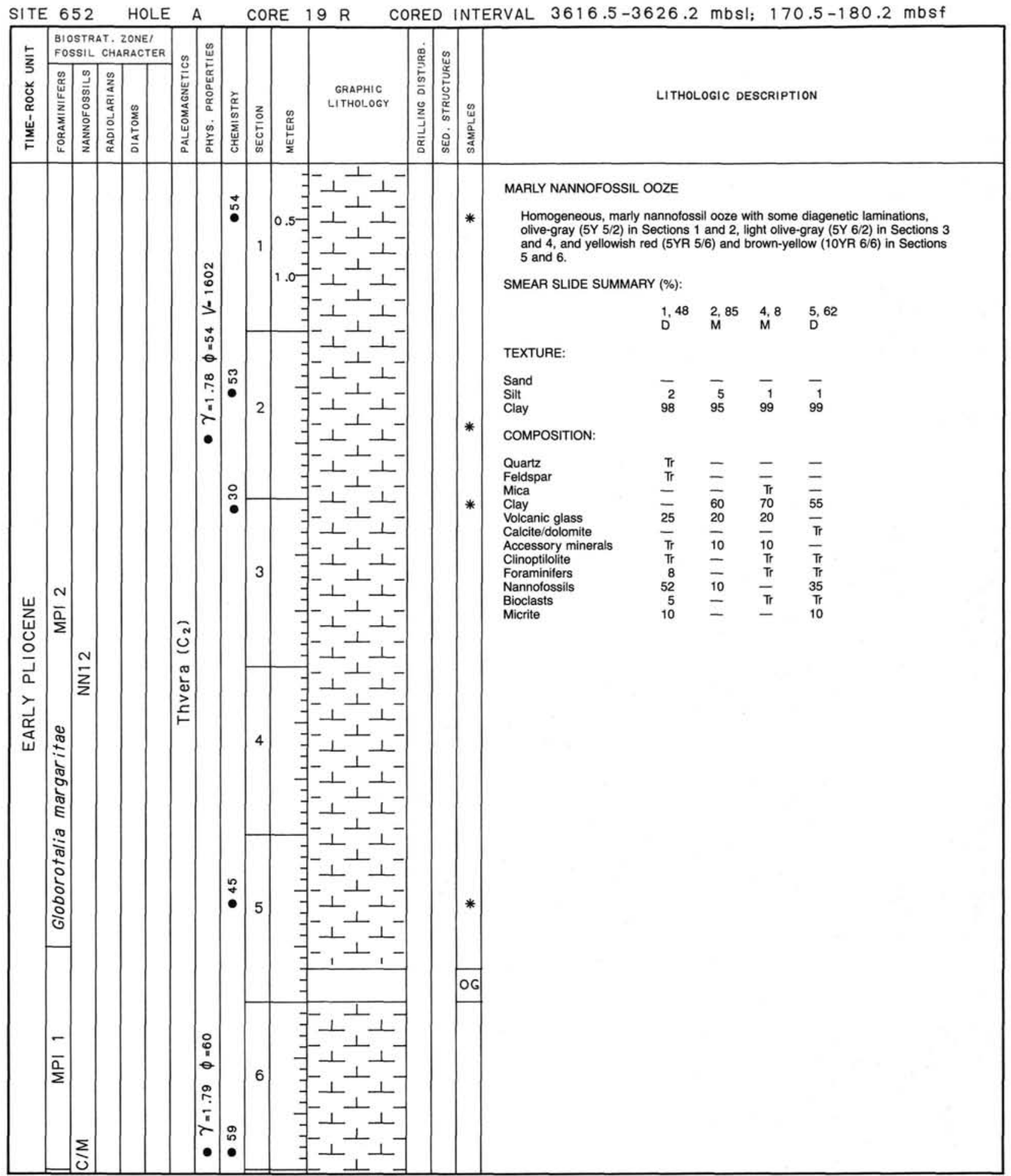




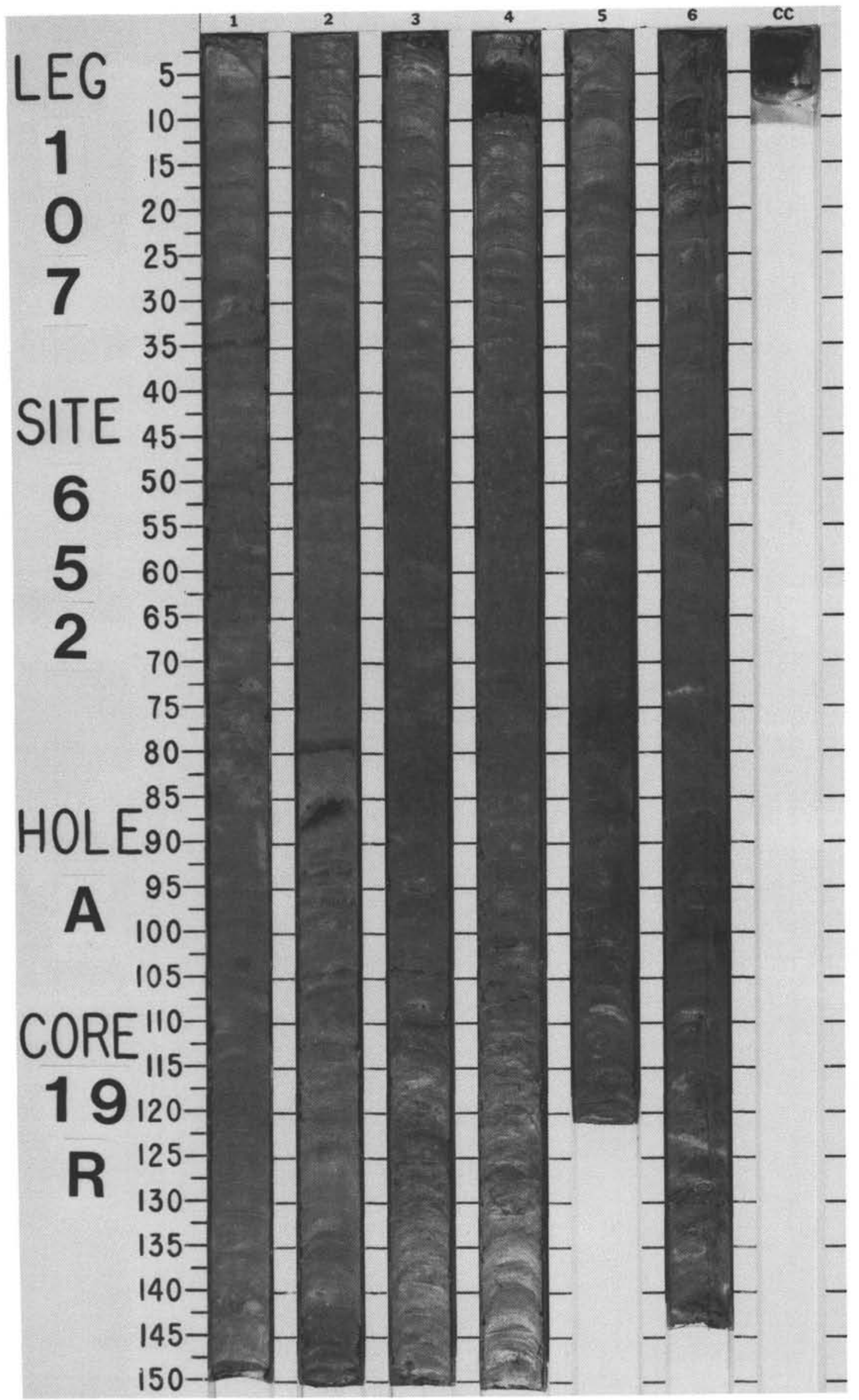




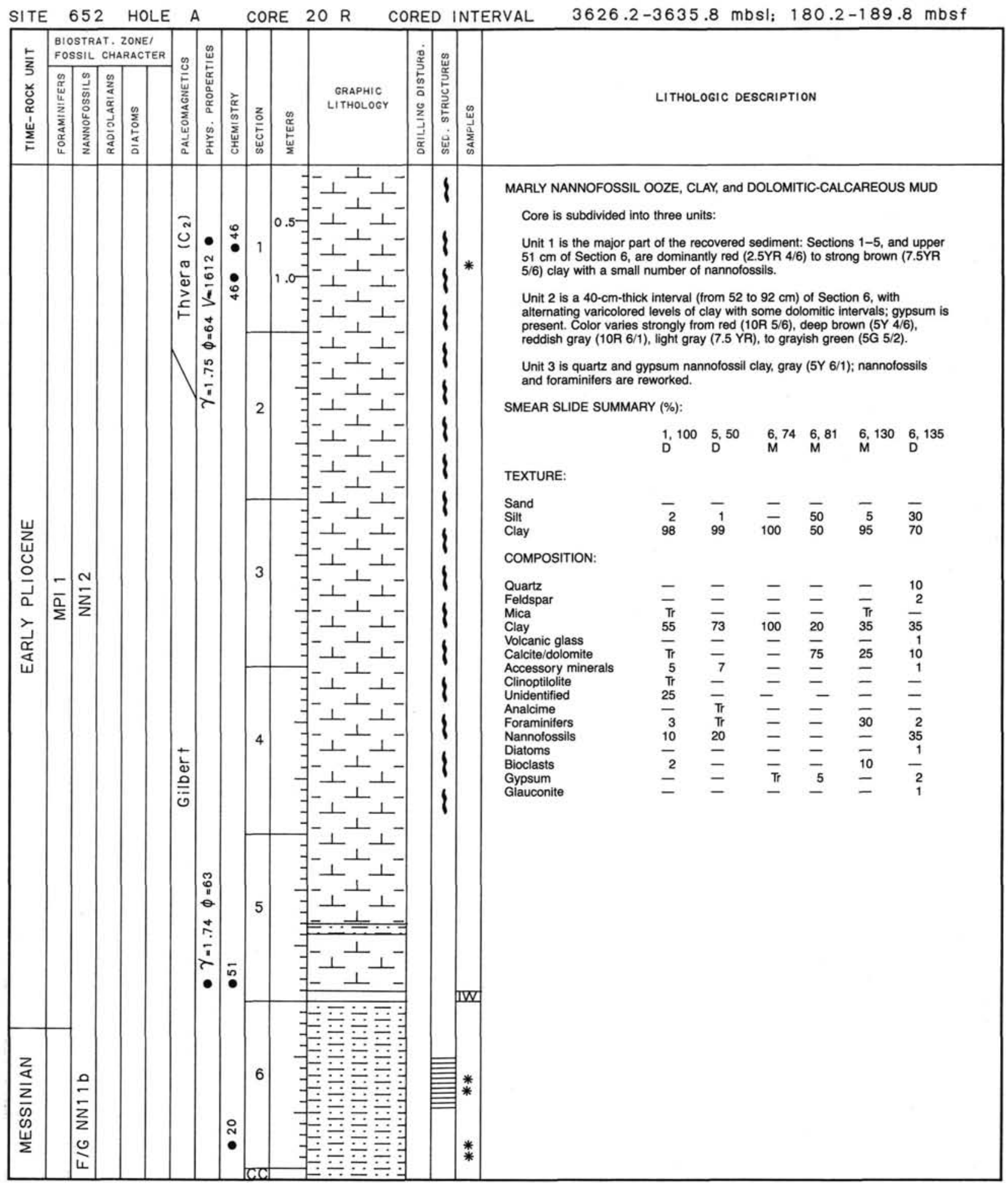




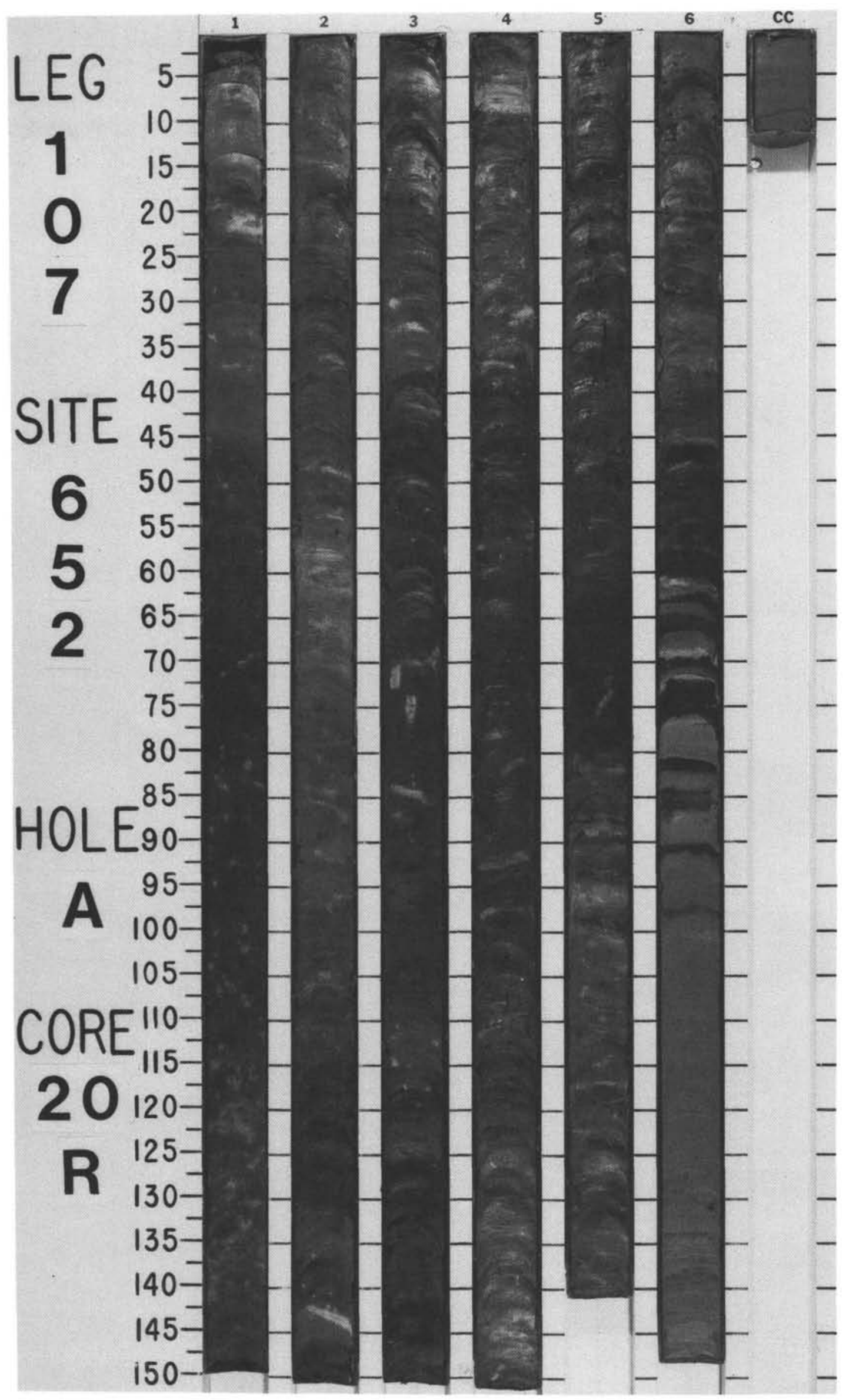




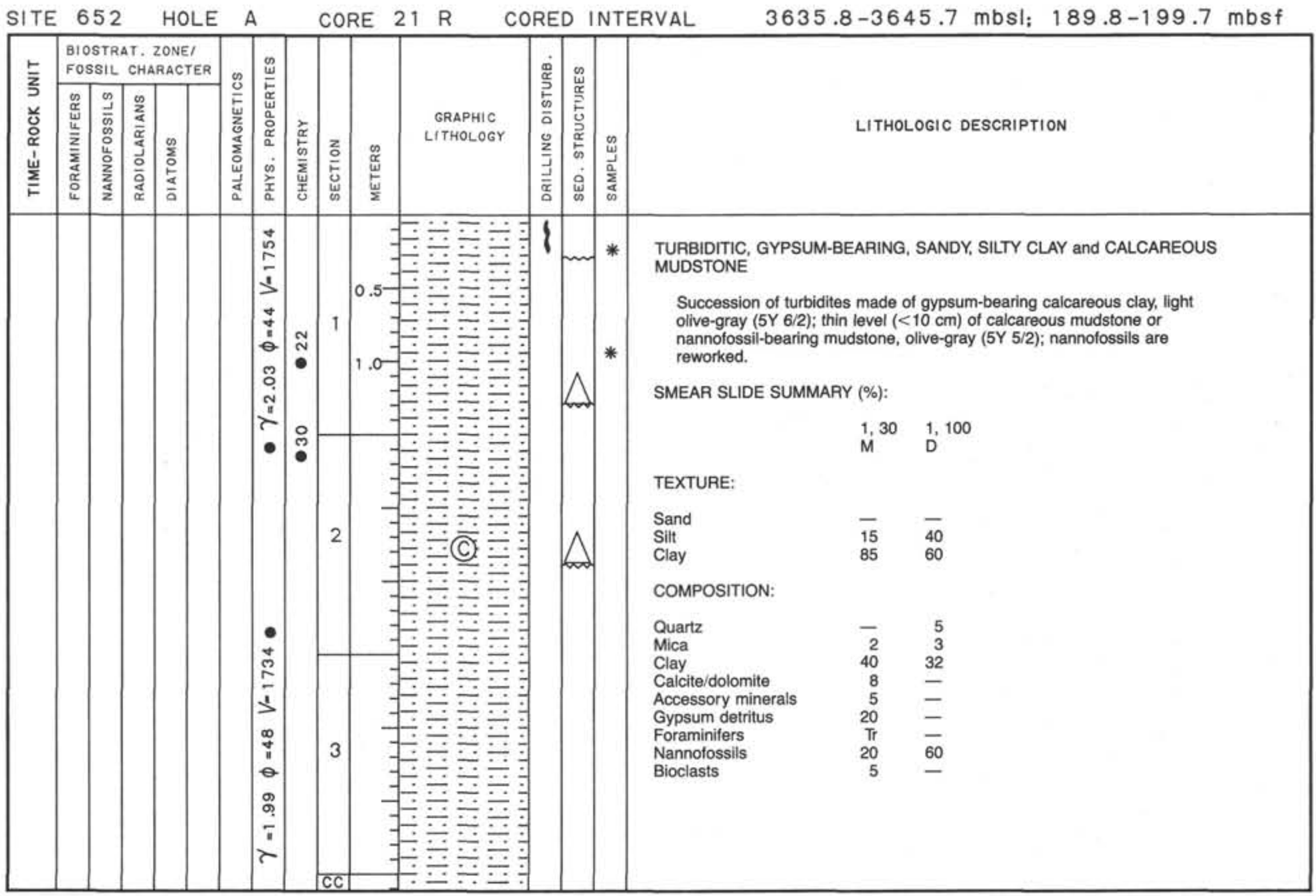




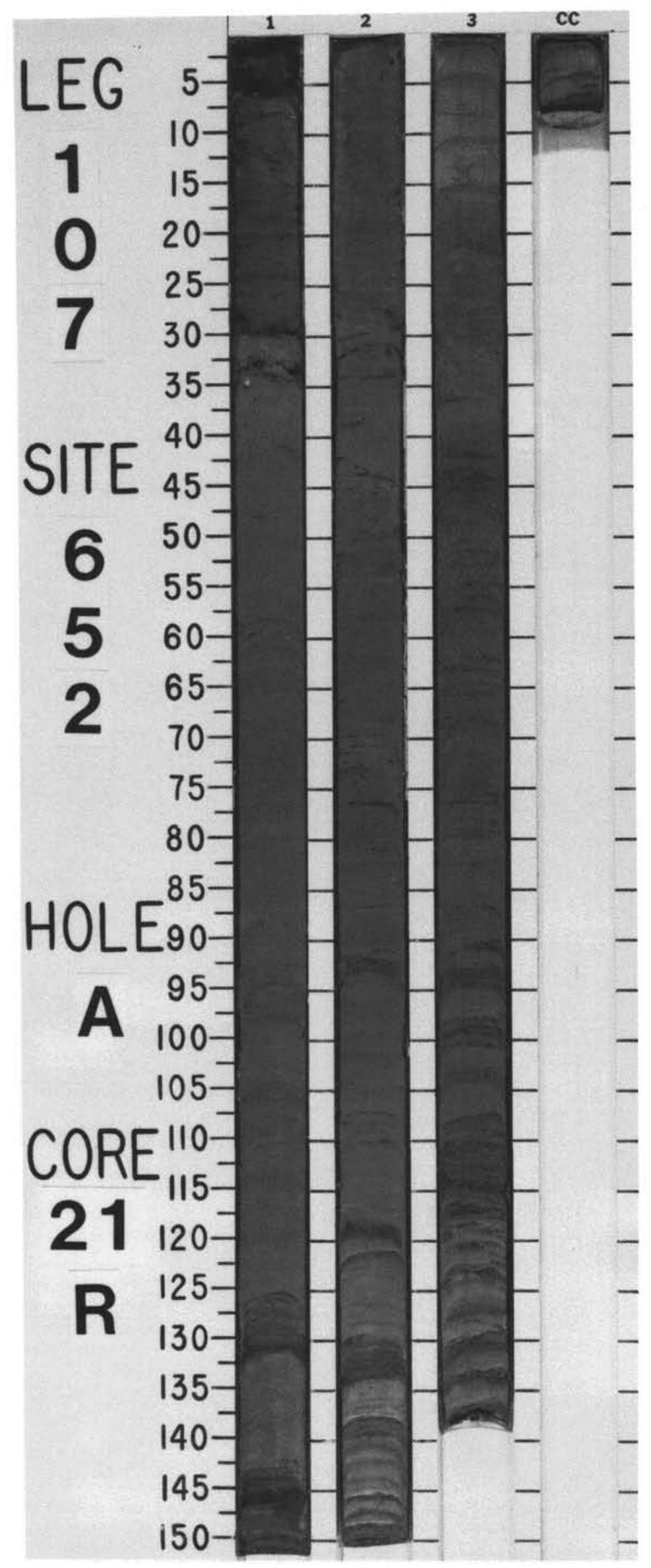




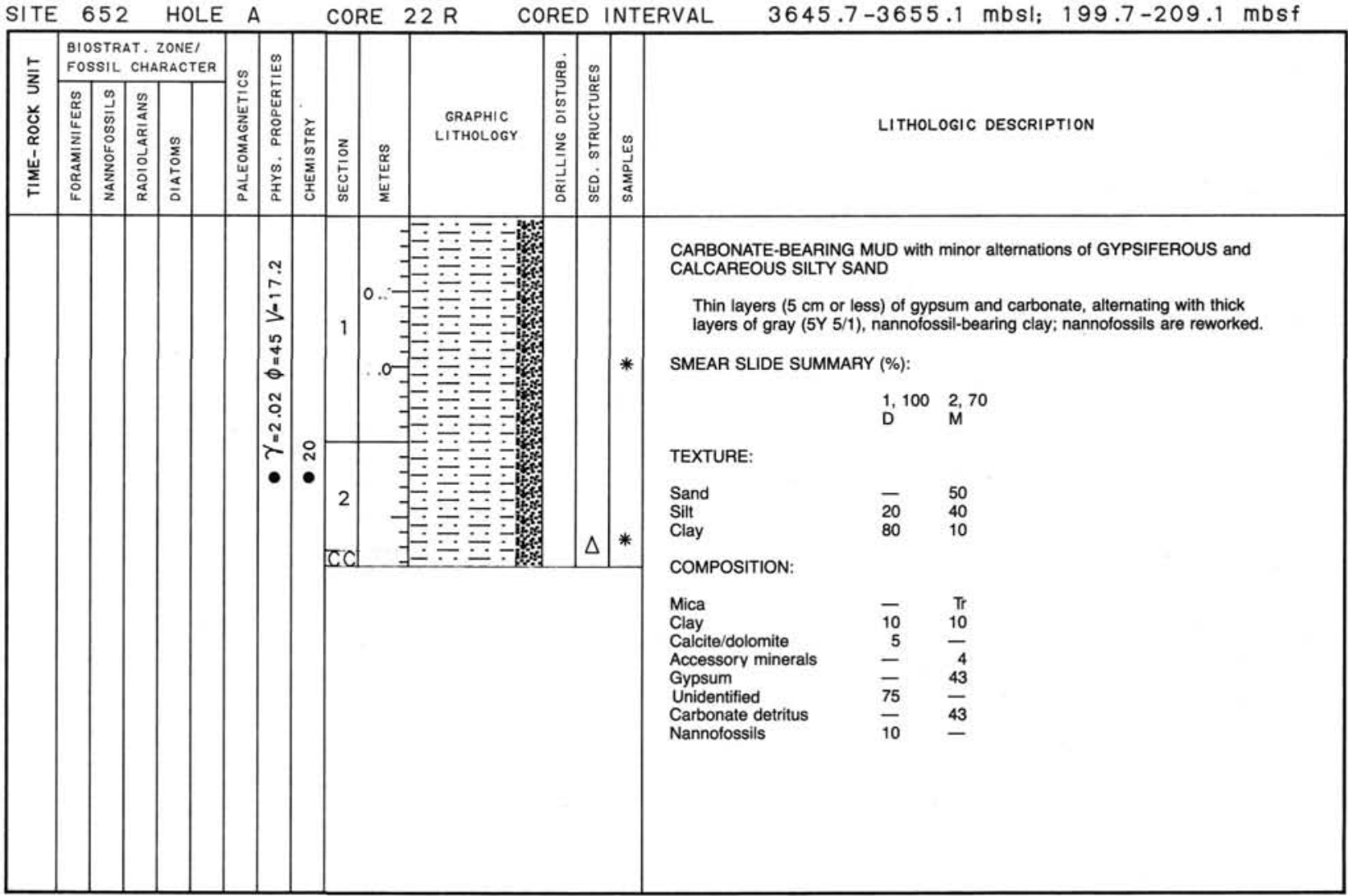

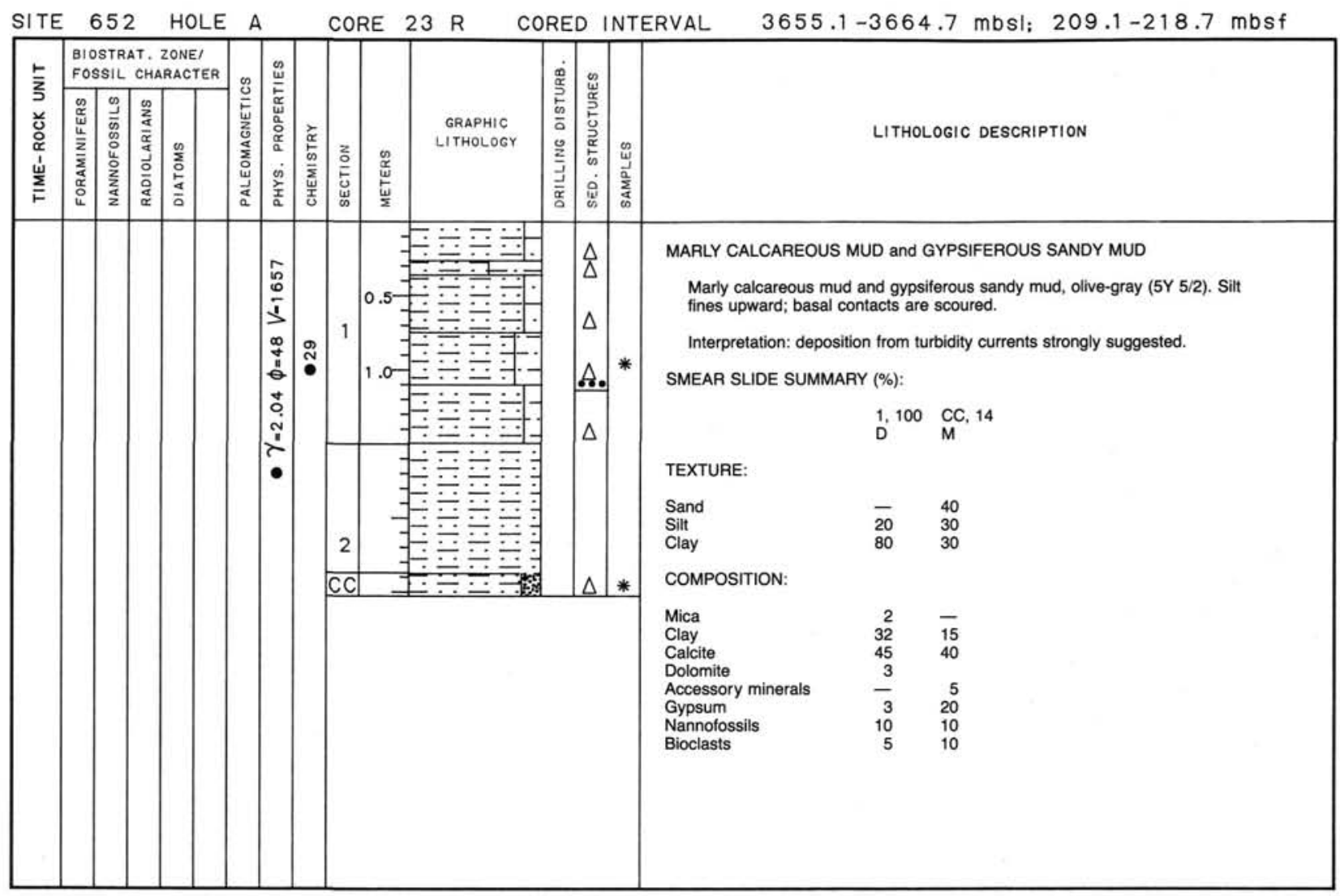




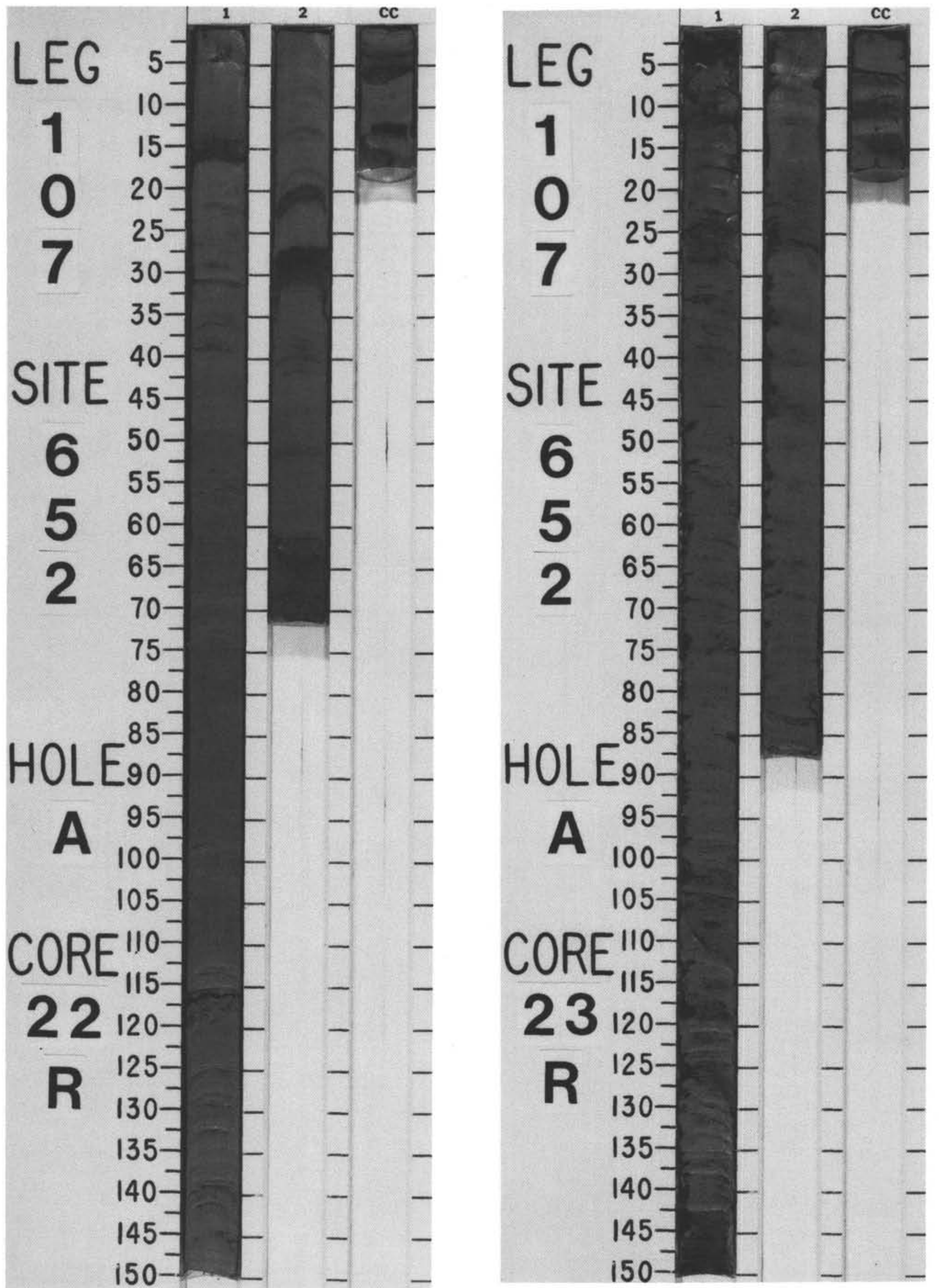




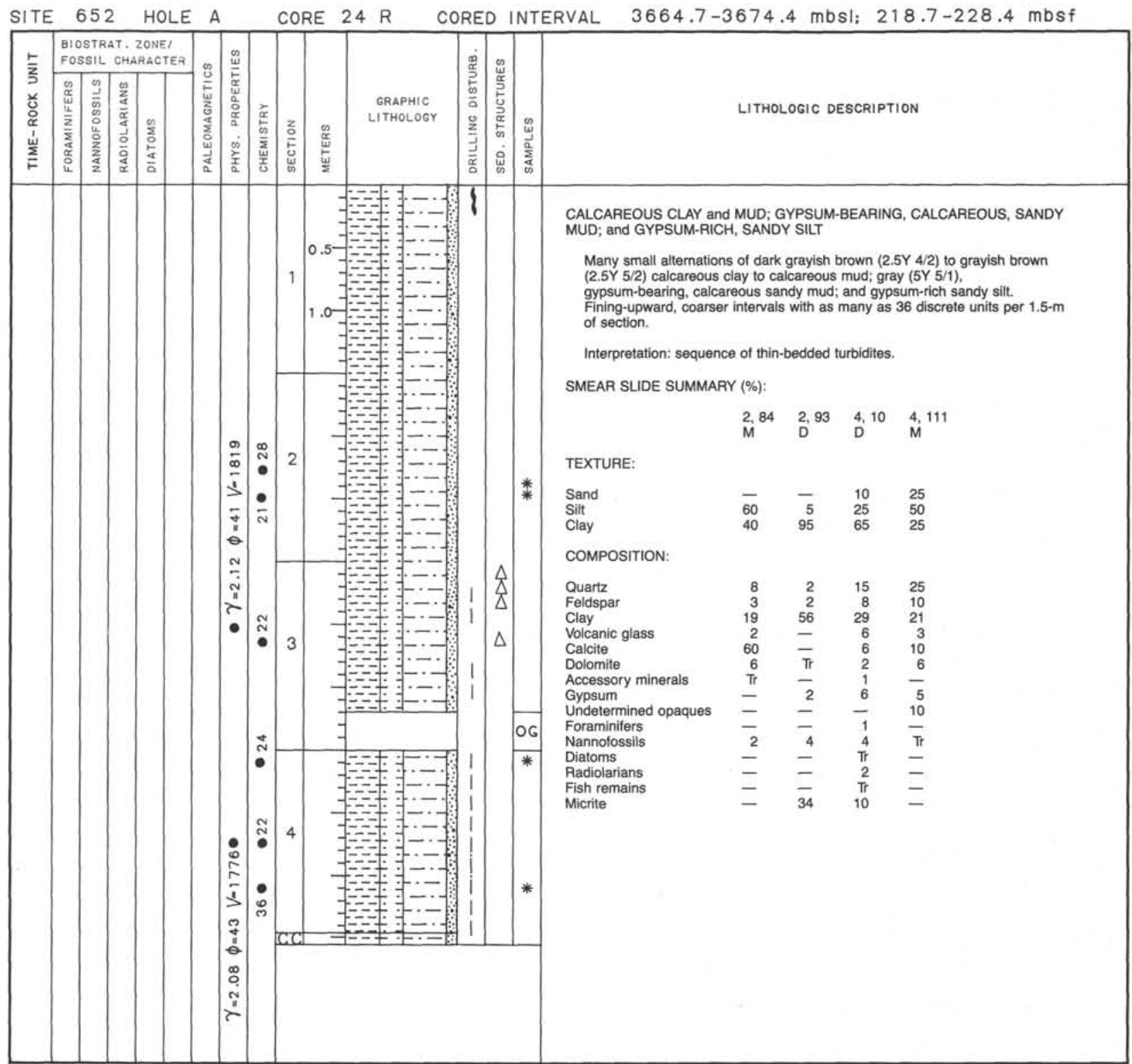




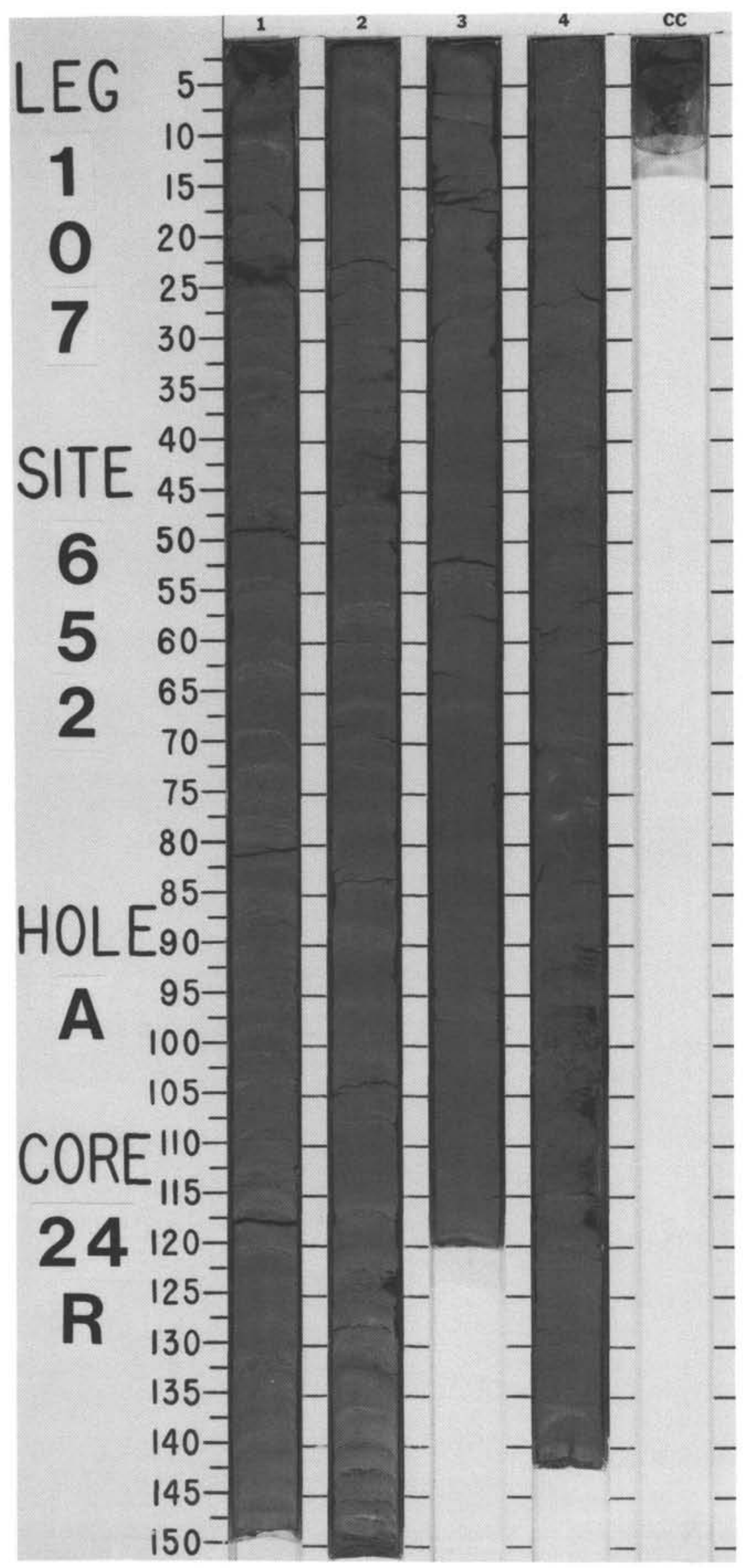




\begin{tabular}{|c|c|c|c|c|c|c|c|c|c|c|c|c|c|c|c|c|c|c|}
\hline \multirow[b]{2}{*}{ 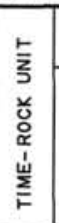 } & \multicolumn{5}{|c|}{$\begin{array}{l}\text { BIOSTRAT, ZONEI } \\
\text { FOSSIL CHARACTER }\end{array}$} & \multirow[b]{2}{*}{ 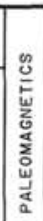 } & \multirow[b]{2}{*}{ 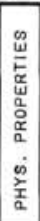 } & \multirow[b]{2}{*}{ 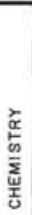 } & \multirow[b]{2}{*}{\begin{tabular}{|l|}
$z$ \\
$o$ \\
0 \\
$\underline{u}$ \\
$w$ \\
$\omega$
\end{tabular}} & \multirow[b]{2}{*}{ 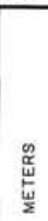 } & \multirow[b]{2}{*}{$\begin{array}{l}\text { GRAPHIC } \\
\text { LITHOLOGY }\end{array}$} & \multirow{2}{*}{\multicolumn{2}{|c|}{ 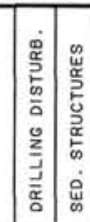 }} & \multirow[b]{2}{*}{ 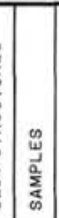 } & & \multirow{2}{*}{\multicolumn{3}{|c|}{ LITHOLOGIC DESCRIPTION }} \\
\hline & 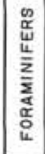 & $\begin{array}{l}0 \\
\frac{2}{5} \\
0 \\
0 \\
0 \\
0 \\
\frac{2}{2} \\
\frac{4}{2}\end{array}$ & \begin{tabular}{|l}
$\frac{\rho}{2}$ \\
$\frac{\alpha}{\alpha}$ \\
$\alpha$ \\
$\frac{\alpha}{\alpha}$ \\
$\frac{0}{\alpha}$ \\
$\frac{\alpha}{\alpha}$
\end{tabular} & 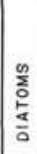 & & & & & & & & & & & & & & \\
\hline & & & & & & & 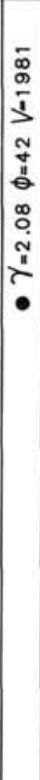 & טֶ. & \begin{tabular}{|c|}
3 \\
$\mathrm{CC}$ \\
\end{tabular} & $\begin{array}{c}0.5- \\
1.0-\end{array}$ & 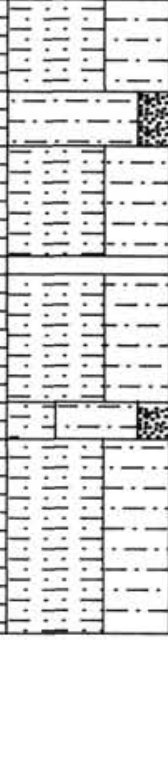 & 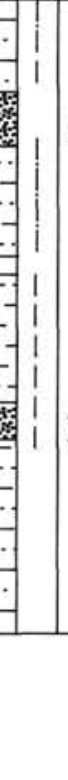 & $\Delta$ & $\begin{array}{l}* \\
* \\
* \\
* \\
\\
\end{array}$ & $\begin{array}{l}\text { GYPSUM, CALCARE } \\
\text { SILTY CARBONATE } \\
\text { Alternations of oli } \\
\text { 4/2) gypsum- and } \\
\text { sandy mud, and g } \\
\text { inorganic calcite } \\
\text { layers being angu } \\
\text { light brownish gra } \\
\text { upward, suggestir } \\
\text { bedded turbidites. } \\
\text { SMEAR SLIDE SUM } \\
\\
\text { TEXTURE: } \\
\text { Sand } \\
\text { Silt } \\
\text { Clay } \\
\text { COMPOSITION: } \\
\text { Quartz } \\
\text { Feldspar } \\
\text { Clay } \\
\text { Calcite } \\
\text { Dolomite } \\
\text { Accessory minerals } \\
\text { Gypsum (detrital) } \\
\text { Nannofossils }\end{array}$ & $\begin{array}{l}\text { MUD; S } \\
\text { DUD } \\
\text { Y 5/3) an } \\
\text { areous-be } \\
\text { m-bearin } \\
\text { nents ar } \\
\text { d subrou } \\
Y \text { s } 6 \text { (2) C } \\
\text { t these a } \\
\text { Y (\%): } \\
1,40 \\
D \\
\overline{40} \\
60\end{array}$ & $\begin{array}{l}\text { ANDY M } \\
\text { d olive-gr } \\
\text { aring mu } \\
\text { g sity car } \\
\text { odetrital, } \\
\text { nded. Th } \\
\text { ay occur } \\
\text { lternation } \\
\\
1,61 \\
\text { D } \\
\\
20 \\
60 \\
20\end{array}$ & $\begin{array}{l}\text { AUD; and GYPSUM-BEARING, } \\
\text { ray (5Y 5/2) to grayish brown (2.5Y } \\
\text { ud, gypsum-and quartz-bearing } \\
\text { arbonate sand. The gypsum and } \\
\text { 1, with the calcite grains in the sand } \\
\text { hin layers (a few millimeters thick) of } \\
\text { in Section } 2 \text {. Coarser beds fine } \\
\text { ns represent a sequence of thinly } \\
\\
1,73 \\
\text { M } \\
25 \\
15\end{array}$ \\
\hline
\end{tabular}

SITE 652 HOLE A CORE $26 \mathrm{R}$ CORED INTERVAL $3684.1-3693.7 \mathrm{mbsl} ; 238.1-247.7 \mathrm{mbs}$

\begin{tabular}{|c|c|c|c|c|c|c|c|c|c|c|c|c|c|}
\hline \multirow[b]{2}{*}{ 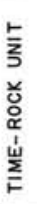 } & \multicolumn{4}{|c|}{$\begin{array}{l}\text { BIOSTRAT, ZONEI } \\
\text { FOSSIL CHARACTER }\end{array}$} & \multirow[b]{2}{*}{ 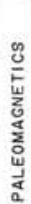 } & \multirow[b]{2}{*}{ 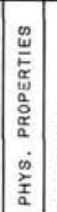 } & \multirow{2}{*}{\multicolumn{2}{|c|}{ 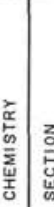 }} & \multirow[b]{2}{*}{$\begin{array}{l}\frac{g}{\sigma} \\
\frac{\tilde{W}}{\omega} \\
\frac{\mathrm{w}}{2}\end{array}$} & \multirow[b]{2}{*}{$\begin{array}{l}\text { GRAPHIC } \\
\text { LITHOLOGY }\end{array}$} & \multirow[b]{2}{*}{ 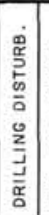 } & \multirow[b]{2}{*}{ 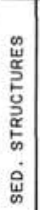 } & \\
\hline & 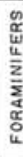 & 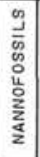 & 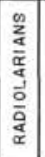 & 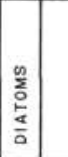 & & & & & & & & & 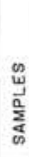 \\
\hline
\end{tabular}

LITHOLOGIC DESCRIPTION

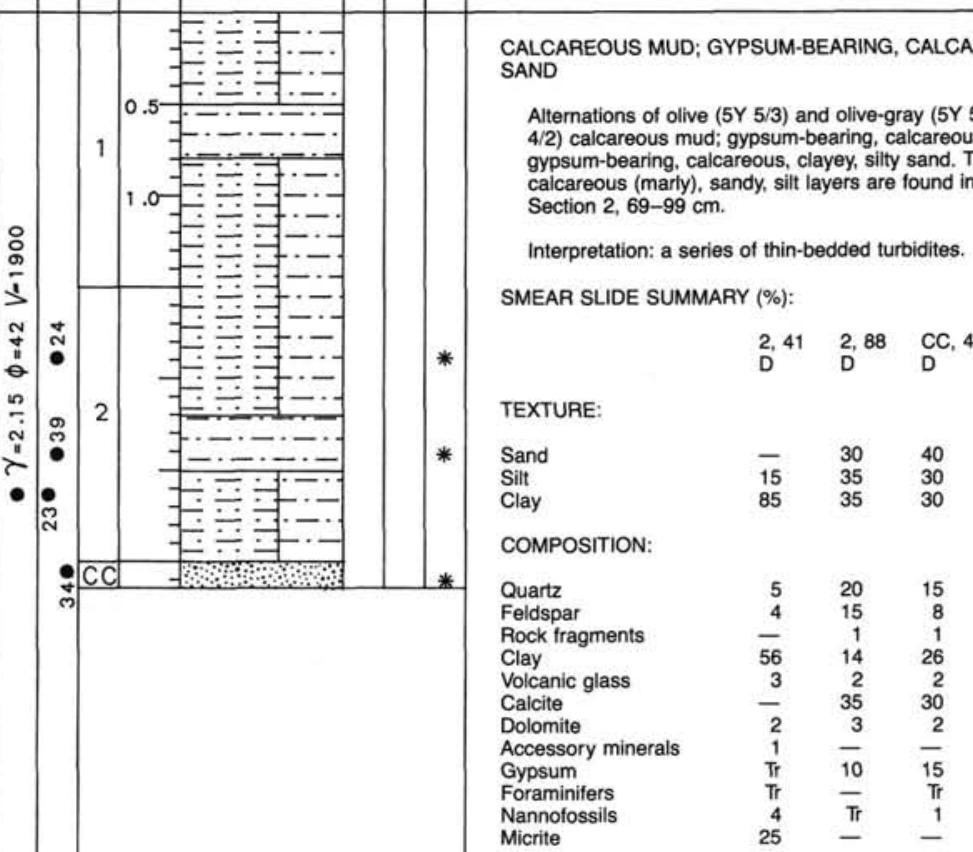




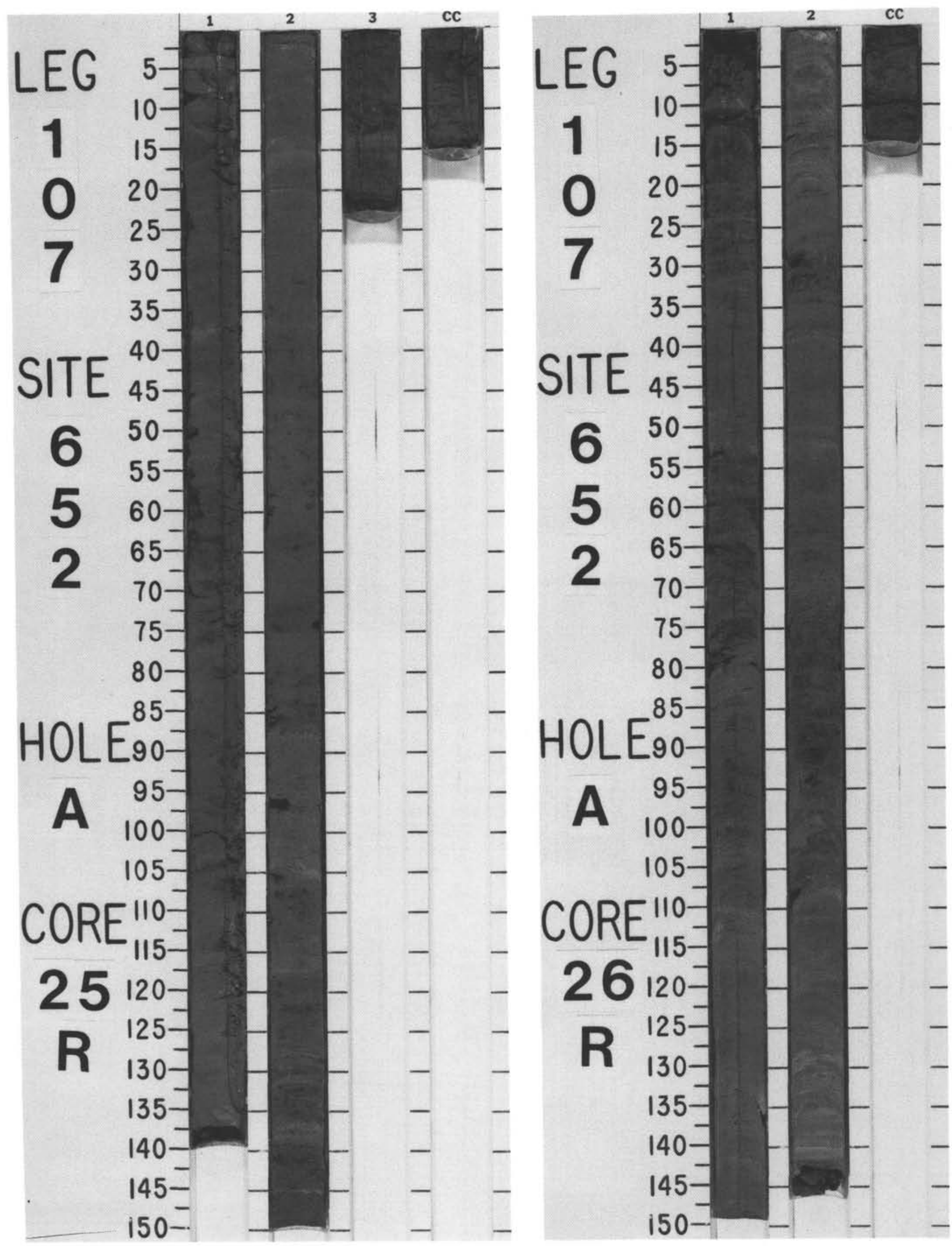




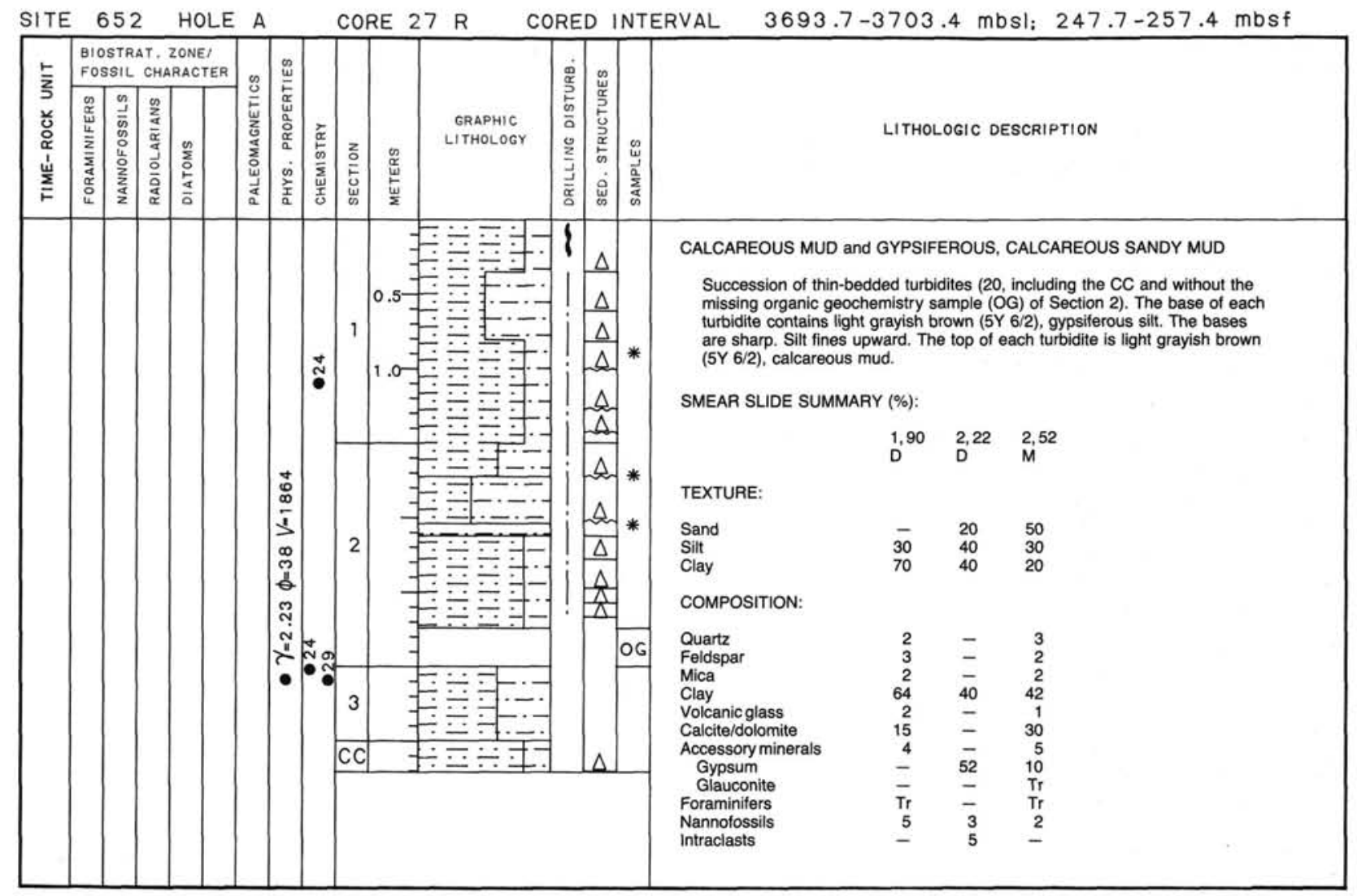

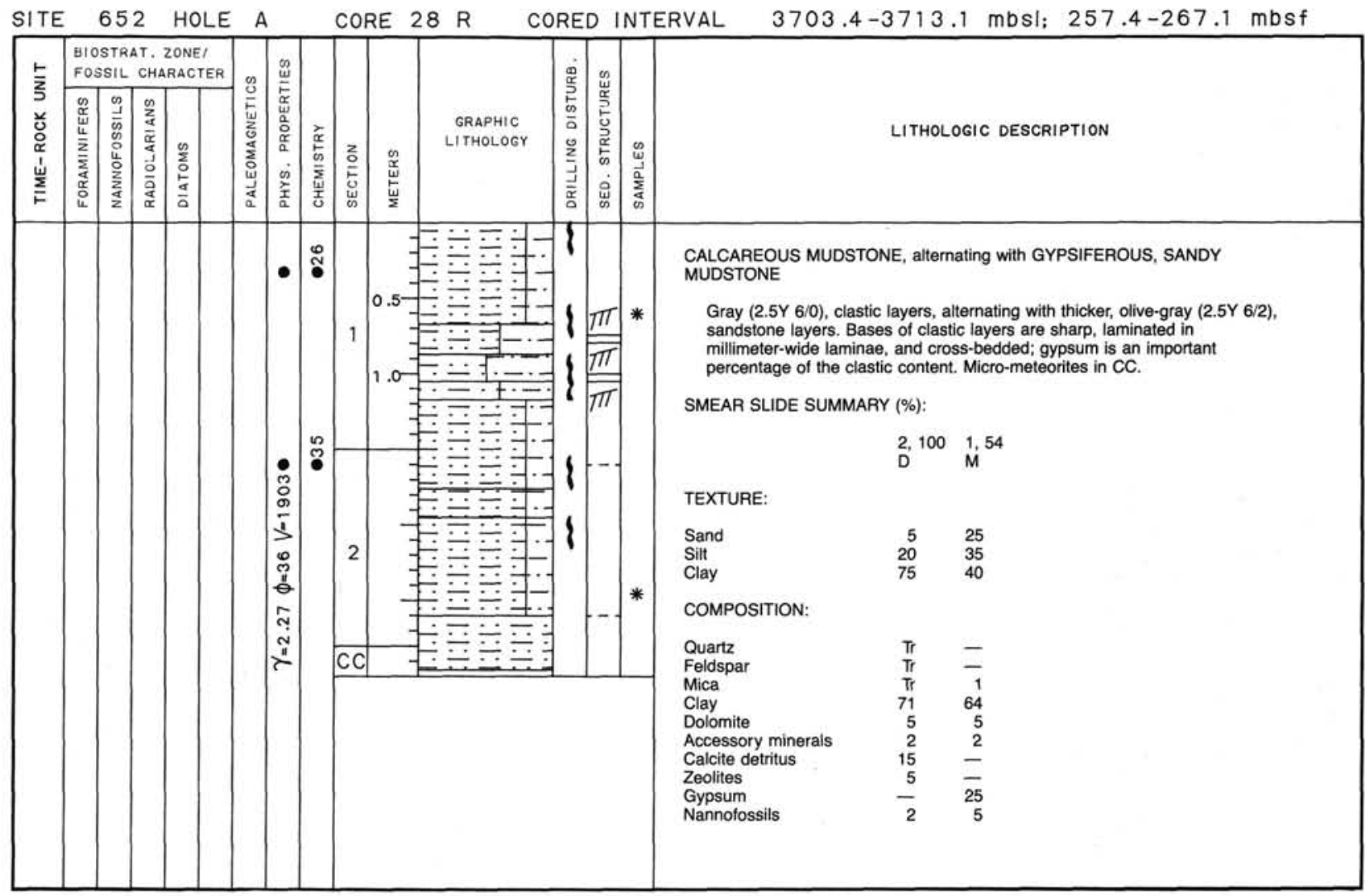




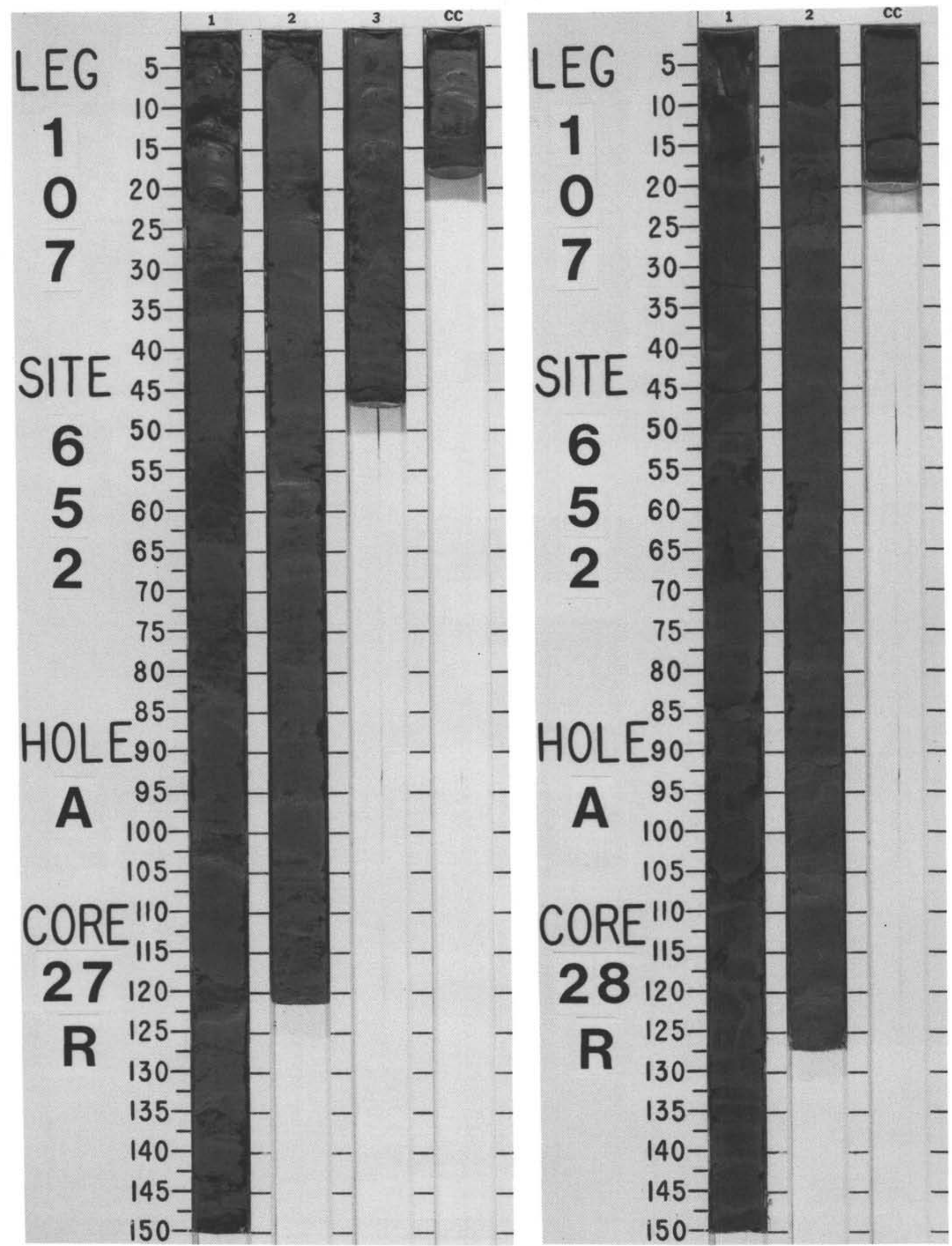




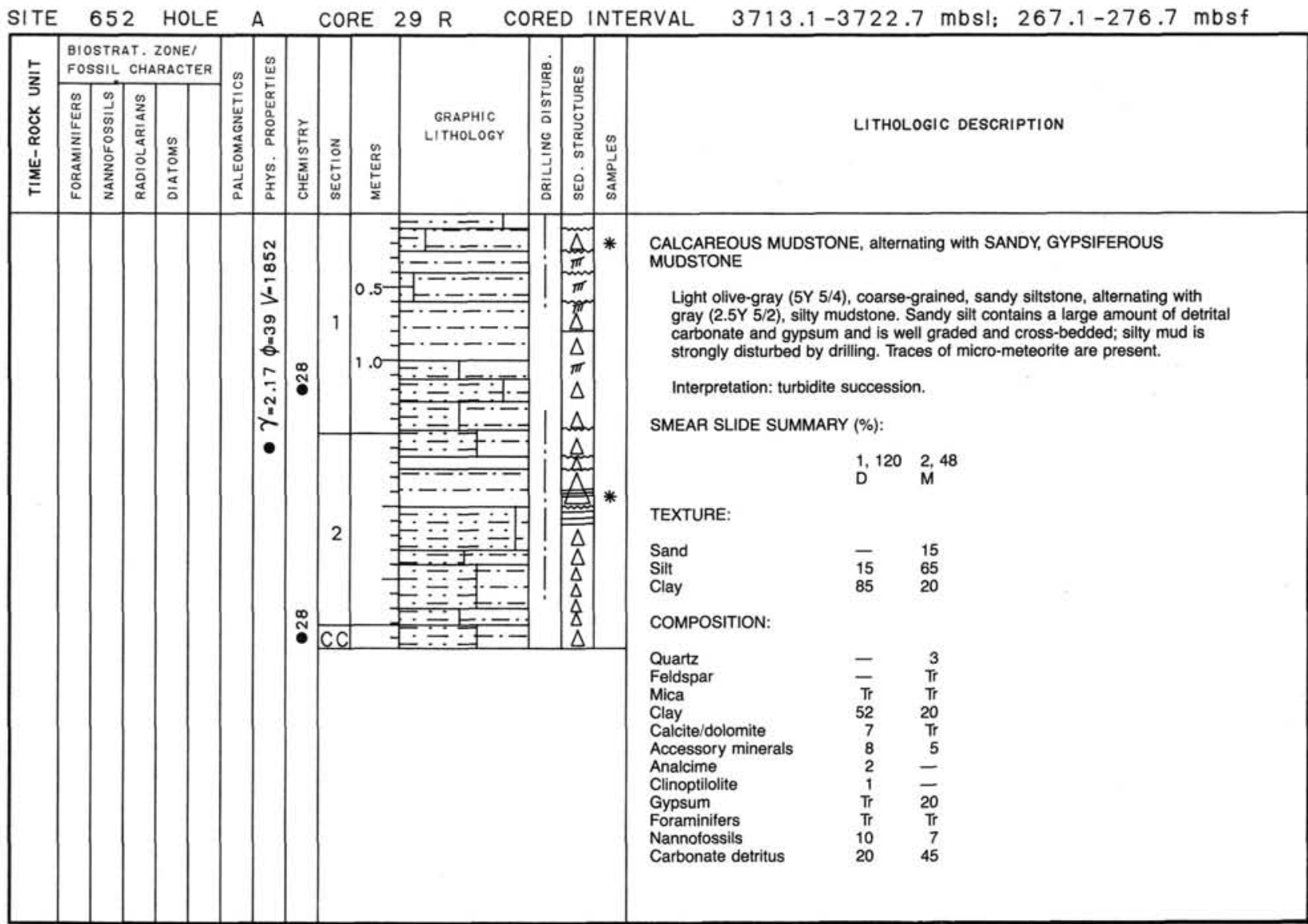

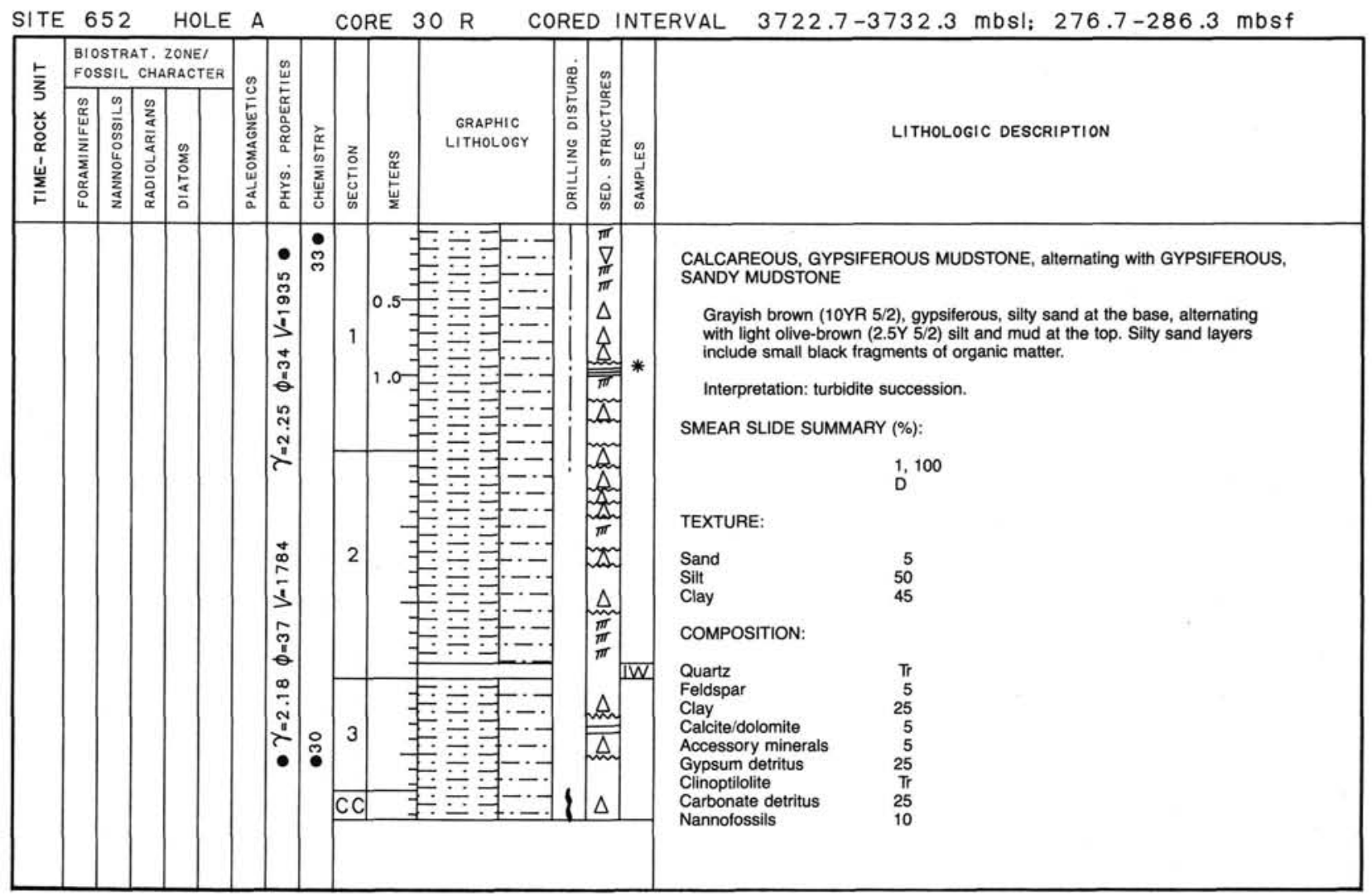


SITE 652 HOLE A CORE 31 R CORED INTERVAL

$3732.3-3741.9 \mathrm{mbsl}: 286.3-295.9 \mathrm{mbsf}$

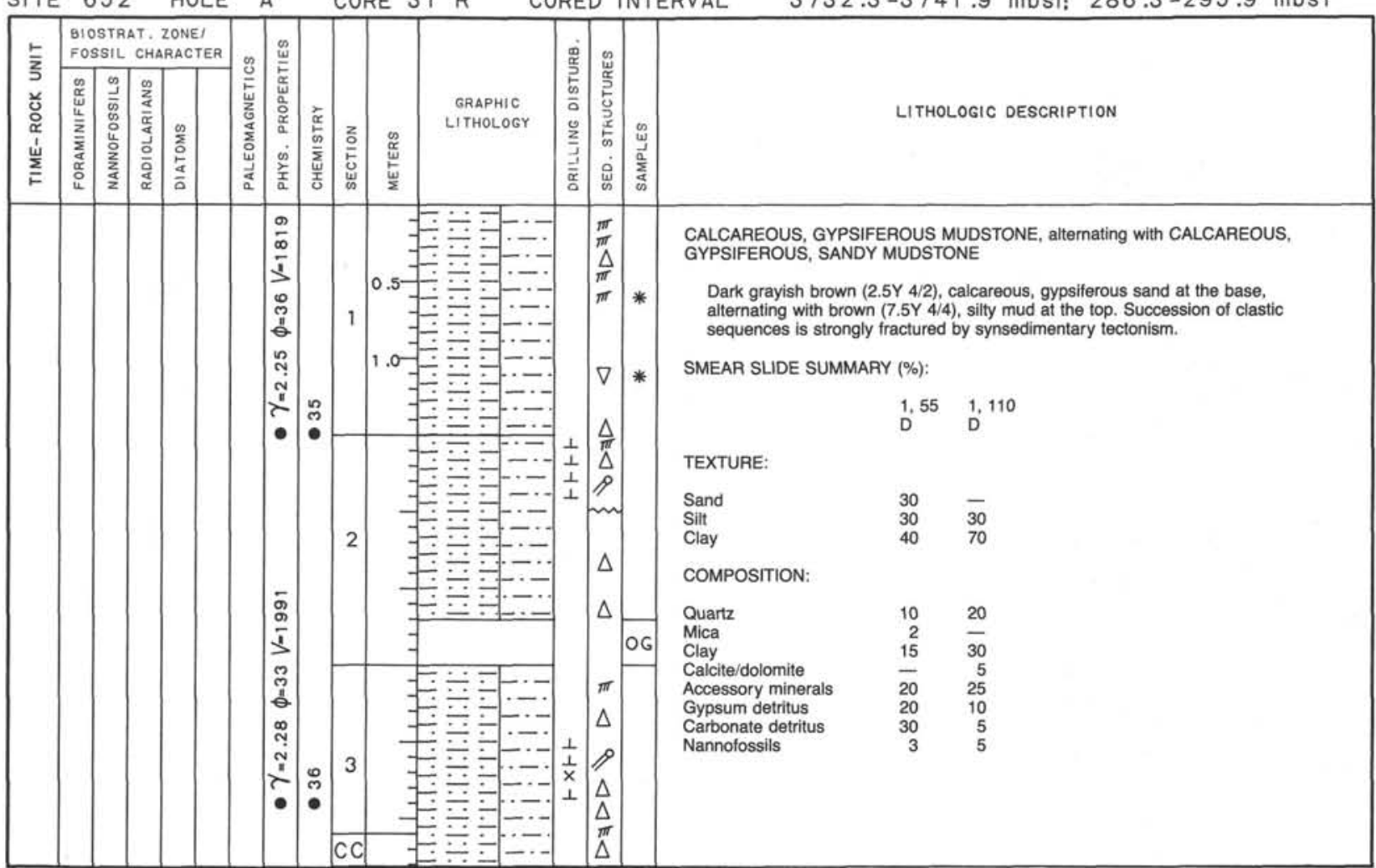




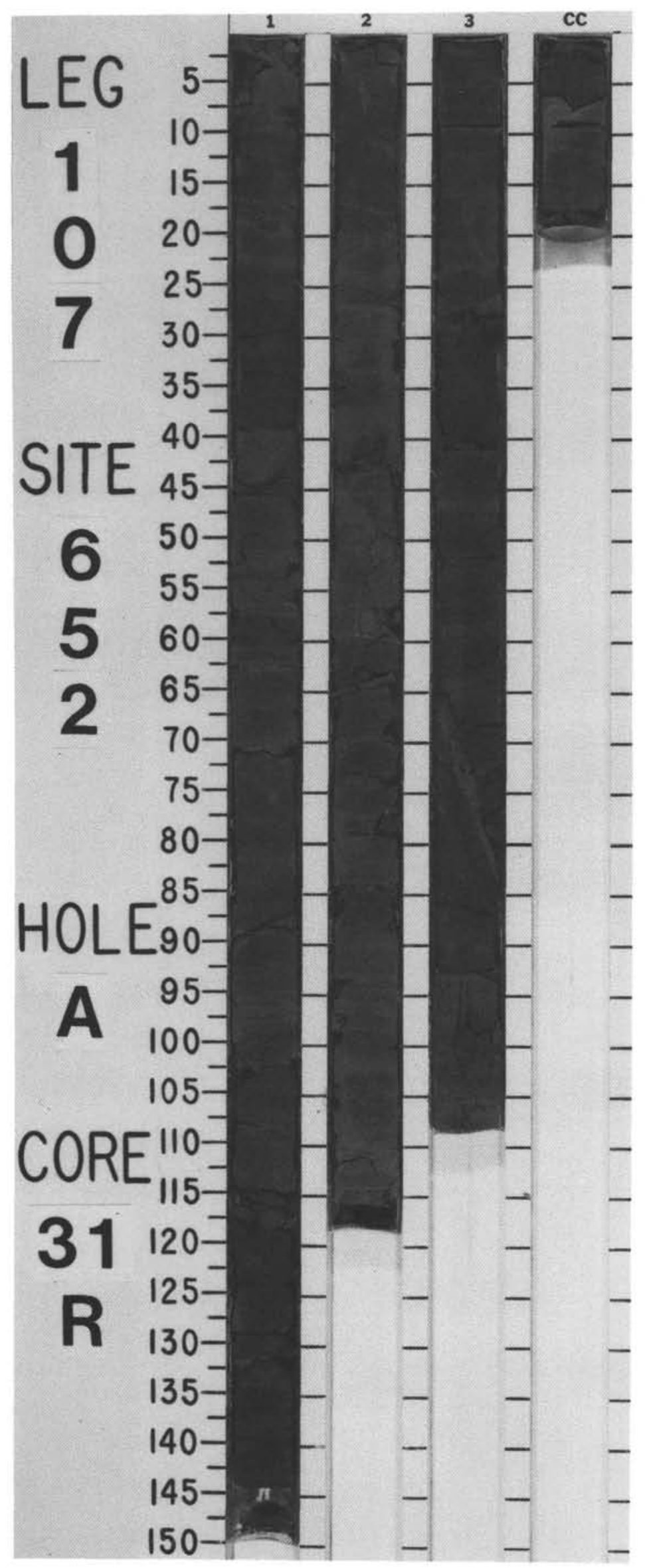




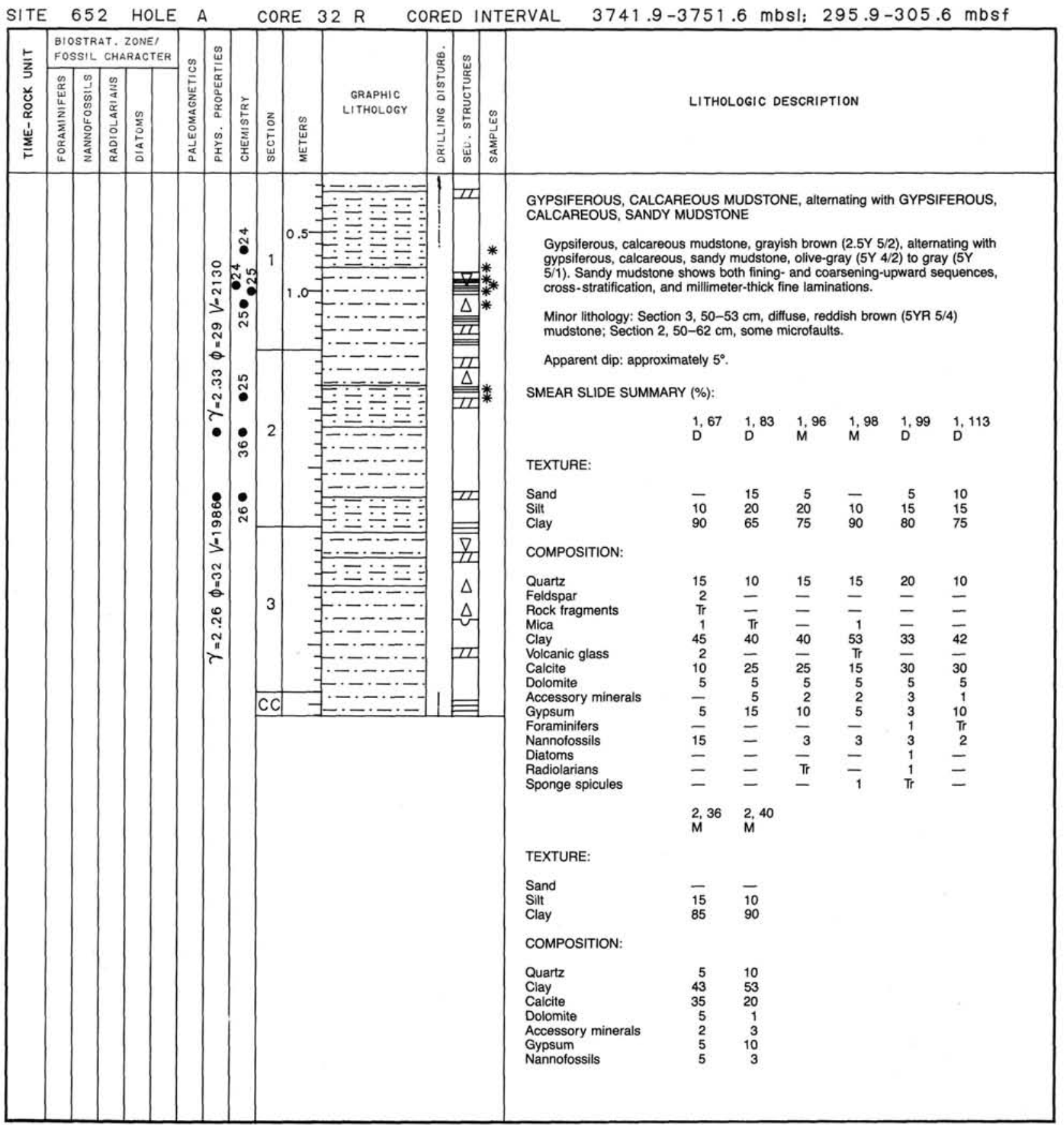




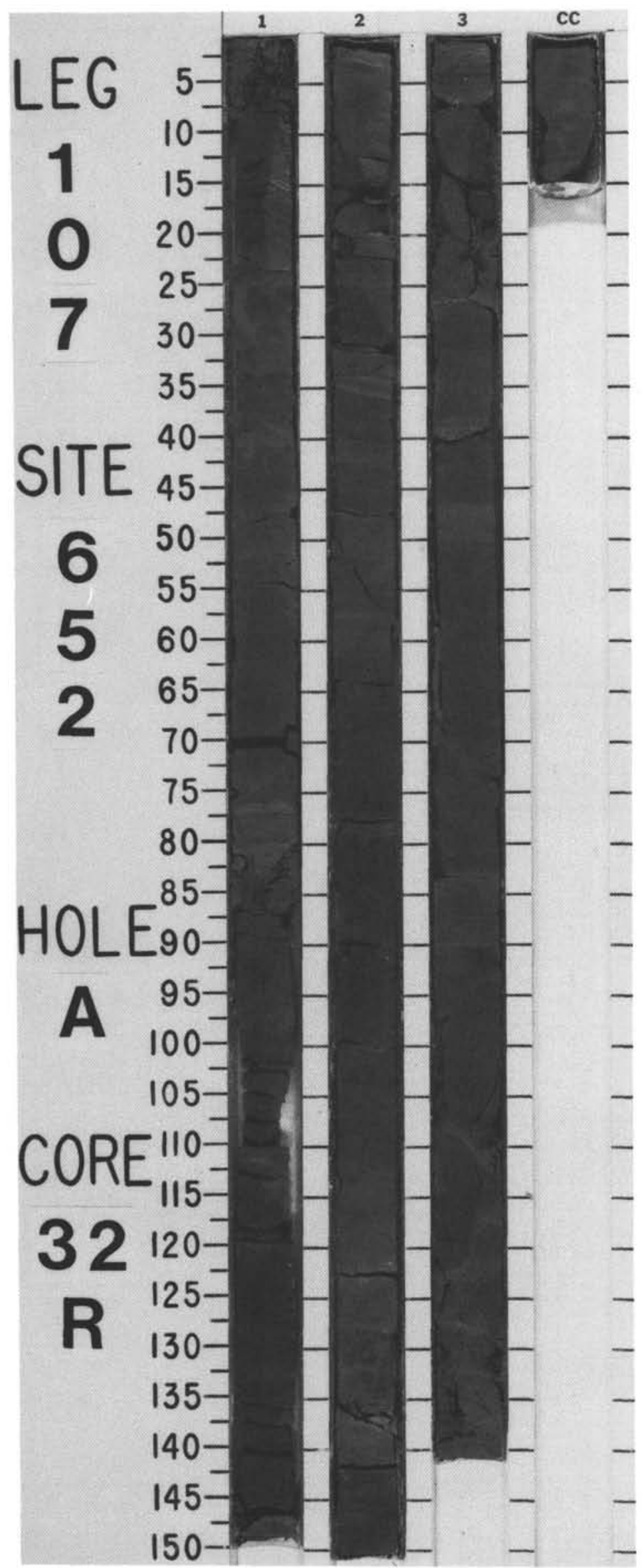




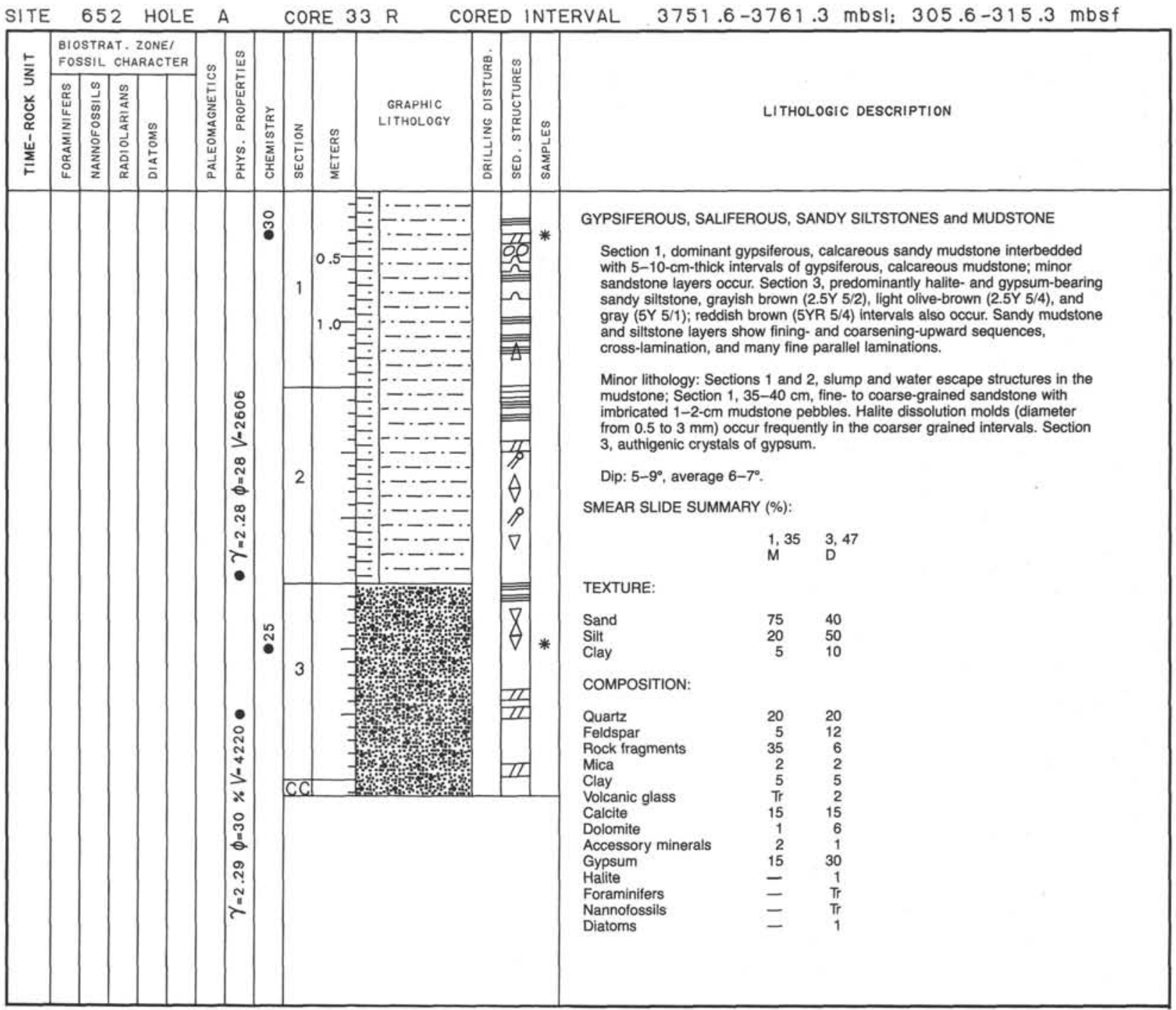




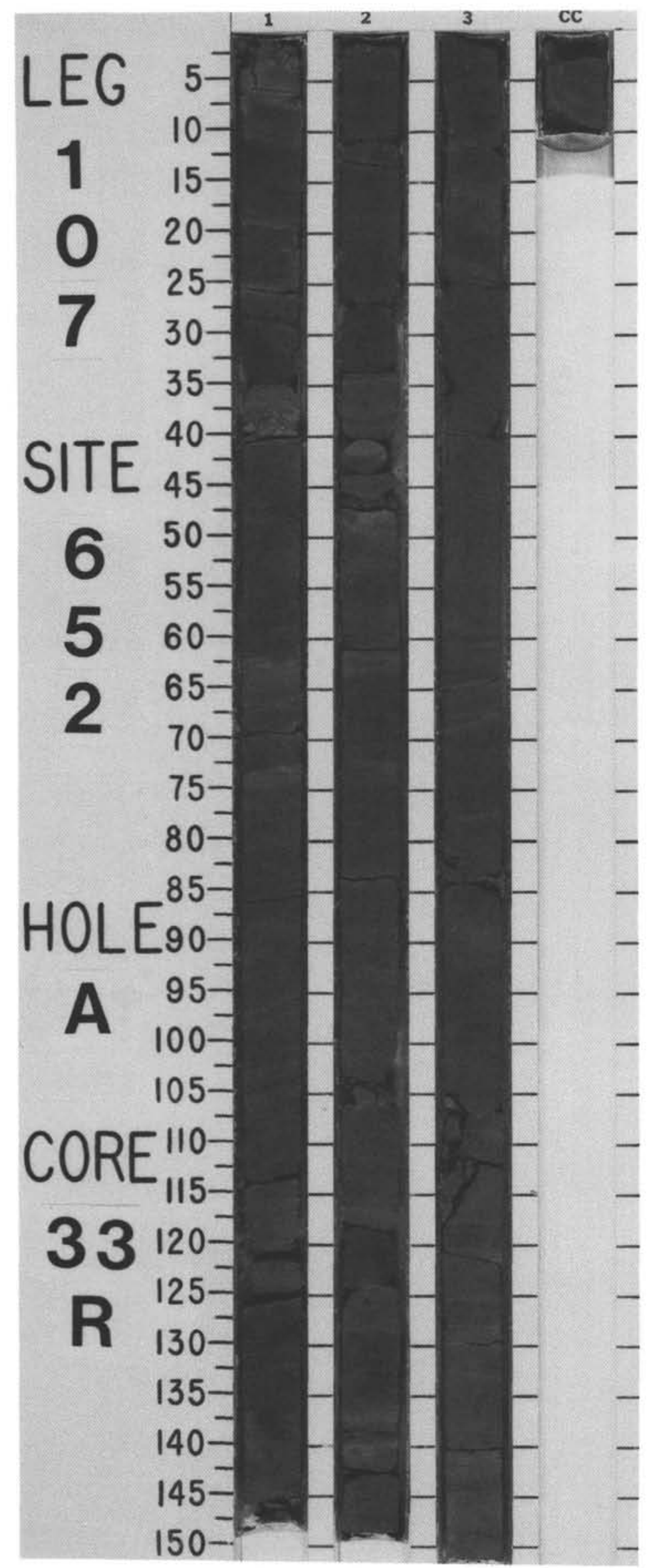




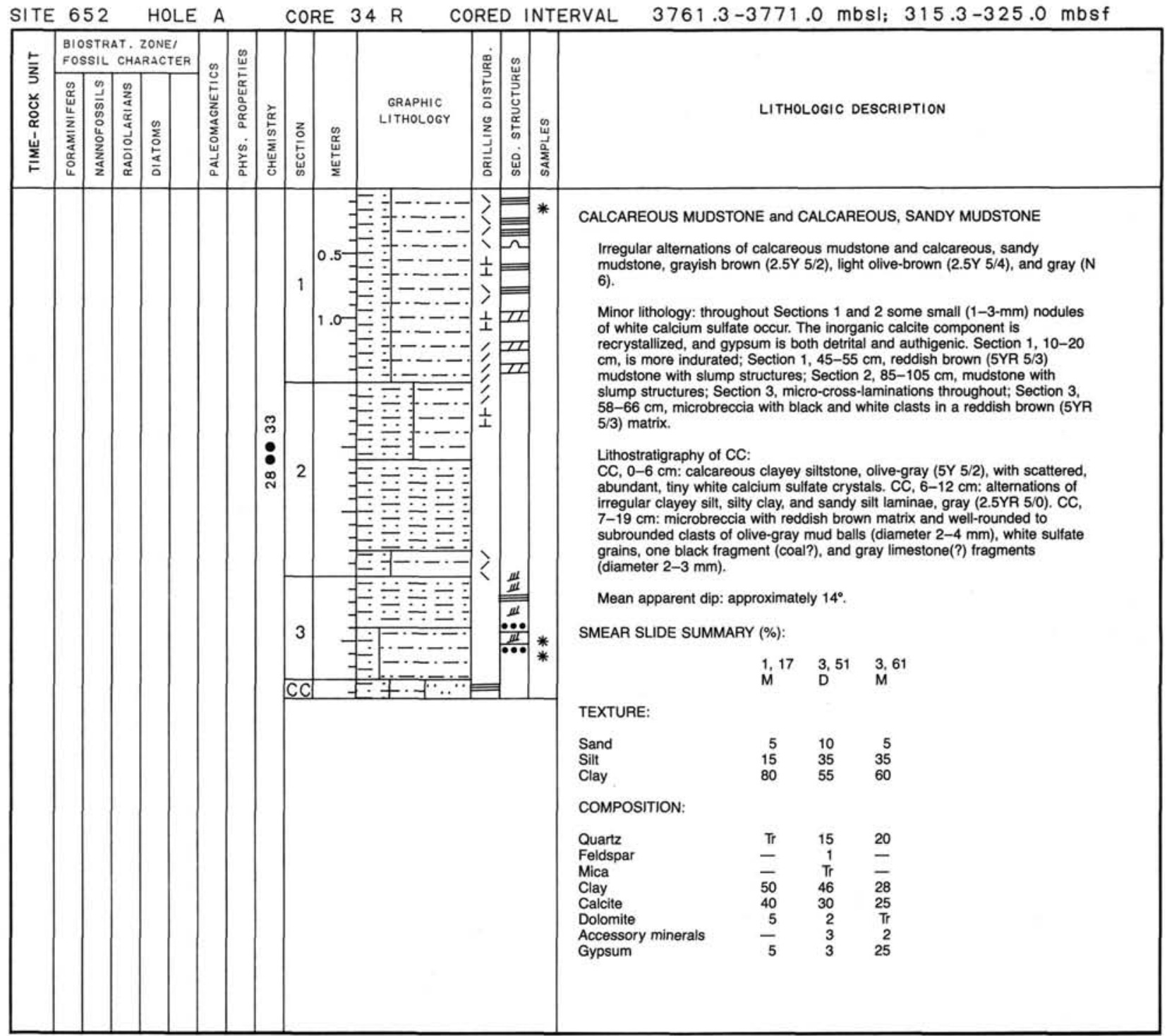




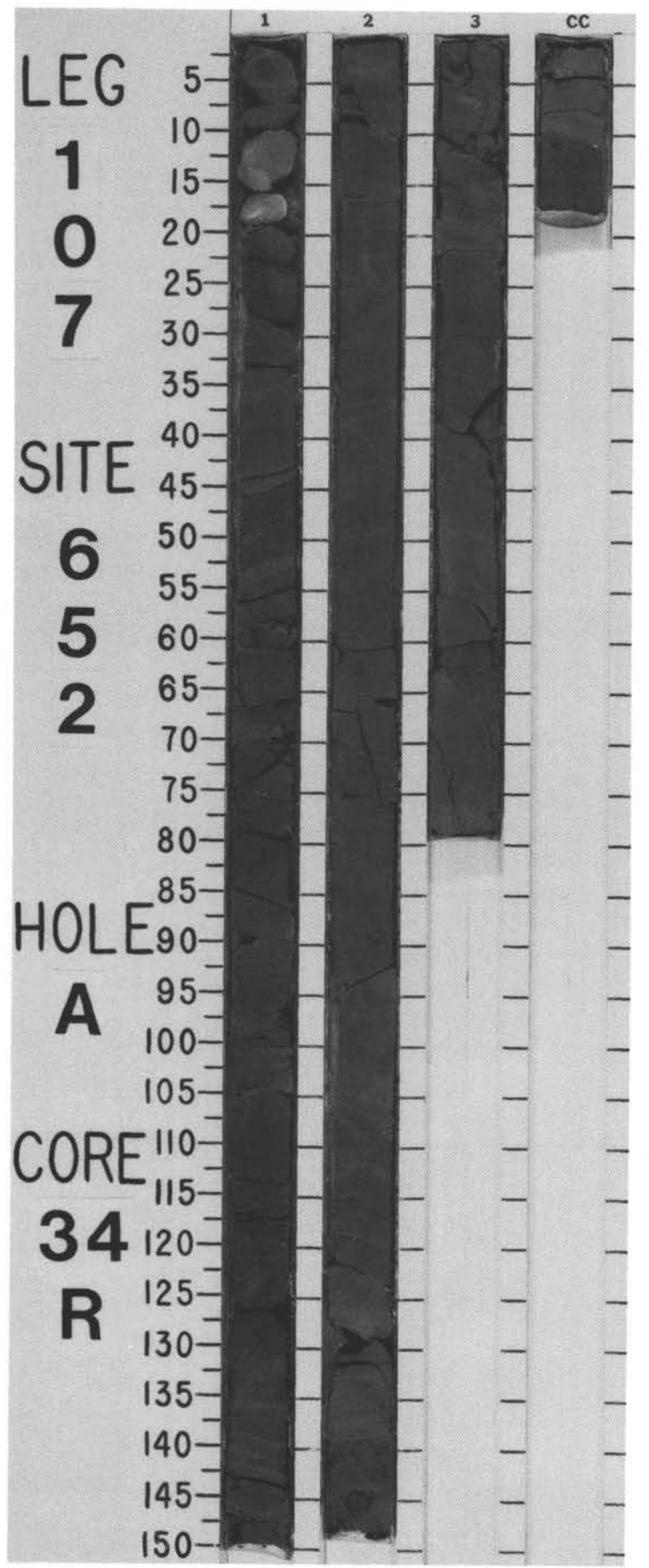




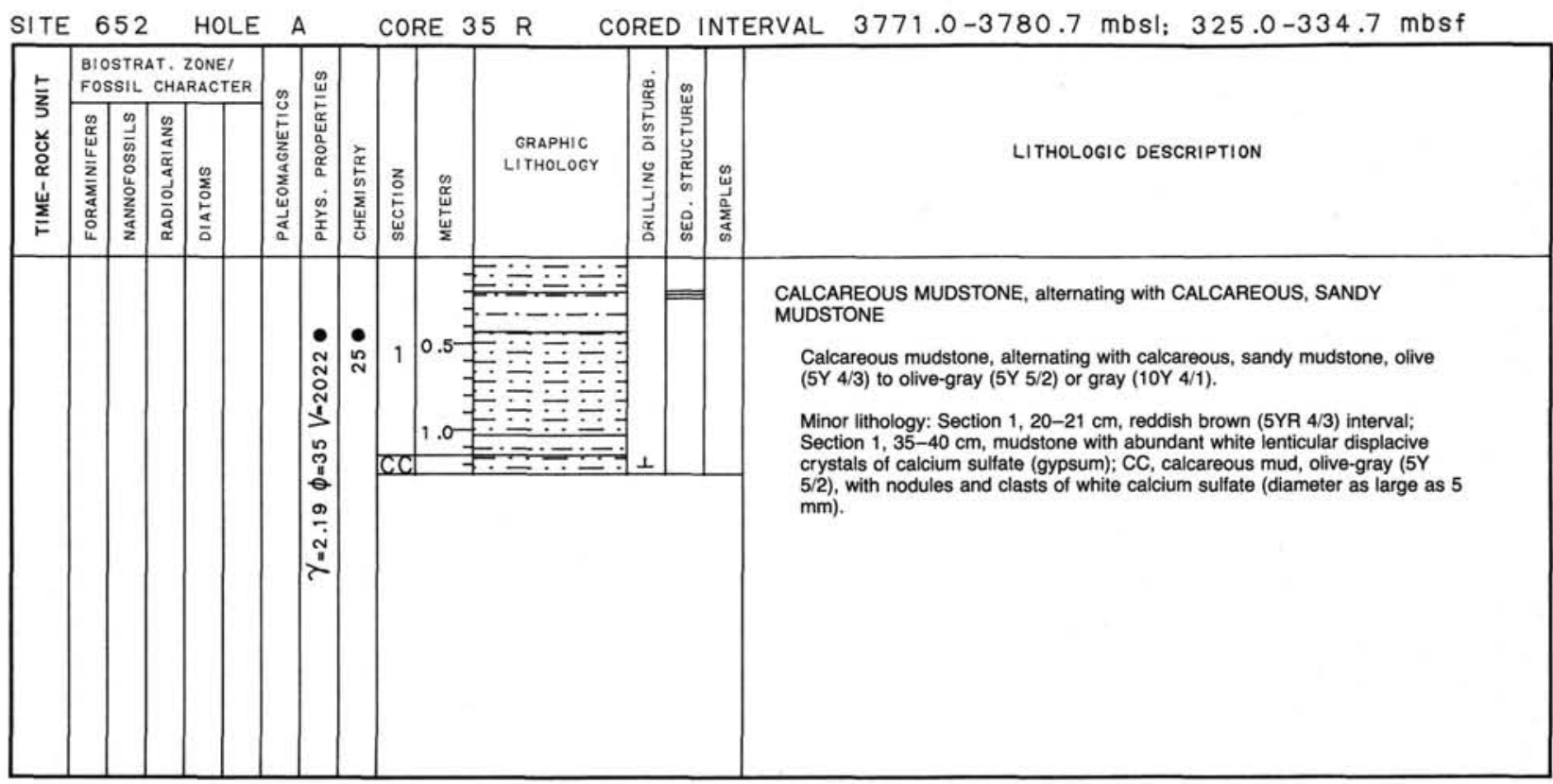

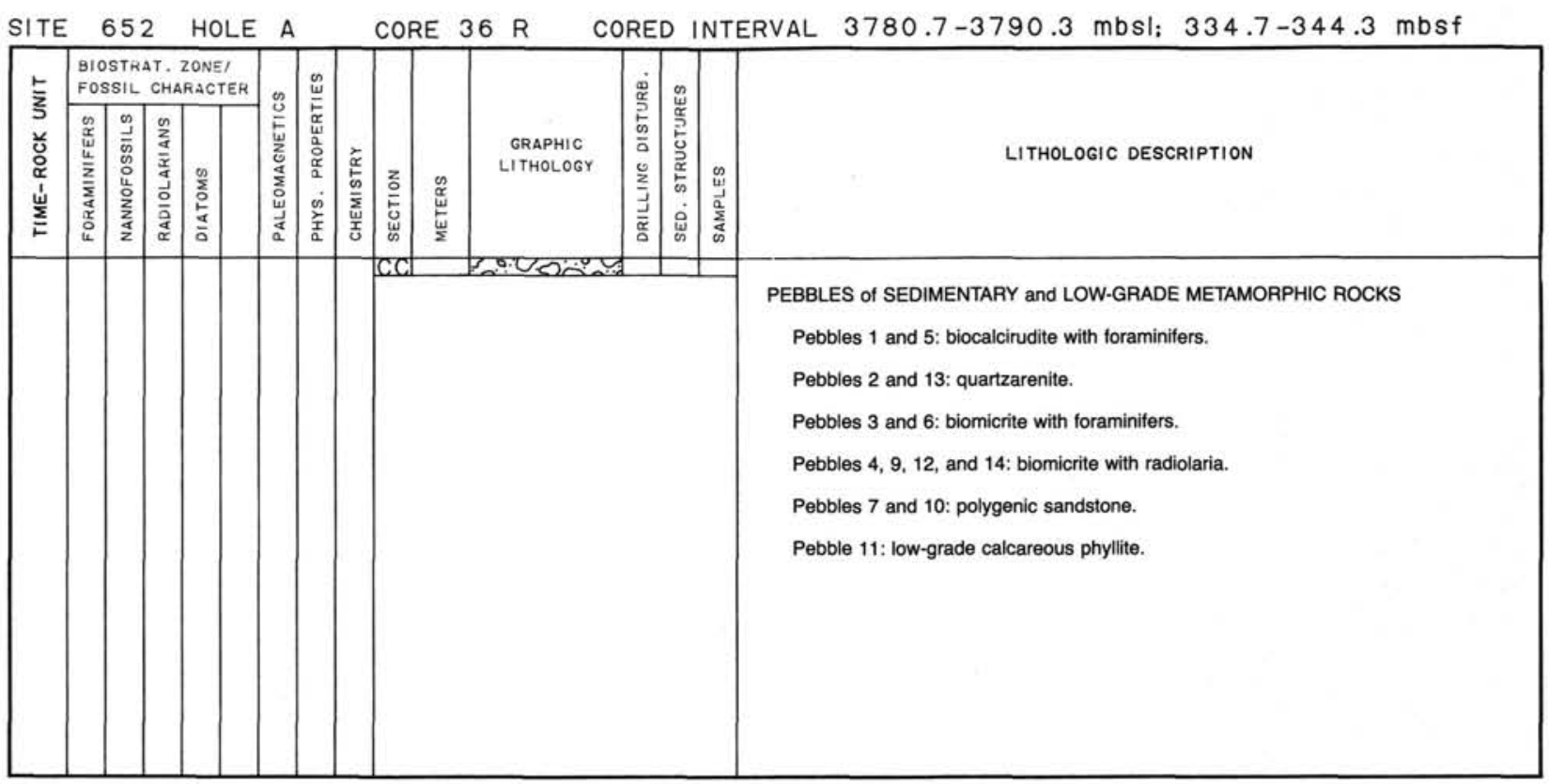




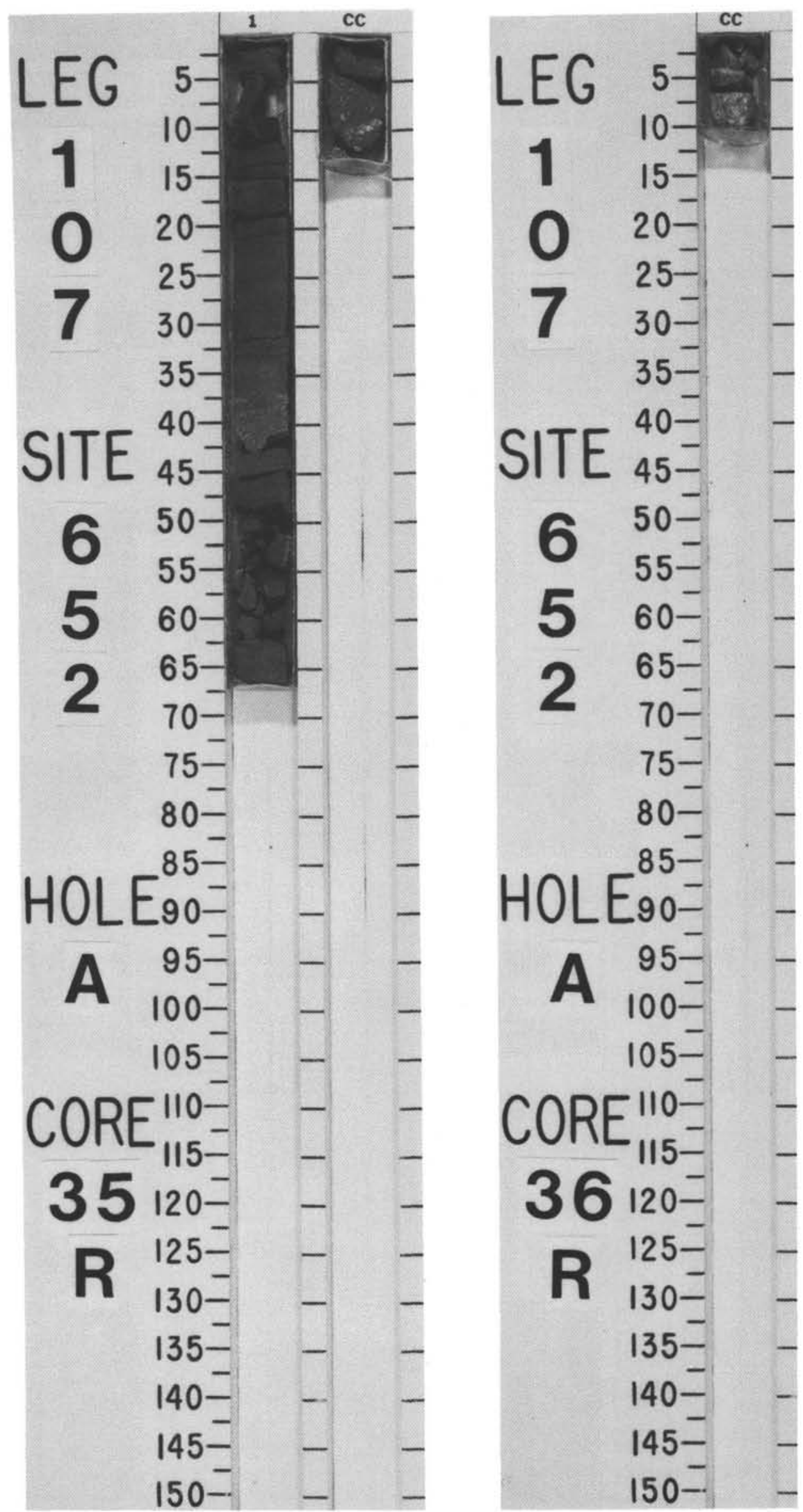




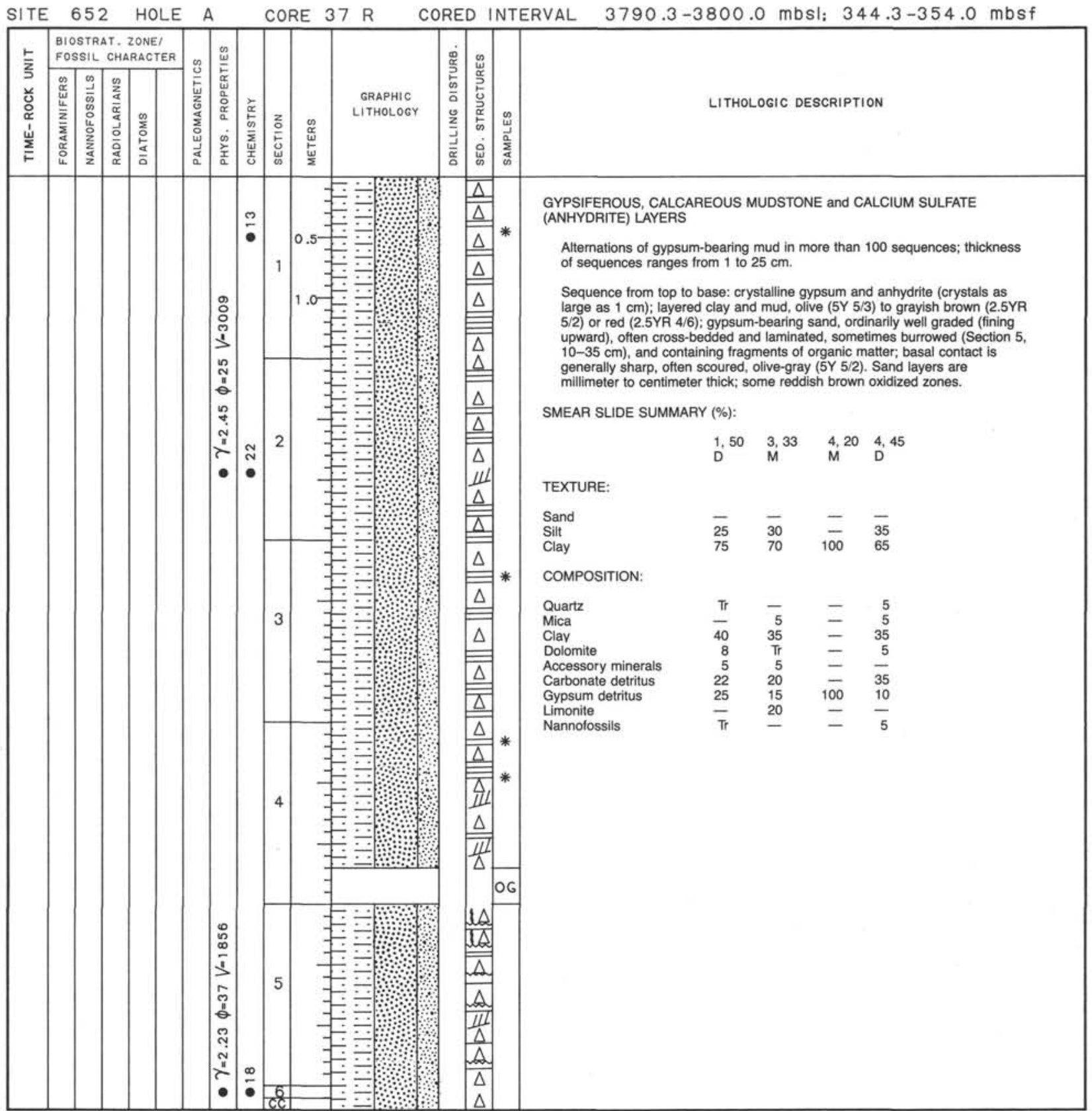




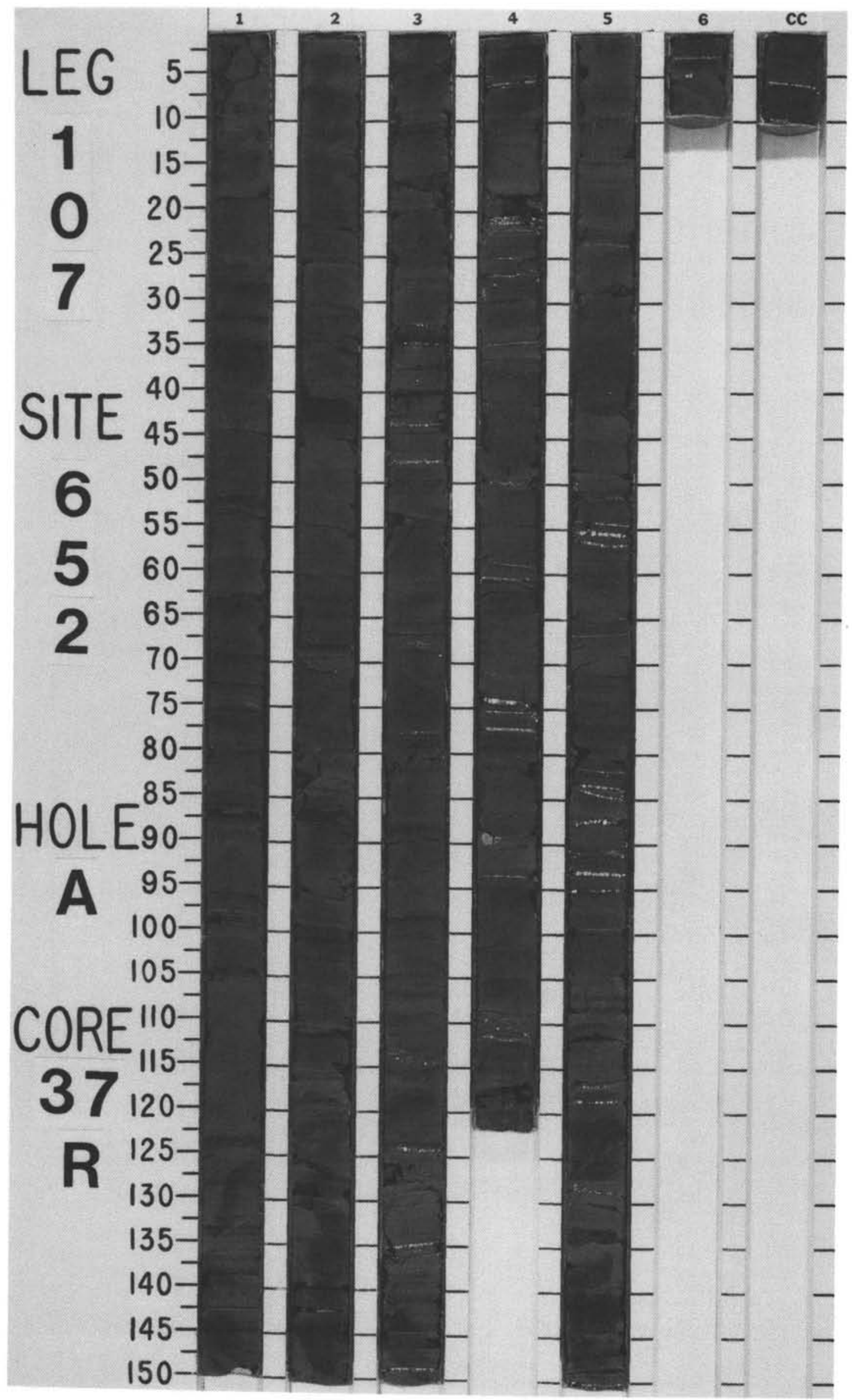




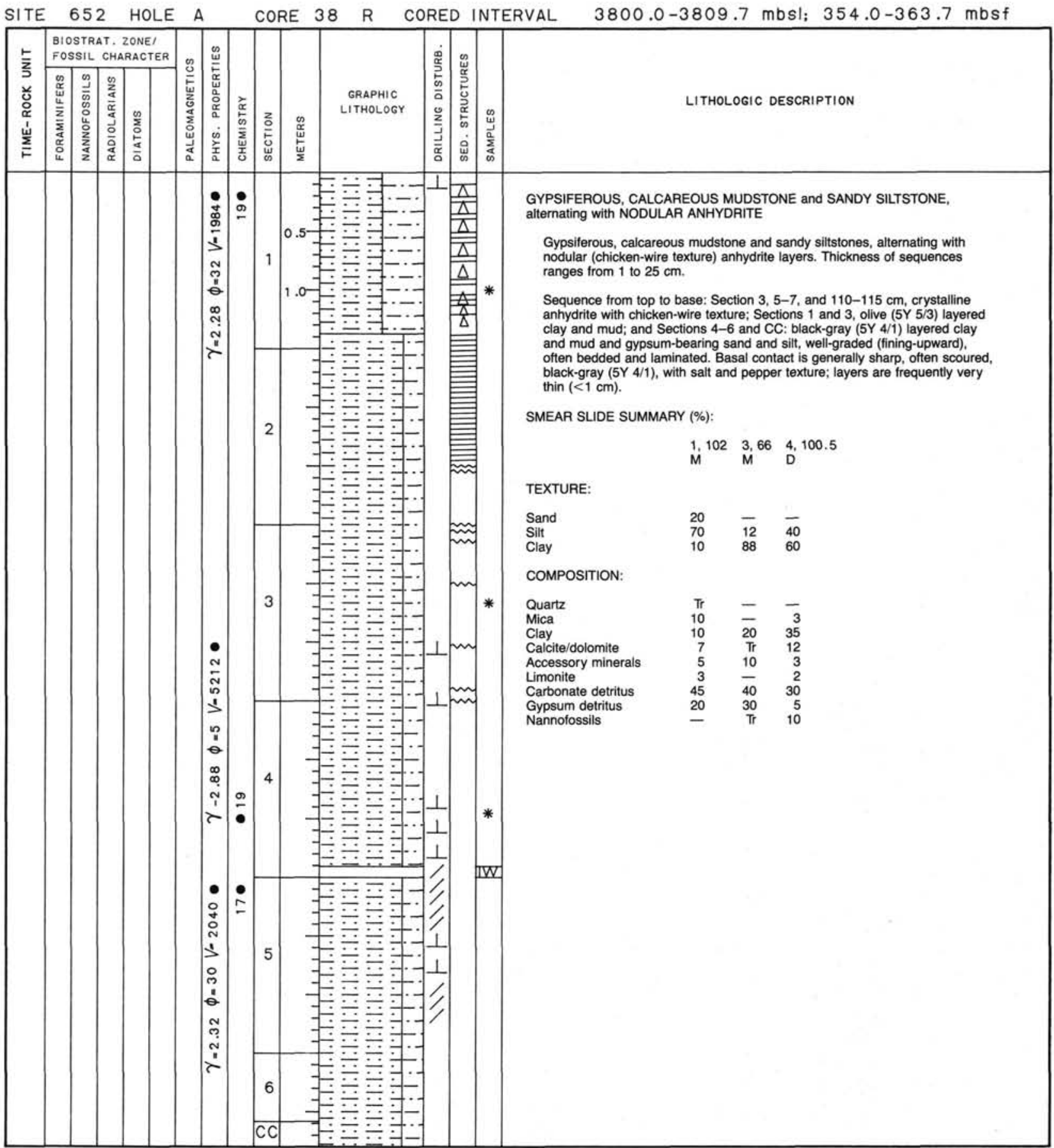




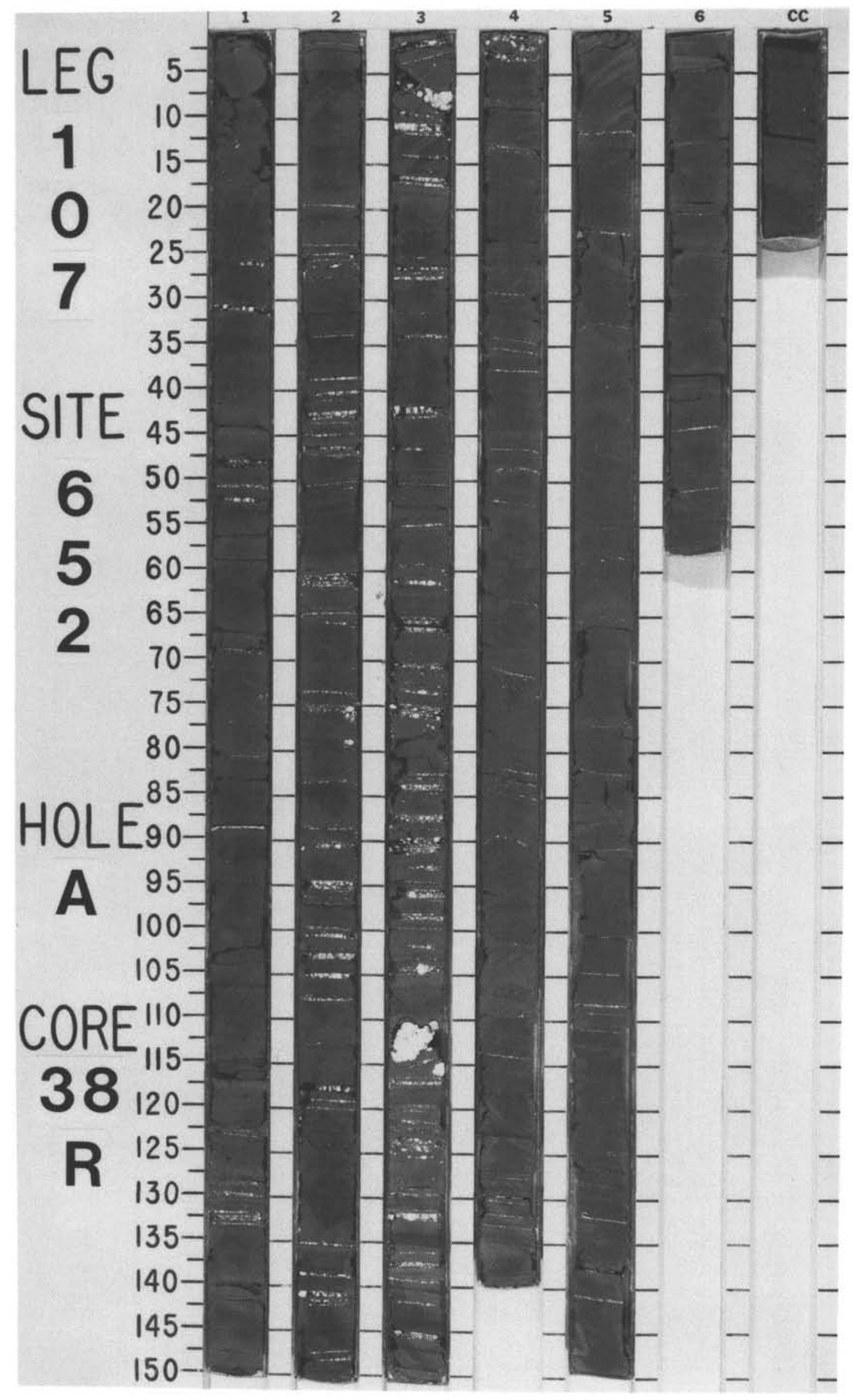




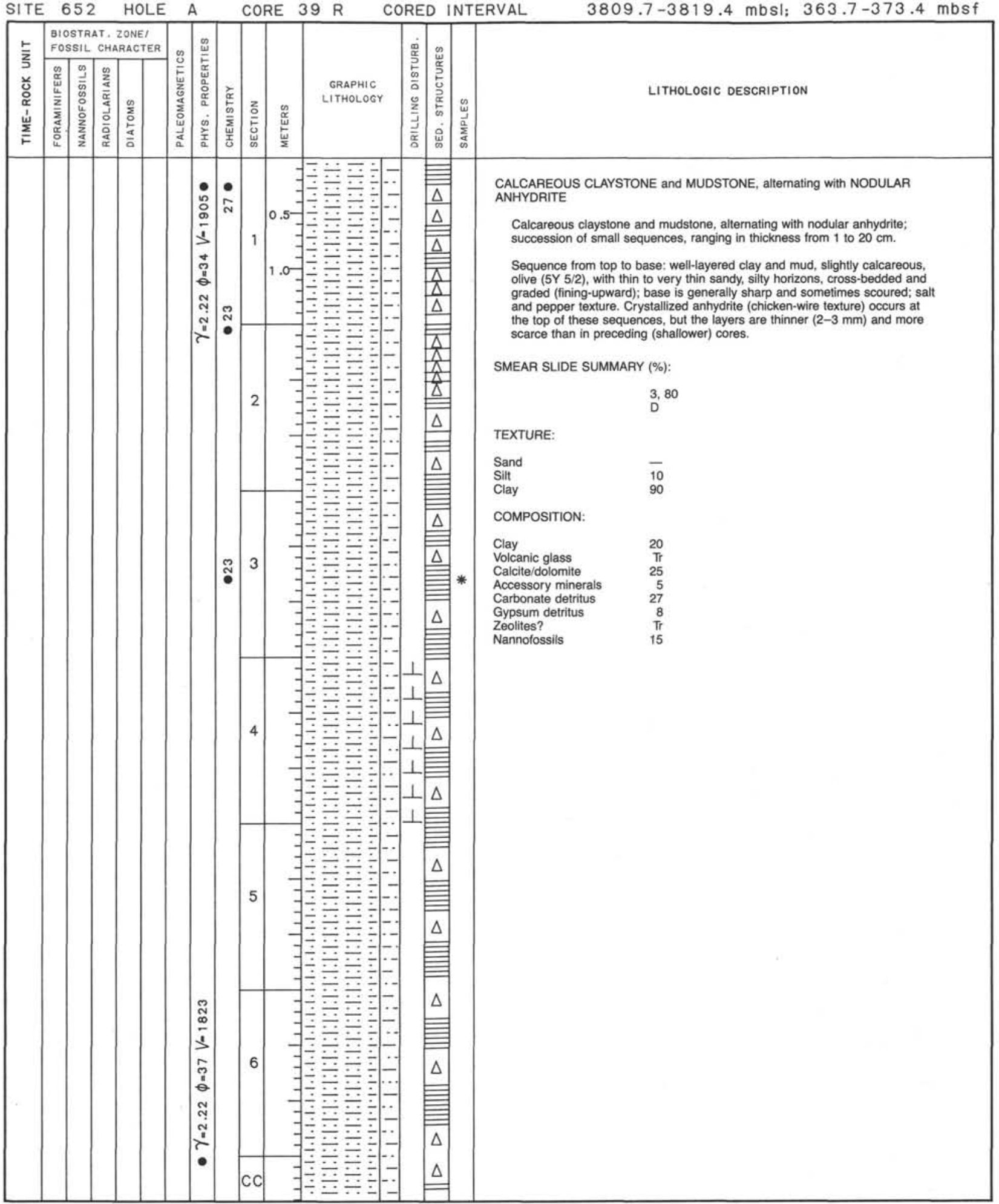




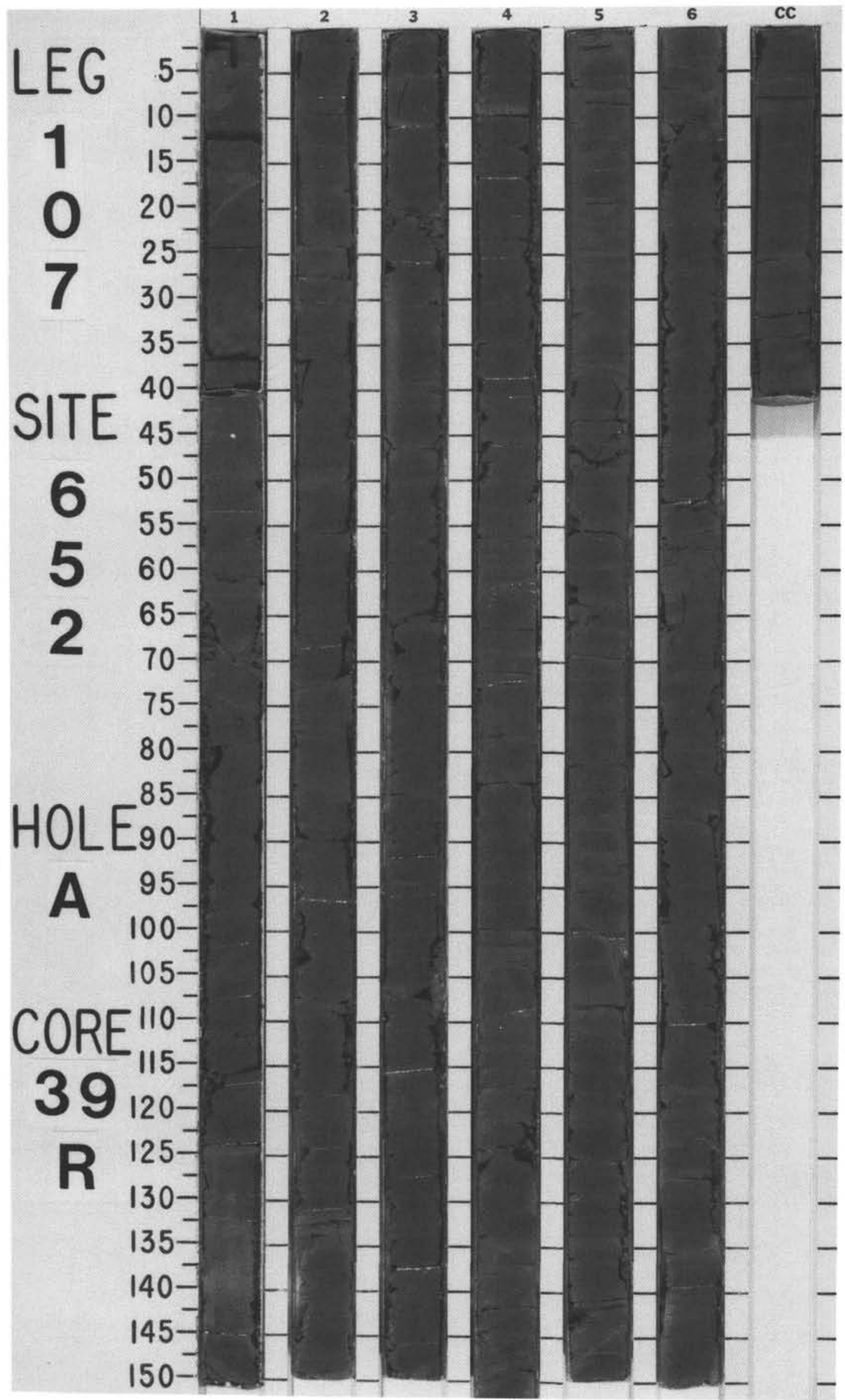




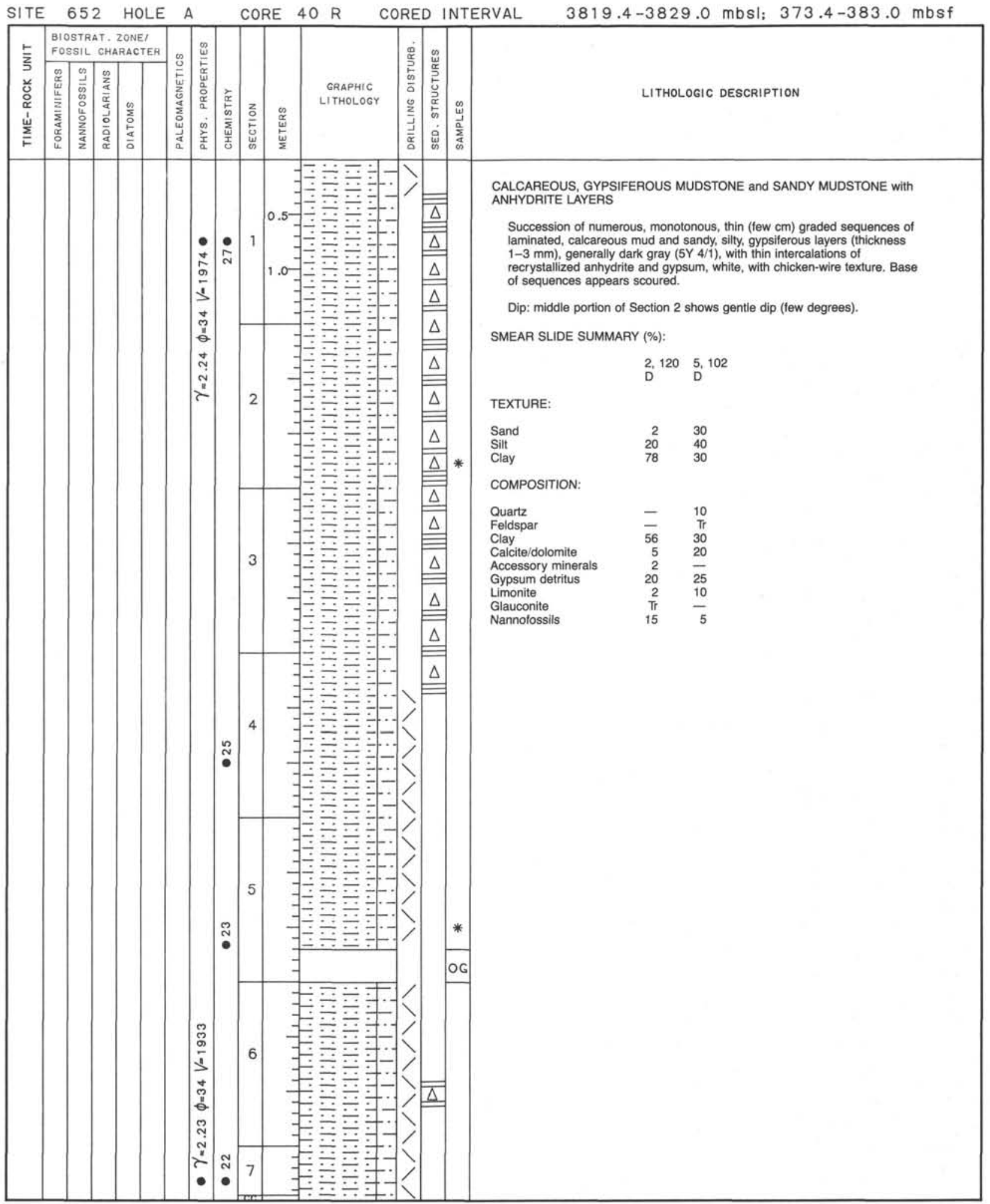




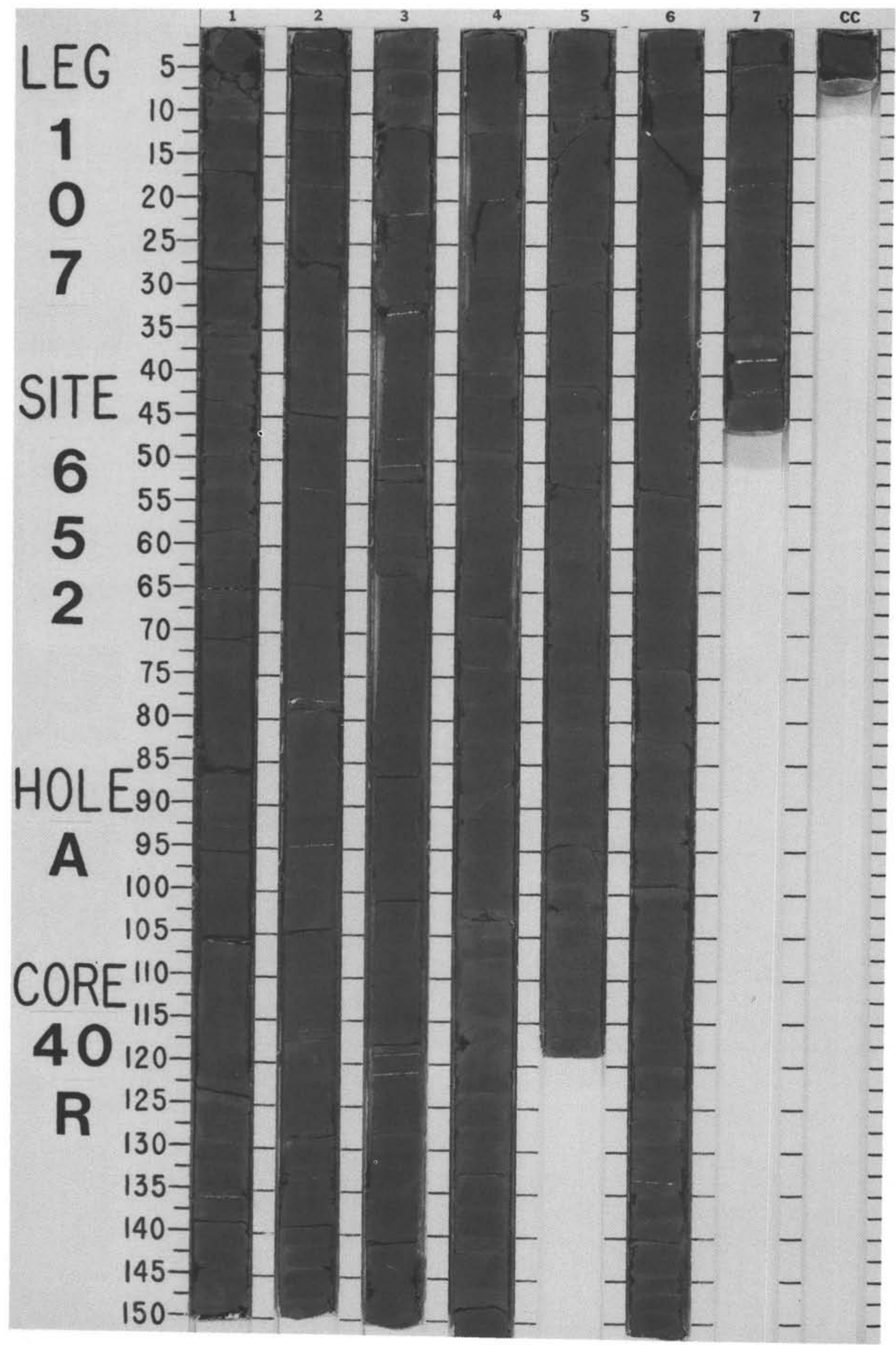




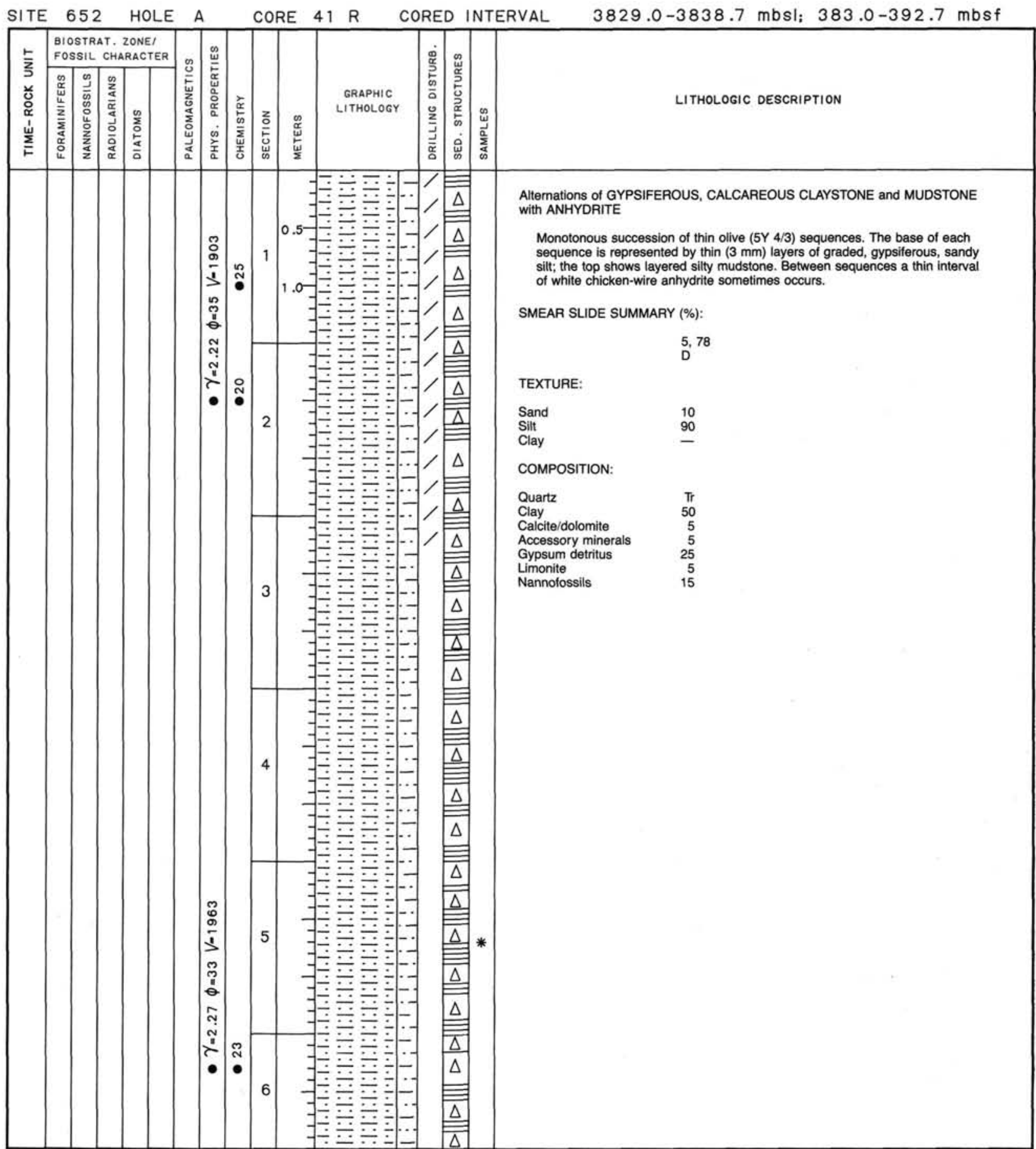




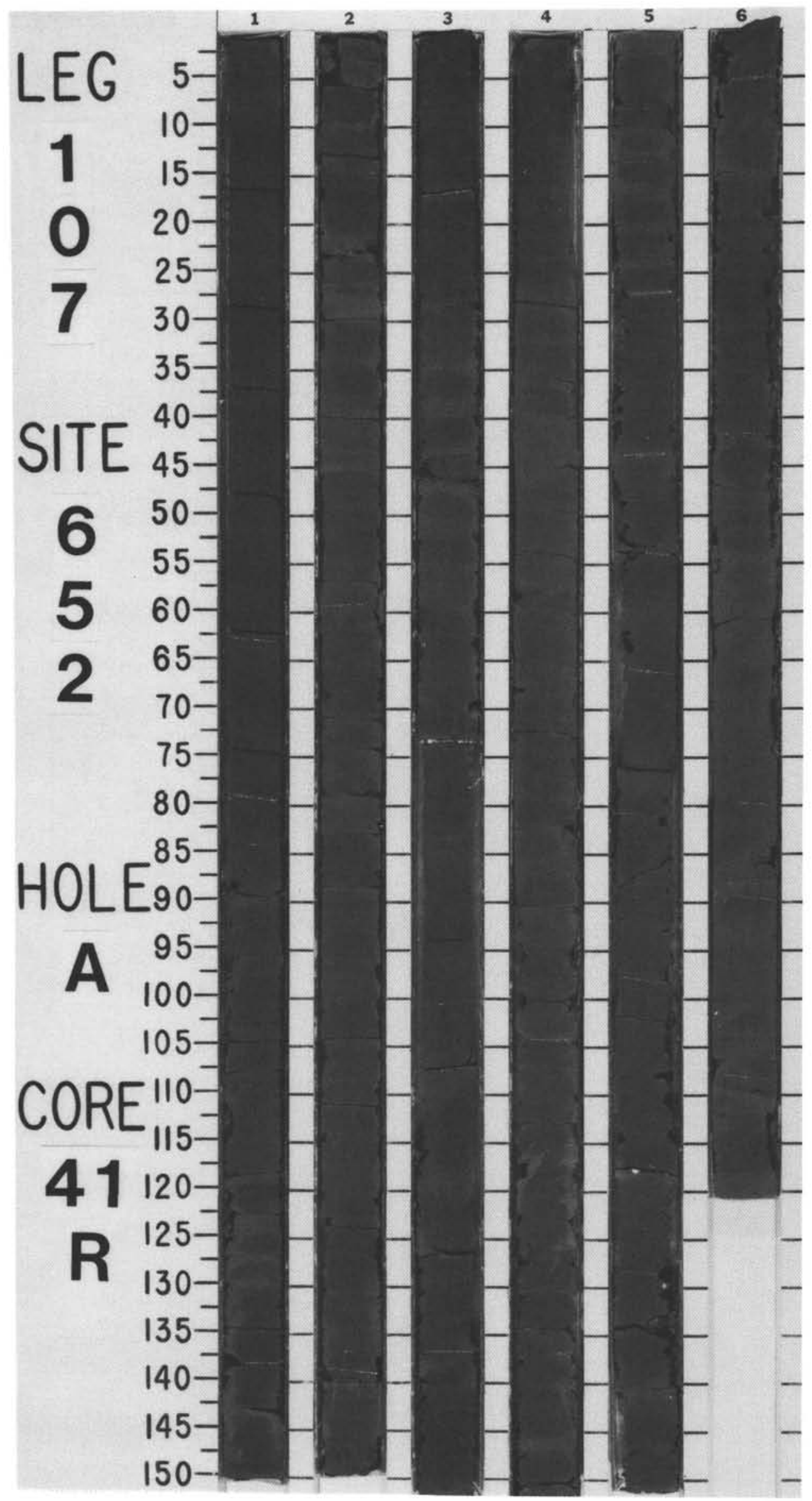




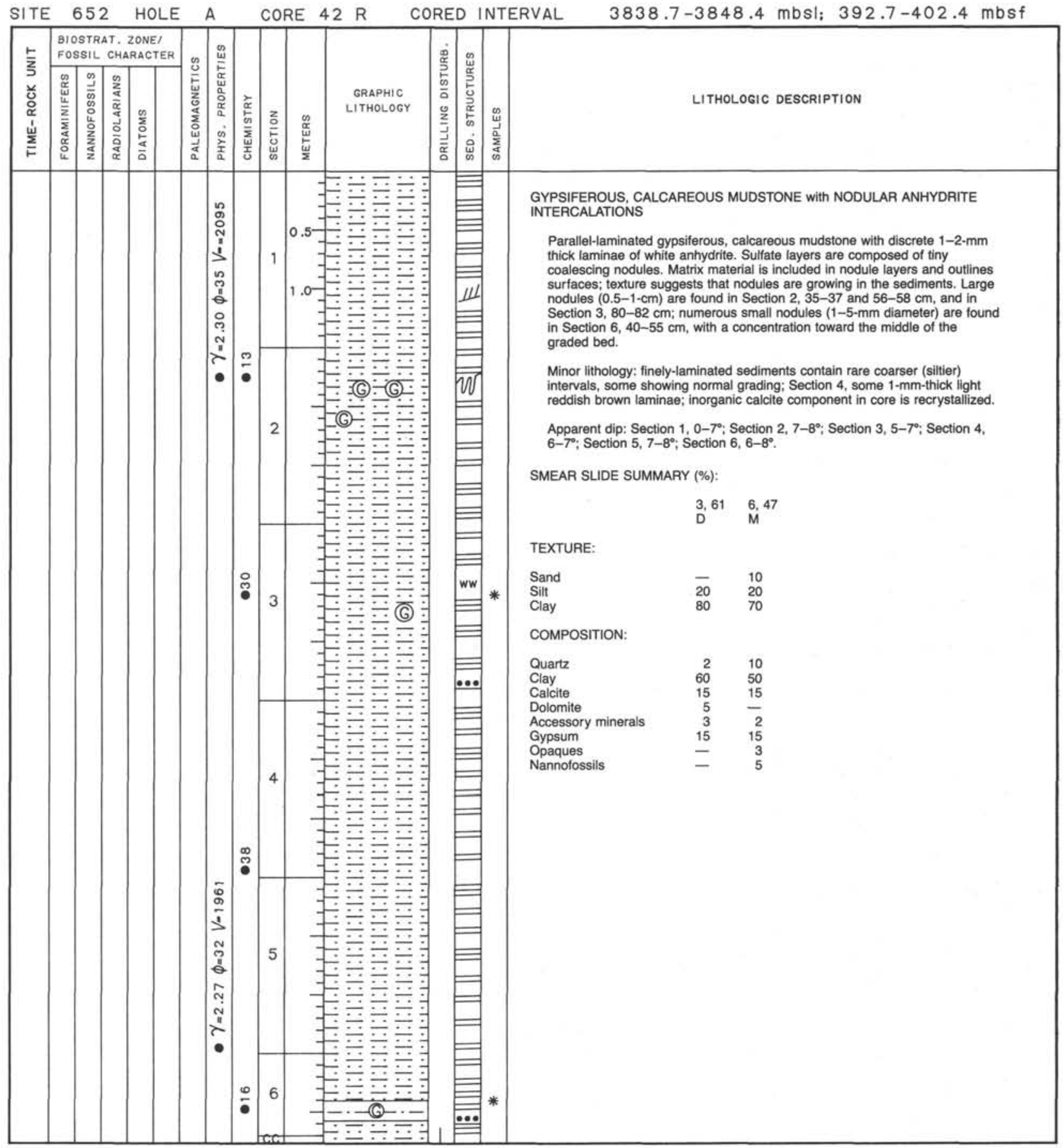




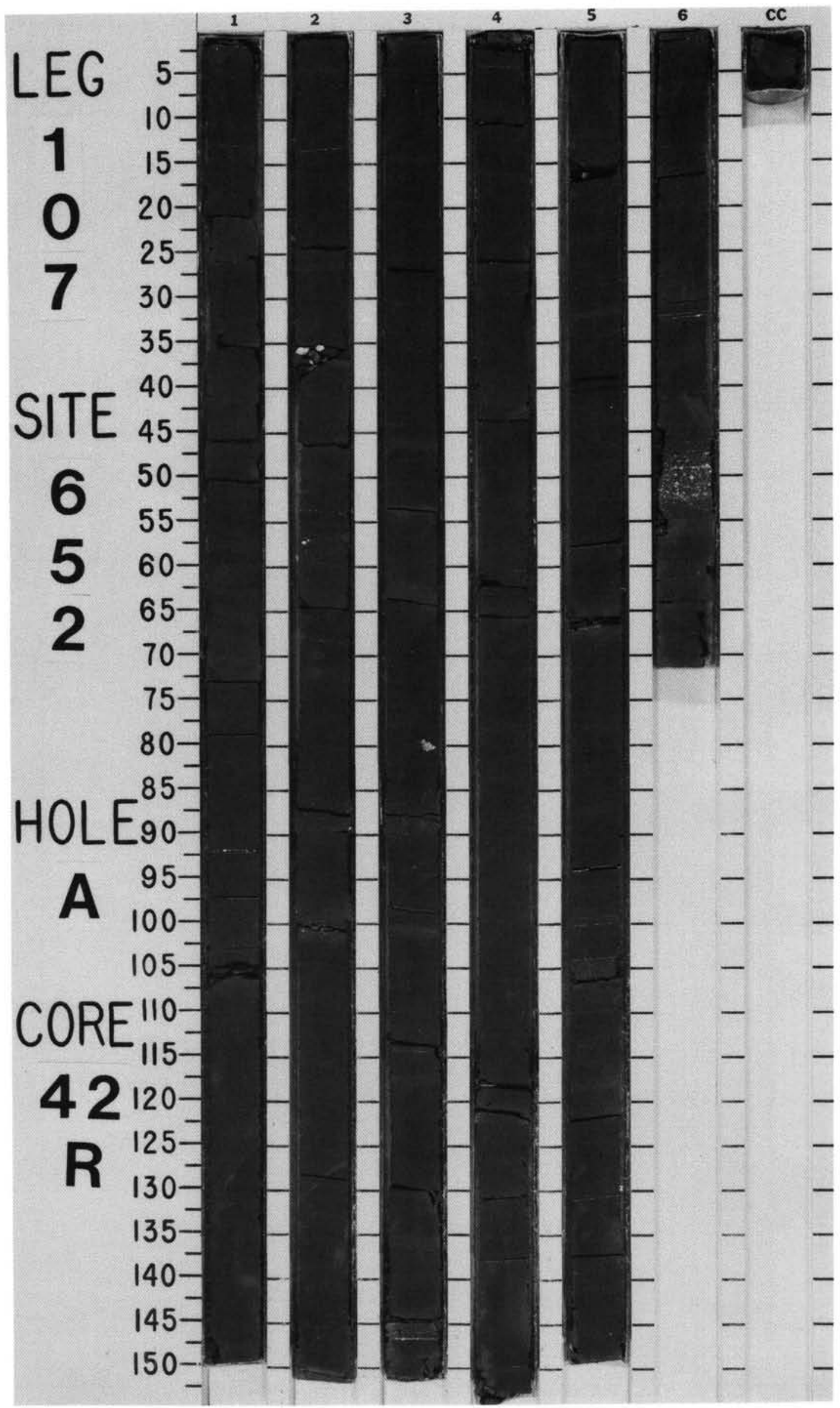




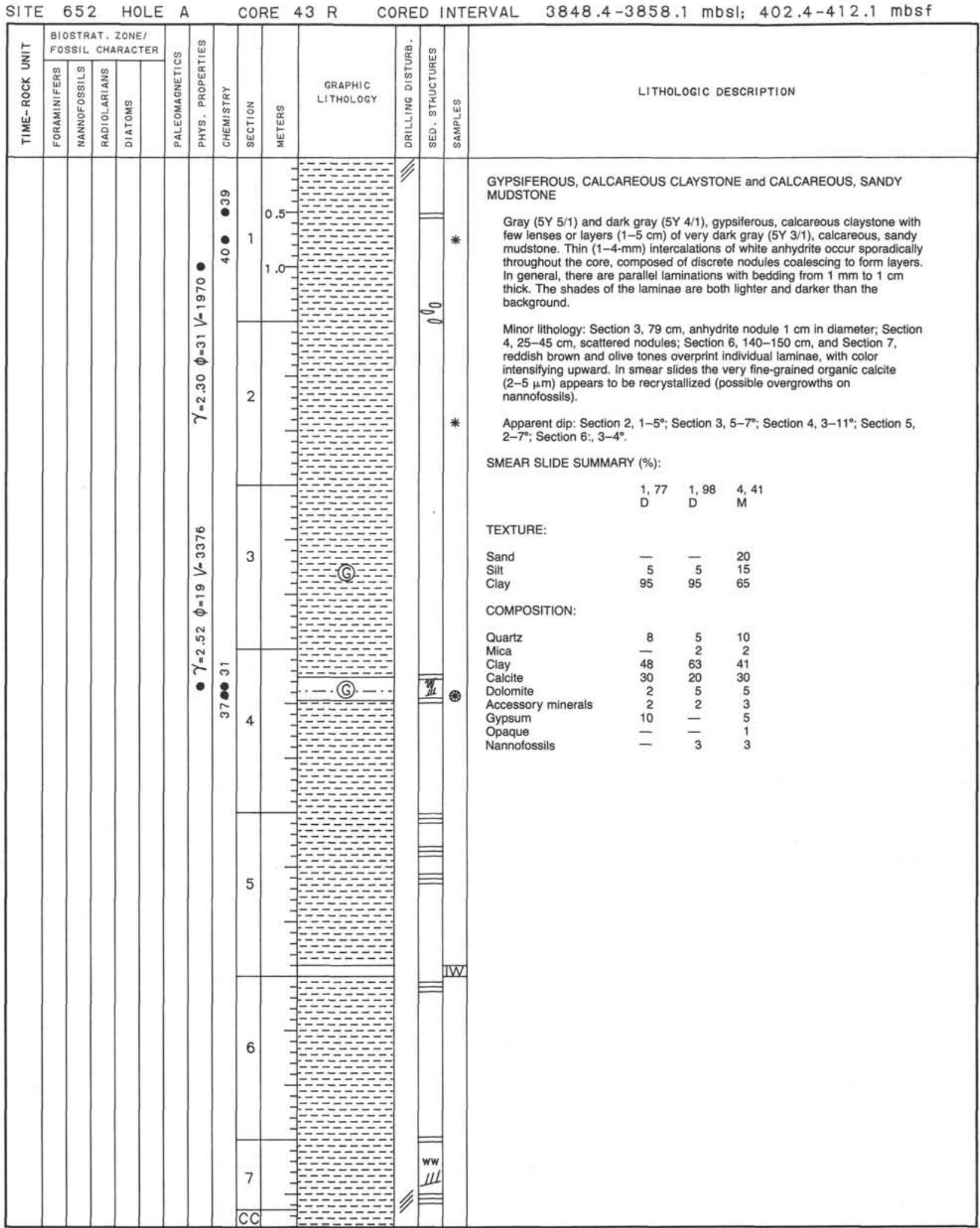




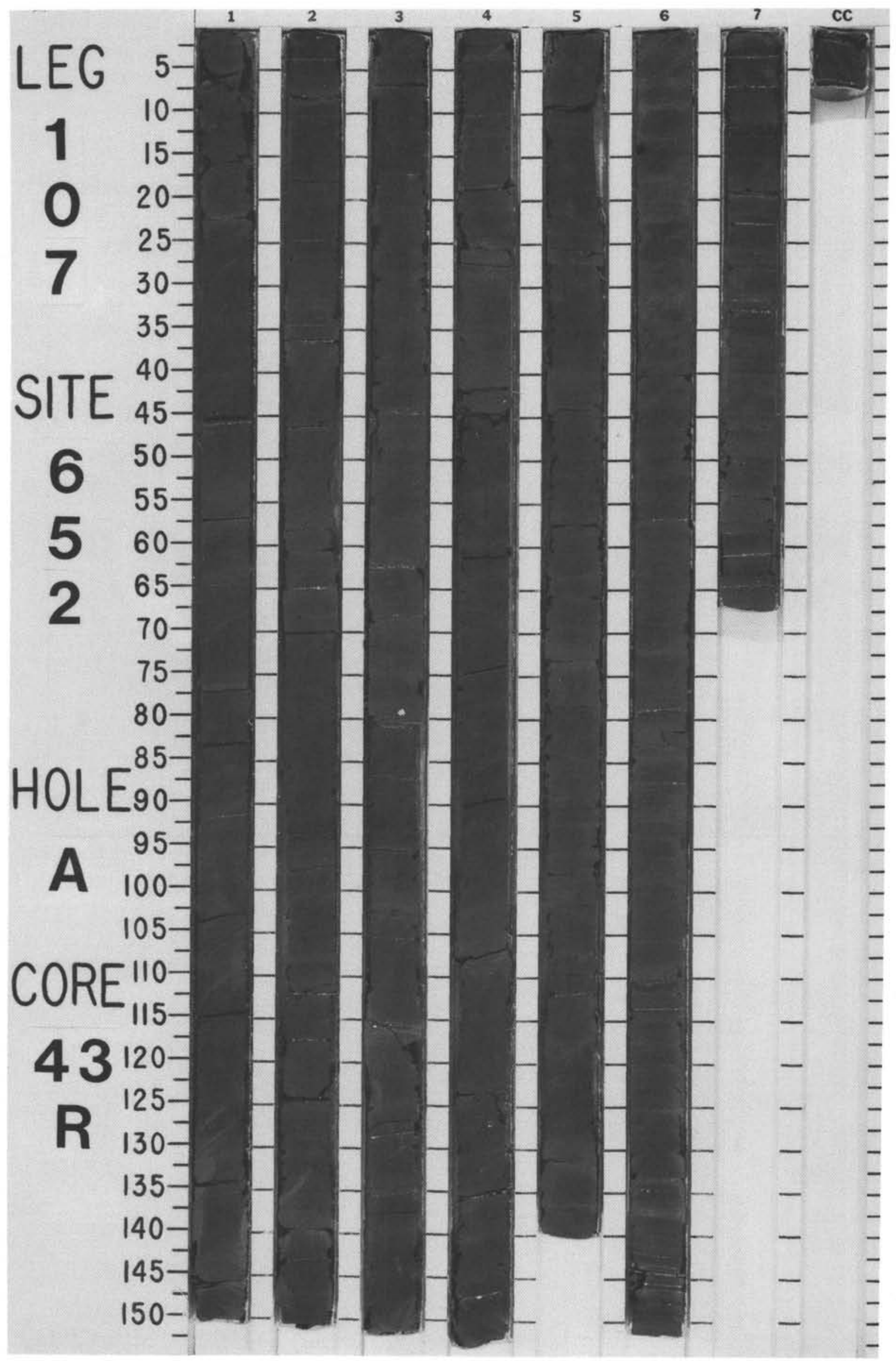




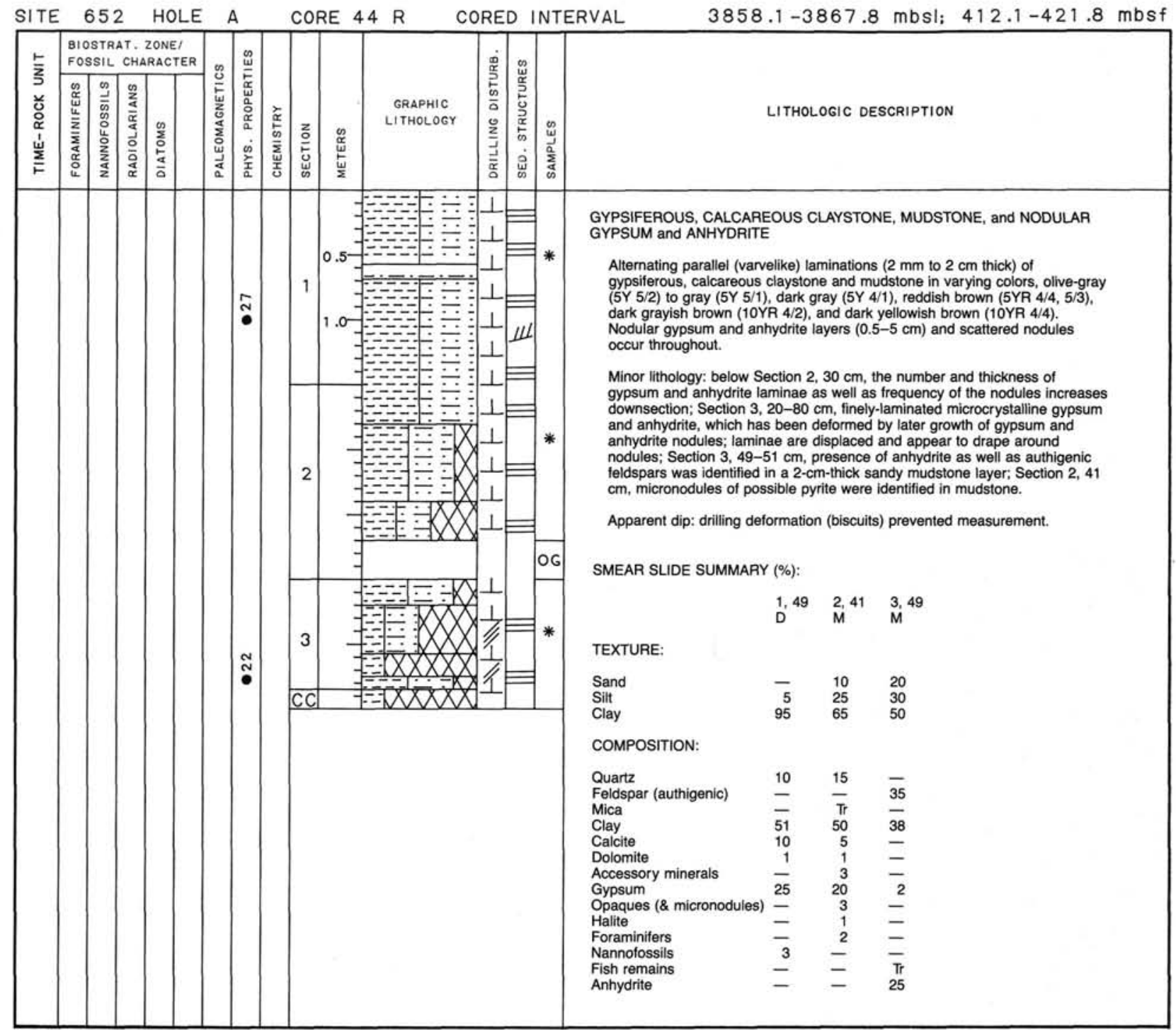




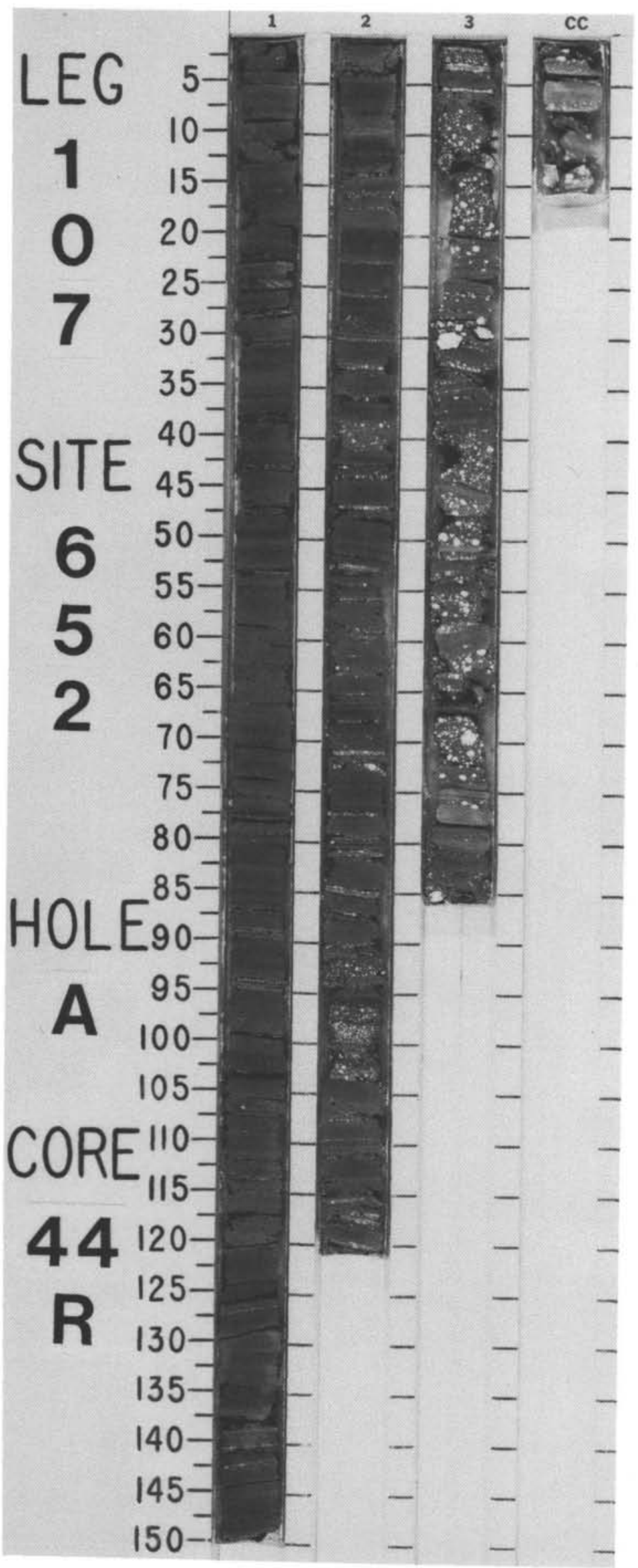




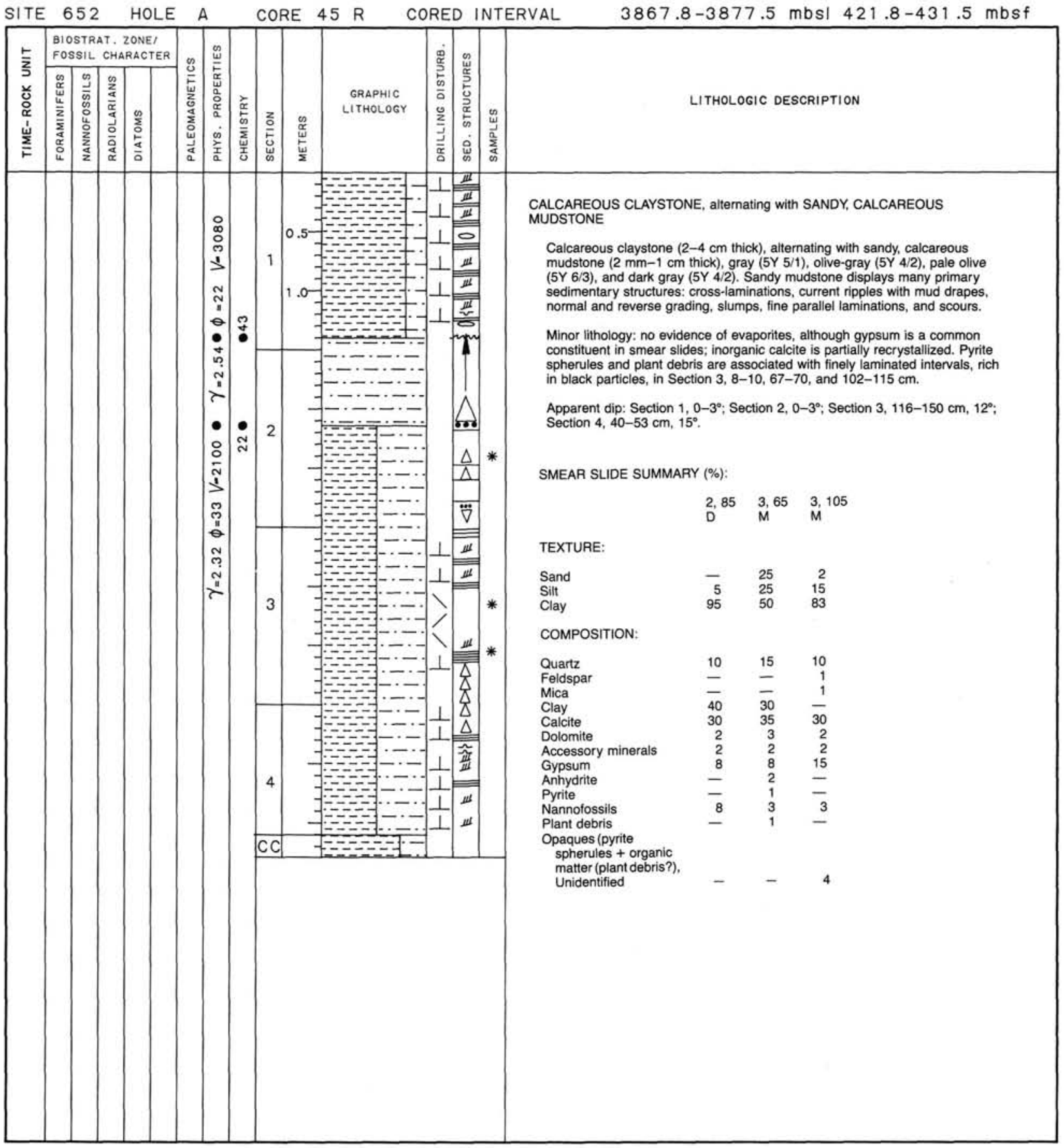




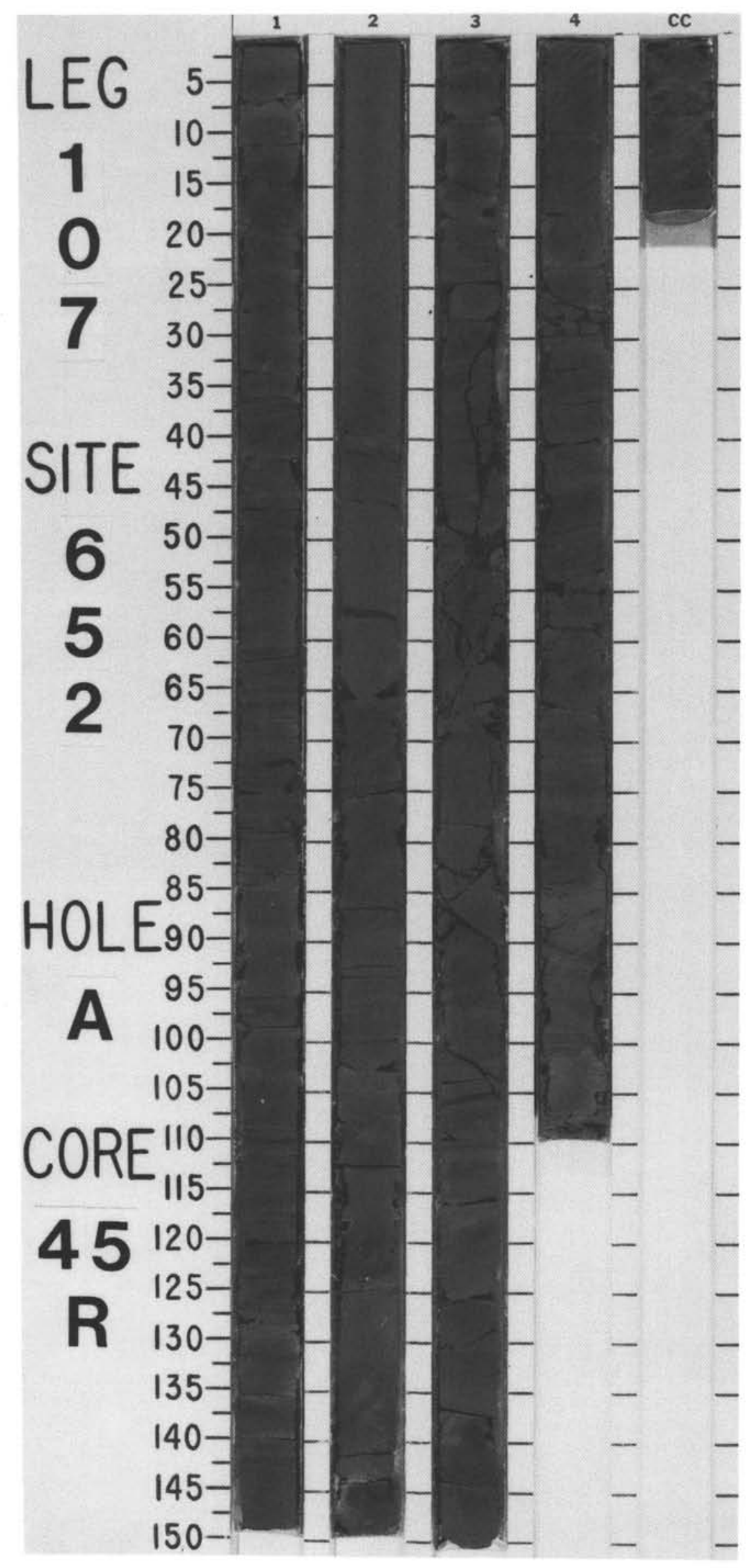




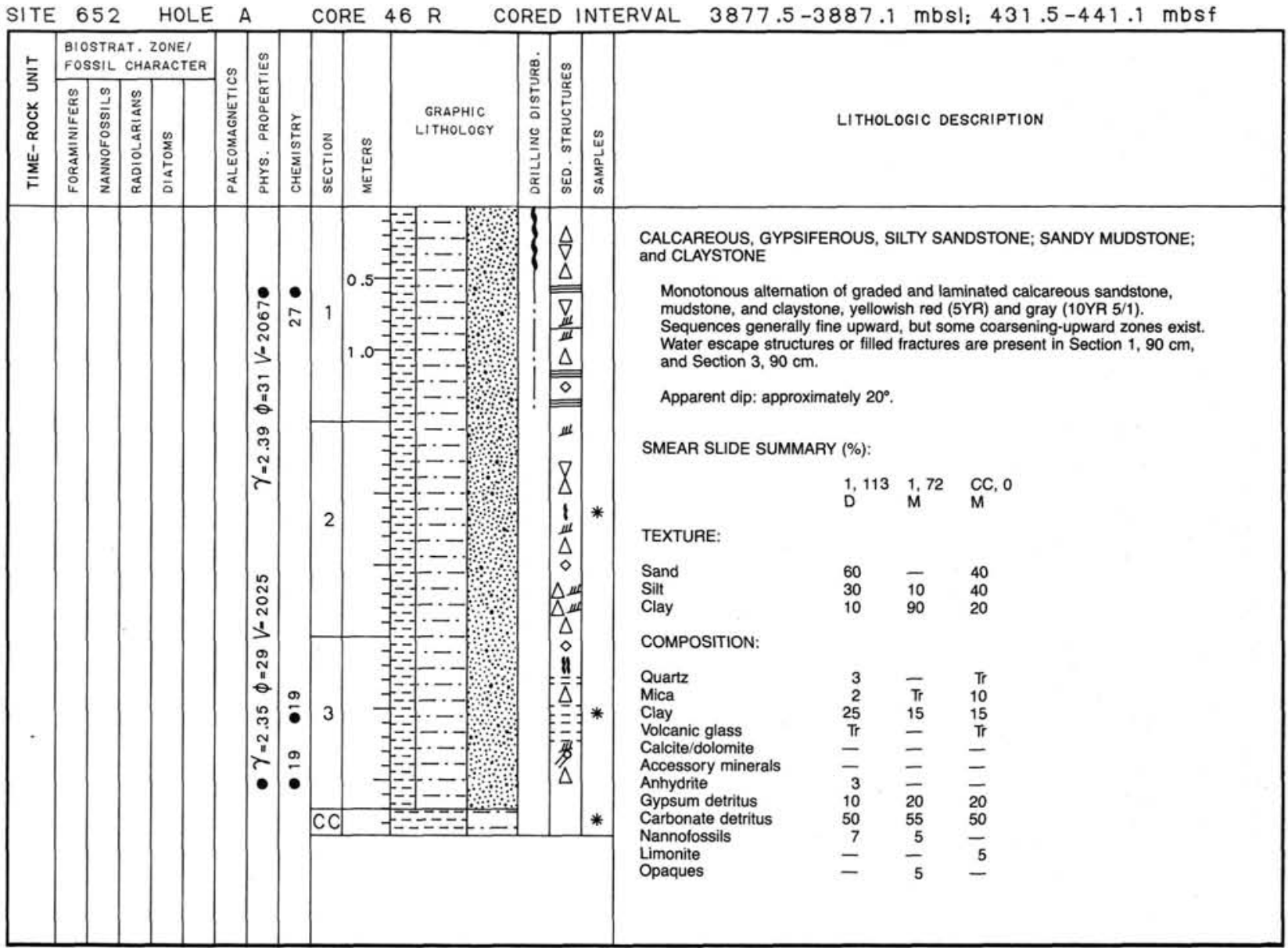




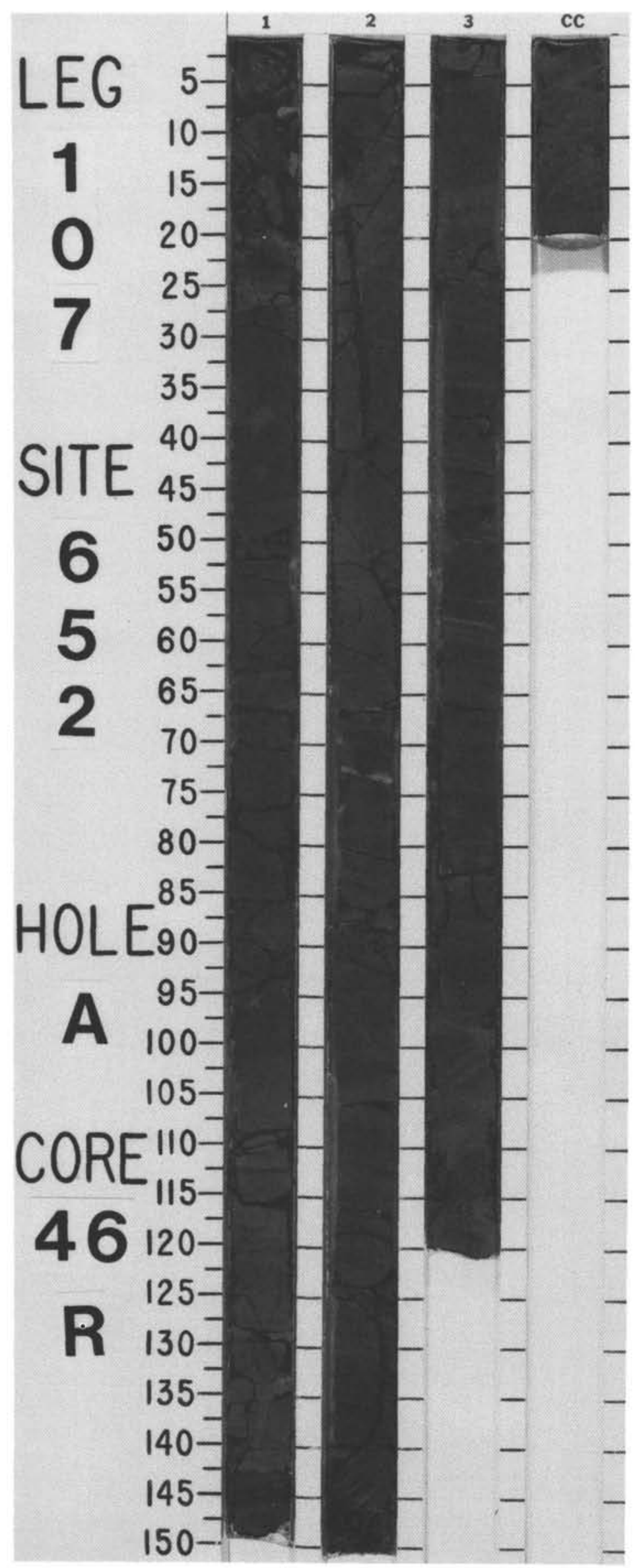


SITE 652 HOLE A CORE $47 \mathrm{R}$ CORED INTERVAL $3887.1-3896.7 \mathrm{mbsl} ; 441.1-450.7 \mathrm{mbs} f$

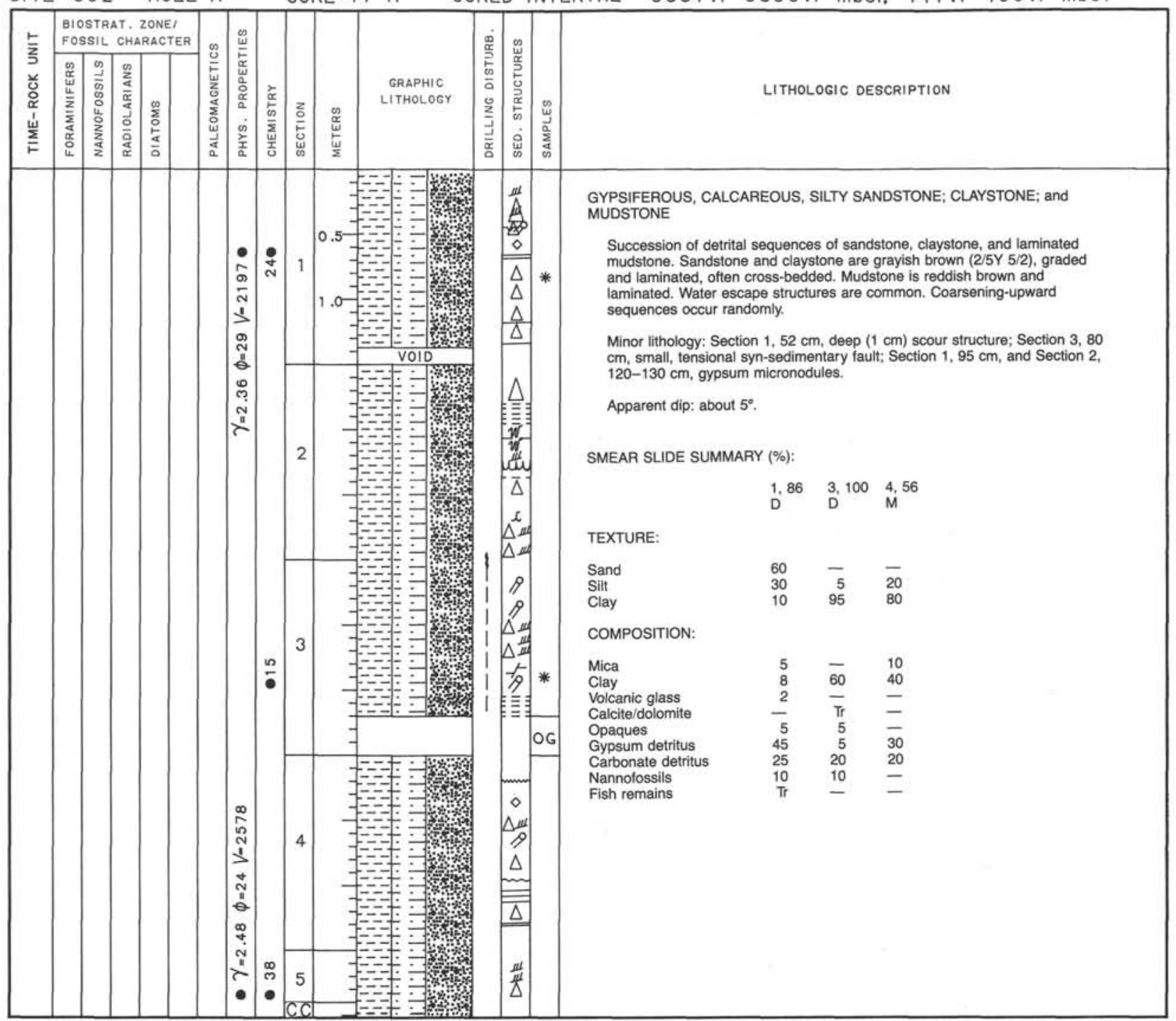




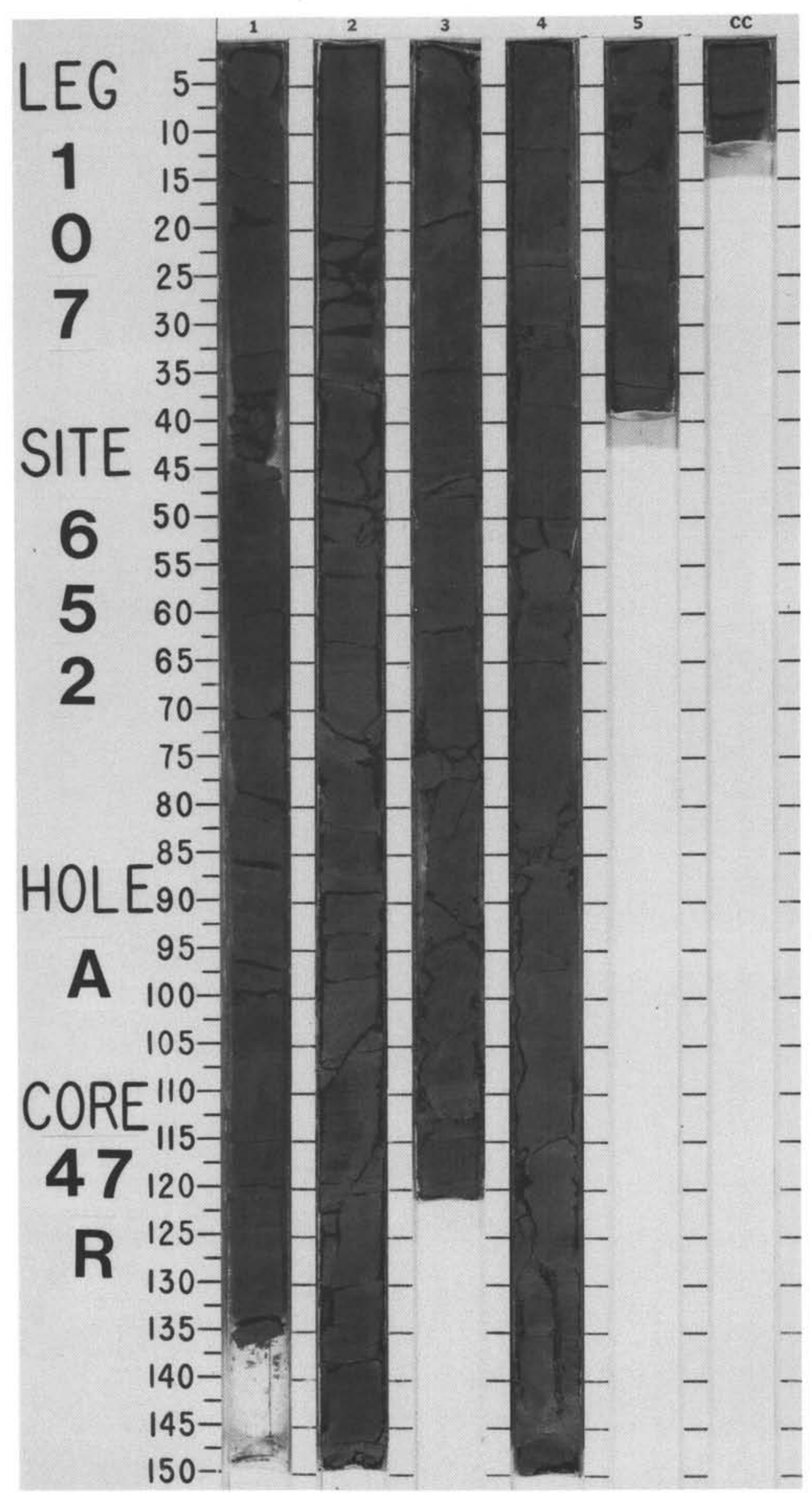




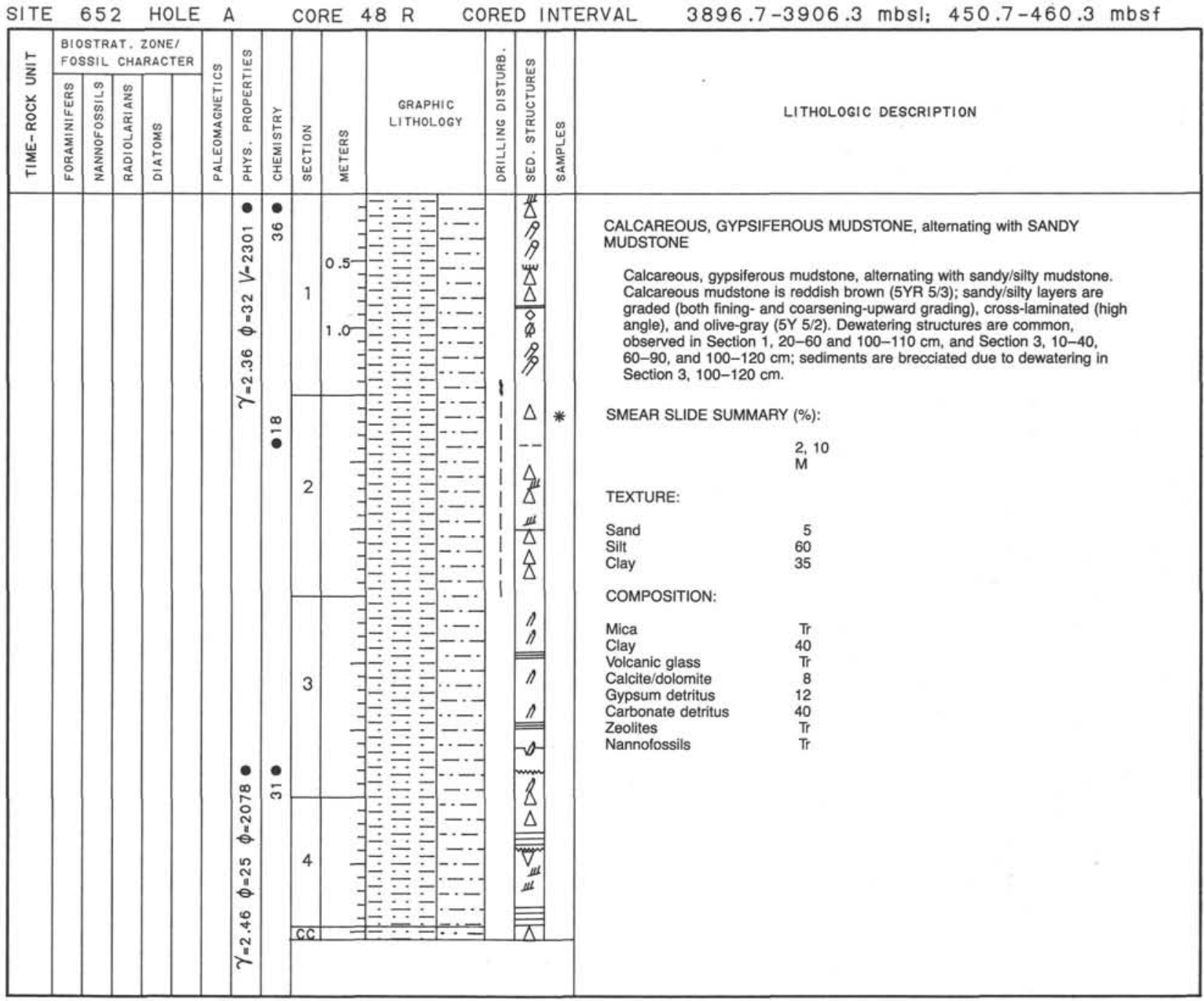




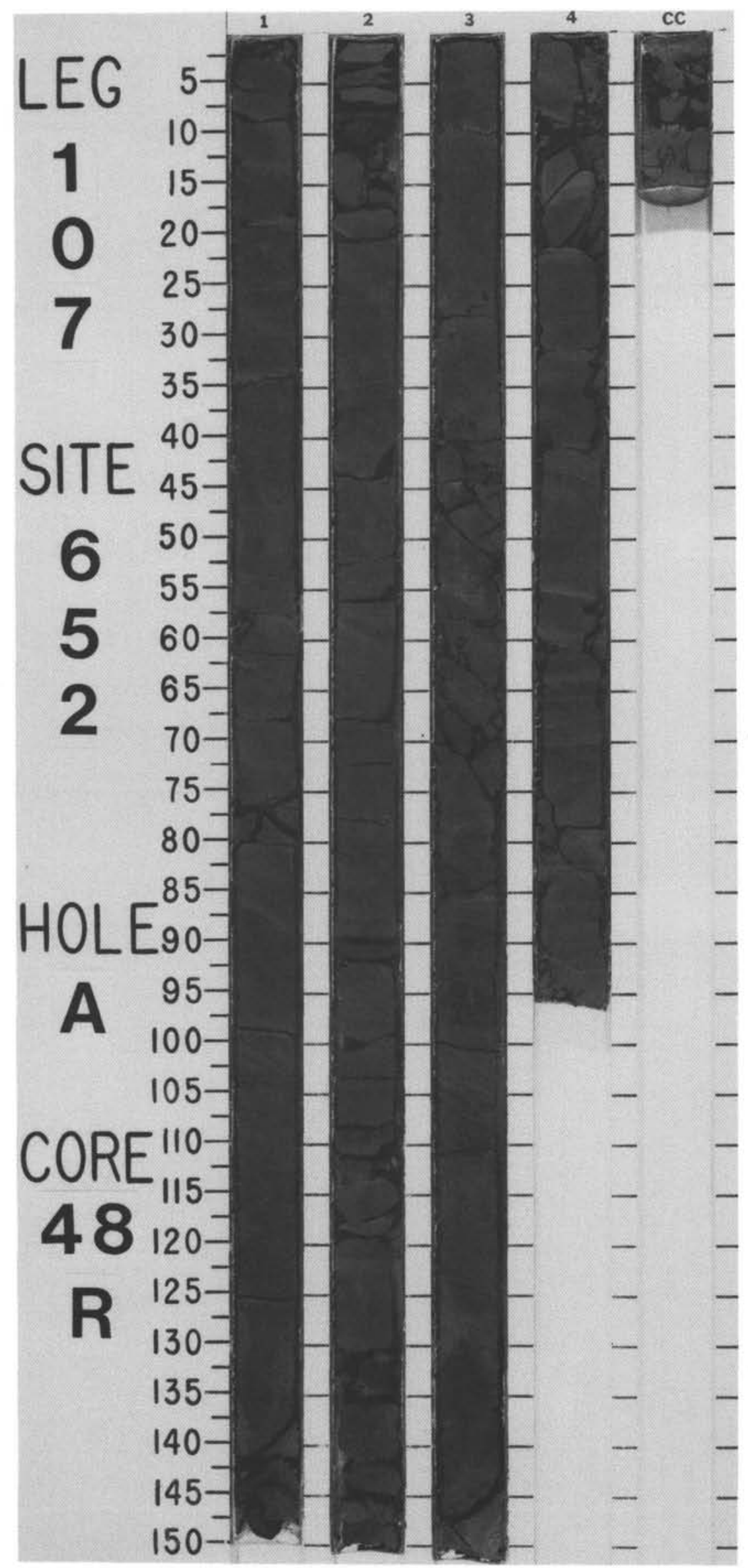




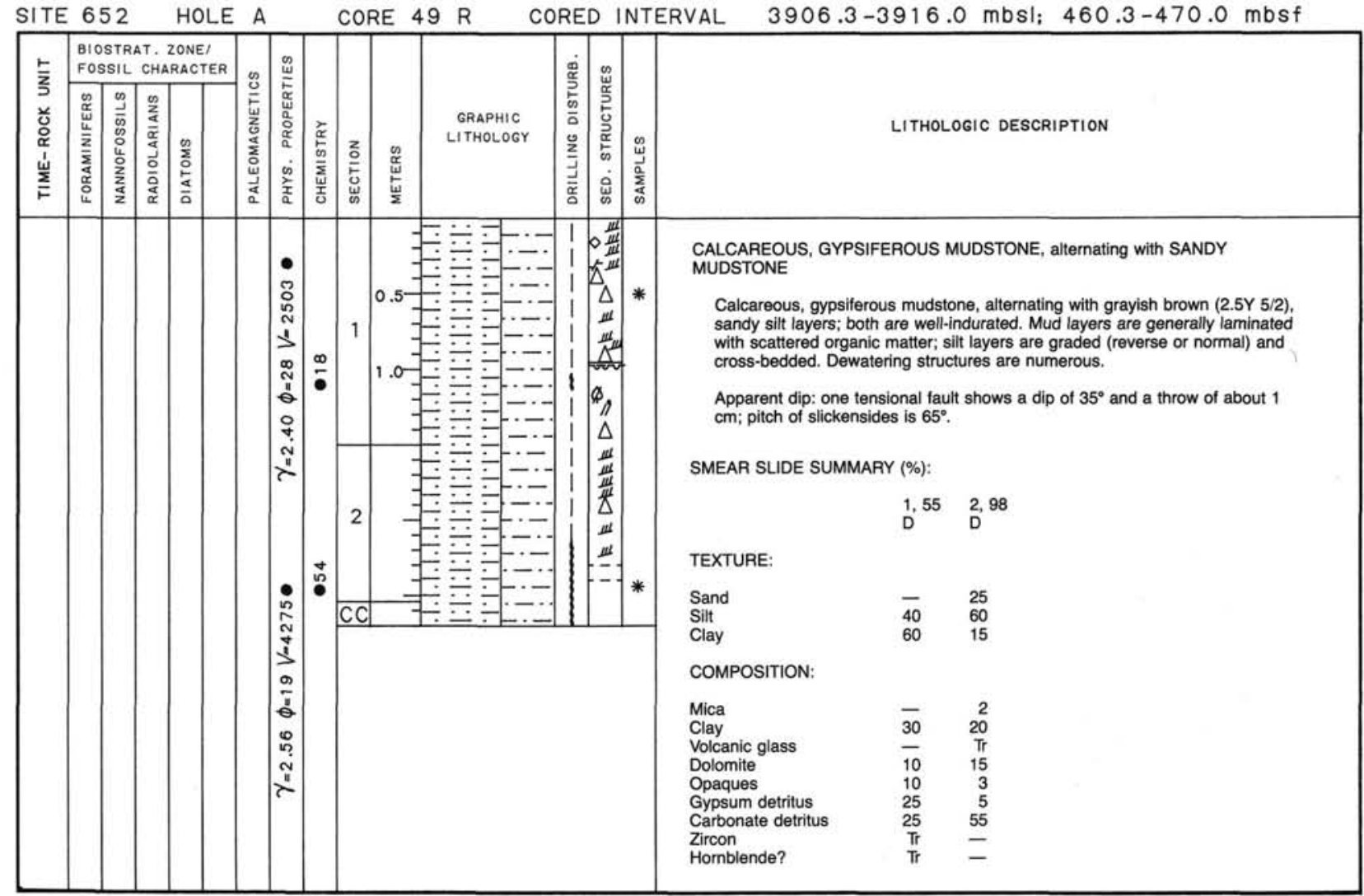

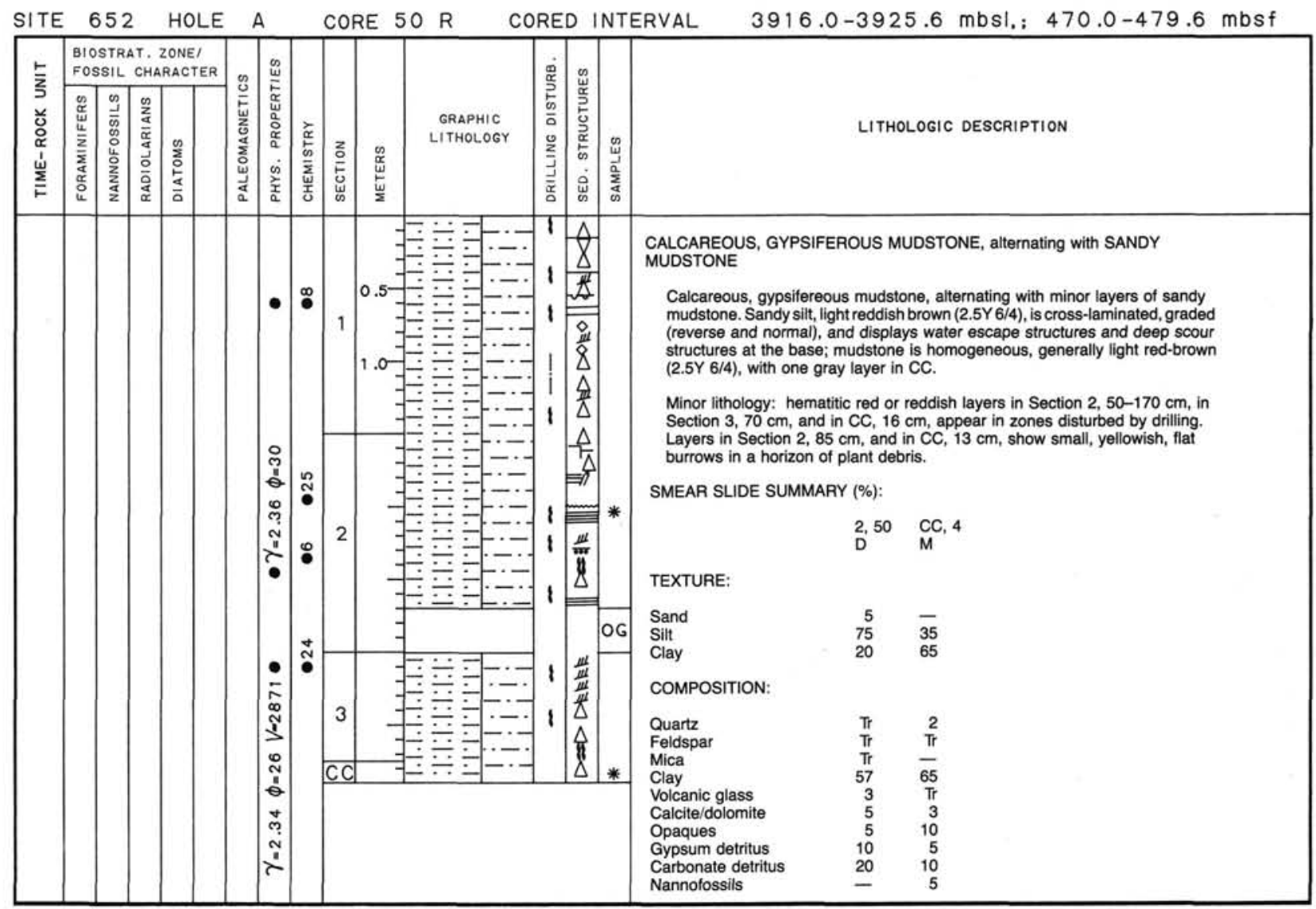




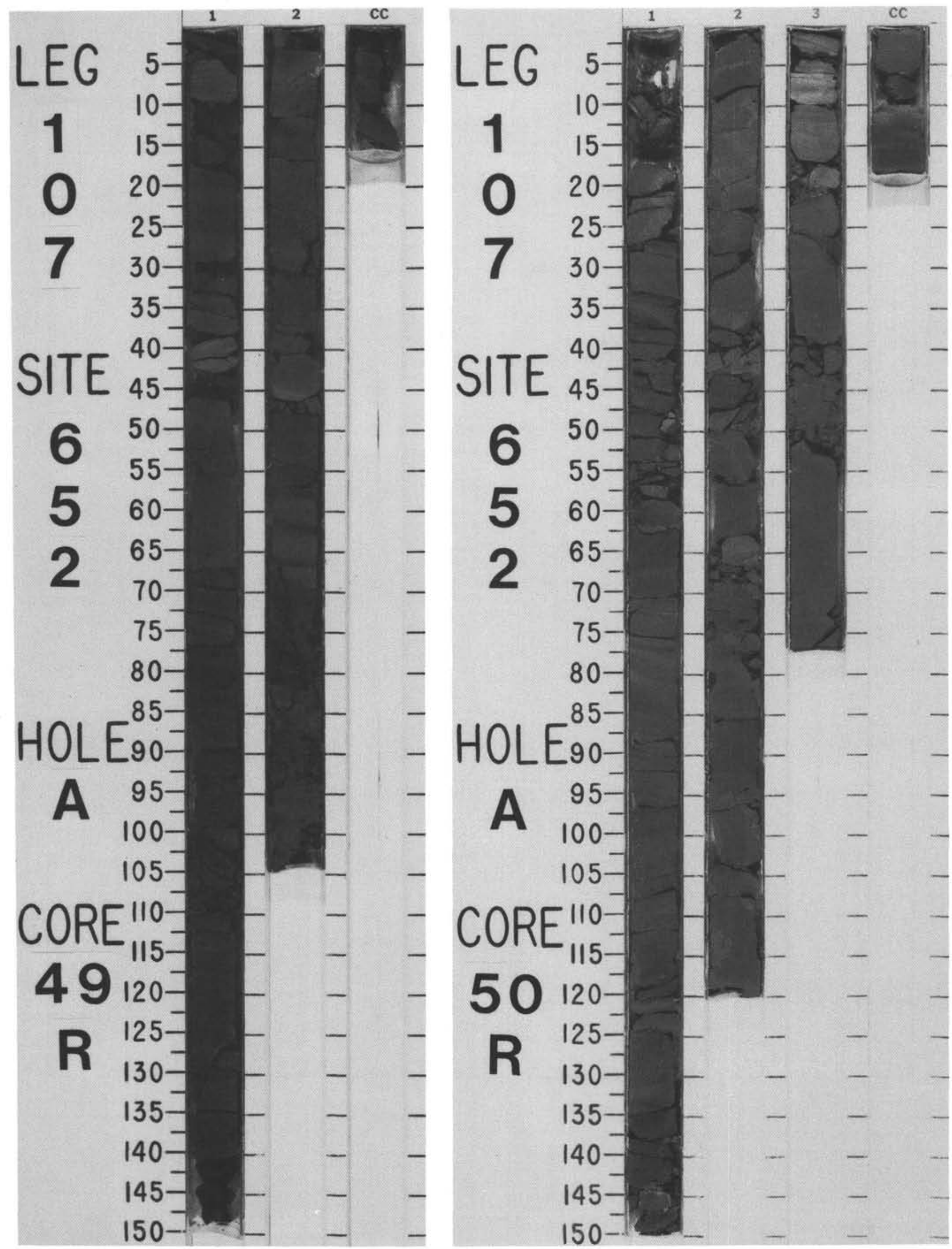




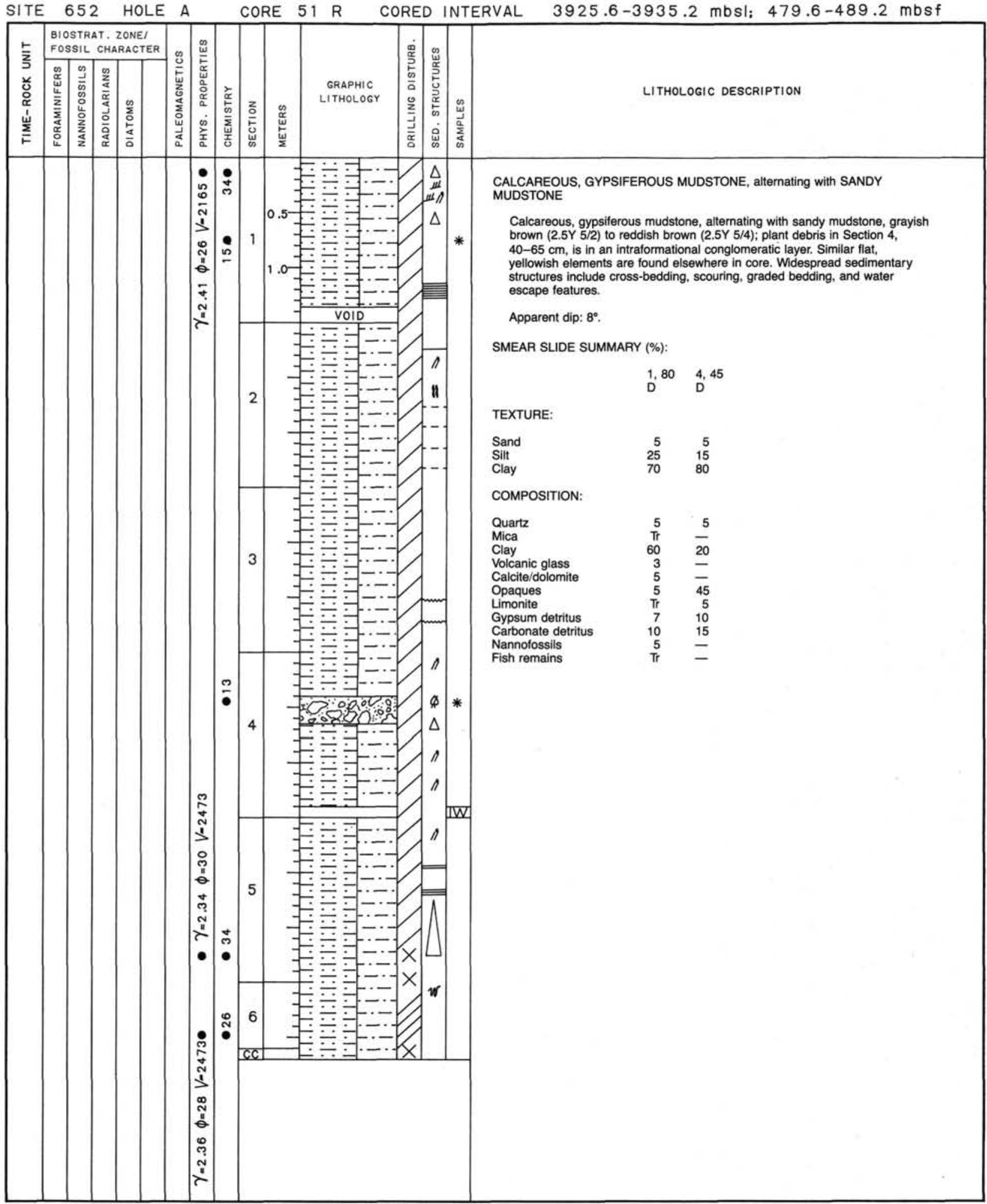




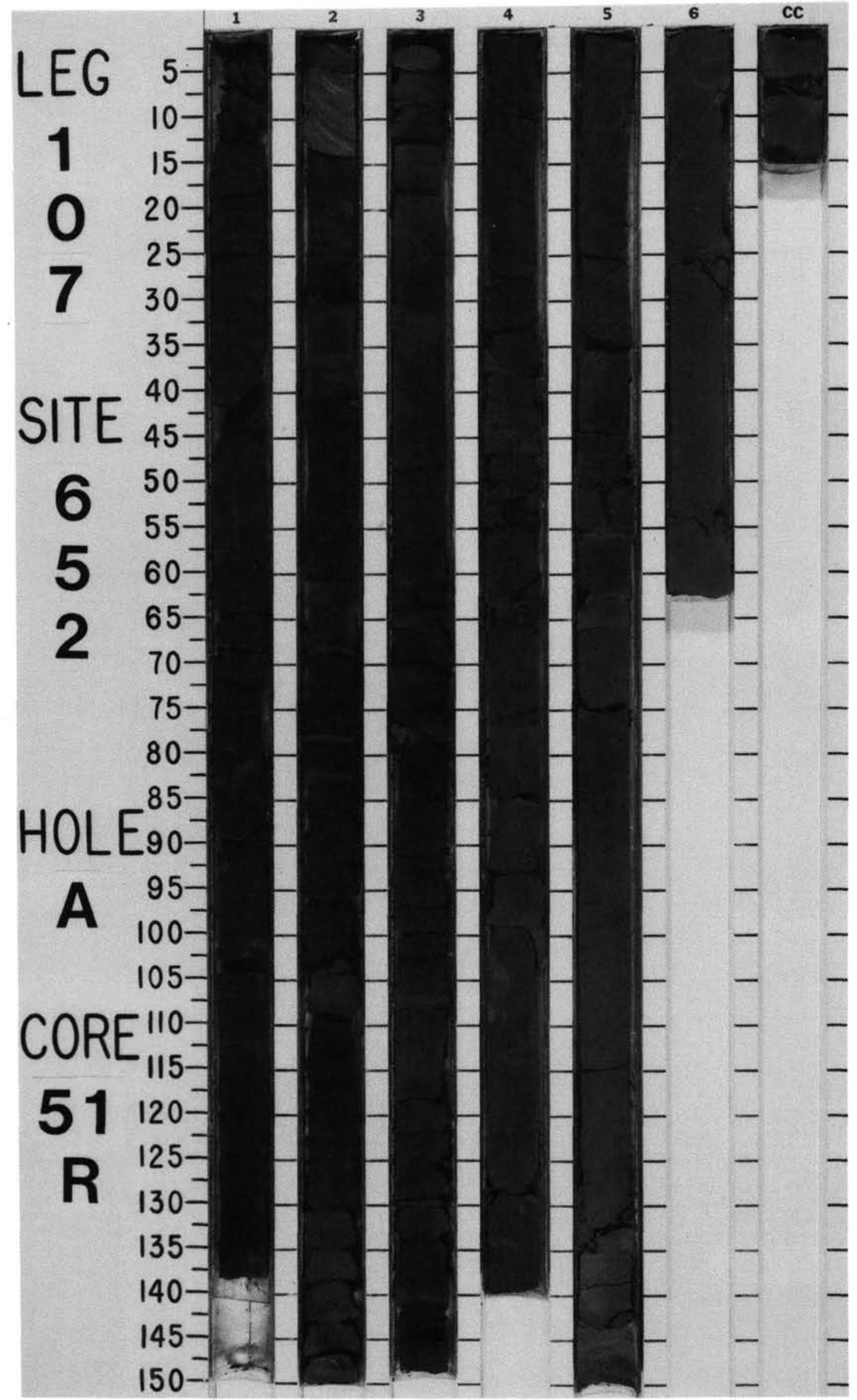




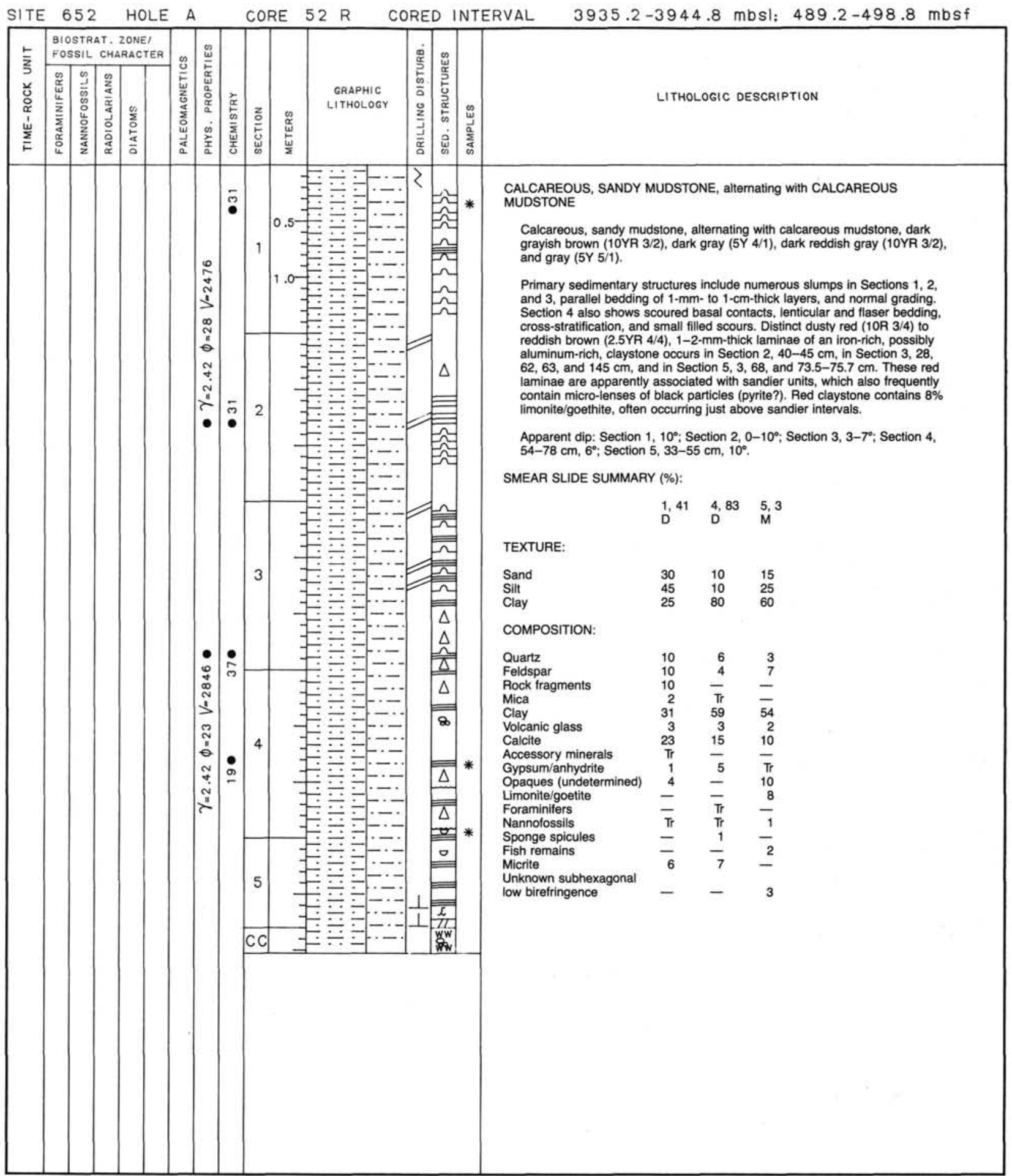




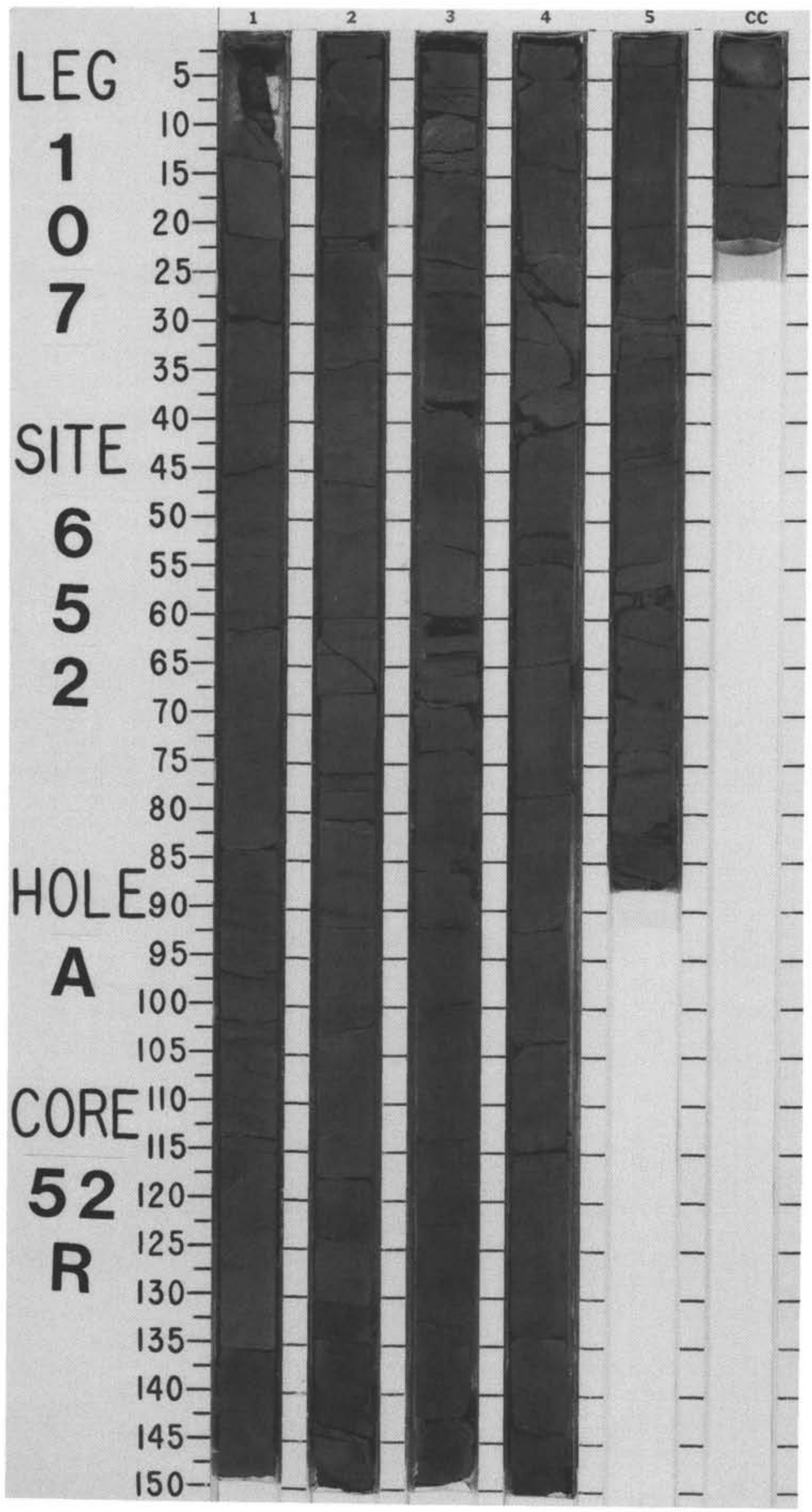




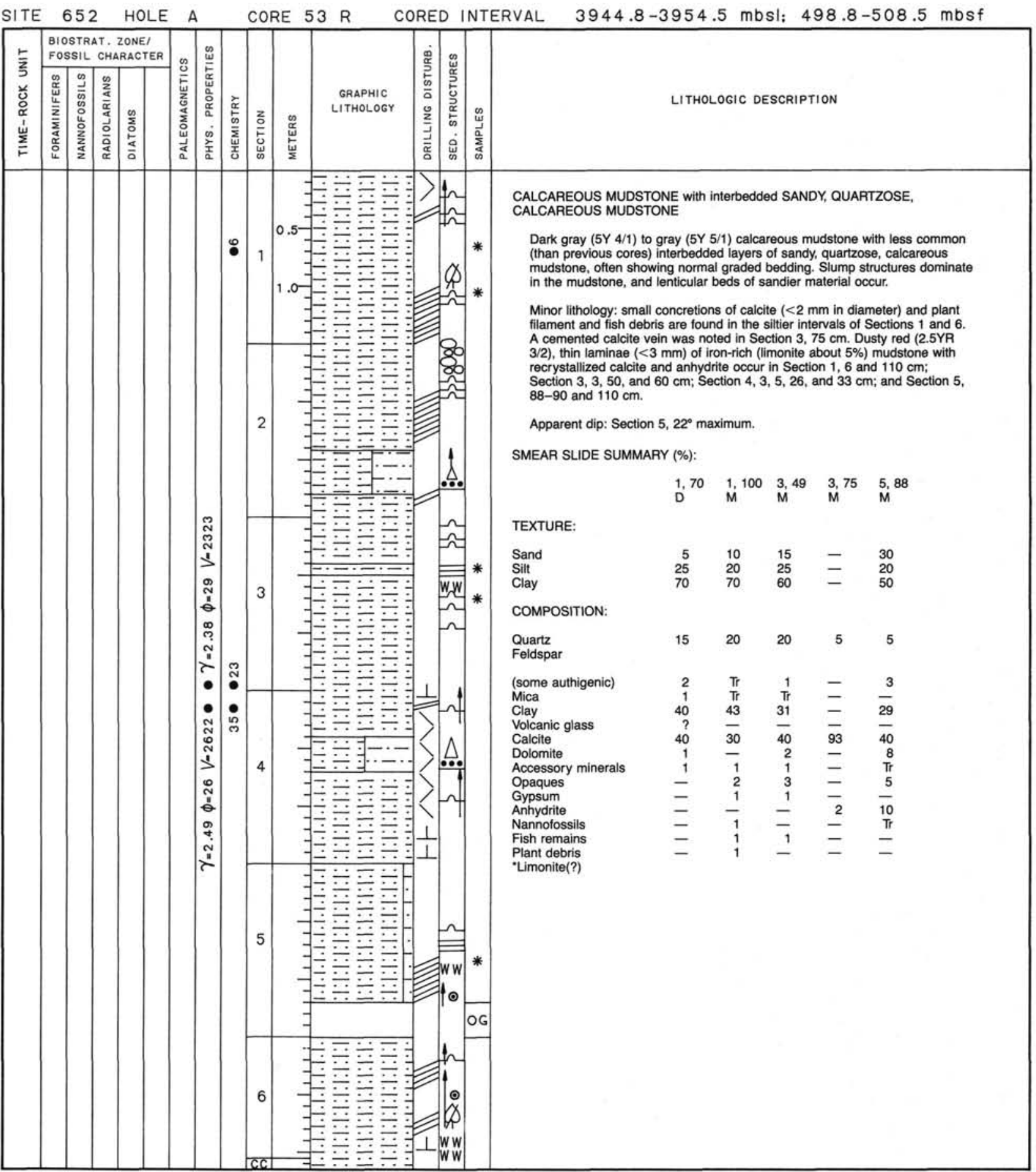




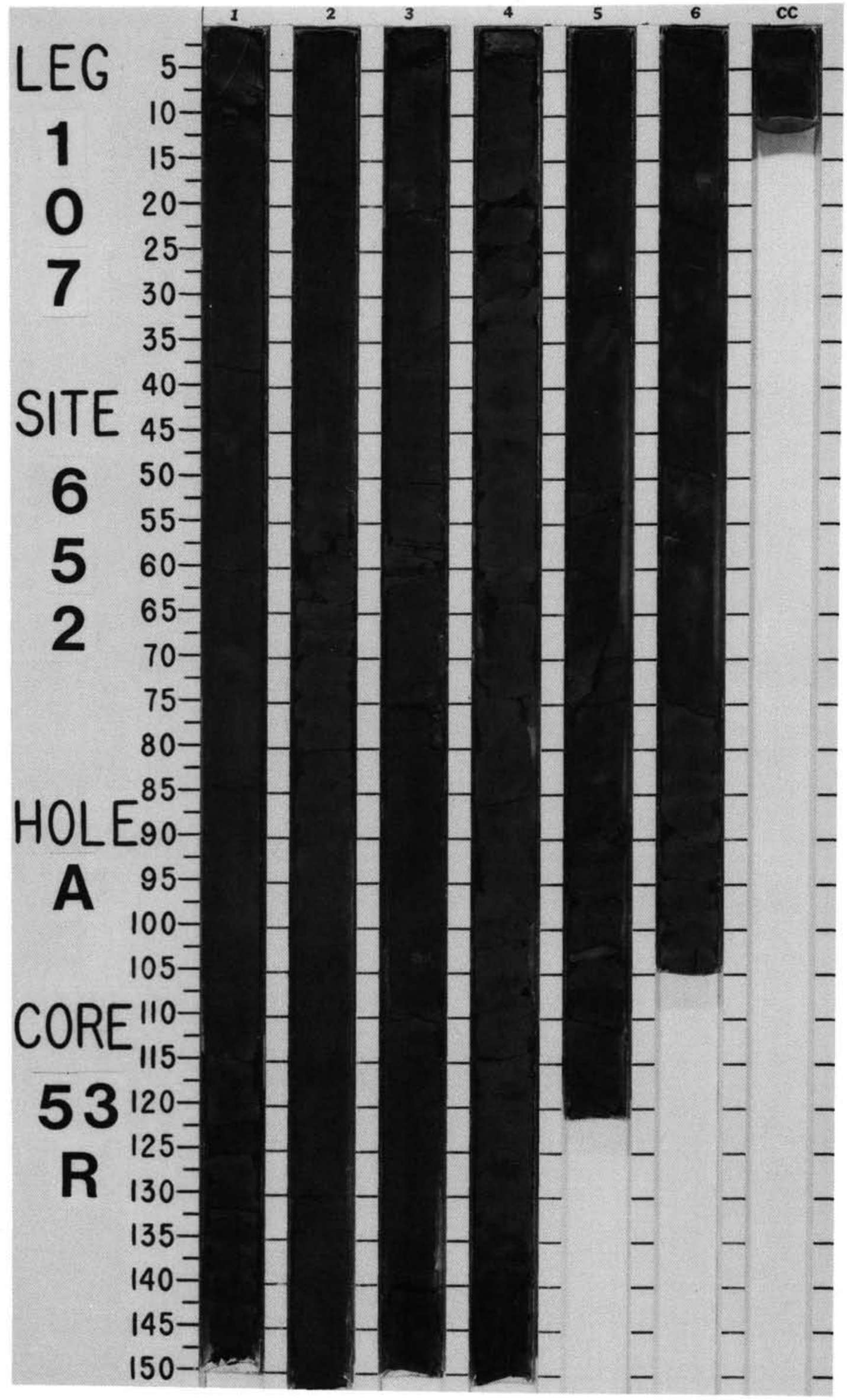




\begin{tabular}{|c|c|c|c|c|c|c|c|c|c|c|c|c|c|c|c|c|c|}
\hline TE & & 552 & & HOLE & 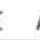 & A & & & & $\mathrm{R}$ & RED & & 395 & -3 & 4.1 & sl: $\quad 508.5-518.1$ & bsf \\
\hline $\bar{z}$ & & $\begin{array}{l}\text { STRA } \\
\text { SSIL }\end{array}$ & & $\begin{array}{l}\text { ZONEI } \\
\text { ZRACTER }\end{array}$ & 6 & $\underline{\tilde{w}}$ & & & & & & & & & & & \\
\hline 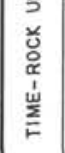 & 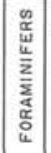 & 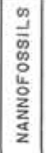 & 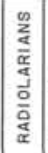 & 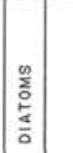 & 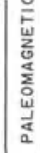 & 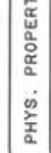 & 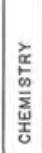 & 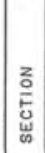 & 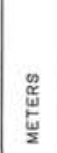 & $\begin{array}{l}\text { GRAPHIC } \\
\text { LITHOLOGY }\end{array}$ & 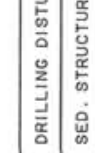 & 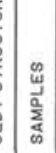 & & LITHOL & OGIC DE & SCRIPTION & \\
\hline & & & & & & 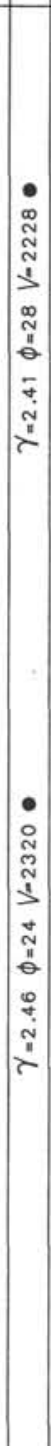 & $\frac{\infty}{6}$ & 4 & & 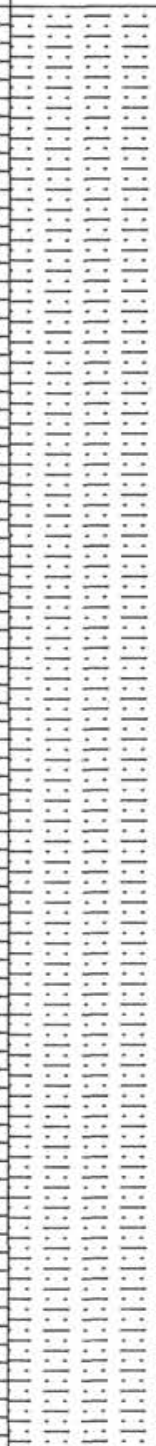 & $\int^{8}$ & $=$ & $\begin{array}{l}\text { CALCAREOUS MUDSTC } \\
\text { Homogeneous calcar } \\
\text { reddish gray (5YR 5/2 } \\
\text { Minor lithology: Sectic } \\
\text { mudstone. Section } 3 \text {, } \\
\text { mudstone with lighter } \\
\text { (2.5Y 8/2) laminae th } \\
\text { slump are irregular fill } \\
\text { sandy mudstone (in' } \\
\text { bedding plane. Sectio } \\
\text { anhydrite/calcite laye } \\
\text { irregular calcite filling } \\
\text { Apparent dip of the s } \\
\text { with an apparent disp } \\
\text { and pitch of the slicke } \\
\text { the right. } \\
\text { Interpretation: fault m } \\
\text { SMEAR SLIDE SUMMA } \\
\\
\text { TEXTURE: } \\
\text { Sand } \\
\text { Silt } \\
\text { Clay } \\
\text { COMPOSITION: } \\
\text { Quartz } \\
\text { Clay } \\
\text { Volcanic glass } \\
\text { Calcite } \\
\text { ACcessory minerals } \\
\text { Opaques (org. matter?) } \\
\text { Opaques } \\
\text { Anhydrite }\end{array}$ & 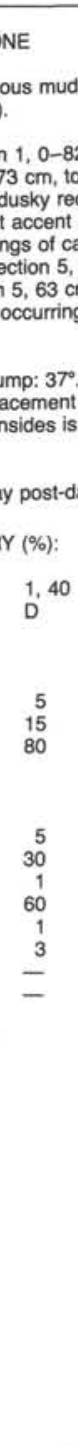 & 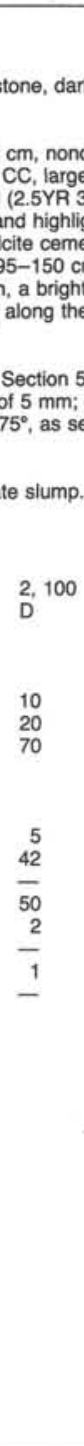 & $\begin{array}{l}\text { Ik gray (5Y 4/1), gray (5Y 5/1), and } \\
\text { calcareous (possibly dolomitic) } \\
\text { e slump deposit of the gray } \\
\text { 3/2), light gray (5Y 5/1), and white } \\
\text { ght the slump structures. Within the } \\
\text { ent and boudin-like, lenticular, } \\
\text { m) that paralliel the disturbed } \\
\text { it white, finely crystalline } \\
\text { e fault plane; this layer difters from } \\
5 \text {, } 59-74 \mathrm{~cm} \text {, is a small reverse fault } \\
\text { dip angle of the fault plane is } 70^{\circ} \\
\text { een with the fault plane deviation to } \\
\\
5,63 \\
\text { M } \\
- \\
- \\
- \\
\frac{-}{40} \\
\frac{-}{60}\end{array}$ & Dit \\
\hline
\end{tabular}




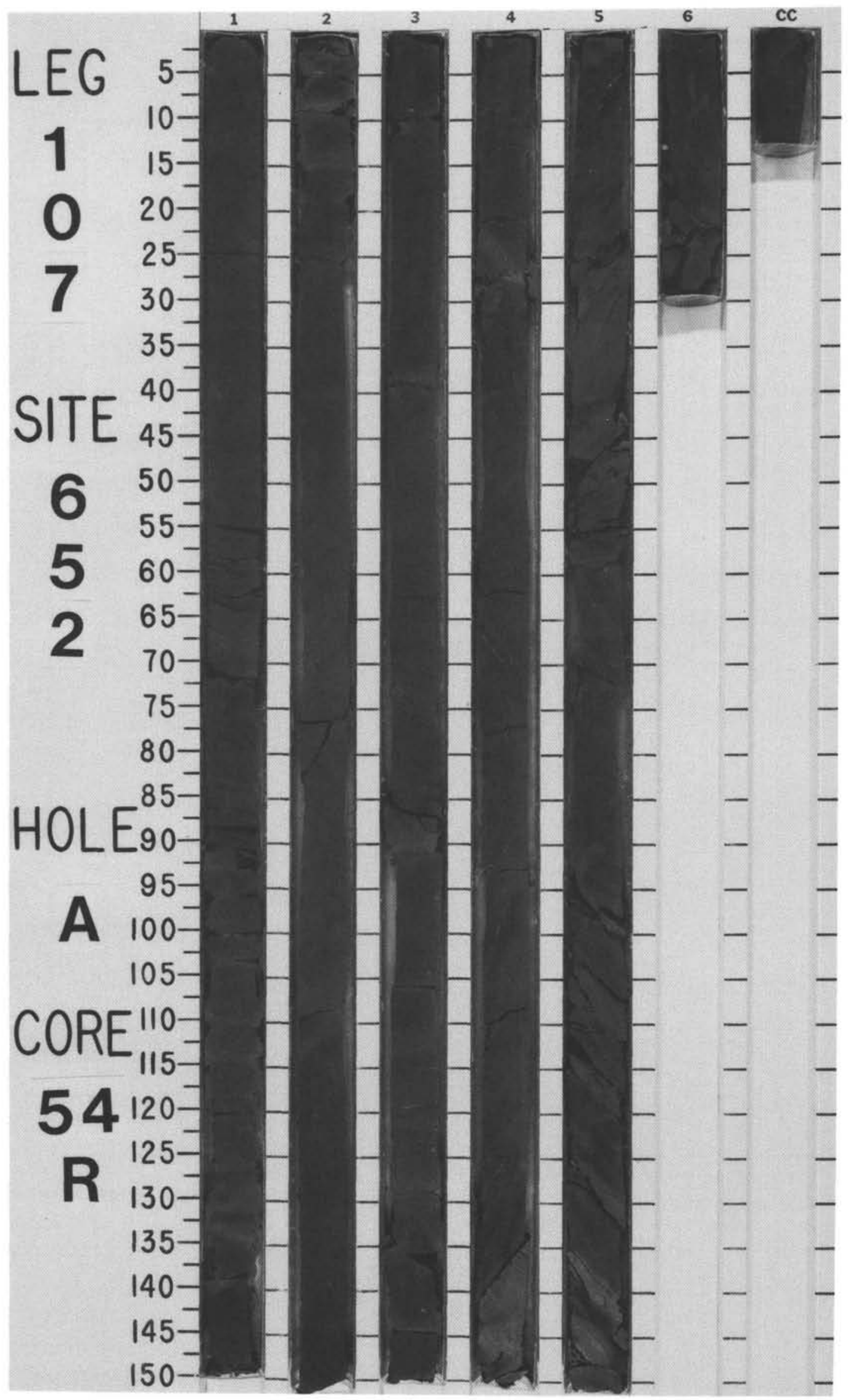




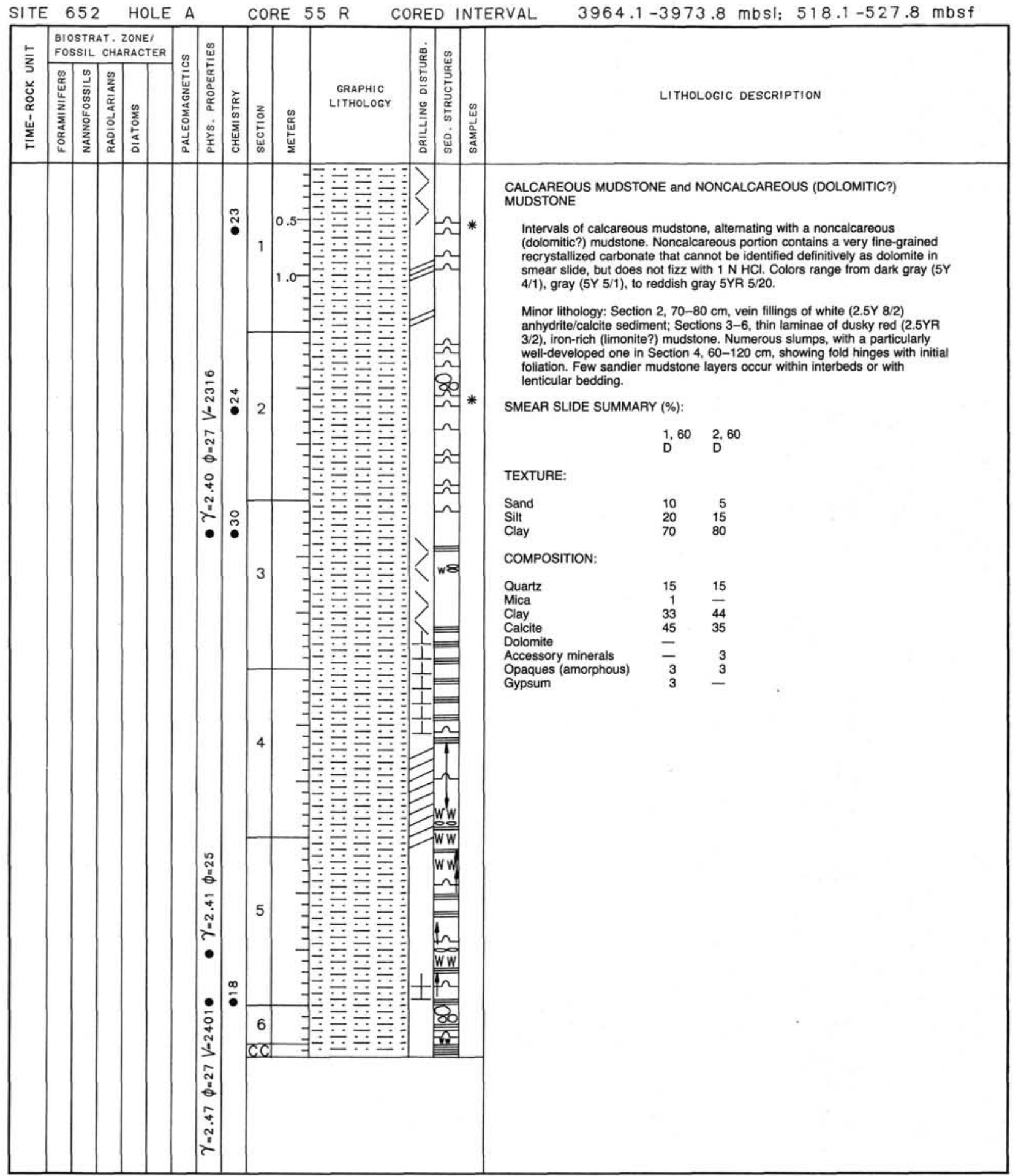




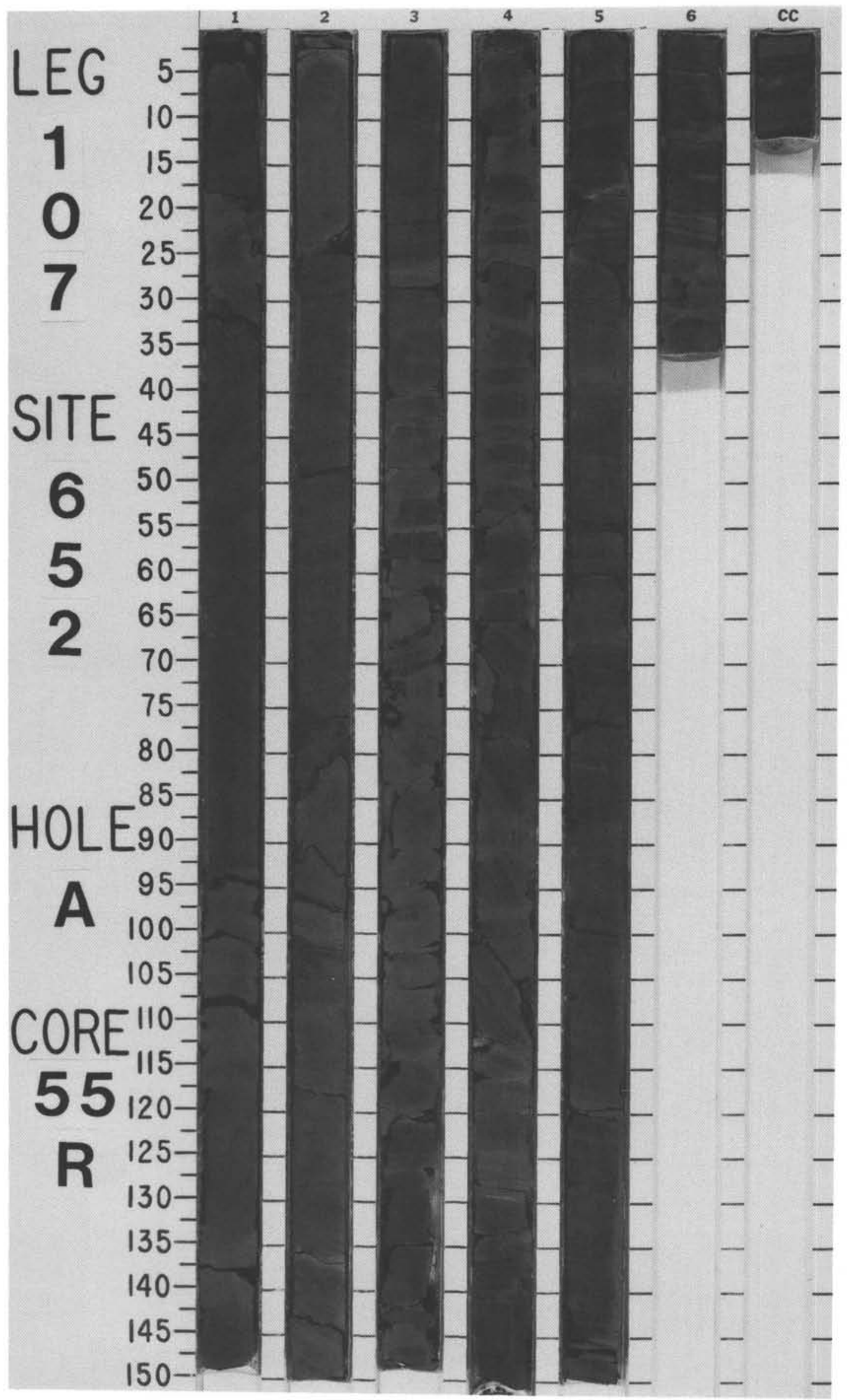




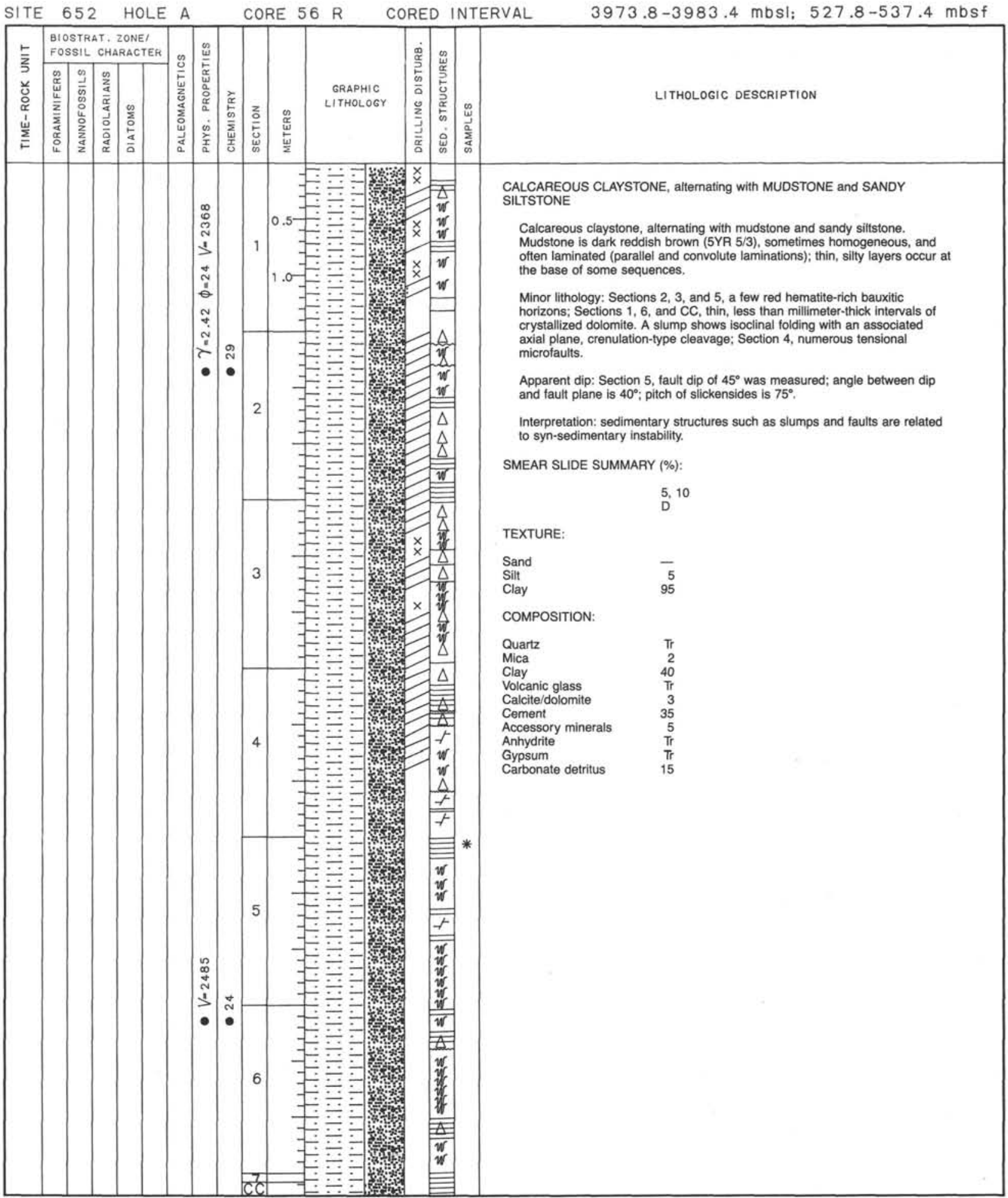




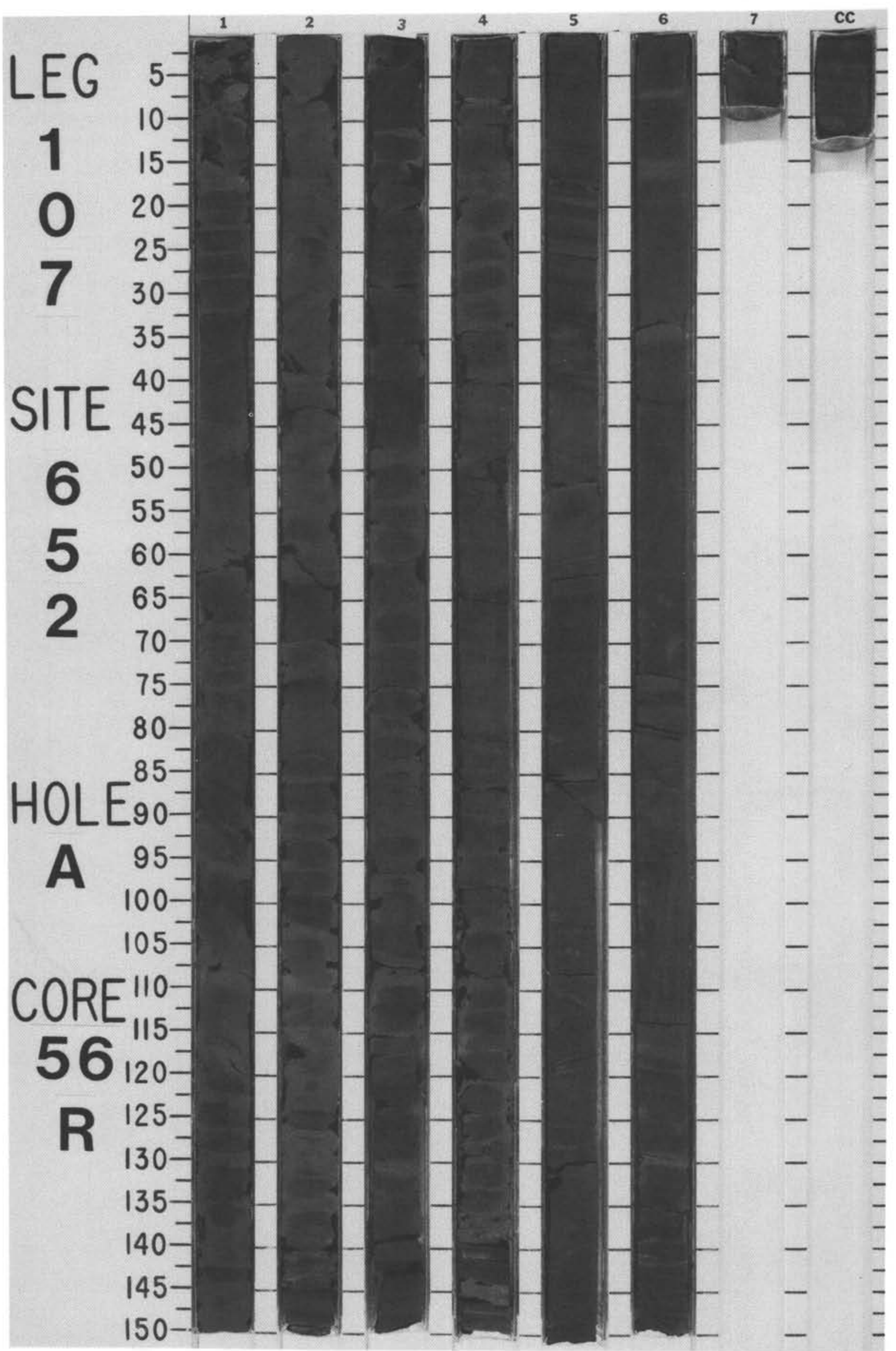




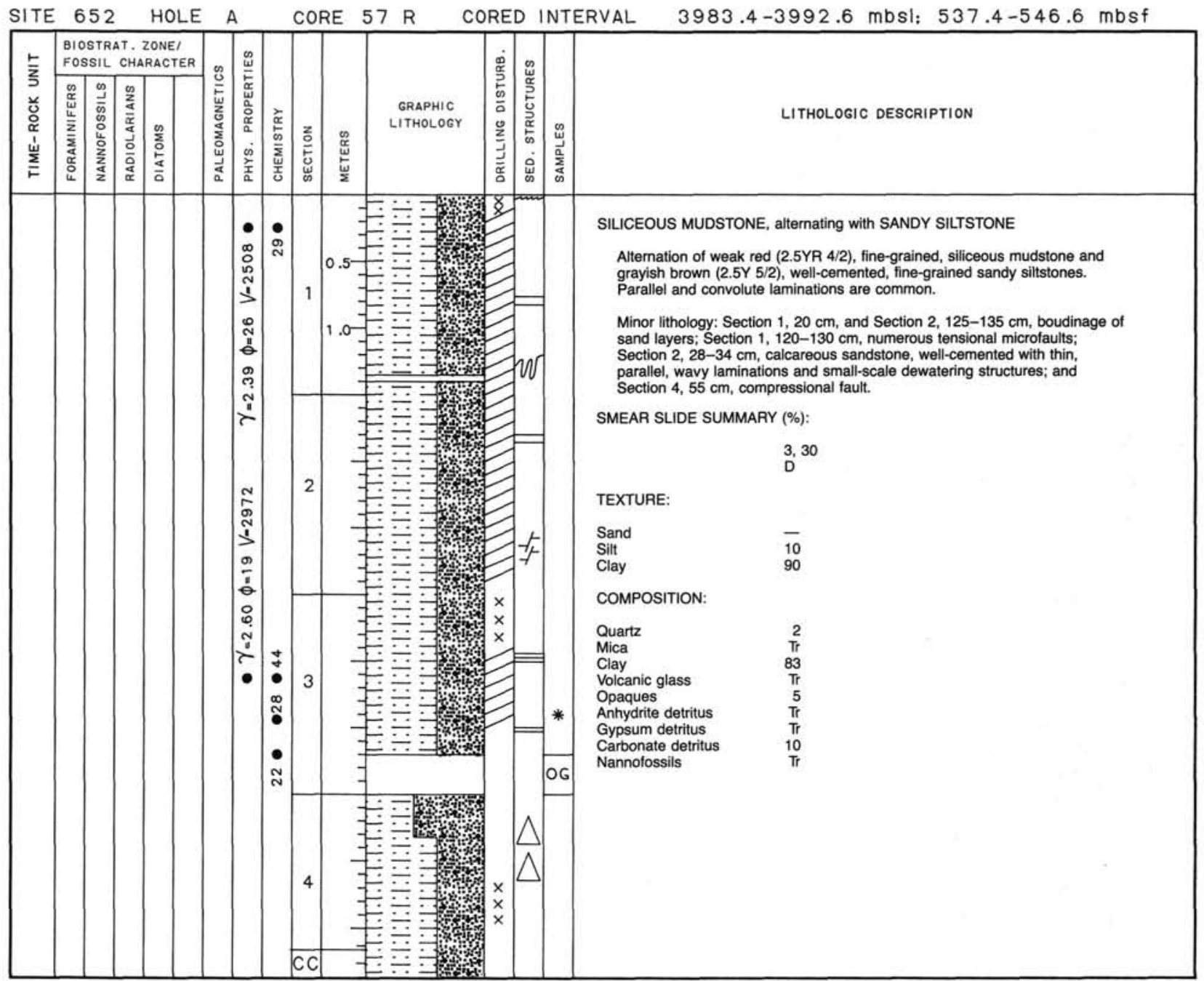




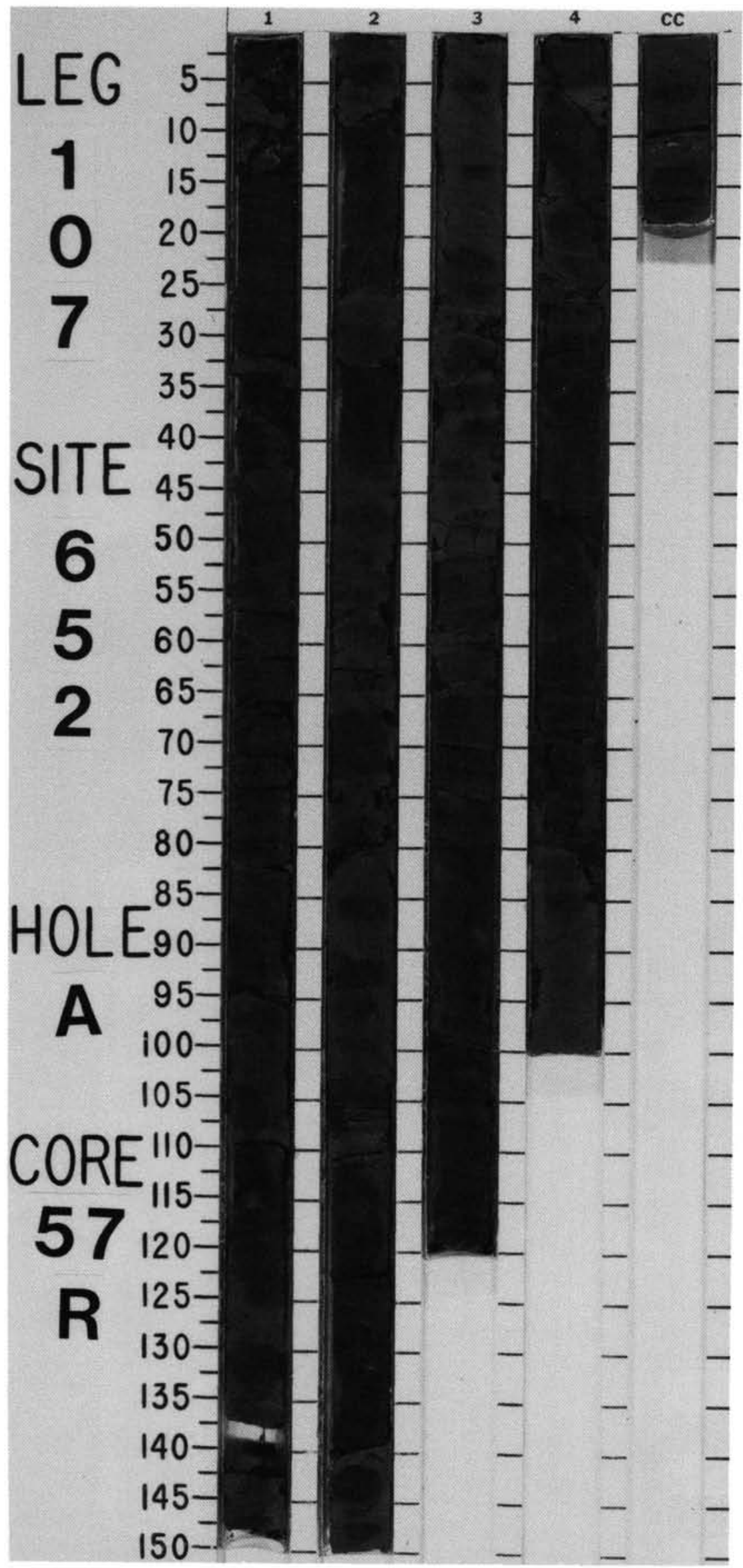




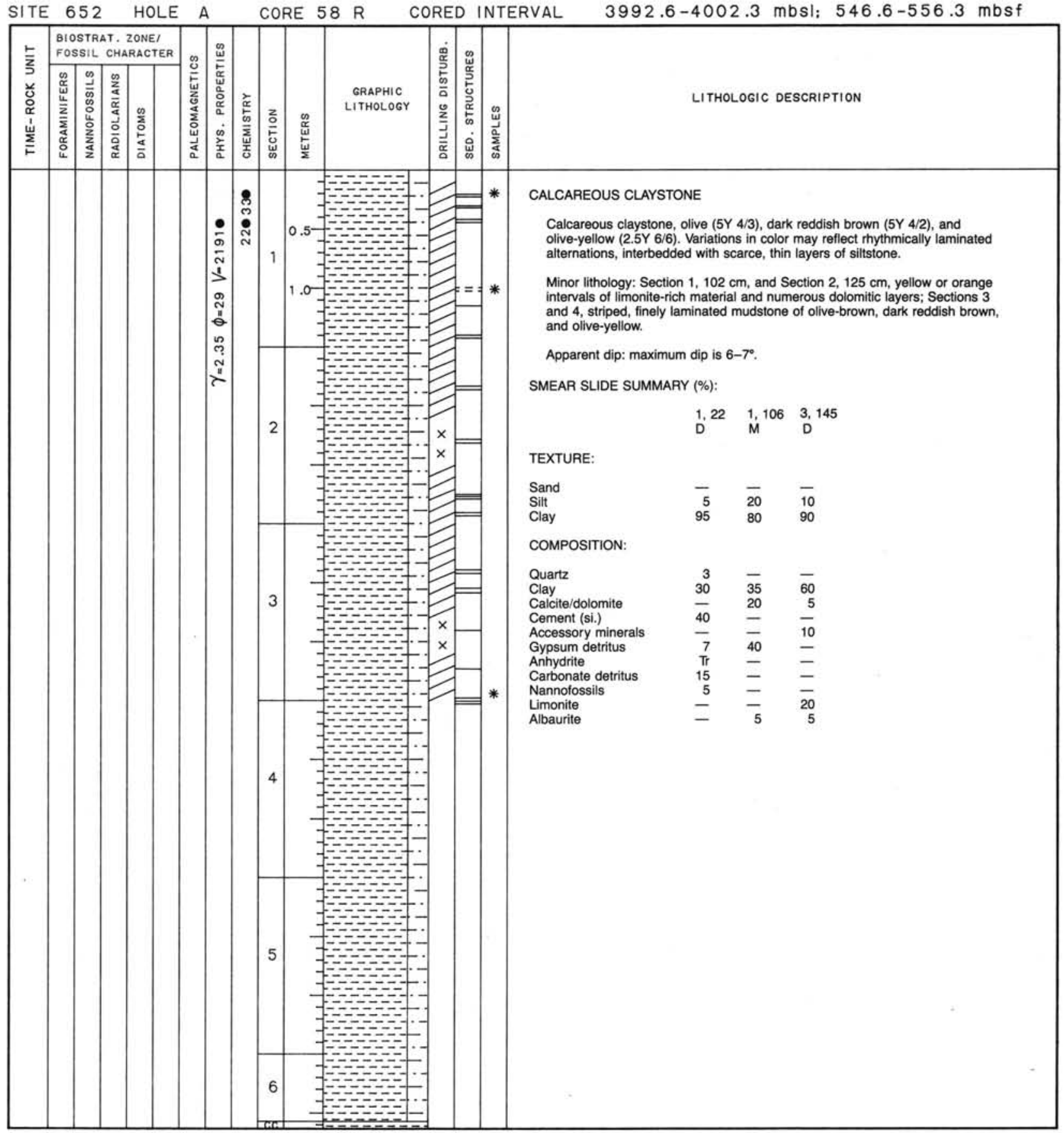




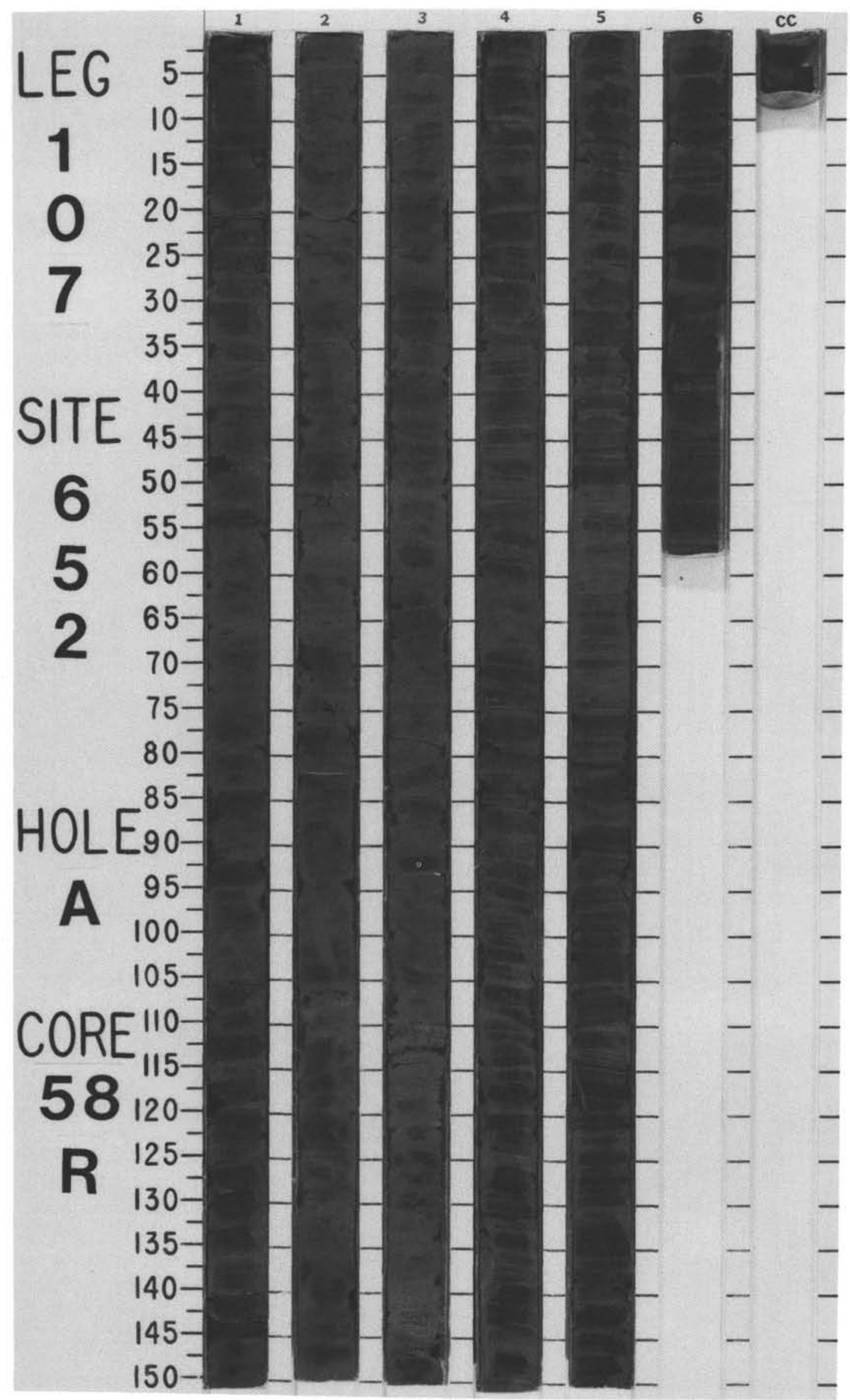




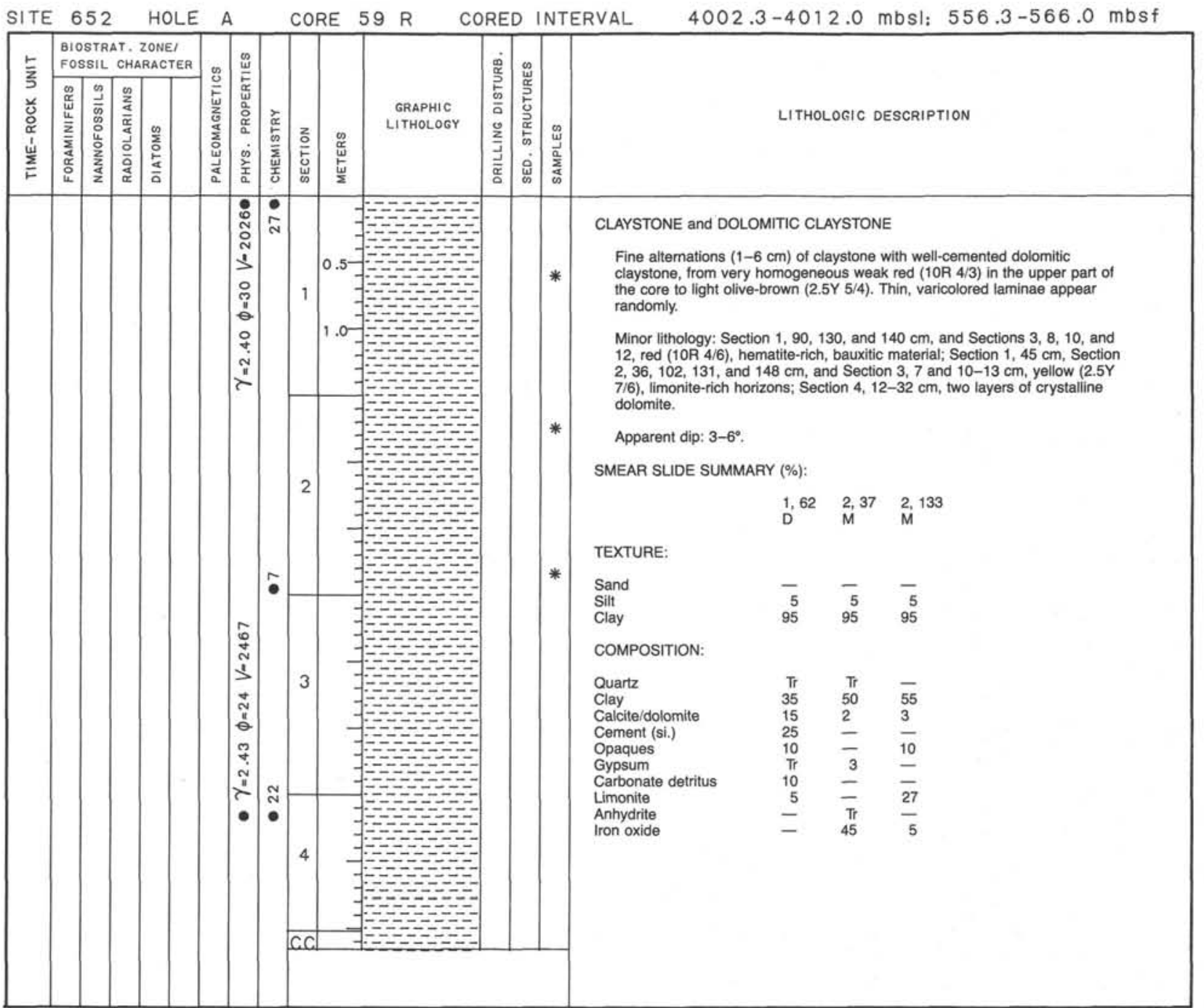




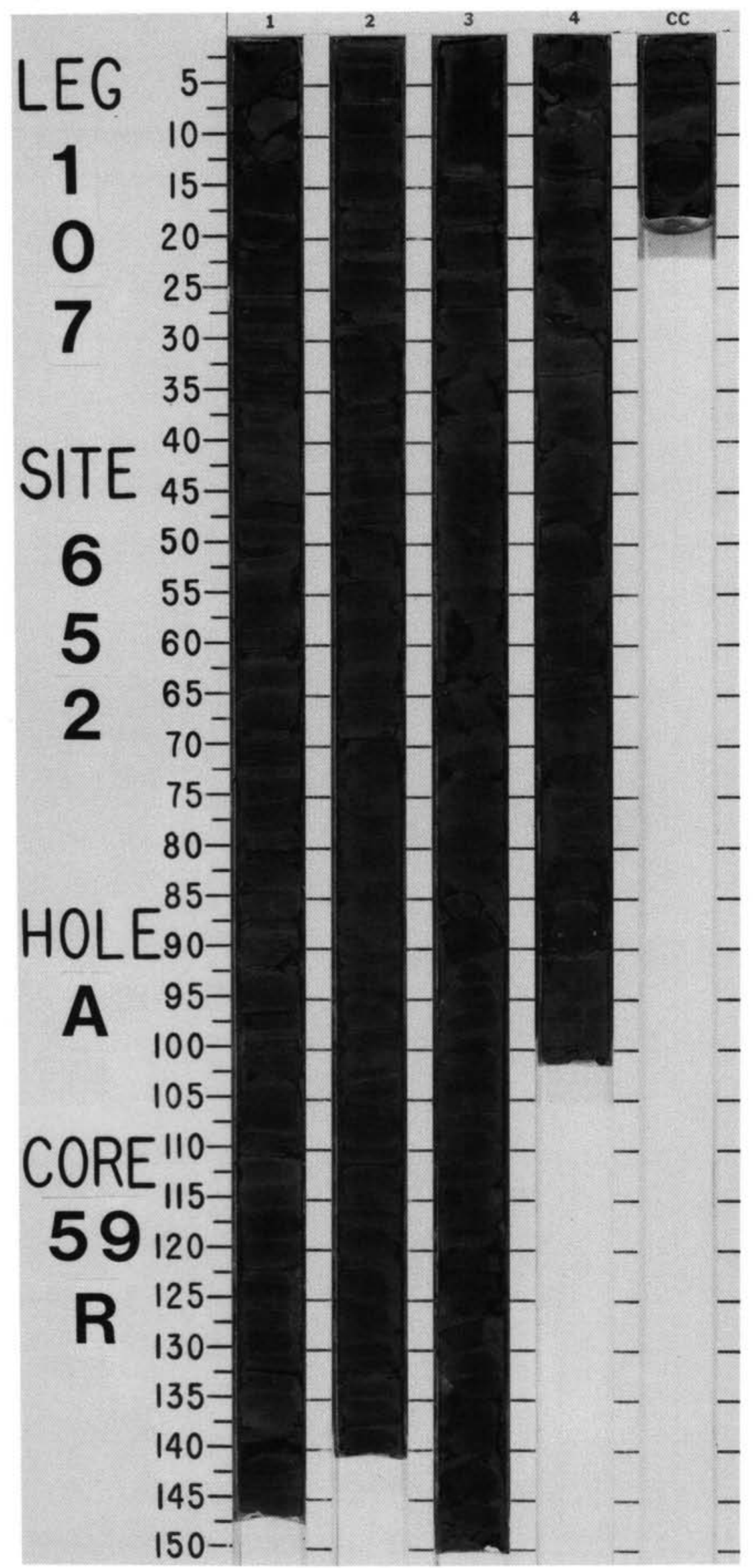




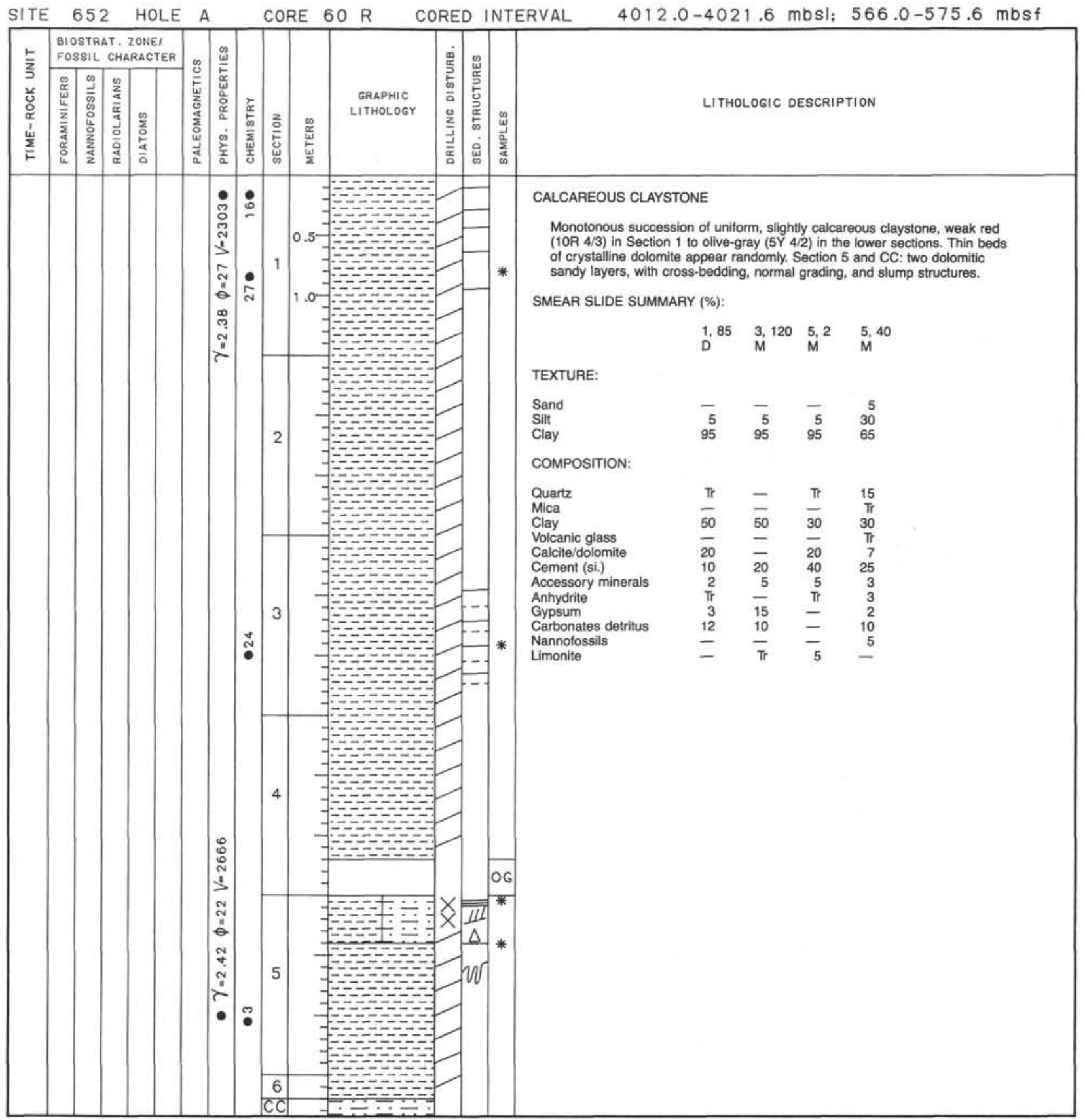




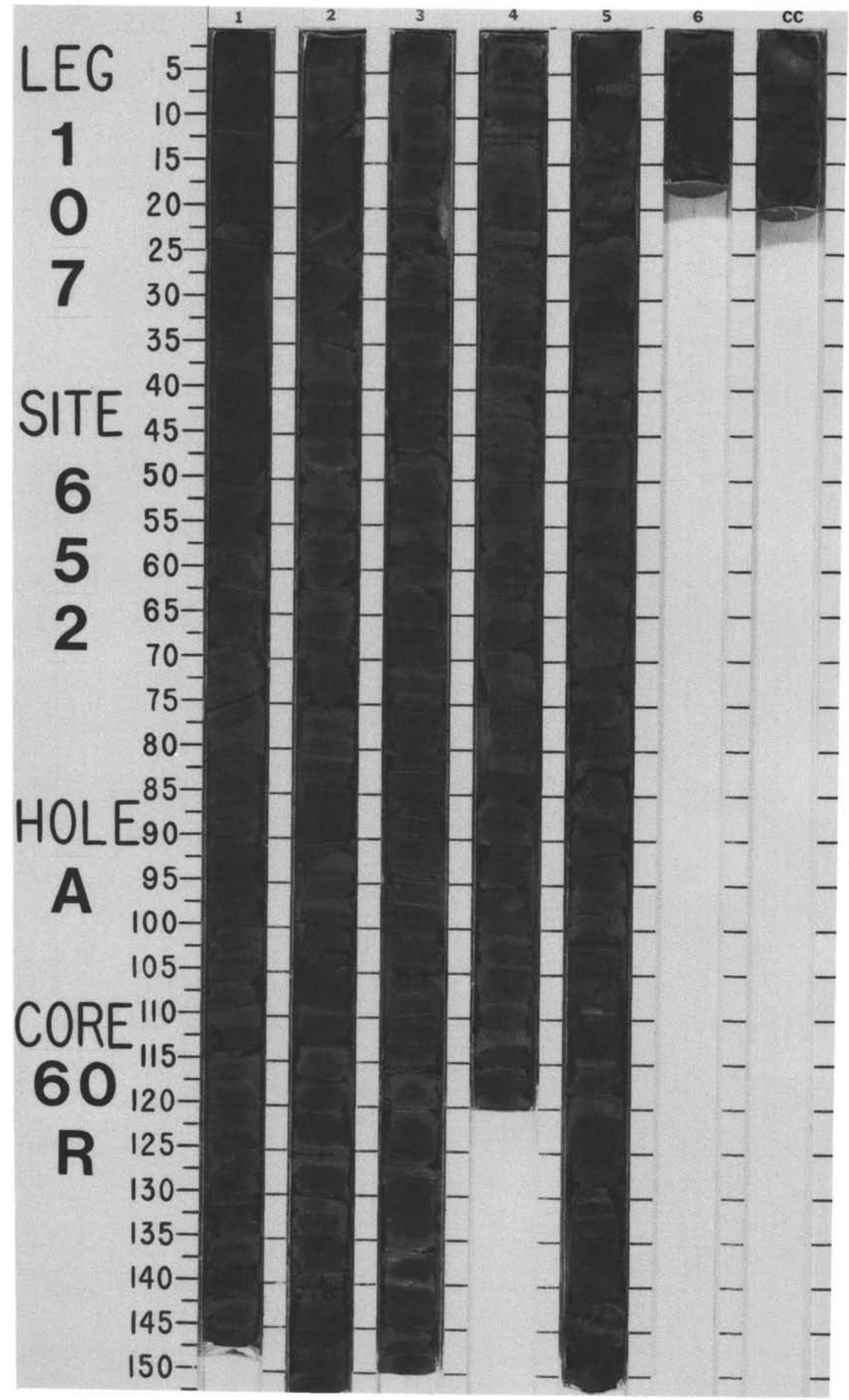




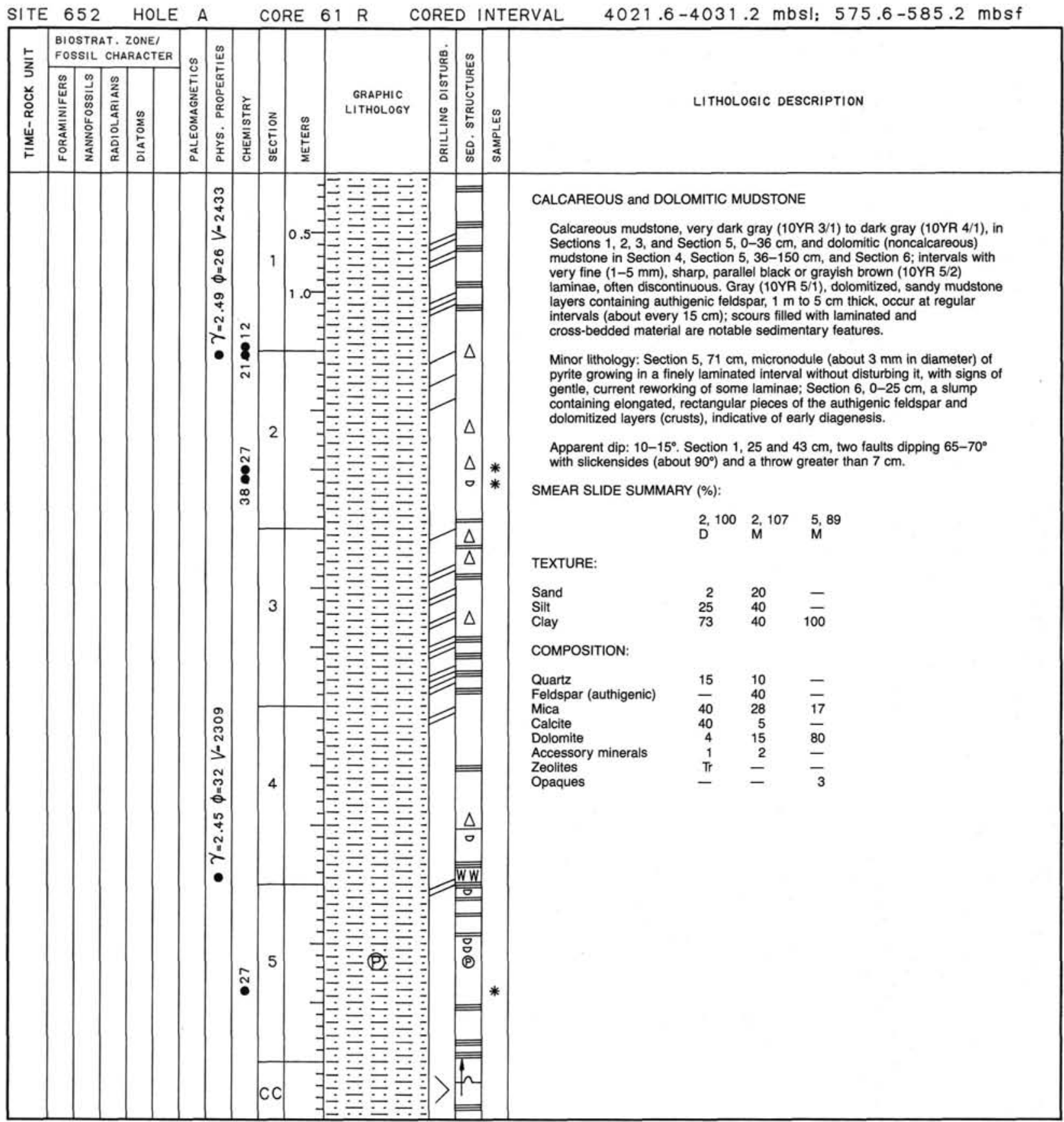




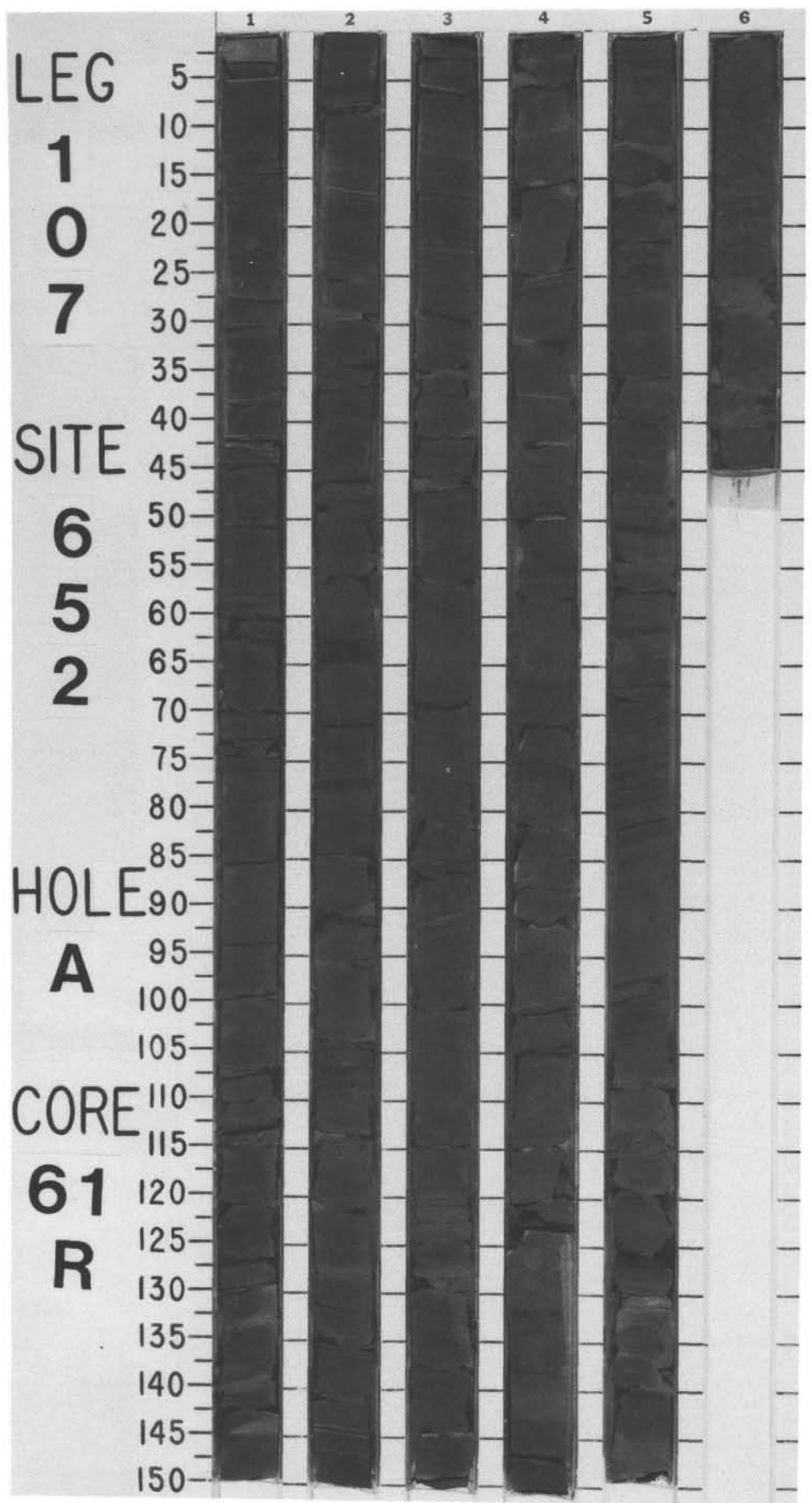




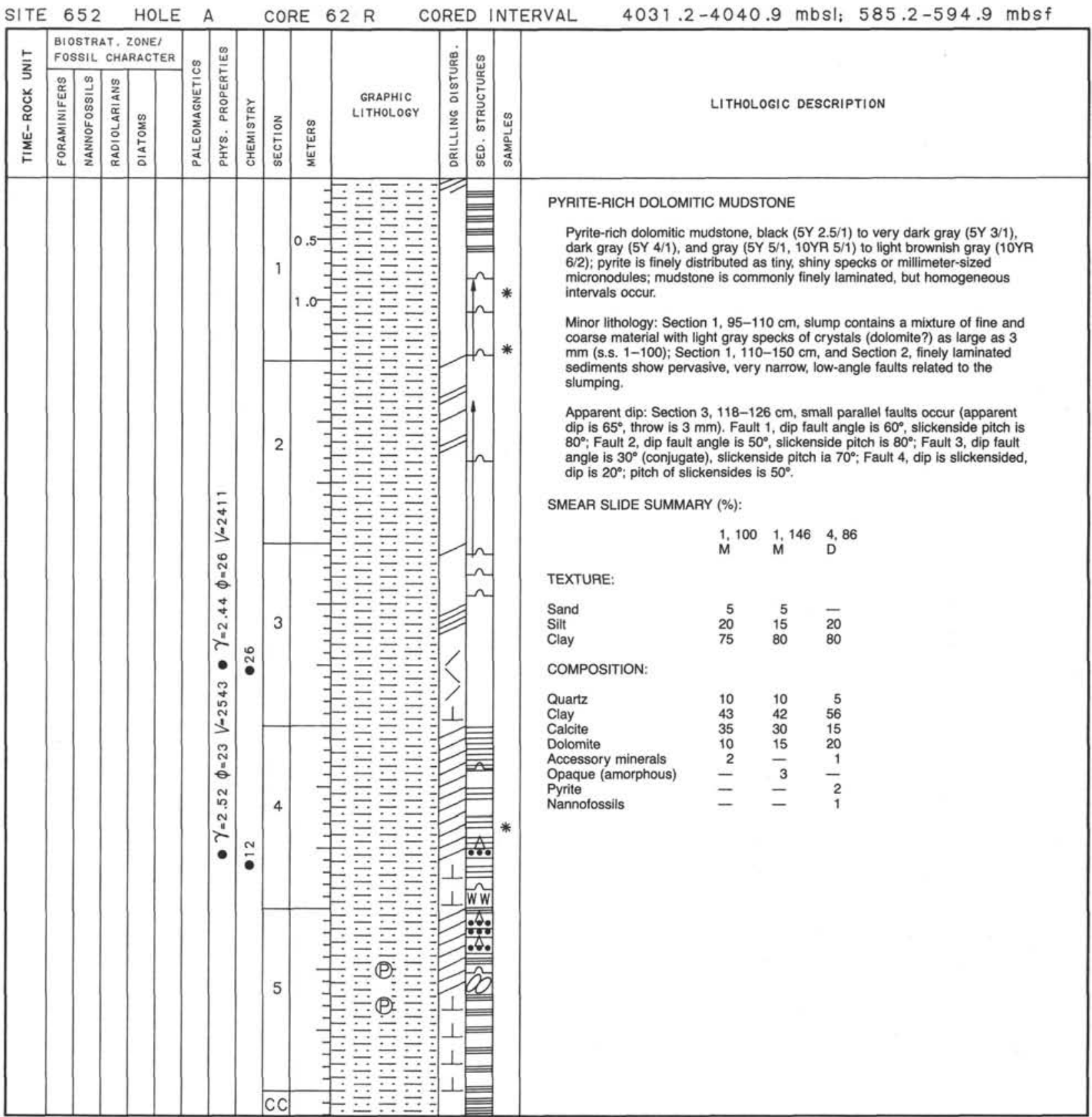




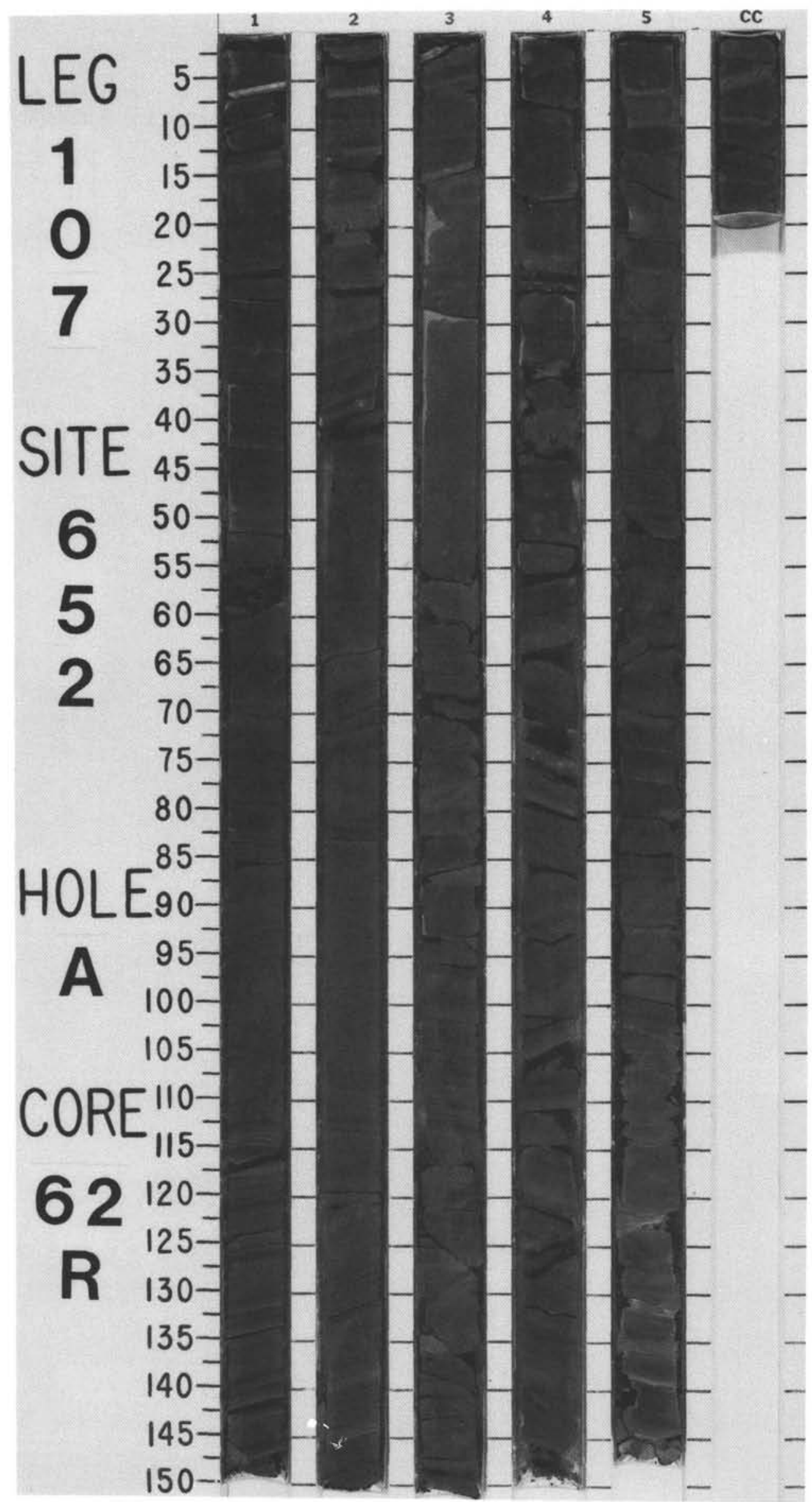


SITE 652 HOLE A CORE 63 R CORED INTERVAL 4040.9-4050.5 mbsl; 594.9-604.5 mbs $\mathrm{f}$

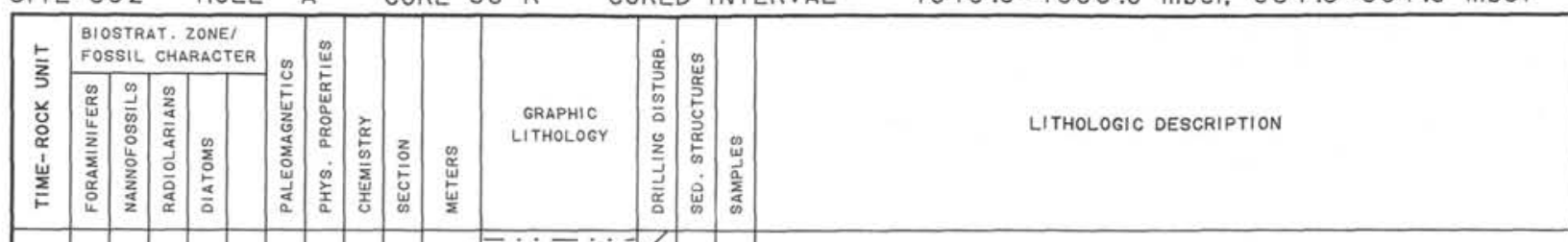

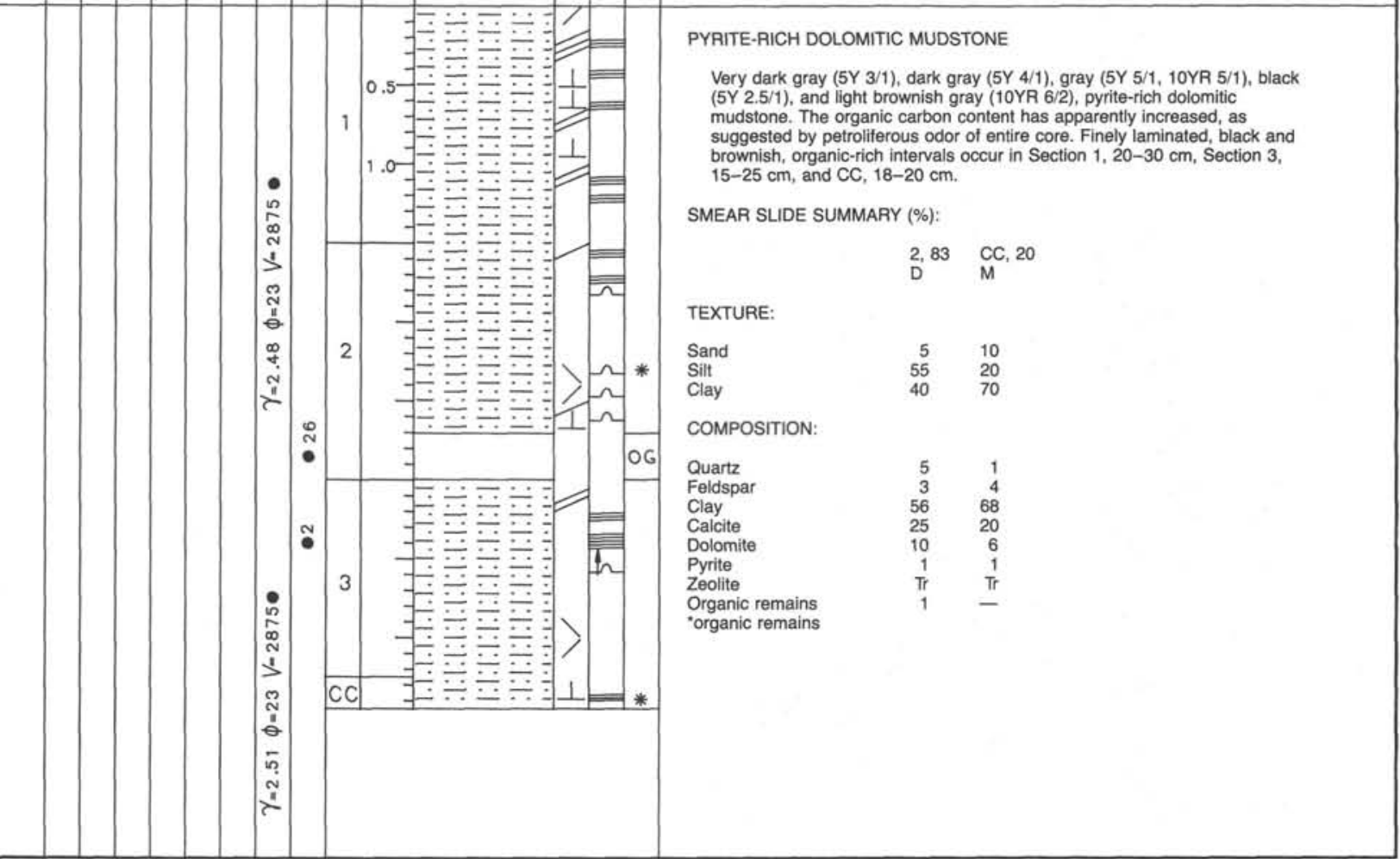




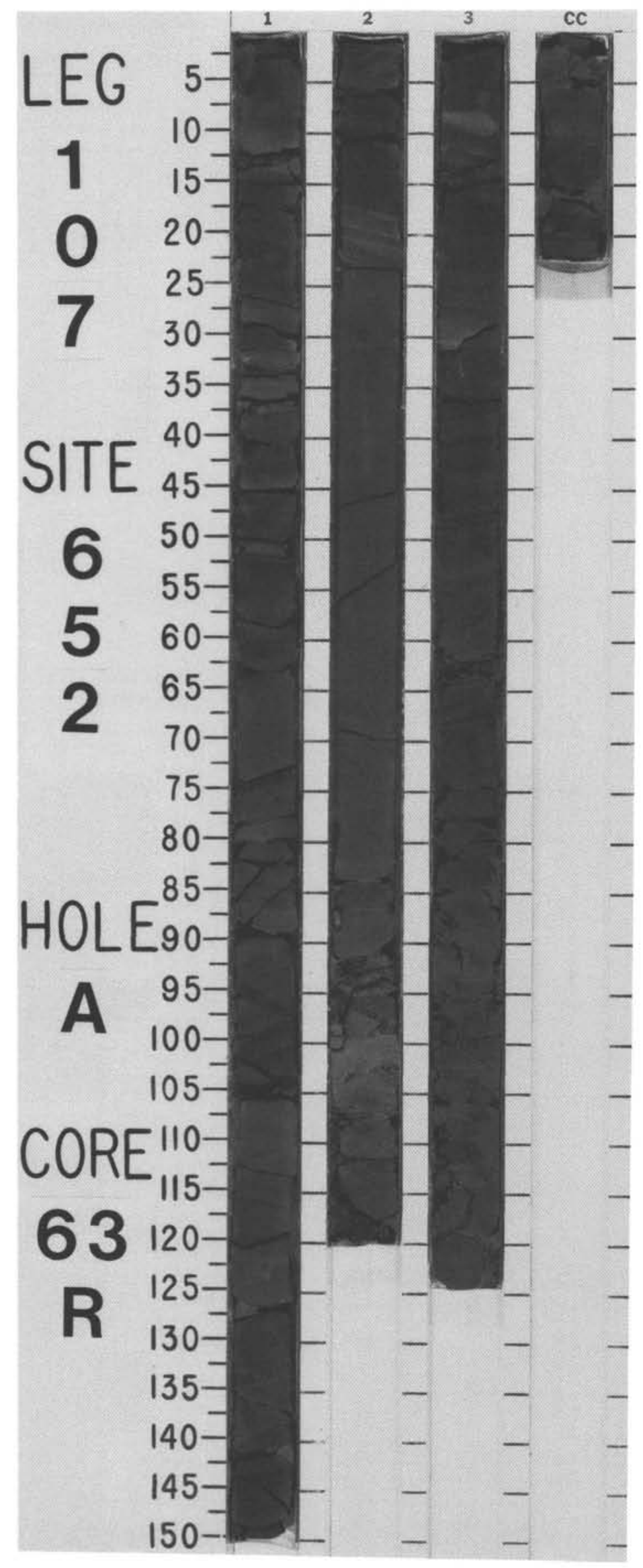




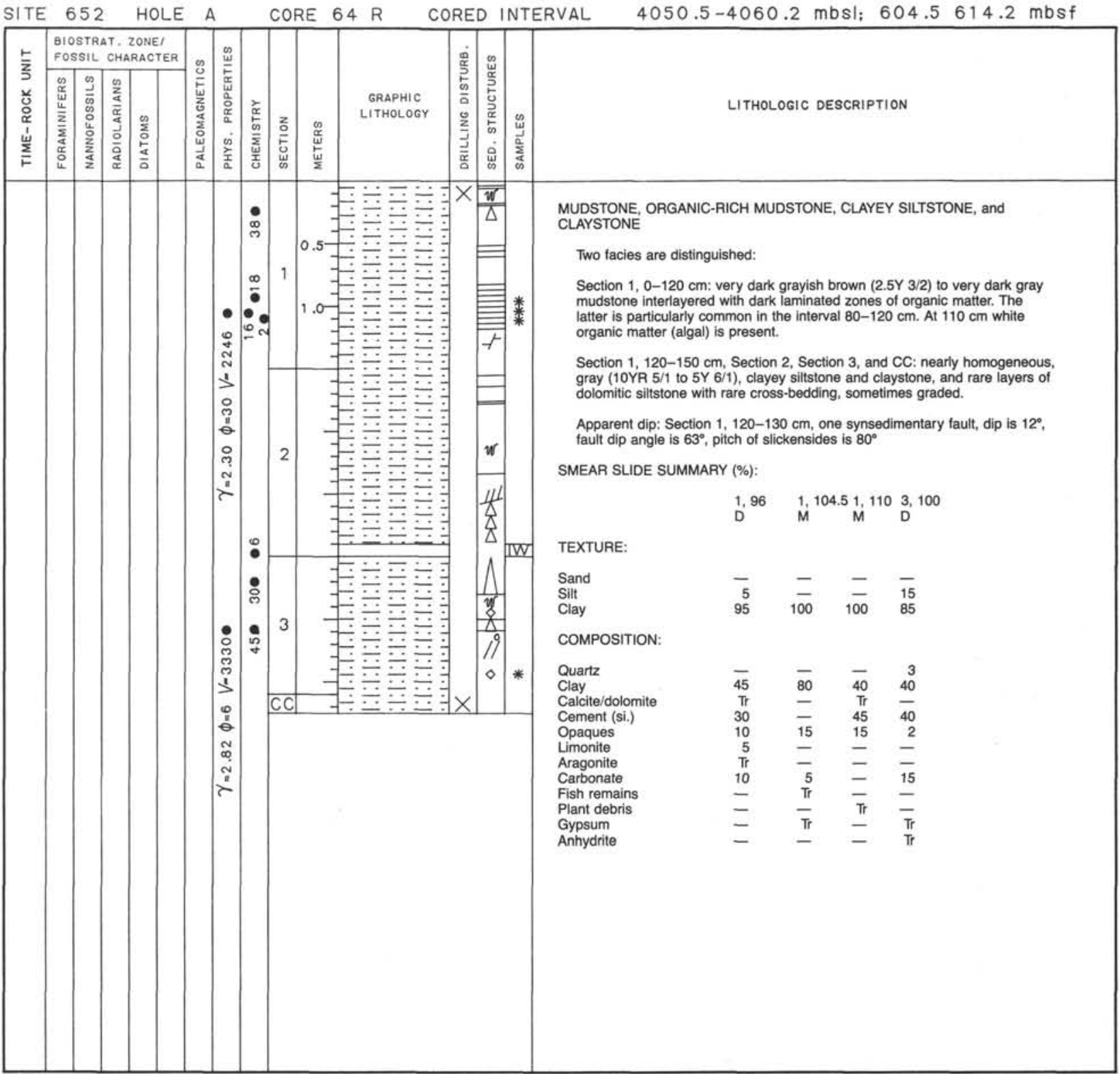




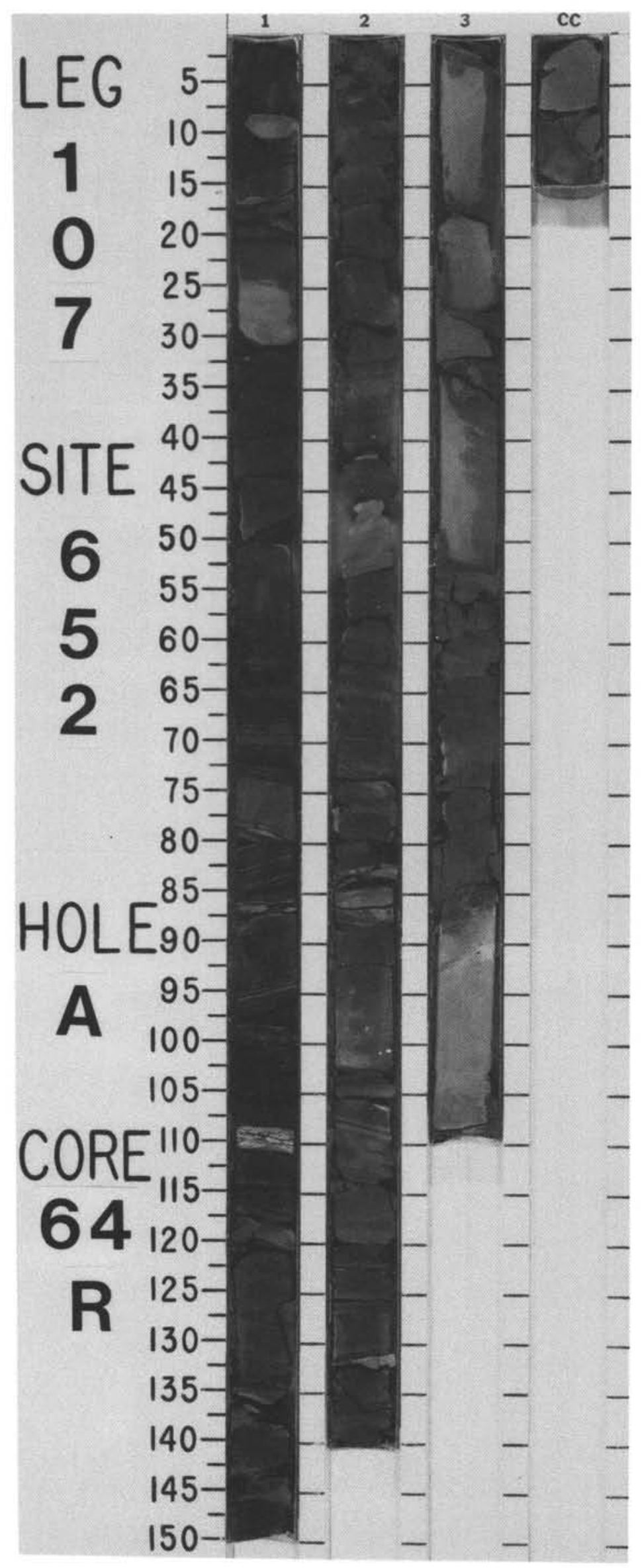


SITE 652 HOLE A CORE $65 \mathrm{R}$ CORED INTERVAL $4060.2-4070.5 \mathrm{mbsl}$ : $614.2-624.5$ mbSf

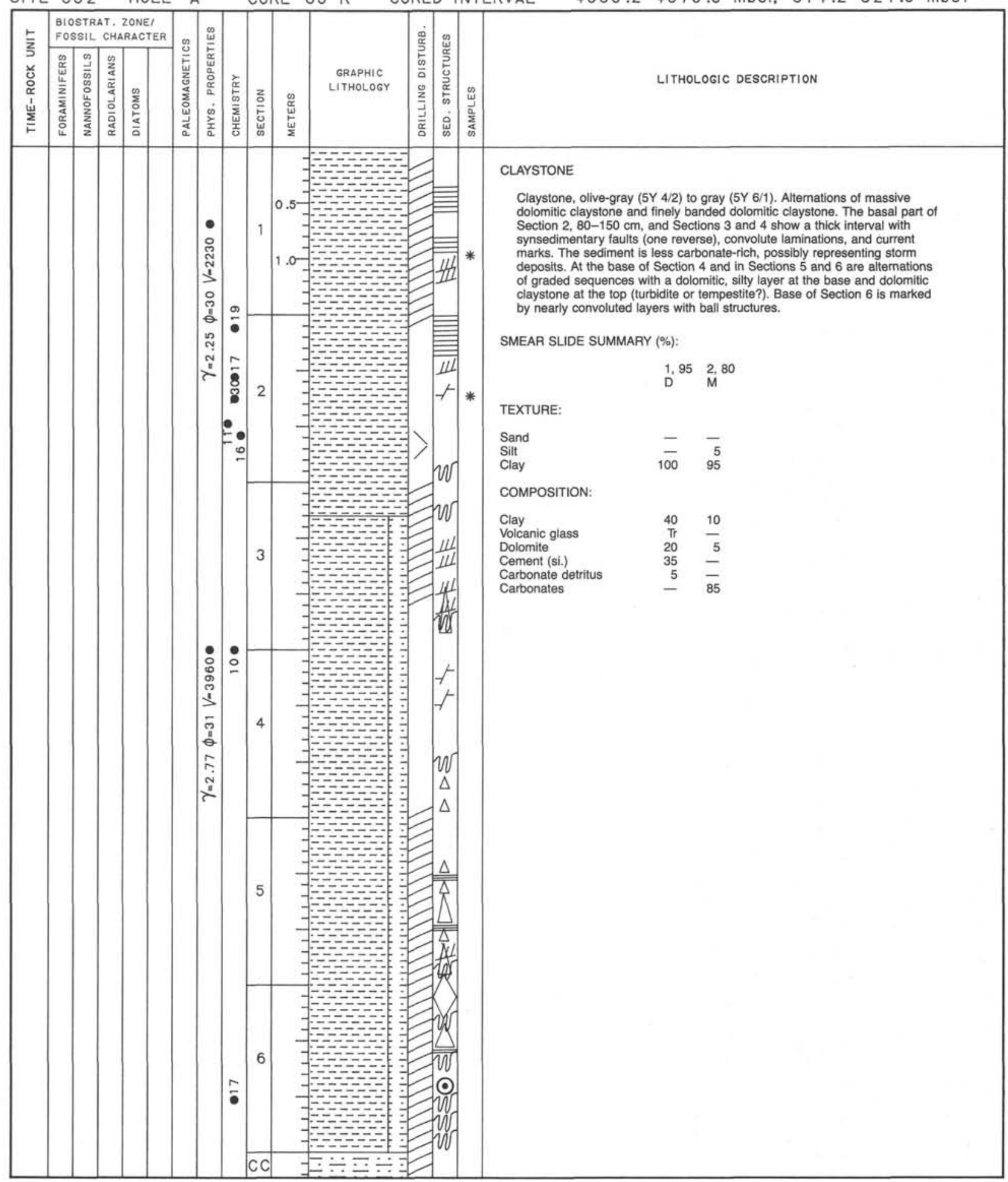




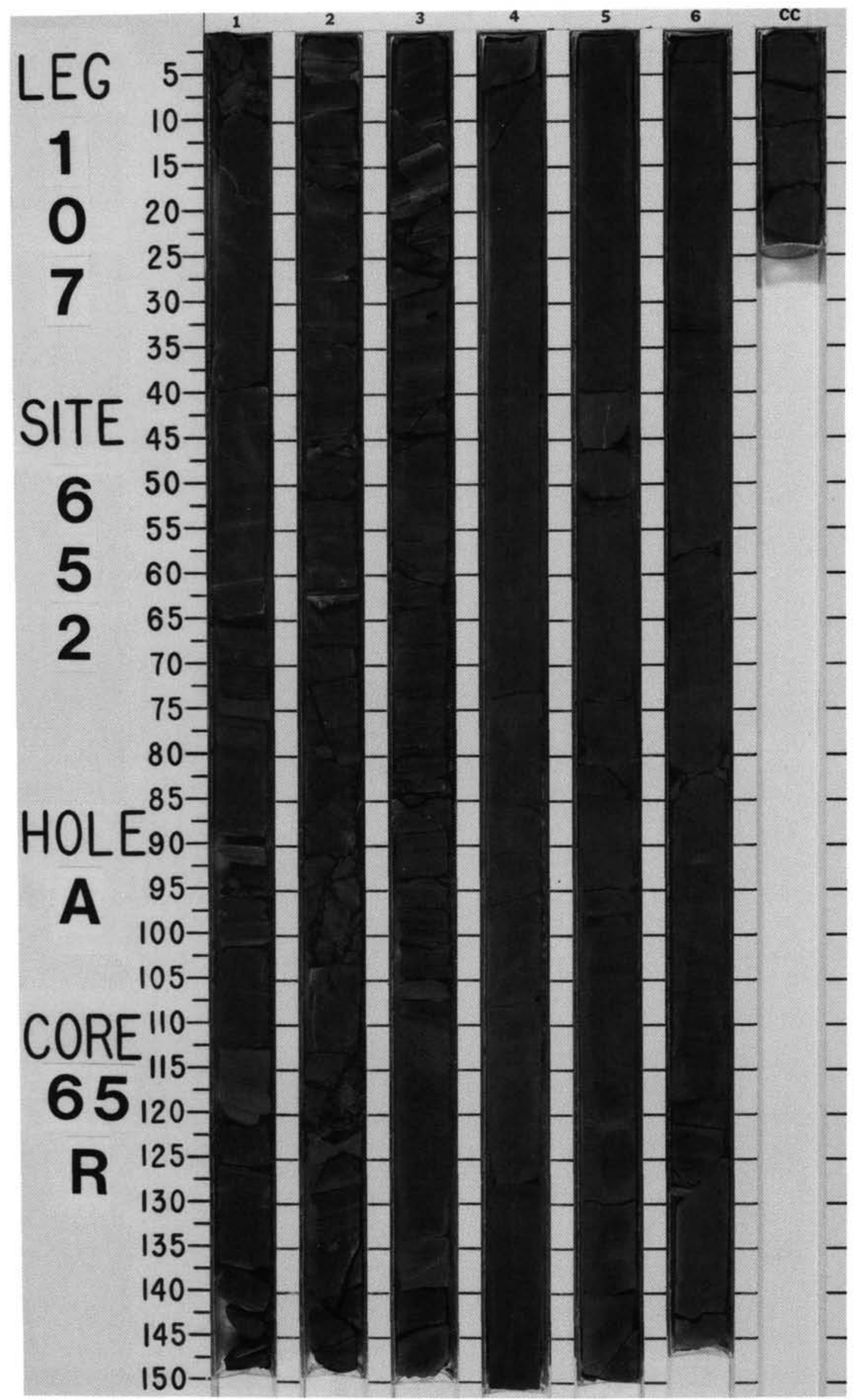




\begin{tabular}{|c|c|c|c|c|c|c|c|c|c|c|c|c|c|c|c|c|c|}
\hline 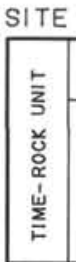 & 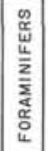 & 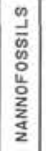 & 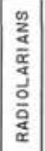 & 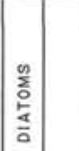 & 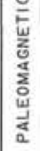 & 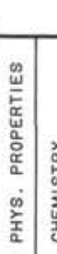 & \multicolumn{2}{|c|}{ 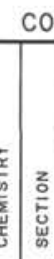 } & 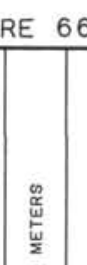 & $\begin{array}{l}\text { GRAPHIC } \\
\text { LITHOLOGY }\end{array}$ & 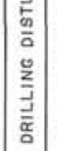 & , & & & \multicolumn{3}{|c|}{ LITHOLOGIC DESCRIPTION } \\
\hline & & & & & & 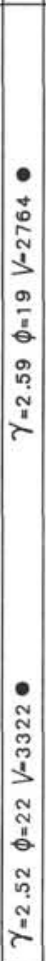 & $\begin{array}{l}0 \\
\infty \\
ల\end{array}$ & CC & 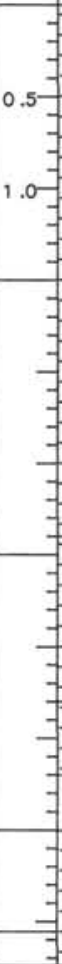 & 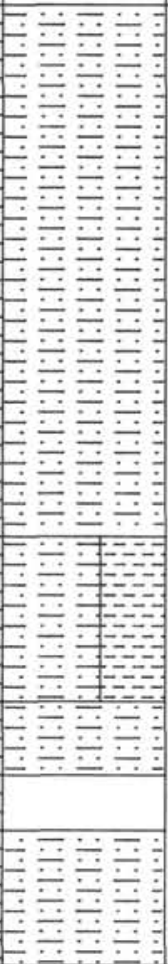 & & 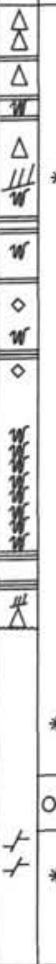 & * & $\begin{array}{l}\text { CALCAREOUS MU } \\
\text { Monotonous suc } \\
\text { sequences. Seq } \\
\text { graded (mainly r } \\
\text { sequences is me } \\
\text { laminations occL } \\
\text { Dip reaches } 52^{\circ} \\
\text { SMEAR SLIDE SUI } \\
\\
\text { TEXTURE: } \\
\text { Sand } \\
\text { Silt } \\
\text { Clay } \\
\text { COMPOSITION: } \\
\text { Quartz } \\
\text { Mica } \\
\text { Clay } \\
\text { Dolomite } \\
\text { Cement (si.) } \\
\text { Opaques } \\
\text { Anhydrite detritus } \\
\text { Gypsum detritus } \\
\text { Carbonate detritus } \\
\text { Nannofossils }\end{array}$ & $\begin{array}{l}\text { NE } \\
\text { nof olive } \\
\text { are gen } \\
\text { dolomit } \\
\text { y paralle } \\
\text { ction } 1 . \\
\text { tion } 2,80 \\
\text { Y (\%): } \\
1,90 \\
\text { D } \\
\\
5 \\
25 \\
70 \\
\\
3 \\
5 \\
20 \\
15 \\
30 \\
\frac{5}{7} \\
7 \\
15 \\
-\end{array}$ & 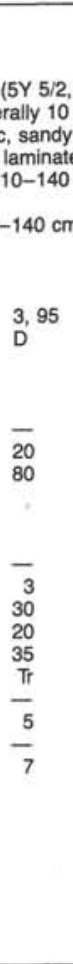 & $\begin{array}{l}\text { 5/3) calcareous mudstone } \\
\mathrm{cm}, \text { beginining with well-indurated, } \\
\text { siltstone with current marks; top of } \\
\text { ed calcareous mudstone. Convolute } \\
\mathrm{cm} \text {, and in Section 2, 80-140 cm. } \\
\\
4,23 \\
\mathrm{D} \\
\overline{20} \\
80 \\
\overline{T r} \\
25 \\
15 \\
25 \\
5 \\
-5 \\
20 \\
5\end{array}$ \\
\hline
\end{tabular}




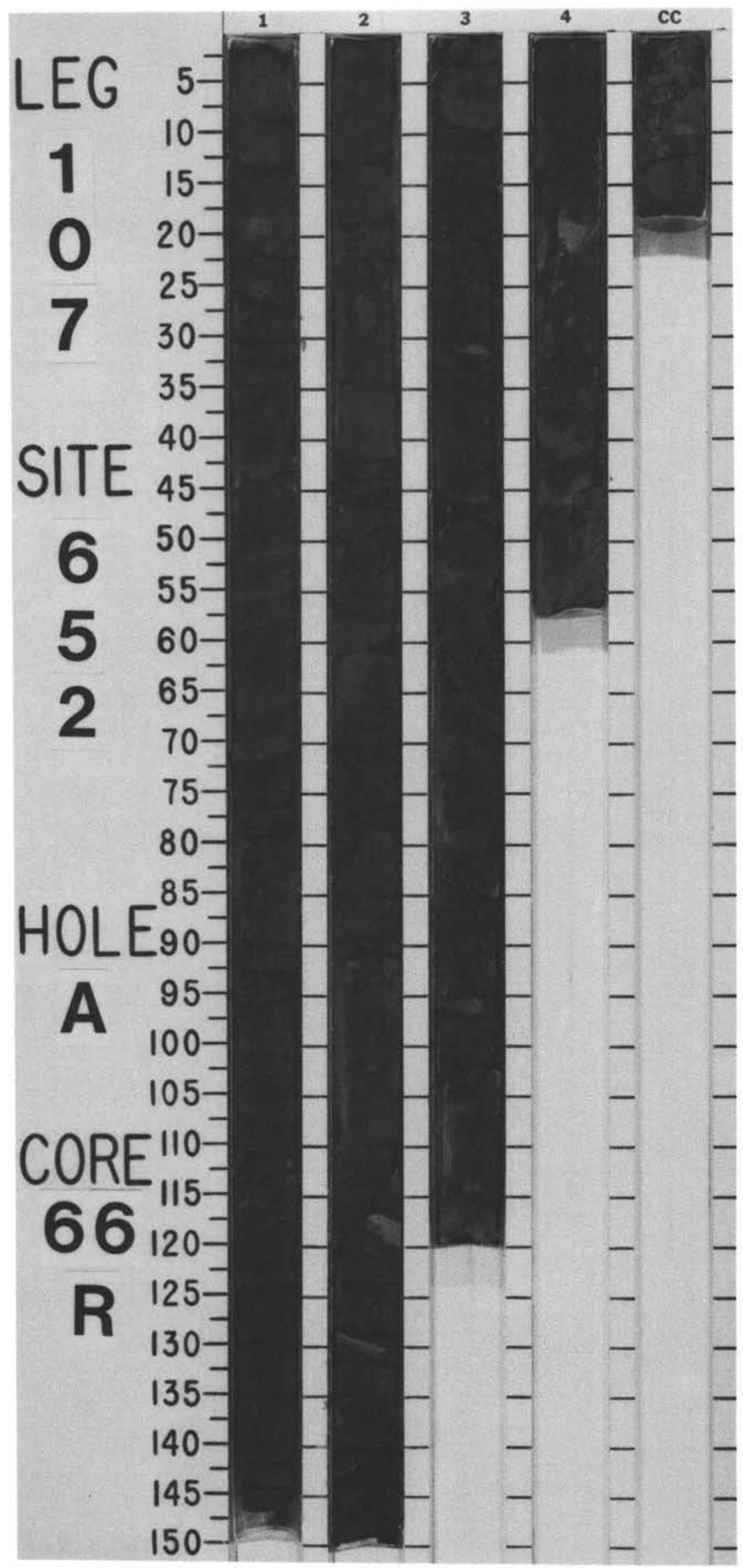




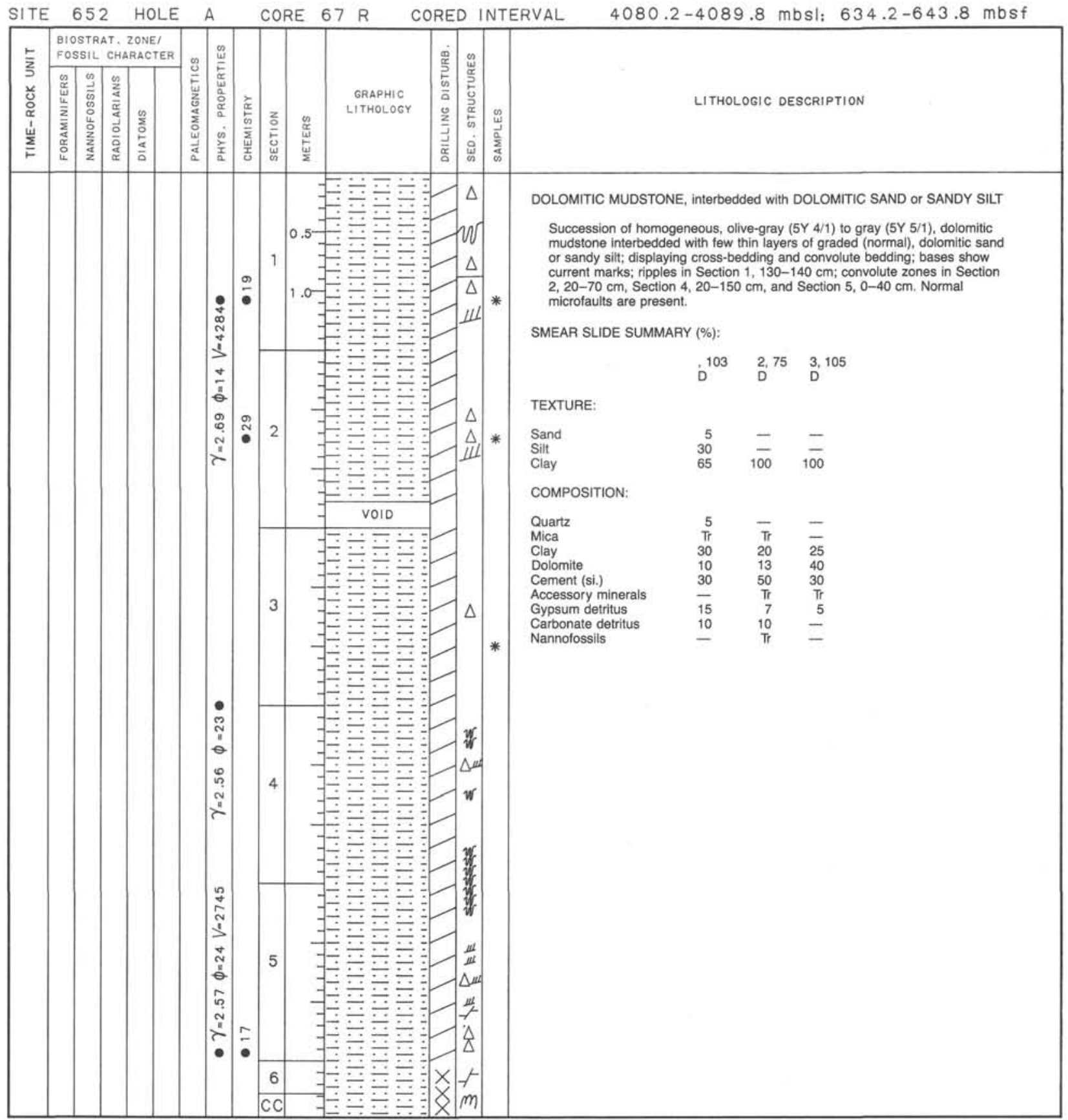




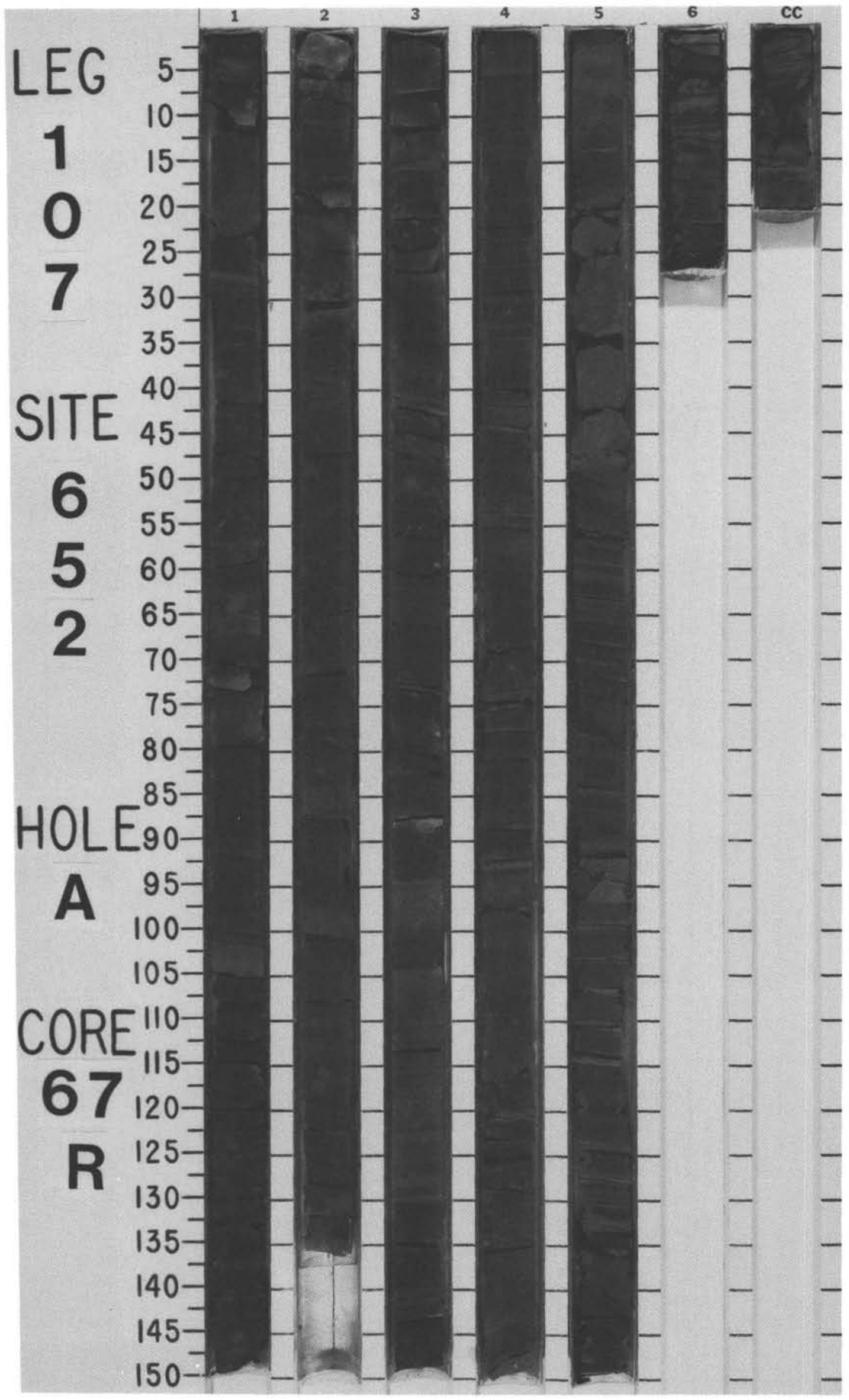




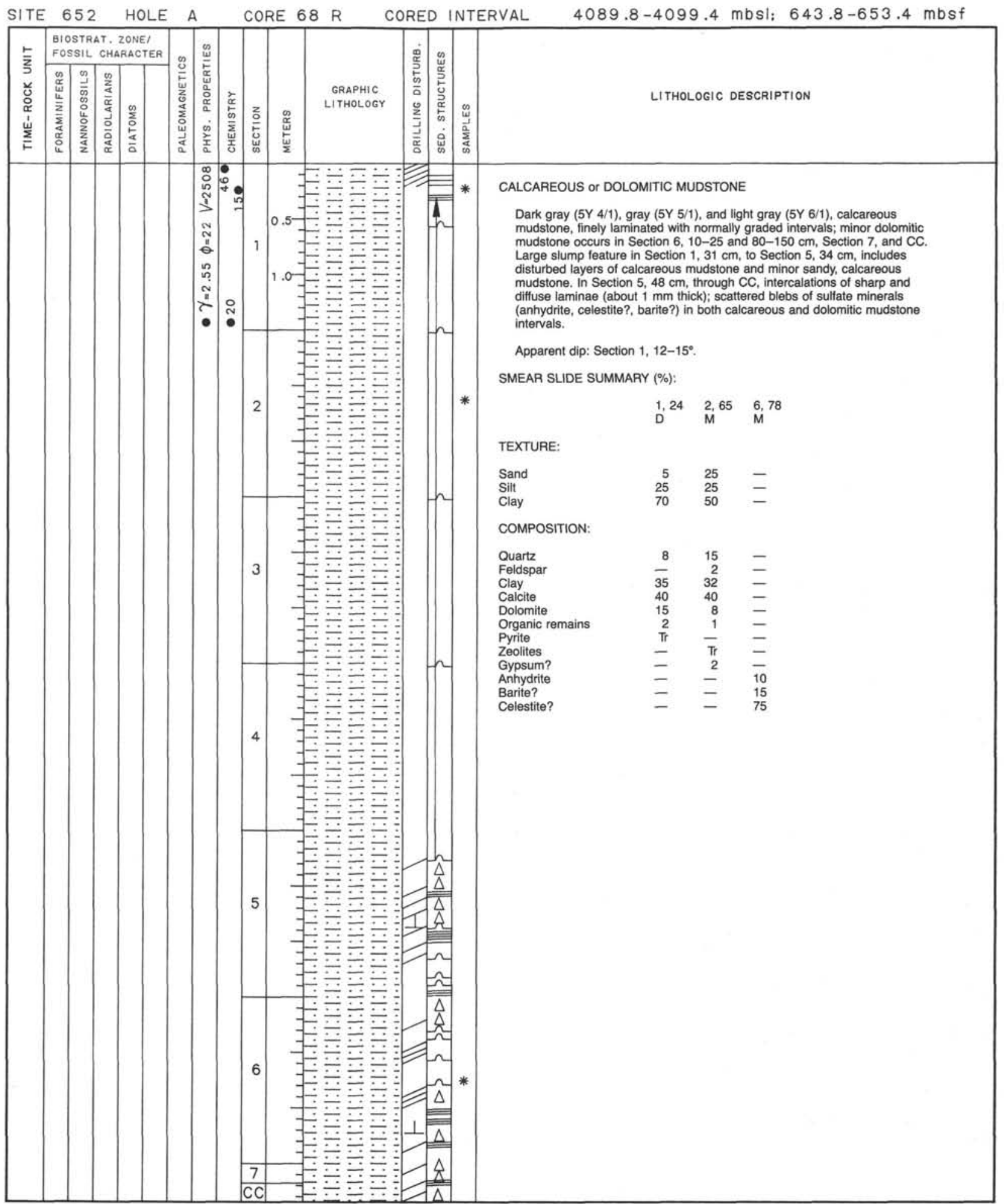




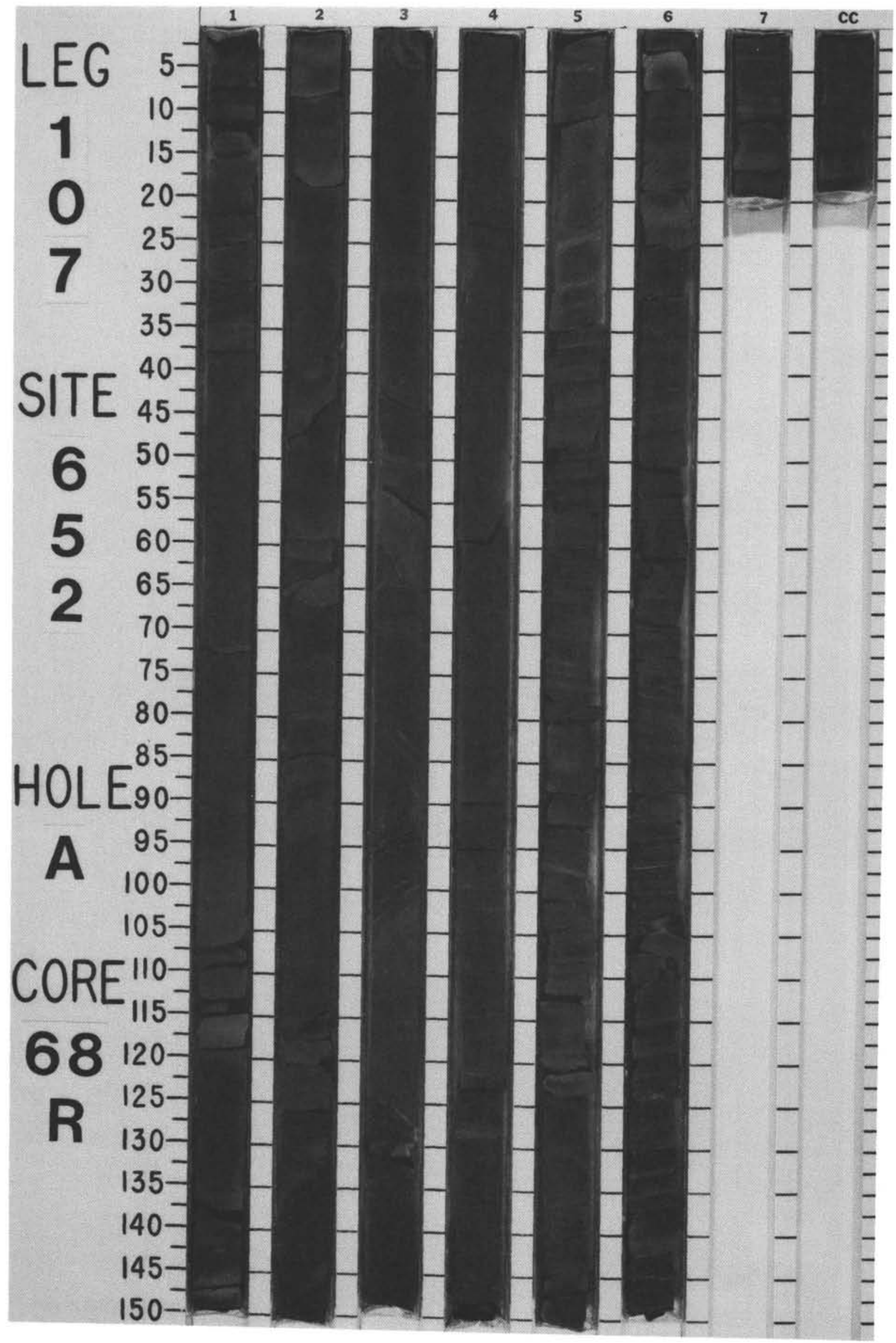




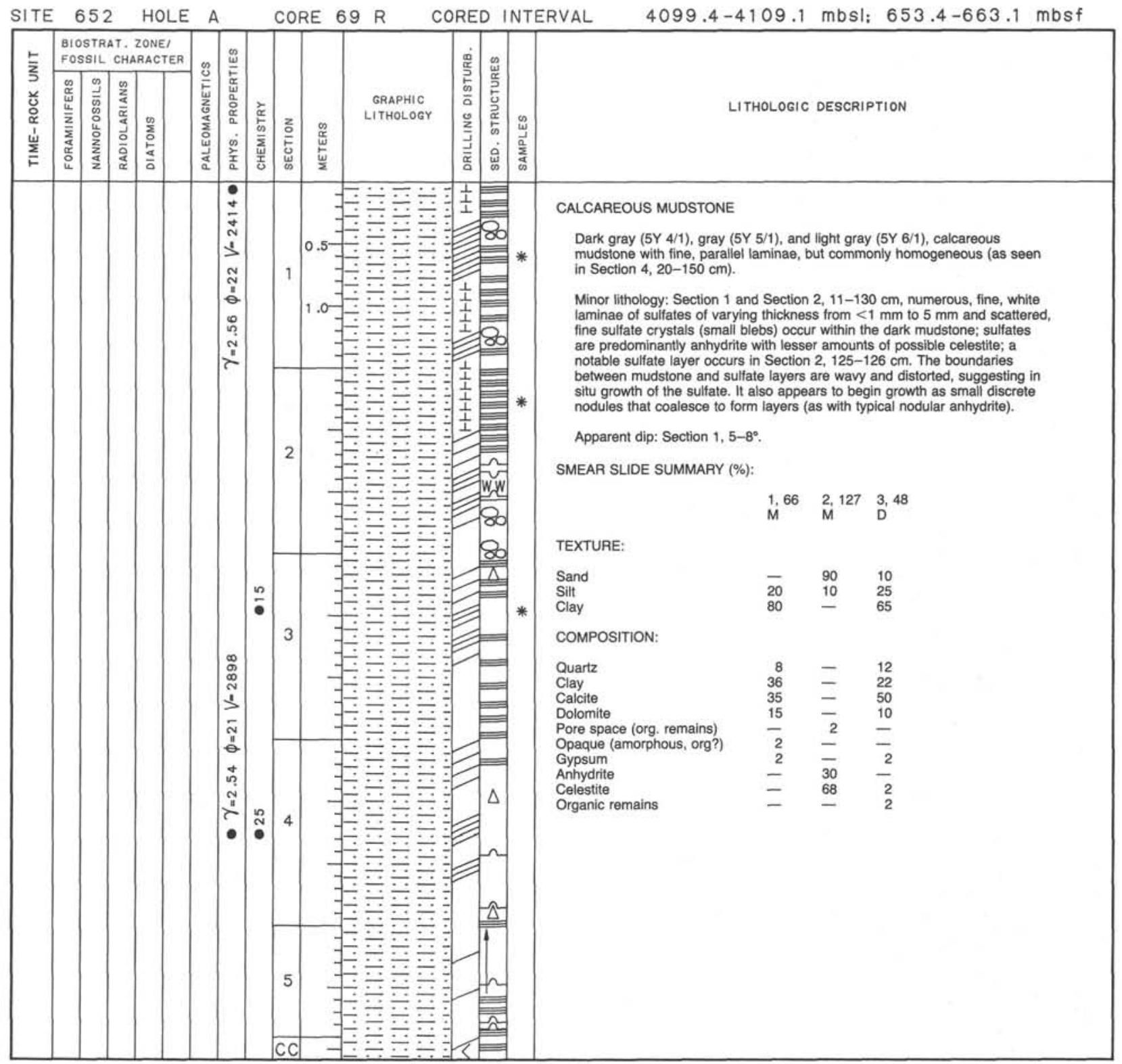




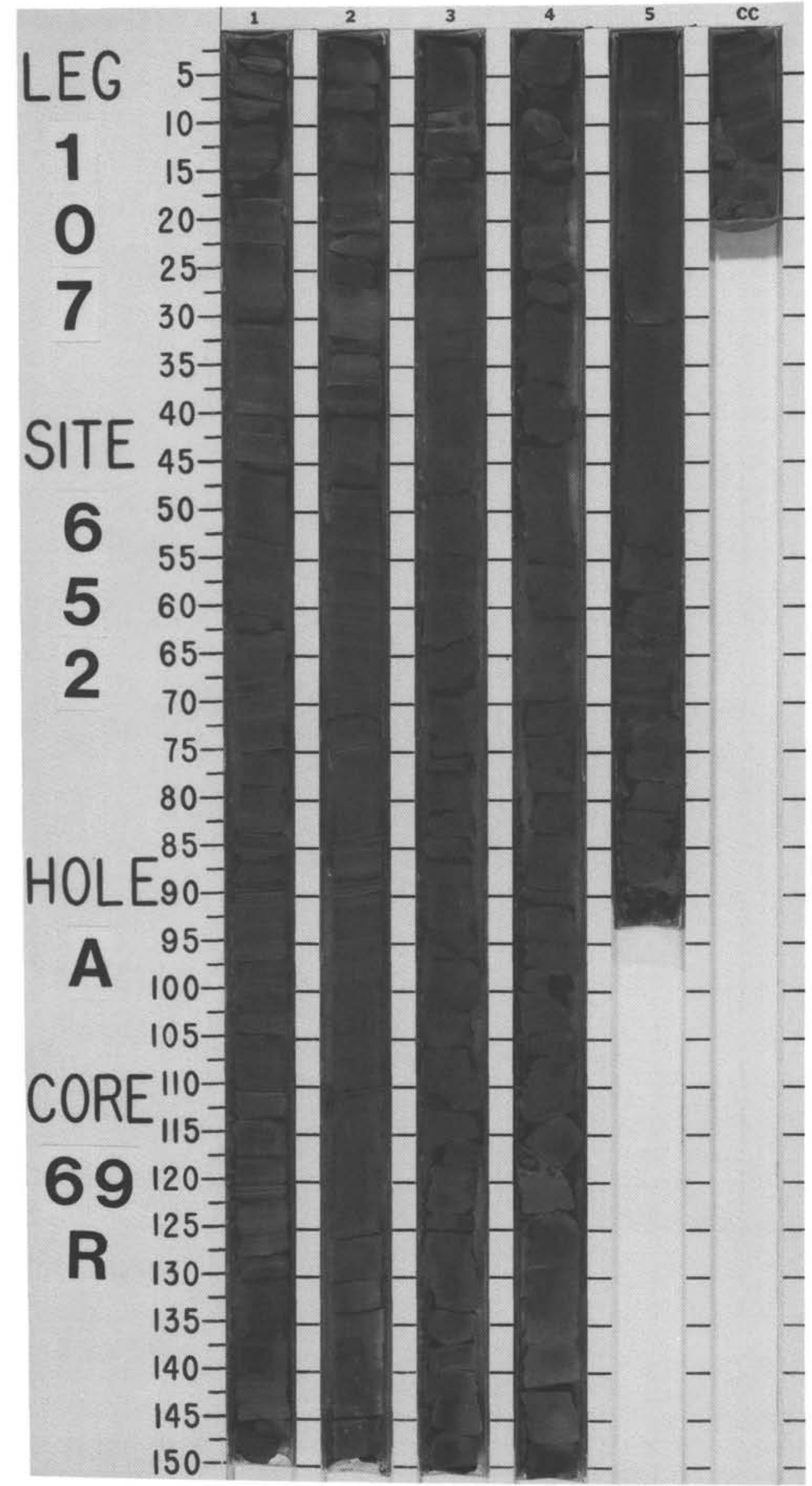




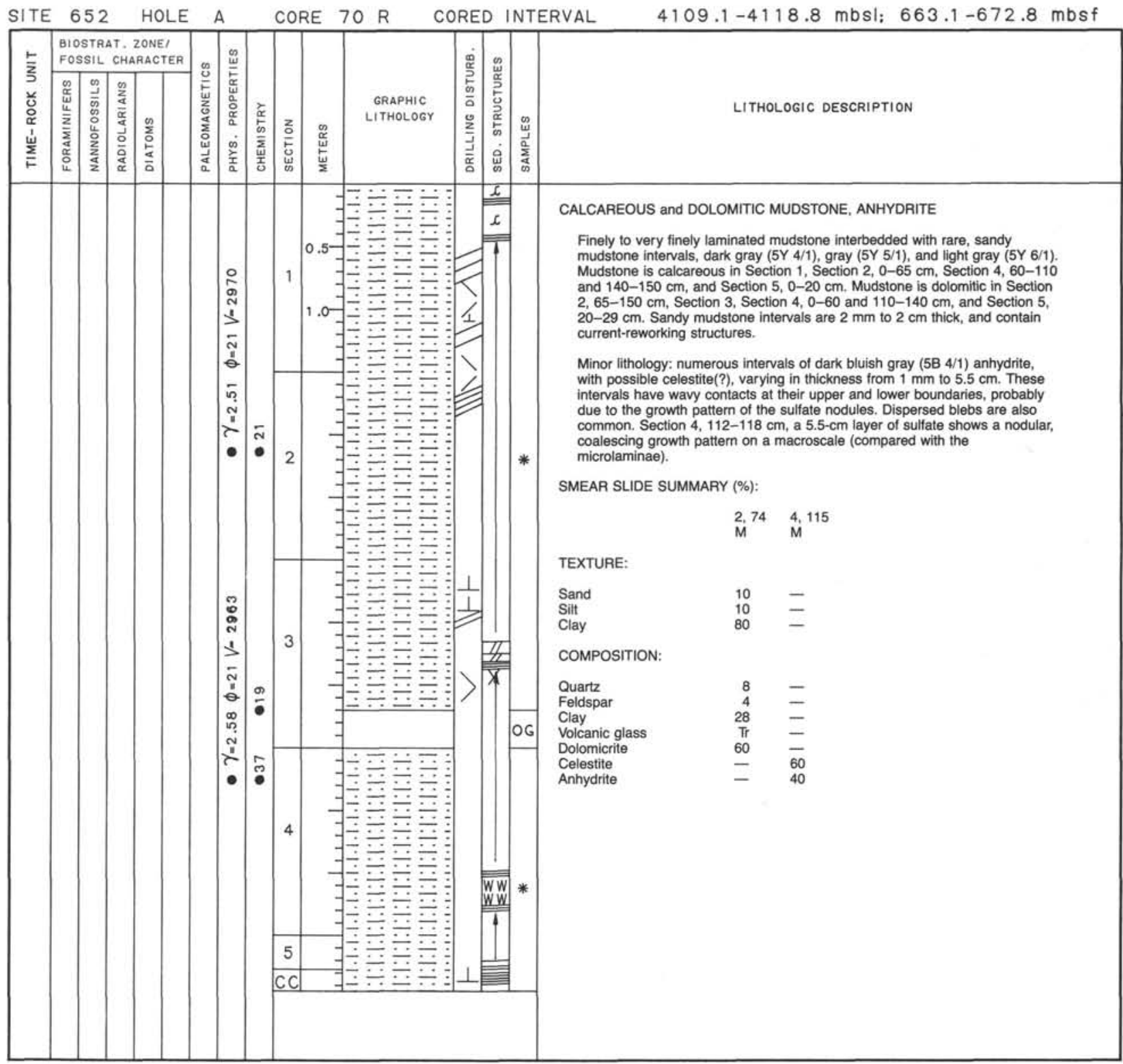




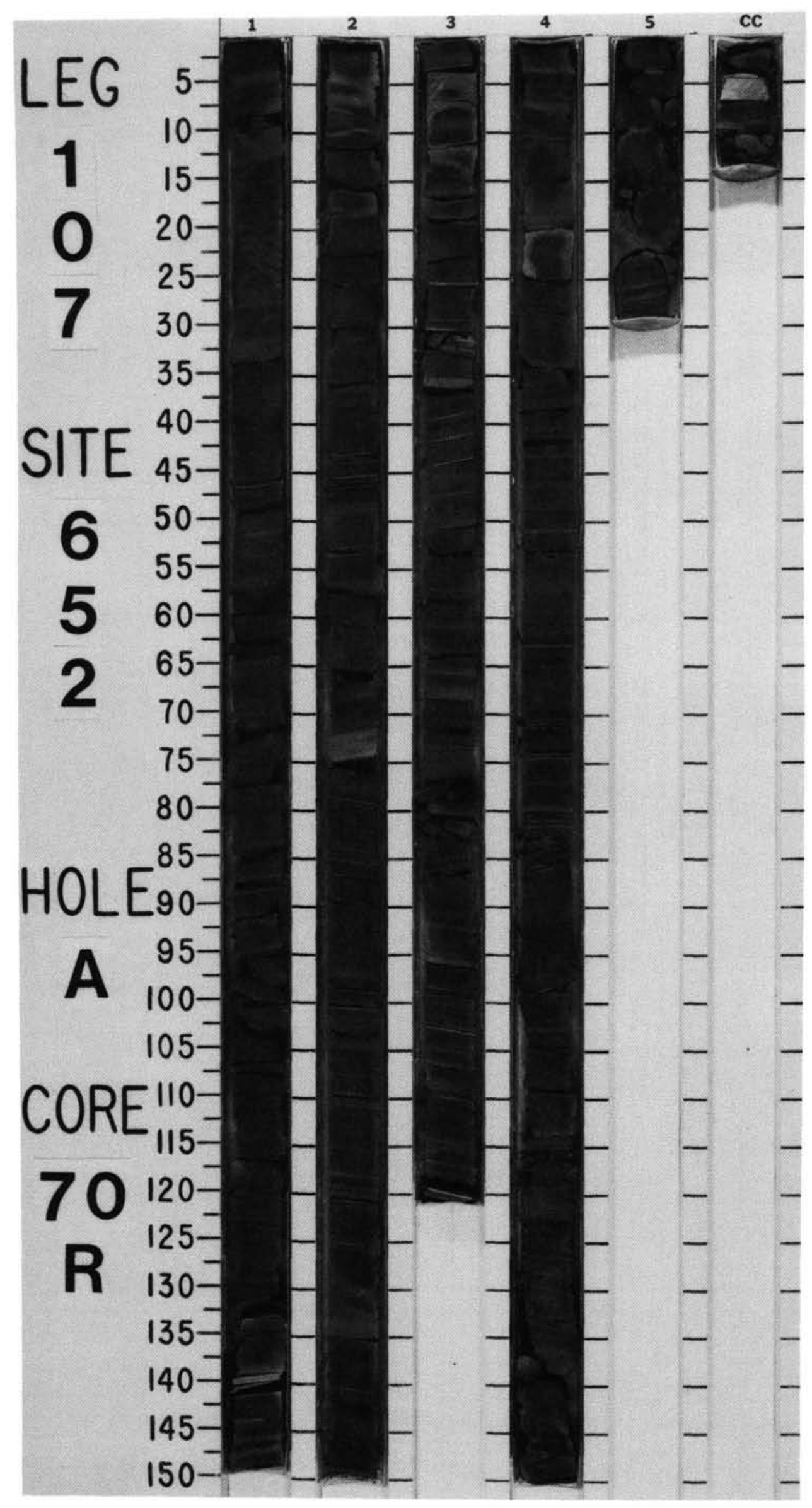




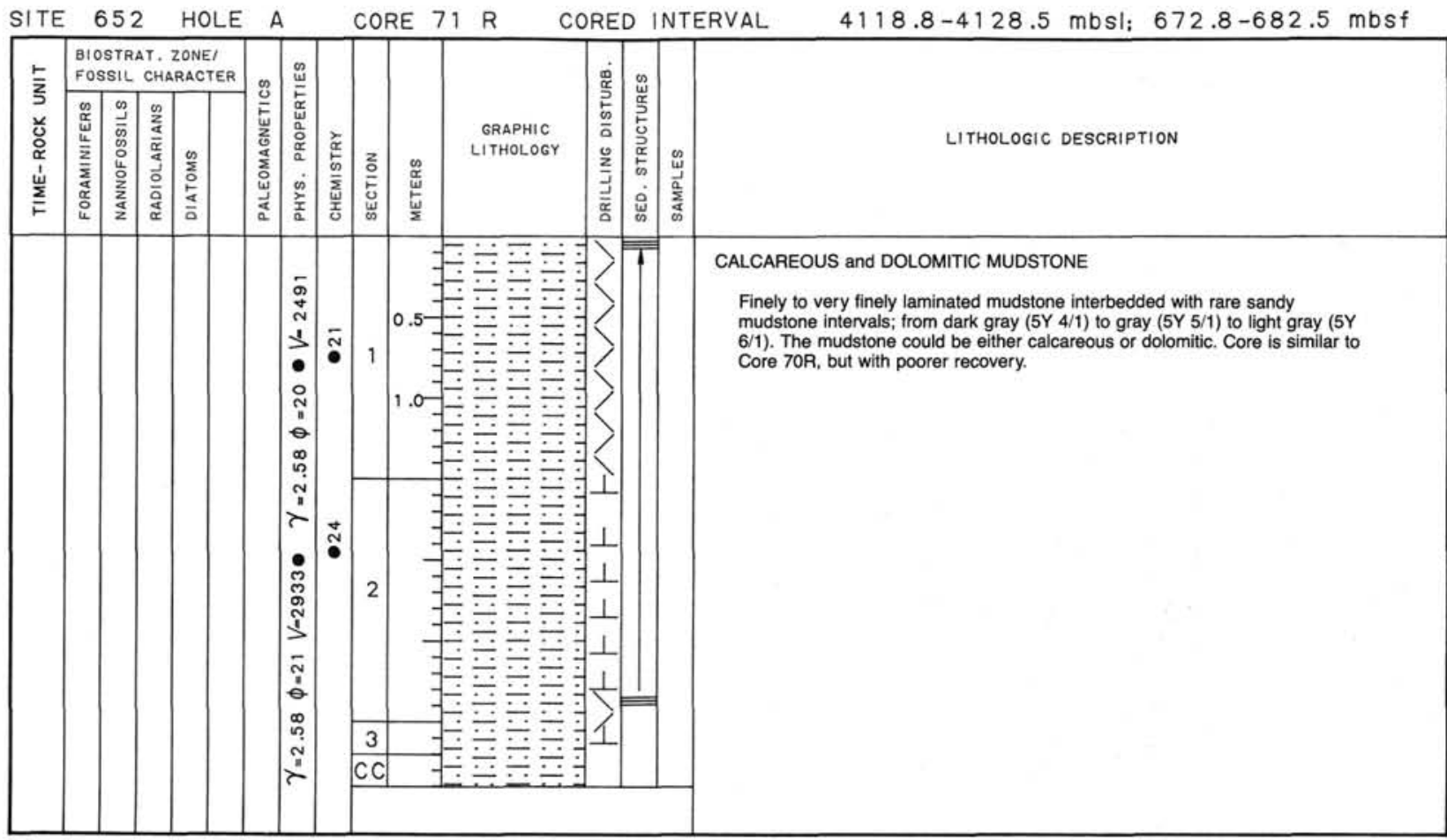

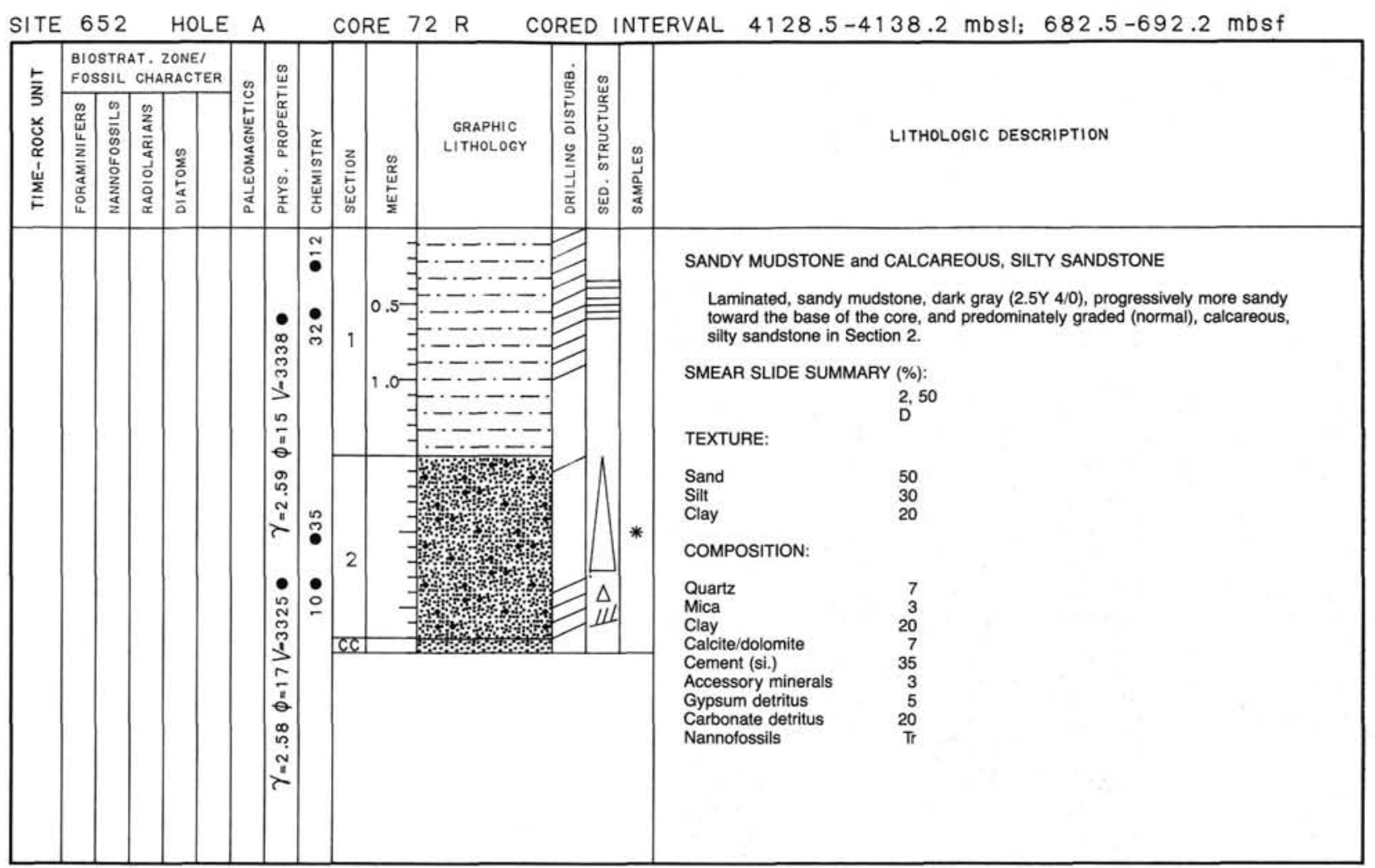




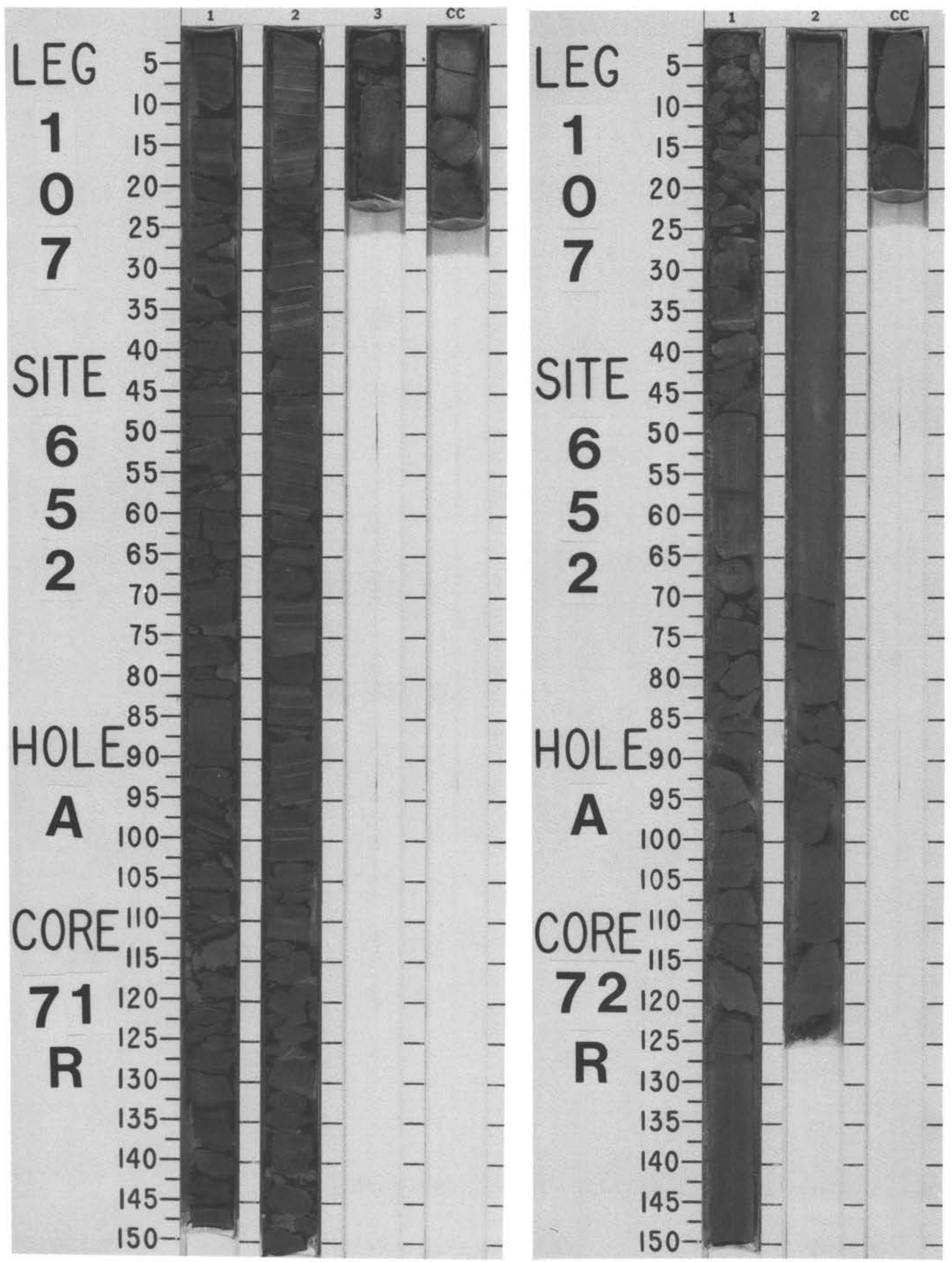




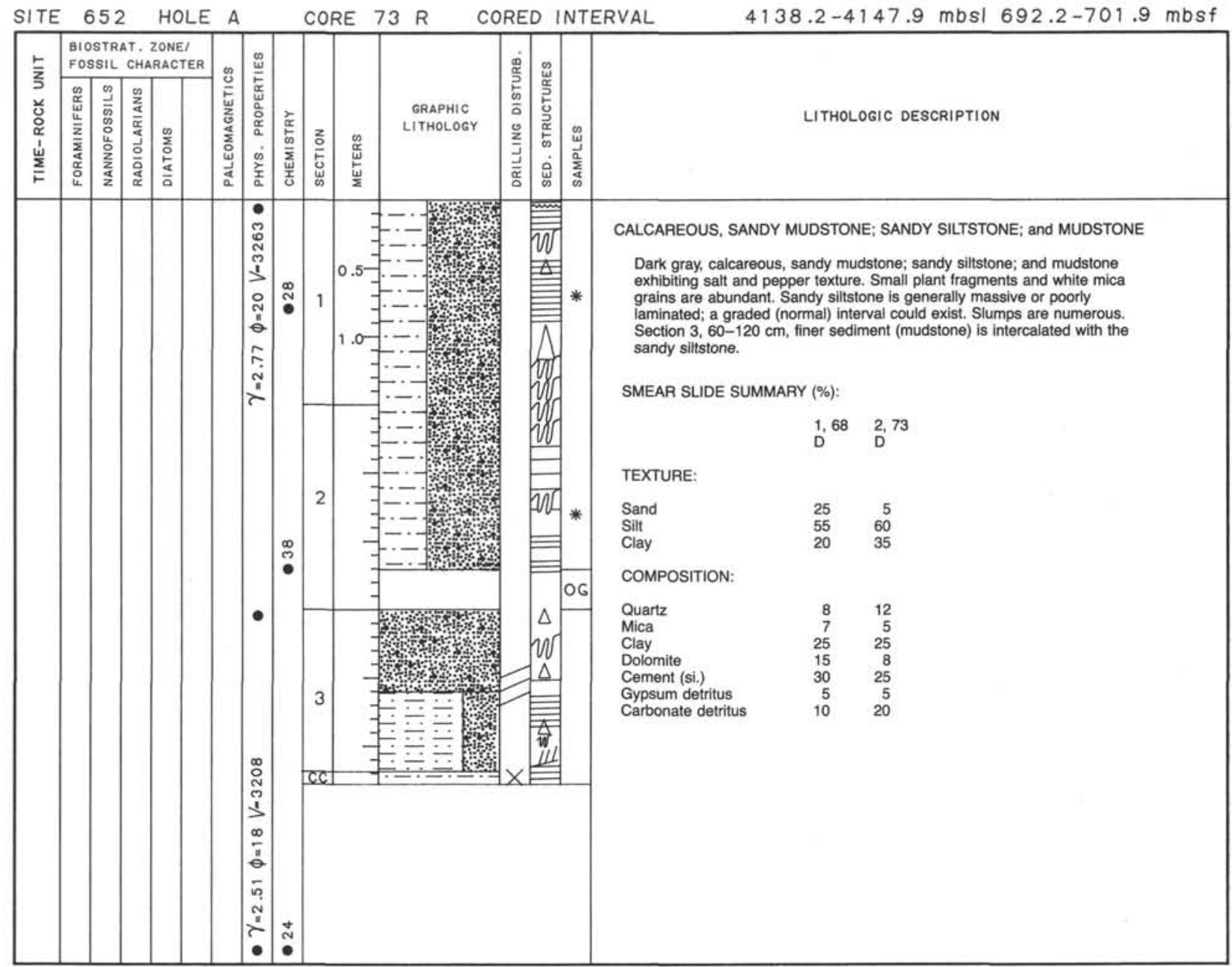




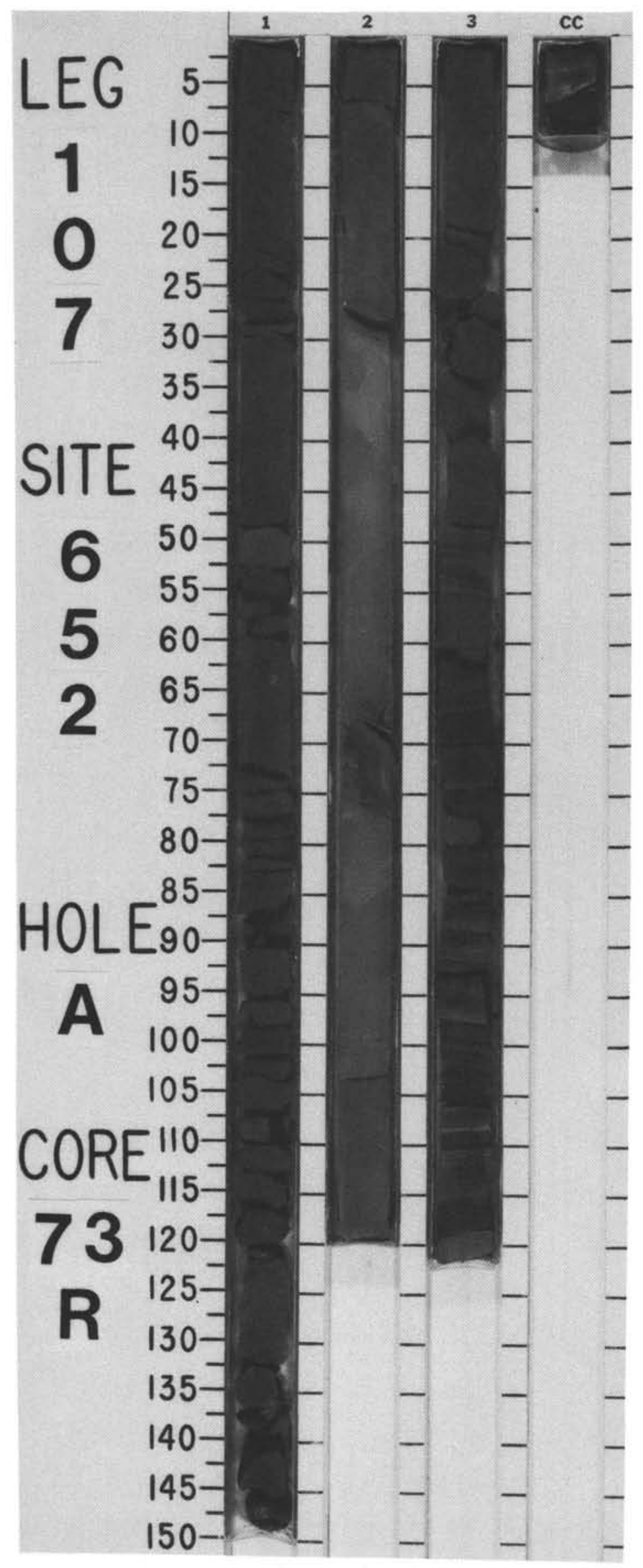




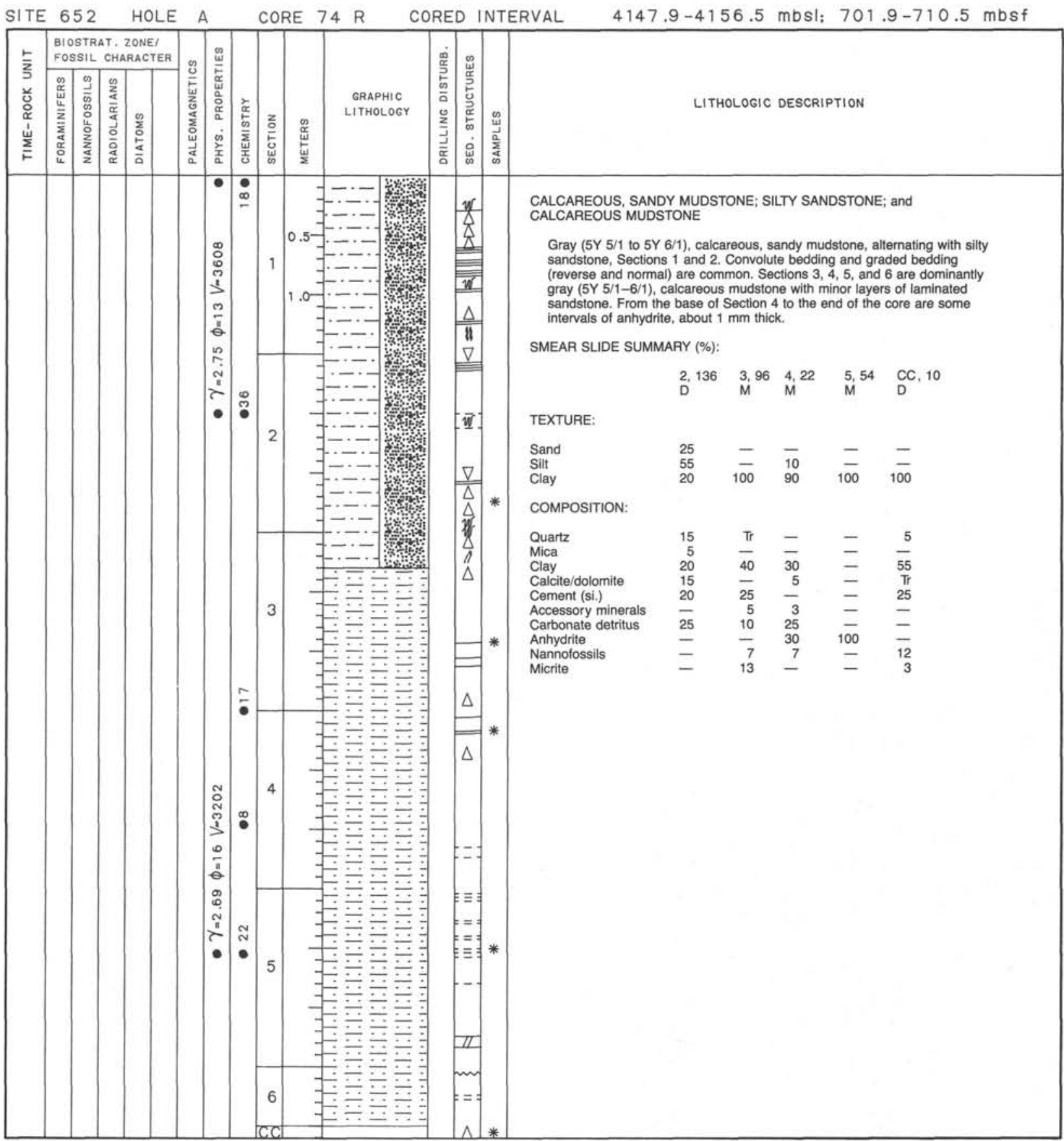




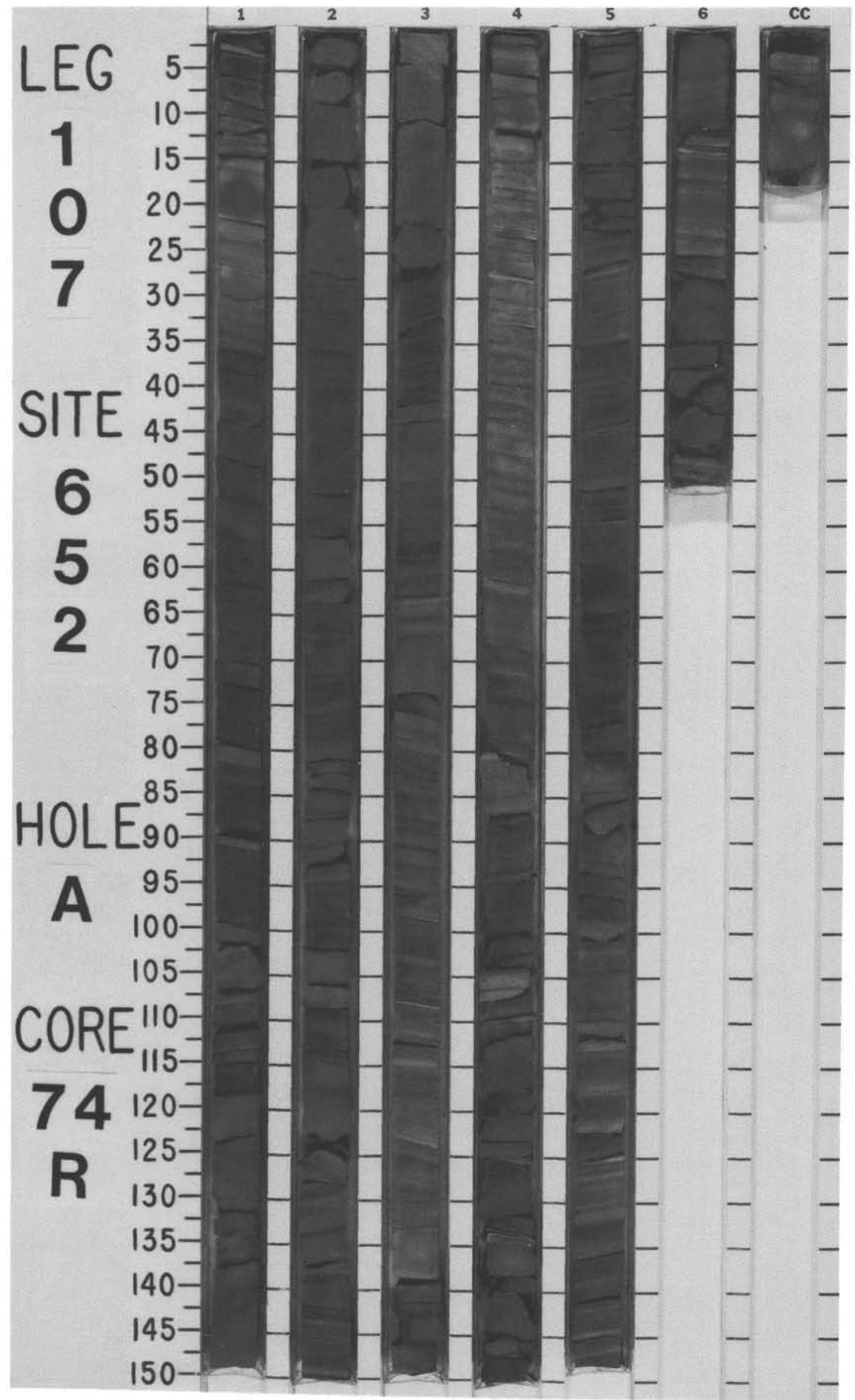




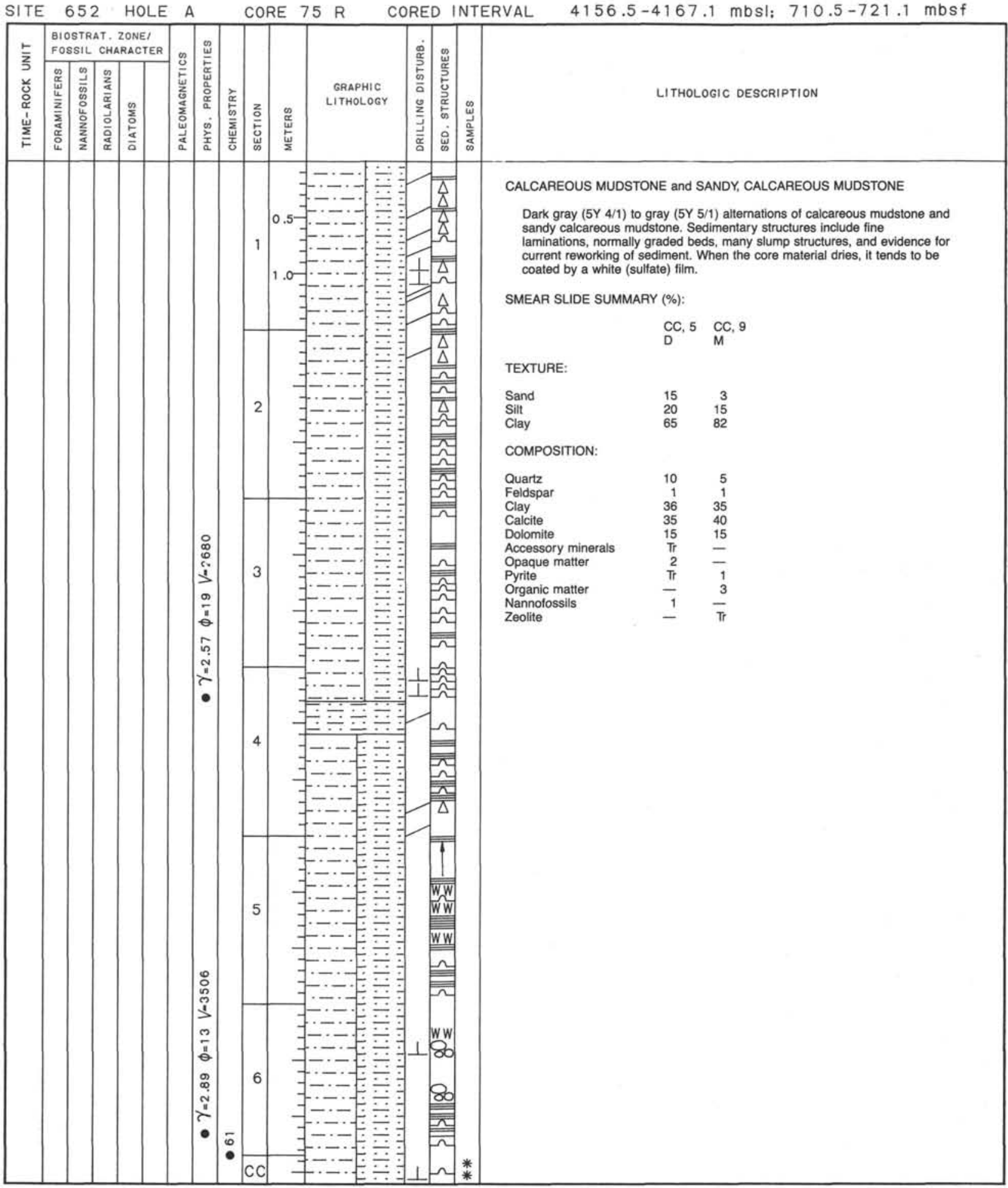




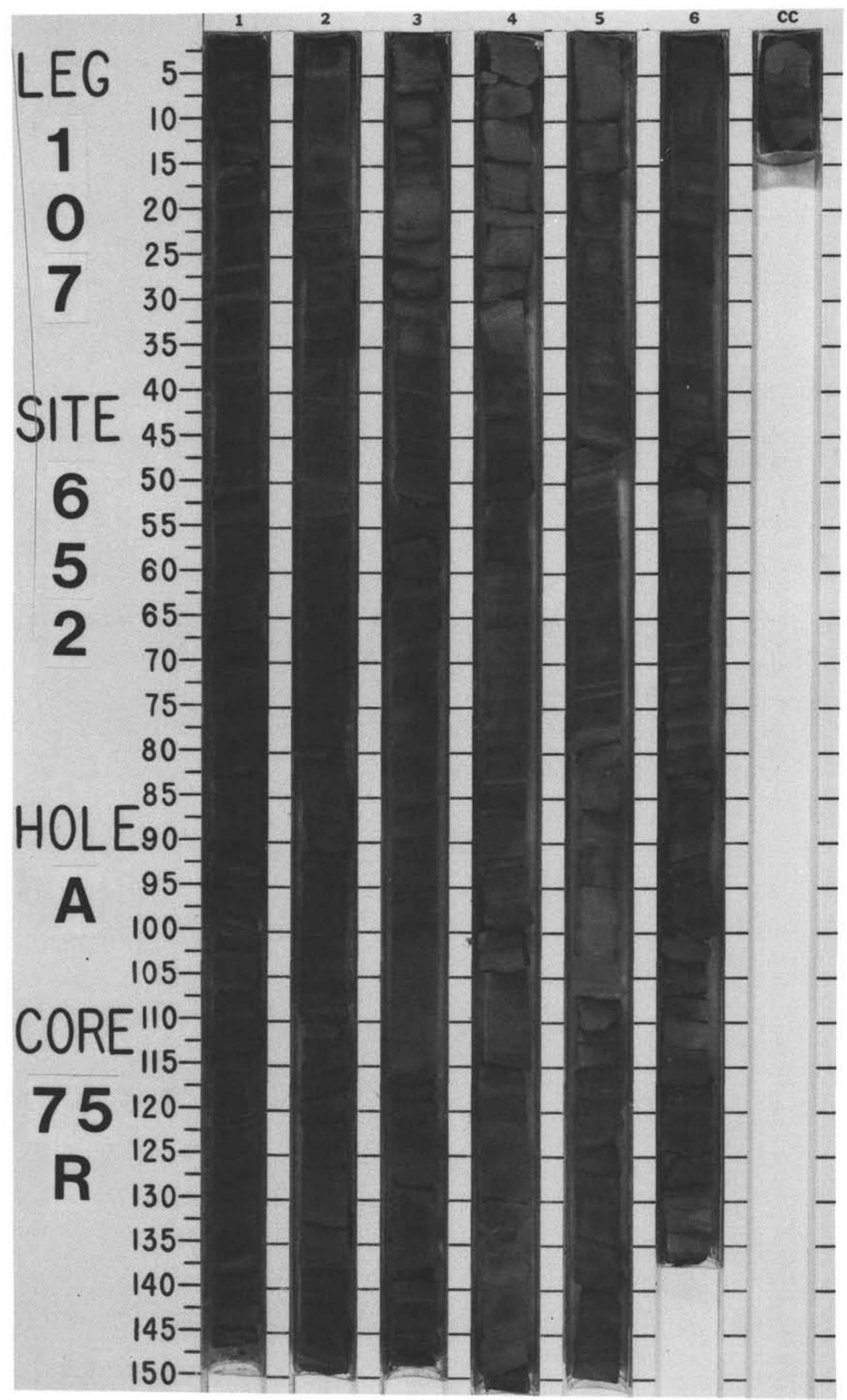

